Florida International University

FIU Digital Commons

3-18-2020

\title{
Lithological and Geochemical Responses to Abrupt Global and Regional Paleoenvironmental Changes During the Aptian in a Hemipelagic Setting of the Eastern Iberian Peninsula: A Multi- Proxy Approach
}

Jander Socorro

Florida International University, jsoco002@fiu.edu

Follow this and additional works at: https://digitalcommons.fiu.edu/etd

Part of the Climate Commons, Geochemistry Commons, Geology Commons, Inorganic Chemistry

Commons, Oceanography Commons, Oil, Gas, and Energy Commons, Organic Chemistry Commons, Paleobiology Commons, Paleontology Commons, Sedimentology Commons, and the Stratigraphy

Commons

\section{Recommended Citation}

Socorro, Jander, "Lithological and Geochemical Responses to Abrupt Global and Regional Paleoenvironmental Changes During the Aptian in a Hemipelagic Setting of the Eastern Iberian Peninsula: A Multi-Proxy Approach" (2020). FIU Electronic Theses and Dissertations. 4425.

https://digitalcommons.fiu.edu/etd/4425

This work is brought to you for free and open access by the University Graduate School at FIU Digital Commons. It has been accepted for inclusion in FIU Electronic Theses and Dissertations by an authorized administrator of FIU Digital Commons. For more information, please contact dcc@fiu.edu. 


\section{FLORIDA INTERNATIONAL UNIVERSITY}

Miami, Florida

LITHOLOGICAL AND GEOCHEMICAL RESPONSES TO ABRUPT GLOBAL AND REGIONAL PALEOENVIRONMENTAL CHANGES DURING THE APTIAN IN A HEMIPELAGIC SETTING OF THE EASTERN IBERIAN PENINSULA: A MULTIPROXY APPROACH

A dissertation submitted in partial fulfillment of the requirements for the degree of DOCTOR OF PHILOSOPHY

in

EARTH SYSTEMS SCIENCE

by

Jander Socorro 
To: Dean Michael R. Heithaus

College of Arts, Sciences and Education

This dissertation, written by Jander Socorro, and entitled, Lithological and Geochemical Responses to Abrupt Global and Regional Paleoenvironmental Changes during the Aptian in a Hemipelagic Setting of the Eastern Iberian Peninsula: A Multi-Proxy Approach, having been approved in respect to style and intellectual content is referred to you for judgment.

We have read this dissertation and recommend that it be approved.

Laurel Collins

Rosemary Hickey-Vargas

Jose Almirall

Florentin Maurrasse, Major Professor

Date of Defense: March 18, 2020

The dissertation of Jander Socorro is approved.

Dean Michael R. Heithaus

College of Arts, Sciences and Education

Andrés G. Gil

Vice President for Research and Economic Development and Dean of the University Graduate School

Florida International University, 2020 
C Copyright 2020 by Jander Socorro

All rights reserved. 


\section{DEDICATION}

I dedicate this dissertation to my parents. This work would not have been possible without their support, understanding and encouragement. 


\section{ACKNOWLEDGMENTS}

The completion of this dissertation could not have been accomplished without the many who were involved in its development. First, I wish to acknowledge my advisor, Dr. Florentin Maurrasse, to whom I am eternally grateful. Thank you for all your assistance, scientific knowledge, financial support and most importantly, life lessons that you have taught me along the way. I have truly enjoyed working with you!

I would also like to thank the rest of my committee members, Dr. Laurel Collins, Dr. Rosemary Hickey-Vargas and Dr. Jose Almirall, for their suggestions, corrections and for allowing me to use their lab facilities. Special thanks to Diane Pirie for helping me keep the carbon analyzer up and running, and for all her help at all steps of this research. I also thank Tom Beasley for assistance with the use of the SEM and EPMA and for his help in electronic repair of our instruments. Thanks to Dr. Cesar Ramirez and Dr. Mario Gomez at the FIU's Mass Spec Facility for their help with analytical questions and instrumentation, and Dr. Sarah Jantzi at TEAF for her help with trace element analysis. I wish to thank Dr. Stephen Haggerty, my office neighbor, for his interesting conversations on lunar oddities and for always being willing to discuss carbon, in all its forms. In addition, I would like to recognize Vanessa Londoño for always being there when I needed beef patties and for staying all night running samples in the lab with me, thank you. Many thanks also, to my friends and colleagues Jose Llaguno and Carlos Herdocia for all their help in field sample collection, data analysis and their overall support of this project. I would also like to express my gratitude to Dr. Tatiana GaonaNarvaez for her willingness to share her vast scientific knowledge and for her thought 
provoking discussions of everything geology. Last, but certainly not least, thanks to all my family members for always encouraging me to do my best. 


\begin{abstract}
OF THE DISSERTATION
LITHOLOGICAL AND GEOCHEMICAL RESPONSES TO ABRUPT GLOBAL AND REGIONAL PALEOENVIRONMENTAL CHANGES DURING THE APTIAN IN A HEMIPELAGIC SETTING OF THE EASTERN IBERIAN PENINSULA: A MULTIPROXY APPROACH
\end{abstract}

by

Jander Socorro

Florida International University, 2020

Miami, Florida

Professor Florentin Maurrasse, Major Professor

Intense episodes of environmental perturbations and regionally to globally

distributed, oxygen-deprived marine facies characterize the Cretaceous sedimentary record. The Organyà Basin in the Spanish Pyrenees chronicles this period in expanded stratigraphic sequences that enabled high-resolution sampling and detailed analysis of disturbances poorly recorded in more lithologically condensed sections. Here, I present an integrated multi-proxy study aimed at understanding the Basin's response to changing paleoenvironmental conditions during the early Aptian stage of the Cretaceous.

Results from the El Pui section indicate that large-scale $(>1 \%$ ), negative carbon isotope excursions (CIEs) that show no corresponding shifts in local sources of organic matter (OM) and are simultaneously recorded at coeval localities result from the increased input of isotopically light carbon into the oceanic/atmospheric system, altering the isotopic ratio $\left(\delta^{13} \mathrm{C}\right)$ of the global carbon reservoir. The El Pujal section, in continuation with the series previously recorded at El Pui, registers a $\delta^{13} \mathrm{C}_{\text {org }}$ curve that is 
consistent with the pattern reported for carbon isotope segment $\mathrm{C} 5$ within Oceanic Anoxic Event 1a (OAE1a). Pulses of fluvial fluxes associated with climatic fluctuations explain the alternating lithology, with limestones representing the least terrestrially influenced end-member and marlstones representing episodes of highest terrigenous influence. Primary production sustained by fluvial inputs of biolimiting elements provided abundant labile OM conducive to oxygen-deprived conditions, as attested by concomitant peaks in total organic carbon (TOC), relatively lower benthic faunal counts, lower bioturbation index, higher concentration of pyrite and peaks in redox-sensitive trace elements. However, OM preservation was not chiefly controlled by redox conditions as physical encapsulation by clay minerals and coincident inputs of terrestrial OM with more recalcitrant properties likely played a significant role. A demise of previous conditions is registered in the uppermost portion with hard limestone low in TOC, and major elements and with lower ratios of autochthonous to allochthonous OM, indicating a reduction in fluvial fluxes and surface-water fertility suggesting dryer climatic conditions. Changes in microfacies, with coarser grain packstones, fewer planktonic foraminifera and an increase in benthic taxa, imply a shallowing of the basin, similar to conditions previously reported in the neighboring Basque-Cantabrian Basin at the end of segment $\mathrm{C} 5$. 


\section{TABLE OF CONTENTS}

CHAPTER

PAGE

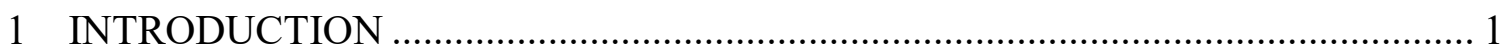

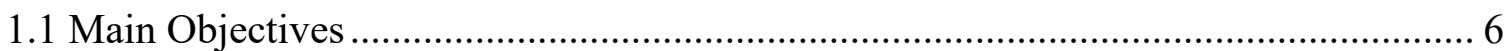

1.2 Questions and Hypotheses ................................................................................. 8

1.3 Summary of the Basis for the Proposed Approach................................................ 10

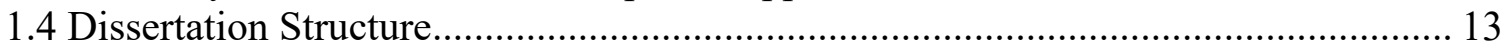

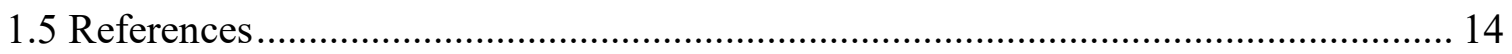

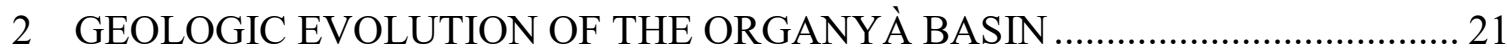

2.1 Locations and General Descriptions of the Study Sites............................................. 24

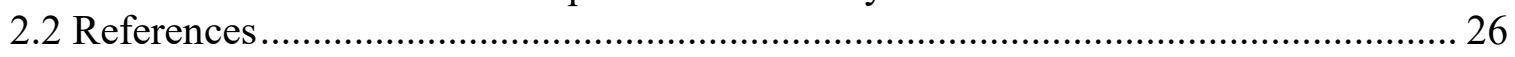

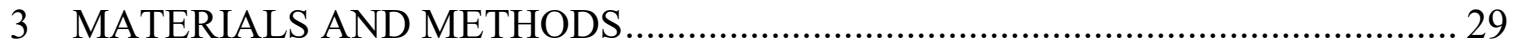

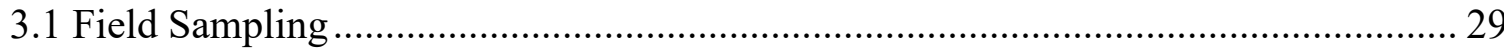

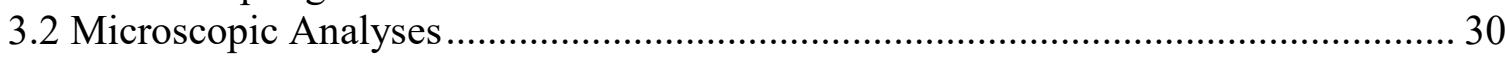

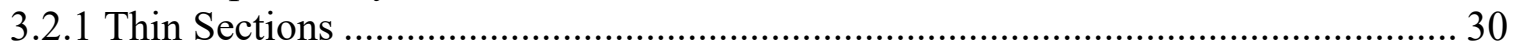

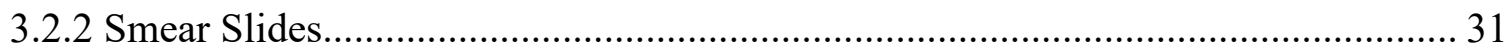

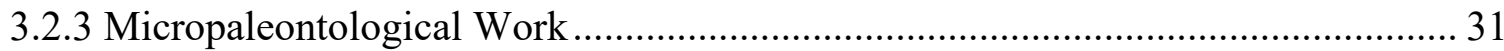

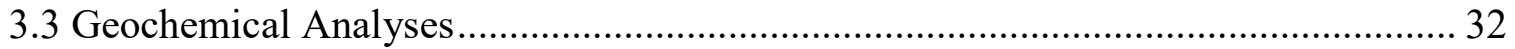

3.3.1 Sample Powdering Procedure ......................................................................... 32

3.3.2 Total Carbon/Carbonate/Organic - TC/TIC/TOC .................................................... 32

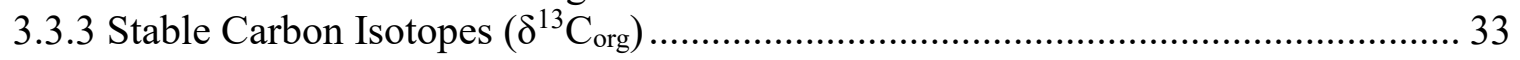

3.3.4 Major and Redox-Sensitive Trace Elements.......................................................... 34

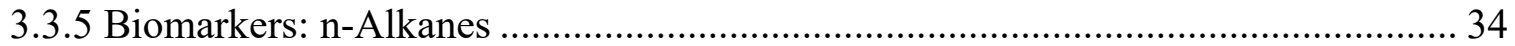

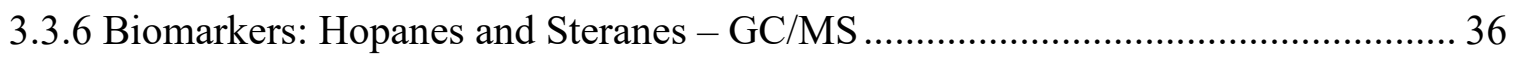

3.3.7 Biomarkers: Hopanes and Steranes - GC-MS/MS …………………………....... 37

3.3.8 Biomarkers: Polycyclic Aromatic Hydrocarbons (PAHs) ...................................... 38

3.3.9 Clay Mineral Analysis $(<2 \mu \mathrm{m}$ Fraction) ............................................................... 40

3.3.10 Bulk Mineral Analysis .................................................................................. 41

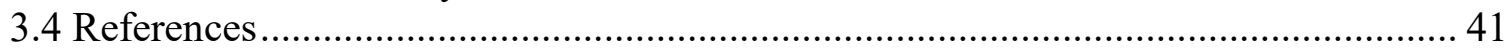

4 CHARACTERIZATION OF THE NEGATIVE CARBON ISOTOPE SHIFT IN SEGMENT C2, ITS GLOBAL IMPLICATIONS AS A HARBINGER OF

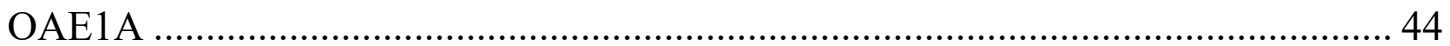

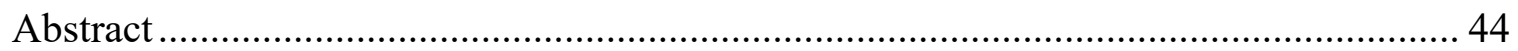

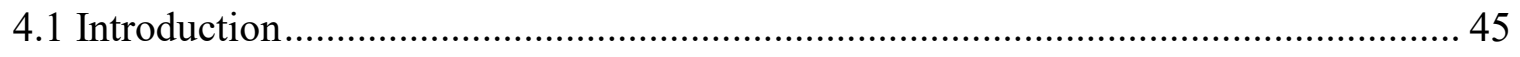

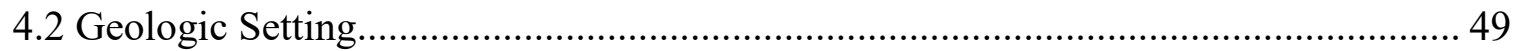

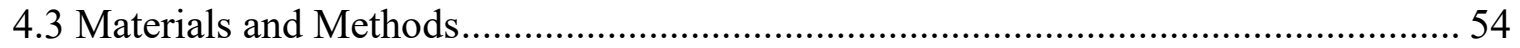

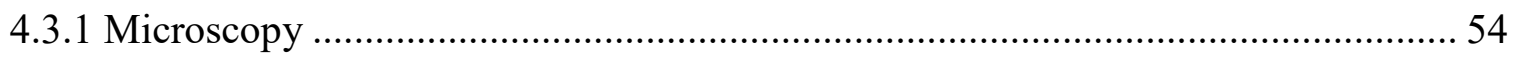

4.3.2 Total Carbon/Carbonate - TC, TIC, TOC, C-isotope............................................. 54

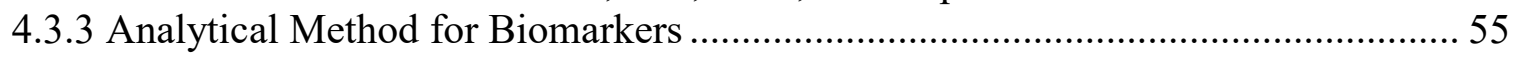

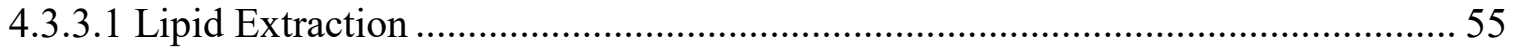




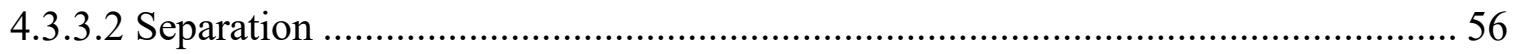

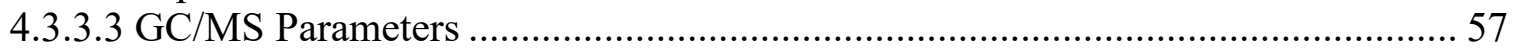

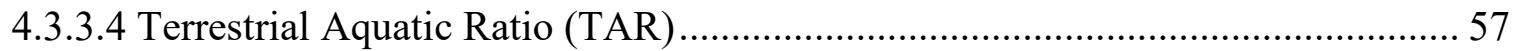

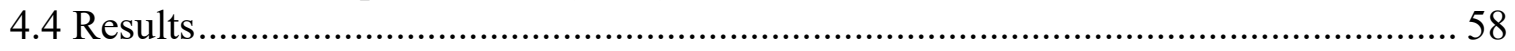

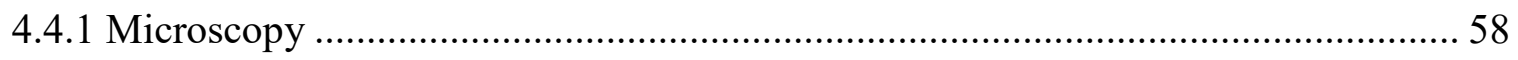

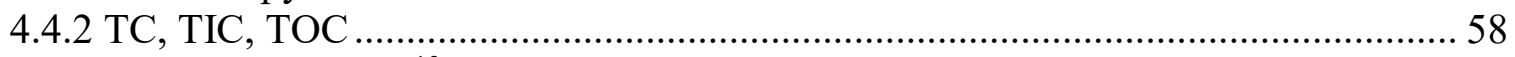

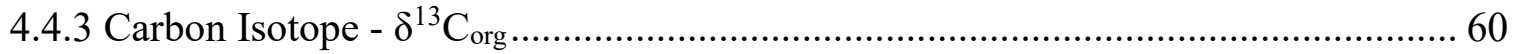

4.4.4 Comparison of the Carbon Isotope Curve at El Pui with Other Locations............... 62

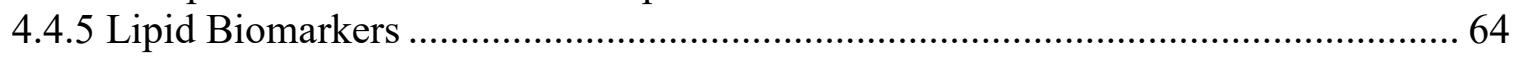

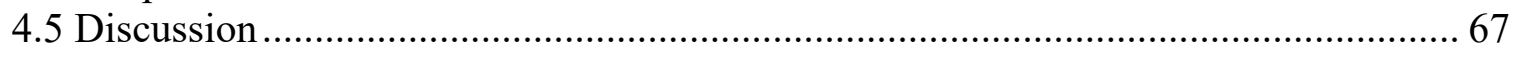

4.5.1 Significance of the n-alkane Distribution in the Intra-Segment C2 Negative

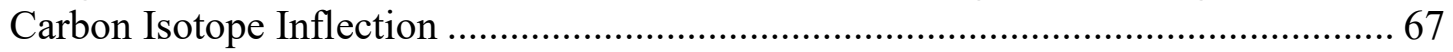

4.5.2 Possible Modulating Factors in the Intra-Segment C2 Negative Excursion............ 69

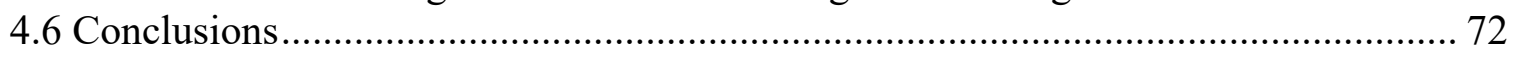

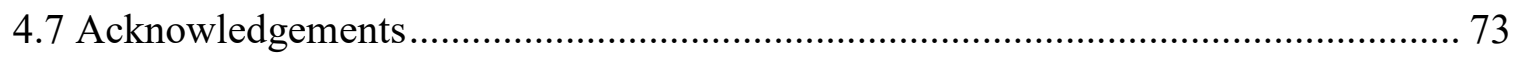

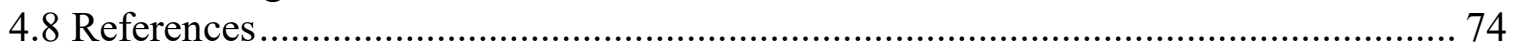

5 CONTINUOUS ACCUMULATION OF ORGANIC MATTER-RICH SEDIMENTS ASSOCIATED WITH OCEANIC ANOXIC EVENT 1A IN THE EL PUJAL SECTION, ORGANYÀ BASIN, CATALUNYÀ SPAIN AND ITS

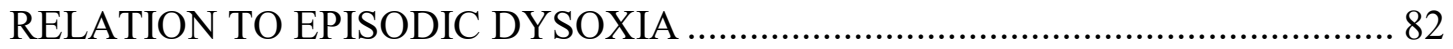

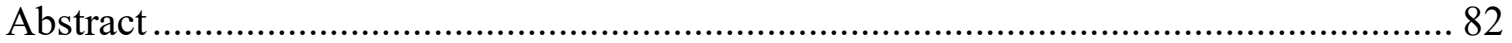

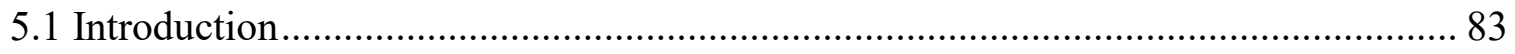

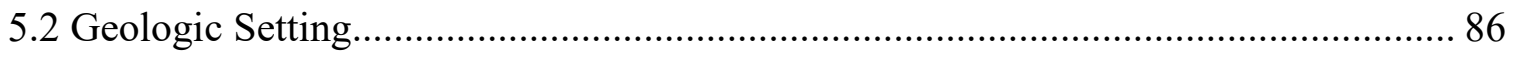

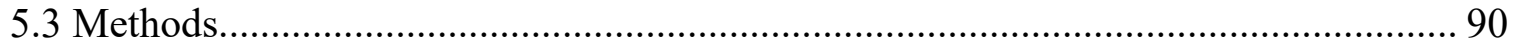

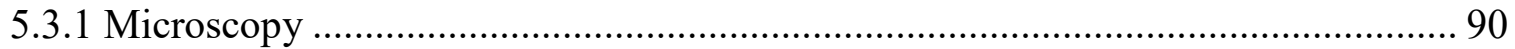

5.3.2 Total Carbon (TC), Total Inorganic Carbon (TIC) and Total Organic Carbon

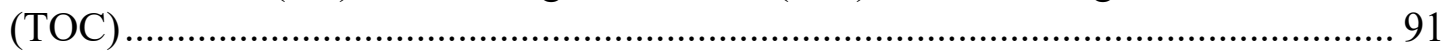

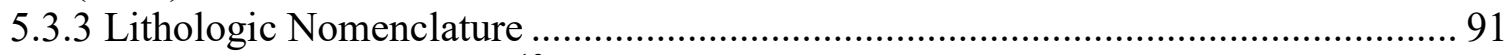

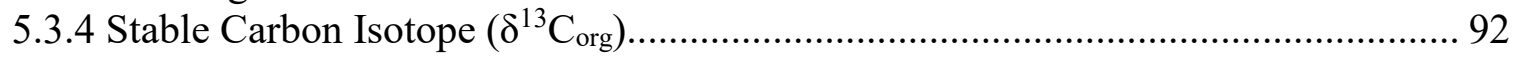

5.3.5 Major, Biolimiting and Redox Sensitive Trace Elements (RSTEs) …………........ 92

5.3.5.1 Enrichment of Redox Sensitive Trace Elements (EIs) ………………………..... 94

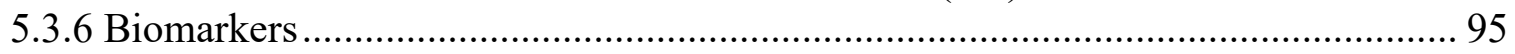

5.3.6.1 Terrestrial Aquatic Ratio (TAR) .................................................................... 96

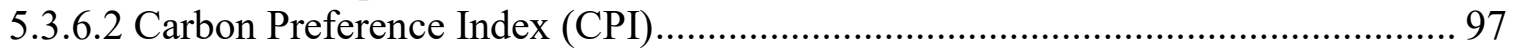

5.3.6.3 Average Chain Length of Longer n-alkanes (ACL) ………............................... 97

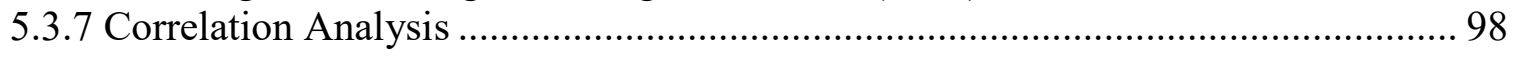

5.3.8 Principal Component Analysis (PCA) ………….............................................. 98

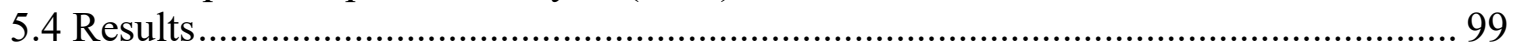

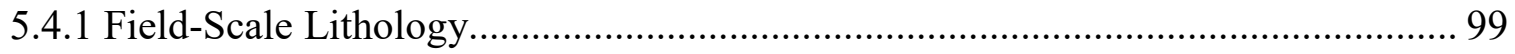

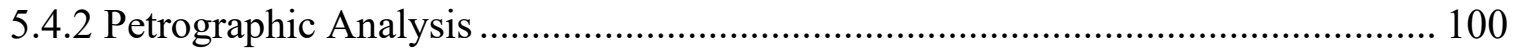

5.4.3 Carbon Geochemistry (TC, TIC, TOC, $\delta^{13} \mathrm{C}_{\text {org }}$ ) ……......................................... 103

5.4.4 Major Terrestrially Derived Elements, Biolimiting Elements, and RSTEs........... 106

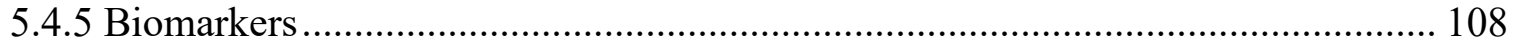

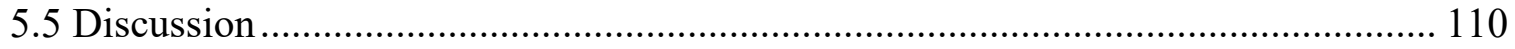


5.5.1 Stable Carbon Isotope and Biostratigraphic Correlations

5.5.2 Accumulation Rate and the Extent of the Carbon Isotope Segments in Different

Sections

5.5.3 Biomarker Interpretation: Source of Organic Matter, Thermal Maturation .......... 117

5.5.4 Evidence of Episodic Dysoxia and its Role in OM Preservation .......................... 122

5.5.5 Water Column Oxygenation ......................................................................... 125

5.5.6 Productivity and Water Column Stratification as Driving Factors in OM

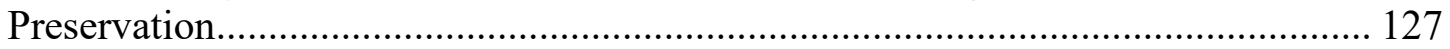

5.5.7 Principal Component Analysis and Paleoecologic Interpretation ........................ 129

5.5.8 Depositional Model of the Organyà Basin during Segment C5 of OAE1a ........... 131

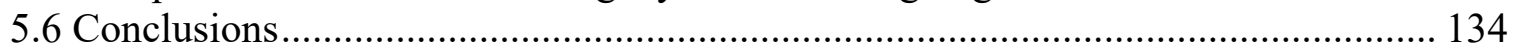

5.7 Acknowledgements.................................................................................. 135

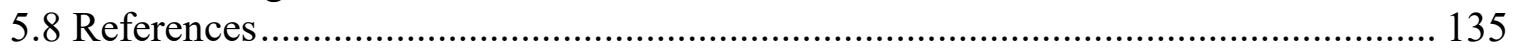

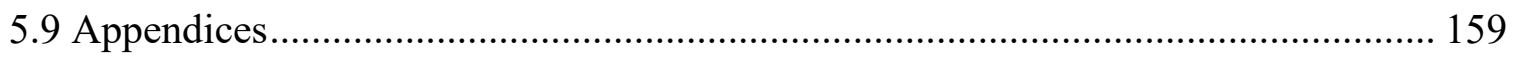

6 REGIONAL PALEOENVIRONMENTAL INFLUENCE ON OM SEQUESTRATION AND CHARACTERISTICS OF CARBON ISOTOPE SEGMENT C5 IN A HEMIPELAGIC SEQUENCE, ORGANYÀ BASIN,

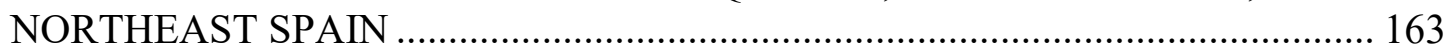

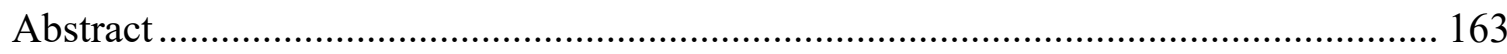

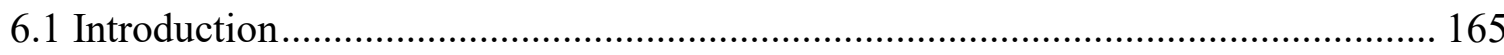

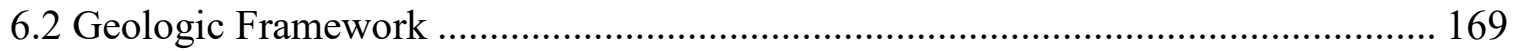

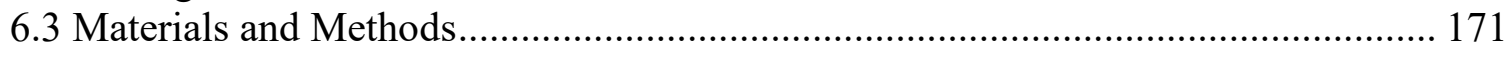

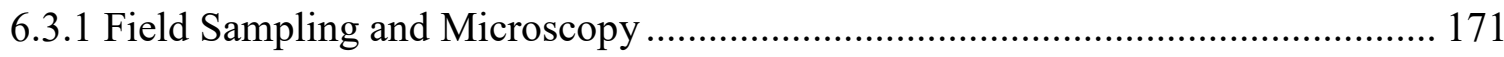

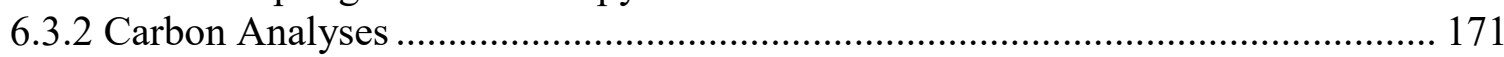

6.3.3 Major and Redox Sensitive Trace Elements (RSTEs) Analysis ............................ 173

6.3.4 Clay Mineral Analysis $(<2 \mu \mathrm{m}$ Fraction) ......................................................... 175

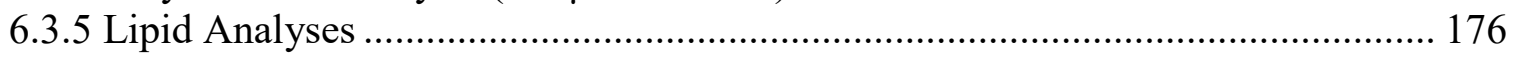

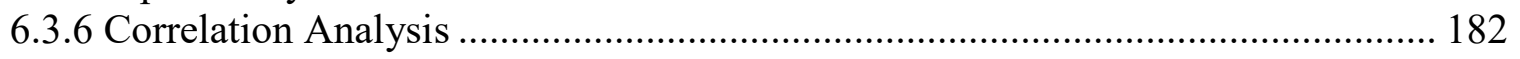

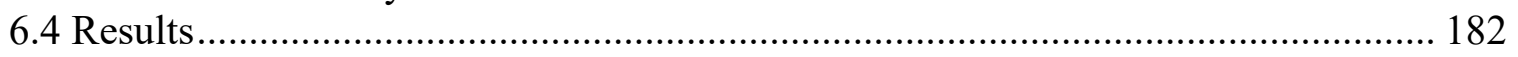

6.4.1 Lithology and Fossil Content........................................................................ 182

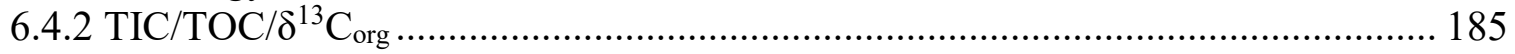

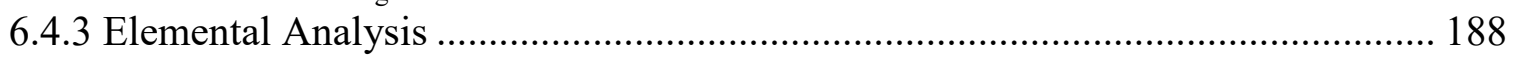

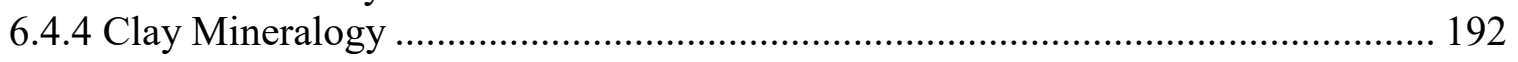

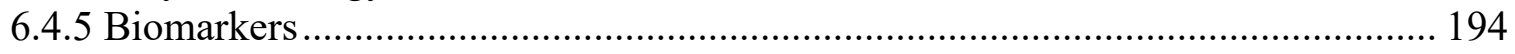

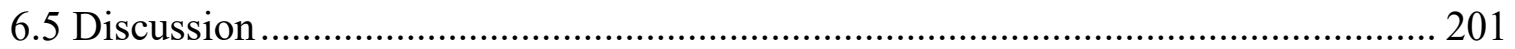

6.5.1 Biomarker Interpretations: Thermal Maturity ………………………………..... 201

6.5.2 Biomarker Interpretations: Biological Source Evaluation..................................... 205

6.5.3 Polycyclic Aromatic Hydrocarbons (PAHs) Distribution: Paleo-implications and their Potential as Geochemical Proxies.............................................................. 211

6.5.4 Significance of Small-sized Mollusks in OM-rich Layers Versus Riverine

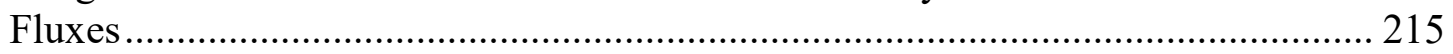

6.5.5 Factors Involved in OM Production and Preservation......................................... 217

6.5.6 Chemo/Biostratigraphic Correlation................................................................ 222

6.5.6.1 Regional Influence on the Distribution of $\delta^{13} \mathrm{C}$ values of TOC .......................... 225 


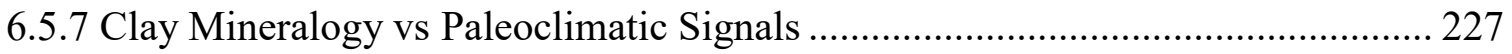

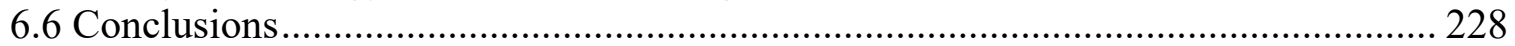

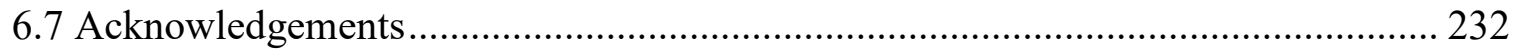

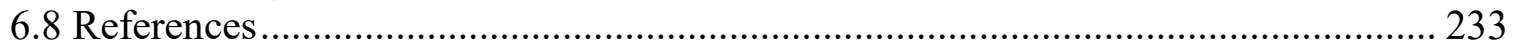

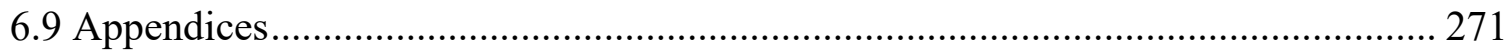

7 DEMISE OF OM-RICH FACIES AND CHANGING PALEOENVIROMENTAL CONDITIONS ASSOCIATED WITH THE END OF CARBON ISOTOPE SEGMENT C5 OF OAE1A IN THE NORTH AND NORTHEASTERN

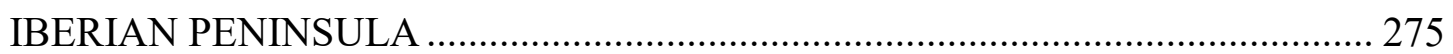

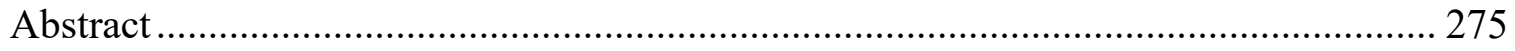

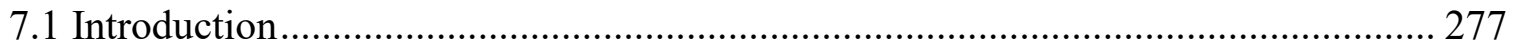

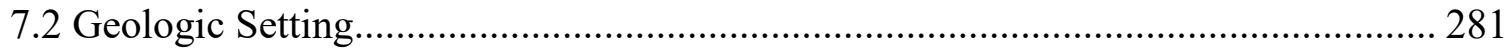

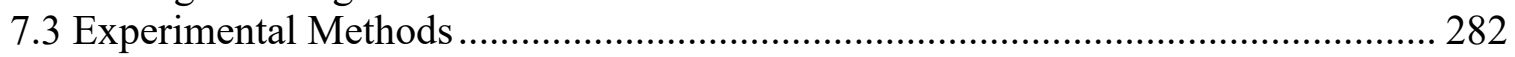

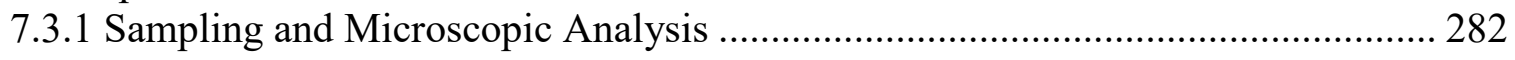

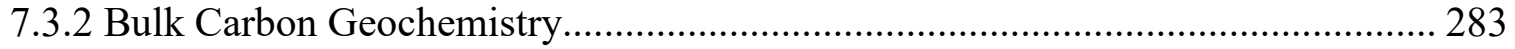

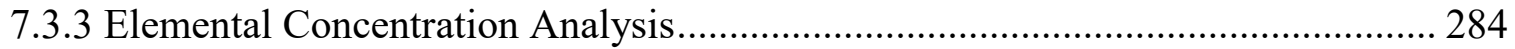

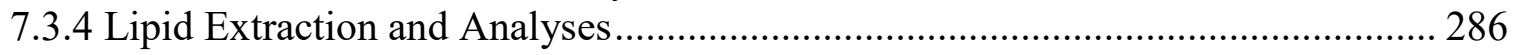

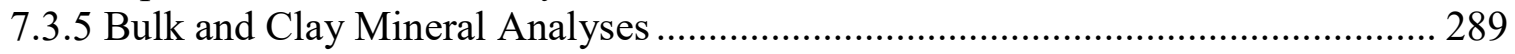

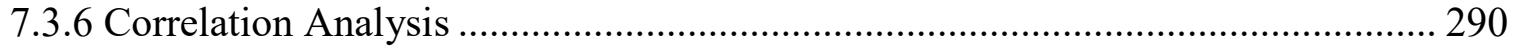

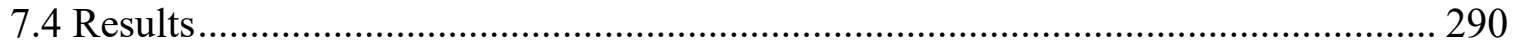

7.4.1 Field Observations and Petrographic Analysis ..................................................... 290

7.4.2 Inorganic, Organic and Carbon Isotope Stratigraphy (TIC, TOC and $\delta^{13} \mathrm{C}_{\mathrm{org}}$ )..... 294

7.4.3 Distribution Pattern of Major and Trace Elements ............................................. 296

7.4.4 Lipid Analysis Results ................................................................................... 299

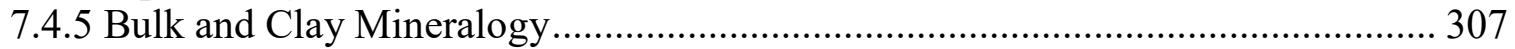

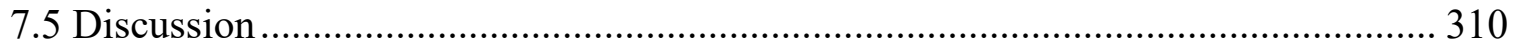

7.5.1 Paleoenviromental Conditions: Integration of Stratigraphy and Geochemistry .... 310

7.5.2 Thermal Maturity Assessment .......................................................................... 313

7.5.3 OM Sources and Temporal Variability ........................................................... 314

7.5.4 Biostratigraphy and Stable Carbon Isotope Stratigraphy....................................... 318

7.5.5 Sedimentation Rate during Carbon Isotope Segment C5 ……............................ 324

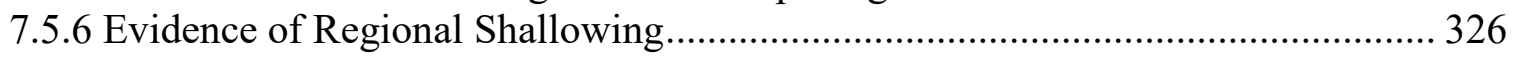

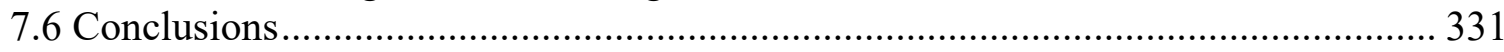

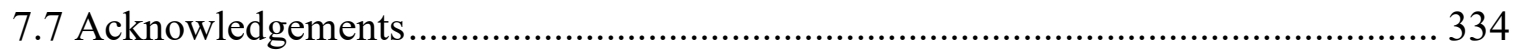

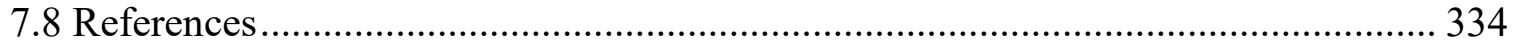

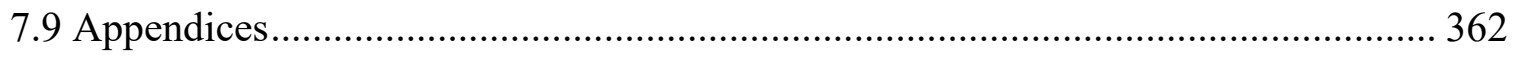

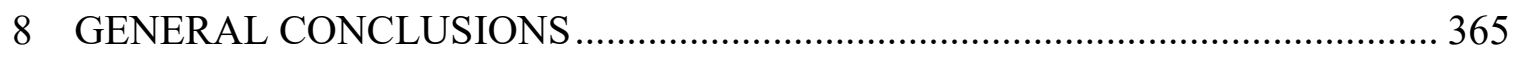

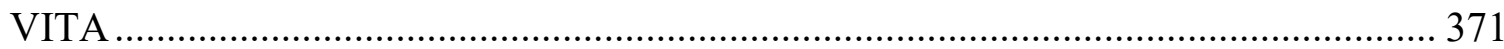




\section{LIST OF TABLES}

TABLE

PAGE

Table 4-1 TIC, TOC, $\delta^{13} \mathrm{C}_{\text {org }}$, and TAR and $\mathrm{Pr} / \mathrm{Ph}$ values in the El Pui section. The lowest value of the negative CIE occurs at a height of $77.2 \mathrm{~m}$, corresponding to sample C-11-202. Samples with asterisks belong to values measured by SanchezHernandez and Maurrasse (2014; 2016).

Table 6-1 Calculated OBABV values for various redox-sensitive elements.

Table 6-2 List of biomarker thermal maturity parameters, their corresponding sample number and stratigraphic position

Table 6-3 Various biomarker compounds. The numbers are used for compound assignment in Figure 6-10A.

Table 7-1 Identified biomarkers compounds. The numbers next to the respective compounds refers to the numbered peaks in Figure 7-10.

Table 7-2 Values of calculated biomarker thermal maturation indices. 306

Table 7-3 Bulk mineralogical composition of selected samples distributed throughout the studied interval. 


\section{LIST OF FIGURES}

FIGURE

PAGE

Figure 1-1 Paleogeographic distribution of major landmasses during the Early Cretaceous $\sim 120$ Mya. Figure from http://cpgeosystems.com/paleomaps.html. 1

Figure 1-2 The mid-Cretaceous record of major black shale deposition associated with oceanic anoxic events (OAEs) in the context of time, emplacement of LIPs, strontium isotope record, the carbon isotope record and eustatic sea level fluctuations. Notice the negative inflections that precede most of the major OAEs in relation to the timing of LIPs. Subsequent positive shifts coincide with the widespread deposition of OM-rich marine sediments. Figure from Leckie et al. (2002) and data from Bralower et al. (1997, 1999), Erbacher et al. (1996) and Haq et al. (1988).

Figure 1-3 Paleogeographic location of the Organyà Basin during the Aptian. Figure from Sanchez-Hernandez et al. (2014), modified from data by Masse et al. (1993), Mancinelli and Chiocchini (2006) and Godet et al. (2013).

Figure 1-4 A) Panoramic picture at the locality of El Pui, scale at $2 \mathrm{~m}$. B) Picture of the OM-rich hemipelagic marlstones near the hamlet of El Pujal, scale at $3 \mathrm{~m}$. Notice the parked car on the road adjacent to the easily accessible outcrop.

Figure 2-1 Plate kinematic reconstruction of Iberia (IB) relative to Europe (EU) during the Tithonian, Late Aptian and Santonian. The syn-rotational rifting of Iberia relative to Europe produced extensional faulting that generated the Organyà Basin. Figure from Jammes et al. (2009).

Figure 2-2 A) Location map of the Organyà Basin in the Iberian Peninsula. B) Regional geologic map showing the area of interest. A) and B) modified from Dinarès-Turell and García-Senz (2000). C) Detailed geologic map of the studied area showing the location of the El Pui section (Sanchez-Hernandez et al., 2014; Sanchez-Hernandez and Maurrasse, 2014, 2016) and the El Pujal section. C) Modified from Gong et al. (2009)

Figure 2-3 Generalized stratigraphic column of the Organyà Basin with geomagnetic polarity time scale (GPTS) after Gradstein et al. (2004) and lithostratigraphic units and formation thicknesses after García-Senz (2002). General figure after Gong et al. (2009).

Figure 2-4 Satellite and outcrop images of the entire El Pujal section covered in this study. Red rectangles labeled A, B, C and D correspond to the location where the outcrop photographs were taken. 
Figure 4-1 Panoramic view of El Pui section showing the approximate position of carbon isotope segments $\mathrm{C} 1, \mathrm{C} 2$ and $\mathrm{C} 3$ correlative with similar chemostratigraphic segments defined by Menegatti et al. (1998).

Figure 4-2 Carbon isotope curve comparing the intra-segment $\mathrm{C} 2$ negative excursion of four different locations. A-Djebel Serdj, Tunisia: Modified from (Heldt et al., 2008). B-Comanche Platform, USA: Modified from Phelps et al. (2015). C-Santa Rosa Canyon, Mexico: Modified from Li et al. (2008). D-El Pui, Spain: Modified from Sanchez-Hernandez and Maurrasse (2016)...

Figure 4-3 Lithostratigraphy and carbon chemostratigraphy of the El Pui section. ASimplified chronostratigraphic column. B-Vertical variation in TOC. C-Vertical variation in TIC. D-Vertical variation in $\delta 13$ Corg including the characteristic intra-segment $\mathrm{C} 2$ negative excursion denoted with a red arrow

Figure 4-4 Lithology and microfacies of selected samples prior to the lowest value of the intra-segment C2 negative excursion (blue), at the lowest value (red) and after (green). Refer to the legend for a detailed description of each symbol.

Figure 4-5A A-Trochospiral benthic foram (scale-100 $\mu \mathrm{m}$ ). B-Planispiral evolute benthic foram infilled with framboidal pyrite (scale-100 $\mu \mathrm{m})$. C-Roveacrinid

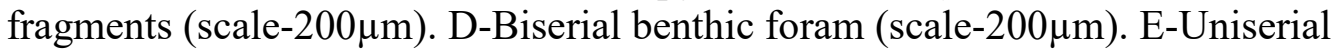

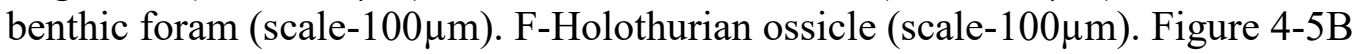
$\mathrm{K} / \mathrm{L} / \mathrm{M} / \mathrm{N}-\mathrm{Abundance}$ of calcareous nannoplankton plates and fragments in smearslide (scale-50 $\mu \mathrm{m})$ and in SEM micrograph. A- Rare ammonite (cm scale). G-

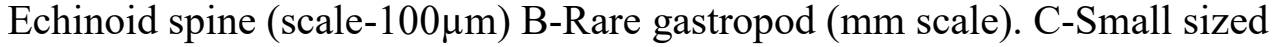

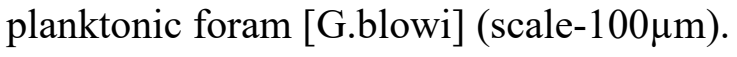

Figure 4-6 Summary of organic geochemistry results and their respective stratigraphic locations along the $\delta 13$ Corg curve. A-Stratigraphic Height vs TAR. B-N-alkane results for selected samples. C-Stratigraphic Height vs $\mathrm{Pr} / \mathrm{Ph}$. Colors (blue, red, green) refers to the duration before, during and after the lowest value reached within the intra-segment $\mathrm{C} 2$ negative excursion respectively.

Figure 5-1 Detailed geologic map of the study area modified after Gong et al. (2009). Red hexagons show the relative location of the El Pui Section (SanchezHernandez et al., 2014; Sanchez-Hernandez and Maurrasse, 2014; 2016) and the El Pujal Section (this study).

Figure 5-2 Stratigraphic column of the Organyà Basin showing the span of the El Pui Section (Sanchez-Hernandez et al., 2014; Sanchez-Hernandez and Maurrasse, $2014 ; 2016)$ and the El Pujal Section (this study) with geomagnetic polarity time scale (GPTS) after Gradstein et al. (2004) and lithostratigraphic units and formation thicknesses after García-Senz (2002). General figure after Gong et al. (2009). 
Figure 5-3 Paleogeographic map of the early Aptian with the location of the Organyà Basin marked with a red star. Figure modified after Masse et al. (2000).

Figure 5-4 Photograph of the top part of the $13.77 \mathrm{~m}$ outcrop showing the differentially weathered beds correlated with the simplified lithostratigraphic column.....

Figure 5-5 (A) Simplified lithostratigraphic column showing the position of various index planktonic foraminifera, Leupoldina cabri - $50 \mu \mathrm{m}$, Globigerinelloides

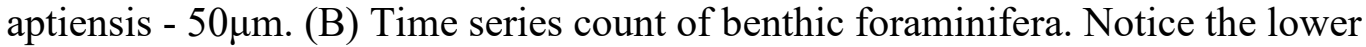
benthic foraminifera $\rho$ during argillaceous limestone and marlstone intervals. (C)

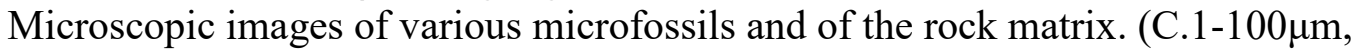
$2-50 \mu \mathrm{m}, 3-100 \mu \mathrm{m})$ Various echinoid fragments in a micritic matrix. (C.4-100 $\mu \mathrm{m}$, $19-200 \mu \mathrm{m}, 20-100 \mu \mathrm{m})$ Petrographic and SEM images of various small-sized

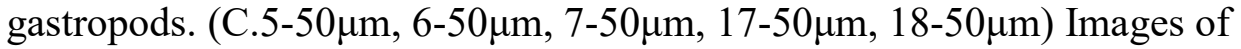
different pyritized planktonic foraminifera (undetermined species). (C.8-50 $\mu \mathrm{m})$ Image of a well preserved calcisphere in a micritic matrix. (C.9-50 $\mu \mathrm{m}, 13-200 \mu \mathrm{m})$ Pyritized example of small-sized bivalve specimens found along the argillaceous limestone and marlstone intervals. (C. $10-50 \mu \mathrm{m}, 11-50 \mu \mathrm{m}, 12-50 \mu \mathrm{m}, 14-50 \mu \mathrm{m}$, $15-100 \mu \mathrm{m}, 16-100 \mu \mathrm{m})$ Images of benthic foraminifera displaying various

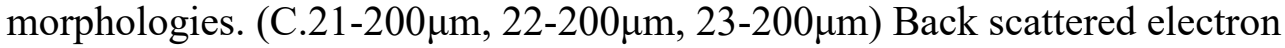
(BSE) images of the matrix from a representative limestone (21), argillaceous limestone (22) and marlstone (23) sample. Notice the increase in pyrite concentration (lighter colored objects) from the limestone sample to the

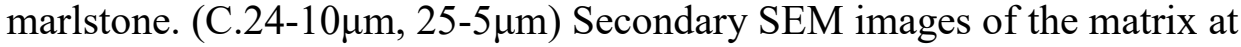
different magnifications. Notice the abundance of coccolith plates and fragments throughout.

Figure 5-6 Stratigraphic correlation of carbon geochemistry data $\left(\delta^{13} \mathrm{C}_{\text {org }}\right.$, TIC, TOC), major terrestrially derived elements $(\mathrm{Si}, \mathrm{Al}, \mathrm{Ti})$ and biolimiting elements $(\mathrm{Fe}, \mathrm{P})$ with lithology. Red dashed line corresponds to the average value of the individual variable. Gray bars correspond to areas depleted in TIC and enriched in TOC, Si, $\mathrm{Al}, \mathrm{Ti}, \mathrm{Fe}$ and $\mathrm{P}$. Elemental concentrations are reported as absolute values in parts per thousand (ppt).

Figure 5-7 Stratigraphic variation in RSTEs, RSTEs EI, $\sum$ RSTEs EI and Th/U correlated with lithology. Red dashed line corresponds to the average value of the individual variable. Gray bars indicate areas enriched in RSTEs. Elemental concentrations are reported as absolute values in parts per million (ppm). 107

Figure 5-8 Stratigraphic position and n-alkanes distribution of 12 of the 42 samples analyzed for biomarkers. Black colored bar graphs represent the $n$-alkanes distribution of samples along intervals enriched in TOC (argillaceous limestone 
and marlstone layers) and the green colored bar graphs represent intervals depleted in TOC (limestone layers).

Figure 5-9 (A-B-C-D) Stratigraphic correlation between lithology and various organic geochemical parameters. Gray bars correspond with intervals of argillaceous limestone and marlstone deposition. (E) Log-log cross-plot of $\mathrm{Pr} / \mathrm{nC} 17$ vs $\mathrm{Ph} / \mathrm{nC} 18$ for all 42 analyzed samples. Notice that in general the samples plot within the mixed type II/III kerogen with only a few plotting below in the marine type II kerogen zone

Figure 5-10 Chemostratigraphic correlation based on $\delta 13$ Corg of the El Pujal section with other Tethyan sections. The $\mathrm{C}$ segments correspond to the $\delta^{13} \mathrm{C}$ subdivisions proposed by Menegatti et al. (1998). Area shaded in gray corresponds to the interval covering OAE1a in each respective section. (E) Plot of El Pui and El Pujal with identical vertical and horizontal scales. The yellow star marks the highest value within segment $\mathrm{C} 5$ and corresponds to equivalent points in each section. The purple dashed line shows the interval corresponding to segment C5... 112

Figure 5-11 Results from PCA based on 17 combined variables. Notice how the samples separate into distinct lithologic groups.

Figure 5-12 Simplified depositional model proposed for each of the different lithology present at El Pujal. The size of the arrows represent the relative magnitude of each variable.

Figure 6-1 A) Location map of the Organyà Basin in the Iberian Peninsula. B) Regional geologic map showing the area of interest. A) and B) modified from Dinarès-Turell and García-Senz, 2000). C) Detailed geologic map of the studied area showing the location of the El Pui Section (Sanchez-Hernandez et al., 2014; Sanchez-Hernandez and Maurrasse, 2014, 2016) and the El Pujal Section (Socorro and Maurrasse, 2019; and this study). C) Modified from Gong et al. (2009). D) Satellite image showing the portion of the El Pujal Section studied thus far. Basal portion refers to a previous study by Socorro and Maurrasse (2019). D) Modified from Google Earth Map Data 2018. E) Photograph of the outcrop showing the expanded sequence of hemipelagic sediments exposed as differentially weathered packets. 168

Figure 6-2 I) Simplified lithostratigraphic column depicting the distribution of various lithologies in this $70.75 \mathrm{~m}$-interval covering from $14.29 \mathrm{~m}$ to $85.04 \mathrm{~m}$ of the El Pujal section. Points marked with an X represent intervals where Leupoldina Cabri specimens are present. II-III) Time series counts of benthic foraminifera and echinoid fragments. IV) Bioturbation index following the proposed scheme in Taylor and Goldring (1993). Greenish bands correspond to argillaceous limestone and marlstone intervals. A-S) Thin section images of common microfossils and fragments as well as the rock matrix found throughout this study, scale at $200 \mu \mathrm{m}$. 
A-F) Images of representative Leupoldina cabri from El Pujal. G) Image of a planktonic foraminfera with chambers partly infilled with pyrite. $\mathrm{H}$ ) Image of an echinoid spine cut perpendicular to axis. I-J) Images of a large echinoid fragment and spine. K) Image of an ostracod valve. L) Image of a benthic foraminifera with pyritized chambers. M) Images of roveacrinid fragments found throughout this interval. N) Image of an Ammodiscus benthic foraminifera. O-Q) Images of minute gastropods and bivalve generally found in marlsone layers. R) Image of a representative limestone sample, with high bioturbation $(\mathrm{BI}=6)$. S) Image of a representative marlsone sample with low bioturbation $(\mathrm{BI}=3)$ and abundant pyrite.

Figure 6-3 A-D) Stratigraphic variation of carbon geochemical data compared with lithology. Vertical red dashed line represents the average value of the respective variable. Greenish bands correspond to argillaceous limestone and marlstone intervals. E) Relative proportion of terrestrial organic matter derived from a simplified two end-member mixing model utilizing carbon isotope data (refer to discussion).

Figure 6-4 A-F) Vertical plots of major elements (Si, Al, Ti) and biolimiting elements (Fe, P) compared with lithology. Values in parts per thousand (ppm·10-3). Vertical red dashed line represents the respective element's average value. Greenish bands correspond to argillaceous limestone and marlstone intervals

Figure 6-5 A-H) Vertical plots of RSTEs reported as absolute values in parts per million (ppm). I) Vertical plot of RSTEs enrichment indices (EI RSTEs) relative to the Organyà Basin's Average Background Value (OBABV) (for a detailed description refer to the methodology section).

Figure 6-6 Temporal variation in clay mineral content ( $<2 \mu \mathrm{m}$ fraction). Selected samples were taken as representative of the various lithologies

Figure 6-7 I-V) Plots of analyzed PAHs compared with lithology and TOC. VI) Coloration of total lipid extract compared with lithology (I) and TOC (II). Letters A-H next to the TOC curve (II) correspond to letters under images in VI showing images taken under ambient light and both, short wave and long wave UV light. Notice the intensity in lipid coloration varies with lithology and TOC content, with darker yellow extracts in argillaceous limestone and marlstone/higher TOC intervals and lighter yellow extracts in limestone/lower TOC intervals.

Figure 6-8 A-D) Comparison between lithology and various organic geochemical proxies. E) Representative total ion chromatograms of the aliphatic fraction from the three lithologies. The large peaks in the chromatograms are mainly a homologous series of n-alkanes. Labeled peaks refer to $n$-alkane's carbon chain length for reference purposes. Peaks labeled as Pr and Ph refer to pristane and phytane, respectively. 
Figure 6-9 A) Cross plot of Pristane/n-C17 vs. Phytane/n-C18 of selected samples. Fields after Shanmugam (1985) from concepts proposed by Lijmbach (1975). B) Ternary diagram showing the sterane composition of selected samples and their relationship with source. Fields after Shanmugam (1985) from concepts proposed by Huang and Meinschein (1979).

Figure 6-10 A) Trace chromatograms of a representative sample showing the relative distribution of hopanes (m/z 191), steranes (m/z 217 and 218) and diasteranes $(\mathrm{m} / \mathrm{z} 259)$. For peak identification, refer to Table 6-3. B-1-3) Total ion chromatograms of the aromatic fraction from representative samples of marlstone (C-16-138), limestone (C-16-120) and argillaceous limestone sample (C-16-47) showing the relative abundance of perylene.

Figure 6-11 Plot of $\mathrm{C} 2920 \mathrm{~S} /(20 \mathrm{~S}+20 \mathrm{R})$ vs $\mathrm{C} 29 \beta \beta /(\beta \beta+\alpha \alpha)$ thermal maturity indicator values for selected samples. Dashed lines indicate equilibrium values..... 205

Figure 6-12 A-E) Chemostratigraphic correlation based on $\delta^{13} \mathrm{C}_{\text {org }}$ of the El Pujal section (Socorro and Maurrasse (2019) and this study) with La Frontera (Aguado et al., 2014a,b), Roter Sattel (Menegatti et al., 1998), Cismon (Menegatti et al., 1998) and El Pui (Sanchez-Hernandez and Maurrasse, 2016). The C segments correspond to the subdivisions proposed by Menegatti et al. (1998). The yellow star marks the highest value within segment C5 and corresponds to equivalent points in each section. The gray band indicates the position of OAE1a or its equivalent for each section. F) Plot of El Pui and El Pujal $\delta^{13} \mathrm{C}_{\text {org }}$ data with identical vertical and horizontal scales. For a detailed description of labeled subsegments $\mathrm{C} 5$-a through $\mathrm{C} 5$-f refer to the discussion section.

Figure 7-1 A) Location map of the Organyà Basin in the Iberian Peninsula. B) Regional geologic map showing the area of interest. A) and B) Modified from Dinarès-Turell and García-Senz, 2000). C) Detailed geologic map of the studied area showing the location of the El Pui Section (Sanchez-Hernandez et al., 2014; Sanchez-Hernandez and Maurrasse, 2014, 2016) and the El Pujal Section (Socorro and Maurrasse, 2019a,b); and this study). C) Modified from Gong et al. (2009). D) Satellite image showing the portion of the El Pujal Section studied thus far (Basal Portion - Socorro and Maurrasse, 2019a; Middle Portion - Socorro and Maurrasse, 2019b; Uppermost Portion - This study). D) Modified from Google Earth Map Data 2018. E). Photograph of the uppermost portion of the outcrop showing remarkably hard, closely spaced grayish orange (10 YR 7/4) beds, intercalated by medium light gray (N6) beds, with an enduring hard nature. F) Photograph of a portion of the outcrop showing a large expanse of dark gray to medium dark gray (N3 to N4), marly beds. 280

Figure 7-2 A) Simplified lithostratigraphic column depicting the distribution of various lithologies present in this studied interval. Units 1-3 refer to various 
lithostratigraphic units demarcated based on their respective lithological pattern. B) Outcrop photographs representative of each Unit, scale at $2 \mathrm{~m}$. C). Thin section images representative of each Unit, scale at $200 \mu \mathrm{m}$.

Figure 7-3 A) and B) Time series counts of benthic foraminifera and echinoid fragments. C) Bioturbation index for each sample following the proposed scheme in Taylor and Goldring (1993). A-C) Bluish bands correspond to argillaceous limestone and marlstone intervals. D) Limestone interval counts of the ratio between planktonic and benthic foraminifera. The ratio is expressed as the percentage of planktonic foraminifera or $\% \mathrm{P}$ calculated as $100 * \mathrm{P} /(\mathrm{P}+\mathrm{B})$, where $\mathrm{P}$ is the number of planktonic individuals and $\mathrm{B}$ is the number of benthic individuals. E) Calculated paleodepths based on the relationship between bathymetry and \%P as proposed by van der Zwaan et al. (1990). Solid red lines represent the average depth value.

Figure 7-4 A-C) Stratigraphic variation of carbon geochemical data including total inorganic carbon (TIC), total organic carbon (TOC) and stable carbon isotope $\left.\left(\delta^{13} \mathrm{C}_{\text {org }}\right) . \mathrm{A}\right)$ and B) Vertical red dashed lines represent the average TIC and TOC values for this interval. A-C) Bluish bands correspond to argillaceous limestone and marlstone intervals.

Figure 7-5 A-E) Vertical plots of major elements compared with lithology. All values are expressed in parts per thousand (ppm·10-3). Vertical red dashed lines represent the respective element's average value. A-E) Bluish bands correspond to argillaceous limestone and marlstone intervals.

Figure 7-6 A-G) Vertical plots of redox-sensitive trace elements (RSTEs) reported as absolute values in parts per million (ppm). H) Vertical plot of RSTEs enrichment indices (EI RSTEs) relative to the Organyà Basin's Average Background Value (OBABV) from Socorro and Maurrasse (2019b). I) Vertical plot of the addition of all the EIs of each element for each sample. A-I) Bluish bands correspond to argillaceous limestone and marlstone intervals.

Figure 7-7 Representative total ion chromatograms of the aliphatic fraction from three samples. Labeled peaks refer to $n$-alkane's carbon chain length. Peaks labeled as $\mathrm{Pr}$ and $\mathrm{Ph}$ refer to pristane and phytane, respectively.

Figure 7-8 A) Vertical plot of the relative proportion of terrestrial to aquatic organic matter (i.e. TAR). B) Vertical plot of the relative proportion of C30 Gammacerane to C30 17 $\alpha, 21 \beta(\mathrm{H})$ hopane (i.e. Gammacerane Index). C) Vertical plot of the relative proportion of $\mathrm{C} 275 \alpha, 14 \alpha, 17 \alpha(\mathrm{H})$ sterane $(20 \mathrm{R})$ to $\mathrm{C} 29$ $5 \alpha, 14 \alpha, 17 \alpha(\mathrm{H})$ sterane (20R) (i.e. C27/C29). A-C) Bluish bands correspond to argillaceous limestone and marlstone intervals. 
Figure 7-9 Log-log cross plot of Pristane/n-C17 vs. Phytane/n-C18 values of selected samples. Kerogen type fields after Shanmugam (1985) from concepts proposed by Lijmbach (1975)

Figure 7-10 MRM transition profiles from a representative sample showing the distribution of various hopanes, steranes and diasteranes. Refer to Table 7-1 for peak identification.

Figure 7-11 Ternary diagram showing the sterane composition of selected samples and their relationship with source input. Fields after Shanmugam (1985) from concepts proposed by Huang and Meinschein (1979).

Figure 7-12 Pie diagrams of average bulk and clay mineralogy for Units 1-3. For a comprehensive bulk mineralogical composition of the analyzed samples, refer to Table 7-3.

Figure 7-13 Temporal variation of clay mineral content compared with lithology 309

Figure 7-14 A-E) Chemostratigraphic correlation based on $\delta^{13} \mathrm{C}_{\text {org }}$ of the El Pujal section with other sections: La Frontera (Aguado et al., 2014a,b), Roter Sattel (Menegatti et al., 1998), Cismon (Menegatti et al., 1998) and El Pui (SanchezHernandez and Maurrasse, 2016). The $\mathrm{C}$ segments correspond to the subdivisions proposed by Menegatti et al. (1998). The yellow star marks the highest value within segment $\mathrm{C} 5$ and corresponds to equivalent points in each section. The gray band indicates the position of OAE1a or its equivalent for each section. F) Plot of El Pui and El Pujal $\delta^{13} \mathrm{C}_{\text {org }}$ data with identical vertical and horizontal scales. For a detailed description of labeled subsegments C5-a through C5-g refer to the discussion section

Figure 7-15 Comparison of the lithostragraphic changes recorded for the end of carbon isotope segment $\mathrm{C} 5$ at El Pujal and various sections in the Basque Cantabrian Basin: Cuchía (García-Mondéjar et al., 2015), Igaratza (Millán et al., 2011), Madotz (Gaona-Narvaez et al., 2013). 


\section{ABBREVIATIONS AND ACRONYMS}

$\%$

$\sum$ EIs

o

${ }^{\circ} \mathrm{C}$

$\mu \mathrm{L}$

$\mu \mathrm{m}$

$\%$

ACL

$\mathrm{Al}$

ASV

$\mathrm{Au}$

BI

BOD

$\mathrm{CaCO}_{3}$

CIE

$\mathrm{cm}$

$\mathrm{cm} / \mathrm{kyr}$

$\mathrm{cm}^{2}$

Co

$\mathrm{CO}_{2}$

CPI

$\mathrm{Cr}$
Percent

Sum of enrichment indices

Degrees

Degrees Celsius

Microliter

Micrometers

Per mille

Average chain length

Aluminum

Average Shale Value

Gold

Bioturbation index

Biological oxygen demand

Calcium carbonate

Carbon isotope excursion

Centimeters

Centimeters per thousand years

Centimeters squared

Cobalt

Carbon dioxide

Carbon preference index

Chromium 


\begin{tabular}{ll} 
Cu & Copper \\
DCM & Dichloromethane \\
DI & Deionized water \\
DIP & Dissolved inorganic phosphate \\
DOP & Dissolved organic phosphate \\
EA-IRMS & Elemental analyzer isotope ratio mass spectrometer \\
ECS & East China Sea \\
EI + & Positive mode electron impact ionization \\
EIs & Enrichment indices \\
GC-MS & Gas chromatography mass spectrometry \\
GC-MS/MS & Gas chromatography tandem mass spectrometry \\
HCl & Hydrochloric acid \\
hrs & Hours \\
ICVS & Minutes \\
K-feldspar & Initial calibration verification standard \\
km & Potassium feldspar \\
Kyr & Kilometers \\
LA-ICP-MS & Thousand years \\
LIPs & Laser ablation-inductively coupled plasma mass spectrometry \\
meOH & Methanol \\
\hline
\end{tabular}




\begin{tabular}{|c|c|}
\hline $\mathrm{mm}$ & Millimeter \\
\hline Mo & Molybdenum \\
\hline MRM & Multiple reaction monitoring \\
\hline $\mathrm{ms}$ & Millisecond \\
\hline Mya & Millions of years ago \\
\hline Myr & Million years \\
\hline$n$-alkanes & Normal alkanes \\
\hline NASC & North American Shale Composite \\
\hline $\mathrm{ng} / \mu \mathrm{L}$ & Nano-grams per microliters \\
\hline$n g / g d w$ & Nano-grams per gram of dry weight \\
\hline $\mathrm{Ni}$ & Nickel \\
\hline NIST & National Institute of Standards and Technology \\
\hline OAE & Oceanic Anoxic Event \\
\hline OAE1a & Oceanic Anoxic Event 1a \\
\hline OAE1b & Oceanic Anoxic Event 1b \\
\hline OAE1c & Oceanic Anoxic Event 1c \\
\hline OAE1d & Oceanic Anoxic Event 1d \\
\hline OAE2 & Oceanic Anoxic Event 2 \\
\hline OAE3 & Oceanic Anoxic Event 3 \\
\hline OBABV & Organyà Basin's average background value \\
\hline OEP & Odd to even preference \\
\hline OJP & Ontong Java Plateau \\
\hline OM & Organic matter \\
\hline
\end{tabular}




\begin{tabular}{|c|c|}
\hline OMZ & Oxygen minimum zone \\
\hline PAAS & Post Archean Australian Shale \\
\hline PAH & Polycyclic aromatic hydrocarbons \\
\hline PCA & Principal Component analysis \\
\hline PETM & Paleocene-Eocene thermal maximum \\
\hline P-feldspar & Plagioclase feldspar \\
\hline $\mathrm{pH}$ & Negative log of the hydrogen ion concentration \\
\hline $\mathrm{Ph}$ & Phytane \\
\hline ppm & Parts per million \\
\hline ppt and ppm* $* 10^{-3}$ & Parts per thousand \\
\hline $\operatorname{Pr}$ & Pristane \\
\hline rpm & Revolutions per minute \\
\hline RSTEs & Redox sensitive trace elements \\
\hline SB-V & Songliao Basin \\
\hline SEM & Scanning electron microscope \\
\hline $\mathrm{Si}$ & Silicon \\
\hline SIM & Selective ion monitoring \\
\hline SPCU & South Pyrenean Central Unit \\
\hline SSTs & Sea surface temperatures \\
\hline TAR & Terrestrial aquatic ratio \\
\hline $\mathrm{TC}$ & Total carbon \\
\hline $\mathrm{TEX}_{86}$ & Tetraether index of 86 carbon atoms \\
\hline Th & Thorium \\
\hline
\end{tabular}


$\mathrm{Ti}$

TIC

TLE

$\mathrm{Tm}$

TOC

Ts

U

UCM

V

VPDB

$w t^{0} \%$

XRD

$\delta^{13} \mathrm{C}_{\text {carb }}$

$\delta^{13} \mathrm{C}_{\text {org }}$
Titanium

Total inorganic carbon

Total lipid extract

17a-22,29,30-trisnorhopane

Total organic carbon

18 $\alpha$-22,29,30-trisnorneohopane

Uranium

Unresolved complex mixture

Vanadium

Vienna-Pee Dee Belemnite

Weight percent

X-ray diffraction

Stable carbon isotopic signature - carbonate fraction

Stable carbon isotopic signature - organic fraction 


\section{INTRODUCTION}

The Earth experienced some of the warmest temperatures during the Cretaceous Period. As the greenhouse condition reached its peak during the Cenomanian/Turonian Cretaceous Thermal Maximum, paleo-sea surface temperature (SST) records extracted from planktonic foraminifera $\left(\delta^{18} \mathrm{O}\right)$ and organic biomarkers $\left(\mathrm{TEX}_{86}\right)$ show that temperatures in the equatorial Atlantic Ocean were substantially warmer than in the present $\left(\sim 27-29^{\circ} \mathrm{C}\right)$, with average values exceeding $35^{\circ} \mathrm{C}$ (Forster et al., 2007; O'Brien et al., 2017). The unusually warm global climatic conditions coupled with a shifting paleogeography (Fig. 1-1) are reported to have led to reduced latitudinal temperature gradients, accelerated hydrological cycles, intensified continental weathering and runoff, and fluctuations in eustatic sea level. (Barron, 1983; Haq et al., 1987; Barron et al., 1989; Frakes et al., 1992; Huber et al., 1995, 2018; Tarduno et al., 1998; Weissert et al., 1998; Blättler et al., 2011; Föllmi, 2012; Jenkyns et al., 2012; Haq, 2014; Mutterlose et al., 2014; Lechler, 2015; O'Brien et al., 2017; Charbonnier et al., 2018). These extreme greenhouse conditions have been attributed to elevated concentrations of atmospheric

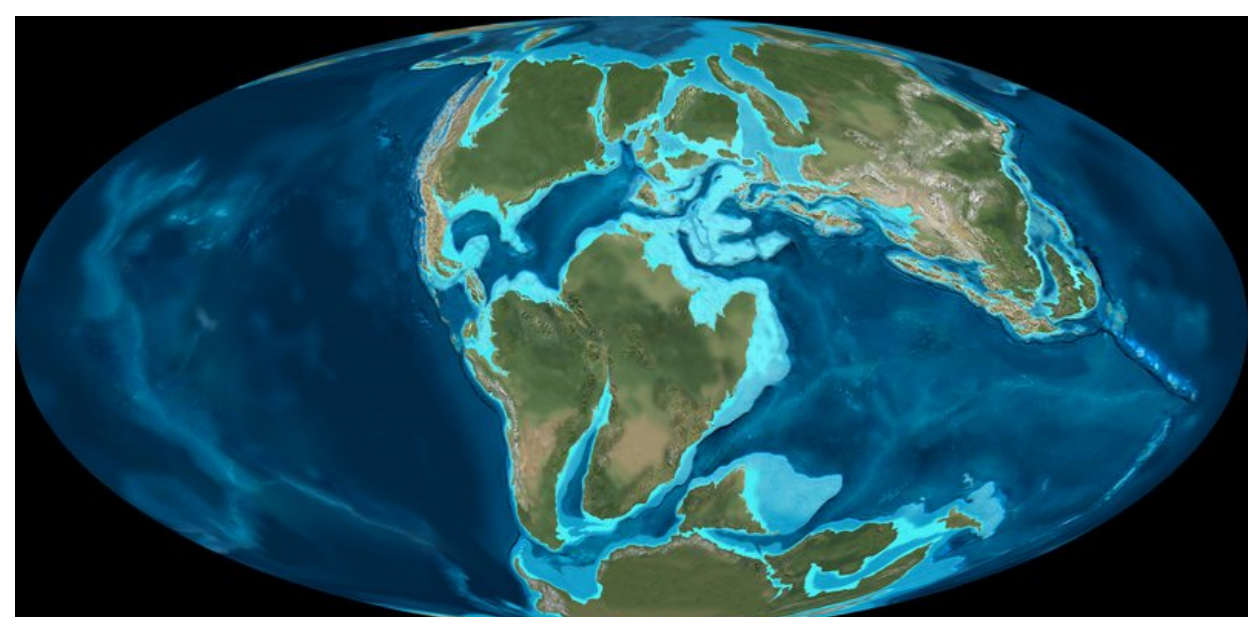

Figure 1-1 Paleogeographic distribution of major landmasses during the Early Cretaceous $~ 120$ Mya. Figure from http://cpgeosystems.com/paleomaps.html. 
$\mathrm{CO}_{2}$ associated with intense tectonic rifting and volcanism, but also to the presence of extensive wetlands that may have provided water vapor as a supplementary greenhouse gas (Arthur et al., 1985; Barron and Washington, 1985; Larson, 1991; Erba and Tremolada, 2004; Weissert and Erba, 2004; Fletcher et al., 2008; Méhay et al., 2009; Wang et al., 2014; Naafs et al., 2016; Hay et al., 2019). Evidence from that time includes remarkably low plant stomatal density, the emplacement of coeval large igneous provinces (LIPs), namely the Ontong Java Plateau ( 120 and $\sim 90$ Mya), Kerguelen Plateau ( 118, 108 and $\sim 95$ Mya) and Caribbean Plateau ( $94-87$ Mya), and characteristic negative excursions in the carbon isotopic record $\left(\delta^{13} \mathrm{C}_{\text {carb }}\right.$ and $\delta^{13} \mathrm{C}_{\text {org }}$ ) (Fig. 1-2) (Tarduno et al., 1991; Erbacher et al., 1996; Bralower et al., 1999; Larson and Erba, 1999; Leckie et al., 2002; Haworth et al., 2005; Tejada et al., 2009; Sun et al 2016; Charbonnier and Föllmi, 2017). While volcanogenic sourced $\mathrm{CO}_{2}$ is relatively depleted in $\delta^{13} \mathrm{C}(\sim-5 \%)$ it is argued that such release is insufficient to produce the drastic negative shifts recorded in the global carbon isotope values (>3\%) (van Breugel et al., 2007). Therefore, dissociation of methane hydrates with much lighter $\delta^{13} \mathrm{C}$ values $(\sim-60 \%)$ (Kvenvolden, 1993) has been proposed as a possible causal factor of the large negative inflections recorded throughout the Cretaceous (Jahren et al., 2001; 2005; Beerling et al., 2006; van Breugel et al., 2007).

Most remarkably, these negative carbon isotope excursions are followed by pronounced positive spikes (Fig. 1-2), spanning $\sim 500 \mathrm{kyr}-1 \mathrm{Myr}$ in marine carbonates $\left(\delta^{13} \mathrm{C}_{\text {carb }}\right)$ and both marine and non-marine organic matter $(\mathrm{OM})\left(\delta^{13} \mathrm{C}_{\text {org }}\right)$ (Arthur et al., 1988; 1990; Weissert, 1989; Erba, 1994; Erbacher et al., 1996; Hasegawa, 1997; Menegatti et al., 1998; Bralower et al., 1999; Larson and Erba, 1999; Leckie et al., 2002; 


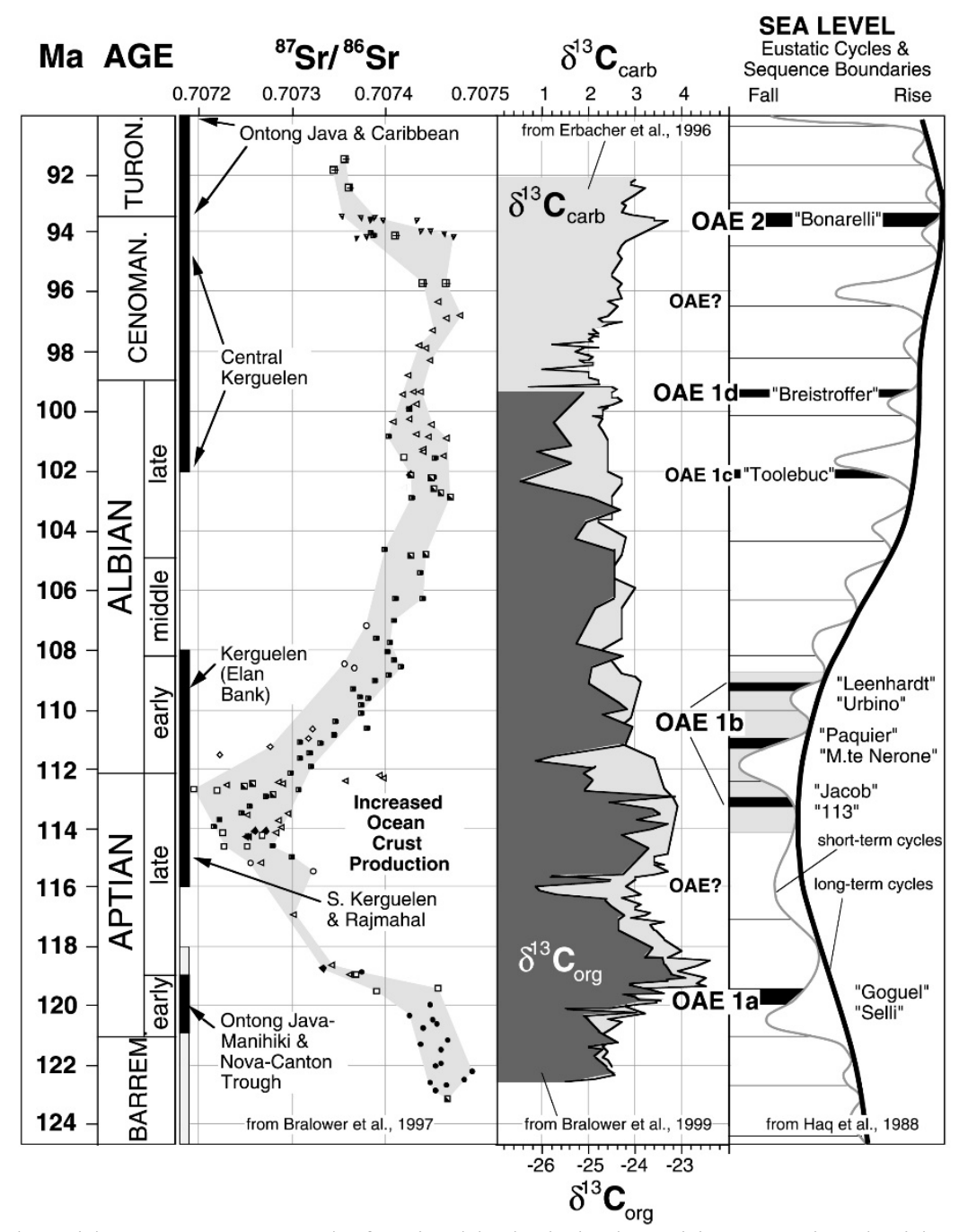

Figure 1-2 The mid-Cretaceous record of major black shale deposition associated with oceanic anoxic events (OAEs) in the context of time, emplacement of LIPs, strontium isotope record, the carbon isotope record and eustatic sea level fluctuations. Notice the negative inflections that precede most of the major OAEs in relation to the timing of LIPs. Subsequent positive shifts coincide with the widespread deposition of OM-rich marine sediments. Figure from Leckie et al. (2002) and data from Bralower et al. (1997, 1999), Erbacher et al. (1996) and Haq et al. (1988).

Weissert and Erba, 2004; Jenkyns, 2010). These positive carbon isotopic excursions (CIEs) reveal periods of enhanced OM sequestration, because photosynthetic organisms preferentially take up the lighter form of carbon $\left({ }^{12} \mathrm{C}\right)$ and the carbon isotopes are fractionated, leaving the remaining global carbon reservoir enriched in ${ }^{13} \mathrm{C}$ (Arthur et al., 1988; van Bentum et al., 2012). In addition, positive carbon isotopic excursions are associated with increased marine productivity, enhanced preservation of $\mathrm{OM}$, and 
appreciable changes in the marine microfauna and nannoflora (Erba, 1994; Jenkyns, 2010; Föllmi, 2012). These changes thus indicate significant perturbation of the global carbon cycle that affected the carbon isotope composition of exchangeable carbon in the global reservoir. Because every reservoir of carbon, whether oceanic, terrestrial or atmospheric, reflects the global isotopic signature, even if it is not directly sequestering carbon, the carbon isotopic pattern can thus serve as an important global correlation tool. The applicability of using stable carbon isotope for global correlation was discussed by Scholle and Arthur (1980), and further supported by subsequent works (Weissert and Bréhéret, 1991; Erbacher et al., 1996; Menegatti et al., 1998, and others). Menegatti et al. (1998) subdivided the carbon isotope curve for the late Barremian and Aptian stages into segments (C1-C8), based on the similar pattern observed in the $\delta^{13} \mathrm{C}_{\text {carb }}$ and $\delta^{13} \mathrm{C}_{\text {org }}$ record of two Alpine Tethys sections (Roter Sattel, Switzerland; Cismon, Italy). Later, Bralower et al. (1999) expanded the carbon isotope segments into the Albian stage using several stratigraphic sections from Mexico. Since then, the stable carbon isotope curve has been calibrated with biostratigraphy and magnetostratigraphy and is becoming one of the main correlation tools for mid-Cretaceous sections.

Several episodes of accelerated carbon sequestration took place during the Cretaceous as attested by globally distributed OM-rich marine black shales, termed Oceanic Anoxic Events or "OAEs" (Schlanger and Jenkyns, 1976). Six major Cretaceous OAEs have been extensively documented (Fig. 1-2), namely the early Aptian OAE1a, Albian OAE1b, 1c, 1d, Cenomanian - Turonian OAE2, and Santonian OAE3, as well as minor local or regional sub-events which are not as easily detectable in lithologically condensed sections. (Schlanger and Jenkyns, 1976; Arthur et al., 1990; Jenkyns and Wilson, 1999; 
Leckie et al., 2002). Previously, these OM-rich sediments had been attributed to the local paleophysiographic arrangement that restricted the inflow of oxygenated water into the respective basin, thus leading to stagnant bottom waters. However, the latter notion does not explain the fact that these OM-rich horizons are found in a great variety of settings, their widespread distribution and their apparent synchronous occurrence (Ryan and Cita, 1977). A comprehensive model that considers several compounding variables provides a better explanation for these quasi-global events: 1) Intense volcanism associated with the rifting of Gondwana and Laurasia coupled with the emplacement of several LIPs led to the effusion of large amounts of $\mathrm{CO}_{2}$. 2) Strong greenhouse conditions resulted in an icefree world with reduced oceanic thermal contrasts, limited vertical mixing and a sluggish circulation. 3) Warm SSTs led to out-gassing of dissolved gases, which could have certainly reduced the concentration of dissolved oxygen in the water column. 4) Widespread rifting resulted in a paleogeographic arrangement conducive for the formation of many semi-restricted basins. 5) Intensified global precipitation cycles led to heightened supplies of trace and bio-limiting nutrients $(\mathrm{Fe}, \mathrm{P})$ from continental weathering, which could have fueled phytoplankton blooms in marine surface waters. 6) Large fluxes of riverine waters could have led to the development of stratified basins, especially those with already impoverished circulation. 7) Enhanced primary production generated large amounts of OM that remineralized simultaneously with poor mixing of bottom and surface waters, which could have expanded the oxygen minimum zone (OMZ) and thereby resulted in the preservation of extensive OM-rich sedimentary deposits. 


\subsection{Main Objectives}

The Organyà Basin, located in northeastern Spain, developed as a semi-enclosed basin during the early Cretaceous (Fig. 1-3). Previous studies document the onset of the early Aptian OAE1a in medium dark gray (N4) to grayish black (N2) hemipelagic

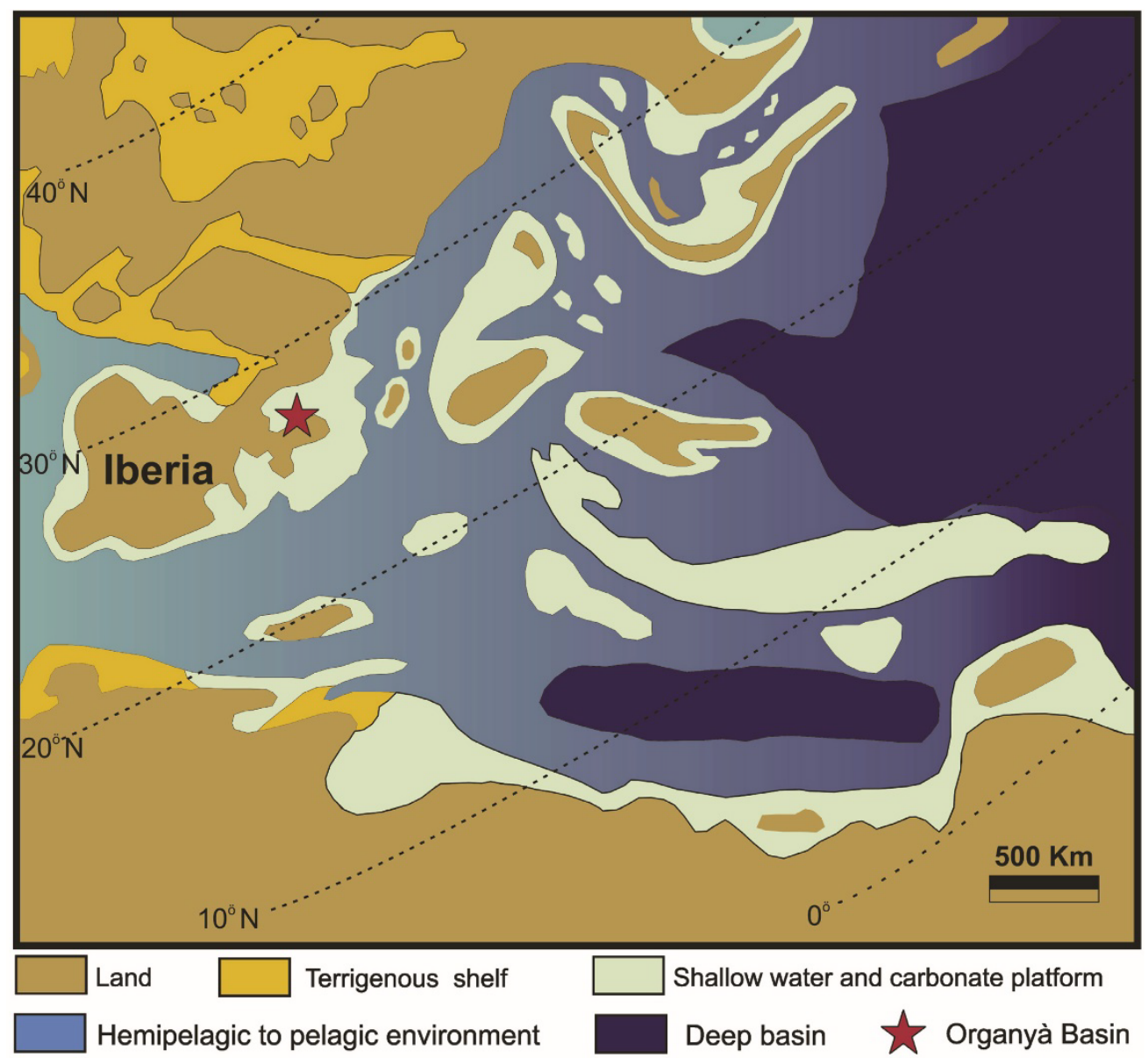

Figure 1-3 Paleogeographic location of the Organyà Basin during the Aptian. Figure from Sanchez-Hernandez et al. (2014), modified from data by Masse et al. (1993), Mancinelli and Chiocchini (2006) and Godet et al. (2013).

limestones (Fig. 1-4) known as the Cabó Marls (García-Senz, 2002) at the locality of El Pui, near the village of Cabó, in Catalunyà, south-central Pyrenees of Spain (SanchezHernandez et al., 2014; Sanchez-Hernandez and Maurrasse, 2014, 2016). Sediments of the Organyà Basin span the entire early Cretaceous (Berriasian to Albian) and the 

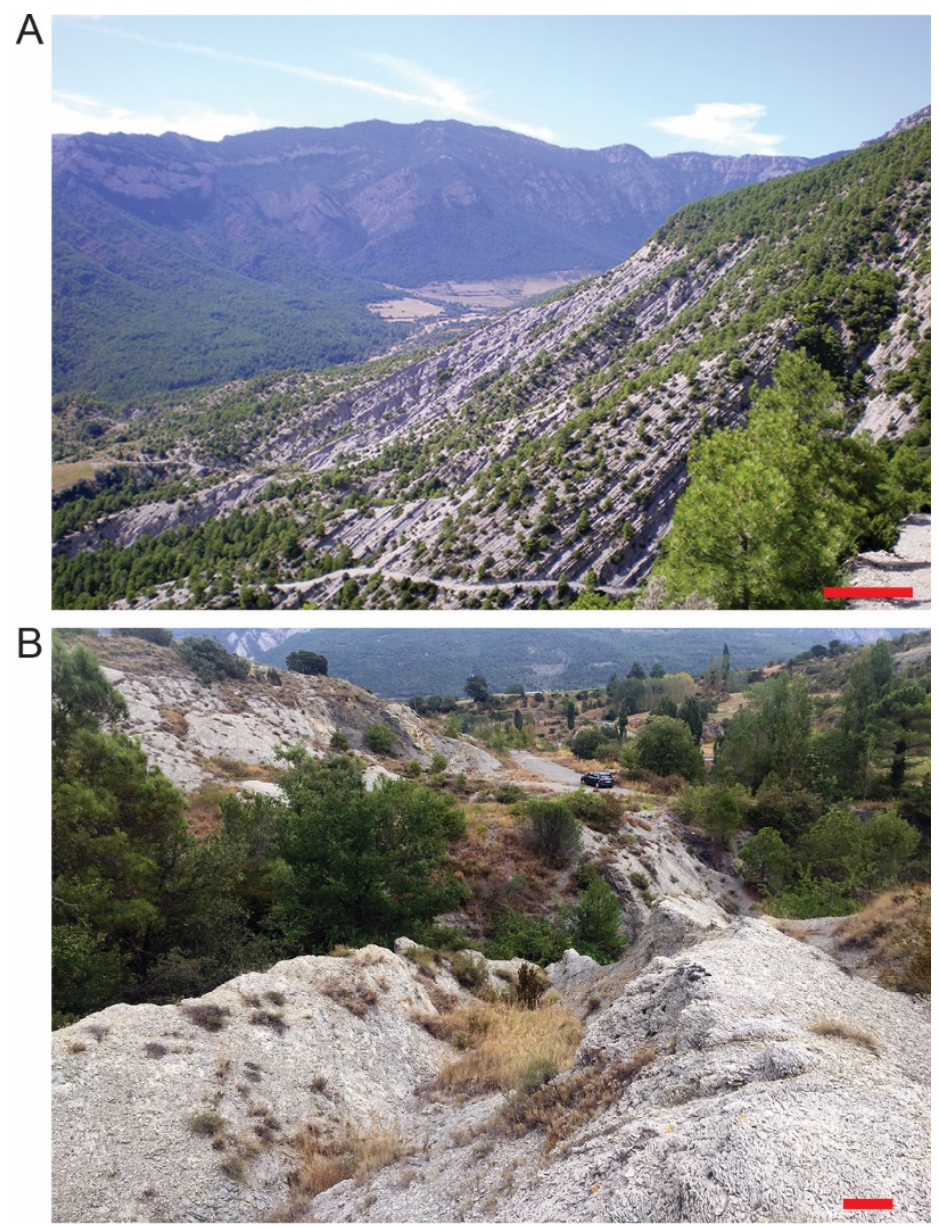

Figure 1-4 A) Panoramic picture at the locality of El Pui, scale at $2 \mathrm{~m}$. B) Picture of the OM-rich hemipelagic marlstones near the hamlet of El Pujal, scale at $3 \mathrm{~m}$. Notice the parked car on the road adjacent to the easily accessible outcrop.

beginning of the late Cretaceous (Cenomanian/Turonian) (García-Senz, 2002), and consist of over 4,000 m of continuous marine sediments, composed mostly of OM-rich hemipelagic marlstones and shallow-water limestones that accumulated during the evolution of a pull-apart phase of the basin (García-Senz, 2002). Coupled with the excellent exposure (Fig. 1-4A) and ease of accessibility (Fig. 1-4B) to the site, the outcrops in the municipality of Organyà offer the opportunity for detailed, highresolution studies. The main objectives of this study were:

1) To utilize the expanded and continuous early Aptian deposits outcropping in Organyà, taking advantage of the unique sedimentary conditions that occurred in a marginal setting 
of the Basin during this time interval, to understand the lithological and geochemical response to changing paleoenvironmental conditions associated with OAE1a.

2) To apply a multi-proxy approach to broaden our understanding of the local factors particular to the Organyà Basin, which maintained continuous deposition of OM-rich sediments in relation to OAEla, their ties to global forcing factors, and determine the possible causes of negative shifts in the $\delta^{13} \mathrm{C}_{\text {org }}$ chemostratigraphic record of the basin. 3) To take the opportunity of the high accumulation rate in the Organyà Basin to achieve the important goal of developing a detailed $\delta^{13} \mathrm{C}_{\text {org }}$ curve, calibrated with index fossils, to serve as a correlation tool without the common problems associated with biostratigraphy.

\subsection{Questions and Hypotheses}

Questions and hypotheses to be tested include:

1) What are the possible causes of negative inflections in the $\delta^{13} \mathrm{C}$ record of Cretaceous sediments of the Organyà Basin? Are they global events or local phenomena?

The presence of coeval negative spikes in widely distributed basins points towards a global causal mechanism. Volcanogenically sourced $\mathrm{CO}_{2}$ and methane hydrates have highly depleted $\delta^{13} \mathrm{C}$ values, $\sim-8 \%$ and $\sim-60 \%$, respectively. While differential fractionation by local photosynthesizers and diagenesis could be mitigating factors associated with negative carbon isotope values, but considering the relatively large magnitude of the negative excursions, it can be hypothesized that these negative inflections are likely the results of large volcanic eruptions and/or the destabilization and release of methane from continental shelfs.

2) What is the specific response of the semi-restricted Organyà Basin to perturbations of the global carbon cycle during the denouement stages of the early Aptian OAE1a? 
Previous studies at El Pui concluded that the Organyà Basin developed as a semirestricted water body affected by intensified precipitation cycles associated with variable climatic conditions. Field observations of the El Pui section show tightly imbricated successions of limestones and marlstones, while at the El Pujal section lithology changes to widely spaced, differentially weathered packets of limestones, argillaceous limestones and marls. As a result, it can be hypothesized that paleoenvironmental conditions during the deposition of the El Pujal sequence shifted towards longer intervals of variable wet and dry climatic conditions, thus yielding the alternating lithology in addition to possible higher sediment accumulation rates.

3) What are the local factors that resulted in the accumulation of OM-rich sediments in the Organyà Basin during a period of severe oxygen-deficient conditions in the ocean (OAE1a)? Did these regional factors affect the global $\delta^{13} \mathrm{C}_{\text {org }}$ signature in the Organyà Basin?

Previously, the El Pui section (latest Barremian - early Aptian) revealed that regional conditions led to a series of interacting factors that caused OM-preservation: heightened supplies of bio-limiting nutrients $\mathrm{Fe}, \mathrm{P}$ from continental weathering, which fueled phytoplankton blooms; large fluxes of riverine waters that induced density stratification within the semi-restricted basin; enhanced primary production generated large amounts of OM that simultaneously with poor mixing could have expanded the OMZ through the water column. Thus, it can be hypothesized that a similar mechanism unique to the Organyà Basin could explain the continuous deposition of OM-rich sediments associated with the El Pujal section. 
Considering that intervals of enhanced continental weathering and discharge of riverine waters must have increased the flux of terrestrially derived OM linked with depleted $\delta^{13} \mathrm{C}_{\text {org }}$ values ( $\sim 26 \%$ to $-28.5 \%$ ), it can be hypothesized that these intervals were linked with minor $(\sim<1 \%)$ negative shifts in the $\delta^{13} \mathrm{C}_{\text {org }}$ curve.

4) Are the sedimentary and geochemical signals recorded in the El Pujal section strictly locally unique to the Organyà Basin, or are these signals regionally expressed in neighboring basins?

The Organyà Basin developed because of extensional faulting in relation to the synrotational rifting that occurred along the northern portion of the Iberian plate during the early Cretaceous. Extensional faulting created a series of elongated depocenters, including the Basque-Cantabrian Basin, the North Pyrenean Basin and the Central Pyrenean Basin which itself harbors the Organyà Basin. Therefore, it can be hypothesized that regional paleoclimatic, paleoceanographic and, in particular, regional sea level changes, should show parallelisms between these locally unique, but regionally and tectonically connected basins.

\subsection{Summary of the Basis for the Proposed Approach}

To accomplish the proposed objectives and test my hypotheses the following generalized approach was developed:

1) Extensive fieldwork was undertaken to understand the overall tectonic and structural setting of the area, as well as to identify small and large-scale facies changes, and sedimentary structures that indicate depositional conditions.

2) High-resolution sampling was employed with the intent of characterizing the minor and major temporal perturbations recorded during this interval of the Organyà Basin. 
3) Petrographic analysis of thin sections under binocular and scanning electron microscopy (SEM) was used as a complement to field observations, to evaluate mineral content, microfacies changes, and for concentration and identification of microfauna. Smear slides were used to examine the calcareous nannoflora content, fine fraction of the matrix, and for possible index nannoflora taxa identification.

4) Quantification of total inorganic carbon (TIC) was used to assess the contribution of carbonate producers to the rocks.

5) Organic matter preservation in marine sediments is a complex process that depends on a series of mechanisms that are usually not mutually exclusive, including: rate of primary production, source of OM (labile or recalcitrant), sedimentation rate, sediment grain size and oxygen content. Therefore, quantification of the total organic carbon (TOC) provides a general idea of the magnitude of these variables.

6) The application of stable carbon isotope relies on the kinetic fractionation of the two main stable isotopes of carbon, ${ }^{12} \mathrm{C}(98.89 \%)$ and ${ }^{13} \mathrm{C}(1.11 \%)$. During photosynthesis, these non-radiogenic isotopes are fractionated in proportions that follow the kinetically favored path where the lighter ${ }^{12} \mathrm{C}$ isotope is preferentially extracted from the system in comparison with ${ }^{13} \mathrm{C}$. Therefore, organically derived carbon is depleted in ${ }^{13} \mathrm{C}$ relative to the atmospheric ${ }^{13} \mathrm{C} /{ }^{12} \mathrm{C}$ ratio. During periods of enhanced organic matter sequestration, large quantities of $\mathrm{OM}$ enriched in ${ }^{12} \mathrm{C}$ are removed from the oceanic reservoir, which becomes enriched in ${ }^{13} \mathrm{C}$. Hence, autotrophs will then fix carbon with enriched values of ${ }^{13} \mathrm{C}$, given that the heavier molecule has become more abundant in the reservoir. Highproductivity events, which sequester large amounts of $\mathrm{OM}$, such as those related to OAEs, are therefore recorded in the $\delta^{13} \mathrm{C}_{\mathrm{org}}$ chemostratigraphic record as positive 
excursions. Furthermore, since these autotrophs uptake $\mathrm{CO}_{2}$ from the global carbon pool, the curves document shifts that signal overall simultaneous responses of temporal changes in the global carbon reservoir. Consequently, the $\delta^{13} \mathrm{C}_{\text {org }}$ curve is used to identify OAEs, and for correlation of widely distributed sections.

7) Major terrestrially derived elements including aluminum (Al), silicon ( $\mathrm{Si}$ ) and titanium (Ti), termed "lithophiles" (Goldschmidt's classification) are elements that have strong affinity for oxygen and form compounds that do not sink to the core and are thus enriched in the Earth's crust. On that basis, their concentrations are used as clues to assess the input of terrigenous fluxes into the basin.

8) Bio-limiting elements including iron $(\mathrm{Fe})$ and phosphorus $(\mathrm{P})$ are essential nutrients used by phytoplankton during photosynthesis and for other biochemical processes. Surface waters are usually depleted in these elements and thus their availability exerts a control on phytoplankton productivity. The concentration of these elements $(\mathrm{Fe}, \mathrm{P})$ helps to estimate the nutrient content in the basin during deposition.

9) Redox-sensitive trace elements (RSTEs) including vanadium (V), nickel (Ni), Cobalt $(\mathrm{Co})$, chromium $(\mathrm{Cr})$, copper $(\mathrm{Cu})$, molybdenum $(\mathrm{Mo})$ and uranium $(\mathrm{U})$, are elements that under reducing conditions form organometallic complexes, complex with sulfides, or form insoluble hydroxides and thus become enriched in sediments that accumulated under such conditions. The concentrations of RSTEs are used here as a proxy to evaluate the oxygen level in the paleoenvironment, which is one of the most critical variables in the development of OM-rich deposits.

10) Biomarkers are organic molecules preserved in rocks or sediments that retain all, or part, of their parent structure. Biomarkers are used here as proxies to determine the 
source of the OM, reconstruct the depositional environment, and determine thermal maturation.

11) Bulk and clay mineral analyses were used to assess the mineralogical composition of the rock matrix, climate, and relative intensity of weathering and runoff from landmasses adjacent to the Organyà Basin.

\subsection{Dissertation Structure}

The main body of the dissertation covered in Chapters 4 to 7 are organized as chapters representing separate research articles that address the objectives and questions stated above. These chapters are either published, in press, or submitted for publication.

- Chapter 1 - Covers general background information of Cretaceous OAEs, main objectives of the dissertation, questions and hypotheses, summary of the basis for the chosen methodology and the structure of the dissertation.

- Chapter 2 - Explains the tectonic evolution of the Organyà Basin.

- Chapter 3 - Describes in detail the specific materials and methods applied to accomplish the objectives and answer the proposed research questions.

- Chapter 4 - Adds supplementary data in a high-resolution study of the interval that includes the negative intra-C2 CIE in the El Pui section to complement earlier works (Sanchez-Hernandez et al., 2014; Sanchez-Hernandez and Maurrasse, 2014, 2016). The geochemical characteristics of the $n$-alkanes in the negative shift are analyzed in order to assess whether local biogeochemical factors were involved. In addition, plausible causal factors are proposed.

- Chapter 5 - Investigates the lithological and geochemical response of the Organyà Basin hemipelagic El Pujal section in relation to perturbations of the global carbon 
cycle during segment C5 of OAE1a. Paleoenvironmental and paleoclimatic models are proposed to integrate regional and global forcing factors influencing the continuous accumulation of OM-rich sediments at El Pujal.

- Chapter 6 - Discusses the influence of regional paleoenvironmental conditions on OM sequestration and analyzes how the input of terrestrial vegetation linked with lower values of $\delta^{13} \mathrm{C}_{\text {org }}$ may have altered the global $\delta^{13} \mathrm{C}_{\text {org }}$ archive in the Organyà Basin.

- Chapter 7 - Investigates the response of the Organyà Basin to changing paleoenvironmental conditions related to the end of carbon isotope segment C5. Documents regional paleoclimatic, paleoceanographic and, in particular, regional sea level changes that may be responsible for synchronous facies variability recorded in the Organyà Basin and at coeval sites in the Basque-Cantabrian Basin. Integrates the sedimentary and geochemical signals recorded at the El Pujal section within a broader spatial frame in order to establish parallels and differences that may help in assessing the regional expression of global perturbations associated with OAE1a.

- Chapter 8 - Summarizes the general conclusions and importance of this investigation.

\subsection{References}

Arthur, M.A., Brumsack, H.J., Jenkyns, H.C., Schlanger, S.O., 1990. Stratigraphy, geochemistry, and paleoceanography of organic carbon- rich Cretaceous sequences. Cretac. Resour. events Rhythm. 75-119. https://doi.org/10.1007/978-94-015-68616_6

Arthur, M.A., Dean, W.E., Schlanger, S.O., 1985. Variations in the Global Carbon Cycle During the Cretaceous Related to Climate, Volcanism, and Changes in Atmospheric $\mathrm{CO} 2$, in: The Carbon Cycle and Atmospheric CO2: Natural Variations Archean to Present. pp. 504-529. https://doi.org/10.1159/000020165 
Arthur, M.A., Dean, W.E., Pratt, L.M., 1988. Geochemical and climatic effects of increased marine organic carbon burial at the Cenomanian/Turonian boundary. Nature 335, 714-717. https://doi.org/10.1038/335714a0

Barron, E.J., 1983. A warm, equable Cretaceous: The nature of the problem. EarthScience Rev. 19, 305-338. https://doi.org/10.1016/0012-8252(83)90001-6

Barron, E.J., Hay, W.W., Thompson, S., 1989. The hydrologic cycle: A major variable during earth history. Glob. Planet. Change 1, 157-174. https://doi.org/10.1016/09218181(89)90001-5

Barron, E.J., Washington, W.M., 1985. Warm Cretaceous Climates: High Atmospheric CO 2 as a Plausible Mechanism, in: The Carbon Cycle and Atmospheric CO2: Natural Variations Archean to Present. pp. 546-553. https://doi.org/10.1029/GM032p0546

Beerling, D.J., 2006. On the nature of methane gas-hydrate dissociation during the Toarcian and Aptian Oceanic anoxic events. Am. J. Sci. 302, 28-49. https://doi.org/10.2475/ajs.302.1.28

Blättler, C.L., Jenkyns, H.C., Reynard, L.M., Henderson, G.M., 2011. Significant increases in global weathering during Oceanic Anoxic Events 1a and 2 indicated by calcium isotopes. Earth Planet. Sci. Lett. 309, 77-88.

https://doi.org/10.1016/J.EPSL.2011.06.029

Bralower, T.J., Cobabe, E., Clement, B., Sliter, W. V, Osburn, C.L., Longoria, J., 1999. The record of global change in mid-Cretaceous (Barremian-Albian) sections from the Sierra Madre, Northeastern Mexico. J. Foraminifer. Res. 29, 418-437.

Bralower, T.J., Fullagar, P.D., Paull, C.K., Dwyer, G.S., Leckie, R.M., 1997. MidCretaceous strontium-isotope stratigraphy of deep-sea sections. GSA Bull. 109, 1421-1442. https://doi.org/10.1130/0016-7606(1997)109<1421:MCSISO > 2.3.CO;2

Charbonnier, G., Boulila, S., Spangenberg, J.E., Adatte, T., Föllmi, K.B., Laskar, J., 2018. Obliquity pacing of the hydrological cycle during the Oceanic Anoxic Event 2. Earth Planet. Sci. Lett. 499, 266-277. https://doi.org/10.1016/J.EPSL.2018.07.029

Charbonnier, G., Föllmi, K.B., 2017. Mercury enrichments in lower Aptian sediments support the link between Ontong Java large igneous province activity and oceanic anoxic episode 1a. Geology 45, 63-66. https://doi.org/10.1130/G38207.1

Erba, E., 1994. Nannofossils and superplumes: The Early Aptian "nannoconid crisis." Paleoceanography 9, 483-501. https://doi.org/10.1029/94PA00258 
Erba, E., Tremolada, F., 2004. Nannofossil carbonate fluxes during the Early Cretaceous: Phytoplankton response to nutrification episodes, atmospheric $\mathrm{CO} 2$, and anoxia. Paleoceanography 19. https://doi.org/10.1029/2003PA000884

Erbacher, J., Thurow, J., Littke, R., 1996. Evolution patterns of radiolaria and organic matter variations: A new approach to identify sea-level changes in mid-Cretaceous pelagic environments. Geology 24, 499-502. https://doi.org/10.1130/00917613(1996)024<0499:EPORAO >2.3.CO;2

Fletcher, B.J., Brentnall, S.J., Anderson, C.W., Berner, R.A., Beerling, D.J., 2008. Atmospheric carbon dioxide linked with Mesozoic and early Cenozoic climate change. Nat. Geosci. 1, 43-48. https://doi.org/10.1038/ngeo.2007.29

Föllmi, K.B., 2012. Early Cretaceous life, climate and anoxia. Cretac. Res. 35, 230-257. https://doi.org/10.1016/j.cretres.2011.12.005

Forster, A., Schouten, S., Moriya, K., Wilson, P.A., Damsté, J.S.S., 2007. Tropical warming and intermittent cooling during the Cenomanian/Turonian oceanic anoxic event 2: Sea surface temperature records from the equatorial Atlantic.

Paleoceanography 22. https://doi.org/10.1029/2006PA001349

Frakes, L.A., Francis, J.E., Syktus, J.I., 1992. Climate Modes of the Phanerozoic: The History of the Earth's Climate Over the Past 600 Million Years. Cambridge University Press. https://doi.org/10.1017/CBO9780511628948

García-Senz, J., 2002. Cuencas extensivas del Cretácico inferior en los Pirineos centrales, formación y subsiguiente inversión. Dpt. Geodinàmica i Geofísica 310.

Godet, A., Föllmi, K., Spangenberg, J., Bodin, S., Vermeulen, J., Adatte, T., Bonvallet, L., Arnaud, H., 2013. Deciphering the message of Early Cretaceous drowning surfaces from the Helvetic Alps: What can be learnt from platform-to-basin correlations? Sedimentology 60, 152-173. https://doi.org/10.1111/sed.12008

Haq, B.U., 2014. Cretaceous eustasy revisited. Glob. Planet. Change 113, 44-58. https://doi.org/10.1016/J.GLOPLACHA.2013.12.007

Haq, B.U., Hardenbol, J.A.N., Vail, P.R., 1987. Chronology of Fluctuating Sea Levels Since the Triassic. Science (80-. ). 235, 1156 LP-1167. https://doi.org/https://doi.org/10.1126/science.235.4793.1156

Haq, B.U., Hardenbol, J., Vail, P.R., Stover, L.E., Colin, J.P., Ioannides, N.S., Wright, R.C., Baum, G.R., Gombos Jr., A.M., Pflum, C.E., Loutit, T.S., Chêne, R.J. du, Romine, K.K., Sarg, J.F., Posamentier, H.W., Morgan, B.E., 1988. Mesozoic and Cenozoic Chronostratigraphy and Cycles of Sea-Level Change, in: Wilgus, C.K., Hastings, B.S., Posamentier, H., Wagoner, J. Van, Ross, C.A., Kendall, C.G.S.C. 
(Eds.), Sea-Level Changes: An Integrated Approach. SEPM Society for Sedimentary Geology, pp. 71-108. https://doi.org/10.2110/pec.88.01.0071

Hasegawa, T., 1997. Cenomanian-Turonian carbon isotope events recorded in terrestrial organic matter from northern Japan. Palaeogeogr. Palaeoclimatol. Palaeoecol. 130, 251-273. https://doi.org/10.1016/S0031-0182(96)00129-0

Haworth, M., Hesselbo, S.P., McElwain, J.C., Robinson, S.A., Brunt, J.W., 2005. MidCretaceous $\mathrm{pCO} 2$ based on stomata of the extinct conifer Pseudofrenelopsis (Cheirolepidiaceae). Geology 33, 749-752. https://doi.org/10.1130/G21736.1

Hay, W.W., DeConto, R.M., de Boer, P., Flögel, S., Song, Y., Stepashko, A., 2019. Possible solutions to several enigmas of Cretaceous climate. Int. J. Earth Sci. 108, 587-620. https://doi.org/10.1007/s00531-018-1670-2

Huber, B.T., Hodell, D.A., Hamilton, C.P., 1995. Middle-late Cretaceous climate of the southern high latitudes: stable isotopic evidence for minimal equator-to-pole thermal gradients. Geol. Soc. Am. Bull. 107, 1164-1191. https://doi.org/10.1130/00167606(1995)107<1164:MLCCOT>2.3.CO;2

Huber, B.T., MacLeod, K.G., Watkins, D.K., Coffin, M.F., 2018. The rise and fall of the Cretaceous Hot Greenhouse climate. Glob. Planet. Change 167, 1-23. https://doi.org/10.1016/J.GLOPLACHA.2018.04.004

Jahren, A.H., Arens, N.C., Sarmiento, G., Guerrero, J., Amundson, R., 2001. Terrestrial record of methane hydrate dissociation in the Early Cretaceous. Geology 29, 159162. https://doi.org/10.1130/0091-7613(2001)029<0159:TROMHD>2.0.CO;2

Jahren, A.H., Conrad, C.P., Arens, N.C., Mora, G., Lithgow-Bertelloni, C., 2005. A plate tectonic mechanism for methane hydrate release along subduction zones. Earth Planet. Sci. Lett. 236, 691-704. https://doi.org/10.1016/j.epsl.2005.06.009

Jenkyns, H.C., Schouten-Huibers, L., Schouten, S., Sinninghe Damsté, J.S., 2012. Warm Middle Jurassic-Early Cretaceous high-latitude sea-surface temperatures from the Southern Ocean. Clim. Past 8, 215-226. https://doi.org/10.5194/cp-8-215-2012

Jenkyns, H.C., 2010. Geochemistry of oceanic anoxic events. Geochemistry, Geophys. Geosystems 11. https://doi.org/10.1029/2009GC002788

Jenkyns, H.C., Wilson, P.A., 1999. Stratigraphy, paleoceanography, and evolution of Cretaceous Pacific guyots: Relics from a greenhouse Earth, American Journal of Science. https://doi.org/10.2475/ajs.299.5.341

Kvenvolden, K.A., 1993. Gas hydrates - geological perspective and global change. Rev. Geophys. 31, 173-187. https://doi.org/10.1029/93RG00268 
Larson, R.L., 1991. Geological consequences of superplumes. Geology 19, 963-966. https://doi.org/10.1130/0091-7613(1991)019<0963:GCOS>2.3.CO;2

Larson, R.L., Erba, E., 1999. Onset of the mid-Cretaceous greenhouse in the BarremianAptian: Igneous events and the biological, sedimentary, and geochemical responses. Paleoceanography 14, 663-678. https://doi.org/10.1029/1999PA900040

Lechler, M., Pogge von Strandmann, P.A.E., Jenkyns, H.C., Prosser, G., Parente, M., 2015. Lithium-isotope evidence for enhanced silicate weathering during OAE 1a (Early Aptian Selli event). Earth Planet. Sci. Lett. 432, 210-222. https://doi.org/10.1016/J.EPSL.2015.09.052

Leckie, R.M., Bralower, T.J., Cashman, R., 2002. Oceanic anoxic events and plankton evolution: Biotic response to tectonic forcing during the mid-Cretaceous. Paleoceanography 17, 13-29. https://doi.org/10.1029/2001PA000623

Mancinelli, A., Chiocchini, M., 2006. Cretaceous benthic foraminifers and calcareous algae from Monte Cairo (southern Latium, Italy). Boll. della Soc. Paleontol. Ital. 45, 91-113.

Masse, J.P., Bellion, Y., Benkhelil, J., Dercourt, J., Guiraud, R., Ricou, L.E., 1993. Lower Aptian Palaeoenvironments (114 to $112 \mathrm{Ma}$ ), in: J. Dercourt, L.E. Ricou, B.V. (Ed.), Atlas Tethys Palaeoenvironmental Maps. BEICIP-FRANLAB, RueilMalmaison, Gauthier-Villars, Paris.

Méhay, S., Keller, C.E., Bermasconi, S.M., Weissert, H., Erba, E., Bottini, C., Hochuli, P.A., 2009. A volcanic CO2 pulse triggered the Cretaceous oceanic Anoxic event 1a and a biocalcification crisis. Geology 37, 819-822. https://doi.org/10.1130/G30100A.1

Menegatti, A.P., Weissert, H., Brown, R.S., Tyson, R. V., Farrimond, P., Strasser, A., Caron, M., 1998. High-resolution $813 \mathrm{C}$ stratigraphy through the early Aptian "Livello Selli" of the Alpine Tethys. Paleoceanography 13, 530-545. https://doi.org/10.1029/98PA01793

Mutterlose, J., Bottini, C., Schouten, S., Sinninghe Damsté, J.S., 2014. High sea-surface temperatures during the early Aptian Oceanic Anoxic Event 1a in the Boreal Realm. Geology 42, 439-442. https://doi.org/10.1130/G35394.1

Naafs, B.D.A., Castro, J.M., De Gea, G.A., Quijano, M.L., Schmidt, D.N., Pancost, R.D., 2016. Gradual and sustained carbon dioxide release during Aptian Oceanic Anoxic Event 1a. Nat. Geosci. 9, 135.

O’Brien, C.L., Robinson, S.A., Pancost, R.D., Sinninghe Damsté, J.S., Schouten, S., Lunt, D.J., Alsenz, H., Bornemann, A., Bottini, C., Brassell, S.C., Farnsworth, A., 
Forster, A., Huber, B.T., Inglis, G.N., Jenkyns, H.C., Linnert, C., Littler, K., Markwick, P., McAnena, A., Mutterlose, J., Naafs, B.D.A., Püttmann, W., Sluijs, A., van Helmond, N.A.G.M., Vellekoop, J., Wagner, T., Wrobel, N.E., 2017. Cretaceous sea-surface temperature evolution: Constraints from TEX86 and planktonic foraminiferal oxygen isotopes. Earth-Science Rev. 172, 224-247. https://doi.org/10.1016/J.EARSCIREV.2017.07.012

Ryan, W.B.F., Cita, M.B., 1977. Ignorance Concerning Episodes of Ocean-Wide Stagnation. Dev. Sedimentol. 23, 197-215. https://doi.org/10.1016/S00704571(08)70558-2

Sanchez-Hernandez, Y., Maurrasse, F.J.M.R., 2016. The influence of regional factors in the expression of oceanic anoxic event 1a (OAE1a) in the semi-restricted Organyà Basin, south-central Pyrenees, Spain. Palaeogeogr. Palaeoclimatol. Palaeoecol. 441, 582-598. https://doi.org/10.1016/j.palaeo.2015.06.031

Sanchez-Hernandez, Y., Maurrasse, F.J.M.R., 2014. Geochemical characterization and redox signals from the latest Barremian to the earliest Aptian in a restricted marine basin: El Pui section, Organyà Basin, south-central Pyrenees. Chem. Geol. 372, 12 31. https://doi.org/10.1016/j.chemgeo.2014.02.011

Sanchez-Hernandez, Y., Maurrasse, F.J.M.R., Melinte-Dobrinescu, M.C., He, D., Butler, S.K., 2014. Assessing the factors controlling high sedimentation rates from the latest Barremian-earliest Aptian in the hemipelagic setting of the restricted Organyà Basin, NE Spain. Cretac. Res. 51, 1-21. https://doi.org/10.1016/j.cretres.2014.05.010

Schlanger, S.O., Jenkyns, H.C., 1976. Cretaceous oceanic anoxic events: Causes and consequences. Geol. en Mijnb. 55, 179-184.

Scholle, P.A., Arthur, M.A., 1980. Carbon isotope fluctuations in Cretaceous pelagic limestones: potential stratigraphic and petroleum exploration tool. Am. Assoc. Pet. Geol. Bull. 64, 67-87. https://doi.org/10.1306/2F91892D-16CE-11D7$8645000102 \mathrm{C} 1865 \mathrm{D}$

Sun, Y., Li, X., Zhao, G., Liu, H., Zhang, Y., 2016. Aptian and Albian atmospheric CO2 changes during oceanic anoxic events: Evidence from fossil Ginkgo cuticles in Jilin Province, Northeast China. Cretac. Res. 62, 130-141. https://doi.org/10.1016/j.cretres.2015.12.007

Tarduno, J.A., Sliter, W. V, Kroenke, L., Leckie, M., Mayer, H., Mahoney, J.J., Musgrave, R., Storey, M., Winterer, E.L., 1991. Rapid Formation of Ontong Java Plateau by Aptian Mantle Plume Volcanism. Science (80-. ). 254, 399-403. 
Tarduno, J.A., Brinkman, D.B., Renne, P.R., Cottrell, R.D., Scher, H., Castillo, P., 1998. Evidence for extreme climatic warmth from late cretaceous arctic vertebrates.

Science (80-. ). 282, 2241-2244. https://doi.org/10.1126/science.282.5397.2241

Tejada, M.L.G., Suzuki, K., Kuroda, J., Coccioni, R., Mahoney, J.J., Ohkouchi, N., Sakamoto, T., Tatsumi, Y., 2009. Ontong Java Plateau eruption as a trigger for the early Aptian oceanic anoxic event. Geology 37, 855-858.

https://doi.org/10.1130/G25763A.1

van Bentum, E.C., Reichart, G.J., Sinninghe Damsté, J.S., 2012. Organic matter provenance, palaeoproductivity and bottom water anoxia during the Cenomanian/Turonian oceanic anoxic event in the Newfoundland Basin (northern proto North Atlantic Ocean). Org. Geochem. 50, 11-18.

https://doi.org/10.1016/j.orggeochem.2012.05.013

van Breugel, Y., Schouten, S., Tsikos, H., Erba, E., Price, G.D., Damsté, J.S.S., 2007. Synchronous negative carbon isotope shifts in marine and terrestrial biomarkers at the onset of the early Aptian oceanic anoxic event 1a: Evidence for the release of 13C-depleted carbon into the atmosphere. Paleoceanography 22, 1-13. https://doi.org/10.1029/2006PA001341

Wang, Y., Huang, C., Sun, B., Quan, C., Wu, J., Lin, Z., 2014. Paleo-CO2 variation trends and the Cretaceous greenhouse climate. Earth-Science Rev. 129, 136-147. https://doi.org/10.1016/J.EARSCIREV.2013.11.001

Weissert, H., Erba, E., 2004. Volcanism, CO2 and palaeoclimate: a Late Jurassic-Early Cretaceous carbon and oxygen isotope record. J. Geol. Soc. London. 161, 695-702. https://doi.org/10.1144/0016-764903-087

Weissert, H., Bréhéret, J.G., 1991. A carbonate-isotope record from Aptian-Albian sediments of the Vocontian Trough (SE France). Bull. la Société Géologique Fr. $162,1133-1140$.

Weissert, H., 1989. C-Isotope stratigraphy, a monitor of paleoenvironmental change: A case study from the early cretaceous. Surv. Geophys. 10, 1-61. https://doi.org/10.1007/BF01901664

Weissert, H., Lini, A., Föllmi, K.B., Kuhn, O., 1998. Correlation of Early Cretaceous carbon isotope stratigraphy and platform drowning events: A possible link?

Palaeogeogr. Palaeoclimatol. Palaeoecol. 137, 189-203. https://doi.org/10.1016/S0031-0182(97)00109-0 


\section{GEOLOGIC EVOLUTION OF THE ORGANYÀ BASIN}

From the late Jurassic to the early Cretaceous the opening of the North Atlantic

Ocean led to the separation of the Iberian Plate from Eurasia and Africa (Fig. 2-1)

(Srivastava et al., 1990; Olivet, 1996; Vergés et al., 2002; Sibuet et al., 2004). Concurrent with this rifting phase, the Bay of Biscay opened, leading to the counter-clockwise rotation of Iberia by $\sim 35^{\circ}$ and a sinistral translation of Iberia relative to Eurasia (Fig. 21) (Van der Voo, 1969; Williams, 1975; Montadert et al., 1979; Montigny et al., 1986; Srivastava et al., 1990; Sibuet and Collette., 1991; Choukroune, 1992; Rosenbaum et al., 2002; Sibuet et al., 2004; Gong et al., 2008; Vissers and Meijer., 2012). The synrotational rifting along the northern portion of the Iberian plate produced significant
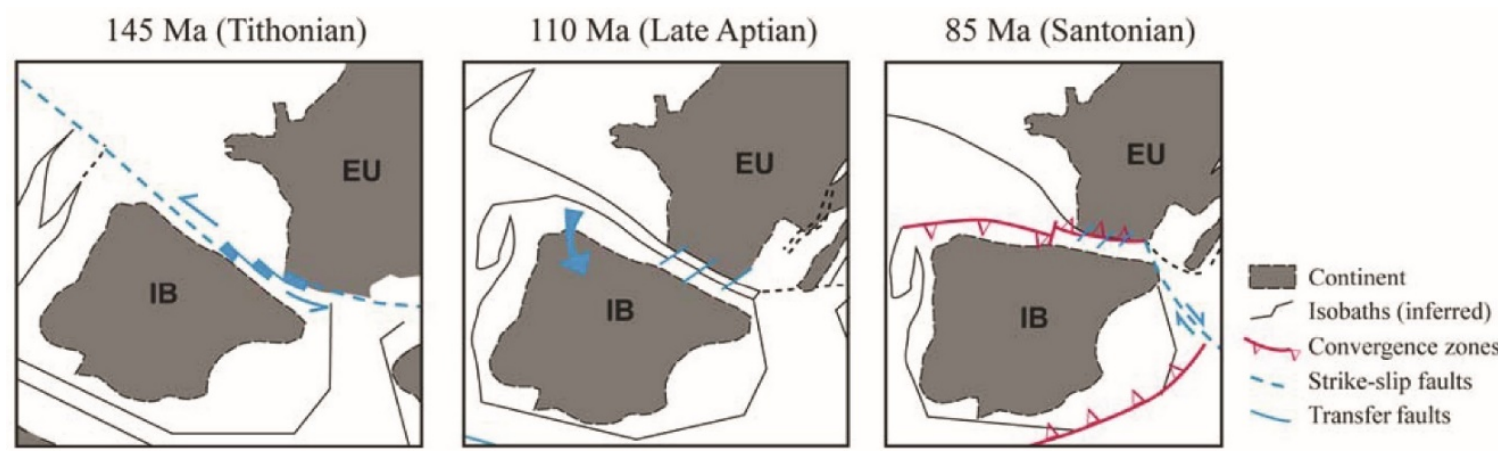

Figure 2-1 Plate kinematic reconstruction of Iberia (IB) relative to Europe (EU) during the Tithonian, Late Aptian and Santonian. The syn-rotational rifting of Iberia relative to Europe produced extensional faulting that generated the Organyà Basin. Figure from Jammes et al. (2009).

extensional faulting which generated a series of elongated depocenters, including the Basque-Cantabrian Basin, the North Pyrenean Basin and the Central Pyrenean Basin (Puigdefàbregas and Souquet, 1986; Berástegui et al., 1990; Vergés and García-Senz., 2001; García-Senz., 2002). From the late Cretaceous onwards, the convergence between Africa, Iberia and Europe brought about the closure and subsequent inversion of these Mesozoic extensional depocenters, which presently lie parallel and on the north and south 


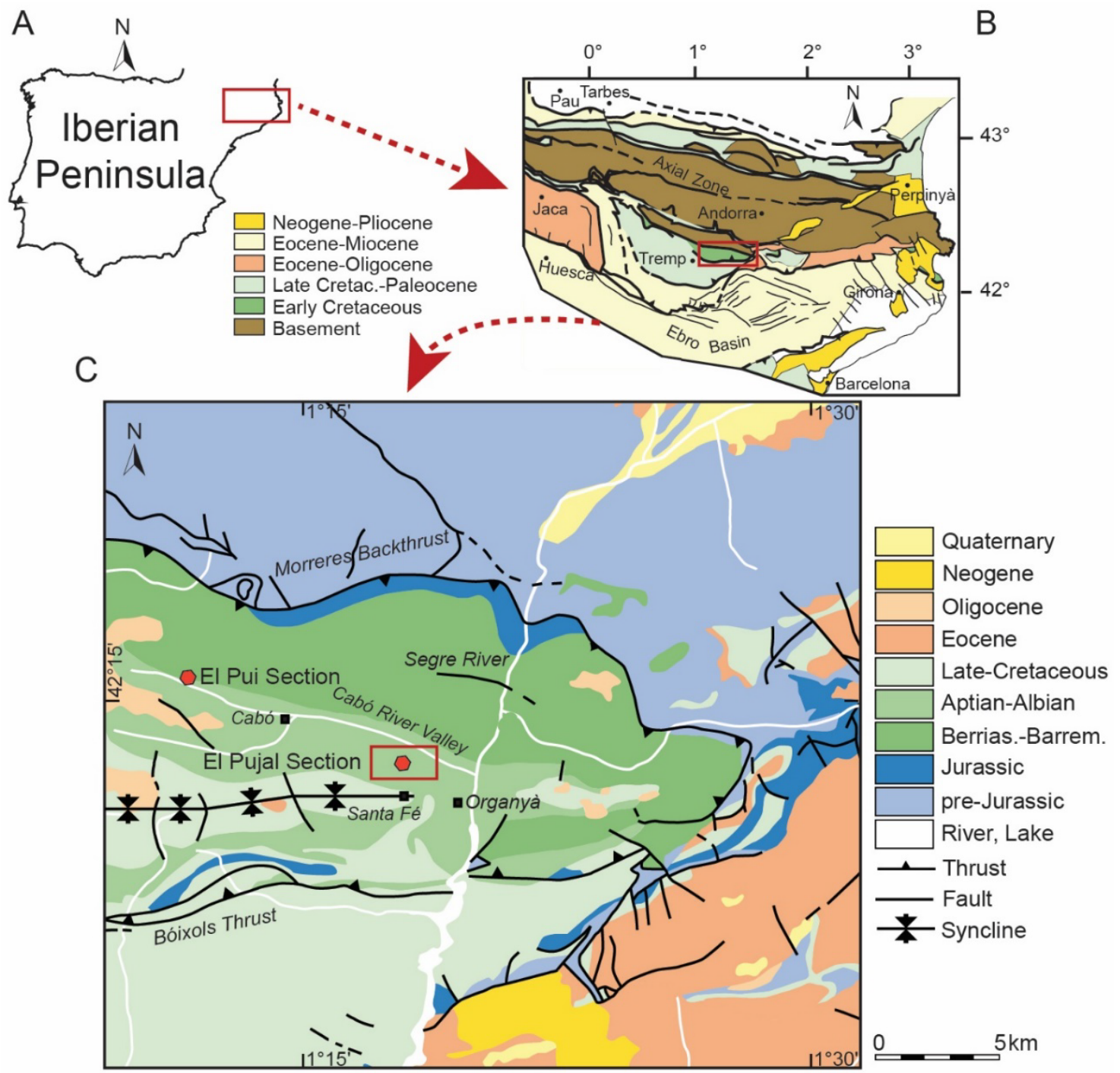

Figure 2-2 A) Location map of the Organyà Basin in the Iberian Peninsula. B) Regional geologic map showing the area of interest. A) and B) modified from Dinarès-Turell and García-Senz (2000). C) Detailed geologic map of the studied area showing the location of the El Pui section (SanchezHernandez et al., 2014; Sanchez-Hernandez and Maurrasse, 2014, 2016) and the El Pujal section. C) Modified from Gong et al. (2009).

Pyrenean zone (Fig. 2-2) (Vergés and Muñoz, 1990; Muñoz, 1992; Vergés and García-

Senz., 2001; García-Senz 2002; Golonka, 2004).

The Organyà Basin forms part of the Central Pyrenean Basin and thus represents one of these extensional depocenters (Berástegui et al., 1990; García-Senz, 2002). During the early Cretaceous, the Basin was located on the northern margin of the Ebro block with an estimated area measuring at least $15 \mathrm{~km}$ wide and about 70-100 km long along its 


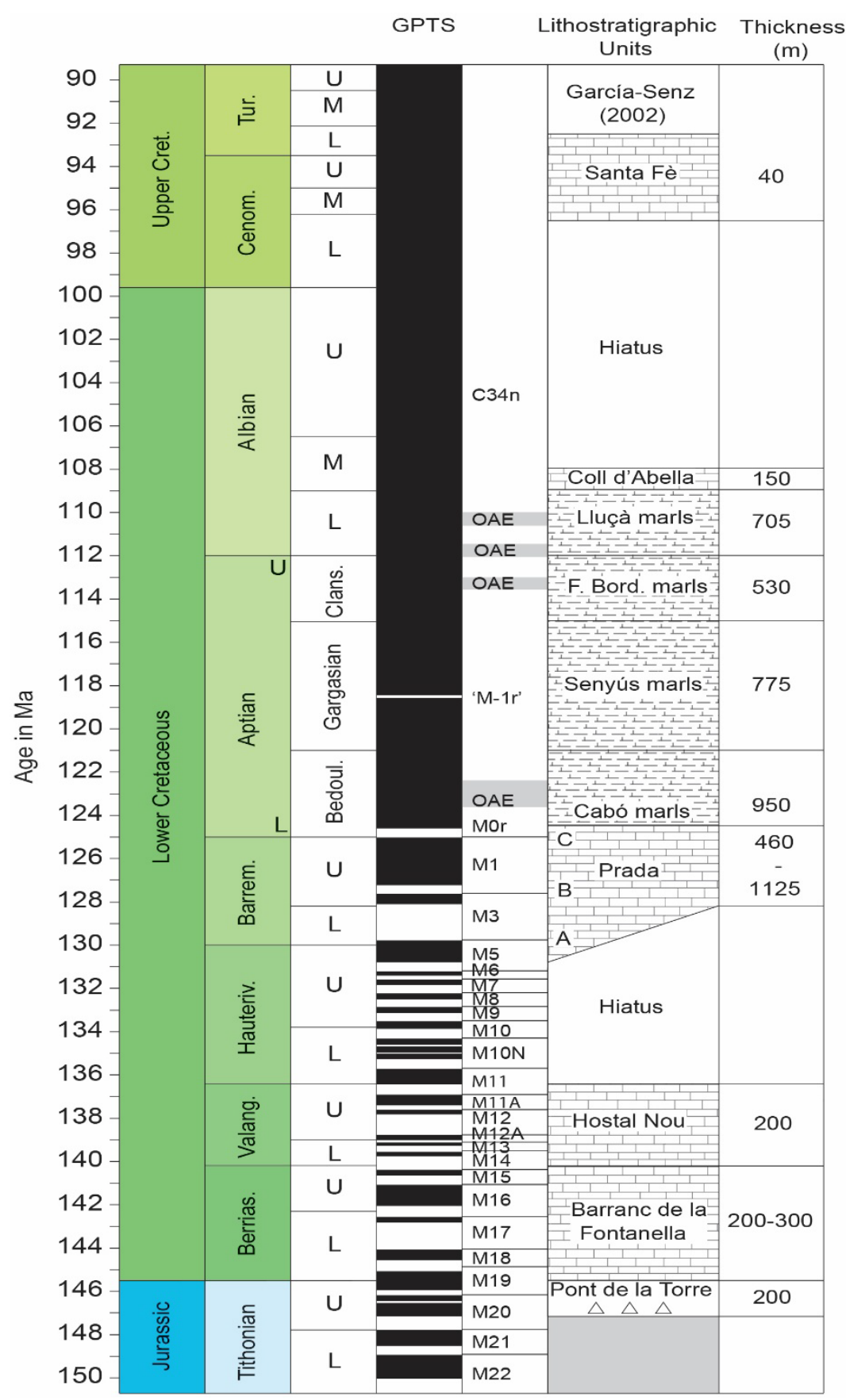

Figure 2-3 Generalized stratigraphic column of the Organyà Basin with geomagnetic polarity time scale (GPTS) after Gradstein et al. (2004) and lithostratigraphic units and formation thicknesses after GarcíaSenz (2002). General figure after Gong et al. (2009).

extensional axis (Dinarès-Turell and García-Senz, 2000; Vacherat et al., 2017). While

relatively small, it accommodated an impressive 4,000 $\mathrm{m}$ sequence consisting of shallow platform carbonates and hemipelagic to pelagic marine sediments (Fig. 2-3) (Berástegui 
et al., 1990; García-Senz, 2002). Sedimentary successions are recorded from the upper Tithonian until the lower Turonian (Fig. 2-3), after which the basin fill was inverted and transported southward above a detachment fault in a compressional phase linked with the Pyrenean orogeny (Vergés and García-Senz., 2001; García-Senz, 2002).

In its present position, the Organyà Basin is part of the South Pyrenean Central Unit (SPCU), which itself is comprised of the Bóixols and Montsec thrust sheets, the Cotiella and Pedraforca nappes and the Sierras Marginales thrust sheets (Seguret 1972; Vergés and Muñoz, 1990; Puigdefäbregas et al., 1992; García-Senz, 2002). Remnants of the Basin outcrop in the hanging wall of the Bóixols thrust system, bounded to the north by the Morreres backthrust (Fig. 2-2C) (García-Senz, 2002; Gong et al., 2009). Along its center, a prominent E-W trending asymmetric syncline (Santa Fé syncline) divides the northern, relatively thick limb from a thinner southern limb (Fig. 2-2C) (Gong et al., 2009).

\subsection{Locations and General Descriptions of the Study Sites}

The investigated sections include the El Pui and El Pujal sections, both of which are located on the northern limb of the Santa Fé syncline, in the municipality of Organyà (Fig. 2-2C). The El Pui section is located at $42^{\circ} 14^{\prime} 36.00^{\prime \prime N}$ and $1^{\circ} 13^{\prime} 33.67^{\prime \prime E}$ on the southern flank of the Sierra de Prada. As described in Sanchez-Hernandez and Maurrasse (2014), erosion by the Cabó River exposes the series of hemipelagic marlstones, organicrich marls and limestones known as the Cabó Formation (García-Senz, 2002) in dip slope topography. The El Pujal composite section, projected to be sequentially continuous with 


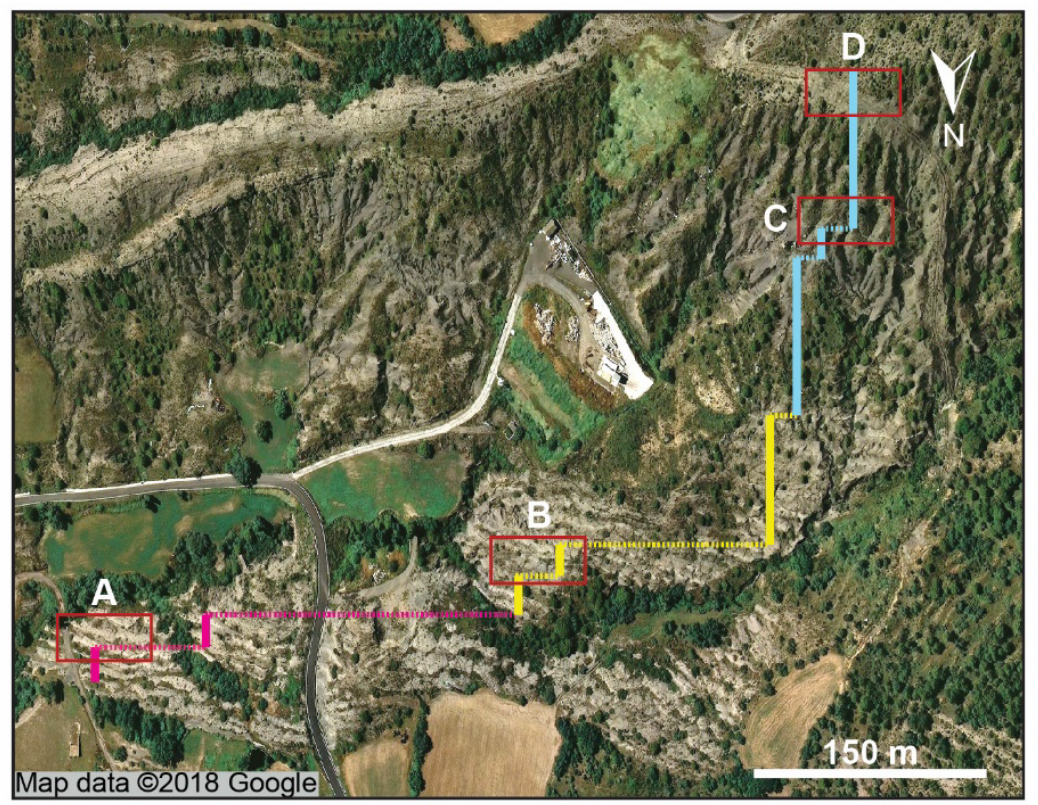

Basal Portion of the El Pujal Section

$\square$ Middle Portion of the El Pujal Section

Uppermost Portion of the El Pujal Section
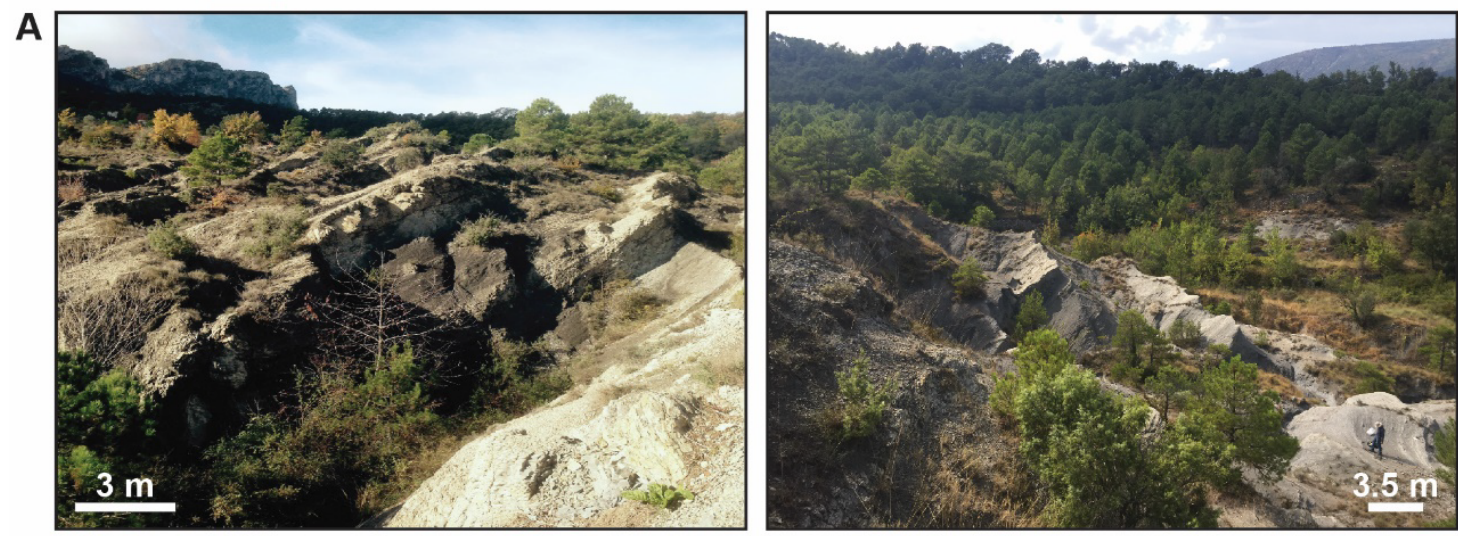

C
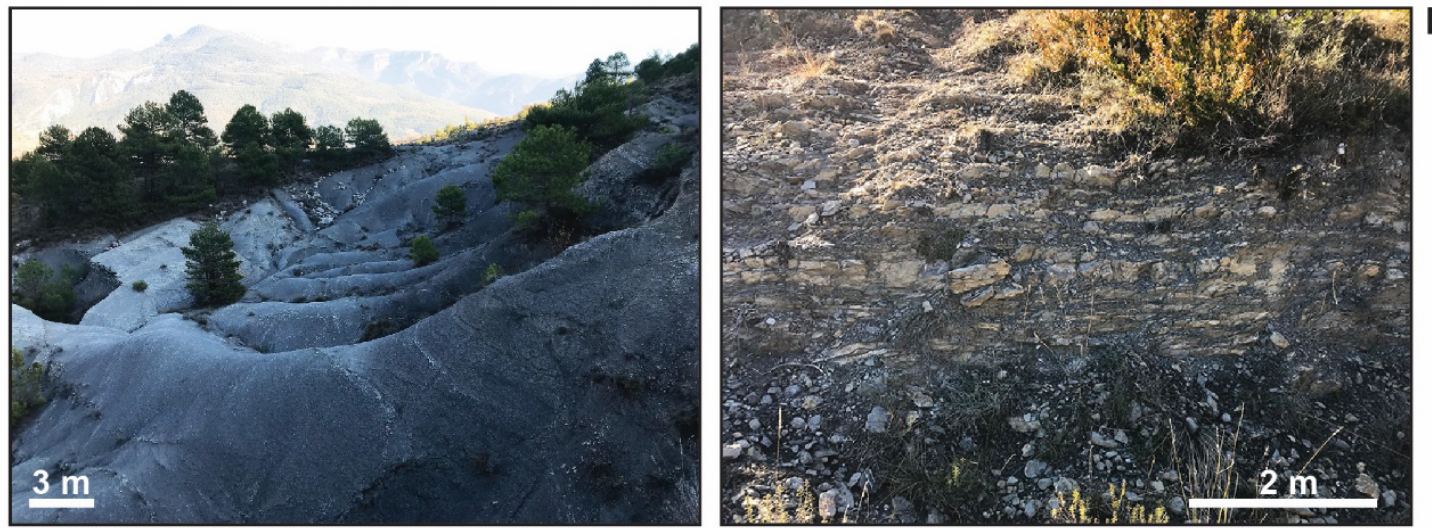

Figure 2-4 Satellite and outcrop images of the entire El Pujal section covered in this study. Red rectangles labeled A, B, C and D correspond to the location where the outcrop photographs were taken.

the El Pui section (Fig. 2-2C), is precisely situated at $42^{\circ} 13^{\prime} 06.15^{\prime \prime} \mathrm{N}$ and $1^{\circ} 18^{\prime} 55.85^{\prime \prime} \mathrm{E}$ 
and consists of the basal $13.77 \mathrm{~m}$-interval (Fig. 2-4), the middle $70.75 \mathrm{~m}$-interval (Fig. 24), and the uppermost 85.82 m-interval (Fig. 2-4). Stratigraphically, the El Pujal sequence is placed within the uppermost Cabo marls that extend $\sim 950 \mathrm{~m}$ within the Aptian (Fig. 23) (García-Senz, 2002). In general, the section includes a continuous and expanded sequence of OM-rich hemipelagic sediments exposed as differentially weathered packets in a scarp slope topography with $\sim 64^{\circ}$ southwest dipping beds that allow exceptionally easy, high-resolution temporal analysis of the succession (Fig. 2-4). The section is well exposed and easily accessible via the Avenida Santa Fé road, which stems from the main town of Organyà.

\subsection{References}

Berástegui, X., Garcia-Senz, J., Losantos, M., 1990. Tecto-sedimentary evolution of the Organyà extensional basin (central south Pyrenean unit, Spain) during the Lower Cretaceous. Bull. la Société géologique Fr. 6, 251-264. https://doi.org/10.2113/gssgfbull.VI.2.251

Choukroune, P., 1992. Tectonic evolution of the Pyrenees. Annu. Rev. Earth Planet. Sci. Vol. 20 20, 143-158. https://doi.org/10.1146/annurev.earth.20.1.143

Dinarès-Turell, J., Garcia-Senz, J., 2000. Remagnetization of Lower Cretaceous limestones from the southern Pyrenees and relation to the Iberian plate geodynamic evolution. J. Geophys. Res. Solid Earth 105, 19405-19418. https://doi.org/10.1029/2000jb900136

García-Senz, J., 2002. Cuencas extensivas del Cretácico inferior en los Pirineos centrales, formación y subsiguiente inversión. Dpt. Geodinàmica i Geofísica 310.

Golonka, J., 2004. Plate tectonic evolution of the southern margin of Eurasia in the Mesozoic and Cenozoic. Tectonophysics 381, 235-273. https://doi.org/10.1016/j.tecto.2002.06.004

Gong, Z., Langereis, C.G., Mullender, T.A.T., 2008. The rotation of Iberia during the Aptian and the opening of the Bay of Biscay. Earth Planet. Sci. Lett. 273, 80-93. https://doi.org/10.1016/j.epsl.2008.06.016 
Gong, Z., van Hinsbergen, D.J.J., Vissers, R.L.M., Dekkers, M.J., 2009. Early Cretaceous syn-rotational extension in the Organyà basin-New constraints on the palinspastic position of Iberia during its rotation. Tectonophysics 473, 312-323. https://doi.org/10.1016/j.tecto.2009.03.003

Gradstein, F.M., Ogg, J.G., Smith, A.G., 2004. A Geologic Time Scale 2004. https://doi.org/10.2277/0521786738

Jammes, S., Manatschal, G., Lavier, L., Masini, E., 2009. Tectonosedimentary evolution related to extreme crustal thinning ahead of a propagating ocean: Example of the western Pyrenees. Tectonics 28. https://doi.org/10.1029/2008TC002406

Montadert, L., de Charpal, O., Roberts, D., Guennoc, P., Sibuet, J., 1979. Northeast Atlantic passive continental margins: rifting and subsidence processes. Deep Drill. results Atl. Ocean Cont. margins Paleoenviron. 3, 154-186.

Montigny, R., Azambre, B., Rossy, M., Thuizat, R., 1986. K-Ar Study of cretaceous magmatism and metamorphism in the pyrenees: Age and length of rotation of the Iiberian Peninsula. Tectonophysics 129, 257-273. https://doi.org/10.1016/00401951(86)90255-6

Muñoz, J.A., 1992. Evolution of a continental collision belt: ECORS-Pyrenees crustal balanced cross-section, in: Thrust Tectonics. pp. 235-246.

https://doi.org/10.1007/978-94-011-3066-0_21

Olivet, J.L., 1996. Kinematics of the Iberian plate, in: Bulletin Des Centres de Recherches Elf Exploration Production. pp. 191-195.

Puigdefäbregas, C., Souquet, P., 1986. Tecto-sedimentary cycles and depositional sequences of the Mesozoic and Tertiary from the Pyrenees. Tectonophysics. https://doi.org/10.1016/0040-1951(86)90251-9

Puigdefäbregas, C., Muñoz, J.A., Vergés, J., 1992. Thrusting and foreland basin evolution in the southern Pyrenees, in: Thrust Tectonics. Springer, pp. 247-254.

Rosenbaum, G., Lister, G.S., Duboz, C., 2002. Relative motions of Africa, Iberia and Europe during Alpine orogeny. Tectonophysics 359, 117-129. https://doi.org/10.1016/S0040-1951(02)00442-0

Seguret, M., 1972. Étude tectonique des nappes et séries décollées de la partie centrale du versant sud des Pyrénées. Pub. Estela, Ser geol. struct. 2, 1-155.

Sibuet, J.C., Collette, B.J., 1991. Triple junctions of Bay of Biscay and North Atlantic: new constraints on the kinematic evolution. Geology 19, 522-525. https://doi.org/10.1130/0091-7613(1991)019<0522:TJOBOB $>2.3 . C O ; 2$ 
Sibuet, J.C., Srivastava, S.P., Spakman, W., 2004. Pyrenean orogeny and plate kinematics. J. Geophys. Res. Solid Earth 109, 1-18.

https://doi.org/10.1029/2003JB002514

Srivastava, S.P., Schouten, H., Roest, W.R., Klitgord, K.D., Kovacs, L.C., Verhoef, J., Macnab, R., 1990. Iberian plate kinematics: A jumping plate boundary between Eurasia and Africa. Nature 344, 756-759. https://doi.org/10.1038/344756a0

Vacherat, A., Mouthereau, F., Pik, R., Huyghe, D., Paquette, J.L., Christophoul, F., Loget, N., Tibari, B., 2017. Rift-to-collision sediment routing in the Pyrenees: A synthesis from sedimentological, geochronological and kinematic constraints. EarthScience Rev. 172, 43-74. https://doi.org/10.1016/j.earscirev.2017.07.004

Van der Voo, R., 1969. Paleomagnetic evidence for the rotation of the Iberian Peninsula. Tectonophysics 7, 5-56. https://doi.org/10.1016/0040-1951(69)90063-8

Verges, J., Muñoz, J.A., 1990. Thrust sequences in the southern central Pyrenees. Bull. Soc. Geol. Fr. 6, 265-271. https://doi.org/10.2113/gssgfbull.vi.2.265

Vergés, J., Fernàndez, M., Martìnez, A., 2002. The Pyrenean orogen: Pre-, syn-, and post-collisional evolution. J. Virtual Explor. 8, 55-74. https://doi.org/10.3809/jvirtex.2002.00058

Vergés, J., García-Senz, J., 2001. Mesozoic evolution and Cainozoic inversion of the Pyrenean rift. Mémoires du Muséum Natl. d'histoire Nat. 186, 187-212.

Vissers, R.L.M., Meijer, P.T., 2012. Mesozoic rotation of Iberia: Subduction in the Pyrenees? Earth-Science Rev. 110, 93-110. https://doi.org/10.1016/j.earscirev.2011.11.001

Williams, C.A., 1975. Sea-floor spreading in the Bay of Biscay and its relationship to the North Atlantic. Earth Planet. Sci. Lett. 24, 440-456. https://doi.org/10.1016/0012821X(75)90151-X 


\section{MATERIALS AND METHODS}

\subsection{Field Sampling}

El Pui section - In 2011, Yosmel Sanchez-Hernandez conducted a field collection of samples analyzed for the El Pui section discussed in Chapter 4 of the dissertation. Sample collection involved systematic bed-by-bed description, including rock colors using the Munsell color system (Goddard et al., 1963), field scale sedimentary and tectonic structures and measurement of bed thickness with a measuring tape (Sanchez-Hernandez, 2014). Samples were taken at least $5 \mathrm{~cm}$ deep from the surface and labeled in continuous numeric order with the year of collection as reference (Sanchez-Hernandez, 2014).

El Pujal section - I carried out sample collection for the El Pujal section over a threeyear period, 2015, 2016, and 2017. The lowermost $13.77 \mathrm{~m}$-interval ( $0 \mathrm{~m}-13.77 \mathrm{~m})$ sampled in 2015 achieved a total sample collection of 42 hand specimens at an average resolution of one sample every $33 \mathrm{~cm}$. The middle $70.75 \mathrm{~m}$-interval $(14.29 \mathrm{~m}-85.04 \mathrm{~m})$ sampled in 2016 achieved a total sample collection of 109 hand specimens at an average resolution of one sample every $65 \mathrm{~cm}$. The uppermost $85.82 \mathrm{~m}$-interval $(86.07 \mathrm{~m}-$ $171.89 \mathrm{~m}$ ) sampled in 2017 achieved a total sample collection of 106 hand specimens at an average resolution of one sample every $81 \mathrm{~cm}$. Samples were collected by targeting apparent beds and by removal of the top $\sim 1 \mathrm{~m}$ surface to ensure collection of unweathered rocks. Samples were systematically labeled with the letter C, indicative of the locality (Cabó), followed by the year of collection and ending with the corresponding continuous numeric order. Bed thickness was measured with a measuring tape and sample positions were recorded in individual photographs for accuracy in determining their stratigraphic positions and as a reference during subsequent analyses. Field-scale 
descriptions included bed geometry, sedimentary and tectonic structures, lithology, and abundance, type and preservation of macrofossils. Field-scale color description of samples is based on the modified Munsell color system as proposed by Goddard et al. (1963).

\subsection{Microscopic Analyses}

\subsubsection{Thin Sections}

At least one thin section per sample was prepared for petrographic analysis. Microscopic analysis of thin sections was conducted using an Olympus BH-2 light transmitting microscope. Selected thin sections were gold (Au) sputter coated using an SPI-MODULE sputter coater and examined using a JEOL JSM 5910LV scanning electron microscope (SEM). Thin section analysis focused on microfacies, mineralogical composition, index fauna identification, bioturbation and presence/absence of benthic fauna and minerals indicative of redox conditions. The micropaleontological analysis for planktonic foraminifera was accomplished primarily using the help of illustrations in the published literature (e.g. Verga and Premoli-Silva, 2002; Heldt et al., 2008; Moullade et al., 2015). Visual estimates of allochems follow Shvetsov's proposed percentage diagrams as summarized by Terry and Chilingarian. (1955). Color description of thin sections used the modified Munsell color system proposed by Goddard et al. (1963). A bioturbation index was assigned to each sample following the proposed scheme in Taylor and Goldring (1993). In addition, the benthic fauna, focusing on benthic foraminifera and echinoid fragments was counted in samples; the total counts were divided by the area of each thin section and are expressed as density $(\rho)$ or number of specimens per $\mathrm{cm}^{2}$. In addition, certain samples (refer to Chapter 7) were selected to be counted for the ratio 
between planktonic and benthic foraminifera as a tool to estimate paleodepths. The ratio is expressed as the percentage of planktonic foraminifera or $\% \mathrm{P}$ and depth is calculated using the relationship between bathymetry and $\% \mathrm{P}$ as proposed by van der Zwaan et al. (1990):

$$
\operatorname{Depth}(\mathrm{m})=\mathrm{e}^{(3.58718+(0.03534 * \% \mathrm{P}))}
$$

The $\% \mathrm{P}$ is the percentage planktonics in the total foraminiferal association, calculated as $100 * \mathrm{P} /(\mathrm{P}+\mathrm{B})$, where $\mathrm{P}$ is the number of planktonic individuals and $\mathrm{B}$ is the number of benthic individuals.

\subsubsection{Smear Slides}

Smear slides were prepared for various samples to test for the presence of calcareous nannofossils (refer to Chapters 4 and 5). Samples were prepared by placing a drop of deionized water (DI) on a clean glass slide and using a wood toothpick, a small amount of sample material was placed on the drop of water and smeared on the slide. The slide was placed on a hot plate at $70^{\circ} \mathrm{C}$ until all of the water was evaporated and only a barely visible veneer of sample was left behind. Afterwards, two drops of epoxy were placed on top of the sediment veneer, avoiding contact with the slide to prevent contamination. A cover slip was placed on the slide and then the slide was transferred to cure at $70^{\circ} \mathrm{C}$ for $30 \mathrm{~min}$. Once completed, smear slides were examined using an Olympus BH-2 light transmitting microscope.

\subsubsection{Micropaleontological Work}

Small cubes $(2.5 \mathrm{~cm} \times 2.5 \mathrm{~cm})$ from selected samples (see Chapter 5) were placed in a $30 \%$ solution of acetic acid $\left(\mathrm{CH}_{3} \mathrm{COOH}\right)$ and left for approximately 24 hrs or until they completely disaggregated. The residue was washed through $150 \mu \mathrm{m}, 63 \mu \mathrm{m}$, and 38 
$\mu \mathrm{m}$ filters and mounted on slides. Slides with mounted specimens were examined using a Wild Heerbrugg binocular reflective light microscope. Some specimens were picked, Au sputter coated, and examined under the SEM.

\subsection{Geochemical Analyses}

\subsubsection{Sample Powdering Procedure}

To prepare the samples for geochemical analyses, they were cut using a wet diamond-cutting saw into $1 \mathrm{~cm} \times 1 \mathrm{~cm}$ cubical pieces, making sure to remove any visible surface weathering and then placed in an oven at $60^{\circ} \mathrm{C}$ to dry overnight ( $\left.\sim 12 \mathrm{hrs}\right)$. Following that, samples were ground to a fine powder and placed in sealed glass vials. To prevent cross contamination of samples the mill's chamber was cleaned with DI water, wiped with a Kimwipe and acetone then air-dried using compressed air.

\subsubsection{Total Carbon/Carbonate/Organic - TC/TIC/TOC}

Samples were analyzed using a LECO CR-412 carbon analyzer following the methodology proposed by Gaona-Narvaez et al. (2013), Sanchez-Hernandez and Maurrasse (2014) and modified as proposed by Socorro and Maurrasse (2019). The LECO CR-412 instrument uses an infrared cell to measure the total $\mathrm{CO}_{2}$ produced by the combustion at $1450 \pm 2 \mathrm{C}^{\circ}$ of $0.3000 \mathrm{~g}$ of a powdered rock sample (Gaona-Narvaez et al., 2013). Calibration of the instrument was performed by producing a 15-point, best-fit calibration curve $(0.0500 \mathrm{~g}, 0.0700 \mathrm{~g}, 0.1000 \mathrm{~g}, 0.1200 \mathrm{~g}, 0.1500 \mathrm{~g}, 0.1700 \mathrm{~g}, 0.2000 \mathrm{~g}$, $0.2200 \mathrm{~g}, 0.2500 \mathrm{~g}, 0.2700 \mathrm{~g}, 0.3000 \mathrm{~g}, 0.3200 \mathrm{~g}, 0.3500 \mathrm{~g}, 0.3700 \mathrm{~g}, 0.4000 \mathrm{~g})$ using pure calcite $\geq 99.0 \%$ (C64-500, Fisher Scientific)(Sanchez-Hernandez and Maurrasse, 2014). Accuracy of the instrument was verified by analyzing reference standard materials (Dolomitic Limestone NIST 88b, Calcite C64-500). To obtain TC measurements, 
$0.3000 \mathrm{~g}$ of powdered sample material was weighed out and processed in the carbon analyzer. To obtain TIC measurements, $0.3000 \mathrm{~g}$ of powdered sample material was weighed out, placed in a furnace at $560^{\circ} \mathrm{C}$ for $2 \mathrm{hrs}$ to remove the organic portion of the sample, and then processed in the carbon analyzer. The TIC results are expressed as $\mathrm{CaCO}_{3} \%$. TOC is then determined by subtracting (TC-TIC), but since the analyzer reports the results as $\mathrm{CaCO}_{3} \%$ the difference is also divided by 8.33 , which is the molecular weight of $\mathrm{CaCO}_{3}$ divided by the molecular weight of carbon (100.086/12.011). Hence, the results for TOC are reported as $\mathrm{C} w \mathrm{w} \%$.

\subsubsection{Stable Carbon Isotopes $\left(\delta^{13} C_{\text {org }}\right)$}

Approximately $1 \mathrm{~g}$ of powdered sample material was placed in a previously cleaned (combusted at $560^{\circ} \mathrm{C}$ for $2 \mathrm{hrs}$ ), 12-dram vial and treated with $10 \%$ hydrochloric acid $(\mathrm{HCl})$ to remove the inorganic carbon $\left(\mathrm{CaCO}_{3}\right)$. The sample was centrifuged, and the supernatant removed. The process was repeated until no carbonate reaction was visible. Subsequently, the sample was vortexed three to five times with DI water, centrifuged for 5 mins and the supernatant removed. This process was repeated until the supernatant reached a $\mathrm{pH}$ of $\sim 7$. The sample was then put in an oven to dry at $60^{\circ} \mathrm{C}$, and then homogenized into a powder using an agate mortar and pestle. The homogenized and dried sample was then placed in a vial, ready for the isotopic analysis. The $\delta^{13} \mathrm{C}_{\text {org }}$ values of the samples were measured using an elemental analyzer isotope ratio mass spectrometer (EA-IRMS). Values are expressed on a per mil (\%) basis relative to the Vienna Peedee Belemnite standard (VPDB). 


\subsubsection{Major and Redox-Sensitive Trace Elements}

The preparation and calibration outlined here follows the rapid and sensitive method developed for routine analysis of trace elements on sediments and soils proposed by Arroyo et al. (2009). One gram (1.0000g) of previously powdered sample material was weighed out in a polypropylene snap cap tube and spiked with two standard solutions, $350 \mu \mathrm{L}[1000 \mathrm{ppm}]$ scandium oxide and $300 \mu \mathrm{L}$ [1000 ppm] indium metal. The tubes were vortexed for $1 \mathrm{~min}$ and left to dry for $48 \mathrm{hrs}$ at $80^{\circ} \mathrm{C}$. Once dried the samples were powdered and homogenized once again using a tungsten ball-mill for $30 \mathrm{~min}$, and pressed into pellets using a hydraulic press. Pellets were analyzed using Laser AblationInductively Coupled Plasma Mass Spectrometry (LA-ICP-MS) at the FIU Trace Evidence Analysis Facility (TEAF) using a quadrupole ELAN DRC II (Perkin Elmer LAS) in the standard operation mode. Sample ablation was achieved using a $266 \mathrm{~nm} \mathrm{Nd-}$ YAG laser (LSX 500, CETAC) with a $200 \mu \mathrm{m}$ spot size and $10 \mathrm{~Hz}$. The same pellet was ablated four times in different locations and the raw data integrated using the Glitter software. Analytical performance of the method was evaluated by running three standard reference materials (NIST2710, PACS-2, NIST2704) at the start, every 10 samples, and at the end of the analysis.

\subsubsection{Biomarkers: n-Alkanes}

Before commencing, all of the lab glassware was washed with tap water and soap, then rinsed three times with DI water and heated in the oven at $560^{\circ} \mathrm{C}$ for $2 \mathrm{hrs}$. Five grams $(5 \mathrm{~g})$ of powdered sample material was weighed out, transferred to a mortar and pestle, and further homogenized. The $5 \mathrm{~g}$ of homogenized sample was transferred to a $12-$ dram vial with the addition of a $10 \mathrm{ml}$ mixture of (1:9) methanol 
$(\mathrm{MeOH}) /$ dichloromethane $(\mathrm{DCM})$. The vial was sonicated for 30 mins and then centrifuged for 10 mins until the supernatant completely separated from the pellet. The supernatant was then transferred to a 4-dram vial and $10 \mathrm{ml}$ of fresh 1:9 MeOH/DCM was again added to the 12-dram vial and the mixture sonicated a second time for 30 mins. The cloudy mixture was centrifuged for 10 mins and the supernatant was pipetted out and combined with the first extract in a 4-dram vial and labeled as total lipid extract (TLE). Activated copper was added to the TLE vial to remove any elemental sulfur. The copper was activated by placing it in $10 \% \mathrm{HCl}$ until it reached its peculiar bright color and then washed 3 times with DI water and 3 more times with DCM. The copper was left in the TLE until it turned completely black $\sim 3-4$ hrs and then it was removed. The TLE was concentrated by evaporation until almost dry, and then $\sim 12$ drops of hexane were added. Following that, a glass pipette was plugged with pre-combusted $\left(560^{\circ} \mathrm{C}\right.$ for $\left.2 \mathrm{hrs}\right)$ glass wool, filled with $0.5 \mathrm{~g}$ of $230-400$ mesh silica gel, and conditioned with $6 \mathrm{ml}$ of hexane. The TLE was mounted on the column and eluted with $4 \mathrm{ml}$ of hexane to collect fraction F1 containing the aliphatic components ( $n$-alkanes).

The samples were analyzed at the FIU Advanced Mass Spectrometry Facility. Separations were achieved by gas chromatography (GC) (Agilent 6890), using method 1506GEO2. M. A volume of $5 \mu \mathrm{L}$ of each sample was injected in split-less mode. Injector temperature was set at $280^{\circ} \mathrm{C}$ and temperature program was as follows: hold at $65^{\circ} \mathrm{C}$ for 2 mins, increase to $300^{\circ} \mathrm{C}$ at a rate of $4^{\circ} \mathrm{C} / \mathrm{min}$, and hold at $300^{\circ} \mathrm{C}$ for 8 mins. Detection was performed by a single quadrupole mass spectrometer (MS) (Agilent 5973) operating in positive mode electron impact ionization (EI+). Scan range was from $\mathrm{m} / \mathrm{z} 42$ to $\mathrm{m} / \mathrm{z} 500$ and a solvent delay time of 4 mins. 


\subsubsection{Biomarkers: Hopanes and Steranes - GC/MS}

Selected samples (refer to Chapter 6) were further purified for the analysis of hopanes and steranes through the removal of $n$-alkanes. The $n$-alkanes were isolated from the branched and cyclic hydrocarbons using urea adduction. For this, an aliquot from the aliphatic fraction (F1) (refer to section 3.3.6 for extraction and separation) was combined in a ratio of 2:1 hexane/acetone ( $4 \mathrm{ml}$ hexane/ $2 \mathrm{ml}$ acetone) in a previously cleaned (combusted at $560^{\circ} \mathrm{C}$ for $2 \mathrm{hrs}$ ) 11 -dram vial. To this, $2 \mathrm{ml}$ of a urea saturated methanol $(\mathrm{MeOH})$ solution was added drop-wise. The saturated urea $\mathrm{MeOH}$ solution was prepared by dissolving $16.6 \mathrm{~g}$ of urea in $100 \mathrm{ml}$ of $\mathrm{MeOH}$ at $60^{\circ} \mathrm{C}$. The dropwise addition of the urea saturated $\mathrm{MeOH}$ solution resulted in the immediate precipitation of white urea crystals. The mixture was allowed to settle overnight and then centrifuged at 2,000 rpm for $5 \mathrm{~min}$ to separate the non-adduct fraction from the urea crystals. The non-adduct fraction was collected and stored in a second 11-dram vial. The dry urea crystals were then washed with $3 \mathrm{ml}$ of a 2:1 hexane/acetone solution and the resulting non-adduct solution was combined with the original non-adduct fraction. The urea adduction procedure was repeated three times on the non-adduct fraction to ensure that all the $n$ alkanes were removed. At the end, the non-adduct fractions containing branched and cyclic hydrocarbons (including hopanes and steranes) were combined and evaporated to $1 \mathrm{ml}$ before GC/MS analysis.

Analysis of the non-adduct fraction focused on hopanes and steranes and was conducted at the FIU Advanced Mass Spectrometry Facility. Separation was performed using an Agilent 6890 GC equipped with an UI HP-5MS UI $30 \mathrm{~m}, 0.250 \mathrm{~mm}, 0.25 \mu \mathrm{m}$, capillary column. Injections $(5 \mu \mathrm{L})$ were performed in split-less mode with an injector 
temperature of $280^{\circ} \mathrm{C}$. The oven temperature program was set to hold at $65^{\circ} \mathrm{C}$ for $2 \mathrm{~min}$. Then ramped to $300^{\circ} \mathrm{C}$ at a rate of $4^{\circ} \mathrm{C} / \mathrm{min}$ and hold at $300^{\circ} \mathrm{C}$ for $8 \mathrm{~min}$. Detection was performed by using a single quadrupole mass spectrometer (Agilent 5973) operating in EI+ mode. The instrument was operated in selective ion monitoring (SIM) with a dwell time of $40 \mathrm{~ms}$ and a solvent delay time of $4 \mathrm{~min}$. Identification of analytes was achieved on the basis of comparison of published retention times and mass spectra (Watson et al., 2000; Peters et al., 2005, 2007).

\subsubsection{Biomarkers: Hopanes and Steranes - GC-MS/MS}

Selected samples (refer to Chapter 7) were analyzed for hopanes and steranes.

Extraction and separation followed the methodology outlined in section 3.3.5

"Biomarkers: $n$-alkanes". The separated aliphatic fraction (F1) was concentrated down to $1 \mathrm{ml}$ and stored at $4{ }^{\circ} \mathrm{C}$ in amber vials before analysis.

The analysis was conducted at the FIU Advanced Mass Spectrometry Facility using a Bruker EvoQ GC triple quadrupole (TQ) MS in metastable reaction monitoring (MRM) mode (MRM-GC-MS/MS). A $1 \mu \mathrm{L}$ volume of each sample was injected in split-less mode through an HP-5MS $60 \mathrm{~m}, 0.25 \mathrm{~mm}, 0.25 \mu \mathrm{m}$, capillary column. The injector temperature was set at $260^{\circ} \mathrm{C}$ and the oven was programmed from $65^{\circ} \mathrm{C}$ for $2 \mathrm{~min}$, followed by a temperate ramp of $4^{\circ} \mathrm{C} / \mathrm{min}$ up to $310^{\circ} \mathrm{C}$ and held isothermally for $10 \mathrm{~min}$. Metastable transitions of $\mathrm{C}_{27}, \mathrm{C}_{28}, \mathrm{C}_{29}, \mathrm{C}_{30}, \mathrm{C}_{31}, \mathrm{C}_{32}, \mathrm{C}_{33}, \mathrm{C}_{34}$ and $\mathrm{C}_{35}$ hopanes included m/z: $370 \rightarrow 191(370.40 \rightarrow 191), 384 \rightarrow 191(384.40 \rightarrow 191), 398 \rightarrow 191(398.4 \rightarrow 191)$, $412 \rightarrow 191(412.40 \rightarrow 191), 426 \rightarrow 191(426.40 \rightarrow 191), 440 \rightarrow 191(440.40 \rightarrow 191), 454 \rightarrow 191$ $(454.50 \rightarrow 191), 468 \rightarrow 191(468.50 \rightarrow 191)$, and $482 \rightarrow 191(482.50 \rightarrow 191)$, respectively. Metastable transition of $\mathrm{C}_{27}, \mathrm{C}_{28}, \mathrm{C}_{29}, \mathrm{C}_{30}$ steranes included $\mathrm{m} / \mathrm{z}: 372 \rightarrow 217$ 
$(372.40 \rightarrow 217), 386 \rightarrow 217(386.40 \rightarrow 217), 400 \rightarrow 217(400.40 \rightarrow 217)$, and $414 \rightarrow 217$

(414.40 $\rightarrow 217)$, respectively. The compounds were identified by comparing retention times and elution patterns with GC-MS/MS results from literature references (Peters et al., 2005, 2007; Ahmed et al 2013).

\subsubsection{Biomarkers: Polycyclic Aromatic Hydrocarbons (PAHs)}

Particular samples (refer to Chapter 6) were chosen for quantification of polycyclic aromatic hydrocarbons (PAHs). Certified deuterated surrogate PAH mixture (Z-014J$0.5 \mathrm{x}$ ), p-Terphenyl-d14 internal standard (M-525-FS-2) and perylene standard solution (H-121S) were purchased from AccuStandard (New Haven, CT, USA). Additional standard mixture EPA 525 PAH Mix A and PAH Mix CRM47543 were purchased from Sigma-Aldrich (St. Louis, Mo, USA). Standard solutions were refrigerated at $4^{\circ} \mathrm{C}$ until needed.

Exactly $5.0000 \mathrm{~g}$ (dry weight) of each powdered sample was weighed and transferred to a cleaned (combusted at $560^{\circ} \mathrm{C}$ for $2 \mathrm{hrs}$ ) 11 -dram vial. To validate the extraction method and efficiency, $100 \mu \mathrm{L}$ of the diluted $(1 \mathrm{ng} / \mu \mathrm{L})$ deuterated surrogate PAH mixture (acenaphthene-d10, chrysene-d12, perylene-d12, phenanthrene-d10) was added to each vial prior to solvent extraction. Then, $10 \mathrm{ml}$ of a 1:9 mixture of $\mathrm{MeOH}$ to DCM was added to each vial and sonicated for $30 \mathrm{~min}$. Each sample was then centrifuged at 2,000 rpm for $10 \mathrm{~min}$ and the sediment-free supernatant transferred to a 4-dram vial. The latter process was repeated with $10 \mathrm{ml}$ 1:9 MeOH/DCM fresh solvent and the extracts combined in the 4-dram vial. Following the extraction, activated copper was added to each extract until the copper turned a black color ( $\sim 3-4 \mathrm{hrs})$, signifying complete reaction with elemental sulfur after which it was removed. The copper was 
activated by placing it in $10 \%$ hydrochloric acid $(\mathrm{HCl})$ solution for approximately $5 \mathrm{~min}$ and then washed three times with DI water and three more times with DCM. The total extracts were concentrated by evaporation until almost dry and then solvent-exchanged with $1 \mathrm{ml}$ of hexane. Separation of the aliphatic fraction (F1) from the aromatic fraction (F2) was achieved using a silica gel-packed glass pipette, first eluted with $4 \mathrm{ml}$ of hexane to remove the aliphatic components (F1) and subsequently eluted with $4 \mathrm{ml}$ of DCM (F2). The second fraction (F2) containing the targeted PAHs was evaporated until almost dry and re-dissolved in $100 \mu \mathrm{L}$ of DCM containing the internal standard, $\mathrm{p}$-Terphenyld14 (1 ng/ $\mu \mathrm{L})$. In addition, for quality control purposes, 3 additional samples were prepared following the previous procedure: A method blank containing only the deuterated surrogate $\mathrm{PAH}$ mixture $(1 \mathrm{ng} / \mu \mathrm{L})$, a fortified blank containing the deuterated surrogate PAH mixture $(1 \mathrm{ng} / \mu \mathrm{L})$ and the targeted PAH standards $(1 \mathrm{ng} / \mu \mathrm{L})$ and a fortified sample containing a powdered sample, the deuterated surrogate PAH mixture (1 $\mathrm{ng} / \mu \mathrm{L})$ and the targeted PAH standards $(1 \mathrm{ng} / \mu \mathrm{L})$.

The PAH analyses were conducted at the FIU Advanced Mass Spectrometry Facility. Sample injection and GC separation were performed by an Agilent 6890 gas chromatograph equipped with an autosampler and an HP-5MS UI $30 \mathrm{~m}, 0.250 \mathrm{~mm}, 0.25$ $\mu \mathrm{m}$, capillary column using Ultra-pure 6.0 helium as the carrier gas maintained at a constant flow of $1 \mathrm{~mL} / \mathrm{min}$. The sample was introduced in splitless mode with a purge time of $1 \mathrm{~min}$. The oven temperature was maintained at $70{ }^{\circ} \mathrm{C}$ for $2 \mathrm{~min}$ and then programmed to increase to $150{ }^{\circ} \mathrm{C}$ at $30^{\circ} \mathrm{C} / \mathrm{min}$ and then to $310{ }^{\circ} \mathrm{C}$ at $4{ }^{\circ} \mathrm{C} / \mathrm{min}$, where it was held isothermally for $10 \mathrm{~min}$. Detection was performed by a single-quadrupole mass spectrometer (Agilent 5973) using EI+ mode. The mass spectrometer was operated under 
selective ion monitoring (SIM) mode with two or three ions per target PAH or deuterated PAH. A calibration curve was prepared by serially diluting the standard solutions to prepare 6 calibration standards of increasing concentrations: $25 \mu \mathrm{g} / \mathrm{L}, 50 \mu \mathrm{g} / \mathrm{L}, 100 \mu \mathrm{g} / \mathrm{L}$, $500 \mu \mathrm{g} / \mathrm{L}, 1000 \mathrm{ug} / \mathrm{L}, 3000 \mu \mathrm{g} / \mathrm{L}$. The internal standard, p-Terphenyl-d14 was introduced by serially diluting the stock solution to yield a concentration of $1000 \mathrm{ug} / \mathrm{L}$. The obtained quadratic calibration equations (all $\mathrm{R}^{2}>0.99$ ) were then used to quantify the unknown samples. Concentrations are reported in nanograms per gram of initial dry weight (5.0000 g) powdered-rock $(\mathrm{ng} / \mathrm{g} \mathrm{dw})$. The serially diluted EPA $525 \mathrm{PAH}$ Mix A was used as an initial calibration verification standard (ICVS), allowing a percent recovery ranging from $80-120 \%$.

\subsubsection{Clay Mineral Analysis ( $<2 \mu \mathrm{m}$ Fraction)}

Specific samples (refer to Chapters 6 and 7) were selected to be analyzed for their clay mineral components. The X-ray diffraction (XRD) analysis of samples was performed at the Illinois State Geological Survey (ISGS) within the Geochemistry Section, Prairie Research Institute, University of Illinois. Samples were gently ground, sieved and the $<250-\mu \mathrm{m}$ fraction was collected. Subsequently, $15 \mathrm{~g}$ of the sample was dispersed in $100 \mathrm{ml}$ DI water for $24 \mathrm{hrs}$. The next day the sample was transferred to a mixer and mixed for one minute. The suspension was then poured back into the beaker and allowed to settle overnight. The next day, one-third of the clear supernatant was poured off and fresh DI water was added. Two drops of dispersant (sodium hexametaphosphate) were added to the suspension and stirred for one minute. After 15 mins, the suspension was transferred on to a glass slide using an eyedropper and dried overnight. All slides were then saturated using ethylene glycol vapors for $48 \mathrm{hrs}$. The 
oriented and glycolated clay slides were analyzed with a Scintag® XDS2000 diffractometer. Step-scanned data were collected from $2^{\circ}$ to $34^{\circ} 2 \theta$ with a fixed rate of $2^{\circ}$ per minute with a step size of $0.05^{\circ} 2 \theta$ for each sample. All resulting traces were analyzed using the semi-quantitative data reduction software from Materials Data Inc. (MDI) known as Jade+ ${ }^{\circledR}$.

\subsubsection{Bulk Mineral Analysis}

Samples for bulk mineral analysis (refer to Chapter 7) were prepared and analyzed via X-ray diffraction (XRD) method at the Illinois State Geological Survey in the Prairie Research Institute of the University of Illinois. For the analysis, samples were micronized with DI water for $10 \mathrm{~min}$ in a McCrone micronizing mill. To remove the majority of the DI water, the samples were transferred to $50 \mathrm{ml}$ tubes and centrifuged for $20 \mathrm{~min}$ at 2000 rpm, after which the clear supernatant was poured off. The remaining sample was dried overnight at $40^{\circ} \mathrm{C}$, homogenized with a mortar and pestle and packed into an end-loading sample holder as a random powder bulk-pack. The prepared samples were analyzed on a Scintag XDS2000 diffractometer with data collection set from $2^{\circ}$ to $60^{\circ} 2 \theta$ with a fixed time of 5 seconds per $0.05^{\circ} 2 \theta$ for each sample. The intensity of the identified mineral phases including quartz, potassium feldspar (K-feldspar), plagioclase feldspar (Pfeldspar), calcite, dolomite, siderite, pyrite/marcasite and bulk clay were analyzed using the semi-quantitative data reduction software Jade+ and reported as relative percent.

\subsection{References}

Ahmed, S. Gong, D. Fuentes, S. Sestak, F. Theobald, K.D., 2013. Molecular Characterisation of Petroleum. Thermo Scientific CSIRO Application Note 30263.

Arroyo, L., Trejos, T., Gardinali, P.R., Almirall, J.R., 2009. Optimization and validation of a Laser Ablation Inductively Coupled Plasma Mass Spectrometry method for the 
routine analysis of soils and sediments. Spectrochim. Acta - Part B At. Spectrosc. 64, 16-25. https://doi.org/10.1016/j.sab.2008.10.027

Gaona-Narvaez, T., Maurrasse, F.J.-M.R., Etayo-Serna, F., 2013. Geochemistry, palaeoenvironments and timing of Aptian organic-rich beds of the Paja Formation (Curití, Eastern Cordillera, Colombia). Geol. Soc. London, Spec. Publ. 382, 31-48. https://doi.org/10.1144/SP382.6

Goddard, E.N., Trask, P.D., De Ford, R.K., Rove, O.N., Singewald, J.T., Overbeck, R.M., 1963. Rock-Color Chart. Geological Society of America, Colorado.

Heldt, M., Bachmann, M., Lehmann, J., 2008. Microfacies, biostratigraphy, and geochemistry of the hemipelagic Barremian-Aptian in north-central Tunisia: Influence of the OAE 1a on the southern Tethys margin. Palaeogeogr. Palaeoclimatol. Palaeoecol. 261, 246-260. https://doi.org/10.1016/j.palaeo.2008.01.013

Moullade, M., Tronchetti, G., Granier, B., Bornemann, A., Kuhnt, W., Lorenzen, J., 2015. High-resolution integrated stratigraphy of the OAE1a and enclosing strata from core drillings in the Bedoulian stratotype (Roquefort-La Bédoule, SE France). Cretac. Res. 56, 119-140. https://doi.org/10.1016/J.CRETRES.2015.03.004

Peters, K.E., Walters, C.C., Meldovan, J.M., 2005. The Biomarker Guide, Volume 1: Biomarkers and Isotopes in the Environment and Human History, Cambridge University Press. Cambridge University Press, New York. https://doi.org/10.1016/0146-6380(93)90028-A

Peters, K.E., Walters, C.C., Moldowan, J.M., 2005. The Biomarker Guide:Biomarkers and Isotopes in Petroleum and Earth History, 2nd ed, Cambridge: Cambridge University Press. Cambridge University Press, New York.

Sanchez-Hernandez, Y., 2014. Paleoenvironments and geochemical signals from the late Barremian to the middle Aptian in a Tethyan marginal basin, northeast Spain: Implications for carbon sequestration in restricted basins. Florida International University.

Sanchez-Hernandez, Y., Maurrasse, F.J.M.R., 2014. Geochemical characterization and redox signals from the latest Barremian to the earliest Aptian in a restricted marine basin: El Pui section, Organyà Basin, south-central Pyrenees. Chem. Geol. 372, 12 31. https://doi.org/10.1016/j.chemgeo.2014.02.011

Socorro, J., Maurrasse, F.J.M.R., 2019. Continuous accumulation of organic matter-rich sediments associated with Oceanic Anoxic Event 1a in the El Pujal section, Organyà Basin, Catalunyà Spain and its relation to episodic dysoxia. Cretac. Res. 95, 225251. https://doi.org/10.1016/j.cretres.2018.11.009 
Taylor, A.M., Goldring, R., 1993. Description and analysis of bioturbation and ichnofabric. J. Geol. Soc. London. 150, 141-148.

https://doi.org/10.1144/gsjgs.150.1.0141

Terry, R.D., Chilingar, G. V., 1955. Summary of "Concerning some additional aids in studying sedimentary formations,” by M. S. Shvetsov. J. Sediment. Res. 25, 229234. https://doi.org/10.1306/74D70466-2B21-11D7-8648000102C1865D

van der Zwaan, G.., Jorissen, F.., de Stigter, H.., 1990. The depth dependency of planktonic/benthic foraminiferal ratios: Constraints and applications. Mar. Geol. 95, 1-16. https://doi.org/10.1016/0025-3227(90)90016-D

Verga, D., Premoli Silva, I., 2002. Early Cretaceous planktonic foraminifera from the Tethys: The genus Leupoldina. Cretac. Res. 23, 189-212. https://doi.org/10.1006/cres.2002.0309

Watson, D.F., Hindle, A.D., Farrimond, P., 2000. Organic geochemistry of petroleum seepages within the Jurassic Bencliff Grit, Osmington Mills, Dorset, UK. Pet. Geosci. 6, 289-297. 


\title{
4 CHARACTERIZATION OF THE NEGATIVE CARBON ISOTOPE SHIFT IN SEGMENT C2, ITS GLOBAL IMPLICATIONS AS A HARBINGER OF OAE1A
}

\section{Socorro, J., Maurrasse, F.J-M.R., Sanchez-Hernandez, Y., 2017. Characterization of the negative carbon isotope shift in segment $\mathrm{C} 2$, its global implications as a harbinger of OAE1a. Science China Earth Sciences https://doi.org/10.1007/s11430-016-0092-5}

\begin{abstract}
Lower Cretaceous C-isotope records show intermittent negative/positive spikes, and consistent patterns of coeval chemostratigraphic curves thus document shifts that signal simultaneous responses of temporal changes in the global carbon reservoir. The standard pattern registered by the $\delta^{13} \mathrm{C}_{\text {org }}$ and $\delta^{13} \mathrm{C}_{\text {carb }}$ in Lower Aptian sediments includes distinct isotope segments C1 to C8 (Menegatti et al., 1998). In the El Pui section, Organyà Basin, Spain, C-isotope segment C2 is the longest interval preceding segments C3 - C6 associated with oceanic anoxic event 1a (OAE1a), and reveals a distinct negative shift of $\sim 1.8 \%$ o to $\sim 2.23 \%$ o defining the $\mathrm{C}$-isotope pattern within that interval. Total inorganic carbon (TIC), total organic carbon (TOC), $\delta^{13} \mathrm{C}_{\text {org }}$, microfacies, $n$-alkanes show no difference before, during, or after the negative inflection. The biomarkers indicate that organic matter $(\mathrm{OM})$ mainly originates from algal/microbial sources because short-chain length homologues $\left(\leq n \mathrm{C}_{19}\right)$ dominate. $n \mathrm{C}_{20}$ through $n \mathrm{C}_{25}$ indicate some contribution from aquatic vegetation, but little from higher plants $\left(>n \mathrm{C}_{25}\right)$, as also suggested by the terrestrial/aquatic ratio of $n$-alkanes or $(\mathrm{TAR})=\left[\left(n \mathrm{C}_{27}+n \mathrm{C}_{29}+n \mathrm{C}_{31}\right) /\left(n \mathrm{C}_{15}+n \mathrm{C}_{17}+n \mathrm{C}_{19}\right)\right]$ (averages 0.085). We suggest that conjoint pulses of contemporaneous LIPs (Ontong Java) and massive explosive volcanism in northeast Asia, the Songliao Basin (SB-V), best conform to plausible causes of the negative intra-C2 carbon isotopic excursion (CIE)
\end{abstract}


at that time. Because of its apparent common occurrence, the intra-C2 inflection could be a useful marker harbinger to the more pronounced CIE C3, the hallmark of OAE1a.

\subsection{Introduction}

Variations in the carbon isotope record of Lower Cretaceous deposits are widely recognized to show intermittent prominent negative and positive shifts. The consistency in the pattern of coeval chemostratigraphic curves thus documents shifts that signal overall simultaneous responses of temporal changes in the ocean carbon reservoir. The original standard pattern registered by the $\delta^{13} \mathrm{C}_{\text {org }}$ and $\delta^{13} \mathrm{C}_{\text {carb }}$ stratigraphy in Lower Aptian sediments of the Alpine Tethys was subdivided into distinct isotope segments defined as $\mathrm{C} 1$ to $\mathrm{C} 8$ by Menegatti et al., (1998), a pattern that has been extensively replicated elsewhere and has been calibrated with dependable microfossils at different Tethyan sections (Menegatti et al., 1998; Moullade et al., 1998; Kuhnt et al., 1998; Erba et al., 1999; de Gea et al., 2003; Erba, 2004; Weissert and Erba, 2004; Godet et al., 2006; Li et al., 2008; Najarro et al., 2010; Stein et al., 2011, 2012; Papp et al., 2013; Erba et al., 2015; Moullade et al., 2015). The El Pui section of the semi-restricted Organyà Basin, south central Pyrenees, shows an exceptional record of the lower Aptian hemipelagic sediments coincident with the interval of time of carbon isotope segments $\mathrm{C} 1$ to $\mathrm{C} 6$ including more than $240 \mathrm{~m}$ of undisrupted sedimentation (Sanchez-Hernandez and Maurrasse, 2014; 2016). This expanded record reveals the details of temporal variations in the Organyà Basin and the global ocean reservoir prior to, and during the Early Aptian prominent oceanic anoxic event 1a (OAE1a), including the short episode not possible to be observed in condensed sections (e.g. $1-5 \mathrm{~m}$ in the Italian and Swiss sections, Menegatti et al., 1998). This remarkable expanded succession displays lengthened carbon 
isotope segments (Sanchez-Hernandez and Maurrasse, 2014; 2016) commensurate with the conventional initial segments (Menegatti et al., 1998). Segment C2 is particularly well developed in the El Pui section (Fig. 4-1, Fig. 4-2D), as it extends $\sim 147.5 \mathrm{~m}$ altogether, between about 15.5 and $163 \mathrm{~m}$ (Sanchez-Hernandez and Maurrasse, 2014; 2016). The expanded $\mathrm{C} 2$ segment also reveals a distinct carbon isotope negative anomaly of $\sim 0.5$ to $2.06 \%$ with the lowest values recorded over an approximate interval of $5.3 \mathrm{~m}$ $(\sim 73.0-78.3 \mathrm{~m})$ (Fig. 4-3). Hence, this carbon isotope excursion heralds the ensuing interval where the lowest values occur that correspond to segment $\mathrm{C} 3$ at the onset of oceanic anoxic event 1a (OAE1a) (C3 - C6) (Sanchez-Hernandez and Maurrasse, 2014; 2016). A review of the literature reveals that the negative shift within $\mathrm{C} 2$ seems to also occur at widely different sites in the Tethyan domain (e.g. Djebel Serdj, Tunisia, Heldt et al., 2008; the Comanche platform, western Texas, United States, Phelps et al., 2015; Phelps, 2011; the Santa Rosa Canyon, Mexico, Li et al., 2008) (Fig. 4-2A, B, C). Because the negative intra-segment $\mathrm{C} 2$ carbon isotopic excursion (CIE) in the Organyà Basin can also be identified in carbon isotope curves elsewhere, we hypothesized that the CIE further concur with previous inference (Sanchez-Hernandez and Maurrasse, 2016) and the anomaly may be related to a global phenomenon.

In such a case, the deviation might represent the record of a weak pulse of geochemical changes in the ocean waters that affected the global carbon reservoir. 


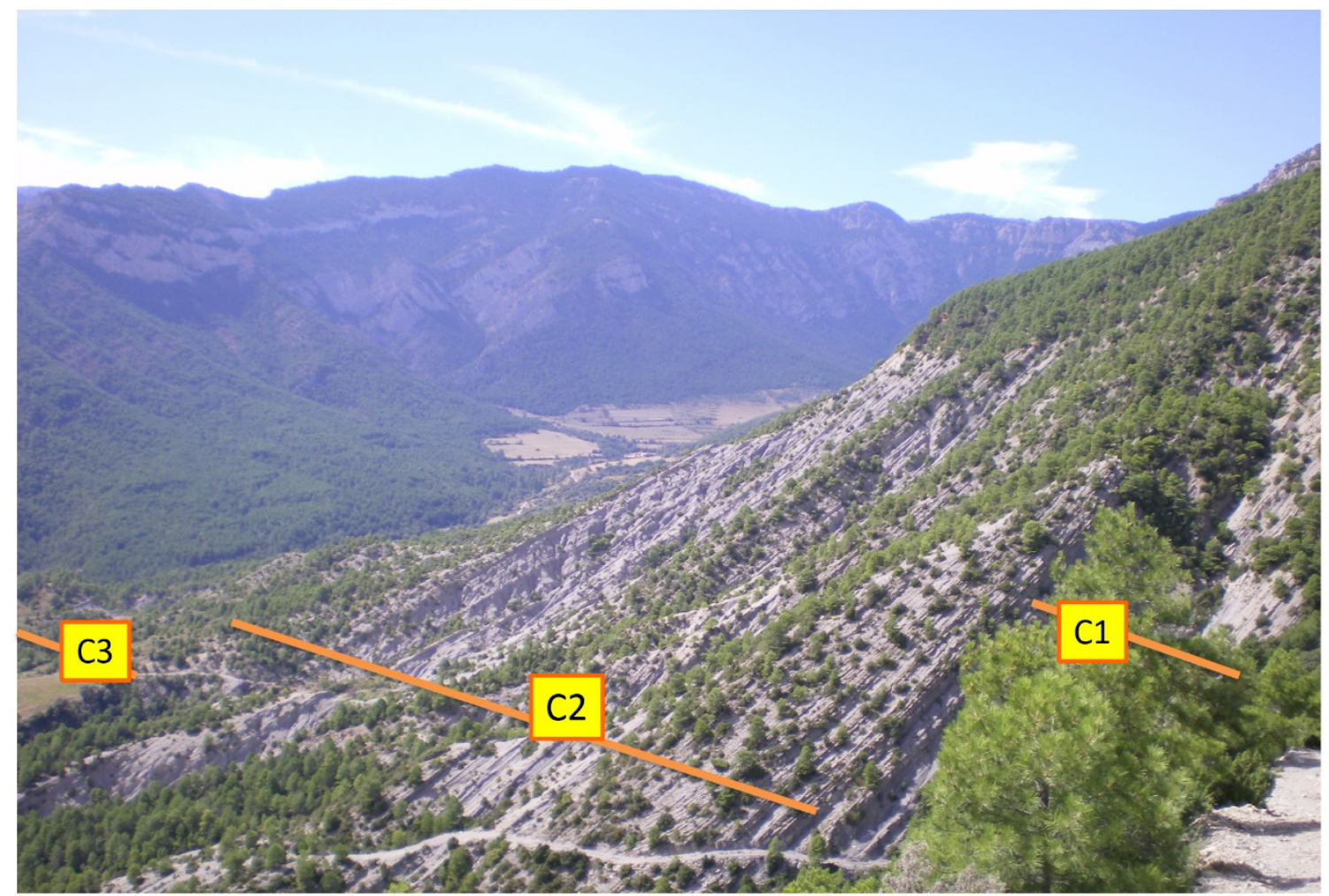

Figure 4-1 Panoramic view of El Pui section showing the approximate position of carbon isotope segments C1, C2 and C3 correlative with similar chemostratigraphic segments defined by Menegatti et al. (1998).

However, because of the apparent greater magnitude of the shift recorded in the El Pui section (Fig. 4-2), the question arises as to whether local factors in the Organyà Basin might have affected the negative shift within segment $\mathrm{C} 2$, or whether it is a genuine record of a short-lived perturbation in the global ocean reservoir harbinger to OAEla?

As shown in Table 4-1, here we present additional data in a high-resolution study of the interval that includes the intra-C2 CIE in the El Pui section (Fig. 4-2, Fig. 4-3) in complement to earlier works (Sanchez-Hernandez and Maurrasse, 2014; 2016; SanchezHernandez et al., 2014). Our main goal is to decipher the geochemical characteristics of $n$-alkanes in the negative shift in order to assess whether or not local biogeochemical factors were involved, and its potential use as a sub-event that may be well defined when sampling spacing permits in non-condensed sections. To address the question we used 


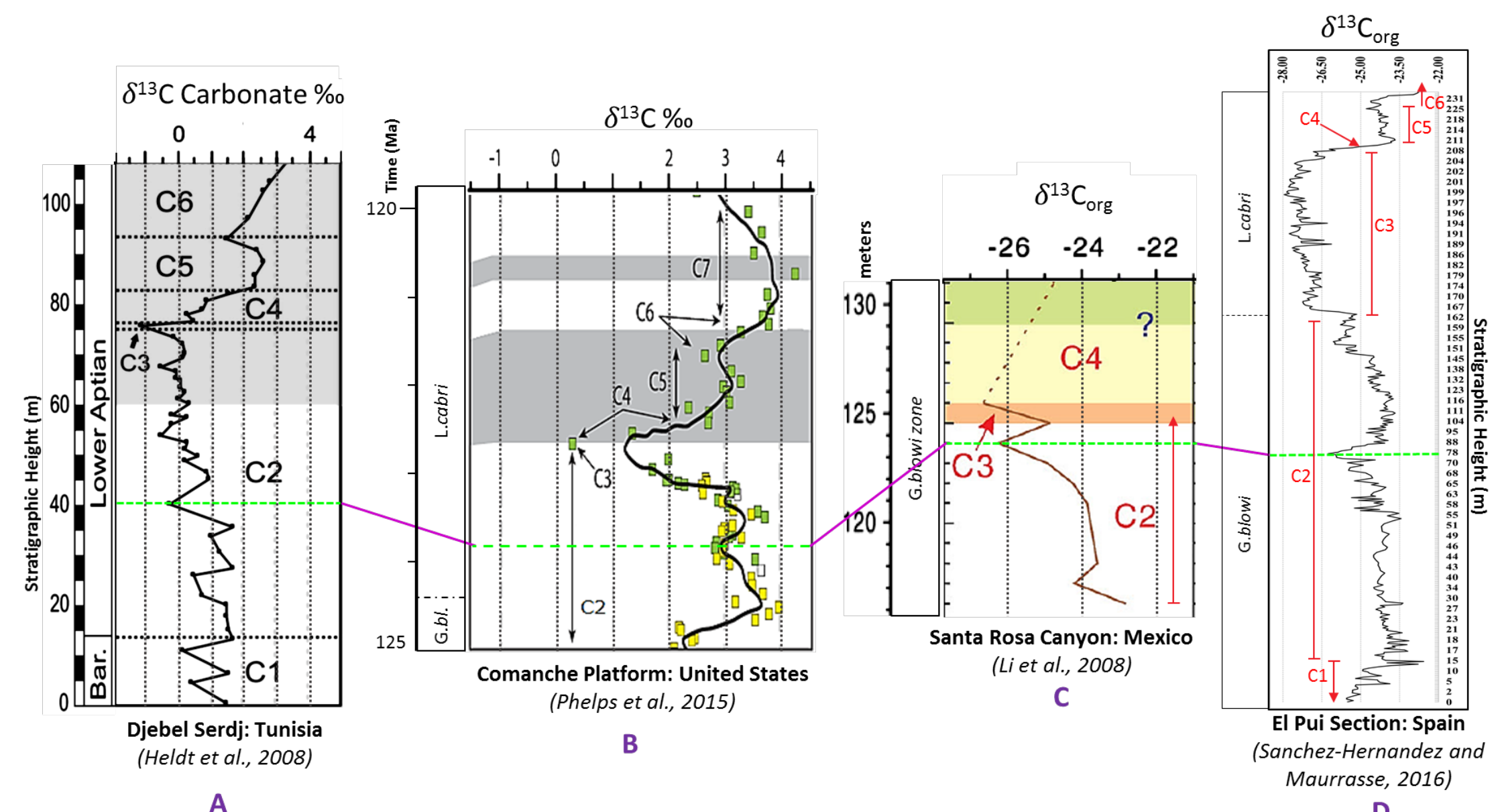

A

Figure 4-2 Carbon isotope curve comparing the intra-segment C2 negative excursion of four different locations. A-Djebel Serdj, Tunisia: Modified from (Heldt et al., 2008). B-Comanche Platform, USA: Modified from Phelps et al. (2015). C-Santa Rosa Canyon, Mexico: Modified from Li et al. (2008). D-El Pui, Spain: Modified from Sanchez-Hernandez and Maurrasse (2016). 
intervening samples (Table 4-1) not previously analyzed that provide additional total organic carbon (TOC), total inorganic carbon (TIC), $\delta^{13} \mathrm{C}_{\text {org, }}, n$-alkanes, microscopic analyses with petrographic microscope and SEM, that increase data resolution within an interval of $61 \mathrm{~m} \mathrm{(39}$ to $100 \mathrm{~m}$, Fig. 4-3, Fig. 4-4) in the section in order to better constrain the characteristics prior to, during, and after the negative intra-C2 CIE (Fig. 4-3, Fig. 44).

\subsection{Geologic Setting}

Previous studies of the Organyà Basin in Catalunya, northeastern Spain, concur that it developed as a Lower Cretaceous semi-restricted water body associated with a pull-apart tectonic system that lasted approximately 25 million years until the Late Albian (Bernaus et al., 2003). Overall, climatic conditions were tropical to subtropical at a paleogeographic latitude of approximately 25 to $30^{\circ}$ above the Equator (García-Senz, 2002). The Basin accommodated a sedimentary succession that includes over $4,500 \mathrm{~m}$ of mostly hemipelagic marls toward the depocenter, and mixed heterozoan/photozoandominated skeletal limestones in adjacent carbonate platforms (García-Senz, 2002; Sanchez-Hernandez and Maurrasse, 2016). The unusual thickness of the sequence thus implies that the basin experienced extreme subsidence coupled with rapid sedimentation in a pull-apart setting (Sanchez-Hernandez and Maurrasse; 2014; 2016). The basin fill became inverted in the final tectonic phase of collision between the Iberian plate and Western Europe due to the northward movement of Africa toward the close of the Mesozoic (Seguret, 1972; Peybernès, 1976; Muñóz et al., 1984; Berástegui et al., 1990; García-Senz, 2002; Capote et al., 2002; Golonka, 2004; Gong et al., 2009; Sanchez- 
Hernandez and Maurrasse, 2014; 2016; Sanchez-Hernandez et al., 2014; Quintana et al., 2015).

The sedimentary remnants of the uplifted Organyà basin are now exposed in the uppermost unit known as the Bòixols thrust sheet, a component of a series of thrust sheets that comprise the south-central Pyrenees (García-Senz, 2002). The El Pui sequence (coordinates: $42^{\circ} 14^{\prime} 36.00^{\prime \prime} \mathrm{N}, 1^{\circ} 13^{\prime} 33.67^{\prime \prime} \mathrm{E}$ ) is part of the asymmetrical Santa Fe syncline (García-Senz, 2002), southern flank of the Sierra de Prada. As described in Sanchez-Hernandez and Maurrasse (2014), erosion by the Cabó River exposes the series of hemipelagic marlstones, organic-rich marls and limestones known as the Cabó Formation (García-Senz, 2002) in dip slope topography that allows exceptionally easy high-resolution temporal study of the succession (Fig. 4-1).

The sedimentary record in the Organyà Basin tells the history of the entire Early Cretaceous, particularly the Aptian that comprises more than $1000 \mathrm{~m}$ of continuous sediment accumulation. Sedimentation occurred during extreme greenhouse conditions of the Early Cretaceous when the world experienced reduced latitudinal temperature gradients, coupled with accelerated hydrological cycles and intensified continental weathering and runoff (Haq et al., 1987; Huber et al., 1995; Ando et al., 2008; DuqueBotero and Maurrasse, 2005).

The initial micropaleontological study of the El Pui section revealed only very rare identifiable planktonic foraminifera, mostly Globigerinelloides blowi (SanchezHernandez and Maurrasse, 2014), nominate zonal marker of the Early Aptian biozone calibrated with the Early Aptian prior to OAE1a. Further study (Sanchez-Hernandez et al., 2014) that focused on the lower part of the El Pui section indicates that carbon isotope 
segment $\mathrm{C} 2$ is in calcareous nannofossils Biozone NC 6 (Sanchez-Hernandez et al., 2014), which is also assigned to the Early Aptian (Roth, 1978). The sediment is dominated by Watznaueria barnesae, particularly below stratigraphic level $30 \mathrm{~m}$ (> $60 \%$ ), but this taxon decreases above that level to $\sim 30 \%$ and stays steady through the interval comprising the intra-C2 CIE (Sanchez-Hernandez et al., 2014. These authors also reported several nannoconid taxa as an important component of the carbonate matrix, and the nannoconid group increases concomitantly with the decrease in $W$. barnesae that parallels the interval with marked dominance of the wide-canal nannoconid group over the narrow canal group (Sanchez-Hernandez et al., 2014), therefore the change in taxonomic dominance occurred before the well-known nannoconid crisis associated with levels above segment $\mathrm{C} 2$.

The carbon isotopic subdivision registered by the $\delta^{13} \mathrm{C}_{\mathrm{org}}$ and $\delta^{13} \mathrm{C}_{\text {carb }}$ curves globally has now become widely accepted as the standard pattern of chronology in the Lower Aptian sediments that have been calibrated with reliable planktonic foraminifera and nannofossils biostratigraphy at other Tethyan sections (Menegatti et al., 1998; Moullade et al., 1998; Kuhnt et al., 1998; Erba et al., 1999; De Gea et al., 2003; Erba, 2004; Weissert and Erba, 2004; Godet et al., 2006; Najarro et al., 2010; Stein et al., 2011, 2012; Papp et al., 2013; Erba et al., 2015). Therefore, the chemostratigraphic curve of the carbon isotope is used here to determine chronologic correlation of the El Pui sequence with sections elsewhere (Fig. 4-2). Compatibility in the chronostratigraphic position of 
the carbon isotopic segments thus permits to reduce biochronologic inconsistencies

(Reboulet et al., 2006; Millán et al., 2009; Moreno-Bedmar, 2010; Reboulet et al., 2012).

Table 4-1 TIC, TOC, $\delta^{13} \mathrm{C}_{\text {org }}$, and TAR and $\mathrm{Pr} / \mathrm{Ph}$ values in the El Pui section. The lowest value of the negative CIE occurs at a height of $77.2 \mathrm{~m}$, corresponding to sample C-11-202. Samples with asterisks belong to values measured by Sanchez-Hernandez and Maurrasse (2014; 2016).

\begin{tabular}{|c|c|c|c|c|c|c|c|c|c|c|c|c|c|}
\hline Sample ID & $\begin{array}{l}\text { Height } \\
\text { (m) }\end{array}$ & TIC & TOC & $\delta^{13} \mathrm{C}_{\text {org }}$ & TAR & $\mathrm{Pr} / \mathrm{Ph}$ & Sample ID & $\begin{array}{l}\text { Height } \\
\text { (m) }\end{array}$ & TIC & TOC & $\delta^{13} \mathrm{C}_{\text {org }}$ & TAR & $\mathrm{Pr} / \mathrm{Ph}$ \\
\hline C-12-223* & 100.2 & 50.3 & 1.8 & -24.24 & - & - & C-11-161* & 57.9 & 65.5 & 0.8 & -24.15 & - & - \\
\hline C-12-222* & 99.2 & 50.8 & 2.1 & -24.04 & - & - & C-11-160 & 57.4 & 61.2 & 0.5 & -24.27 & - & - \\
\hline C- $12-221^{*}$ & 97.4 & 78.9 & 1.7 & -24.7 & - & - & C-11-159* & 57 & 57.9 & 0.7 & -24.55 & - & - \\
\hline C- $12-220^{*}$ & 96.1 & 57.1 & 2.4 & -24.03 & - & - & C-11-158 & 56.7 & 63.2 & 0.4 & -25.25 & - & - \\
\hline C-12-219* & 95.4 & 47.8 & 2.1 & -24.33 & - & - & C-11-157* & 56.3 & 52.6 & 0.7 & -24.27 & - & - \\
\hline C-12-218* & 94.2 & 46.2 & 2.1 & -24.78 & - & - & C-11-156 & 56.1 & 66.2 & 0.8 & -25.02 & - & - \\
\hline C-12-217* & 93.6 & 52.9 & 1.4 & -24.18 & - & - & C-11-155* & 55.6 & 66.4 & 0.7 & -23.82 & - & - \\
\hline C-12-216* & 92.5 & 59.8 & 1.4 & -24.13 & - & - & C-11-153* & 55.1 & 63.5 & 0.8 & -23.53 & - & - \\
\hline C-12-215* & 90.9 & 43.2 & 1.7 & -24.44 & - & - & C-11-152 & 54.9 & 63.0 & 0.6 & - & 0.00 & 1.26 \\
\hline C-12-214* & 90.2 & 42.8 & 1.8 & -24.32 & - & - & C-11-151* & 54.3 & 52.9 & 0.8 & -23.98 & - & - \\
\hline C-12-213* & 89.5 & 44.5 & 2.0 & -24.22 & - & - & C-11-150 & 53 & 63.8 & 0.5 & - & - & - \\
\hline C- $12-212^{*}$ & 88.9 & 55.6 & 0.4 & -23.95 & - & - & C-11-149* & 52.6 & 65.0 & 0.7 & -23.44 & - & - \\
\hline C-12-211* & 88 & 69.0 & 0.8 & -24.48 & - & - & C-11-148 & 52 & 63.8 & 0.5 & - & - & - \\
\hline C-12-210 & 87.3 & 44.7 & 1.7 & -24.08 & - & - & C-11-147* & 51.6 & 77.7 & 0.5 & -23.79 & - & - \\
\hline C-12-209* & 86.6 & 64.3 & 2.0 & -24.73 & - & - & C-11-146 & 51.5 & 74.2 & 0.5 & - & - & - \\
\hline C-12-208 & 86 & 61.9 & 1.5 & -24.84 & - & - & C-11-145* & 51.3 & 67.9 & 0.4 & -24.1 & - & - \\
\hline C-11-207* & 84.5 & 64.9 & 0.6 & -25.33 & - & - & C-11-144 & 51 & 72.2 & 0.6 & - & - & - \\
\hline C-11-206 & 83.1 & 68.9 & 0.6 & - & 0.00 & 1.22 & C-11-143* & 50.8 & 68.5 & 0.5 & -24.2 & - & - \\
\hline C-11-205* & 81.1 & 58.1 & 0.7 & -25.36 & - & - & C-11-142 & 50.6 & 70.6 & 0.6 & - & - & - \\
\hline C-11-204 & 79.6 & 67.5 & 0.3 & -25.74 & 0.00 & 0.71 & C-11-141* & 50.3 & 71.0 & 0.4 & -24.19 & - & - \\
\hline C-11-203* & 78.3 & 59.1 & 0.7 & -25.89 & - & - & C-11-140 & 49.9 & 71.0 & 0.6 & - & - & - \\
\hline C-11-202 & 77.2 & 69.0 & 0.5 & -26.26 & 0.00 & 1.02 & C-11-139* & 49.5 & 67.6 & 0.5 & -24.18 & - & - \\
\hline C-11-201* & 75.7 & 59.6 & 0.7 & -25.95 & - & - & C-11-138 & 48.9 & 59.9 & 0.9 & - & - & - \\
\hline C-11-200 & 74.1 & 68.1 & 0.4 & - & 0.00 & 1.40 & C-11-137* & 48.7 & 61.5 & 0.7 & -23.9 & - & - \\
\hline C-11-199* & 73 & 77.6 & 0.6 & -25.93 & - & - & C-11-136 & 48.5 & 68.3 & 0.7 & - & - & - \\
\hline C-11-198 & 71.5 & 70.5 & 0.4 & -25.7 & 0.00 & 0.84 & C-11-135* & 48 & 75.0 & 0.6 & -24.03 & - & - \\
\hline C-11-197* & 70.7 & 66.9 & 0.8 & -24.45 & - & - & C-11-134 & 47.8 & 78.8 & 0.4 & - & - & - \\
\hline C-11-196 & 70.6 & 79.4 & 0.8 & - & - & - & C-11-133* & 47.3 & 73.7 & 0.5 & -24.12 & - & - \\
\hline C-11-195* & 70.2 & 80.3 & 0.4 & -25.52 & - & - & C-11-132 & 47.1 & 76.9 & 0.6 & - & - & - \\
\hline C-11-194 & 70 & 84.3 & 0.9 & - & - & - & C-11-131* & 46.9 & 75.3 & 0.4 & -24.17 & - & - \\
\hline C-11-193* & 69.7 & 84.3 & 0.3 & -24.9 & - & - & C-11-130 & 46.7 & 70.6 & 0.6 & - & - & - \\
\hline C-11-192 & 69.5 & 77.9 & 0.7 & - & - & - & C-11-129* & 46.3 & 70.0 & 0.6 & -24.13 & - & - \\
\hline C-11-191* & 69.3 & 79.8 & 0.4 & -25.42 & - & - & C-11-128 & 46 & 71.2 & 0.6 & - & - & - \\
\hline C-11-190 & 69 & 75.7 & 0.7 & - & 0.30 & 1.15 & C-11-127* & 45.8 & 72.1 & 0.5 & -23.98 & - & - \\
\hline C-11-189* & 68.8 & 79.4 & 0.4 & -25.47 & - & - & C-11-126 & 45.6 & 72.7 & 0.6 & - & - & - \\
\hline C-11-188 & 68.5 & 77.4 & 0.7 & - & - & - & C-11-125* & 45.5 & 74.0 & 0.5 & -24.05 & - & - \\
\hline C-11-187* & 68.3 & 82.5 & 0.4 & -24.81 & - & - & C-11-124 & 45.2 & 81.0 & 0.5 & - & - & - \\
\hline C-11-186 & 68 & 75.2 & 0.6 & - & - & - & C-11-123* & 45 & 75.9 & 0.6 & -24.39 & - & - \\
\hline C-11-185* & 67.6 & 70.4 & 0.6 & -24.6 & - & - & C-11-122 & 44.9 & 80.0 & 0.6 & - & - & - \\
\hline C-11-184 & 67.3 & 73.0 & 0.5 & - & - & - & C-11-121* & 44.4 & 75.7 & 0.6 & -24.5 & - & - \\
\hline C-11-183* & 67 & 81.5 & 0.6 & -24.55 & - & - & C-11-120 & 44 & 80.0 & 0.6 & - & - & - \\
\hline C-11-182 & 66.5 & 81.2 & 0.6 & - & 0.00 & 1.11 & C-11-119* & 43.9 & 77.3 & 0.6 & -24.5 & - & - \\
\hline C-11-181* & 66.3 & 84.4 & 0.4 & -25.25 & - & - & C-11-118 & 43.7 & 76.1 & 0.7 & - & - & - \\
\hline C-11-180 & 65.8 & 77.3 & 0.6 & - & - & - & C-11-117* & 43.6 & 80.7 & 0.5 & -24.42 & - & - \\
\hline C-11-179* & 65.4 & 68.5 & 0.6 & -24.32 & - & - & C-11-116 & 43.5 & 80.3 & 0.6 & - & - & - \\
\hline C-11-177* & 64.7 & 69.6 & 0.7 & -24.58 & - & - & C-11-115* & 43.1 & 81.3 & 0.5 & -24.32 & - & - \\
\hline C-11-176 & 64.4 & 66.4 & 1.2 & - & 0.00 & 1.32 & C-11-114 & 42.9 & 82.4 & 0.6 & - & - & - \\
\hline C-11-175* & 64 & 69.2 & 0.8 & -24.03 & - & - & C-11-113* & 42.7 & 81.7 & 0.4 & -24.33 & - & - \\
\hline C-11-174 & 63.9 & 68.9 & 0.6 & - & - & - & C-11-112 & 42.5 & 83.6 & 0.6 & - & - & - \\
\hline C-11-173* & 63.6 & 72.5 & 0.7 & -24.2 & - & - & C-11-111* & 42.3 & 80.8 & 0.5 & -24.27 & - & - \\
\hline C-11-172 & 63.3 & 76.5 & 0.5 & - & - & - & C-11-110 & 42 & 87.7 & 0.5 & - & - & - \\
\hline C-11-171* & 63.1 & 79.4 & 0.5 & -24.5 & - & - & C-11-109* & 41.8 & 80.9 & 1.0 & -24.25 & - & - \\
\hline C-11-170 & 62.5 & 73.5 & 0.9 & - & - & - & C-11-108 & 41.5 & 88.5 & 0.5 & - & - & - \\
\hline C-11-169* & 62 & 59.6 & 0.8 & -24.62 & - & - & C-11-107* & 41.3 & 85.3 & 0.4 & -24.08 & - & - \\
\hline C-11-167* & 60.3 & 76.5 & 0.6 & -24.43 & - & - & C-11-106 & 40.8 & 79.4 & 0.6 & - & 0.34 & 0.90 \\
\hline C-11-166 & 59.5 & 66.6 & 0.3 & -25.36 & 0.00 & 1.30 & C-11-105* & 40.5 & 74.1 & 0.7 & -24.2 & - & - \\
\hline C-11-165* & 59.1 & 71.6 & 0.5 & -24.2 & - & - & C-11-104 & 40.1 & 79.3 & 0.8 & - & 0.38 & 1.00 \\
\hline C-11-164 & 58.7 & 60.7 & 0.7 & -25.09 & - & - & C-11-103* & 39.4 & 78.1 & 0.5 & -24.27 & - & - \\
\hline C-11-163* & 58.3 & 68.4 & 0.8 & -24.1 & - & - & C-11-102 & 39 & 75.6 & 0.7 & - & - & - \\
\hline C-11-162 & 58.1 & 69.6 & 0.4 & -24.48 & - & - & & & & & & & \\
\hline
\end{tabular}




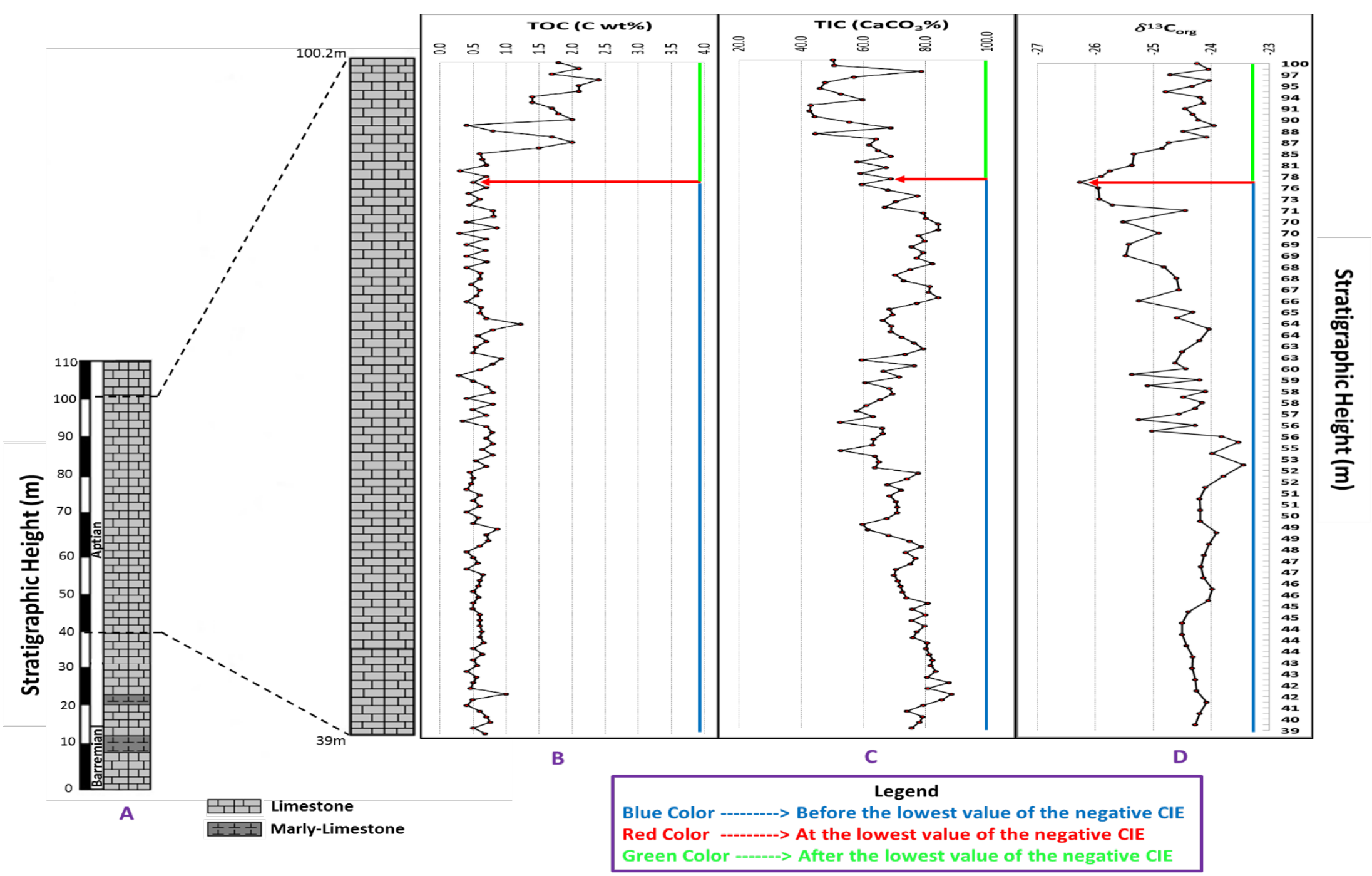

Figure 4-3 Lithostratigraphy and carbon chemostratigraphy of the El Pui section. A-Simplified chronostratigraphic column. B-Vertical variation in TOC. CVertical variation in TIC. D-Vertical variation in $\delta^{13} \mathrm{C}_{\mathrm{org}}$ including the characteristic intra-segment C2 negative excursion denoted with a red arrow. 


\subsection{Materials and Methods}

\subsubsection{Microscopy}

Additional thin sections in intervening samples (Table 4-1) were made to complement previous materials available for both petrographic and SEM analyses as described in earlier works of the El Pui section (Sanchez-Hernandez and Maurrasse; 2014; 2016; Sanchez et al., 2014).

\subsubsection{Total Carbon/Carbonate - TC, TIC, TOC, C-isotope}

Total carbon (TC) and total inorganic carbon (TIC) and total organic carbon (TOC) contents for all samples were analyzed at Florida International University using a LECO CR-412 carbon analyzer as described in detail in previous studies (Gaona-Narvaez et al., 2013a; 2013b; Sanchez-Hernandez and Maurrasse, 2014), and TIC/TOC are expressed as $\mathrm{CaCO}_{3}$ and $\mathrm{C}-\mathrm{wt} \%$ respectively of bulk sediment.

Initial preparation of the samples for carbon isotope was carried at the FIU's sample preparation laboratory, and the isotopic analyses completed at the Stable Isotope Laboratory using a Finnigan Delta C EA-IRMS (with TC/EA). Values are reported according to the standard Vienna Pee Dee Belemnite (VPDB).

In Sanchez-Hernandez and Maurrasse (2014), the TIC, TOC and the $\delta^{13} \mathrm{C}_{\text {org }}$ straddling the negative inflection shown in their Figure 7B, C, D, includes results from thirteen (13) samples covering about $18 \mathrm{~m}$ (beginning with C-11-183, at $67 \mathrm{~m}$; C-11-185; C-11-187; C-11-189; C-11-191; C-11-193; C-11-195; C-11- 197; C-11-199; C-11-201; C-11-203; C-11-205; and C-11-207, at $85 \mathrm{~m})$. The pattern of the negative inflection and the recovery was further established with additional data (Sanchez-Hernandez and Maurrasse, 2016, Fig. 3D, 11) with the positive recovery ending at $\sim 88.9 \mathrm{~m}(\mathrm{C} 12-212)$, 
thus extending the complete overall inflection event within $\mathrm{C} 2$ to $21.9 \mathrm{~m}$. We complemented the dataset with five more intervening carbon isotope analyses (Table 4$1)$, thereby increasing the accuracy of the pattern of $\delta^{13} \mathrm{C}_{\text {org }}$ variation associated with the intra-C2 negative inflection. Also, our curve greatly increases the chemostratigraphic resolution with 52 additional intervening samples (Table 4-1) analyzed for TC, TIC and TOC, from 39 to $102 \mathrm{~m}$ (Fig. 4-3).

\subsubsection{Analytical Method for Biomarkers}

Soxhlet extraction is the standard method for lipid extraction from solid media. However, this method is very time consuming, requiring $24 \mathrm{hrs}$ per sample just to remove the total lipid extract (TLE) and takes high volumes of solvent, $300 \mathrm{ml}$ or more. A new alternative is the technique of accelerated solvent extraction (ASE). This technique relies on the fact that solvents boil at higher temperatures when they are exposed to higher pressures. As a result, extraction of lipids from a solid media can occur at higher temperatures, leading to better extraction and shortened time (1hr). The only downside to this technique is the high cost of the equipment. As a result, a new extraction method, modified from a method used mainly onboard research drilling vessels, was used in the present study.

\subsubsection{Lipid Extraction}

Before commencing the procedure, all of the lab glassware was washed with tap water and soap, then washed 3 times with deionized water and put in the oven at $560^{\circ} \mathrm{C}$ for $2 \mathrm{hrs}$ to remove any remaining organic matter. A piece of each hand sample was cut into small cubes, approximately $1 \mathrm{~cm}$ by $1 \mathrm{~cm}$ and allowed to dry overnight at $50^{\circ} \mathrm{C}$ in the oven. After drying, the samples were ground to a powder using a Bell-Art micromill 
and stored in labeled glass vials. 5 grams of powdered rock were transferred to a mortar and pestle and further homogenized. The 5 grams of homogenized sample was transferred to a 12 -dram vial and to that, a $10 \mathrm{ml}$ mixture of (1:9) methanol $(\mathrm{MeOH}) /$ dichloromethane (DCM) was also added. The vial was then sonicated for 30 min and then the sediment was allowed to settle. The cloudy supernatant was removed and passed through a glass Pasteur pippete plugged with pre-combusted $\left(560^{\circ} \mathrm{C}\right)$ glass wool.

In the following step, $10 \mathrm{ml}$ of fresh 1:9 $\mathrm{MeOH} / \mathrm{DCM}$ was again added to the $12-$ dram vial and the mixture was sonicated a second time for $30 \mathrm{~min}$. The cloudy supernatant was removed and filtered as before. Both extracts were combined in a 4-dram vial where activated copper was added to remove any elemental sulfur. The copper was activated when placed in $10 \% \mathrm{HCl}$ until it reached its peculiar bright color and then washed 3 times with deionized water, and 3 more times with DCM. The copper was left in the TLE until it turned completely black $\sim 3-4 \mathrm{hrs}$ and then it was removed. The TLE was then concentrated by evaporation until the total volume reached $\sim 1 \mathrm{ml}$.

\subsubsection{Separation}

To recover the non-saponifiable lipids (neutral lipids) the sample was saponified with $10 \%$ methanolic $\mathrm{KOH}$ solution $(5 \mathrm{ml})$ for $1 \mathrm{hr}$ at $60^{\circ} \mathrm{C}$. The sample was then transferred to a separatory funnel and extracted 3 times with hexane. The top layer (hexane + neutral lipids) was collected and concentrated to less than $1 \mathrm{ml}$ and stored for further fractionation. In the subsequent step, a glass pipette was plugged with pre combusted $\left(560^{\circ} \mathrm{C}\right)$ glass wool, filled with .5 grams of $230-400$ mesh silica gel, and conditioned with $6 \mathrm{ml}$ of hexane. The neutral lipid extract was loaded onto the column 
and eluted with $5 \mathrm{ml}$ of hexane. This fraction, F1, containing the hydrocarbons ( $n$-alkanes) was stored in a glass vial for GC/MS analysis.

\subsubsection{GC/MS Parameters}

The samples were analyzed by GC (Agilent 6890), using method 1506GEO2.M. A volume of $5 \mu \mathrm{L}$ of each sample was injected in splitless mode. Injector temperature was $280^{\circ} \mathrm{C}$ and temperature program was as follows: hold at $65^{\circ} \mathrm{C}$ for $2 \mathrm{~min}$, increase to $300^{\circ} \mathrm{C}$ at a rate of $4^{\circ} \mathrm{C} / \mathrm{min}$, hold at $300^{\circ} \mathrm{C}$ for $8 \mathrm{~min}$. Detection was performed by a singlequadrupole mass spectrometer (Agilent 5973) operating in positive mode electron impact ionization (EI+). Scan range was from $\mathrm{m} / \mathrm{z} 42$ to $\mathrm{m} / \mathrm{z} 500$ and solvent delay time was 4 $\min$.

\subsubsection{Terrestrial Aquatic Ratio (TAR)}

Because land-derived organic matter is less labile, sediments may contain higher proportions of these $n$-alkanes than those from aquatic phototrophs. Previous $n$-alkane $\leq$ $n \mathrm{C}_{19}$ are mainly derived from marine planktonic organisms and/or bacterial communities (Forster et al., 2004; Peters et al., 2005) $n \mathrm{C}_{20}-n \mathrm{C}_{25}$ are mainly derived from aquatic macrophytes both marine and non-marine (Cranwell, 1984) and $>n \mathrm{C}_{25}$ are mainly derived from terrestrial plants (Cranwell, 1982). It has also been shown that $\mathrm{C}_{27}, \mathrm{C}_{29}$, and $\mathrm{C}_{31} n$ alkanes derived from epicuticular land plant waxes could be an important source of lipids in the sediments (Eglinton and Hamilton 1967; Cranwell 1973; Rieley et al., 1991a; 1991b; Bourbonniere and Meyers, 1996). The presence of $\mathrm{C}_{17} n$-alkanes indicates algal contributions (Blumer et al., 1971; Giger et al., 1980; Cranwell et al., 1987; Bourbonniere and Meyers, 1996). Because land-derived biomarkers can enhance light carbon isotopic values, in order to identify the relative contribution of the two different sources in the 
terrigenous-aquatic mixture of hydrocarbons in the intra-C2 negative shift of the El Pui section we used the terrestrial aquatic ratio (TAR) of $n$-alkanes as an indicator index (Bourbonniere and Meyers, 1996; Peters et al., 2005; Holtvoeth et al., 2010).

$$
\mathrm{TAR}=\frac{\mathrm{nC}_{27}+\mathrm{nC}_{29}+\mathrm{nC}_{31}}{\mathrm{nC}_{15}+\mathrm{nC}_{17}+\mathrm{nC}_{19}}
$$

Higher TAR values indicate increased land-derived sources of lipid matter relative to aquatic sources.

\subsection{Results}

\subsubsection{Microscopy}

Additional petrographic details of the samples in the interval associated with the intra-C2 negative CIE concur with previous detailed petrographic analyses of the $240 \mathrm{~m}$ El Pui section (Sanchez-Hernandez and Maurrasse, 2014; 2016). As shown in Figure 4-4, the sediments show persistent isotropic fabric related to bioturbation, and consist of monotonous sparse fossiliferous biomicrite. The overall allochemical components remain unchanged throughout. Visible microfossils (Fig. 4-5) include mostly benthic foraminifera: trochospiral $(\sim 100 \mu \mathrm{m})$; planispiral evolute infilled with framboidal pyrite $(\sim 100 \mu \mathrm{m})$; uniserial $(\sim 100 \mu \mathrm{m})$; biserial $(\sim 200 \mu \mathrm{m})$, roveacrinid fragments $(\sim 200 \mu \mathrm{m})$, and holothurian ossicles $(\sim 100 \mu \mathrm{m})$. SEM analyses of the matrix also revealed a consistent abundance of coccolithophores, as previously discussed in Sanchez-Hernandez and Maurrasse (2014; 2016); Sanchez-Hernandez et al., 2014).

\subsubsection{TC, TIC, TOC}

The additional analyses (Table 4-1) carried out to complement the previous study (Sanchez-Hernandez and Maurrasse, 2014; 2016) show a TC content that averages 


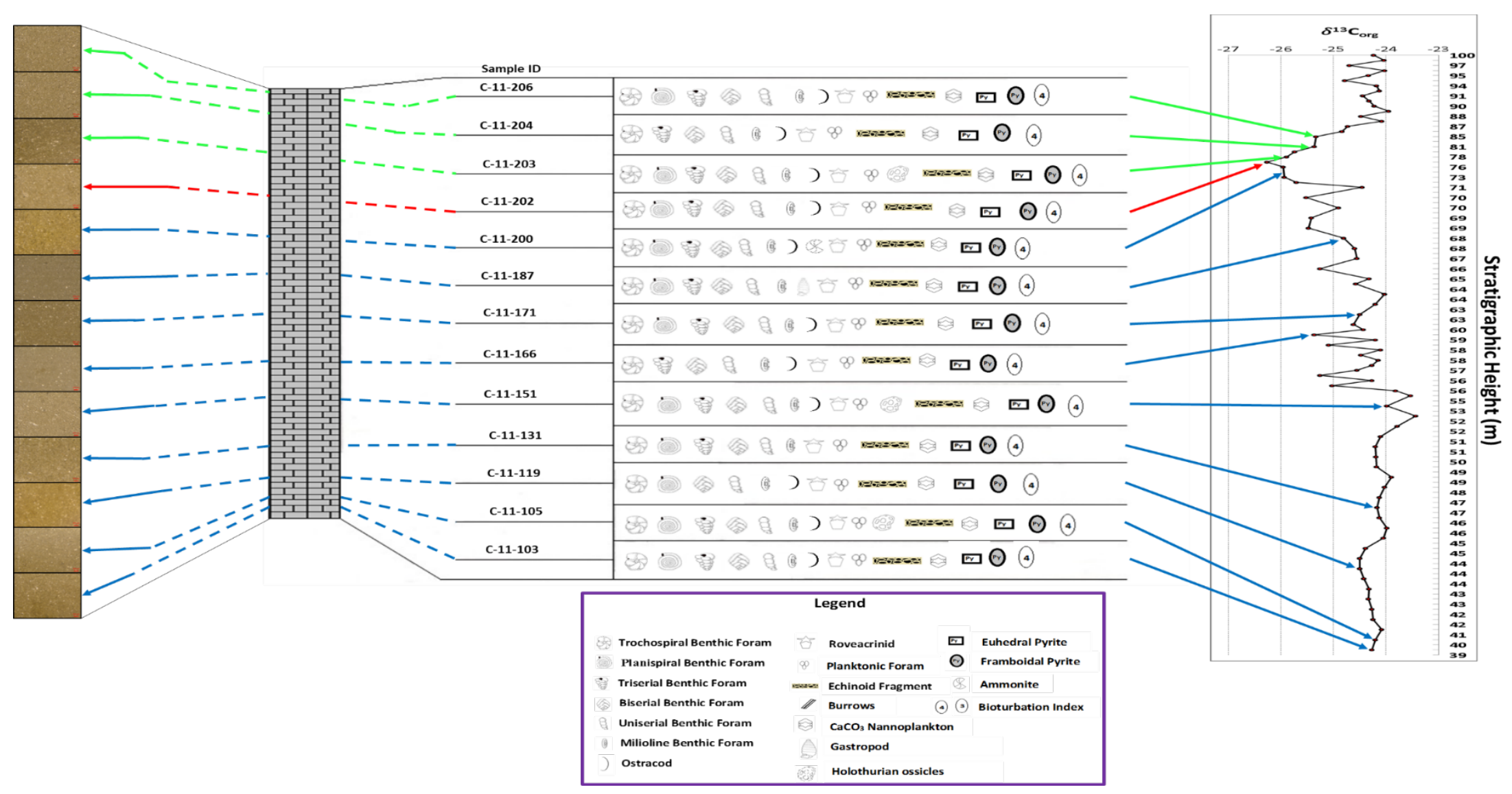

Figure 4-4 Lithology and microfacies of selected samples prior to the lowest value of the intra-segment C2 negative excursion (blue), at the lowest value (red) and after (green). Refer to the legend for a detailed description of each symbol. 
$77.78 \%$ throughout the $39-100.2 \mathrm{~m}$ interval. As can be seen in Figure 4-3, the TIC for this $61.2 \mathrm{~m}$ interval averages $70.2 \mathrm{wt} \%$. Below the negative inflection and shown in blue, the TIC averages $73.1 \mathrm{wt} \%$. The average TIC value within the interval of the negative inflection is $\sim 69 \mathrm{wt} \%$, and subsequently the average decreases to $56.6 \mathrm{wt} \%$. Unlike the TIC, the TOC values do not fluctuate as much and stay relatively stable at an average of $0.7 \mathrm{wt} \%$. The average TOC prior to the negative inflection is $0.6 \mathrm{wt} \%$, while at the interval correlative with the negative inflection it measures $\sim 0.5 \mathrm{wt} \%$, but interestingly the average increases to $1.4 \mathrm{wt} \%$ afterwards.

\subsubsection{Carbon Isotope $-\delta^{13} C_{\text {org }}$}

The high-resolution carbon isotope curve concurrent with TIC and TOC curves shown in Figure 4-3 revealed no correlation in the temporal variations of these three components. The $\delta^{13} \mathrm{C}_{\text {org }}$ record shows that the lower part of segment $\mathrm{C} 2$ includes values almost steadily around $-24 \%$, reaching two small positive peaks of $-23.44 \%$ and $23.53 \%$, at $52.6 \mathrm{~m}$ and $55.1 \mathrm{~m}$, respectively. From $55.1 \mathrm{~m}$ upward, the $\delta^{13} \mathrm{C}_{\text {org }}$ values fluctuate in a high frequency oscillating pattern toward a negative trend between $23.82 \% 0(\sim 55.6 \mathrm{~m})$ and $-25.52 \%$ ( $(70.2 \mathrm{~m})$ with an average of $-24.62 \%$. An ultimate positive increase to $-24.45 \%$ occurs at $70.7 \mathrm{~m}$, preceding a sharp drop to $-25.7 \%$ at 71.5 $\mathrm{m}$ that distinguishes a net negative shift of $1.45 \%$ preceding a further shift to the lowest value of $-26.26 \%$ at $77.2 \mathrm{~m}$, thus yielding a net negative excursion of $1.81 \%$. From 77.2 $\mathrm{m}$ up section, the isotopic values increase regularly up to a maximum of $-23.95 \%$ at 88.9 $\mathrm{m}$ (Table 4-1). Hence, if the overall negative excursion is taken between the two highest values comprising the anomaly or more precisely between $64 \mathrm{~m}\left(\delta^{13} \mathrm{C}_{\text {org }}-24.03 \%\right)$ and $~$ $89 \mathrm{~m}\left(\delta^{13} \mathrm{C}_{\text {org }}-23.95 \%\right)$ the net negative excursion characteristic of the intra-C2 anomaly 


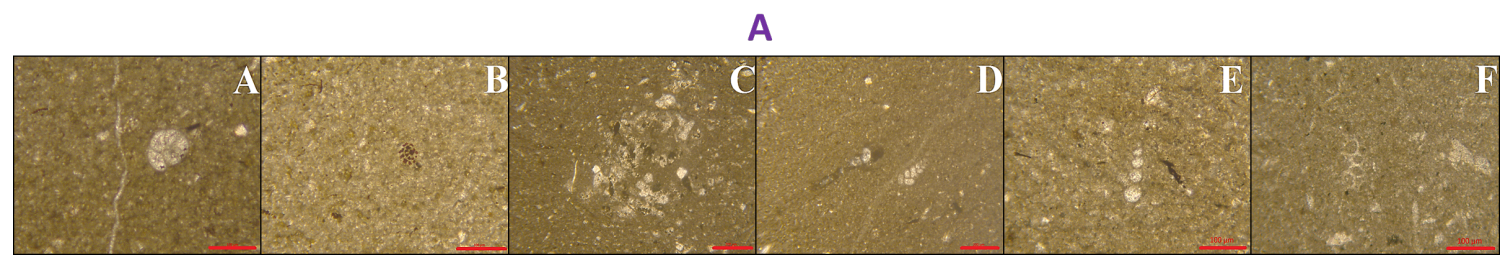

B
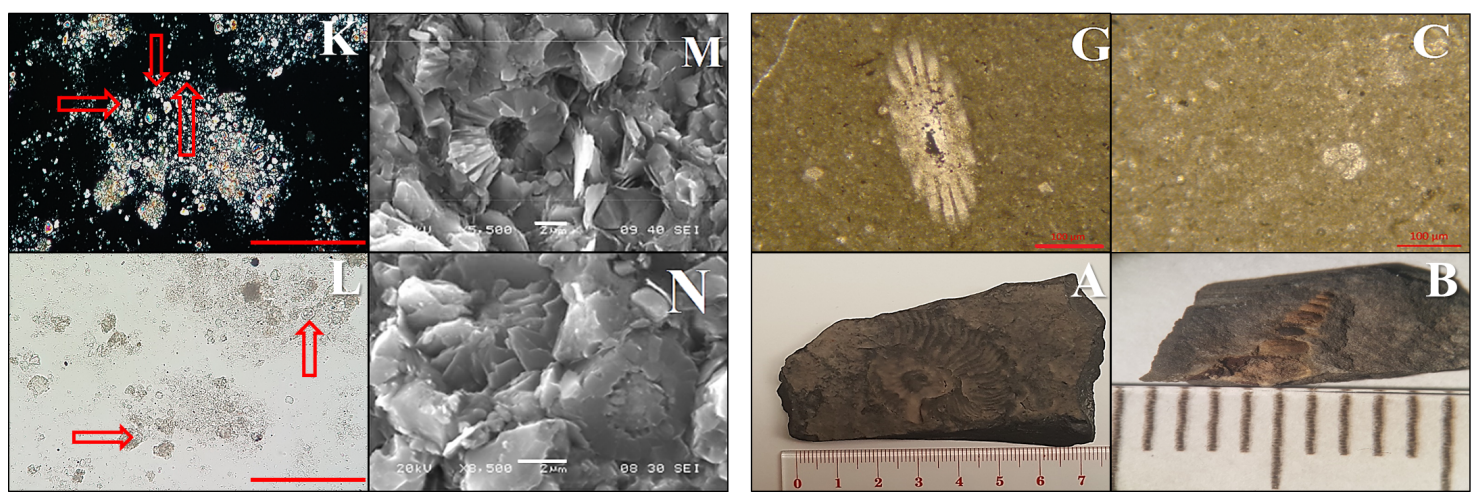

Figure 4-5A A-Trochospiral benthic foram (scale-100 $\mu \mathrm{m}$ ). B-Planispiral evolute benthic foram infilled

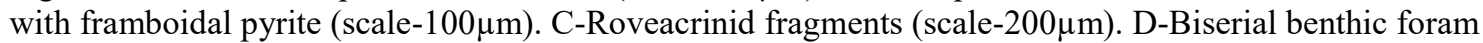

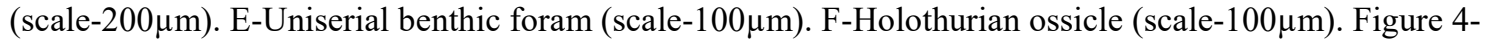
$5 \mathrm{~B} \mathrm{~K} / \mathrm{L} / \mathrm{M} / \mathrm{N}$-Abundance of calcareous nannoplankton plates and fragments in smear-slide (scale-50 $\mu \mathrm{m}$ ) and in SEM micrograph. A- Rare ammonite (cm scale). G-Echinoid spine (scale-100 $\mu \mathrm{m}$ ) B-Rare gastropod

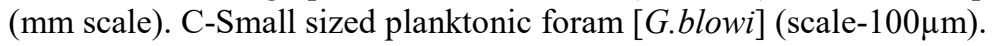

can be estimated at $2.23 \%$ in the lowering phase and $\sim 2.31 \%$ in the recovery phase.

Carbon isotopic values in the remainder younger levels of segment C2 fluctuate around 24\%o with minor cyclical variations, as discussed in Sanchez-Hernandez and Maurrasse (2016). As pointed out by these authors, the detailed $\delta^{13} \mathrm{C}_{\text {org }}$ profile of segment $\mathrm{C} 2$ therefore encloses a distinct negative shift between $1.81 \%$, and $2.23 \%$ preceding the most prominent negative shift up to $\sim 4 \%$ assigned to carbon isotope segment C3 (Menegatti et al., 1998).

Thus, the high-resolution carbon isotope curve in the expanded El Pui section allows to clearly define the intra-segment C2 CIE that provides a pattern that could be used as a reference harbinger to carbon isotope segment C3. At El Pui C3 yields the lowest value of $\sim-28.0 \%$ which has been the minimum recorded in the entire section (Sanchez-Hernandez and Maurrasse, 2016). 


\subsubsection{Comparison of the Carbon Isotope Curve at El Pui with Other Locations}

A review of the $\delta^{13} \mathrm{C}_{\text {org }}$ curves from three different geographic locations, namely the Djebel Serdj Basin in Tunisia (Heldt et al., 2008), the Comanche Platform in the United States (Phelps et al., 2015; Phelps, 2011), the Santa Rosa Canyon section in Mexico (Li et al., 2008) and the El Pui section in Spain (Sanchez-Hernandez and Maurrasse, 2014; 2016), reveals a noticeable negative inflection during carbon isotope segment $\mathrm{C} 2$ at each site (Fig. 4-2). A similar inflection seems to occur in the C2 segment of the Italian Gorgo a Cerbara section (Li et al., 2016) but the low accumulation rate at that location masks the overall expression of the pattern.

In the Djebel Serdj Basin (Fig. 4-2) values of the carbon isotope curve are reported from the carbonate fraction (cf. Fig. 3 in Heldt et al., 2008). Segment C2 is coeval with the Lower Aptian Globigerinelloides blowi Zone and yields fluctuating $\delta^{13} \mathrm{C}_{\text {carb values }}$ between $\sim 1.8 \%$ and $\sim 0.5 \%$, starting from about stratigraphic level $\sim 16 \mathrm{~m}$ up to $35 \mathrm{~m}$ (low of $0 \%$ at $25 \mathrm{~m}$, high of $1.5 \%$ at $30 \mathrm{~m}$, low of $1 \%$ at $35 \mathrm{~m}$ ). The maximum positive value of $\sim 1.8 \%$ is reached at $35 \mathrm{~m}$. This positive value is followed by a sudden negative excursion to $\sim-0.35 \%$ at $40 \mathrm{~m}$, and up again to $\sim 0.95 \%$ around $45 \mathrm{~m}$ where the values oscillate between 1 and $-.7 \%$ with an average $\sim 0.3 \%$ prior to the large negative excursion associated with $\mathrm{C} 3$ at $\sim 71 \mathrm{~m}\left(\delta^{13} \mathrm{C}_{\text {carb }}\right.$ minimum of $-1 \%$ ). The range of the anomaly in this section is $\sim 2.35 \%$, a magnitude concurrent with the excursion recorded in the El Pui sediments.

Carbon isotope values for the Comanche Platform are also reported from the carbonate fraction (cf. Figure 11 in Phelps et al., 2015). At that location, the lower part of C2 overlaps the Lower Aptian G.blowi and Leupoldina cabri Zones. The $\delta^{13} \mathrm{C}_{\text {carb }}$ values 
range from $\sim 2.4 \%$ in the lowest level to a maximum positive shift to $3.7 \%$. Immediately succeeding this high value a negative shift to $\sim 2.7 \%$ distinguishes the transition from the lower part to the upper part of isotope segment $\mathrm{C} 2$. Thus, in sediments of the Comanche platform the range of this intra-C2 negative $\mathrm{CIE}$ is $\sim 1 \%$. The remainder of $\mathrm{C} 2$ yields fluctuating values between 3\%o and 3.5\%o before dropping to the lowest value of $1 \% 0$ associated with segment C3 (Fig. 4-2).

The $\delta^{13} \mathrm{C}$ record of the Santa Rosa Canyon section is reported from the organic carbon fraction (cf. Fig. 4 (B) in Li et al., 2008). At that location carbon isotope segment C2 lays within the Lower Aptian G. blowi Zone and nannofossil NC6 Zone (Li et al., 2008). Part of the segment $C 2$ reported starts at the stratigraphic height of $116 \mathrm{~m}$ with a value of $\sim-23 \%$, which is followed by a minor negative shift to $\sim-24.3 \%$ at $\sim 117 \mathrm{~m}$ (Fig. 4-2). This negative shift is succeeded by a positive value to $\sim-23.7 \%$ at $\sim 118 \mathrm{~m}$. The $\delta^{13} \mathrm{C}_{\text {org }}$ remains relatively stable around $-24 \%$ up to the approximate height of $121 \mathrm{~m}$ where the values decrease remarkably to the minimum of $\sim-26.2 \%$ at $124 \mathrm{~m}$. A positive recovery takes place immediately thereafter to the maximum of $\sim-25 \%$ at $\sim 125 \mathrm{~m}$, hence forming the characteristic modulation of intra-segment $\mathrm{C} 2$ negative shift with an anomaly of $\sim 2.2 \%$ preceding the more negative excursion characteristic of segment $\mathrm{C} 3$. The CIE at the Santa Rosa Canyon further concurs with the amplitude of variation recorded at the sites previously discussed and supports the similarity with the Organyà Basin site at El Pui.

While there is an overall similar pattern in all of the sections discussed, it is evident that differences in amplitude could be attributed to local forcing factors such as source of OM, maturation etc. However, to postulate a causal factor with any certitude to explain 
the differences in amplitude would require a more detailed geochemical characterization of each of the locations. While this intra-segment C2 CIE may not be very distinct in a number of Lower Aptian sections in the published literature, clearly, factors such as sampling resolution, reduced thickness of section or even hiatuses in sediments during that time interval will affect the occurrence or absence of the inflection.

\subsubsection{Lipid Biomarkers}

The biomarker results rely on accepted $n$-alkane values attributed to certain biota as follows:

$* \leq n \mathrm{C}_{19}$ are mainly derived from marine planktonic organisms and /or bacterial communities (Forster et al., 2004; Peters et al., 2005)

${ }^{*} n \mathrm{C}_{20}-n \mathrm{C}_{25}$ are mainly derived from aquatic macrophytes both marine and non-marine (Cranwell, 1984; Ficken et al., 2000; Mead et al., 2005)

${ }^{*}>n \mathrm{C}_{25}$ are mainly derived from terrestrial plants (Cranwell, 1982)

Since the OM shows low maturity (Sanchez-Hernandez and Maurrasse, 2016) we can postulate that the carbon isotopic values $\delta^{13} \mathrm{C}_{\text {org }}$ are primary with little diagenetic overprinting.

In the interval studied the $n$-alkanes (Fig. 4-6) represent the most abundant fraction of the total extractable lipids from all the samples. In general, the aliphatic fraction is dominated by short chain homologues $\leq n \mathrm{C}_{19}$ with a range of $n \mathrm{C}_{10}-n \mathrm{C}_{30}$ and no apparent odd or even preference. Since the OM shows low maturity (Sanchez-Hernandez and Maurrasse, 2016) and very labile short chain $\leq n \mathrm{C}_{13}$ alkanes are present, the results suggest that there has been little to no diagenetic alteration of the $n$-alkanes distribution. Since short chain $n$-alkanes indicate an algal or microbial source, while longer chain 
B

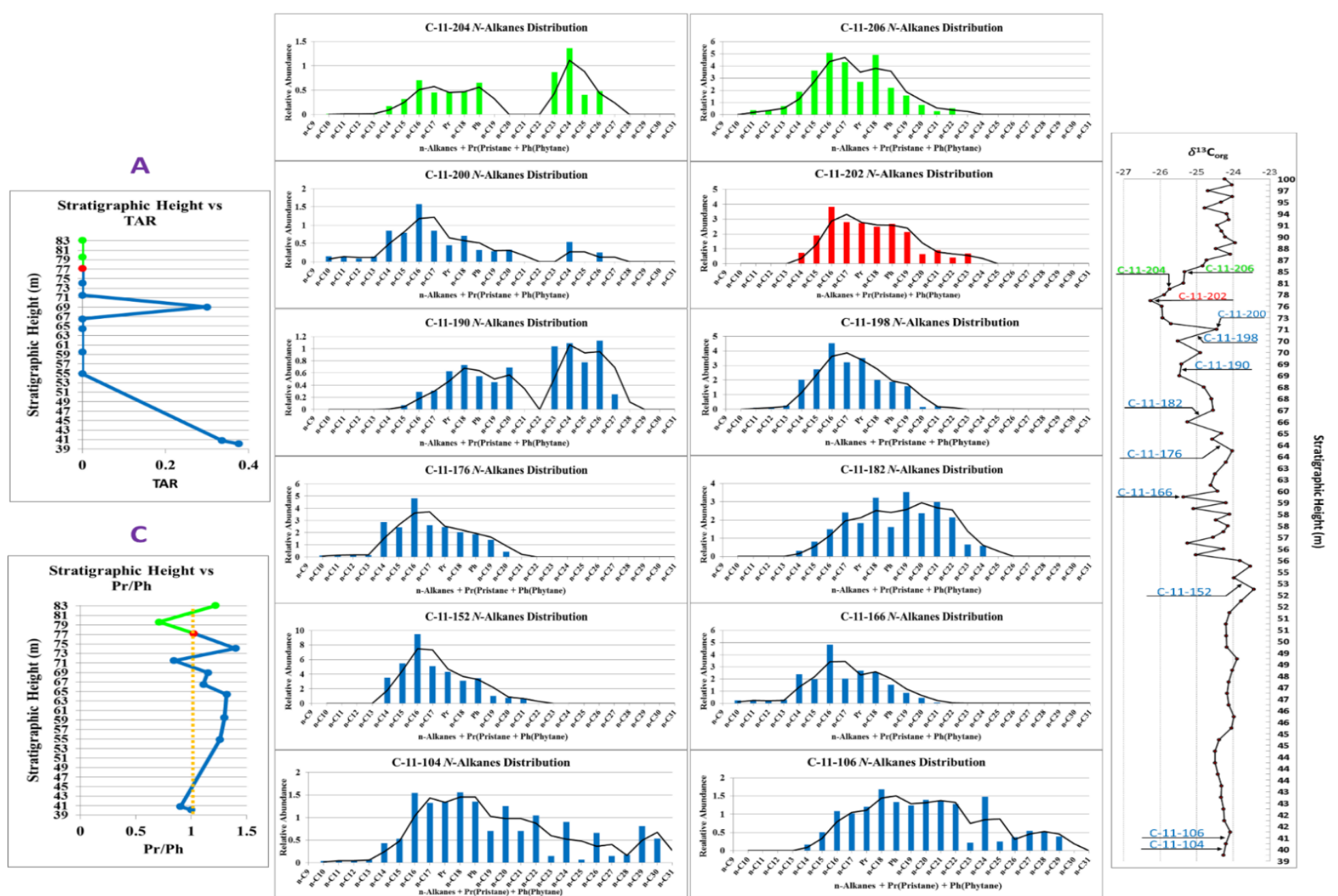

Figure 4-6 Summary of organic geochemistry results and their respective stratigraphic locations along the $\delta^{13} \mathrm{C}_{\text {org }}$ curve. A-Stratigraphic Height vs TAR. B-N-alkane results for selected samples. C-Stratigraphic Height vs $\mathrm{Pr} / \mathrm{Ph}$. Colors (blue, red, green) refers to the duration before, during and after the lowest value reached within the intra-segment $\mathrm{C} 2$ negative excursion respectively. 
$>n \mathrm{C}_{25}$ indicates terrestrial plant matter, (Bourbonniere and Meyers, 1996), in the El Pui section the TAR $\left.\left[\left(n \mathrm{C}_{27}+n \mathrm{C}_{29}+n \mathrm{C}_{31}\right) / n \mathrm{C}_{15}+n \mathrm{C}_{17}+n \mathrm{C}_{19}\right)\right]$ values shown in Figure 4-6A (blue color) imply some contribution of terrestrially derived OM at stratigraphic levels $40.1 \mathrm{~m}$ (sample C-11-104, TAR $=0,38) ; 40.8 \mathrm{~m}($ sample $\mathrm{C}-11-106$, TAR $=0.34)$ and $69 \mathrm{~m}$ (sample C-11-190, TAR $=0.3$ ), respectively. At the lowest levels, the $n$-alkanes distribution is slightly bimodal, but sample C-11-190 at $69 \mathrm{~m}$ shows a stronger allochthonous input as attested by the abundance of the longer chain $n$-alkanes (Fig. 46B). The TAR average for the interval $(39 \mathrm{~m}-75.7 \mathrm{~m})$, corresponding to the time before the negative inflection is 0.112 , whereas at the negative inflection (Fig. 4-6A, B in red), there is a more normal distribution with a range of $n \mathrm{C}_{14}-n \mathrm{C}_{23}$ and the highest abundance being attributed to $n \mathrm{C}_{16}$. The TAR value at the lowest point $(77.2 \mathrm{~m})$ of the negative inflection is zero. Following the negative inflection (Fig. 4-6A, B in green), the $n$-alkanes distribution is dominated by short chain $\leq n \mathrm{C}_{19}$ homologues with some minor contribution from aquatic macrophytes, $n \mathrm{C}_{20}-n \mathrm{C}_{25}$ (bimodal distribution shown in graph C-11-204 (Fig. 4-6A). The $n$-alkanes as well as the TAR of zero corroborate the lack of contribution from terrestrial vegetation. As previously stated, the occurrence of $n$-alkanes ranging from values between $n \mathrm{C}_{23}$ to $n \mathrm{C}_{25}$ has been shown by several authors to belong to submerged aquatic vegetation, from both marine and non-marine environments. Namely, Ficken et al. (2000) where they looked at lipid extracts from submerged and emergent aquatic plants in freshwater lakes on Mt. Kenya and more recently by Mead et al.(2005) where the authors looked at lipid extracts from submerged and emergent marine/estuarine vegetation in the coastal Everglades region of South Florida. These authors also demonstrated that emergent aquatic vegetation such as mangroves have very similar $n$ - 
alkanes distribution to terrestrial vegetation, with chain lengths ranging from $n \mathrm{C}_{26}-n \mathrm{C}_{29}$. It is worth noting the unusual abundance of these $n$-alkanes in two periods constituting to sample C-11-190 (69 m) and C-11-204 (79.6 m). Hence, we conclude that during these two intervals the basin was getting significant input of organic matter from estuarine and or wetlands sources.

The second most abundant molecules present in the aliphatic fraction are pristane (Pr) and phytane $(\mathrm{Ph})$. These acyclic isoprenoids are derived from the phytol side chain of chlorophyll and their concentrations are dependent on the oxygen content, or lack thereof in the water column during deposition. Under reducing conditions, the reaction favors the formation of phytane while under oxidizing conditions pristane is produced (Brooks et al., 1969; Didyk et al., 1978). Ratios of Pr/Ph higher than 1 signify deposition under oxidizing conditions while values lower than 1 indicate dysoxic to anoxic conditions. The $\mathrm{Pr} / \mathrm{Ph}$ values in the lower portion (Fig. 4-6C) corresponding to the time before the negative inflection indicate that deposition occurred under relatively oxygenated conditions, except for sample C-11-106 and C-11-198, which show slightly dysoxic conditions. During the negative inflection, the $\mathrm{Pr} / \mathrm{Ph}$ ratio stays slightly above unity, while after the negative inflection a lowest value of 0.71 is observed and then returns to oxygenated conditions with a value of 1.2.

\subsection{Discussion}

\subsubsection{Significance of the $n$-alkane Distribution in the Intra-Segment C2 Negative Carbon Isotope Inflection}

It is well established that elemental carbon includes two non-radiogenic isotopes, ${ }^{12} \mathrm{C}(98.89 \%)$ and ${ }^{13} \mathrm{C}(1.11 \%)$, which are fractionated during photosynthesis in 
proportions that depend on the method of carbon fixation followed by the organism. Thus, most terrestrial plants undergo $\mathrm{C} 3$ photosynthesis, which fixes more light carbon atoms thereby leading to negative $\delta{ }^{13} \mathrm{C}$ values ranging from -24 to $-34 \%$. In phytoplankton and photosynthetic bacteria kinetic fractionation (Guy et al., 1993) is less pronounced thus $\delta^{13} \mathrm{C}$ values are far more positive, ranging from -12 to $-23 \%$. These accepted ranges of carbon isotope values coupled with $n$-alkanes will allow us to find whether there is absence of terrestrial plant influences during the interval of carbon isotope negative shift, or whether the amplitude observed is being "artificially" inflated by allochthonous, terrestrially derived OM.

As previously discussed, when assessing the biological sources of organic matter the basic principle employed relies on the presence of lipid biomarkers that are specific to their origin (Brocks et al., 2005). One such general source indicator is the presence of short versus long chain $n$-alkanes originating from phytoplankton/microbial and terrestrial vegetation, respectively. As can be seen in Figure 4-6B most samples show an $n$-alkane distribution dominated by shorter chain $\left(n \mathrm{C}_{10}-n \mathrm{C}_{19}\right)$, suggesting that the source of the $\mathrm{OM}$ is mostly autochthonous. However, the ratio of allochthonous $\mathrm{OM}$ to autochthonous OM shows some temporal changes that include terrestrially derived $n$ alkanes at levels $40.1 \mathrm{~m}$ and $40.8 \mathrm{~m}$, respectively (C-11-104, C-11-106), far below the onset of the negative carbon isotope shift (Fig. 4-6B). Similar terrestrial OM recurs at 69 m (C-11-190), shortly prior to, but not coincident with the most negative values characteristic of the intra-C2 CIE. The shorter chain homologues $n$-alkanes derived from phytoplankton/microbial sources that dominate during the negative inflection suggest that the $\delta^{13} \mathrm{C}_{\text {org }}$ curve is not being altered by the input of very light $\delta^{13} \mathrm{C}$ OM derived from 
terrestrial plant. These values thus imply that the negative shift can be related to a global perturbation in the carbon reservoir.

In addition to OM source identification, $n$-alkane distribution is also a good index for the relative maturation/degradation state of the OM. Maturation and microbial degradation of OM can alter the $n$-alkane distribution through the selective removal of the more labile, shorter chain $n$-alkanes and thus cause an enrichment in the more recalcitrant, terrestrial plant derived portion. In effect, the predominant phytoplankton/microbial signature $\left(\leq n \mathrm{C}_{19}\right)$ in the $n$-alkane distributions of most of the samples indicates good preservation conditions, therefore lending support that the $\mathrm{OM}$ in the basin was most likely preserved with $n$-alkanes that characterize the original composition.

\subsubsection{Possible Modulating Factors in the Intra-Segment C2 Negative Excursion}

Given the regional and global geologic settings of the Early Aptian, several plausible interactive factors could have been involved in causing the intra-segment $\mathrm{C} 2$ negative inflection as follows:

1. - Based on the tectonic history of the area, and given that hydrothermal processes are associated with pull-apart basins (Rubin, 1997; Bjørlykke, 2010) it is plausible that magmatic degassing could have introduced large concentrations of light carbon in the Organyà Basin, thereby affecting the overall carbon isotopic intake in the semi-restricted basin. However, extensive studies of the area do not report evidence of igneous processes (Peybernès and Souquet, 1973; Peybernès, 1976; Martínez, 1982; Muñóz et al., 1984;

Caus et al., 1990; Berástegui et al., 1990; Dinarès-Turell and García-Senz, 2000; GarcíaSenz, 2002; Bernaus et al., 2002, 2003; Capote et al., 2002; Gong et al., 2009; Sanchez- 
Hernandez and Maurrasse, 2014; 2016; Sanchez-Hernandez et al., 2014). Furthermore, trace element analyses point rather to terrigenous fluxes in the basin in compatibility with the paleophysiography and climatic conditions at that time (García-Senz, 2002; SanchezHernandez and Maurrasse, 2014; 2016; Sanchez-Hernandez et al., 2014). Hence, the possibility of local magmatic influence can be ruled out.

2. - Given the semi-restricted setting of the Organyà Basin and extensive terrigenous fluxes associated with conditions at that time (Dinarès-Turell and GarcíaSenz, 2000; García-Senz, 2002; Bernaus et al., 2002, 2003; Sanchez-Hernandez and Maurrasse, 2014; 2016; Sanchez-Hernandez et al., 2014) such fluxes could account for significant organic molecule input of terrestrial origin. Since dissolved organic matter (DOC) entering the surface waters exhibit tendency to concentrate at interfaces, therefore this DOC could be rapidly adsorbed in contact with particles suspended in sea water and particulate organic matter (POM), thereby being transformed into aggregates and zooplankton feces and settled rapidly (Asper, et al., 1992). This organic matter would therefore be sequestrated and the terrestrial origin preserved in the sediments, thus possibly contributing to a light carbon isotopic signature in the record. Also, terrestrial DOC that were rapidly mixed into the upper ocean (Williams and Druffel, 1987; Bauer et al., 1992) and not remineralized (Bauer et al., 1992) could maintain a significant steady input of isotopically light carbon to be fixed by in situ primary producers in the euphotic zone. By this process, fixed carbon by photosynthesizers would reflect the effects of terrestrially derived organic matter. Trace elements results indicate oxygen-deficient conditions likely associated with water column stratification (SanchezHernandez and Maurrasse, 2014); therefore, recirculation must have been limited in the 
basin. Furthermore, the $n$-alkane results from the interval that includes the intra-segment C2 CIE do not support a land-derived influence in the organic matter supplied into the basin at that time. Thus, this second possibility can be safely excluded as well.

3.- Another possible scenario may invoke external influences affecting the global ocean carbon reservoir, albeit local mitigating factors (accumulation rate, tectonism, strong ecosystem variability) that could overprint in situ isotopic ratios not significantly affected by direct input from terrigenous OM. In the latter case, the isotopic signature would be worldwide and the record would mirror the extant isotopic ratio of the global carbon reservoir. Since methane derived carbon is $\sim 12$ times lighter (Méhay et al., 2009), Jahren and Ahrens (1998) suggested that gas hydrate dissociation might have caused rapid rate of $\delta{ }^{13} \mathrm{C}$ changes during the negative carbon isotope shifts in Lower Aptian sediments. This possibility remains conjectural because of the long duration of these negative anomalies. On the other hand, recent studies of Lower Cretaceous explosive volcanism in Asia (Songliao Basin or northeast Asia SB-V volcanism; Wang et al., 2002; 2016) appear to be coeval with effusion of the large igneous provinces (Larson, 1991). Thus, the coupled effects of massive LIPs and land volcanism suggest that volcanic $\mathrm{CO}_{2}$ release in pulses of different magnitudes and duration could have been the driving mechanisms for the worldwide occurrences of negative carbon isotope shifts. Indeed, the signals are also recorded in lacustrine deposits (Zhang et al., 2016), which substantiates the non-strictly marine causal origin for the forcing mechanism of light carbon input into the global carbon reservoir systems. The widespread occurrence of the negative intrasegment $\mathrm{C} 2 \mathrm{CIE}$ at different sites supports the possible combined effects of intermittent pulses of contemporaneous Ontong Java Plateau (OJP) flood basalt and widespread 
massive continental volcanism in Asia (Wang et al., 2002; 2016). The results suggest that long lasting global volcanism appears to be the most plausible driving factors that led to the variations observed in the Lower Aptian deposits, including the negative isotope shift in $\mathrm{C} 2$.

\subsection{Conclusions}

Carbon isotope segment $\mathrm{C} 2$ in the expanded El Pui section of the Organyà Basin, south central Pyrenees sections of the Tethyan realm includes a marked negative inflection of $\sim 1.81 \%$ o to $2.23 \%$. Carbon isotope segment $\mathrm{C} 2$ is the longest interval preceding the segments assigned to anoxic event 1a (OAE1a) $(\mathrm{C} 3-\mathrm{C} 6)$. TIC, TOC, $\delta$

${ }^{13} \mathrm{C}_{\text {org }}$, microfacies, paleontological and biomarker ( $n$-alkanes) reveal no difference in biota between the time before, during or after the negative inflection. During the negative shift, the $n$-alkanes are predominantly short-chain length homologues with very little to no contribution from shallow marine $\left(n \mathrm{C}_{20}-n \mathrm{C}_{25}\right)$, land-derived aquatic vegetation, and absolutely none from higher plants $\left(>n \mathrm{C}_{25}\right)$. The terrestrial/aquatic ratios TARs $\left(n \mathrm{C}_{27}+n \mathrm{C}_{29}+n \mathrm{C}_{31}\right) /\left(n \mathrm{C}_{15}+n \mathrm{C}_{17}+n \mathrm{C}_{19}\right)$ averaging 0.112 before and 0 during the negative inflection indicate that local factors did not enhance the $\delta^{13} \mathrm{C}_{\mathrm{org}}$ negative inflection during $\mathrm{C} 2$. Thus, the negative inflection in $\mathrm{C} 2$ reflects a true change within the ocean carbon isotopic reservoir independent from local sea level fluctuations at that time. Variations in magnitude and duration of Lower Cretaceous massive explosive volcanism in Asia and northeast Asia SB-V (Songliao Basin) coupled with contemporaneous LIPs offer a plausible explanation for the negative carbon isotopic excursions recorded at El Pui and elsewhere. The intra-segment C2 negative excursion indicating a change in the global ocean reservoir can be a useful chemostratigraphic marker harbinger to OAE1a. 
Additional high-resolution studies are required in non-condensed sections to resolve if smaller-scale regional differences in $\delta^{13} \mathrm{C}$ are observed specific to these areas. The results further highlight the value of chemostratigraphy in correlation, and the apparent common occurrence of the intra-C2 inflection implies that it may be a useful anticipatory marker to the more pronounced CIE C3 associated with the onset of OAE1a.

\subsection{Acknowledgements}

We gratefully acknowledge the support of the Glenn A. Goodfriend Memorial funds for fieldwork and laboratory analyses. Many thanks are due to Diane Pirie for her unwavering help with our carbon analyzer and gracious help at all steps of this research. We thank Bill Anderson for the carbon isotope analyses, and Cesar Ramirez at FIU's Advanced Mass Spectrometry Facility for the biomarker analyses. Special thanks to Xiumian Hu and his collaborators for graciously hosting the IGCP 609 Workshop in China (September 2015) where we had the opportunity to discuss the ideas presented in this paper. We are most grateful to our colleague Josep Moreno-Bedmar for logistic support during part of the fieldwork, and discussions about ammonites. Mr. Ferran is gratefully acknowledged for his amiable authorization to carry out sampling of the El Pui section on his private hunting property. We also thank two anonymous reviewers for providing detailed comments that helped refine the manuscript, and the editor of SCIENCE CHINA Earth Sciences, Dr. Yamin LI for his help with the editing of the manuscript. The Earth and Environment Department at FIU generously provided supplies and other laboratory materials.

This paper is a contribution of IGCP 609 . 


\subsection{References}

Ando, A., Kaiho, K., Kawahata, H., Kakegawa, T., 2008. Timing and magnitude of early Aptian extreme warming: Unraveling primary $\delta 180$ variation in indurated pelagic carbonates at Deep Sea Drilling Project Site 463, central Pacific Ocean.

Palaeogeogr. Palaeoclimatol. Palaeoecol. 260, 463-476. https://doi.org/10.1016/J.PALAEO.2007.12.007

Asper, V.L., Deuser, W.G., Knauer, G.A., Lohrenz, S.E., 1992. Rapid coupling of sinking particle fluxes between surface and deep ocean waters. Nature 357, 670672. https://doi.org/10.1038/357670a0

Bauer, J.E., Williams, P.M., Druffel, E.R.M., 1992. 14C activity of dissolved organic carbon fractions in the north-central Pacific and Sargasso Sea. Nature 357, 667-670. https://doi.org/10.1038/357667a0

Berástegui, X., Garcia-Senz, J., Losantos, M., 1990. Tecto-sedimentary evolution of the Organyà extensional basin (central south Pyrenean unit, Spain) during the Lower Cretaceous. Bull. la Société géologique Fr. 6, 251-264. https://doi.org/10.2113/gssgfbull.VI.2.251

Bernaus, J.M., Arnaud-Vanneau, A., Caus, E., 2002. Stratigraphic distribution of Valanginian-Early Aptian shallow-water benthic foraminifera and algae, and depositional sequences of a carbonate platform in a tectonically-controlled basin: The Organyà Basin, Pyrenees, Spain. Cretac. Res. 23, 25-36. https://doi.org/10.1006/cres.2001.0300

Bernaus, J.M., Arnaud-Vanneau, A., Caus, E., 2003. Carbonate platform sequence stratigraphy in a rapidly subsiding area: The Late Barremian-Early Aptian of the Organyà basin, Spanish Pyrenees. Sediment. Geol. 159, 177-201. https://doi.org/10.1016/S0037-0738(02)00316-0

Bjørlykke, K., 2010. Petroleum Geoscience: From Sedimentary Environments to Rock Physics. Springer Berlin Heidelberg, Berlin, Heidelberg. https://doi.org/10.1007/978-3-642-02332-3

Blumer, M., Guillard, R.R.L., Chase, T., 1971. Hydrocarbons of marine phytoplankton. Mar. Biol. 8, 183-189. https://doi.org/10.1007/BF00355214

Bourbonniere, R.A., Meyers, P.A., 1996. Sedimentary geolipid records of historical changes in the watersheds and productivities of Lakes Ontario and Erie. Limnol. Oceanogr. 41, 352-359. https://doi.org/10.4319/1o.1996.41.2.0352 
Brocks, J.J., Love, G.D., Summons, R.E., Knoll, A.H., Logan, G.A., Bowden, S.A., 2005. Biomarker evidence for green and purple sulphur bacteria in a stratified Palaeoproterozoic sea. Nature 437, 866-870. https://doi.org/10.1038/nature04068

Brooks, J.D., Gould, K., Smith, J.W., 1969. Isoprenoid hydrocarbons in coal and petroleum. Nature. https://doi.org/10.1038/222257a0

Capote R, Muñoz J A, Simón J L, Liesa C L, A.L.E., 2002. Alpine Tectonics I: the Alpine System North of the Betic Cordillera, in: W, G., T, M. (Eds.), The Geology of Spain. Geol Soc London, London, pp. 367-400.

Caus, E., García-Senz, J., Rodés, D., Simó, A., 1990. Stratigraphy of the Lower Cretaceous (Berriasian-Barremian) sediments in the Organyà Basin, Pyrenees, Spain. Cretac. Res. 11, 313-320. https://doi.org/10.1016/S0195-6671(05)80015-1

Cranwell, P.A., 1973. Chain-length distribution of n-alkanes from lake sediments in relation to post-glacial environmental change. Freshw. Biol. 3, 259-265. https://doi.org/10.1111/j.1365-2427.1973.tb00921.x

Cranwell, P.A., 1982. Lipids of aquatic sediments and sedimenting particulates. Prog. Lipid Res. https://doi.org/10.1016/0163-7827(82)90012-1

Cranwell, P.A., 1984. Lipid geochemistry of sediments from Upton Broad, a small productive lake. Org. Geochem. 7, 25-37. https://doi.org/10.1016/01466380(84)90134-7

Cranwell, P.A., Eglinton, G., Robinson, N., 1987. Lipids of aquatic organisms as potential contributors to lacustrine sediments-II. Org. Geochem. 11, 513-527. https://doi.org/10.1016/0146-6380(87)90007-6

de Gea, G.A., Castro, J.M., Aguado, R., Ruiz-Ortiz, P.A., Company, M., 2003. Lower Aptian carbon isotope stratigraphy from a distal carbonate shelf setting: The Cau section, Prebetic zone, SE Spain. Palaeoge

Didyk, B.M., Simoneit, B.R.T., Brassell, S.C., Eglinton, G., 1978. Organic geochemical indicators of palaeoenvironmental conditions of sedimentation. Nature 272, $216-$ 222. https://doi.org/10.1038/272216a0

Dinarès-Turell, J., Garcia-Senz, J., 2000. Remagnetization of Lower Cretaceous limestones from the southern Pyrenees and relation to the Iberian plate geodynamic evolution. J. Geophys. Res. Solid Earth 105, 19405-19418.

https://doi.org/10.1029/2000jb900136 
Duque-Botero, F., Maurrasse, F.J.M.R., 2005. Cyanobacterial productivity, variations in the organic carbon, and facies of the Indidura Formation (Cenomanian-Turonian), Northeastern Mexico. J. Iber. Geol. 3, 85-98.

Eglinton, G., Hamilton, R.J., 1967. Leaf epicuticular waxes. Science (80-. ). 156, 13221335. https://doi.org/10.1126/science.156.3780.1322

Erba, E., 2004. Calcareous nannofossils and Mesozoic oceanic anoxic events. Mar. Micropaleontol. 52, 85-106. https://doi.org/10.1016/j.marmicro.2004.04.007

Erba, E., Channell, J.E.T., Claps, M., Jones, C., Larson, R., Opdyke, B., Premoli Silva, I., Riva, A., Salvini, G., Torricelli, S., 1999. Integrated stratigraphy of the Cismon Apticore (southern Alps, Italy); a "reference section" for the Barremian-Aptian interval at low latitudes. J. Foraminifer. Res. 29, 371-391.

Erba, E., Duncan, R.A., Tiraboschi, D., 2015. Environmental consequences of Ontong Java Plateau and Kerguelen Plateau volcanism, The Geological Soceity of America Special Paper 511. Geological Society of America Special Paper. https://doi.org/10.1130/2015.2511(15)

Ficken, K.J., Li, B., Swain, D.L., Eglinton, G., 2000. An n-alkane proxy for the sedimentary input of submerged/floating freshwater aquatic macrophytes. Org. Geochem. 31, 745-749. https://doi.org/10.1016/S01

Forster, A., Sturt, H., Meyers, P., Party, L., 2004. Molecular biogeochemistry of Cretaceous black shales from the Demerara Rise; preliminary shipboard results from Sites 1257 and 1258, ODP Leg 207. Proc. Ocean Drill. Progr. Initial Rep 207, 1-22.

Gaona-Narvaez, T., Maurrasse, F.J.-M.R., Moreno-Bedmar, J.A., 2013a. Stable carbonisotope stratigraphy and ammonite biochronology at Madotz, Navarra, northern Spain: implications for the timing and duration of oxygen depletion during OAE-1a. Cretac. Res. 40, 143-157. https://doi.org/10.1016/J.CRETRES.2012.06.005

Gaona-Narvaez, T., Maurrasse, F.J.-M.R., Etayo-Serna, F., 2013b. Geochemistry, palaeoenvironments and timing of Aptian organic-rich beds of the Paja Formation (Curití, Eastern Cordillera, Colombia). Geol. Soc. London, Spec. Publ. 382, 31-48. https://doi.org/10.1144/SP382.6

García-Senz, J., 2002. Cuencas extensivas del Cretácico inferior en los Pirineos centrales, formación y subsiguiente inversión. (PhD Diss) Dpt. Geodinàmica i Geofísica 310.

Giger, W., Schaffner, C., Wakeham, S.G., 1980. Aliphatic and olefinic hydrocarbons in recent sediments of Greifensee, Switzerland. Geochim. Cosmochim. Acta 44, 119 129. https://doi.org/10.1016/0016-7037(80)90182-9 
Godet, A., Bodin, S., Föllmi, K.B., Vermeulen, J., Gardin, S., Fiet, N., Adatte, T., Berner, Z., Stüben, D., van de Schootbrugge, B., 2006. Evolution of the marine stable carbon-isotope record during the ear

Golonka, J., 2004. Plate tectonic evolution of the southern margin of Eurasia in the Mesozoic and Cenozoic. Tectonophysics 381, 235-273. https://doi.org/10.1016/j.tecto.2002.06.004

Gong, Z., van Hinsbergen, D.J.J., Vissers, R.L.M., Dekkers, M.J., 2009. Early Cretaceous syn-rotational extension in the Organyà basin-New constraints on the palinspastic position of Iberia during its rotation. Tectonophysics 473, 312-323. https://doi.org/10.1016/j.tecto.2009.03.003

Guy, R.D., Fogel, M.L., Berry, J.A., 1993. Photosynthetic Fractionation of the Stable Isotopes of Oxygen and Carbon. Plant Physiol. 101, 37-47. https://doi.org/10.1104/pp.101.1.37

H, J.A., C., A.N., 1998. Methane hydrate dissociation implicated in Aptian OAE events. Geol. Soc. Am. Abstr. Progr 30, 53.

Haq, B.U., Hardenbol, J.A.N., Vail, P.R., 1987. Chronology of Fluctuating Sea Levels Since the Triassic. Science (80-. ). 235, 1156 LP-1167. https://doi.org/https://doi.org/10.1126/science.235.4793.1156

Heldt, M., Bachmann, M., Lehmann, J., 2008. Microfacies, biostratigraphy, and geochemistry of the hemipelagic Barremian-Aptian in north-central Tunisia: Influence of the OAE 1a on the southern Tethys margin. Palaeogeogr. Palaeoclimatol. Palaeoecol. 261, 246-260. https://doi.org/10.1016/j.palaeo.2008.01.013

Holtvoeth, J., Vogel, H., Wagner, B., Wolff, G.A., 2010. Lipid biomarkers in Holocene and glacial sediments from ancient Lake Ohrid (Macedonia, Albania). Biogeosciences 7, 3473-3489. https://doi.org/10.5194/bg-7-3473-2010

Huber, B.T., Hodell, D.A., Hamilton, C.P., 1995. Middle-late Cretaceous climate of the southern high latitudes: stable isotopic evidence for minimal equator-to-pole thermal gradients. Geol. Soc. Am. Bull. 107, 1164-1191. https://doi.org/10.1130/00167606(1995)107<1164:MLCCOT>2.3.CO;2

Kuhnt, W., Moullade, M., Masse, J.-P., Erlenkeuser, H., 1998. Carbon isotope stratigraphy of the lower Aptian historical stratotype at Cassis-La Bédoule (SE France). Geol. Mediterr. 25, 63-79.

Larson, R.L., 1991. Geological consequences of superplumes. Geology 19, 963-966. https://doi.org/10.1130/0091-7613(1991)019<0963:GCOS>2.3.CO;2 
Li, J., Hu, X., Zhao, K., Cai, Y., Sun, T., 2016. Paleoceanographic evolution and chronostratigraphy of the Aptian Oceanic Anoxic Event 1a (OAE1a) to oceanic red bed 1 (ORB1) in the Gorgo a Cerbara section (

Li, Y.X., Bralower, T.J., Montañez, I.P., Osleger, D.A., Arthur, M.A., Bice, D.M., Herbert, T.D., Erba, E., Premoli Silva, I., 2008. Toward an orbital chronology for the early Aptian Oceanic Anoxic Event (OAE1a, $120 \mathrm{Ma}$ ). Earth Planet. Sci. Lett. 271, 88-100. https://doi.org/10.1016/j.eps1.2008.03.055

Martinez, R., 1982. Ammonoideos cretácicos del Prepirineo de la provincia de Lleida. (PhD Diss) publicaciones la Univ. Autónoma Barcelona 17, 0-197.

Maurrasse, F.J.M.R., Sanchez-Hernandez, Y., 2014. High-resolution chemostratigraphy and facies analysis of an Early Cretaceous expanded section of the Organyà Basin: implications for Barremian-Aptian global d13C correlation and sea level changes, in: 2nd Workshop IGCP 609: Climate-Environmental Deteriorations during Greenhouse Phases: Causes and Consequences of Short-Term Cretaceous Sea-Level Change. p. Abstract 21.

Mead, R., Xu, Y., Chong, J., Jaffé, R., 2005. Sediment and soil organic matter source assessment as revealed by the molecular distribution and carbon isotopic composition of n-alkanes. Org. Geochem. 36, 363-370. https://doi.org/10.1016/j.orggeochem.2004.10.003

Méhay, S., Keller, C.E., Bermasconi, S.M., Weissert, H., Erba, E., Bottini, C., Hochuli, P.A., 2009. A volcanic CO2 pulse triggered the Cretaceous oceanic Anoxic event 1a and a biocalcification crisis. Geology 37, 819-822.

https://doi.org/10.1130/G30100A.1

Menegatti, A.P., Weissert, H., Brown, R.S., Tyson, R. V., Farrimond, P., Strasser, A., Caron, M., 1998. High-resolution $\delta 13 \mathrm{C}$ stratigraphy through the early Aptian "Livello Selli" of the Alpine Tethys. Paleoceanography 13, 530-545. https://doi.org/10.1029/98PA01793

Millán, M.I., Weissert, H.J., Fernández-Mendiola, P.A., García-Mondéjar, J., 2009. Impact of Early Aptian carbon cycle perturbations on evolution of a marine shelf system in the Basque-Cantabrian Basin (Aralar, N Spain). Earth Planet. Sci. Lett. 287, 392-401. https://doi.org/10.1016/j.eps1.2009.08.023

Moreno-Bedmar, J.A., 2010. Ammonits de l'Aptià inferior de la península Ibèrica. Bioestatigrafia i aportacions a l'estudi del Oceanic Anoxic Event 1a. Universitat de Barcelona.

Moullade, M., Kuhnt, W., Bergen, J.A., Masse, J.P., Tronchetti, G., 1998. Correlation of biostratigraphic and stable isotope events in the Aptian historical stratotype of La 
Bedoule (southeast France). Comptes Rendus l'Academie Sci. - Ser. IIa Sci. la Terre des Planetes 327, 693-698. https://doi.org/10.1016/S1251-8050(99)80027-5

Moullade, M., Tronchetti, G., Granier, B., Bornemann, A., Kuhnt, W., Lorenzen, J., 2015. High-resolution integrated stratigraphy of the OAEla and enclosing strata from core drillings in the Bedoulian stratotype (Roquefort-La Bédoule, SE France).

Cretac. Res. 56, 119-140. https://doi.org/10.1016/J.CRETRES.2015.03.004

Muñóz J A, Puig de Fábregas C, F.J.M., 1984. Orógenos alpinos, in: M, R.L.J.J. (Ed.), El Pirineo. Inst Geol Min España. Geología de España, pp. 161-205.

Najarro, M., Rosales, I., Moreno-Bedmar, J.A., de Gea, G.A., Barrón, E., Company, M., Delanoy, G., 2010. High-resolution chemo- and biostratigraphic records of the Early Aptian oceanic anoxic event in Cantabria (N Spain): Palaeoceanographic and palaeoclimatic implications. Palaeogeogr. Palaeoclimatol. Palaeoecol. 299, 137-158. https://doi.org/10.1016/j.palaeo.2010.10.042

Papp, D.C., Cociuba, I., Lazâr, D.F., 2013. Carbon and oxygen-isotope stratigraphy of the Early Cretaceous carbonate platform of Pâdurea Craiului (Apuseni Mountains, Romania): A chemostratigraphic correlation and paleoenvironmental tool. Appl. Geochemistry 32, 3-16. https://doi.org/10.1016/j.apgeochem.2012.09.005

Peters, K.E., Walters, C.C., Moldowan, J.M., 2005. The Biomarker Guide Volume 2: Biomarkers and isotopes in petroleum systems and earth history, Cambridge University Press.

Peybernès, B., 1976. Le Jurassique et le Crétacé inférieur des Pyrénées francoespagnoles. (PhD Diss) Lab. Géologie, Univ. Paul Sabatier, Toulouse 459.

Peybernès, B., Souquet, P., 1973. Biostratigraphie des marnes noires de l'Aptien-Albien de la zone sud-pyrénéenne. CR Acad. Sc. Paris 276, 2501-2504.

Phelps, R.M., 2011. Middle-Hauterivian to Lower-Campanian sequence stratigraphy and stable isotope geochemistry of the Comanche Platform, south Texas. (PhD Diss) Univ. Texas, Austin, TX 227.

Phelps, R.M., Kerans, C., Da-Gama, R.O.B.P., Jeremiah, J., Hull, D., Loucks, R.G., 2015. Response and recovery of the Comanche carbonate platform surrounding multiple Cretaceous oceanic anoxic events, northern Gulf of Mexico. Cretac. Res. 54, 117-144. https://doi.org/10.1016/j.cretres.2014.09.002

Quintana, L., Pulgar, J.A., Alonso, J.L., 2015. Displacement transfer from borders to interior of a plate: A crustal transect of Iberia. Tectonophysics 663, 378-398. https://doi.org/10.1016/J.TECTO.2015.08.0 
Reboulet, S., Hoedemaeker, P.J., Aguirre-Urreta, M.B., Alsen, P., Atrops, F., Baraboshkin, E.Y., Company, M., Delanoy, G., Dutour, Y., Klein, J., Latil, J.-L., Lukeneder, A., Mitta, V., Mourgues, F.A., Ploch, I., Raisossadat, N., Ropolo, P., Sandoval, J., Tavera, J.M., Vasicek, Z., Vermeulen, J., Arnaud, H., Granier, B., Premoli-Silva, I., 2006. Report on the 2nd international meeting of the IUGS lower Cretaceous ammonite working group, the "Kilian Group" (Neuchâtel, Switzerland, 8 September 2005). Cretac. Res. 27, 712-715. https://doi.org/10.1016/J.CRETRES.2006.03.006

Reboulet, S., Rawson, P.F., Moreno-Bedmar, J.A., Aguirre-Urreta, M.B., Barragán, R., Bogomolov, Y., Company, M., González-Arreola, C., Stoyanova, V.I., Lukeneder, A., Matrion, B., Mitta, V., Randrianaly, H., Vašiček, Z., Baraboshkin, E.J., Bert, D., Stéphane Bersac, Bogdanova, T.N., Bulot, L.G., Latil, J.-L., Mikhailova, I.A., Ropolo, P., Szives, O., 2012. Report on the 4th International Meeting of the IUGS Lower Cretaceous Ammonite Working Group, the "Kilian Group" (Dijon, France, 30th August 2010). Cretac. Res. 32, 786-793.

https://doi.org/10.1016/J.CRETRES.2011.05.007

Rieley, G., Collier, R.J., Jones, D.M., Eglinton, G., 1991a. The biogeochemistry of Ellesmere Lake, U.K.-I: source correlation of leaf wax inputs to the sedimentary lipid record. Org. Geochem. 17, 901-912.

Rieley, G., Collier, R.J., Jones, D.M., Eglinton, G., Eakin, P.A., Fallick, A.E., 1991 b. Sources of sedimentary lipids deduced from stable carbon-isotope analyses of individual compounds. Nature 352, 425-427. https://doi.org/10.1038/352425a0

Roth, P.R., 1978. Cretaceous Nannoplankton Biostratigraphy and Oceanography of the Northwestern Atlantic Ocean, in: Initial Reports of the Deep Sea Drilling Project, 44. U.S. Government Printing Office, pp. 731-759.

https://doi.org/10.2973/dsdp.proc.44.134.1978

Rubin, K., 1997. Degassing of metals and metalloids from erupting seamount and midocean ridge volcanoes: Observations and predictions. Geochim. Cosmochim. Acta 61, 3525-3542. https://doi.org/10.1016/S0016-7

Sanchez-Hernandez, Y., Maurrasse, F.J.M.R., 2014. Geochemical characterization and redox signals from the latest Barremian to the earliest Aptian in a restricted marine basin: El Pui section, Organyà Basin, south-central Pyrenees. Chem. Geol. 372, 12 31. https://doi.org/10.1016/j.chemgeo.2014.02.011

Sanchez-Hernandez, Y., Maurrasse, F.J.M.R., 2016. The influence of regional factors in the expression of oceanic anoxic event 1a (OAE1a) in the semi-restricted Organyà Basin, south-central Pyrenees, Spain. Palaeogeogr. Palaeoclimatol. Palaeoecol. 441, 582-598. https://doi.org/10.1016/j.palaeo.2015.06.031 
Sanchez-Hernandez, Y., Maurrasse, F.J.M.R., Melinte-Dobrinescu, M.C., He, D., Butler, S.K., 2014. Assessing the factors controlling high sedimentation rates from the latest Barremian-earliest Aptian in the hemipelagic setting of the restricted Organyà Basin, NE Spain. Cretac. Res. 51, 1-21. https://doi.org/10.1016/j.cretres.2014.05.010

Seguret, M., 1972. Étude tectonique des nappes et séries décollées de la partie centrale du versant sud des Pyrénées. Pub. Estela, Ser geol. struct. 2, 1-155.

Stein, M., Föllmi, K.B., Westermann, S., Godet, A., Adatte, T., Matera, V., Fleitmann, D., Berner, Z., 2011. Progressive palaeoenvironmental change during the Late Barremian-Early Aptian as prelude to Oceanic Anoxic Event 1a: Evidence from the Gorgo a Cerbara section (Umbria-Marche basin, central Italy). Palaeogeogr.

Palaeoclimatol. Palaeoecol. 302, 396-406. https://doi.org/10.1016/J.PALAEO.2011.01.025

Stein, M., Westermann, S., Adatte, T., Matera, V., Fleitmann, D., Spangenberg, J.E., Föllmi, K.B., 2012. Late Barremian-Early Aptian palaeoenvironmental change: The Cassis-La Bédoule section, southeast France. Cretac. Res. 37, 209-222. https://doi.org/10.1016/j.cretres.2012.03.021

Wang, P., Chen, C., Liu, H., 2016. Aptian giant explosive volcanic eruptions in the Songliao Basin and northeast Asia: A possible cause for global climate change and OAE-1a. Cretac. Res. 62, 98-108. https://doi.org/10.1016/J.CRETRES.2015.09.021

Wang, P., Ren, Y., Shan, X., Sun, S., Wan, C., Bian, W., 2002. The Cretaceous volcanic succession around the Songliao Basin, NE China: relationship between volcanism and sedimentation. Geol. J. 37, 97-115. https://doi.org/10.1002/gj.905

Weissert, H., Erba, E., 2004. Volcanism, CO2 and palaeoclimate: a Late Jurassic-Early Cretaceous carbon and oxygen isotope record. J. Geol. Soc. London. 161, 695-702. https://doi.org/10.1144/0016-764903-087

Williams, P.M., Druffel, E.R.M., 1987. Radiocarbon in dissolved organic matter in the central North Pacific Ocean. Nature 330, 246-248. https://doi.org/10.1038/330246a0

Zhang, X., Zhang, G., Sha, J., 2016. Lacustrine sedimentary record of early Aptian carbon cycle perturbation in western Liaoning, China. Cretac. Res. 62, 122-129. https://doi.org/10.1016/J.CRETRES.2015.10.001 
5 CONTINUOUS ACCUMULATION OF ORGANIC MATTER-RICH SEDIMENTS ASSOCIATED WITH OCEANIC ANOXIC EVENT 1A IN THE EL PUJAL SECTION, ORGANYÀ BASIN, CATALUNYÀ SPAIN AND ITS RELATION TO EPISODIC DYSOXIA

\title{
Socorro, J., Maurrasse, F.J-M.R., 2019. Continuous accumulation of organic matter-rich sediments associated with Oceanic Anoxic Event 1a in the EI Pujal section, Organyà Basin, Catalunyà Spain and its relation to episodic dysoxia. Cretaceous Research. 95, 225-251. \\ https://doi.org/10.1016/J.CRETRES.2018.11.009
}

\begin{abstract}
A detailed lithostratigraphic and geochemical analysis was performed on a $13.77 \mathrm{~m}$ sequence consisting of a succession of limestones, argillaceous limestones and marlstones at the El Pujal section in the Organyà Basin of the south-central Spanish Pyrenees. Biostratigraphic analysis reveals the presence of the foraminifer Leupoldina cabri positioning the sequence within OAE1a. Corroborating evidence from stable carbon isotope data permits the correlation of the El Pujal section with other Tethyan sections, namely Roter Sattel (Switzerland), Cismon (Italy) and El Pui (Spain) to within carbon isotope segment C5. Geochemical results reveal periodic increase of redox sensitive trace elements (RSTEs: V, Ni, Co, Cr, Cu, Mo), biolimiting (P, Fe) and terrestrially derived elements (Al, $\mathrm{Si}, \mathrm{Ti})$ at argillaceous limestone and marlstone intervals, concurrent with episodes of enhanced organic matter preservation (TOC $>1.18 \%$ ). Further evidence from microfacies characterized by higher pyrite concentration, impoverished benthic fauna and lower degree of bioturbation are in accord with geochemical proxies. Biomarker data shows $n$-alkanes distributions ranging from $n \mathrm{C}_{10}$ to $n \mathrm{C}_{31}$, suggesting that the organic matter $(\mathrm{OM})$ is a mixture of in-situ produced and terrestrially derived. Calculated average chain length ( $\left.\mathrm{ACL}_{n} \mathrm{C} 25-n \mathrm{C} 33\right)$ shows lower values
\end{abstract}


in intervals associated with argillaceous limestones and marlstones, suggesting wetter climate during these periods. The results imply that fluvial influences controlled by regional hydrologic variability related to climatic fluctuations probably exacerbated the already sluggish basinal conditions through the development of density stratification in the water column. Integration of the data from the El Pujal section shows that changes in paleoproductivity, terrigenous input, and redox conditions characterize the deposition of OAE1a in the Organyà Basin without the hallmark of an anoxic phase. Conditions remained similar to those recorded in the preceding sequence at El Pui, thus revealing continuous deposition of OM under impoverished oxygen conditions, punctuated by episodes of dysoxia.

\subsection{Introduction}

During the mid-Cretaceous the Earth experienced profound oceanographic and climatic changes (Leckie et al., 2002) attributed to the concurrent paleogeographic reconfiguration associated with continuing rifting of Gondwana and Laurasia which led to the rearrangement of oceanic and atmospheric circulation patterns together with the formation of numerous restricted to semi-restricted basins in the Tethyan realm (e.g. Barron, 1987; Koutsoukos et al., 1991a; Hay, 1995; Poulsen et al., 1999, 2001, 2003). The intense tectonic activity and emplacement of several large igneous provinces (LIPs), such as the Ontong Java Plateau, Kerguelen Plateau and Caribbean Plateau resulted in a marked increase in volcanic outgassing of $\mathrm{CO}_{2}$ (Arthur et al., 1985; Barron and Washington, 1985; Caldeira and Rampino 1991; Sinton and Duncan, 1997; Leckie et al, 2002; Neal et al., 2008; Tejada et al., 2009) which may also have been determining factors in these changes. Furthermore, the prevailing warm global equable climate led to 
reduced oceanic thermal contrasts disrupting vertical mixing while accelerating hydrological cycles, intensifying weathering and runoff. These conditions induced eutrophication of shallow and deep-water environments concurrently with eustatic sea level rise (Barron et al., 1989; 1995; Koutsoukos et al., 1991b; Frakes et al., 1992; Huber et al., 1995; Tarduno et al., 1998; Weissert et al., 1998; Haq et al., 1987). Hence, these factors compounded by a paleogeography particular to many semi-restricted basins led to widespread burial of organic matter $(\mathrm{OM})$ in sediments deposited under dysoxic to anoxic conditions. These relatively brief periods lasting $\sim 1 \mathrm{Myr}$ (Li et al., 2008) of enhanced OM sequestration termed as Oceanic Anoxic Events (OAEs) (Schlanger and Jenkyns, 1976; Jenkyns, 1980) are thus the geologic expression of extreme perturbations in the global carbon cycle. Most importantly, OAEs can also be identified by their distinct global stable carbon isotope signature identifiable in carbonates $\left({ }^{13} \mathrm{C}_{\text {carb }}\right)$ and both marine and non-marine organic matter $\left(\delta^{13} \mathrm{C}_{\text {org }}\right)$ (Erbacher et al., 1996; Hasegawa, 1997; Menegatti et al., 1998; Bralower et al., 1999). Their global isotopic signature thus permits inter-basinal correlation via vertical carbon isotope profiles further constrained through the use of biostratigraphic markers (Wendler, 2013).

As demonstrated in the Organyà Basin of the south-central Pyrenees of Spain, (Fig. 51) (Sanchez-Hernandez and Maurrasse, 2014; 2016) the onset of one such event (OAE1a) is recorded in the lower Aptian hemipelagic limestones that outcrop at the locality of El Pui (Fig. 5-1) in the Cabó Formation (García-Senz, 2002). Marine sediments that comprise more than 4,000 $\mathrm{m}$ of continuous accumulation filled the Organyà Basin during the entire Early Cretaceous (Berriasian to Albian) through the beginning of the Late Cretaceous (Cenomanian/Turonian) (García-Senz, 2002). The succession consists mostly 
of OM-rich hemipelagic marlstones and shallow-water limestones that accumulated during the evolution of a pull-apart phase of the basin (García-Senz, 2002; SanchezHernandez and Maurrasse, 2016). While the extensive published literature indicates that the record of OAE1a shows wide spatial variation, in most locations where the event is recorded its hallmark is a distinct interval of higher OM, laminated sediments, redox sensitive trace elements (RSTE's) peaks, and perturbation or complete absence of benthic life, all indicative features of oxygen-deprived conditions. Furthermore, the onset includes a constant pronounced negative carbon isotopic excursion ( $0.5-3 \%)$, followed by a positive excursion $(>1.5-5 \%$ ) believed to be related to primary production and intensified OM burial (Menegatti et al., 1998). Thus, characteristically the event interval is lithologically distinct from interrelated and adjacent sediments, as in most pelagic and hemipelagic settings OAE1a usually documents oxygen-deficient conditions with shales, marls and or bituminous limestones enriched in OM. By contrast, adjacent intercalated limestones are low in OM, and accumulated under fully oxic conditions (Menegatti et al., 1998; Bellanca et al., 2002; Yilmaz et al., 2004; Dumitrescu and Brassell, 2005, 2006; Luciani et al., 2006; Rückheim et al., 2006; Ando et al., 2008; Heldt et al., 2008; Li et al., 2008, and others herein). Other shallow-water carbonate systems experienced severe disruption and drowning (Burla et al., 2008; Heldt et al., 2008), especially in areas of the northern Tethyan region (Funk et al., 1993), in France (Hunt and Tucker, 1993; Masse, 1993), Italy (Bosellini et al., 1999; Graziano, 1999), Spain (Ruiz-Ortiz and Castro, 1998; Gaona-Narvaez et al., 2013), the northeastern North American margin (Jansa, 1993), and in the Texas and Mexican region (Scott, 1993; Lehman et al., 1998). However, in certain areas of shallow-water environments along the southern and central Tethyan realm the 
event may not include a distinct lithologic interval as the facies is uninterrupted, showing continuously full oxic conditions (e.g. Grötsch et al., 1998; Chaabani and Razgallah, 2006; Heldt et al., 2010; Huck et al., 2010).

The semi-restricted Organyà Basin also shows no distinct lithologic response to the overall forcing factors generally associated with OAE1a, since the sediments have relatively high total organic carbon (TOC) of up to $1.7 \%$ and high total inorganic carbon (TIC) (average 70\%) prior and during the event (Sanchez-Hernandez and Maurrasse, 2014; 2016). In the present work, we studied the El Pujal section, which is sequentially continuous with the neighboring El Pui section (Sanchez-Hernandez and Maurrasse, 2014; 2016). The study is a multiproxy analysis where we (1) present new geochemical data for samples associated with the denouement stages of OAE1a, (2) investigate the uninterrupted response of a semi-restricted basin in a hemipelagic setting to perturbations of the carbon cycle during the Aptian and (3) propose environmental and climatic models that integrate regional and global forcing factors influencing the continuous accumulation of OM-rich sediments of the Organyà Basin. The results will provide further understanding on the controlling environmental mechanisms that led to continuous accumulation of OM-rich sediments.

\subsection{Geologic Setting}

Remnants of the Organyà Basin deposits are presently exposed as part of the uppermost unit of the series of Bòixols thrust sheets that comprise the south-central Pyrenees (García-Senz, 2002). The sequence from the Sierra de Prada that continues in the Santa Fè syncline (Fig. 5-1) includes a complete succession up to the Cenomanian/Turonian (Bernaus et al., 2003). Sediments in the Organyà Basin 


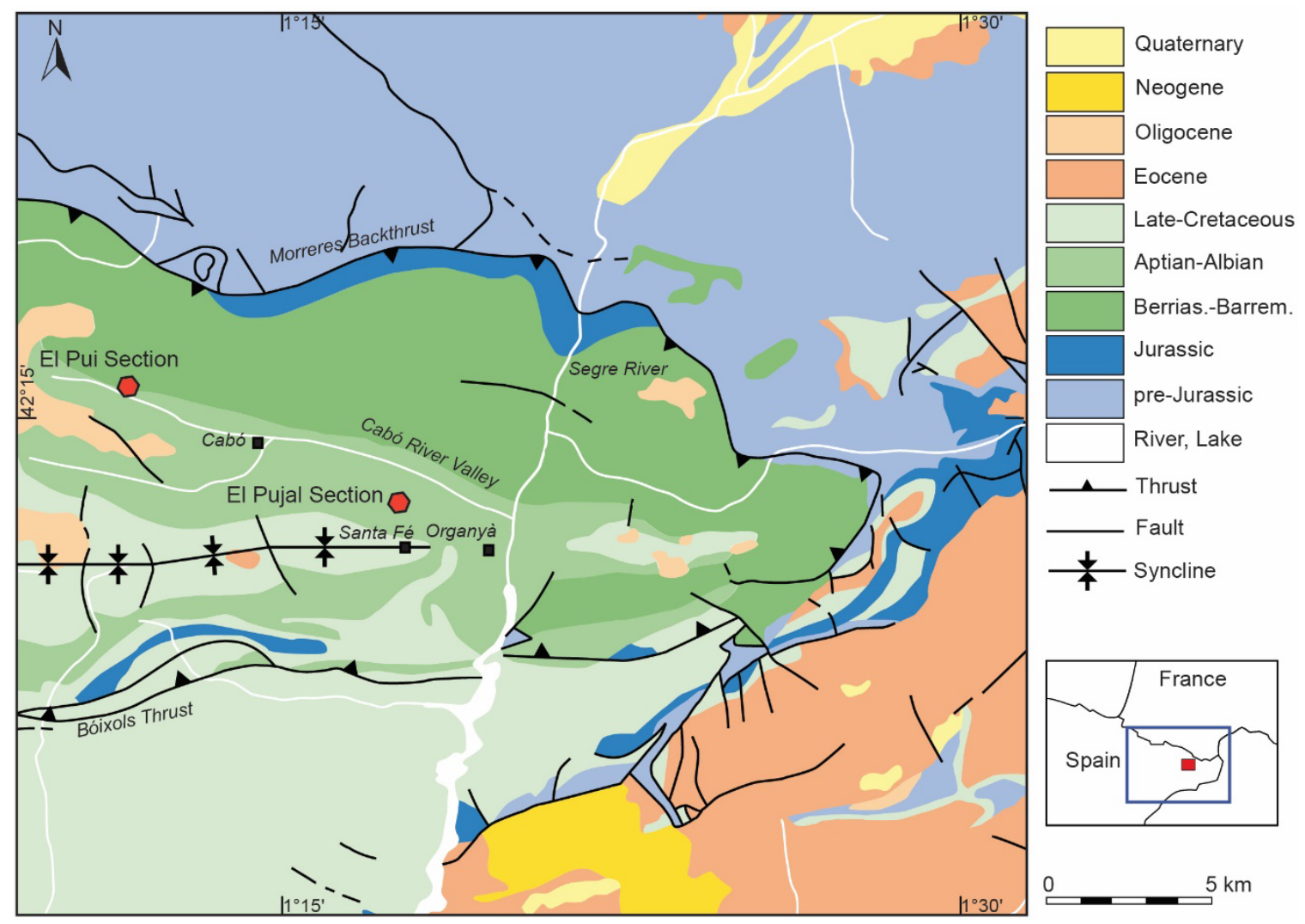

Figure 5-1 Detailed geologic map of the study area modified after Gong et al. (2009). Red hexagons show the relative location of the El Pui Section (Sanchez-Hernandez et al., 2014; Sanchez-Hernandez and Maurrasse, 2014; 2016) and the El Pujal Section (this study).

accumulated from the latest Jurassic to the Late Cretaceous (Fig. 5-2) concurrent with the breakup of the supercontinent Pangaea into Laurasia and Gondwana, and the complex tectonic evolution of the Iberian plate (Berástegui et al., 1990; Salas and Casas, 1993; Dañobeitia et al., 1990; Salas et al., 2001; Torsvik et al., 2008). Laurasia included mostly the Iberian plate, North America and Eurasia, while Gondwana comprised South America, Africa, Australia and Antarctica. Rifting continued during the Cretaceous, leading to the opening of the North Atlantic Ocean and the separation of the Iberian plate from Eurasia and Africa (Olivet, 1996, Vergés et al., 2002). During the Early Cretaceous the $\sim 30$ to $35^{\circ}$ counter clockwise rotation of Iberia led to the opening of the Bay of Biscay (e.g., Van der Voo, 1969; Williams, 1975) and the development of several pull- 


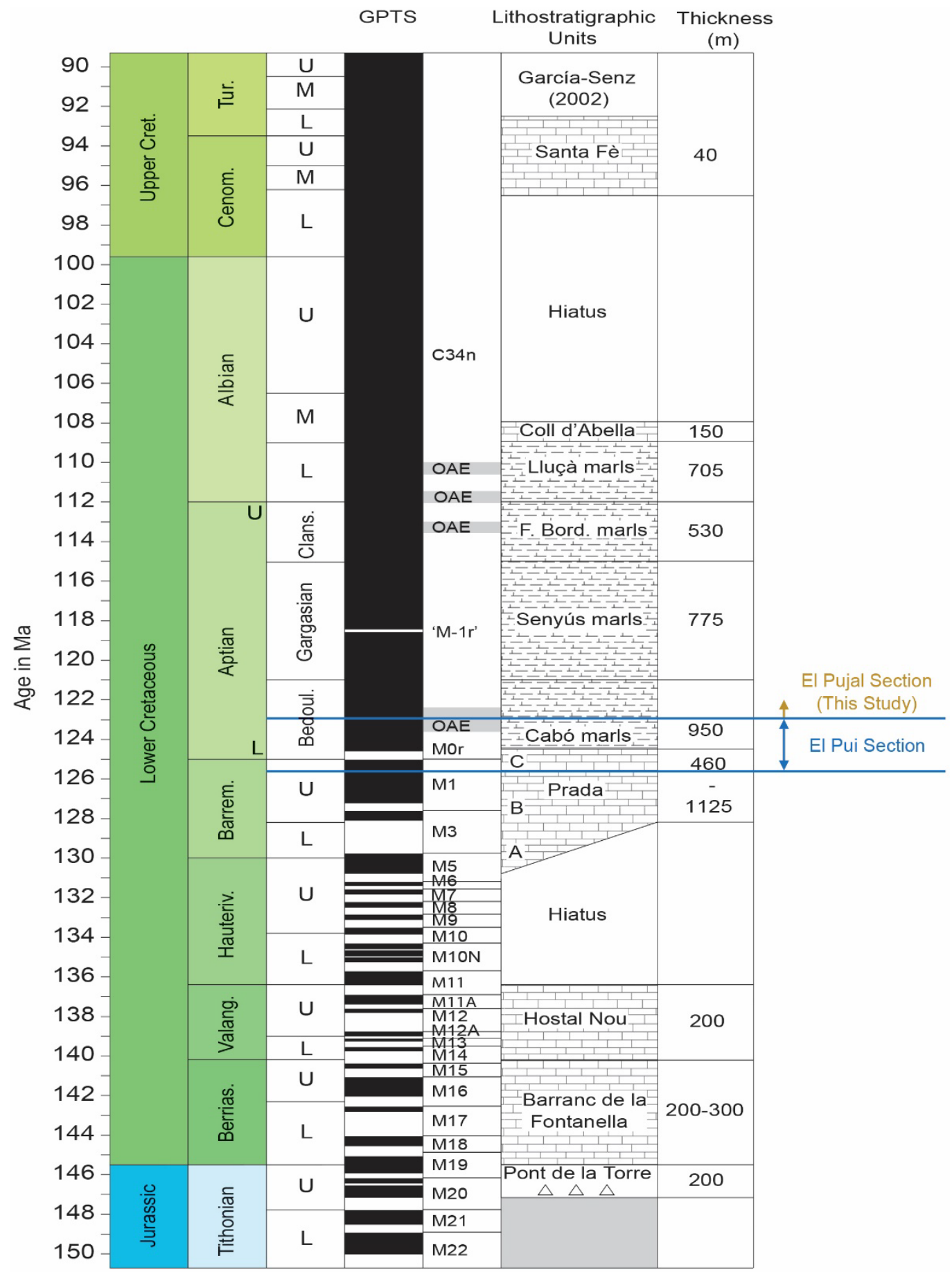

Figure 5-2 Stratigraphic column of the Organyà Basin showing the span of the El Pui Section (SanchezHernandez et al., 2014; Sanchez-Hernandez and Maurrasse, 2014; 2016) and the El Pujal Section (this study) with geomagnetic polarity time scale (GPTS) after Gradstein et al. (2004) and lithostratigraphic units and formation thicknesses after García-Senz (2002). General figure after Gong et al. (2009).

apart basins, including the Basque Cantabrian Basin, and the Central Pyrenean Basin

together with the Organyà Basin (García-Senz, 2002). Previous studies report that the 


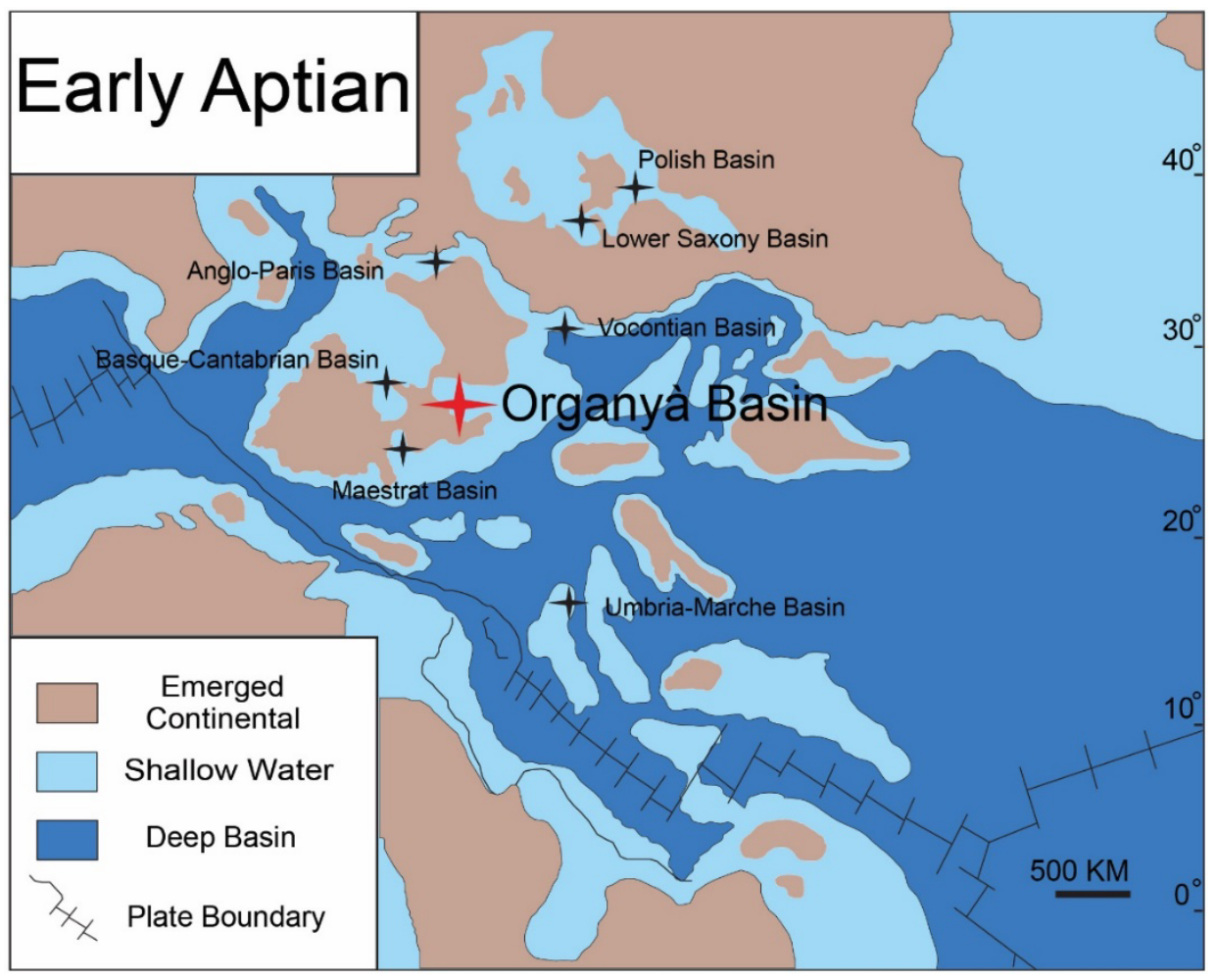

Figure 5-3 Paleogeographic map of the early Aptian with the location of the Organyà Basin marked with a red star. Figure modified after Masse et al. (2000).

area was located under a wet tropical to subtropical paleogeographic latitude of approximately $25^{\circ}$ to $30^{\circ}$ north of the Equator (Fig. 5-3) (Masse et al., 2000). As shown in Figure 5-3, paleogeographic reconstructions indicate that the basin was somewhat restricted by several land masses which provided ample terrigenous influx while experiencing extreme subsidence that allowed for the accommodation of over $4000 \mathrm{~m}$ (Fig. 5-2) of mostly hemipelagic marls and platform limestones (Beràstegui et al., 1990; García-Senz, 2002). Near the end of the Mesozoic the northward movement of Africa eventually led to the collision of Iberia with Eurasia, and closure of these Pyrenean basins concomitant with the Alpine orogeny during the Cenozoic (Golonka, 2004). The present work investigates a $13.77 \mathrm{~m}$ section starting at the base of outcrops near the hamlet of El Pujal (42 $\left.13^{\prime} 06.15^{\prime \prime} \mathrm{N}, 1^{\circ} 18^{\prime} 55.85^{\prime \prime} \mathrm{E}\right)$ situated on the southern flank of the Cabó river 
valley. The outcrops show a succession projected to be sequentially continuous with the El Pui section, based on three-dimensional views on Google maps. Their position implies that stratigraphically, the succession may be placed within the upper portion of the Cabó marls, approximately correlative with carbon isotope C5 (Sanchez-Hernandez and Maurrasse, 2014; 2016), further extending into the lower portion of the Senyús marls (Fig. 5-2) (García-Senz, 2002).

\subsection{Methods}

\subsubsection{Microscopy}

Thin sections $(\mathrm{n}=42)$ and smear slides $(\mathrm{n}=11)$ were examined using an Olympus $\mathrm{BH}-2$ light transmitting microscope. Selected thin sections were gold ( $\mathrm{Au}$ ) sputter coated using an SPI-MODULE sputter coater and examined using a JEOL JSM 5910LV scanning electron microscope $(\mathrm{SEM})$. Small cubes $(2.5 \times 2.5 \mathrm{~cm})$ from selected samples were placed in a $30 \%$ solution of acetic acid $\left(\mathrm{CH}_{3} \mathrm{COOH}\right)$ and left for approximately 24 hrs or until they completely disaggregated. The residue was washed through $150 \mu \mathrm{m}, 63$ $\mu \mathrm{m}$, and $38 \mu \mathrm{m}$ filters and mounted on slides. Slides with mounted specimens were examined using a Wild Heerbrugg binocular reflective light microscope. Some specimens were picked, Au sputter coated, and examined under the SEM. Color description of samples was based on the modified Munsell color system (Goddard et al., 1963). Visual percentage estimates are after Terry and Chilingar (1955). Bioturbation index (BI) follows the proposed scheme in Taylor and Goldring (1993). Benthic foraminifera were counted with the intent of assessing the oxygenic conditions at the very bottom of the water column. Their total counts are divided by the area of each thin section and are expressed as benthic foraminifera density $(\rho)$ or number of specimens per $\mathrm{cm}^{2}$. 


\subsubsection{Total Carbon (TC), Total Inorganic Carbon (TIC) and Total Organic Carbon (TOC)}

Total carbon (TC) and total inorganic carbon (TIC) were carried out on 42 samples analyzed at Florida International University using a LECO CR-412 carbon analyzer following the procedure detailed in Sanchez-Hernandez and Maurrasse (2014). The method was modified with an additional cleaning procedure for previously used combustion boats to ensure complete removal of residual inorganic portion $\left(\mathrm{CaCO}_{3}\right)$. Briefly, used combustion boats were brushed under running water, then placed in a $10 \%$ hydrochloric acid $(\mathrm{HCl})$ solution for $3 \mathrm{hrs}$ or until bubbling stopped. The boats were then washed 3 times with deionized water and placed in a furnace at $560^{\circ} \mathrm{C}$ for $2 \mathrm{hrs}$ to remove any remaining organic matter. The results for TC and TIC are expressed as $\mathrm{CaCO}_{3} \mathrm{wt} \%$.

\subsubsection{Lithologic Nomenclature}

TIC values were used to assign a general lithologic classification modified from Sanchez-Hernandez and Maurrasse (2014). To allow for a greater range of lithologic units based on field observation of the El Pujal section, here we use TIC values $>73 \%=$ limestone; $65-73 \%=$ argillaceous limestone; $35-65 \%=$ marlstone; $10-35 \%=$ calcareous shale; and $0-10 \%=$ mudrock/shale. Total organic carbon $(\mathrm{TOC})$ is determined by subtracting (TC-TIC), but since the analyzer gives the results expressed as $\mathrm{CaCO}_{3} \%$ the difference is also divided by 8.33 , which is the molecular mass of $\mathrm{CaCO}_{3}$ divided by the mass of carbon $(100.086 \mathrm{~g} / 12.011 \mathrm{~g})$. Hence, the results for TOC are expressed as C $\mathrm{wt} \%$. 


\subsubsection{Stable Carbon Isotope $\left(\delta^{13} C_{\text {org }}\right)$}

Samples $(\mathrm{n}=42)$ were cut using a wet diamond saw into $1 \times 1 \mathrm{~cm}$ cubical pieces making sure to remove any signs of surface weathering, and then placed in an oven at $60^{\circ} \mathrm{C}$ to dry overnight. Each dried sample was ground for 3 mins in a Bell-Art micro-mill and placed in a sealed glass vial. After each use, to prevent cross contamination of samples the micromill's chamber was cleaned with deionized water, wiped with a Kimwipes tissue paper and acetone then air-dried using compressed air. Approximately 1 $\mathrm{g}$ of each sample was placed in a previously cleaned (combusted at $560^{\circ} \mathrm{C}$ for $2 \mathrm{hrs}$ ) 12 dram vial and treated with $10 \% \mathrm{HCl}$ to remove the inorganic carbon $\left(\mathrm{CaCO}_{3}\right)$. The sample was centrifuged, and the supernatant removed. This process was repeated until no carbonate reaction was visible. Subsequently, the sample was vortexed 3 to 5 times with deionized (DI) water, centrifuged for 5 mins and the supernatant removed. This process was repeated until the supernatant reached a $\mathrm{pH}$ of $\sim 7$. The sample was then put in an oven to dry at $60^{\circ} \mathrm{C}$, and then homogenized into a powder using an agate mortar and pestle. The powdered dried sample was then placed in a vial, ready for the isotopic analysis. The $\delta^{13} \mathrm{C}_{\text {org }}$ values of the 42 samples were measured at the Rosenstiel School of Marine and Atmospheric Science (RSMAS) stable isotope laboratory (SIL) using a Costech elemental combustion system interfaced with a Thermo Scientific Delta V Advantage continuous flow isotope ratio mass spectrometer. Values are expressed on a per mil (\%) basis relative to the Vienna Pee Dee Belemnite standard (VPDB).

\subsubsection{Major, Biolimiting and Redox Sensitive Trace Elements (RSTEs)}

The preparation and calibration applied here followed the rapid and sensitive method developed for routine analysis of trace elements on sediments and soils proposed 
by Arroyo et al., (2009). As outlined in Sanchez-Hernandez and Maurrasse (2014), all samples (42) were powdered in the same way as those used for carbon analysis previously described. One gram $(1.0000 \mathrm{~g})$ of powder was weighed out in a polypropylene snap cap tube and spiked with two standard solutions, $350 \mu 1$ [1000 ppm] scandium oxide and $300 \mu 1$ [1000 ppm] indium metal. The tubes were vortexed for $1 \mathrm{~min}$ and left to dry for $48 \mathrm{hrs}$ at $80^{\circ} \mathrm{C}$. Once dried the samples were powdered once again and homogenized using a tungsten ball-mill for 30 mins and pressed into pellets using a hydraulic press. Pellets were analyzed for concentrations of major elements (Al, Si, Ti), biolimiting elements $(\mathrm{Fe}, \mathrm{P})$, RSTEs $(\mathrm{V}, \mathrm{Ni}, \mathrm{Co}, \mathrm{Cr}, \mathrm{Cu}, \mathrm{Mo})$ and potential redox index elements (Th, U) using Laser Ablation-Inductively Coupled Plasma Mass Spectrometry (LA-ICP-MS) at the FIU Trace Evidence Analysis Facility (TEAF) using a quadrupole ELAN DRC II (Perkin Elmer LAS) in the standard operation mode. Sample ablation was achieved using a $266 \mathrm{~nm}$ Nd-YAG laser (LSX 500, CETAC) with a $200 \mu \mathrm{m}$ spot size and $10 \mathrm{~Hz}$. The same pellet was ablated 4 times in different locations and the raw data integrated using the Glitter software. Analytical performance of the method was evaluated by running 3 standard reference materials (NIST2710, PACS-2, NIST2704) at the start, every 10 samples, and at the end of the analysis. Data for elemental concentration is expressed as absolute concentrations as parts per thousand (ppt) for major terrestrially derived elements and biolimiting elements, and as parts per million (ppm) for RSTEs. Elemental concentrations are not normalized to aluminum in this study because the values obtained can lead to "spurious" correlations between uncorrelated elements, and correlation coefficients can increase or decrease with some cases where they even change signs (Van der Weijden, 2002). It has been recognized in the statistical 
analysis of biological samples (Pearson, 1896) that when two ratio variables have the same common divisor ( $\mathrm{Al}$ in this case) and a correlation coefficient is determined for the two ratio variables, false correlations are produced not because of natural relationships between the two variables, but for arithmetic reasons. For a detailed explanation and case studies on this subject, refer to Van der Weijden (2002).

\subsubsection{Enrichment of Redox Sensitive Trace Elements (EIs)}

As compared to their relative crustal abundances, certain elements consistently show higher concentrations in sediments rich in $\mathrm{OM}$ which are widely recognized to be characteristic of reducing environments. The enrichment factor has been used in previous studies (e.g. Turekian and Wedepohl, 1961; Wignall and Myers, 1988; Calvert and Pedersen, 1993; Rimmer, 2004; Brumsack, 2006; Sanchez-Hernandez and Maurrasse, $2014 ; 2016$ and others), to assess the changes relative to the average shale as a proxy for crustal abundance (Turekian and Wedepohl, 1961; Wedepohl, 1971). To ascertain the redox attributes of sediments in the El Pujal section here we use the average value of the background level (Bodin et al., 2007) to estimate the relative enrichment for each RSTE $(\mathrm{V}, \mathrm{Ni}, \mathrm{Co}, \mathrm{Cr}, \mathrm{Cu}$, and $\mathrm{Mo}$ ) based on the following equation:

$$
E I s=\frac{[\text { RSTEs }]}{[\text { RSTEs]background }}
$$

where [RSTEs] represents the concentration of each sample in ppm and [RSTEs]background is the average value in ppm of the corresponding RSTE in the entire section. To make comparison between RSTEs as a whole and other proxies, enrichment indexes ( $\sum$ EIs) were calculated by adding all the EIs of each element at each sample point. 


\subsubsection{Biomarkers}

The procedures followed a modified methodology from Socorro et al., (2017). Before commencing the procedure all the lab glassware was washed with tap water and soap, then washed 3 times with deionized water and put in the oven at $560^{\circ} \mathrm{C}$ for $2 \mathrm{hrs}$ to remove any remaining organic matter. Samples $(n=42)$ were powdered in the same way as those used for carbon analysis. Five grams ( $5 \mathrm{~g}$ ) of powder was weighed out, transferred to a mortar and pestle, and further homogenized. The $5 \mathrm{~g}$ of homogenized sample was then transferred to a 12-dram vial with the addition of a $10 \mathrm{ml}$ mixture of (1:9) methanol $(\mathrm{MeOH}) /$ dichloromethane (DCM). The vial was then sonicated for 30 mins and then centrifuged for 10 mins until the supernatant completely separated from the pellet. The supernatant was then transferred to a 4-dram vial and $10 \mathrm{ml}$ of fresh 1:9 $\mathrm{MeOH} / \mathrm{DCM}$ was again added to the 12-dram vial and the mixture sonicated a second time for 30 mins. The cloudy mixture was again centrifuged for 10 mins and the supernatant was pipetted out and combined with the first extract in a 4-dram vial and labeled as total lipid extract (TLE). Activated copper was added to the TLE vial to remove any elemental sulfur. The copper was activated by placing it in $10 \% \mathrm{HCl}$ until it reached its peculiar bright color and then washed 3 times with deionized water and 3 more times with DCM. The copper was left in the TLE until it turned completely black 3-4 hrs and then it was removed. The TLE was then concentrated by evaporation until almost dry and then $\sim 12$ drops of hexane were added. Following that, a glass pipette was plugged with pre-combusted $\left(560^{\circ} \mathrm{C}\right.$ for $\left.2 \mathrm{hrs}\right)$ glass wool and filled with $0.5 \mathrm{~g}$ of 230 400 mesh silica gel and conditioned with $6 \mathrm{ml}$ of hexane. The TLE was mounted on the 
column and eluted with $4 \mathrm{ml}$ of hexane to collect fraction $\mathrm{F} 1$ containing the aliphatic components ( $n$-alkanes).

The samples were analyzed at the FIU Advanced Mass Spectrometry Facility. Separations were achieved by gas chromatography (GC) (Agilent 6890), using method 1506GEO2. M. A volume of $5 \mu \mathrm{l}$ of each sample is injected in split-less mode. Injector temperature was set at $280^{\circ} \mathrm{C}$ and temperature program was as follows: hold at $65^{\circ} \mathrm{C}$ for 2 mins, increase to $300^{\circ} \mathrm{C}$ at a rate of $4^{\circ} \mathrm{C} /$ minute, and hold at $300^{\circ} \mathrm{C}$ for 8 mins. Detection was performed by a single quadrupole mass spectrometer (MS) (Agilent 5973) operating in positive mode electron impact ionization (EI+). Scan range was from $\mathrm{m} / \mathrm{z} 42$ to $\mathrm{m} / \mathrm{z}$ 500 and a solvent delay time of 4 mins.

\subsubsection{Terrestrial Aquatic Ratio (TAR)}

The terrestrial aquatic ratio (TAR) as originally proposed by Bourbonniere and Meyers (1996) provides clues as to the relative influence of terrestrially derived versus autochthonously produced organic matter and is calculated here by dividing the sum of the longer odd-numbered $n$-alkanes by the sum of the shorter chain odd-numbered $n$ alkanes.

$$
\mathrm{TAR}=\frac{\mathrm{nC}_{27}+\mathrm{nC}_{29}+\mathrm{nC}_{31}}{\mathrm{nC}_{15}+\mathrm{nC}_{17}+\mathrm{nC}_{19}}
$$

Based on this equation higher values $>1$ indicate predominance of land-derived OM sources. 


\subsubsection{Carbon Preference Index (CPI)}

In ancient sediments the carbon preference index (CPI) is a proxy used mainly to determine the degree of thermal maturation (Bray and Evans, 1961). CPI was calculated as follows:

$$
\mathrm{CPI}=\frac{1}{2}\left[\frac{\mathrm{nC}_{25}+\mathrm{nC}_{27}+\mathrm{nC}_{29}+\mathrm{nC}_{31}+\mathrm{nC}_{33}}{\mathrm{nC}_{24}+\mathrm{nC}_{26}+\mathrm{nC}_{28}+\mathrm{nC}_{30}+\mathrm{nC}_{32}}+\frac{\mathrm{nC}_{25}+\mathrm{nC}_{27}+\mathrm{nC}_{29}+\mathrm{nC}_{31}+\mathrm{nC}_{33}}{\mathrm{nC}_{26}+\mathrm{nC}_{28}+\mathrm{nC}_{30}+\mathrm{nC}_{32}+\mathrm{nC}_{34}}\right]
$$

\subsubsection{Average Chain Length of Longer $n$-alkanes (ACL)}

Average chain length (ACL) of higher plant's $n$-alkanes $\left(n \mathrm{C}_{25}-n \mathrm{C}_{33}\right)$ (Poynter and Eglinton, 1990) is a parameter that describes the average number of carbon atoms based on the abundance of the odd numbered carbon chain. Here it is calculated as follows:

$$
\mathrm{ACL}=\frac{25 * \mathrm{nC} 25+27 * \mathrm{nC} 27+29 * \mathrm{nC} 29+31 * \mathrm{nC} 31+33 * \mathrm{nC} 33}{\mathrm{nC} 25+\mathrm{nC} 27+\mathrm{nC} 29+\mathrm{nC} 31+\mathrm{nC} 33}
$$

The main source of these longer chain $n$-alkanes are leaf waxes (Riederer and Markstädter, 1996; Koch et al., 2009), and their molecular weight may vary depending on different photosynthetic pathways (C3 or $\mathrm{C} 4)$, type of vegetation and climatic conditions (e.g. Krull et al., 2006; Diefendorf et al., 2017). It has been documented that lipid extracts derived from grasslands tend to be enriched in longer chain $n$-alkanes than those from forest vegetation (Schwark et al., 2002; Zech 2006; Zhang et al., 2006). Furthermore, because the main function of these molecules is to prevent the plant from adverse uncontrolled water loss, $n$-alkanes chain length distribution is also a response to temperature and humidity (Sachse et al., 2006; Hoffmann et al., 2013). Accordingly, higher molecular weight $n$-alkanes are more common in response to warmer climates (Bush and McInerney, 2015), and studies of eastern broadleaf forest trees, Acacia and 
Eucalyptus, showed that higher temperatures along with aridity are both strong controls on the production of longer-chain-enriched leaf wax (Tipple and Pagani, 2013; Hoffmann et al., 2013). In this study, we use ACL variability as a proxy for the broad identification of terrestrial vegetation as well as for deducing climatic conditions on land.

\subsubsection{Correlation Analysis}

Correlation coefficients were determined for various proxies using Microsoft Office Excel 2013. The correlation coefficient is based on the Pearson's r equation (1896) expressed as:

$$
\text { Correl }(X, Y)=\frac{\sum(x-\bar{x})(y-\bar{y})}{\sqrt{\sum(x-\bar{x})^{2} \sum(y-\bar{y})^{2}}}
$$

where $\bar{x}$ and $\bar{y}$ are the corresponding sample's average. The results of this equation go from a perfect negative correlation (-1), no correlation (0) to a perfect positive correlation (1). Values in between will be labeled as: $0.1-0.3=$ weak, $0.4-0.6=$ moderate, $0.7-0.9=$ strong.

\subsubsection{Principal Component Analysis (PCA)}

PCA was run on the data to exemplify the major variables controlling prevailing paleoenvironmental and paleoclimatological conditions during the studied time interval. PCA on the integrated proxy dataset was analyzed using the statistical software Past3 (https://folk.uio.no/ohammer/past/). Since the variables included in the analysis have different units of measure, and because PCA will emphasize variables with highest variances in component one and two, all variables were standardized. This was achieved by subtracting the average of the variable from the actual value and dividing everything by its standard deviation: 


$$
Z i=\frac{X i-\bar{X} i}{S T D E V i}
$$

where $Z_{i}$ is the standardized variable value, $X_{i}$ is the variable's value, $\bar{X}_{i}$ is the variable's average, and $\mathrm{STDEV}_{\mathrm{i}}$ is the variable's standard deviation.

\subsection{Results}

\subsubsection{Field-Scale Lithology}

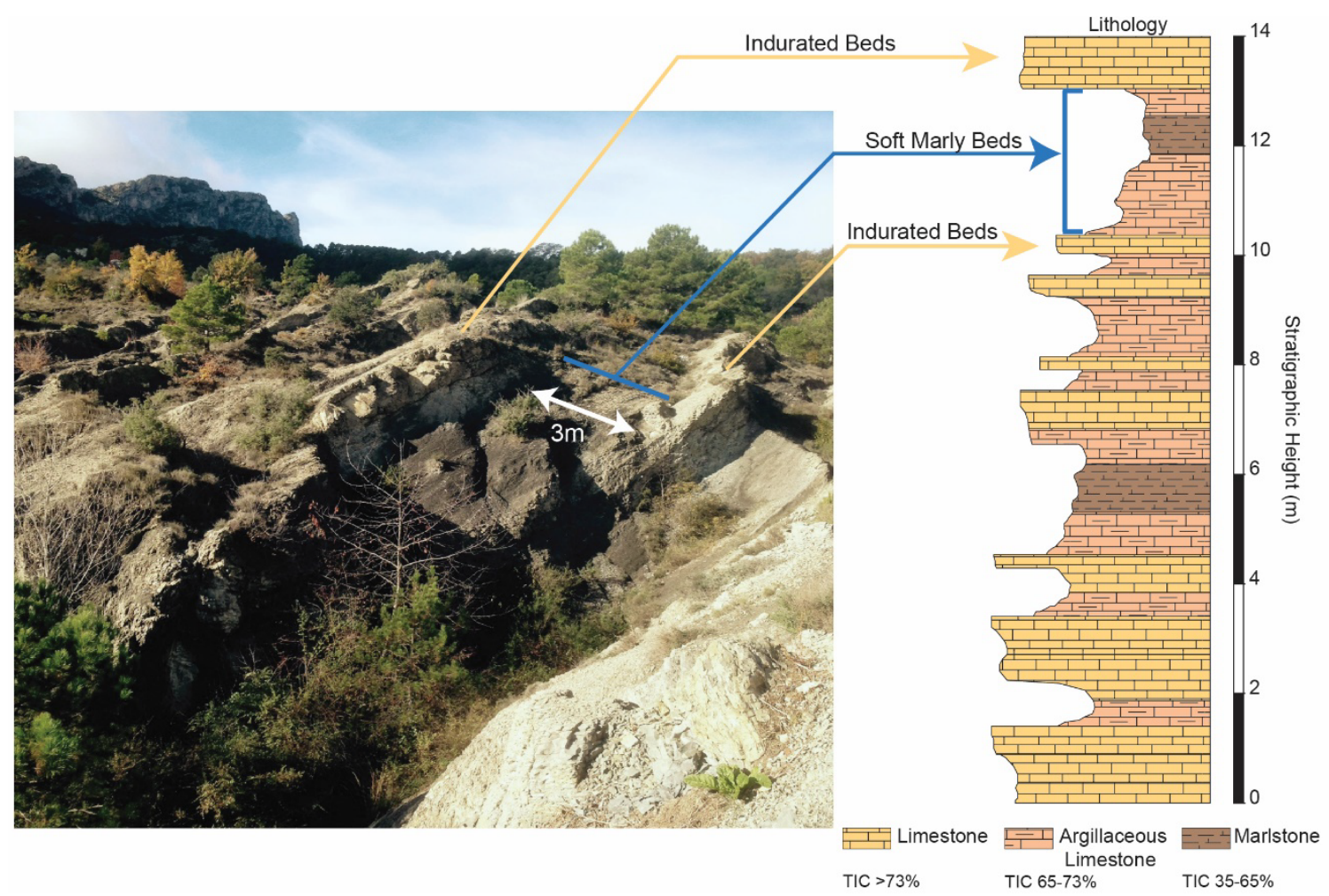

Figure 5-4 Photograph of the top part of the $13.77 \mathrm{~m}$ outcrop showing the differentially weathered beds correlated with the simplified lithostratigraphic column.

In outcrop, the section is homogenously dark gray in color (N6) with no apparent change in color and shows repeated differentially weathered packets composed of more indurated beds followed by softer beds that are apparently argillaceous or marly (Fig. 54). On the surface, they display a gray coloration (N6) with streaks of iron oxide, while on a freshly cut face they are medium dark gray (N4) when dry and grayish black (N2) when wet. The soft, flaky appearance only occurs at the surface because it dissipates with 
depth as the material becomes more indurated. This cyclical pattern of hard/soft beds continues throughout the section. At the field scale, no macrofossils are visible except for sparsely distributed pyritized burrows and unidentifiable ferruginous bioclasts. In hand samples, the rocks can be described as fine grained, biocalcilutites, or carbonaceous limestones. Neither samples show appreciable difference between those taken from the previously discussed indurated and softer beds. The samples show very few visible allochems, mainly ferruginous and pyritized fossils and sparse iron oxide nodules, apparently associated with burrow fillings.

\subsubsection{Petrographic Analysis}

In thin section, the samples are mainly composed of a fine-grained (micritic) matrix, rich in kerogen, organic matter $(\mathrm{OM})$, pyrite and iron oxide. While the finegrained nature of the matrix stays unvarying throughout, allochems vary, but are mainly composed of small sized planktonic foraminifera $<50 \mu \mathrm{m}$, roveacrinid fragments, ostracods, echinoid fragments, microscopic gastropods and bivalves $(<100 \mu \mathrm{m})$, calcispheres, and benthic foraminifera dominated by a few morphotypes: mainly trochospiral, milioline, biserial and uniserial (Fig. 5-5C). In addition, the first occurrence of the index planktonic foraminifera Globigerinelloides aptiensis is recorded at $5.52 \mathrm{~m}$, while Leupoldina cabri occurs at $13.77 \mathrm{~m}$ (Fig. 5-5A) along with several other morphotypes assigned to the Aptian (Longoria, 1974; Sigal, 1952; Verga and Premoli Silva, 2002; www.mikrotax.org). In smear slide and SEM, calcareous nannoplankton plates and fragments are dominant (Fig. 5-5C24, C25), with additional bioclasts of previously discussed taxa (Fig. 5-5A, C). Although in hand sample the softer layers display no apparent lithological difference with the more indurated layers, upon closer 
inspection of the thin section, variations become evident. The softer, easily weathered beds layers (TIC $<72.26 \%$, TOC $>1.18 \%$ ) may show a bioturbation index (BI) of 3, fewer bioclasts overall $(<10 \%)$ associated with a fabric that is slightly anisotropic. They also contain higher proportion of pyrite and pyritized bioclasts $(\sim 60 \%)$, pyritized microscopic gastropods and bivalves (Fig. 5-5C), and higher abundance of calcispheres. However, benthic foraminifera and echinoid fragments become rare with $<2$ specimens per slide in some cases. The time series count of benthic foraminifera shown in Figure 5-5B illustrate these variations which reveal at least 6 detectable declines in benthic foraminifera $\rho$ occurring at stratigraphic heights of $\sim 1.47 \mathrm{~m}, 3.68 \mathrm{~m}, 5.82 \mathrm{~m}, 7.67 \mathrm{~m}, 9.78 \mathrm{~m}$, and 12.2 $\mathrm{m}$, respectively. The more indurated, less marly samples (TIC $>72.26 \%$, TOC $<1.18 \%$ ) show a BI of 4, almost isotropic allochem distribution, and lower concentration of pyrite (Fig. 5-5). Bioclasts are also more abundant in these samples $>20 \%$ with less pyritized specimens $\sim 40 \%$. In contrast to the softer layers, these samples lack microscopic gastropods or bivalves, contain very few calcispheres, but yield the highest benthic foraminifera $\rho$ and echinoid fragments. 
A

Index Planktonic Foraminifera

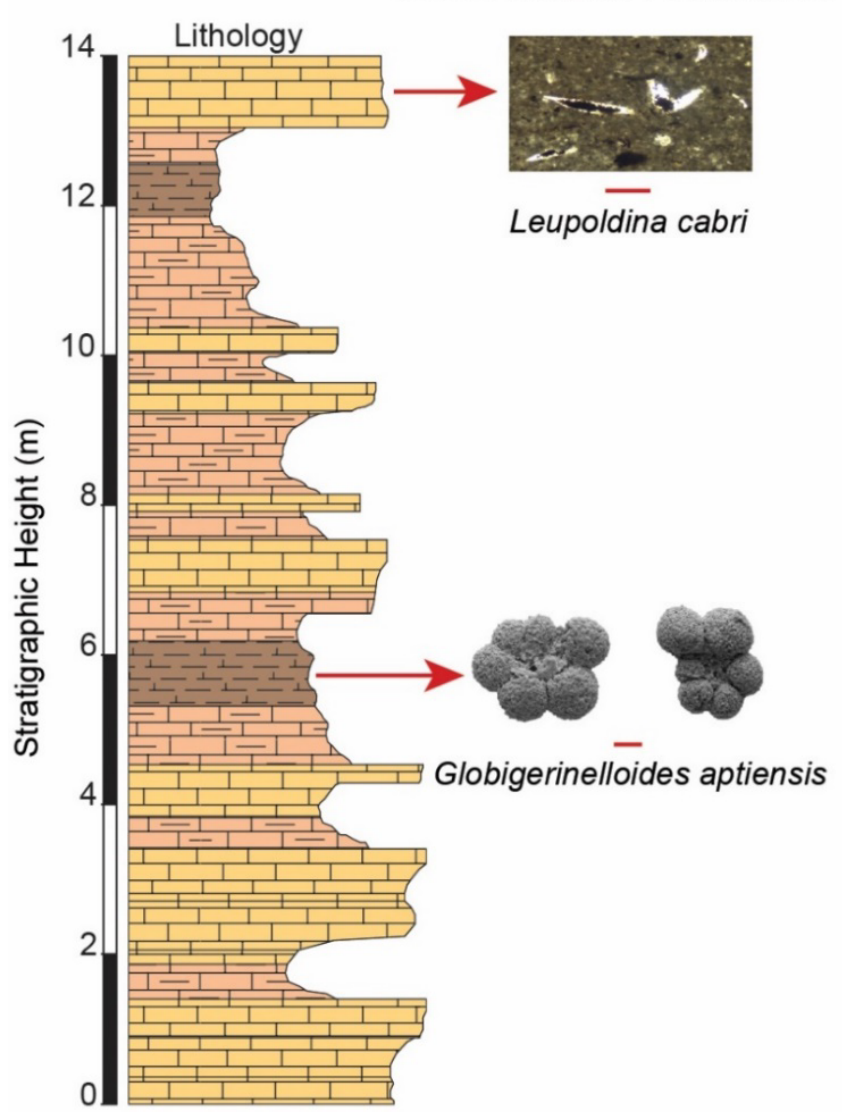

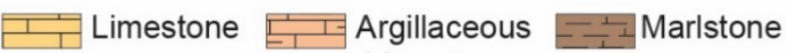
Limestone
B

Benthic Foram $\rho$
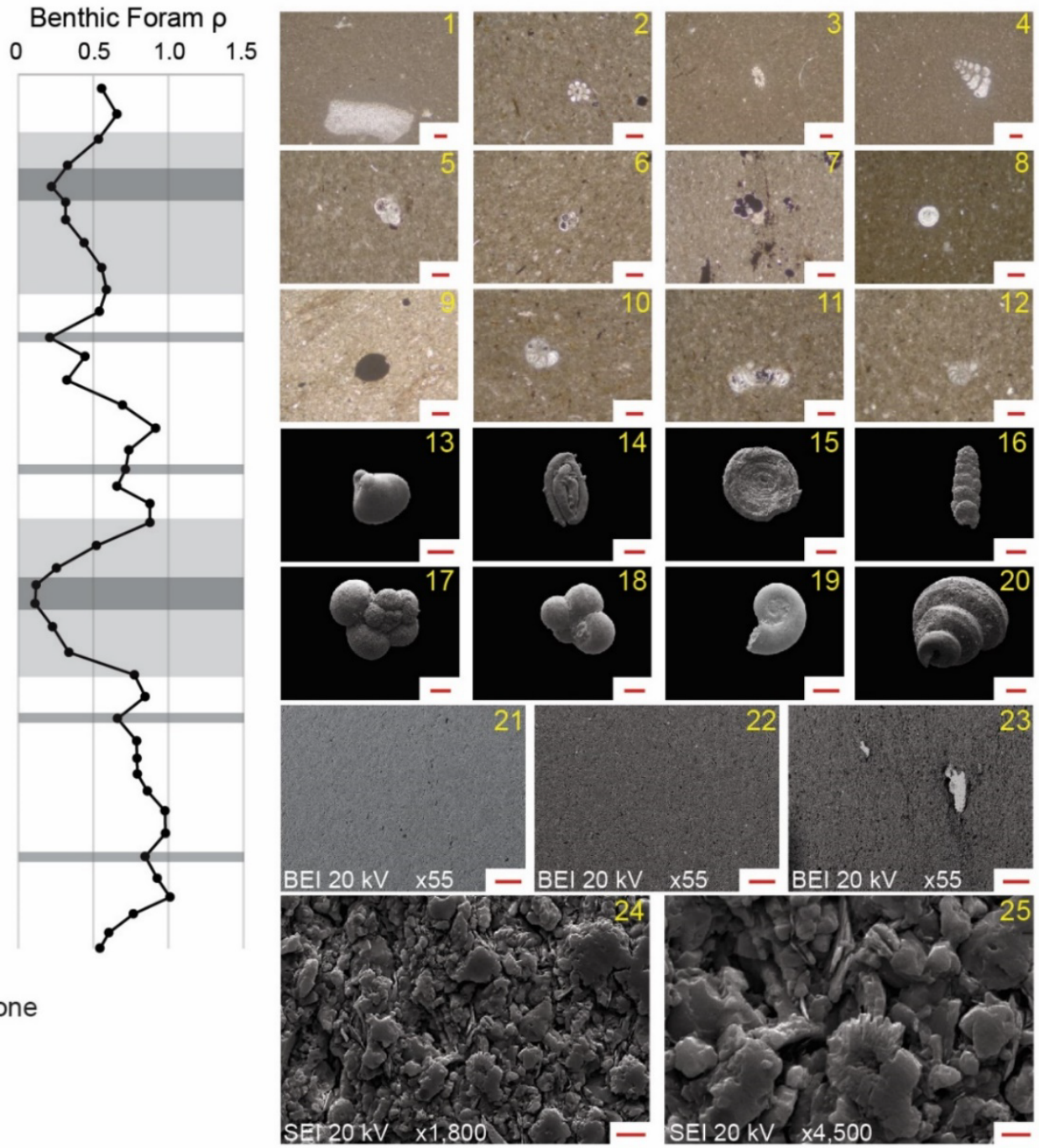
Figure 5-5 (A) Simplified lithostratigraphic column showing the position of various index planktonic

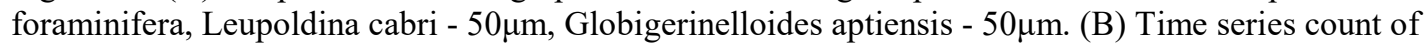
benthic foraminifera. Notice the lower benthic foraminifera $\rho$ during argillaceous limestone and marlstone

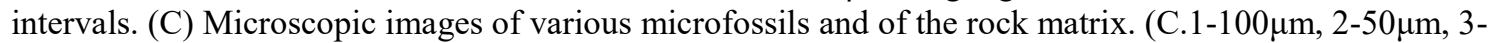
$100 \mu \mathrm{m})$ Various echinoid fragments in a micritic matrix. (C.4-100 $\mu \mathrm{m}, 19-200 \mu \mathrm{m}, 20-100 \mu \mathrm{m})$ Petrographic and SEM images of various small-sized gastropods. (C.5-50 $\mu \mathrm{m}, 6-50 \mu \mathrm{m}, 7-50 \mu \mathrm{m}, 17-50 \mu \mathrm{m}, 18-50 \mu \mathrm{m}$ )

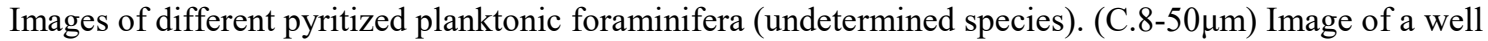

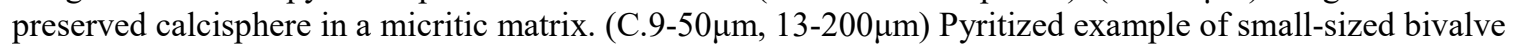
specimens found along the argillaceous limestone and marlstone intervals. (C. $10-50 \mu \mathrm{m}, 11-50 \mu \mathrm{m}, 12-50 \mu \mathrm{m}$, $14-50 \mu \mathrm{m}, 15-100 \mu \mathrm{m}, 16-100 \mu \mathrm{m})$ Images of benthic foraminifera displaying various morphologies. (C.21$200 \mu \mathrm{m}, 22-200 \mu \mathrm{m}, 23-200 \mu \mathrm{m}$ ) Back scattered electron (BSE) images of the matrix from a representative limestone (21), argillaceous limestone (22) and marlstone (23) sample. Notice the increase in pyrite

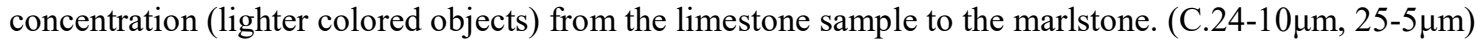
Secondary SEM images of the matrix at different magnifications. Notice the abundance of coccolith plates and fragments throughout.

\subsubsection{Carbon Geochemistry (TC, TIC, TOC, $\delta^{13} \mathrm{Corg}_{\text {org }}$}

TC values fluctuate between $74.51 \%$ and $88.56 \%$ throughout the studied section, with all measured values rising above $70 \%$. As shown in Figure 5-6B, TIC stays relatively high, above $60 \%$ throughout, averaging $72.26 \%$, (22 samples below the average; 20 above). Here the average is taken as the TIC background value of the section. Thus, based on these values three recurrent lithologies are represented: limestones, argillaceous limestones and marlstones. The harder beds always coincide with those labeled as limestone, and the softer beds concurring with argillaceous limestone and marlstone. TIC has a strong correlation $(r=0.75)$ with benthic foraminiferal $\rho$, and 


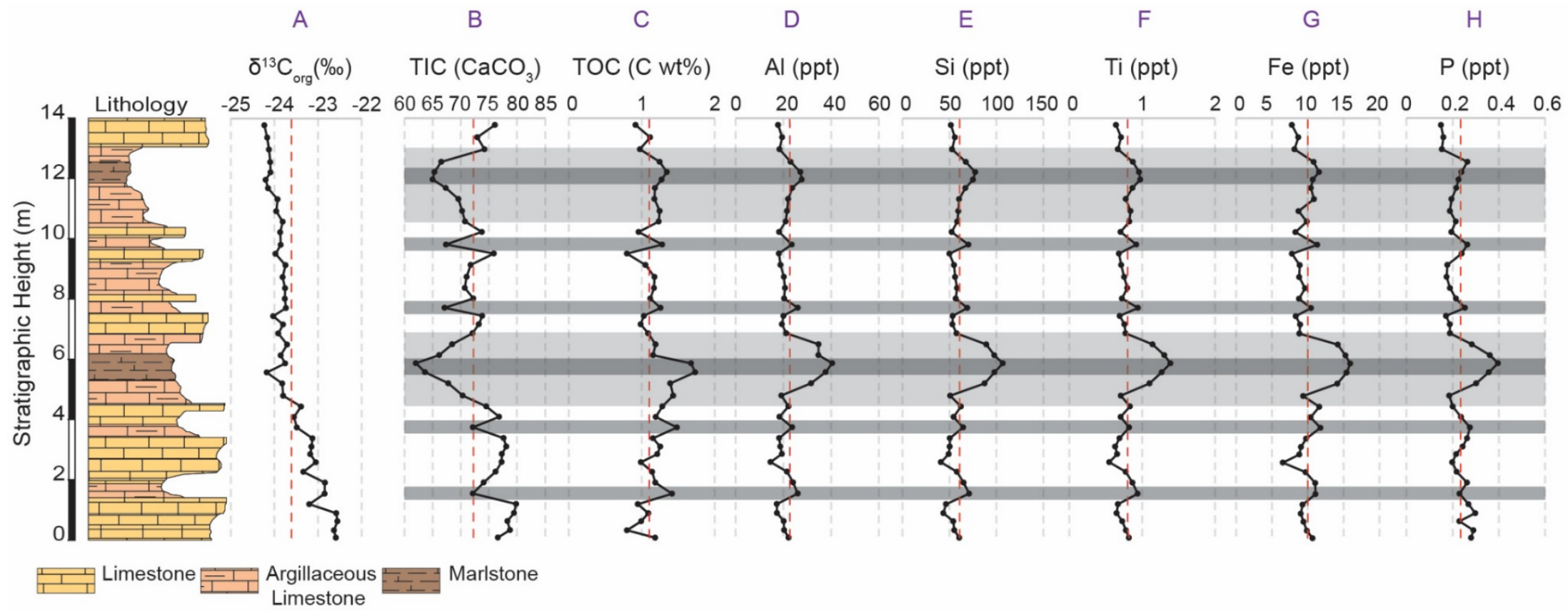

Figure 5-6 Stratigraphic correlation of carbon geochemistry data ( $813 \mathrm{Corg}$, TIC, TOC), major terrestrially derived elements (Si, Al, Ti) and biolimiting elements $(\mathrm{Fe}, \mathrm{P})$ with lithology. Red dashed line corresponds to the average value of the individual variable. Gray bars correspond to areas depleted in TIC and enriched in TOC, $\mathrm{Si}, \mathrm{Al}, \mathrm{Ti}, \mathrm{Fe}$ and $\mathrm{P}$. Elemental concentrations are reported as absolute values in parts per thousand (ppt). 
concurrently shows 6 perceivable fluctuations with values below the background at the respective heights of $1.47 \mathrm{~m}(72.15 \%), 3.68 \mathrm{~m}(72.12 \%), 5.82 \mathrm{~m}(62.03 \%), 7.67 \mathrm{~m}$ $(67.13 \%), 9.78 \mathrm{~m}(67.38 \%)$, and $12.2 \mathrm{~m}(65.33 \%)$.

The TOC values vary from a low of $0.80 \%$ to a high of $1.73 \%$ with an average of $1.18 \%$, which is taken as the background value for this studied section (Fig. 5-6C). TOC shows an inverse correlation with benthic foraminifera $\rho(\mathrm{r}=-0.41)$ and TIC $(\mathrm{r}=-0.65)$. Hence, the curve for TOC also shows 6 distinct peaks above the background average $(1.18 \%)$ with values of $1.42 \%, 1.48 \%, 1.68 \%, 1.26 \%, 1.28 \%$, and $1.34 \%$ respectively correlative with the previously defined 6 intervals.

As shown in Appendix 5A and Figure 5-6A carbon isotopes values show a general negative trend upward in the studied section. The measured $\delta^{13} \mathrm{C}_{\mathrm{org}}$ values fluctuate from a high of $-22.55 \%$ at $0.55 \mathrm{~m}$ to a low of $-24.23 \%$ at $13.77 \mathrm{~m}$ (Fig. 5-6A), with an overall negative shift of $1.68 \%$, and an average of $-23.61 \%$ taken as the background value for the studied section. The negative trend is saw-toothed with a slope of -7.36, including minor variations characterized in the following detail (Fig. 5-6A). Carbon isotope values in the lowermost $0.82 \mathrm{~m}$ are relatively unvarying with an average of $-22.59 \%$, succeeded by a slight negative shift to $-23.20 \%$ at $1.12 \mathrm{~m}$, and then a return to a positive of $-22.84 \%$ o at $1.84 \mathrm{~m}$. The negative trend continues with a shift to $-23.34 \%$ at $2.2 \mathrm{~m}$ followed by a rise to $-23.05 \%$ at $2.52 \mathrm{~m}$. Subsequently, the curve fluctuates slightly trending down reaching a low of $-24.18 \%$ at $5.52 \mathrm{~m}$, below the average value, and characterizing a net negative shift of $\sim-1.59 \%$. A slight positive change of $-23.75 \%$ recurs at $5.82 \mathrm{~m}$ followed by a series of low amplitude positive and negative oscillations down to $-24.03 \%$ o at $7.40 \mathrm{~m}$. The interval from $7.67 \mathrm{~m}$ to $9.10 \mathrm{~m}$ shows a trend of comparatively constant 
values with an average of $-23.76 \%$. The curve is punctuated by a minor negative spike ($23.97 \%$ ) at $9.48 \mathrm{~m}$ continued by a rebound to an average of $-23.88 \%$ between $9.78 \mathrm{~m}$ to $11.30 \mathrm{~m}$. Thereafter, another more distinct negative shift reaches $-24.20 \%$ at $11.95 \mathrm{~m}$ continued by a discrete positive shift of $-24.09 \%$ and decreasing steadily to the lowest value of $-24.23 \%$ at 13.77 m (Fig. 5-6A; Appendix 5A).

\subsubsection{Major Terrestrially Derived Elements, Biolimiting Elements, and RSTEs}

Terrestrially derived elemental concentrations in rocks of the El Pujal section show at least 6 episodes of enrichment positively correlated with TOC (Fig. 5-6C, D, E, F; Appendix 5B), but inversely correlated with TIC (Fig. 5-6B, D, E, F) and benthic foraminifera $\rho$ (Fig. 5-5B). Al concentrations vary from a low of $14.63 \mathrm{ppt}$ to a high of $40.50 \mathrm{ppt}$ at $2.52 \mathrm{~m}$ and $5.82 \mathrm{~m}$, respectively, with an average value of $22.64 \mathrm{ppt}$. Si concentrations fluctuate from $40.88 \mathrm{ppt}$ to $106.87 \mathrm{ppt}$ with an average of $62.18 \mathrm{ppt}$ and shows an almost perfect correlation with $\mathrm{Al}(\mathrm{r}=0.98)$. Ti follows the same pattern as $\mathrm{Al}$ $(\mathrm{r}=0.98)$ and $\mathrm{Si}(\mathrm{r}=0.99)$ with a minimum of $0.55 \mathrm{ppt}$ at $2.52 \mathrm{~m}$ and a maximum of 1.39 ppt at $5.82 \mathrm{~m}$ and a mean of $0.82 \mathrm{ppt}$, concurrent with the biolimiting elements (Fe, P) shown in Figure 5-6G-H. Fe values average 10.24 ppt and show similar correlation with $\mathrm{Al}(\mathrm{r}=0.94), \mathrm{Si}(\mathrm{r}=0.94)$ and $\mathrm{Ti}(\mathrm{r}=0.88)$ with 6 coincident peaks of enrichment 11.08 ppt, 11.77 ppt, 15.92 ppt, 10.46 ppt, 11.33 ppt and 11.57 ppt (Appendix 5B). Temporal variations in the values of $\mathrm{P}$ display a similar pattern but with only 5 correlative heights of enrichment (Fig. 5-6H), which coincide with all the previously defined levels except at $1.47 \mathrm{~m}$ where $\mathrm{P}(0.20 \mathrm{ppt})$ is slightly below the average value $(0.23 \mathrm{ppt})$. The other 5 stratigraphic heights show peaks above the average with values of $0.28 \mathrm{ppt}, 0.40 \mathrm{ppt}, 0.25$ ppt, $0.26 \mathrm{ppt}$, and $0.23 \mathrm{ppt}$, respectively (Appendix 5B). 


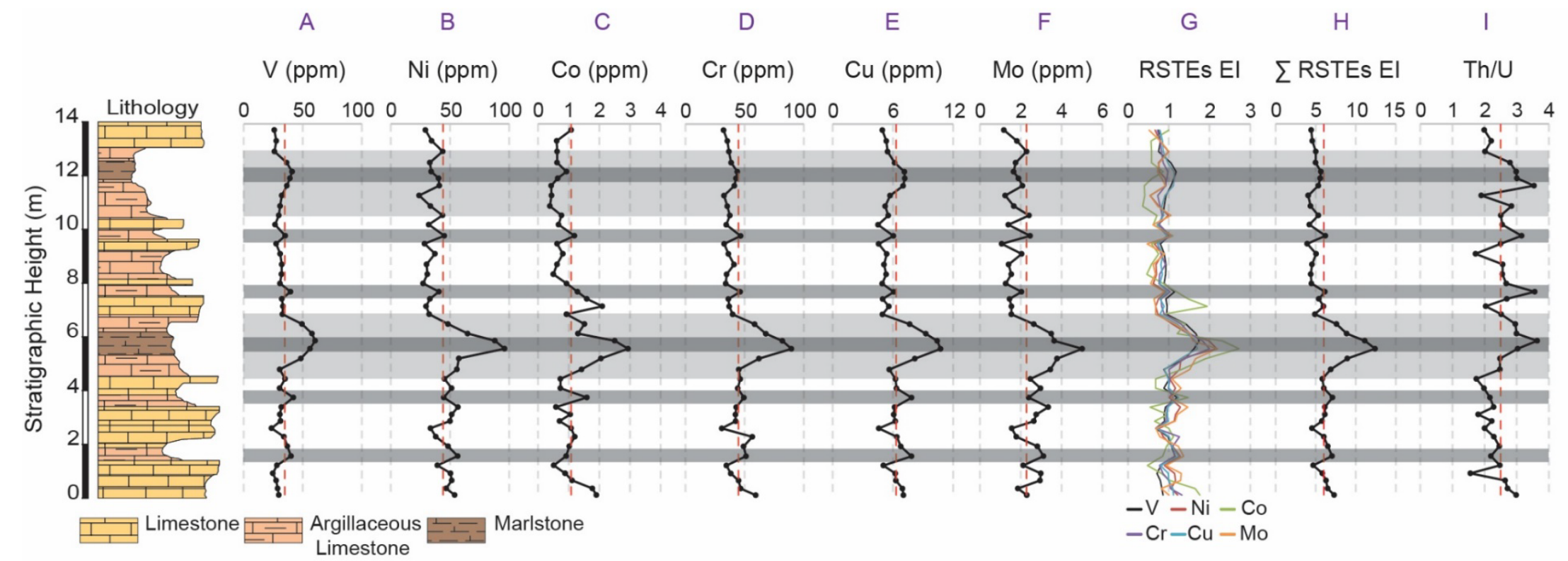

Figure 5-7 Stratigraphic variation in RSTEs, RSTEs EI, $\sum$ RSTEs EI and Th/U correlated with lithology. Red dashed line corresponds to the average value of the individual variable. Gray bars indicate areas enriched in RSTEs. Elemental concentrations are reported as absolute values in parts per million (ppm). 
RSTEs reveal a very similar trend with 6 peaks of enrichment and a positive correlation with terrestrially- derived elements, biolimiting elements and TOC $(\mathrm{V}, \mathrm{r}=$ $0.69 ; \mathrm{Ni}, \mathrm{r}=0.70 ; \mathrm{Co}, \mathrm{r}=0.44 ; \mathrm{Cr}, \mathrm{r}=0.44 ; \mathrm{Cu}, \mathrm{r}=0.71 ; \mathrm{Mo}, \mathrm{r}=0.69)$, but an inverse trend to TIC and benthic foraminifera $\rho$ (Fig. 5-5B; Fig. 5-6B, C, D, E, F; Fig.5-7A, B, C, D, E, F). Moreover, relative elemental enrichments were calculated for each RSTE in order to quantify their variations with regards to the background level or average in the section. All RSTEs show increases coeval with the 6 previously discussed levels (Fig. 57G; Appendix 5B). For instance, compared to the background average, V shows an enrichment of 1.16, 1.21, 1.74, 1.14, 1.01, at $1.18 \mathrm{~m}, 1.47 \mathrm{~m}, 3.68 \mathrm{~m}, 5.82 \mathrm{~m} 7.67 \mathrm{~m}, 9.78$ $\mathrm{m}$ and $12.2 \mathrm{~m}$, respectively. The calculated enrichment index for RSTEs ( $\sum$ EIs) (Fig. 5$7 \mathrm{H})$, yields a positive correlation with TOC $(\mathrm{r}=0.71)$, major terrestrially derived elements $(\mathrm{Al} \mathrm{r}=0.81)$, and biolimiting elements $(\mathrm{P} \mathrm{r}=0.80)$, but it shows a negative correlation with benthic foraminifera $\rho(\mathrm{r}=-0.42)$, and TIC $(\mathrm{r}=-0.43)$. Th/U ratios vary from a low of 1.6 to a maximum value of 3.6 at $5.82 \mathrm{~m}$, with an average of 2.5 (Fig. 5-7I; Appendix 5B). The overall $\mathrm{Th} / \mathrm{U}$ trend covaries with lithology where highest values appear in marly and argillaceous layers, as shown in the following correlations; TOC ( $\mathrm{r}=$ 0.30), major terrestrially derived elements $\mathrm{Al}(\mathrm{r}=0.61)$, biolimiting elements $\mathrm{P}(\mathrm{r}=$ 0.44), and RSTEs V $(r=0.54)$; however, it shows a negative correlation with benthic foraminifera $\rho(\mathrm{r}=-0.53)$ and TIC $(\mathrm{r}=-0.65)$.

\subsubsection{Biomarkers}

GC-MS analysis of lipid extracts on the aliphatic portion of 42 samples of the El Pujal section reveals $n$-alkanes (m/z 57) with a bimodal distribution, showing two maxima, one that covers $\leq n \mathrm{C}_{17}$ and another one at $\geq n \mathrm{C}_{19}$ with a minimum between 

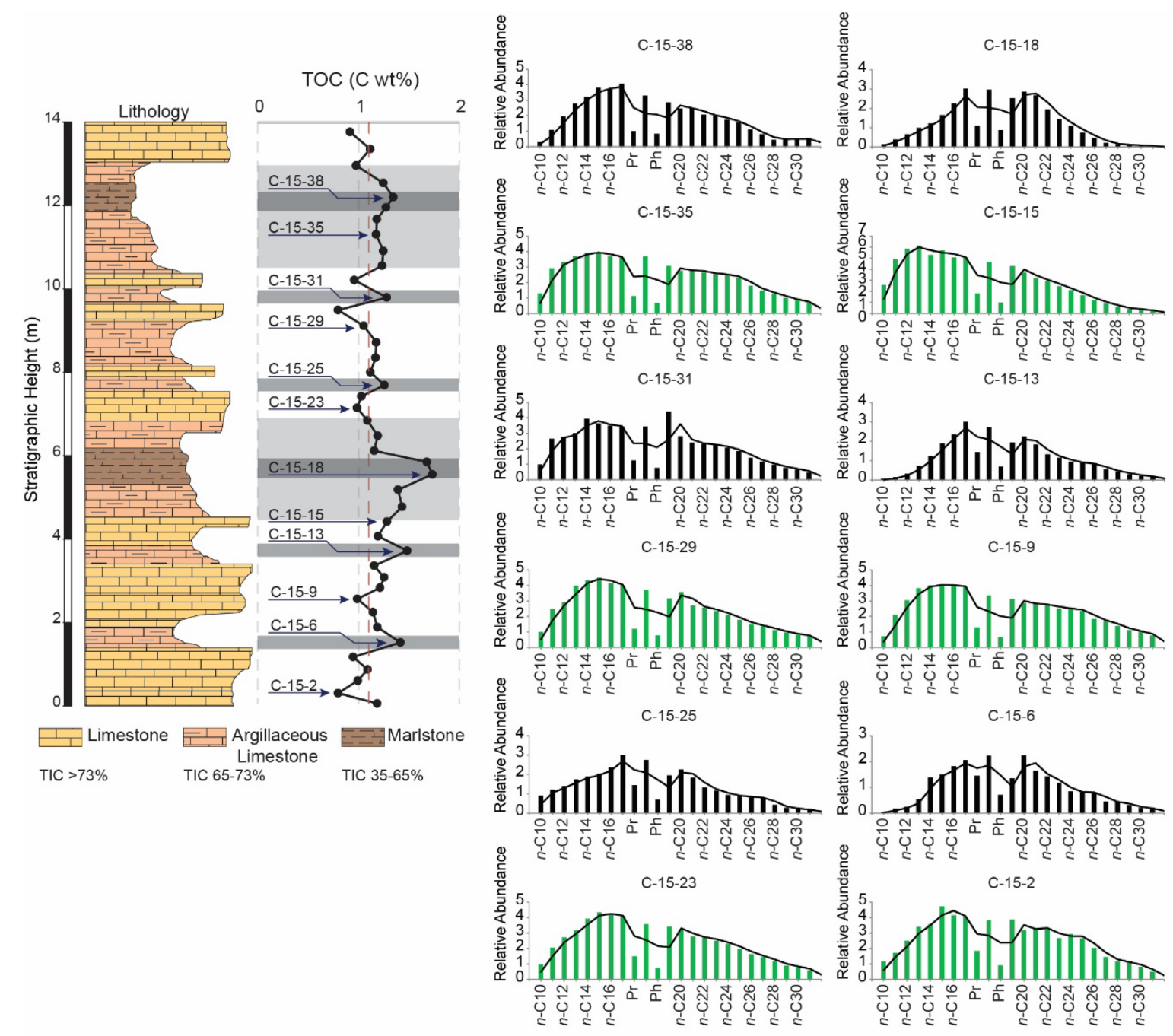

Figure 5-8 Stratigraphic position and n-alkanes distribution of 12 of the 42 samples analyzed for biomarkers. Black colored bar graphs represent the n-alkanes distribution of samples along intervals enriched in TOC (argillaceous limestone and marlstone layers) and the green colored bar graphs represent intervals depleted in TOC (limestone layers).

pristane $(\mathrm{Pr})$ and phytane $(\mathrm{Ph})($ Fig. 5-8). The aliphatic fraction in all chromatograms is dominated primarily by $n$-alkanes and acyclic isoprenoids. The $n$-alkanes show a distribution ranging from $n \mathrm{C}_{10}$ to a maximum of $n \mathrm{C}_{31}$ in all the analyzed samples, with no difference in carbon chain length between limestone, argillaceous limestone, or marlstone intervals (Fig. 5-8). CPI calculated from the longer chain $n$-alkanes $\left(n \mathrm{C}_{25}-n \mathrm{C}_{34}\right)$ is used here as a maturity index (refer to methods), with values that average 1.41 for the entire 
section with no particular stratigraphic pattern. Since there is no difference in the carbon chain length of samples throughout the section, TAR ratios were calculated (refer to methods). TAR values average 0.23 and display a remarkable trend whereby they drop below the average in argillaceous limestone and marlstone beds, while the values rise above the average in the limestone layers (Fig. 5-9A). Other biomarker parameters such as the ACL of leaf wax components $\left(n \mathrm{C}_{25}-n \mathrm{C}_{33}\right)$ commonly used as a proxy to determine the type of terrestrial vegetation, as well as for deducing climatic conditions on land (refer to methods), were also calculated. The ACL of El Pujal section yields values from 26.02 to 27.23 , with an average of 26.88 (Fig. 5-9C; Appendix 5C) and shows a negative

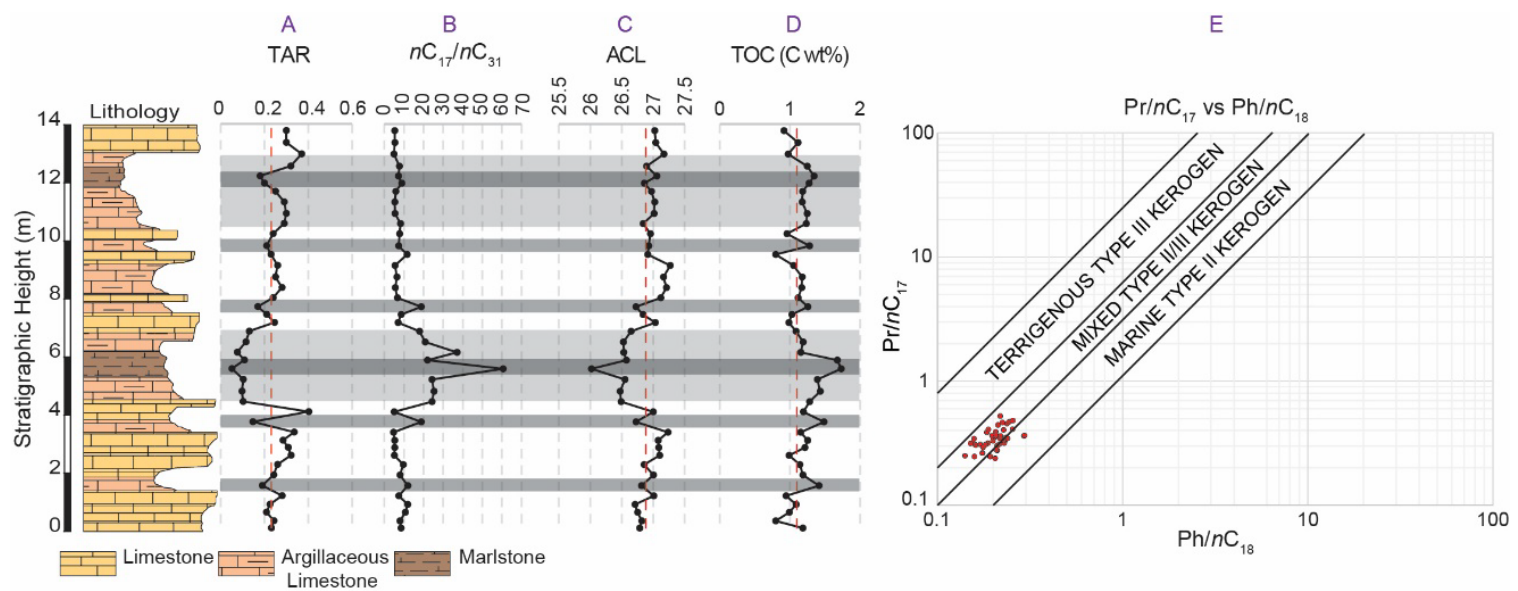

Figure 5-9 (A-B-C-D) Stratigraphic correlation between lithology and various organic geochemical parameters. Gray bars correspond with intervals of argillaceous limestone and marlstone deposition. (E) Log-log cross-plot of $\mathrm{Pr} / \mathrm{nC} 17 \mathrm{vs} \mathrm{Ph} / \mathrm{nC} 18$ for all 42 analyzed samples. Notice that in general the samples plot within the mixed type II/III kerogen with only a few plotting below in the marine type II kerogen zone.

correlation to TOC $(r=-0.53)$, whereby the lower values correspond to argillaceous limestone and marlstone intervals.

\subsection{Discussion}

\subsubsection{Stable Carbon Isotope and Biostratigraphic Correlations}

Coeval variations in stable carbon isotope $\left(\delta^{13} \mathrm{C}_{\text {org }}\right.$ and $\left.\delta^{13} \mathrm{C}_{\text {carb }}\right)$ profiles of Cretaceous pelagic and shallow water deposits are generally regarded as reflecting 
perturbations in the global carbon cycle (Scholle and Arthur, 1980; Arthur et al., 1987; Schlanger et al., 1987; Weissert, 1989; Jenkyns, 1995; Leckie et al., 2002; Weissert and Erba, 2004; Tejada et al., 2009). Hence, the concordance in the $\delta^{13} \mathrm{C}$ pattern of widely distributed Barremian-Aptian sections has become the hallmark of this interval of the Lower Cretaceous and attests to the utility of this proxy as a correlation tool, especially when corroborated by biostratigraphic markers and magnetostratigraphy (Gale et al., 1993; Moullade et al., 1998; Kuhnt et al., 1998; de Gea et al., 2003; Erba, 2004; Najarro et al., 2011; Moullade et al., 2015; Erba et al., 2015). Specifically, based on the similar pattern registered in various Barremian - Aptian sites, Menegatti et al. (1998) introduced a temporal subdivision of the $\delta^{13} \mathrm{C}$ curve into segments labeled $\mathrm{C} 1-\mathrm{C} 8$ that have been calibrated with index fossils and now serve as a standard for correlating Lower Cretaceous sections (e.g. Kuhnt et al., 1998; Erba, 2004; Millán et al., 2009; Stein et al., 2012; Papp et al., 2013; Sanchez-Hernandez and Maurrasse, 2014; Phelps et al., 2015; Scott, 2016). Although regional modulating factors such as the source of OM, biological fractionation, and degree of thermal maturation, and/or diagenesis, can affect the original isotopic signal, most sites record concurrent $\delta^{13} \mathrm{C}$ signatures (e.g. Menegatti et al., 1998; Godet et al., 2014; Sanchez-Hernandez and Maurrasse, 2016). Here we use the established constancy of the Aptian $\delta^{13} \mathrm{C}_{\text {org }}$ curve to correlate the El Pujal sequence with other well-studied Tethyan realm sections (Fig. 5-10), namely Roter Sattel, Cismon and the El Pui section (Menegatti et al., 1998; Sanchez-Hernandez and Maurrasse, 2016).

A detailed examination of the $\delta^{13} \mathrm{C}_{\text {org }}$ trend for segment C5 at Roter Sattel shows that the values start at $\sim-25 \%$ and then take a negative dip to $\sim-25.2 \%$ at $\sim 5.125 \mathrm{~m}$. Upwards, the values stay relatively stable with an approximate average of $-25.2 \%$ up to 
A

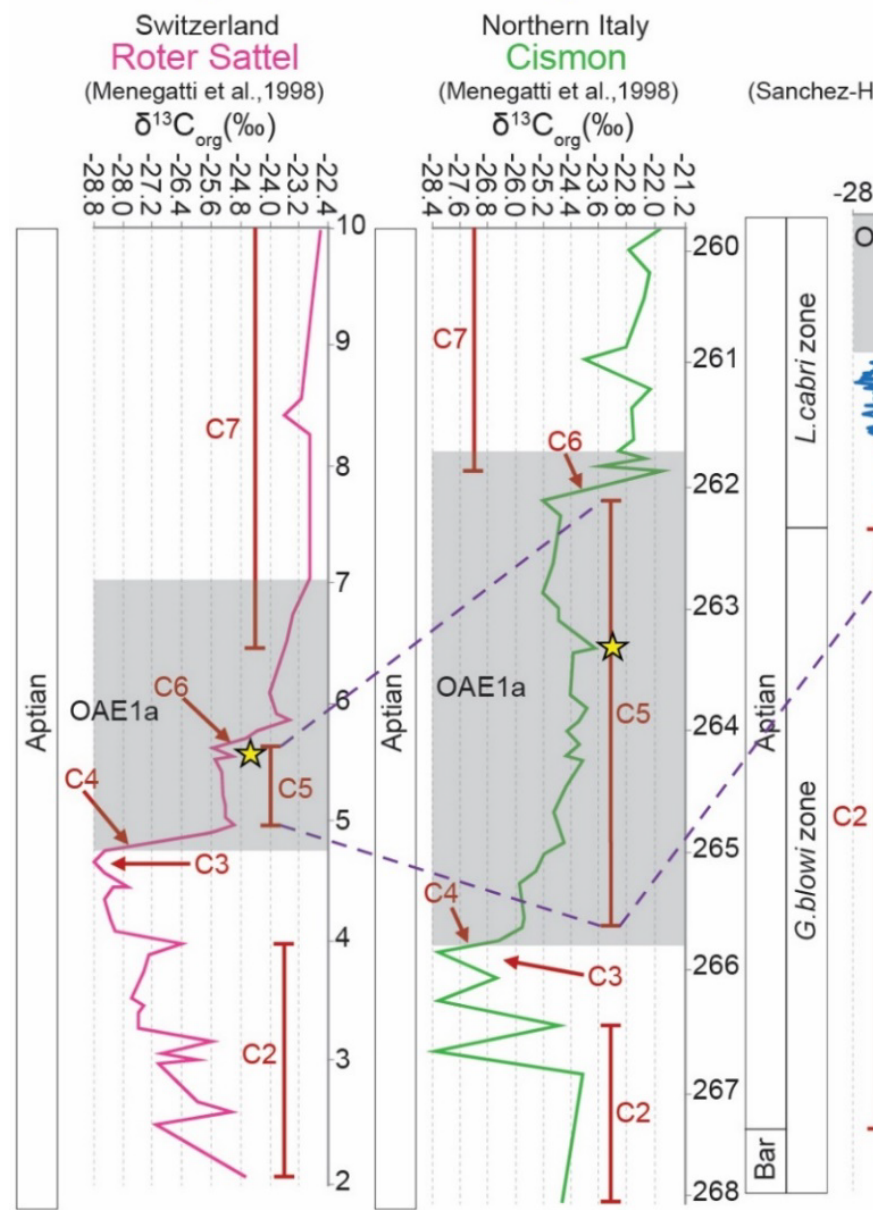

C

Spain

El Pui

$\bar{\delta}^{13} \mathrm{C}_{\text {org }}(\% \circ)$
D

Spain

El Pujal

(This Study) $\delta^{13} \mathrm{C}_{\text {org }}(\% \circ)$

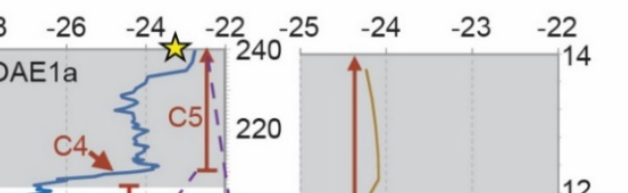

El Pui and El Pujal

12

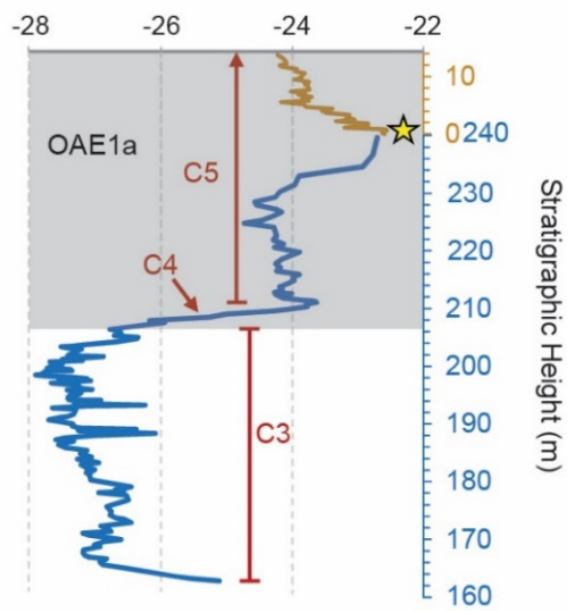

Figure 5-10 Chemostratigraphic correlation based on $\delta^{13} \mathrm{C}_{\text {org }}$ of the El Pujal section with other Tethyan sections. The C segments correspond to the $\delta^{13} \mathrm{C}$ subdivisions proposed by Menegatti et al. (1998). Area shaded in gray corresponds to the interval covering OAE1a in each respective section. (E) Plot of El Pui and El Pujal with identical vertical and horizontal scales. The yellow star marks the highest value within segment C5 and corresponds to equivalent points in each section. The purple dashed line shows the interval corresponding to segment C5. 
$5.5 \mathrm{~m}$ where they take a positive shift to $\sim-24.9 \%$ (Fig. $5-10 \mathrm{~A}$, point marked with a star) followed by a decrease past $-25.6 \%$, marking the end of $\mathrm{C} 5$ and the assigned beginning of segment C6. Similarly, the carbon isotope trend in the $\delta^{13} \mathrm{C}_{\text {org }}$ record of the Cismon section shows segment $\mathrm{C} 5$ starting with a value of $\sim-25.8 \%$, but gradually decreasing to $\sim-26 \%$ at $265.25 \mathrm{~m}$, succeeded by a series of positive and negative variations culminating in the most positive value (-23.6\%) recorded for segment C5 at $263.375 \mathrm{~m}$ (Fig. 5-10B, point marked with a star). A negative excursion ensues to just below $25.2 \%$, designated as the end of $\mathrm{C} 5 /$ beginning of segment $\mathrm{C} 6$.

By comparison, at El Pui, segment C5 begins at $212 \mathrm{~m}$ (Fig. 5-10C) with a value of $-23.68 \%$ and decreases to $-24.32 \%$, succeeded by a series of positive and negative variations ending at a value of $-24.62 \%$ at $228.80 \mathrm{~m}$ (interval of $\sim 16.8 \mathrm{~m}$ ). Above that interval, the $\delta^{13} \mathrm{C}_{\text {org }}$ values take a positive shift reaching up to $-22.63 \%$ within the last samples analyzed at that site (Sanchez-Hernandez and Maurrasse, 2016). In the absence of further samples, these authors indicated that the rise to positive values implied the onset of segment C6 at the end of the studied El Pui section. To establish the continuity of the chemostratigraphic data between the El Pui and El Pujal sections we first used the physical correlation of the beds. Because the beds that compose the homoclinal structure of the asymmetric Santa Fè syncline are clearly visible and undisturbed (García-Senz, 2002; Sanchez-Hernandez and Maurrasse, 2014), thus it was possible to use their strike to project their continuity farther east across the south side of the Cabo valley and ensure correlation with the El Pujal site (Fig. 5-1). Based on this continuity the projected beds from each other side of the valley provide an initial physical correlation and coupling of 
the two sites to form a continuous composite section that further extend the study of lower Aptian sedimentary deposits of the Organyà Basin (Fig. 5-2).

The lithologic correlation is confirmed by the carbon isotope results which yield values at the base of the El Pujal section starting with a $\delta^{13} \mathrm{C}_{\text {org }}$ of $-22.59 \%$, consistent with the El Pui section where the terminal value recorded in sample C12-480 is $-22.76 \%$ (Fig. 5-10D, E, point marked with a star). Unlike the conventional segment C6, however, this initial positive shift recorded at El Pui coinciding with the value at El Pujal does not maintain its rise. Instead, the $\delta^{13} \mathrm{C}_{\text {org }}$ values decrease shortly thereafter to $-24.23 \% 0$ (Fig. 5-10D, point marked with a star), and continue upwards with a more negative trend hovering around an average of $\sim-23.40 \%$ (Fig. $5-10 \mathrm{E}$ ). By comparison, we may deduce that the slight positive shift observed in the extended sequence of the Organyà sediments thus forms a short-lived spike comparable to the more condensed Roter Sattel and Cismon sections shown in Figure 5-10A, B, and marked with a star. Hence, we consider the $\delta^{13} \mathrm{C}_{\text {org }}$ values recorded at the end of the El Pui section and the base of the El Pujal section to be equivalent to the highest values for segment C5 at Roter Sattel and Cismon (Fig. 5-10A, B, point marked with a star). While there is an overall similar trend for segment $\mathrm{C} 5$ in all of these sections, there are distinct differences in amplitude between them. Such discrepancies are well known in the chemostratigraphic record because of the different factors such as, provenance of OM and diagenesis that may affect the actual isotopic values. In fact, because of these modulating factors such unequal variations are not exclusive to the lower Aptian sections, similar cases have been reported for coeval carbon isotope curves elsewhere at either older (e.g. Sandoval et al., 2012) or younger stratigraphic levels (Schouten et al., 2007). In the latter case that addresses the Paleocene- 
Eocene thermal maximum (PETM) CIEs the carbon isotopic values show magnitudes with a difference as large as $6.5 \%$ between diverse marine sites worldwide (see Table 1 in Schouten, et al., 2007). Although the driver of these discrepancies is poorly constrained and may be unique to each basin, since the sediments in the El Pujal section have $\mathrm{Pr} / \mathrm{Phy}$ ratios $<2$, we may rule out an overmature state as a factor affecting the carbon isotope values (ten Haven et al., 1987, 1988; Powell, 1988; Sanchez-Hernandez et al., 2014). Of special importance in the El Pujal section is the obvious contribution of terrestrially-derived organic matter (Fig. 5-8; also, see discussion of biomarkers below) which may be part of the local factors, because of the possible effects of carbon isotope fractionation specific to photosynthetic pathways (O’Leary, 1988) associated with the types of extant vegetation that contributed organic remains to the Organyà Basin. Indeed, a clear difference between $\mathrm{C} 3$ plants (average $\delta^{13} \mathrm{C}_{\text {org }} \sim-27 \%$ /-28\%o), as compared to $\mathrm{C} 4$ plants (average $\delta^{13} \mathrm{C}_{\mathrm{org}} \sim-13 \%$ ) is well demonstrated (O'Leary, 1988). Clearly, the magnitude of the positive inflection suggests forcing mechanisms related to local sources of organic matter. Given that variations in physiological traits that may cause wide range of carbon isotope values (e.g. Ehleringer et al., 1993) in the extant vegetation are yet unknown, further work is necessary to resolve such relationship and fully understand their effects on the actual regional amplitude of these shifts.

With the evidence at hand, we propose that the apparent carbon isotope positive shift in the carbon isotope $\mathrm{C} 5$ of the extended Organyà succession is a minor episode within that segment because the succeeding values continue toward a negative trend (Fig. 5-10E). Thus, the El Pujal section further documents carbon isotopic variations in segment $\mathrm{C} 5$, as previously reported in preceding segments of the El Pui section due to the 
high bulk accumulation rate in the basin (García-Senz, 2002; Sanchez-Hernandez et al., 2014).

The micropaleontological associations at El Pujal give further credence to the chemostratigraphic correlation because petrographic analysis and results from selected disaggregated samples show that hedbergellids (Fig. 5-5C5, C6, C7, C17, C18) are the most common planktonic foraminifers in this interval, accompanied by rare to common globigerinelloidids and Leupoldina cf. cabri. Since L. cabri is recorded at $13.77 \mathrm{~m}$ and its biozone is within OAE1a (Erba, 1994; Moullade et al., 1998; Cobianchi et al., 1999; Erba et al., 1999; Bellanca et al., 2002; Verga and Premoli Silva 2002; Erba, 2004; Coccioni et al., 2004; Heldt et al., 2008; Moullade et al., 2015) its presence further corroborates the $\delta^{13} \mathrm{C}_{\text {org }}$ results that permit to position the basal part of the studied El Pujal section within the event interval correlative with carbon isotope segment C5.

\subsubsection{Accumulation Rate and the Extent of the Carbon Isotope Segments in Different Sections}

The high-resolution carbon isotope curve of the studied El Pujal section provides greater detail of the temporal variations because of its extended thickness that reflects a much greater accumulation rate in the Organyà Basin as compared to other Tethyan localities (García-Senz, 2002; Sanchez-Hernandez et al., 2014; Sanchez-Hernandez and Maurrasse, 2016). By comparison, the Selli level (OAE1a) in the Cismon Apticore site extends over $\sim 5.11 \mathrm{~m}(18.77 \mathrm{~m}$ to $23.68 \mathrm{~m}$; Erba et al., 1999). If we apply the estimated durations of $\sim 1 \mathrm{Ma}$ (Larson and Erba, 1999) to a maximum of $\sim 1,271 \mathrm{ky}$ (Li et al., 2008; Scott, 2016) for OAE1a, they yield an estimated mass accumulation rate at the Cismon Apticore site of $\sim 0.50 \mathrm{~cm} \mathrm{Ky}^{-1}$ maximum, for the entire event. In contrast, the interval 
C3 - C5 (only partial C5) in the adjacent El Pui section of the Organyà Basin comprises at least $\sim 66 \mathrm{~m}(\mathrm{C} 3=36 \mathrm{~m} ; \mathrm{C} 4=13 \mathrm{~m}$; partial $\mathrm{C} 5=17 \mathrm{~m})($ Sanchez-Hernandez and Maurrasse, 2016). Based on the overall maximum suggested duration of $1,271 \mathrm{Ky}$ at Cismon, Italy (Table 2, in Li et al., 2008), our estimate for the dry bulk accumulation rate of the three segments at El Pui is $\sim 5.19 \mathrm{~cm} \mathrm{Ky}^{-1}(66 \mathrm{~m} \div 1,271 \mathrm{ky})$, which is in agreement with previous estimates (Sanchez-Hernandez and Maurrasse, 2016). Taking account of the variability in the accumulation rates of segments $\mathrm{C} 2$ to $\mathrm{C} 4$ reported by these authors, here we forgo to estimate a specific rate for $\mathrm{C} 5$ alone because its magnitude is not fully constrained as the study of the upper part of the El Pujal section is ongoing. Nonetheless, such high mass accumulation rate in the Organyà Basin may foretell a greater detailed record of minor temporal changes in the succession. The high mass accumulation rate recorded in the El Pujal section asserts the instability of the adjacent land masses at that time and is comparable to active tectonic areas where such high values are reported in coeval Cretaceous forearc basin sediments, as for instance the Yezo Group exposed in Hokkaido, northern Japan where dry bulk accumulation rates may exceed $\sim 11 \mathrm{~cm} \mathrm{Ky}^{-1}$ (Takashima et al., 2004).

\subsubsection{Biomarker Interpretation: Source of Organic Matter, Thermal Maturation}

Biomarker analysis of the El Pujal section (Fig. 5-8) yielded $n$-alkanes distribution ranging from $n \mathrm{C}_{10}$ to a maximum of $n \mathrm{C}_{31}$ revealing two maxima that include shorter chain lengths at $\geq n \mathrm{C}_{19}$ and longer chain lengths at $\geq n \mathrm{C}_{19}$ with a minimum between pristane ( $\mathrm{Pr}$ ) and phytane $(\mathrm{Ph})$. Different sources of higher plants (C3 trees, $\mathrm{C} 4$ grasses) may contribute to observed short chain $n$-alkanes in modern sediments (e.g. Kuhn et al., 2010), nonetheless previous studies have demonstrated that lipid extracts derived from marine 
planktonic organisms and or bacterial sources have a recognizable enrichment in shorter chain $n$-alkanes $\left(\leq n \mathrm{C}_{19}\right)$, in particular those with odd-number of carbons $\left(n \mathrm{C}_{15}, n \mathrm{C}_{17}\right.$, $n \mathrm{C}_{19}$ ) (Forster et al., 2004; Peters et al., 2005). Conversely, aquatic macrophytes from both marine and non-marine environments show an enrichment in the mid-chain length region $\left(n \mathrm{C}_{20}-n \mathrm{C}_{25}\right)$, while terrestrial vegetation shows higher proportions of longer chain $n$-alkanes ( $\left.>n \mathrm{C}_{25}\right)$, especially in the longer odd-numbered homologues $\left(n \mathrm{C}_{27}, n \mathrm{C}_{29}, n \mathrm{C}_{31}\right)$ (Cranwell, 1982; 1984; Ficken et al., 2000; Mead et al., 2005; Feakins et al., 2007; Kuhn et al., 2010). Thus, the aliphatic fraction of lipid extracts from the El Pujal section sediments reveals $n$-alkanes that represent a mixed source of OM in the basin (Fig. 5-8).

The carbon preference index (CPI) is a proxy used mainly to determine the degree of thermal maturation of ancient sediments and relies on the observation that lipids derived from terrestrial OM display a predominance of odd-over even-carbon (OEP) number of long chain $n$-alkanes $\left(n \mathrm{C}_{25}-n \mathrm{C}_{34}\right)$ (e.g. Bray and Evans., 1961; Kuhn et al., 2010). Although this predominance can be affected by a number of variables, such as climatic conditions, source of longer chain $n$-alkanes and biodegradation, the CPI indicative of low maturity and predominantly terrestrially derived OM should result in a high value $(>1)$, whereas when it decreases and approaches 1 it should correspond to higher levels of maturation (Bray and Evans., 1961). The calculated CPI of the longer chain homologues in the El Pujal sediments is relatively low (1.41), suggesting some degree of thermal maturity. However, the total ion chromatogram throughout the section shows the concurrence of low molecular weight $n$-alkanes $\left(<\mathrm{C}_{13}\right)$ with longer molecular constituents in a bimodal distribution associated with a very low hump of unresolved compounds (UCM) (Fig. 5-8), which indicates that the $n$-alkanes distribution is authentic 
with little to no thermal alteration, in agreement with previous studies based on $\mathrm{Pr} / \mathrm{Ph}$ ratios (Sanchez-Hernandez and Maurrasse, 2016).

The terrestrial aquatic ratios (TAR) were calculated to further aid in the interpretation of the $n$-alkanes and determine the contribution of terrestrial vegetation relative to in-situ production of the total OM. Analysis of the data shows that TAR values remain consistently low with an average of about 0.23 , but with distinct differences between intervals enriched and those depleted in TOC, respectively (Fig. 5-9A). The mean TAR suggests noticeable contribution of terrestrial OM, and the values vary along with a trend similar to fluctuations associated with lithologies observed in multiple characteristic geochemical components and benthic foraminifers shown in Figures 5-5, 56 and 5-7, respectively. However, in contrast to expected results, TAR values dip below the average $(0.19,0.15,0.05,0.17,0.21,0.18)$ in concordance with these respective levels of increased terrigenous materials $(1.47 \mathrm{~m}, 3.68 \mathrm{~m}, 5.82 \mathrm{~m}, 7.67 \mathrm{~m}, 9.78 \mathrm{~m}, 12.2$ m). Temporal correlation with the different parameters analyzed shows that on the overall, these minimum TAR values reveal an inverse trend relative to RSTEs, TOC $(r=$ $-0.52)$ and major elements, but a positive correlation with TIC $(\mathrm{r}=0.52)$ and benthic foraminifera $\rho(\mathrm{r}=0.41)$. This discrepancy may be explained by the dilution effect of enhanced in-situ primary productivity that increased the input of OM from shorter chain $n$-alkanes relative to the land-derived longer chain $n$-alkanes. As the distribution patterns of major and trace elements reveal (Fig. 5-6; Fig. 5-7), these intervals characterize higher input of biolimiting nutrients $(\mathrm{Fe}, \mathrm{P})$ into the basin that heightened productivity, thereby decreasing the TAR values. To help illustrate this dilution effect, a plot (Fig. 5-9B) of the inverse TAR (terrestrial/marine) marine/terrestrial $\left(n \mathrm{C}_{17} / n \mathrm{C}_{31}\right)$ results in a positive 
correlation with TOC $(\mathrm{r}=0.58)$, major terrestrially derived elements, RSTEs, but a negative correlation with TIC $(r=-0.47)$ and benthic foraminifera $\rho(r=-0.41)$.

The average chain length (ACL) of $n$-alkanes $\left(n \mathrm{C}_{25}-n \mathrm{C}_{33}\right)$ based on the abundance of the odd numbered carbon chain (Poynter and Eglinton, 1990) of terrestrial $n$-alkanes is used primarily in sediments to distinguish the source vegetation producing them (Jansen et al., 2010; Carr et al., 2010; Diefendorf and Freimuth, 2017) and climatic conditions of adjacent land masses (e.g. Feakins et al., 2007). As observed for the parameters discussed previously, the ACL of the leaf wax components in the El Pujal sediments also varies with the lithologic facies (Fig. 5-9C) and ranges from 26.02 to 27.23, with an average of 26.88. Notably, there is a moderate negative correlation $(\mathrm{r}=-0.53)$ between TOC and ACL, whereby intervals of higher TOC (Fig. 5-8) are more strongly influenced by the lower range of the ACL parameter or $n$-alkanes derived from terrestrial plants which would be more enriched in $n \mathrm{C}_{26}$. This close compatibility suggests that the source of the longer homologues is derived from woodland vegetation, and also points towards wetter conditions during the deposition of argillaceous limestone and marlstone intervals.

The pristane $(\mathrm{C} 19)$-phytane $(\mathrm{C} 20)(\mathrm{Pr} / \mathrm{Ph})$ ratios have been used as means of deducing the redox conditions during deposition. This is based on the knowledge that these acyclic isoprenoids are derived from degradation of the phytol side chain of chlorophyll $\mathrm{a}$ and $\mathrm{b}$ molecules which during reducing conditions leads to the formation of phytane, whereas under oxidizing conditions pristane is preferentially synthesized (e.g. Brooks et al., 1969; Didyk et al., 1978). Therefore, the values taken as useful metric for assessing depositional redox conditions suggested ratios of $\mathrm{Pr} / \mathrm{Ph}<1$ to indicate anoxic conditions, while ratios >1 would imply oxic environments (Powell and Mckirdy 1973; 
Didyk et al., 1978). However, some ambiguity may arise because the pristane-phytane ratios may increase with increasing terrigenous contributions (Rashid, 1979), and other biomolecules can serve as precursors to pristane and / or phytane through mechanisms that are independent of redox conditions. Some examples include unsaturated isoprenoids derived from zooplanktons (Blumer and Snyder, 1965), tocopherols derived from plants (Goossens et al., 1984), and archaebacterial glycerol ether lipids especially in the presence of clay minerals (Navale, 1994). The $\mathrm{Pr} / \mathrm{Ph}$ ratios in the El Pujal section are consistently $>1$ (Appendix 5C) averaging $\sim 1.81$ and show a weak negative correlation ( $\mathrm{r}$ $=-0.13$ ) with TOC and RSTEs (Appendix 5A, 5C), thus suggesting that extant depositional redox conditions might not be the major factors that affected the $\mathrm{Pr} / \mathrm{Ph}$ origin. Given the mix character of the OM (Fig. 5-8), a combination of factors might have been involved, including OM source, which will need further explicit data from other geochemical redox proxies (Peters et al., 2007).

Figure 5-9E illustrates our use of the values of $\mathrm{Pr} / n \mathrm{C}_{17}$ and $\mathrm{Ph} / n \mathrm{C}_{18}$ (Lijmbach, 1975; Shanmugam, 1985) as source indicators to determine the potential type of kerogen (II, III) present in the section. Since the $\mathrm{Pr} / \mathrm{Ph}$ ratios are predominately below the threshold (>2.5) (ten Haven et al., 1987, 1988; Powell, 1988), therefore thermal overmaturity can be ruled out as a possible factor to decrease these values. Although biodegradation could have also increased these values because bacteria preferentially degrade the more labile $n$-alkanes over the isoprenoids, but the lack of evidence of any such factor supports the assertion that the values obtained yield representative results. $\operatorname{Pr} / n \mathrm{C}_{17}$ shows consistently low values with an average of 0.35 . Similarly, $\mathrm{Ph} / n \mathrm{C}_{18}$ are also low with an average value of 0.21 . Log-log cross-plots of $\operatorname{Pr} / n \mathrm{C}_{17} \mathrm{vs} \mathrm{Ph} / n \mathrm{C}_{18}$ 
indicates a mixed source of OM with most samples plotting in the type II-III kerogen mixture zone, corroborating previous results from biomarkers, TAR and extracted ion $(\mathrm{m} / \mathrm{z} 57) n$-alkanes distributions, which also suggest a mixture of algal and terrestrial OM (Fig. 5-9E).

\subsubsection{Evidence of Episodic Dysoxia and its Role in OM Preservation}

Chemostratigraphic records showing high abundance and depletion of different redox sensitive trace metals (RSTEs) are widely corroborated to provide helpful metric for the assessment of redox conditions of modern and paleo-depositional systems (e.g. Brumsack, 1980, 2006; Calvert and Pederson, 1993; Dean, 1999; Yarincik et al., 2000; Tribovillard et al., 2004; Pattan and Pearce, 2009; Sanchez-Hernandez and Maurrasse, 2014; 2016). The general consensus discussed in the literature recognizes that under reducing conditions RSTEs such as $\mathrm{V}, \mathrm{Ni}, \mathrm{Co}, \mathrm{Cr}, \mathrm{Cu}$, Mo may become enriched in sediments through different reactive pathways: formation of organometallic complexes, precipitation as oxides and hydroxides, adsorption on organic surfaces, or by forming insoluble sulfides (e.g. Tribovillard et al., 2004 ; Bodin et al 2007).

Because of various alternative deliveries of these elements to the ocean via continental overflow and the nature of adjacent source rocks the values of relative high abundance of RSTEs alone may not provide enough evidence asserting oxygen deprived conditions. Accordingly, mindful of conflicting results that may arise with the use of these paleoredox proxies (Rimmer, 2004; Xu et al., 2012; Sanchez-Hernandez and Maurrasse, 2014), we used complementary co-factors to further validate potential oxygen deficient conditions. Hence, here we also use the combination of other oxygenation proxies (TOC, benthic foraminifera $\rho$, pyrite concentration, bioturbation index), in 
concert with $\sum$ RSTEs EI to approximately characterize oxygen conditions during sedimentation.

We used elemental ratios of thorium and uranium $(\mathrm{Th} / \mathrm{U})$ in an effort to add additional supporting evidence to assess redox conditions, because previous studies have successfully relied on this elemental ratio as a proxy to explain anoxic deposition of sediments (Wignall and Twitchett, 1996). This redox proxy is based on the fact that Th only has one redox state (IV), hence its concentration in sediments is unrelated to redox conditions (Hazen et al., 2009). In contrast, dissolved U(VI) is removed from oxidizing seawater to reducing sediments as insoluble U(IV) by various biogeochemical processes (Langmuir, 1978; Anderson et al., 1989; Yamada and Tsunogai, 1984; Calvert and Pedersen, 1993; Bura-Nakić et al., 2018). In the reduced state U removal includes uranous fluoride complexes, organometallic complexes with humic acids and particulate organic matter, or through the direct precipitation as uraninite $\left(\mathrm{UO}_{2}\right)($ Anderson et al., 1989; Klinkhammer and Palmer, 1991; Zheng et al., 2002). Consequently, a decrease of oxygen during deposition reduces the concentration of soluble U(VI) in the water column, hence the resulting depletion of $U$ in seawater is reflected in the increased concentration of $\mathrm{U}$ in sediments deposited during this time. Therefore, this parameter should be representative of redox conditions and should thus show lower $\mathrm{Th} / \mathrm{U}$ values during intervals of oxygen deprived conditions. However, $\mathrm{Th} / \mathrm{U}$ ratios in the sequence at El Pujal fall afield of the expected theoretical assumption because higher values correlate with organic-rich layers that yield lower concentration of benthic fauna (Fig. 5-5B), lower bioturbation index, higher pyrite concentration, significant enrichments in RSTEs, and $\sum$ RSTEs EI well above the background average (Fig. 5-7). Thus, Th is relatively 
enriched within these intervals even though the basin was evidently experiencing episodic oxygen-deficient conditions, a process that should have enriched U instead. As neither of the accepted conventional biogeochemical processes could resolve this apparent discrepancy, an understanding of the regional paleogeography with regards to the provenance of the terrigenous materials (Sanchez-Hernandez et al., 2014) provides a helpful explanation in relation to the extant crystalline terranes that constituted the watersheds adjacent to the basin. The Pyrenees include pre-Variscan (Ordovician) and Variscan (Late Paleozoic/ Carboniferous) crystalline terranes with granitoid plutons (Ábalos et al., 2002; Denèle et al., 2014) ranging in size from a few $\mathrm{km}^{2}$ to over $100 \mathrm{~km}^{2}$, and regions of high grade mica schists and migmatites (Boulvais et al., 2007; Poujol et al., 2010; Olivier et al., 2016). These crystalline terranes also incorporate large bodies of orthogneiss (Barbey et al., 2001; Cocherie et al., 2005; Castiñeiras et al., 2008; Denèle et al., 2009; Navidad et al., 2010; Castiñeiras et al., 2011; Liesa et al., 2011) and are coeval with comparable rocks found in Galicia, northwest area of the Iberian Peninsula, known as the Galiñeiro Igneous Complex. This crystalline complex is of particular interest because it contains significant enrichments in REE and high field strength elements (HFSE), especially Th which reaches values as high as $4923 \mathrm{ppm}$ in orthogneisses (Montero, 1993; Montero et al., 1998; 2009). Comparatively the Pyrenean correlative tends to have lower Th concentrations with values rarely exceeding $1000 \mathrm{ppm}$ (Castiñeiras et al., 2011), but other available sources which consist of differentiated crystalline rocks that include monazite $(\mathrm{Ce}, \mathrm{La}, \mathrm{Nd}, \mathrm{Th})\left(\mathrm{PO}_{4}, \mathrm{SiO}_{4}\right)$ may also be recognized as potential contributors to the relatively high Th concentrations in the Organyà Basin (Fig. 5-7; Appendix 5B). Magmatic differentiation and/or partial melting 
of the crust may have induced monazite fractionation in the Variscan granites and migmatites, as this process leads to concentration of rare-earth elements (REE) and Th in various accessory minerals (Miller and Mittlefehldt, 1982; Weber et al., 1985; Maruéjol et al., 1990; Ditz et al., 1990; Schandl and Gorton, 2004; Boulvais et al., 2007). Relatively high concentration of Th (up to $12 \mathrm{wt} \%$ ) is found mainly with the rare-earth phosphate phases, monazite and xenotime $\left(\mathrm{YPO}_{4}\right)$ (Wark and Miller, 1993). Monazite containing relatively low Th (rarely exceeding $1 \mathrm{wt} \%$ ) also occurs with abundant albitites produced during extensive magmatic hydrothermal metasomatism throughout the Pyrenees (Clavières, 1990; Ditz et al., 1990; Ayers et al., 1999; Spear and Pyle, 2002; Schandl and Gorton, 2004; Boulvais et al., 2007; Poujol et al., 2010; Grand'Homme, 2016). The regional geologic record of rocks adjacent to the Organyà Basin thus provides a robust evidence that helps to clarify the surprisingly high Th in sediments of the El Pujal section despite lacking anoxia. In fact, the excellent correlation of Th with $\mathrm{P}(\mathrm{r}=$ 0.77) further lends support to our assertion that intervals of higher $\mathrm{Th} / \mathrm{U}$ in the El Pujal sequence document periods of enhanced terrigenous riverine fluxes that delivered detrital Th to the basin comparable to previous discussions assessing the provenance of $\mathrm{P}$ in the Organyà Basin (Sanchez-Hernandez and Maurrasse, 2014; Sanchez-Hernandez et al., 2014). Our results underscore the need to also consider conterminous terranes when using $\mathrm{Th} / \mathrm{U}$ ratios, because the relationship between these two elements might not be as simply influenced by the redox conditions within the basin.

\subsubsection{Water Column Oxygenation}

The sedimentary record of the El Pujal section correlated with carbon isotope segment $\mathrm{C} 5$ shows no distinctive lithologic changes with pronounced increase in TOC 
reflective of anoxic conditions as documented with the continuous development of OAE1a in most locations worldwide. Nevertheless, our data indicate that the perturbation of the global carbon reservoir characteristic of the event was essentially reflected in the overall isotopic composition of the Organyà Basin. Arguably, the six intermittent intervals characterized by increase in $\sum$ RSTEs EI, slightly laminated organic-rich layers coincident with lower concentration of benthic fauna, lower bioturbation index, and higher pyrite concentration imply that oxygen-deficient conditions recurred intermittently during these times. Complete anoxic conditions can be ruled out because of the persistence of a few benthic foraminifera taxa, including both infauna and epifauna morphotypes (Jorissen et al., 1995; Jorissen, 1999), throughout the different layers. Variation of the benthic fauna indicates that oxygen may have decreased to sensitive level at the sediment water interface, but the water column never reached anoxic levels (Wignall and Myers, 1988; Tyson and Pearson, 1991, Murray, 2001; Meyer and Kump, 2008). Temporal variations in the distribution patterns of RSTEs and the other oxygen proxies throughout the studied section further characterize fluctuating conditions in the basin as the limestone layers indicate higher ventilation of the water column. The results of the El Pujal section further corroborate previous studies that determined mainly intermittent dysoxic and oxic conditions in the progression of OAE1a in the Organyà Basin (Sanchez-Hernandez and Maurrasse, 2014; Sanchez-Hernandez et al., 2014). Similar records have been documented in pelagic and hemipelagic deposits from the Tethys, northern and southern Atlantic and the Pacific from the Hauterivian up to the Aptian (Weissert et al., 1979, 1985; Koutsoukos et al., 1991b; Mutterlose and Ruffell, 1999; Bersezio et al., 2002, Heldt et al., 2008; Sanchez-Hernandez and Maurrasse, 2016). 
Perhaps, the recurrent pattern recorded in the sediment conveys respective modulating local factors that may obscure possible orbital effects that are yet to be determined.

\subsubsection{Productivity and Water Column Stratification as Driving Factors in OM Preservation}

As sediments of the El Pujal section show punctuated peaks of enhanced OM abundance, interrelated $n$-alkanes document their origin from a mixture of in-situ and terrestrially-derived photosynthetic producers (Fig. 5-8). In addition to the concurrence of these levels with increased abundance of environmentally characteristic trace metals (Fig. 5-7), the fluctuations further show a striking pattern of synchronicity with peaks in P and Fe (Fig. 5-6), which are critical biolimiting elements to sustain organic productivity (DNA, RNA, polypeptides, ATP, phospholipids, proteins, photosynthesis) (Hart, 1934; Rueter and Ades, 1987; Martin and Fitzwater, 1988; Krom et al., 1991; Geider and La Roche, 1994; Kumar et al., 1995; Zohary and Robarts, 1998; Tyrrell, 1999; BenitezNelson, 2000; Boyd et al., 2000; Diaz et al., 2001; Gervais et al., 2002; Coale et al., 2004; Paytan and McLaughlin, 2007; Falkowski and Raven, 2007; Blain et al., 2007). Since the respective roles of $\mathrm{P}$ and $\mathrm{Fe}$ are well established as critical in the marine biogeochemical cycle of primary producers and heterotrophic communities in modern oceans (e.g. Popendorf and Duhamel, 2015), variations recorded in the El Pujal sediments may be interpreted as archives of similar ecosystem relationships in the Organyà Basin. Indeed, our environmental interpretation relies on known delivery pathways of $\mathrm{P}$ and $\mathrm{Fe}$ to organisms in the ocean because they derive essentially from land areas (e.g. Kumar et al., 1995). Recycling of P occurs in the upwelling and oligotrophic environments of the ocean via remineralization within a complex pool of dissolved organic phosphate (DOP), 
dissolved inorganic phosphate (DIP), and mostly as tri-Phosphate ions that sustain the cycle of productivity. In the semi-restricted Organyà Basin the absence of biogenic silica (Sanchez-Hernandez and Maurrasse, 2016) implies lack of upwelling, therefore sustained productivity depended permanently on riverine input of $\mathrm{P}$. The correlative abundance of terrestrially-derived elements ( $\mathrm{Si}, \mathrm{Al}, \mathrm{Ti})$ during intervals of OM sequestration (Fig. 5-6) provides supportive evidence relating increased riverine fluxes that simultaneously supplied biolimiting nutrients ( $\mathrm{P}$ and $\mathrm{Fe}$ ), and other terrestrial matters incorporating allochthonous OM (Fig. 5-8), as attest the biomarker composition correlated with these OM spikes (Fig. 5-8). The effect of abundant influx of less dense freshwater would have also led to water column stratification lacking ventilation, analogous to the modern day Black Sea (Özsoy and Ünlüata, 1997; Giosan et al., 2012) and discussed for the early stages of OAE1a in the basin (Sanchez-Hernandez and Maurrasse, 2016).

In essence, the data in the lower portion of the El Pujal section suggest that the combined effect of periodic increase of riverine fluxes delivering biolimiting $\mathrm{P}$ and $\mathrm{Fe}$ enhanced export production together with water column stratification. It ensued that recurring maximum biological oxygen demand (BOD) in the water column exacerbated oxygen deficiency that heightened OM preservation in the basin. Higher Al content at these levels (Fig. 5-6) interpreted as derived from clays (Eslinger and Pevear, 1988) and previously documented in the basin (Sanchez-Hernandez et al., 2014; SanchezHernandez and Maurrasse, 2016) further supports this assumption. In addition to essential productivity factors and hydrodynamic conditions involved in OM production and preservation in the Organyà Basin, the increase in clays most likely functioned as protective agents of the OM either through sorption, or through physical encapsulation 
preventing it from remineralization by microbial exoenzymes (Mayer, 1994; Keil et al., 1994; Hedges and Keil, 1995; Ransom et al., 1997; Keil and Cowie, 1999; Satterberg et al., 2003; Kennedy et al., 2002, 2014).

Since the various proxy data provide concurrence of continuous open marine environmental conditions in the basin punctuated by episodes of increased freshwater input, the pattern suggests the effects of regional climate variability. Accordingly, increased hydrologic conditions on land were related to much wetter conditions during these intervals. The presence of smaller values in ACL of the leaf wax components $\left(n \mathrm{C}_{25}\right.$ $n \mathrm{C}_{33}$ ) from terrestrially derived vegetation lends support to this interpretation.

\subsubsection{Principal Component Analysis and Paleoecologic Interpretation}

To further shed light on the main variables controlling OM sequestration and its paleoenvironmental significance, principal component analysis (PCA) was conducted on 17 variables (TIC, TOC, Si, Al, Ti, Fe, P, V, Cr, Co, Ni, Cu, Mo, Th/U, benthic foraminifera $\rho, \mathrm{TAR}, \mathrm{ACL})$. The analysis permitted the separation of the samples into 3 clusters that coincide with the three identified lithologies (Cluster I = Limestones; Cluster $\mathrm{II}=$ Argillaceous Limestones; Cluster III = Marlstones (Fig. 5-11). The first principal component (PC1) accounts for $67.42 \%$ of the variance, with most variables showing strong loadings except for $\mathrm{Th} / \mathrm{U}(0.17)$ and benthic foraminifera $\rho$ (-0.17). Principal component 2 (PC2) accounts for $11.33 \%$ of the variance with TIC, Th/U, Mo, Ni and benthic foraminifera $\rho$ showing the strongest loadings (Scores and Loadings summarized in Appendix 5D). Samples plotting along PC1 with high positive scores correspond with intervals showing higher values of TOC, terrestrial matter, biolimiting nutrients, and RSTEs, whereas samples with strong negative scores correspond with high values of TIC, 


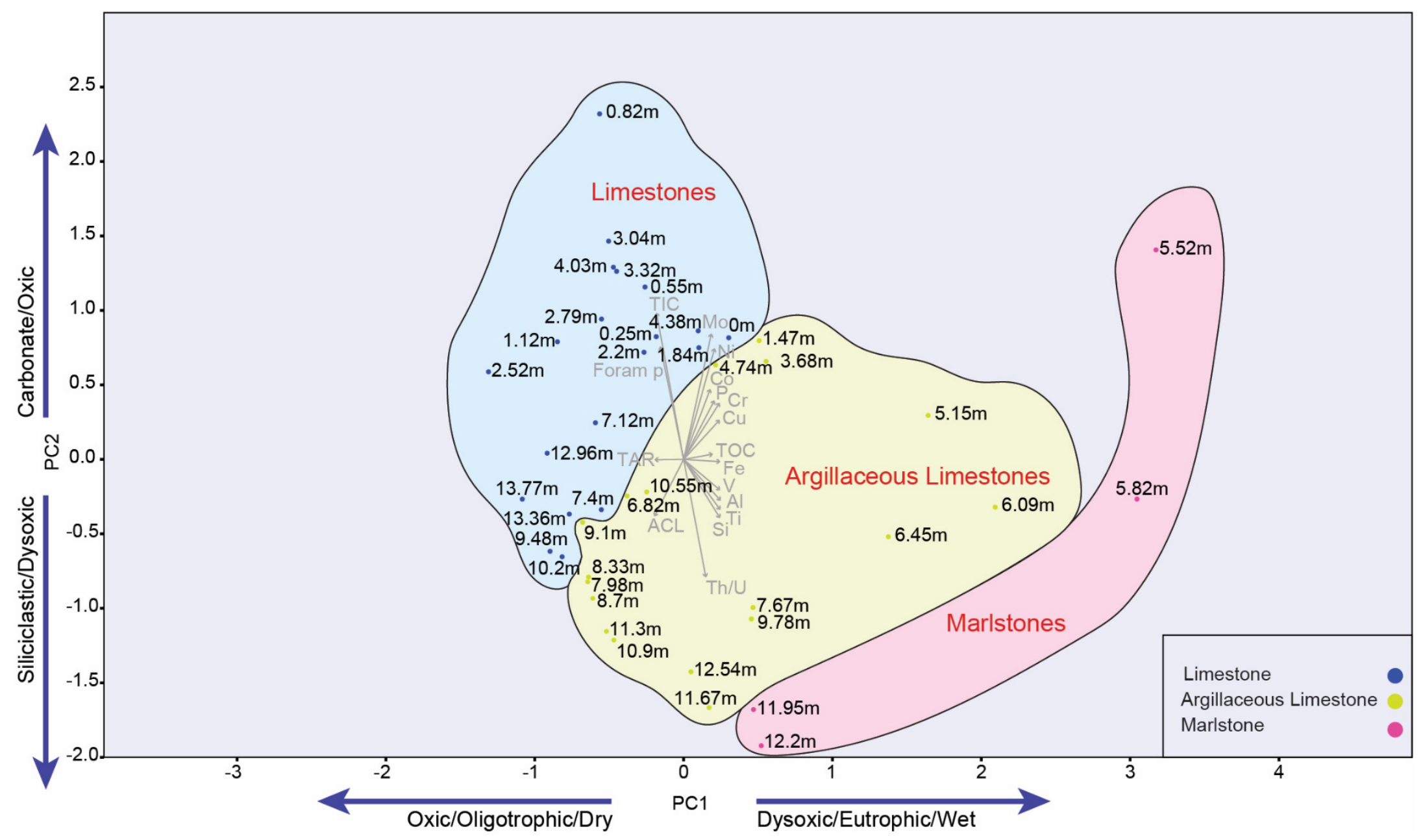

Figure 5-11 Results from PCA based on 17 combined variables. Notice how the samples separate into distinct lithologic groups. 
foraminifera $\rho$, TAR and ACL. High positive scores along PC1 are therefore interpreted as intervals of highest dysoxia consistent with wetter periods (smallest ACL) delivering increased volumes of riverine water containing highest $\mathrm{Si}, \mathrm{Al}$, Ti, and biolimiting nutrients $(\mathrm{P}, \mathrm{Fe}) . \mathrm{PC} 1$ represents more extreme variability from oxic/oligotrophic/dry to dysoxic/eutrophic/wet. High negative scores along PC1 are interpreted as dryer periods with less freshwater input, more oligotrophic conditions and higher oxygen content. The strongest positive loadings along PC2 belong to TIC, Mo, Ni and foraminifera $\rho$, while strong negative loadings belong to $\mathrm{Th} / \mathrm{U}, \mathrm{Si}$ and ACL. Samples plotting along PC2 with high positive scores are mostly associated with high carbonate content and more oxic depositional environment. A noteworthy contrast however, is that all RSTEs in PC1 have an inverse loading trend to TIC, but some RSTEs, especially Ni and Mo, show a positive loading trend with TIC. Samples with high negative scores plotting along PC2 have a stronger siliciclastic and dysoxic signature, therefore $\mathrm{PC} 2$ is interpreted to represent the transition carbonate/oxic to siliciclastic/dysoxic trend.

\subsubsection{Depositional Model of the Organyà Basin during Segment C5 of OAE1a}

Based on the results discussed for the El Pujal section, delivery of terrigenous elements into the Organyà Basin was the primary modulating factor superimposed on the overall extant global conditions associated with OAE1a. Watershed forcing can be inferred to have been driven by the paleophysiographic setting of a semi-restricted basin influenced by landmasses of crystalline terranes (Barbey et al., 2001; García-Senz, 2002; García-Alcade et al., 2002; Ábalos et al., 2002) coupled with a paleolatitude of approximately $25^{\circ}$ to $30^{\circ}$ north of the Equator under humid tropical climatic conditions (Molina and Salas, 1993; Salas et al., 1995; Barron et al., 1995; Masse et al., 2000; 
García-Senz, 2002; Yuste et al., 2017). We propose that continuous evolution of environmental conditions during segment $\mathrm{C} 5$ of OAE1a in the Organyà Basin were fairly analogous to those recorded in the modern-day Black Sea (Özsoy and Ünlüata, 1997; Giosan et al., 2012), or the eastern Mediterranean (e.g. Wu et al., 2018). Likewise, the lithofacies in the El Pujal section extend the trend in the subjacent hemiplegic facies of the El Pui section (Sanchez-Hernandez and Maurrasse, 2014; 2016; Sanchez-Hernandez et al., 2014) and presumably reflect regional climatic effects of insolation-driven fresh water forcing of continental runoff as demonstrated in the Mediterranean area for similar cycles (Wu et al., 2018), and as characterized in the following models (Fig. 5-12A, B, C):

1. Fig. 5-12A. Continuous riverine fluxes in the basin supplied Fe and P likely derived from the weathering of apatite-bearing Variscan crystalline terranes in the watershed areas (García-Alcade et al., 2002; Ábalos et al., 2002; Sanchez-Hernandez et al., 2014) that sustained productivity under mesotrophic conditions. These times were correlative with sedimentation associated with some degree of mixing because of weakly stratified water column.

2. Fig. 5-12B. The results suggest periodic riverine increases as indicated by greater abundance of major elements RSTEs associated with increased TOC and diminished density of benthic fauna signal relatively higher fluvial loads creating a stronger density gradient in the water column together with heightened export production leading to further oxygen deficient conditions recorded at these levels.

3. Fig. 5-12C. The lowest values of ACL in the two marlstones denote more pronounced shifts toward wetter climatic conditions on land, and highest $\mathrm{Si}, \mathrm{Al}, \mathrm{Ti}, \mathrm{P}$ and $\mathrm{Fe}$ values provide evidence of largest increase in the input of riverine fluxes into 
the basin. In addition, greatest abundance of TOC, RSTEs that coincide with the lowest densities in benthic fauna attest to conditions of exacerbated oxygen deficiency interpreted to represent enhanced water column stratification and

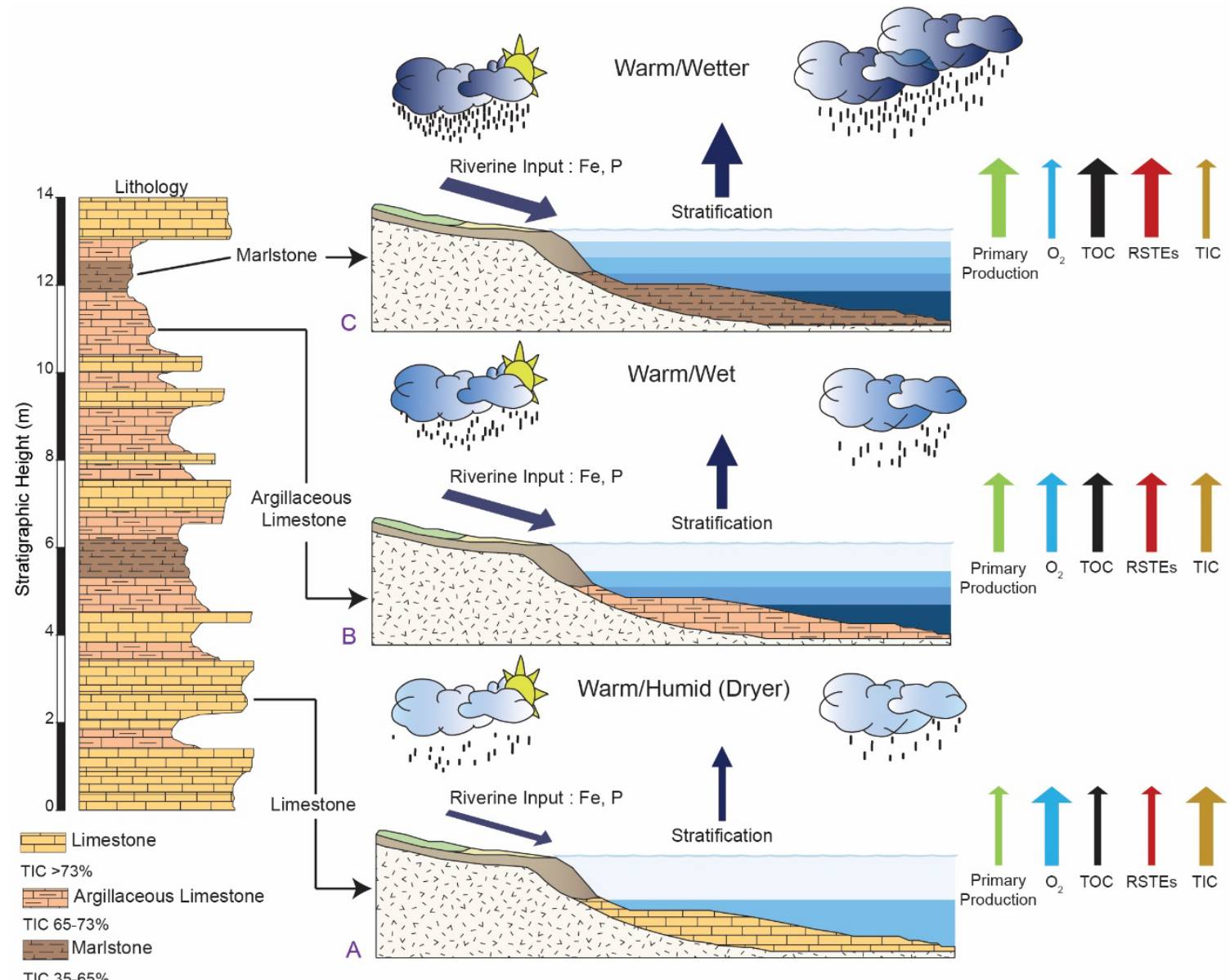

Figure 5-12 Simplified depositional model proposed for each of the different lithology present at El Pujal. The size of the arrows represent the relative magnitude of each variable.

augmented influx of export production. Furthermore, lower TAR values permit to postulate heightened in-situ primary production to the point of diluting the TAR signal. 


\subsection{Conclusions}

The results of a high-resolution lithostratigraphic and geochemical study of the basal 13.77 m El Pujal section in the semi-restricted Organyà Basin, south-central Spanish Pyrenees allow to conclude as follows:

1. - The $\delta^{13} \mathrm{C}_{\text {org }}$ signal reveals a temporal pattern similar to those recorded for carbon isotope segment C5 in the pelagic sections of the Swiss Préalpes (Roter Sattel), southern Italian Alps (Cismon) and the hemipelagic section of the south-central Spanish Pyrenees (E1 Pui). Additional corroborating evidence from the biostratigraphic framework documents the presence of L.cabri thus situating the section within this biozone wellrecognized within OAE1a. This implies that the El Pujal section is in continuity with the nearby El Pui section and more precisely further extends carbon isotope segment C5. 2. - Integration of sedimentological, micropaleontological, and geochemical data provides a sequence of events that reveal intermittent changes in fluxes of land-derived biolimiting nutrients concurrent with variations in major elements, TOC, RSTEs and benthic fauna. These fluctuations are reflective of water column oxygen level regulated by regional hydrologic fluctuations and riverine supplies that affected OM production and preservation. Similar fluctuating coeval sedimentary facies recorded in other Tethyan sections and partially reproducible worldwide for the period associated with OAE1a reveal possible indeterminate climate variability recorded in the continuous succession of the Organyà Basin.

3. - Variations in redox proxies throughout the studied section imply continuous OM accumulation under impoverished oxygen conditions punctuated by episodes of dysoxia without an anoxic phase which is the hallmark of OAE1a at most sites elsewhere. 
The results underscore how unique conditions associated with semi-restricted basins and type of adjacent geologic terranes can play a critical role in modulating divergent sedimentation and carbon sequestration under global forcing factors.

\subsection{Acknowledgements}

We gratefully acknowledge major financial support for this research from the Glenn A. Goodfriend memorial funds. We thank the Earth and Environment Department at FIU for partial support for laboratory supplies and other laboratory materials for analyses.

Sincere thanks are due to Diane Pirie for her consistent help with our carbon analyzer and gracious help at all steps of this research. We thank Peter Swart at the Rosenstiel School of Marine and Atmospheric Sciences (RSMAS) for the carbon isotope analyses, Cesar Ramirez at FIU's Advanced Mass Spectrometry Facility for the biomarker analyses, and Sarah Jantzi at FIU's Trace Elements Analytical Facilities (TEAF) for elemental analyses. We also thank Relu Dimitriu Roban and an anonymous reviewer for their constructive input. Special thanks to Eduardo Koutsoukos for his help throughout the entire editorial process.

\subsection{References}

Ábalos, B., Carreras, J., Druguet, E., Escuder Viruete, J., Gómez Pugnaire, T., Lorenzo Alvarez, S., Quesada, C., Rodríguez Fernández, L.R., Gil-Ibarguchi, J.., 2002. Variscan and pre-Variscan Tectonics, in: Gibbons, W., Moreno, T. (Ed.), The Geology of Spain. The Geological Society of London, pp. 155-183.

Anderson, R.F., Fleisher, M.Q., LeHuray, A.P., 1989. Concentration, oxidation state, and particulate flux of uranium in the Black Sea. Geochim. Cosmochim. Acta 53, 22152224. https://doi.org/10.1016/0016-7037(89)90345-1

Ando, A., Kaiho, K., Kawahata, H., Kakegawa, T., 2008. Timing and magnitude of early Aptian extreme warming: Unraveling primary $\delta 18 \mathrm{O}$ variation in indurated pelagic carbonates at Deep Sea Drilling Project Site 463, central Pacific Ocean. 
Palaeogeogr. Palaeoclimatol. Palaeoecol. 260, 463-476.

https://doi.org/10.1016/j.palaeo.2007.12.007

Arroyo, L., Trejos, T., Gardinali, P.R., Almirall, J.R., 2009. Optimization and validation of a Laser Ablation Inductively Coupled Plasma Mass Spectrometry method for the routine analysis of soils and sediments. Spectrochim. Acta - Part B At. Spectrosc. 64, 16-25. https://doi.org/10.1016/j.sab.2008.10.027

Arthur, M.A., Schlanger, S.O., Jenkyns, H.C., 1987. The Cenomanian-Turonian Oceanic Anoxic Event, II. Palaeoceanographic controls on organic-matter production and preservation. Geol. Soc. London, Spec. Publ. 26, 401-420. https://doi.org/10.1144/GSL.SP.1987.026.01.25

Arthur, M.A., Dean, W.E., Schlanger, S.O., 1985. Variations in the Global Carbon Cycle During the Cretaceous Related to Climate, Volcanism, and Changes in Atmospheric $\mathrm{CO} 2$, in: The Carbon Cycle and Atmospheric CO2: Natural Variations Archean to Present. pp. 504-529. https://doi.org/10.1159/000020165

Ayers, J.C., Miller, C., Gorisch, B., Milleman, J., 1999. Textural development of monazite during high-grade metamorphism: Hydrothermal growth kinetics, with implications for U,Th-Pb geochronology. Am. Mineral. 84, 1766-1780. https://doi.org/10.2138/am-1999-11-1206

Barbey, P., Cheilletz, A., Laumonier, B., 2001. Les orthogneiss du massif du canigou (Pyrénées orientales, France, Espagne): Un laccolite de granite rapakivi d'âge ordovicien inférieur et son auréole de contact. Comptes Rendus l'Academie Sci. Ser. IIa Sci. la Terre des Planetes 332, 129-136. https://doi.org/10.1016/S12518050(00)01506-8

Barron, E.J., 1987. Cretaceous plate tectonic reconstructions. Palaeogeogr. Palaeoclimatol. Palaeoecol. 59, 3-29. https://doi.org/10.1016/0031-0182(87)90071$\mathrm{X}$

Barron, E.J., Fawcett, P.J., Peterson, W.H., Pollard, D., Thompson, S.L., 1995. A "simulation" of Mid-Cretaceous climate. Paleoceanography 10, 953-962. https://doi.org/10.1029/95PA01624

Barron, E.J., Hay, W.W., Thompson, S., 1989. The hydrologic cycle: A major variable during earth history. Glob. Planet. Change 1, 157-174. https://doi.org/10.1016/09218181(89)90001-5

Barron, E.J., Washington, W.M., 1985. Warm Cretaceous Climates: High Atmospheric $\mathrm{CO} 2$ as a Plausible Mechanism, in: The Carbon Cycle and Atmospheric CO2: Natural Variations Archean to Present. pp. 546-553. https://doi.org/10.1029/GM032p0546 
Bellanca, A., Erba, E., Neri, R., Premoli Silva, I., Sprovieri, M., Tremolada, F., Verga, D., 2002. Palaeoceanographic significance of the Tethyan "Livello Selli" (Early Aptian) from the Hybla Formation, northwestern Sicily: Biostratigraphy and highresolution chemostratigraphic records. Palaeogeogr. Palaeoclimatol. Palaeoecol. 185, 175-196. https://doi.org/10.1016/S0031-0182(02)00299-7

Benitez-Nelson, C.R., 2000. The biogeochemical cycling of phosphorus in marine systems. Earth Sci. Rev. 51, 109-135. https://doi.org/10.1016/S00128252(00)00018-0

Berástegui, X., Garcia-Senz, J., Losantos, M., 1990. Tecto-sedimentary evolution of the Organyà extensional basin (central south Pyrenean unit, Spain) during the Lower Cretaceous. Bull. la Société géologique Fr. 6, 251-264. https://doi.org/10.2113/gssgfbull.VI.2.251

Bernaus, J.M., Arnaud-Vanneau, A., Caus, E., 2003. Carbonate platform sequence stratigraphy in a rapidly subsiding area: The Late Barremian-Early Aptian of the Organyà basin, Spanish Pyrenees. Sediment. Geol. 159, 177-201. https://doi.org/10.1016/S0037-0738(02)00316-0

Bersezio, R., Erba, E., Gorza, M., Riva, A., 2002. Berriasian-Aptian black shales of the Maiolica formation (Lombardian Basin, Southern Alps, Northern Italy): Local to global events. Palaeogeogr. Palaeoclimatol. Palaeoecol. 180, 253-275. https://doi.org/10.1016/S0031-0182(01)00416-3

Blain, S., Quéguiner, B., Armand, L., Belviso, S., Bombled, B., Bopp, L., Bowie, A., Brunet, C., Brussaard, C., Carlotti, F., Christaki, U., Corbière, A., Durand, I., Ebersbach, F., Fuda, J.-L., Garcia, N., Gerringa, L., Griffiths, B., Guigue, C., Guillerm, C., Jacquet, S., Jeandel, C., Laan, P., Lefèvre, D., Lo Monaco, C., Malits, A., Mosseri, J., Obernosterer, I., Park, Y.-H., Picheral, M., Pondaven, P., Remenyi, T., Sandroni, V., Sarthou, G., Savoye, N., Scouarnec, L., Souhaut, M., Thuiller, D., Timmermans, K., Trull, T., Uitz, J., van Beek, P., Veldhuis, M., Vincent, D., Viollier, E., Vong, L., Wagener, T., 2007. Effect of natural iron fertilization on carbon sequestration in the Southern Ocean. Nature 446, 1070.

Blumer, M., Snyder, W.D., 1965. Isoprenoid hydrocarbons in recent sediments: Presence of pristane and probable absence of phytane. Science (80-. ). 150, 1588-1589. https://doi.org/10.1126/science.150.3703.1588

Bodin, S., Godet, A., Matera, V., Steinmann, P., Vermeulen, J., Gardin, S., Adatte, T., Coccioni, R., Föllmi, K.B., 2007. Enrichment of redox-sensitive trace metals (U, V, Mo, As) associated with the late Hauterivian Faraoni oceanic anoxic event. Int. J. Earth Sci. 96, 327-341. https://doi.org/10.1007/s00531-006-0091-9 
Bosellini, a., Morsilli, M., Neri, C., 1999. Long-term event stratigraphy of the Apulia Platform margin (Upper Jurassic to Eocene, Gargano, southern Italy). J. Sediment. Res. 69, 1241-1252. https://doi.org/10.2110/jsr.69.1241

Boulvais, P., Ruffet, G., Cornichet, J., Mermet, M., 2007. Cretaceous albitization and dequartzification of Hercynian peraluminous granite in the Salvezines Massif (French Pyrénées). Lithos 93, 89-106. https://doi.org/10.1016/j.lithos.2006.05.001

Bourbonniere, R.A., Meyers, P.A., 1996. Sedimentary geolipid records of historical changes in the watersheds and productivities of Lakes Ontario and Erie. Limnol. Oceanogr. 41, 352-359. https://doi.org/10.4319/lo.1996.41.2.0352

Boyd, P.W., Watson, A.J., Law, C.S., Abraham, E.R., Trull, T., Murdoch, R., Bakker, D.C.E., Bowie, A.R., Buesseler, K.O., Chang, H., Charette, M., Croot, P., Downing, K., Frew, R., Gall, M., Hadfield, M., Hall, J., Harvey, M., Jameson, G., LaRoche, J., Liddicoat, M., Ling, R., Maldonado, M.T., McKay, R.M., Nodder, S., Pickmere, S., Pridmore, R., Rintoul, S., Safi, K., Sutton, P., Strzepek, R., Tanneberger, K., Turner, S., Waite, A., Zeldis, J., 2000. A mesoscale phytoplankton bloom in the polar Southern Ocean stimulated by iron fertilization. Nature 407, 695-702. https://doi.org/10.1038/35037500

Bralower, T.J., Cobabe, E., Clement, B., Sliter, W. V, Osburn, C.L., Longoria, J., 1999. The record of global change in mid-Cretaceous (Barremian-Albian) sections from the Sierra Madre, Northeastern Mexico. J. Foraminifer. Res. 29, 418-437.

Bray, E.E., Evans, E.D., 1961. Distribution of n-paraffins as a clue to recognition of source beds. Geochim. Cosmochim. Acta. 22, 2-15. https://doi.org/10.1016/00167037(61)90069-2

Brooks, J.D., Gould, K., Smith, J.W., 1969. Isoprenoid hydrocarbons in coal and petroleum. Nature 222, 257-259. https://doi.org/10.1038/222257a0

Brumsack, H.J., 1980. Geochemistry of Cretaceous black shales from the Atlantic Pcean (DSDP Legs 11, 14, 36 and 41). Chem. Geol. 31, 1-25. https://doi.org/10.1016/0009-2541(80)90064-9

Brumsack, H.J., 2006. The trace metal content of recent organic carbon-rich sediments: Implications for Cretaceous black shale formation. Palaeogeogr. Palaeoclimatol. Palaeoecol. 232, 344-361. https://doi.org/10.1016/j.palaeo.2005.05.011

Bura-Nakić, E., Andersen, M.B., Archer, C., de Souza, G.F., Marguš, M., Vance, D., 2018. Coupled Mo-U abundances and isotopes in a small marine euxinic basin: Constraints on processes in euxinic basins. Geochim. Cosmochim. Acta 222, 212 229. https://doi.org/10.1016/j.gca.2017.10.023 
Burla, S., Heimhofer, U., Hochuli, P.A., Weissert, H., Skelton, P., 2008. Changes in sedimentary patterns of coastal and deep-sea successions from the North Atlantic (Portugal) linked to Early Cretaceous environmental change. Palaeogeogr.

Palaeoclimatol. Palaeoecol. 257, 38-57.

https://doi.org/10.1016/j.palaeo.2007.09.010

Bush, R.T., McInerney, F.A., 2015. Influence of temperature and C4abundance on nalkane chain length distributions across the central USA. Org. Geochem. 79, 65-73. https://doi.org/10.1016/j.orggeochem.2014.12.003

Caldeira, K., Rampino, M.R., 1991. The Mid-Cretaceous Super Plume, carbon dioxide, and global warming. Geophys. Res. Lett. 18, 987-990.

https://doi.org/10.1029/91GL01237

Calvert, S.E., Pedersen, T.F., 1993. Geochemistry of Recent oxic and anoxic marine sediments: Implications for the geological record. Mar. Geol. 113, 67-88.

https://doi.org/10.1016/0025-3227(93)90150-T

Carr, A.S., Boom, A., Chase, B.M., 2010. The potential of plant biomarker evidence derived from rock hyrax middens as an indicator of palaeoenvironmental change.

Palaeogeogr. Palaeoclimatol. Palaeoecol. 285, 321-330.

https://doi.org/10.1016/j.palaeo.2009.11.029

Castiñeiras, P., Navidad, M., Casas, J.M., Liesa, M., Carreras, J., 2011. Petrogenesis of Ordovician Magmatism in the Pyrenees (Albera and Canigó Massifs) Determined on the Basis of Zircon Minor and Trace Element Composition. J. Geol. 119, 521-534. https://doi.org/10.1086/660889

Castiñeiras, P., Navidad, M., Liesa, M., Carreras, J., Casas, J.M., 2008. U-Pb zircon ages (SHRIMP) for Cadomian and Early Ordovician magmatism in the Eastern Pyrenees: New insights into the pre-Variscan evolution of the northern Gondwana margin. Tectonophysics 461, 228-239. https://doi.org/10.1016/J.TECTO.2008.04.005

Chaabani, F., Razgallah, S., 2006. Aptian sedimentation: an example of interaction between tectonics and eustatics in Central Tunisia. Geol. Soc. London, Spec. Publ. 262, 55-74. https://doi.org/10.1144/GSL.SP.2006.262.01.03

Clavières, V., 1990. Muscovitisation et feldspathisation hydrothermale dans le massif granitique de Millas (Pyrénées Orientales). Géométrie, Géochimie, Modélisation. University of Paris VI.

Coale, K.H., Johnson, K.S., Chavez, F.P., Buesseler, K.O., Barber, R.T., Brzezinski, M.A., Cochlan, W.P., Millero, F.J., Falkowski, P.G., Bauer, J.E., Wanninkhof, R.H., Kudela, R.M., Altabet, M.A., Hales, B.E., Takahashi, T., Landry, M.R., Bidigare, R.R., Wang, X., Chase, Z., Strutton, P.G., Friederich, G.E., Gorbunov, M.Y., Lance, 
V.P., Hilting, A.K., Hiscock, M.R., Demarest, M., Hiscock, W.T., Sullivan, K.F., Tanner, S.J., Gordon, R.M., Hunter, C.N., Elrod, V.A., Fitzwater, S.E., Jones, J.L., Tozzi, S., Koblizek, M., Roberts, A.E., Herndon, J., Brewster, J., Ladizinsky, N., Smith, G., Cooper, D., Timothy, D., Brown, S.L., Selph, K.E., Sheridan, C.C., Twining, B.S., Johnson, Z.I., 2004. Southern Ocean Iron Enrichment Experiment: Carbon Cycling in High- and Low-Si Waters. Science (80-. ). 304, 408-414. https://doi.org/10.1126/science. 1089778

Cobianchi, M., Luciani, V., Menegatti, A., 1999. The Selli Level of the Gargano Promontory, Apulia, southern Italy: Foraminiferal and calcareous nannofossil data. Cretac. Res. 20, 255-269. https://doi.org/10.1006/cres.1999.0155

Coccioni, R., Marsili, A., Venturati, A., 2004. Chamber elongation in Early Cretaceous planktonic Foraminifera: A case study from the Lower Hauterivian-Lower Aptian Rio Argos succession (southern Spain), in: Coccioni, R., Galeotti, S., Lirer, F. (Eds.), Proceedings of the First Italian Meeting on Environmental Micropaleontology. Grzybowski Found. Spec. Publ, pp. 37-43.

Cocherie, A., Baudin, T., Autran, A., Guerrot, C., Fanning, C.M., Laumonier, B., 2005. $\mathrm{U}-\mathrm{Pb}$ zircon (ID-TIMS and SHRIMP) evidence for the early ordovician intrusion of metagranites in the Late Proterozoic Canaveilles Group of the Pyrenees and the Montagne Noire (France). Bull. la Soc. Geol. Fr. 176, 269-282. https://doi.org/10.2113/176.3.269

Cranwell, P.A., 1984. Lipid geochemistry of sediments from Upton Broad, a small productive lake. Org. Geochem. 7, 25-37. https://doi.org/10.1016/01466380(84)90134-7

Cranwell, P.A., 1982. Lipids of aquatic sediments and sedimenting particulates. Prog. Lipid Res. 21, 271-308. https://doi.org/10.1016/0163-7827(82)90012-1

Dañobeitia, J.J., Alonso, B., Maldonado, A., 1990. Geological framework of the Ebro continental margin and surrounding areas. Mar. Geol. 95, 265-287. https://doi.org/10.1016/0025-3227(90)90120-9

de Gea, G.A., Castro, J.M., Aguado, R., Ruiz-Ortiz, P.A., Company, M., 2003. Lower Aptian carbon isotope stratigraphy from a distal carbonate shelf setting: The Cau section, Prebetic zone, SE Spain, in: Palaeogeography, Palaeoclimatology, Palaeoecology. pp. 207-219. https://doi.org/10.1016/S0031-0182(03)00451-6

Dean, W.E., Piper, D.Z., Peterson, L.C., 1999. Molybdenum accumulation in Cariaco basin sediment over the past 24 k.y.: A record of water-column anoxia and climate. Geology 27, 507-510. https://doi.org/10.1130/00917613(1999)027<0507:MAICBS>2.3.CO;2 
Denèle, Y., Laumonier, B., Paquette, J.-L., Olivier, P., Gleizes, G., Barbey, P., 2014. Timing of granite emplacement, crustal flow and gneiss dome formation in the Variscan segment of the Pyrenees. Geol. Soc. London, Spec. Publ. 405, 265-287. https://doi.org/10.1144/SP405.5

Denèle, Y., Barbey, P., Deloule, E., Pelleter, E., Olivier, P., Gleizes, G., 2009. Middle Ordovician $\mathrm{U}-\mathrm{Pb}$ age of the Aston and Hospitalet orthogneissic laccoliths: their role in the Variscan evolution of the Pyrenees. Bull. la Société Géologique Fr. 180, 209 216. https://doi.org/10.2113/gssgfbull.180.3.209

Diaz, P., Raimbault, F., Boudjellal, B., Garcia, N., Moutin, T., 2001. Early spring phosphorus limitation of primary productivity in a NW Mediterranean coastal zone (Gulf of Lions). Mar. Ecol. Prog. Ser. 211, 51-62. https://doi.org/10.3354/meps211051

Didyk, B.M., Simoneit, B.R.T., Brassell, S.C., Eglinton, G., 1978. Organic geochemical indicators of palaeoenvironmental conditions of sedimentation. Nature 272, $216-$ 222. https://doi.org/10.1038/272216a0

Diefendorf, A.F., Freimuth, E.J., 2017. Extracting the most from terrestrial plant-derived n-alkyl lipids and their carbon isotopes from the sedimentary record: A review. Org. Geochem. 103, 1-21. https://doi

Ditz, R., Sarbas, B., Schubert, P., Töpper, W., 1990. Th Thorium: Natural Occurrence. Minerals (Excluding Silicates). Springer Science \& Business Media.

Dumitrescu, M., Brassell, S.C., 2005. Biogeochemical assessment of sources of organic matter and paleoproductivity during the early Aptian Oceanic Anoxic Event at Shatsky Rise, ODP Leg 198. Org. Geochem. 36,

Dumitrescu, M., Brassell, S.C., 2006. Compositional and isotopic characteristics of organic matter for the early Aptian Oceanic Anoxic Event at Shatsky Rise, ODP Leg 198. Palaeogeogr. Palaeoclimatol. Palaeoecol. 235, 168-191. https://doi.org/10.1016/j.palaeo.2005.09.028

Ehleringer, J.R., Hall, A.E., Anthony, E., Farquhar, G.D., 1993. Stable isotopes and plant carbon/water relations. Academic Press.

Erba, E., 2004. Calcareous nannofossils and Mesozoic oceanic anoxic events, in: Marine Micropaleontology. pp. 85-106. https://doi.org/10.1016/j.marmicro.2004.04.007

Erba, E., 1994. Nannofossils and superplumes: The Early Aptian "nannoconid crisis." Paleoceanography 9, 483-501. https://doi.org/10.1029/94PA00258 
Erba, E., Channell, J.E.T., Claps, M., Jones, C., Larson, R., Opdyke, B., Premoli Silva, I., Riva, A., Salvini, G., Torricelli, S., 1999. Integrated stratigraphy of the Cismon Apticore (southern Alps, Italy); a "reference section" for the Barremian-Aptian interval at low latitudes. J. Foraminifer. Res. 29, 371-391.

Erba, E., Duncan, R.A., Tiraboschi, D., 2015. Environmental consequences of Ontong Java Plateau and Kerguelen Plateau volcanism. The Geological Society of America Special Paper 511, 271-303. https://doi.org/10.1130/2015.2511(15)

Erbacher, J., Thurow, J., Littke, R., 1996. Evolution patterns of radiolaria and organic matter variations: A new approach to identify sea-level changes in mid-Cretaceous pelagic environments. Geology 24, 499-502. https://doi.org/10.1130/00917613(1996)024<0499:EPORAO >2.3.CO;2

Eslinger, E., Pevear, D., 1988. Introduction, Clay Minerals for Petroleum Geologists and Engineers, SEPM Short Course Notes. https://doi.org/10.2110/scn.88.01.0000

Falkowski, P.G., Raven, J.A., 2007. Aquatic Photosynthesis, 2nd ed. Princeton University Press.

Feakins, S.J., Eglinton, T.I., deMenocal, P.B., 2007. A comparison of biomarker records of northeast African vegetation from lacustrine and marine sediments (ca. 3.40 Ma). Org. Geochem. 38, 1607-1624. https://doi.org/10.1016/j.orggeochem.2007.06.008

Ficken, K.J., Li, B., Swain, D.L., Eglinton, G., 2000. An n-alkane proxy for the sedimentary input of submerged/floating freshwater aquatic macrophytes, in: Organic Geochemistry. pp. 745-749. https://doi.org/10.1016/S0146-6380(00)000814

Forster, A., Sturt, H., Meyers, P., Party, L., 2004. Molecular biogeochemistry of Cretaceous black shales from the Demerara Rise; preliminary shipboard results from Sites 1257 and 1258, ODP Leg 207. Proc. Ocean Drill. Progr. Initial Rep 207, 1-22.

Frakes, L.A., Francis, J.E., Syktus, J.I., 1992. Climate Modes of the Phanerozoic: The History of the Earth's Climate Over the Past 600 Million Years. Cambridge University Press. https://doi.org/10.1017/CBO9

Funk, H., Follmi, K.B., Mohr, H., 1993. Evolution of the Tithonian-Aptian carbonate platform along the northern Tethyan margin, eastern Helvetic Alps. Cretac. carbonate platforms 387-407.

Gale, A.S., Jenkyns, H.C., Kennedy, W.J., Corfield, R.M., 1993. Chemostratigraphy versus biostratigraphy: data from around the Cenomanian-Turonian boundary. J. Geol. Soc. London. 150, 29-32. https://doi.org/ 
Gaona-Narvaez, T., Maurrasse, F.J.-M.R., Etayo-Serna, F., 2013. Geochemistry, palaeoenvironments and timing of Aptian organic-rich beds of the Paja Formation (Curití, Eastern Cordillera, Colombia). Geol. Soc. London, Spec. Publ. 382, 31-48. https://doi.org/10.1144/SP382.6

García-Alcade J.L., Carls, P., Pardo Alonso, M.V., Sanz Lopez, J., Soto, F., T.-M., M., Valenzuela-Ríos, J.I., 2002. Devonian, in: Gibbons, W., and Moreno, T. (Ed.), The Geology of Spain. The Geological Society of London, pp. 67-91.

García-Senz, J., 2002. Cuencas extensivas del Cretácico inferior en los Pirineos centrales, formación y subsiguiente inversión. Dpt. Geodinàmica i Geofísica 310.

Geider, R.J., La Roche, J., 1994. The role of iron in phytoplankton photosynthesis, and the potential for iron-limitation of primary productivity in the sea. Photosynth. Res. 39, 275-301. https://doi.org/10.1007/BF00014588

Gervais, F., Riebesell, U., Gorbunov, M.Y., 2002. Changes in primary productivity and chlorophyll a in response to iron fertilization in the Southern Polar Frontal Zone. Limnol. Oceanogr. 47, 1324-1335. https://doi.org/10.4319/lo.2002.47.5.1324

Giosan, L., Coolen, M.J.L., Kaplan, J.O., Constantinescu, S., Filip, F., FilipovaMarinova, M., Kettner, A.J., Thom, N., 2012. Early anthropogenic transformation of the danube-black sea system. Sci. Rep. 2. https://doi.org/10.1038/srep00582

Goddard, E.N., Trask, P.D., De Ford, R.K., Rove, O.N., Singewald, J.T., Overbeck, R.M., 1963. Rock-Color Chart. Geological Society of America, Colorado.

Godet, A., Hfaiedh, R., Arnaud-Vanneau, A., Zghal, I., Arnaud, H., Ouali, J., 2014. Aptian palaeoclimates and identification of an OAE1a equivalent in shallow marine environments of the southern Tethyan margin: Evidence from Southern Tunisia (Bir Oum Ali section, Northern Chott Chain). Cretac. Res. 48, 110-129. https://doi.org/10.1016/j.cretres.2013.12.006

Golonka, J., 2004. Plate tectonic evolution of the southern margin of Eurasia in the Mesozoic and Cenozoic. Tectonophysics 381, 235-273. https://doi.org/10.1016/j.tecto.2002.06.004

Gong, Z., van Hinsbergen, D.J.J., Vissers, R.L.M., Dekkers, M.J., 2009. Early Cretaceous syn-rotational extension in the Organyà basin-New constraints on the palinspastic position of Iberia during its rotation. Tectonophysics 473, 312-323. https://doi.org/10.1016/j.tecto.2009.03.003

Goossens, H., De Leeuw, J.W., Schenck, P.A., Brassell, S.C., 1984. Tocopherols as likely precursors of pristane in ancient sediments and crude oils. Nature 312, 440-442. https://doi.org/10.1038/312440a0 
Gradstein, F.M., Ogg, J.G., Smith, A.G., 2004. A Geologic Time Scale 2004. https://doi.org/10.2277/0521786738

Grand'Homme, A., 2016. Hydrothermal monazite: the unavoidable accessory. Université Grenoble Alpes.

Graziano, R., 1999. The Early Cretaceous drowning unconformities of the Apulia carbonate platform (Gargano Promontory, southern Italy): Local fingerprints of global palaeoceanographic events. Terra Nov. 11, 245-250. https://doi.org/10.1046/j.1365-3121.1999.00256.x

Grötsch, J., Billing, I., Vahrenkamp, V., 1998. Carbon-isotope stratigraphy in shallowwater carbonates: Implications for Cretaceous black-shale deposition. Sedimentology 45, 623-634. https://doi.org/10.1046/j.1365-3091.1998.00158.x

Haq, B.U., Hardenbol, J.A.N., Vail, P.R., 1987. Chronology of Fluctuating Sea Levels Since the Triassic. Science (80-. ). 235, 1156 LP-1167. https://doi.org/https://doi.org/10.1126/science.235.4793.1156

Hart, T.J., 1934. On the phytoplankton of the south-west Atlantic and the Bellingshausen Sea, 1929-31. Discov. Rep. VIII, 1-268.

Hasegawa, T., 1997. Cenomanian-Turonian carbon isotope events recorded in terrestrial organic matter from northern Japan. Palaeogeogr. Palaeoclimatol. Palaeoecol. 130, 251-273. https://doi.org/10.1016/S0031-0182(96)00129-0

Hay, W.W., 1995. Cretaceous paleoceanography. Geol. Carpathica 46, 257-266.

Hazen, R.M., Ewing, R.C., Sverjensky, D.A., 2009. Evolution of uranium and thorium minerals. Am. Mineral. 94, 1293-1311. https://doi.org/10.2138/am.2009.3208

Hedges, J.I., Keil, R.G., 1995. Sedimentary organic matter preservation: an assessment and speculative synthesis. Mar. Chem. 49, 81-115. https://doi.org/10.1016/03044203(95)00008-F

Heldt, M., Bachmann, M., Lehmann, J., 2008. Microfacies, biostratigraphy, and geochemistry of the hemipelagic Barremian-Aptian in north-central Tunisia: Influence of the OAE 1a on the southern Tethys margin. Palaeogeogr. Palaeoclimatol. Palaeoecol. 261, 246-260. https://doi.org/10.1016/j.palaeo.2008.01.013

Heldt, M., Lehmann, J., Bachmann, M., Negra, H., Kuss, J., 2010. Increased terrigenous influx but no drowning: Palaeoenvironmental evolution of the Tunisian carbonate platform margin during the Late Aptian. Sedimentology 57, 695-719. https://doi.org/10.1111/j.1365-3091.2009.01115.x 
Hoffmann, B., Kahmen, A., Cernusak, L.A., Arndt, S.K., Sachse, D., 2013. Abundance and distribution of leaf wax n-alkanes in leaves of acacia and eucalyptus trees along a strong humidity gradient in Northern Australia. Org. Geochem. 62, 62-67. https://doi.org/10.1016/j.orggeochem.2013.07.003

Huber, B.T., Hodell, D.A., Hamilton, C.P., 1995. Middle-late Cretaceous climate of the southern high latitudes: stable isotopic evidence for minimal equator-to-pole thermal gradients. Geol. Soc. Am. Bull. 107, 1164-1191. https://doi.org/10.1130/00167606(1995)107<1164:MLCCOT>2.3.CO;2

Huck, S., Rameil, N., Korbar, T., Heimhofer, U., Wieczorek, T.D., Immenhauser, A., 2010. Latitudinally different responses of Tethyan shoal-water carbonate systems to the Early Aptian oceanic anoxic event (OAE 1a). Sedimentology 57, 1585-1614. https://doi.org/10.1111/j.1365-3091.2010.01157.x

Hunt, D., Tucker, M., 1993. The middle Cretaceous Urgonian platform of southeastern France. Cretac. Carbonate Platforms 409-453.

Jansa, L.F., 1993. Early Cretaceous Carbonate Platforms of the Northeastern North American Margin, in: AAPG Memoir Cretaceous Carbonate Platforms. American Association of Petroleum Geologists. https://doi.org/https://doi.org/10.1306/M56578

Jansen, B., van Loon, E.E., Hooghiemstra, H., Verstraten, J.M., 2010. Improved reconstruction of palaeo-environments through unravelling of preserved vegetation biomarker patterns. Palaeogeogr. Palaeoclimatol. Palaeoecol. 285, 119-130. https://doi.org/10.1016/j.palaeo.2009.10.029

Jenkyns, H.C., 1980. Cretaceous anoxic events: from continents to oceans. J. Geol. Soc. London. 137, 171-188. https://doi.org/10.1144/gsigs.137.2.0171

Jenkyns, H.C., 1995. Carbon-isotope stratigraphy and Paleoceanographic signiicance of the lower Cretaceous shallow water carbonates of resolution guyot, mid-pacific mountains. Proceeings Ocean Drill. Program, Sci. Results 143, 99.

Jorissen, F.J., 1999. Benthic foraminiferal microhabitats below the sediment-water interface, in: Barun K. Sen Gupta (Ed.), Modern Foraminifera. pp. 161-179. https://doi.org/10.1007/0-306-48104-9_10

Jorissen, F.J., de Stigter, H.C., Widmark, J.G.V., 1995. A conceptual model explaining benthic foraminiferal microhabitats. Mar. Micropaleontol. 26, 3-15. https://doi.org/10.1016/0377-8398(95)00047-X

Keil, R.G., Cowie, G.L., 1999. Organic matter preservation through the oxygen-deficient zone of the NE Arabian Sea as discerned by organic carbon:mineral surface area 
ratios, in: Marine Geology. pp. 13-22. https://doi.org/10.1016/S00253227(99)00052-3

Keil, R.G., Montluçon, D.B., Prahl, F.G., Hedges, J.I., 1994. Sorptive preservation of labile organic matter in marine sediments. Nature 370, 549-552. https://doi.org/10.1038/370549a0

Kennedy, M.J., Pevear, D.R., Hill, R.J., 2002. Mineral surface control of organic carbon in black shale. Science (80-. ). 295, 657-660. https://doi.org/10.1126/science.1066611

Kennedy, M.J., Löhr, S.C., Fraser, S.A., Baruch, E.T., 2014. Direct evidence for organic carbon preservation as clay-organic nanocomposites in a Devonian black shale; from deposition to diagenesis. Earth Planet. Sci. Lett. 388, 59-70. https://doi.org/10.1016/j.epsl.2013.11.044

Klinkhammer, G.P., Palmer, M.R., 1991. Uranium in the oceans: Where it goes and why. Geochim. Cosmochim. Acta 55, 1799-1806. https://doi.org/10.1016/00167037(91)90024-Y

Koch, K., Bhushan, B., Barthlott, W., 2009. Multifunctional surface structures of plants: An inspiration for biomimetics. Prog. Mater. Sci. 54, 137-178. https://doi.org/10.1016/j.pmatsci.2008.07.003

Koutsoukos, E.A.M., Mello, M.R., De Azambuja Filho, N.C., Hart, M.B., Maxwell, J.R., 1991a. The Upper Aptian-Albian succession of the Sergipe Basin, Brazil: an integrated paleoenvironmental assessment. Am. Assoc. Pet. Geol. Bull. 75, 479498. https://doi.org/10.1306/0C9B2817-1710-11D7-8645000102C1865D

Koutsoukos, E.A.M., Mello, M.R., de Azambuja Filho, N.C., 1991 b. Micropalaeontological and geochemical evidence of mid-Cretaceous dysoxic-anoxic palaeoenvironments in the Sergipe Basin, northeastern Brazil. Geol. Soc. London, Spec. Publ. 58, 427-447. https://doi.org/10.1144/GSL.SP.1991.058.01.27

Krom, M.D., Kress, N., Brenner, S., Gordon, L.I., 1991. Phosphorus limitation of primary productivity in the eastern Mediterranean Sea. Limnol. Oceanogr. 36, 424432. https://doi.org/10.1021/acsami.5b10724

Krull, E., Sachse, D., Mügler, I., Thiele, A., Gleixner, G., 2006. Compound-specific $\delta 13 \mathrm{C}$ and $\delta 2 \mathrm{H}$ analyses of plant and soil organic matter: A preliminary assessment of the effects of vegetation change on ecosystem hydrology. Soil Biol. Biochem. 38, 3211-3221. https://doi.org/10.1016/j.soilbio.2006.04.008 
Kuhn, T.K., Krull, E.S., Bowater, A., Grice, K., Gleixner, G., 2010. The occurrence of short chain n-alkanes with an even over odd predominance in higher plants and soils. Org. Geochem. 41, 88-95. https://doi.org/10.1016/j.orggeochem.2009.08.003

Kuhnt, W., Moullade, M., Masse, J.-P., Erlenkeuser, H., 1998. Carbon isotope stratigraphy of the lower Aptian historical stratotype at Cassis-La Bédoule (SE France). Geol. Mediterr. 25, 63-79.

Kumar, N., Anderson, R.F., Mortlock, R.A., Froelich, P.N., Kubik, P., Dittrich-Hannen, B., Suter, M., 1995. Increased biological productivity and export production in the glacial southern Ocean. Nature 378, 675-680. https://doi.org/10.1038/378675a0

Langmuir, D., 1978. Uranium solution-mineral equilibria at low temperatures with applications to sedimentary ore deposits. Geochim. Cosmochim. Acta 42, 547-569. https://doi.org/10.1016/0016-7037(78)90001-7

Larson, R.L., Erba, E., 1999. Onset of the mid-Cretaceous greenhouse in the BarremianAptian: Igneous events and the biological, sedimentary, and geochemical responses. Paleoceanography 14, 663-678. https://doi.org/10.1029/1999PA900040

Leckie, R.M., Bralower, T.J., Cashman, R., 2002. Oceanic anoxic events and plankton evolution: Biotic response to tectonic forcing during the mid-Cretaceous. Paleoceanography 17, 13-29. https://doi.org/10.1029/2001PA000623

Lehmann, C., Osleger, D.A., Montañez, I.P., 1998. Controls on cyclostratigraphy of Lower Cretaceous carbonates and evaporites, Cupido and Coahuila platforms, northeastern Mexico. J. Sediment. Res. 68, 1109-1130. https://doi.org/10.2110/jsr.68.1109

Li, Y.X., Bralower, T.J., Montañez, I.P., Osleger, D.A., Arthur, M.A., Bice, D.M., Herbert, T.D., Erba, E., Premoli Silva, I., 2008. Toward an orbital chronology for the early Aptian Oceanic Anoxic Event (OAE1a, $120 \mathrm{Ma}$ ). Earth Planet. Sci. Lett. 271, 88-100. https://doi.org/10.1016/j.epsl.2008.03.055

Liesa, M., Carreras, J., Castiñeiras, P., Casas, J.M., Navidad, M., Vilà, M., 2011. U-Pb zircon age of Ordovician magmatism in the Albera massif (Eastern Pyrenees). Geol. Acta 9, 93-101. https://doi.org/10.1344/105.000001651

Lijmbach, G.W.M., 1975. On the origin of petroleum, in: Proceedings Ninth World Petroleum Congress. Applied Sciences Publisher, London, pp. 357-369.

Longoria, J.F., 1974. Stratigraphic, morphologic and taxonomic studies of Aptian planktonic Foraminifera. Rev. Española Micropaleontol. Numer. Extraordin., pp. 1107. 
Luciani, V., Cobianchi, M., Lupi, C., 2006. Regional record of a global oceanic anoxic event: OAE1a on the Apulia Platform margin, Gargano Promontory, southern Italy. Cretac. Res. 27, 754-772. https://doi.org/10.1016/j.cretres.2006.01.003

Martin, J.H., Fitzwater, S.E., 1988. Iron deficiency limits phytoplankton growth in the north-east pacific subarctic. Nature 331, 341-343. https://doi.org/10.1038/331341a0

Maruéjol, P., Cuney, M., Turpin, L., 1990. Magmatic and hydrothermal R.E.E. fractionation in the Xihuashan granites (SE China). Contrib. to Mineral. Petrol. 104, 668-680. https://doi.org/10.1007/BF01167286

Masse, J.P., 1993. Valanginian-early Aptian carbonate platforms from Provence, southeastern France. Cretac. carbonate platforms 363-374. https://doi.org/10.1029/2006PA001313/full

Masse, J.P., Bellion, Y., Benkhelil, J., Boulin, J., Cornee, J.J., Dercourt, J., Guiraud, R., Mascle, G., Poisson, A., Ricou, L.E., Sandulescu, M., 2000. Early Aptian (114-112 Ma), in: Dercourt, J., Ricou, L.E., Vrielynck, B. (Ed.), Atlas Tethys, Palaeoenvironmental Maps. CCGM/CGMW, Paris.

Mayer, L.M., 1994. Surface area control of organic carbon accumulation in continental shelf sediments. Geochim. Cosmochim. Acta 58, 1271-1284. https://doi.org/10.1016/0016-7037(94)90381-6

Mead, R., Xu, Y., Chong, J., Jaffé, R., 2005. Sediment and soil organic matter source assessment as revealed by the molecular distribution and carbon isotopic composition of n-alkanes. Org. Geochem. 36, 363-370. https://doi.org/10.1016/j.orggeochem.2004.10.003

Menegatti, A.P., Weissert, H., Brown, R.S., Tyson, R. V., Farrimond, P., Strasser, A., Caron, M., 1998. High-resolution $\delta 13 \mathrm{C}$ stratigraphy through the early Aptian "Livello Selli" of the Alpine Tethys. Paleoceanography 13, 530-545. https://doi.org/10.1029/98PA01793

Meyer, K.M., Kump, L.R., 2008. Oceanic Euxinia in Earth History: Causes and Consequences. Annu. Rev. Earth Planet. Sci. 36, 251-288. https://doi.org/10.1146/annurev.earth.36.031207.124256

Millán, M.I., Weissert, H.J., Fernández-Mendiola, P.A., García-Mondéjar, J., 2009. Impact of Early Aptian carbon cycle perturbations on evolution of a marine shelf system in the Basque-Cantabrian Basin (Aralar, N Spain). Earth Planet. Sci. Lett. 287, 392-401. https://doi.org/10.1016/j.eps1.2009.08.023 
Miller, C.F., Mittlefehldt, D.W., 1982. Depletion of light rare-earth elements in felsic magmas. Geology 10, 129-133. https://doi.org/10.1130/0091-

7613(1982)10<129:DOLREI $>2.0 . C O ; 2$

Molina, J.M., Salas, R., 1993. Bauxitas kársticas del Cretácico inferior en Fuentespalda (provincia de Teruel): Estratigrafía, origen y paleogeografía. Cuad. Geol. Ibérica 17, 207-230.

Montero, P., 1993. Geoquímica y petrogénesis del complejo peralcalino de la Sierra del Galiñeiro (Pontevedra, España). Universidad de Oviedo, Spain.

Montero, P., Bea, F., Corretgé, L.G., Floor, P., Whitehouse, M.J., 2009. U-Pb ion microprobe dating and $\mathrm{Sr}$ and $\mathrm{Nd}$ isotope geology of the Galiñeiro Igneous Complex. A model for the peraluminous/peralkaline duality of the CambroOrdovician magmatism of Iberia. Lithos 107, 227-238.

https://doi.org/10.1016/j.lithos.2008.10.009

Montero, P., Floor, P., Corretgé, G., 1998. The accumulation of rare-earth and high-fieldstrength elements in peralkaline granitic rocks: The Galiñeiro orthogneissic complex, northwestern Spain. Can. Mineral. 36, 683-700.

Moullade, M., Kuhnt, W., Bergen, J.A., Masse, J.P., Tronchetti, G., 1998. Correlation of biostratigraphic and stable isotope events in the Aptian historical stratotype of $\mathrm{La}$ Bedoule (southeast France). Comptes Rendus l'Academie Sci. - Ser. IIa Sci. la Terre des Planetes 327, 693-698. https://doi.org/10.1016/S1251-8050(99)80027-5

Moullade, M., Tronchetti, G., Granier, B., Bornemann, A., Kuhnt, W., Lorenzen, J., 2015. High-resolution integrated stratigraphy of the OAE1a and enclosing strata from core drillings in the Bedoulian stratotype (Roquefort-La Bédoule, SE France). Cretac. Res. 56, 119-140. https://doi.org/10.1016/j.cretres.2015.03.004

Murray, J.W., 2001. The niche of benthic foraminifera, critical thresholds and proxies. Mar. Micropaleontol. 41, 1-7. https://doi.org/10.1016/S0377-8398(00)00057-8

Mutterlose, J., Ruffell, A., 1999. Milankovitch-scale palaeoclimate changes in pale-dark bedding rhythms from the Early Cretaceous (Hauterivian and Barremian) of eastern England and northern Germany. Palaeogeogr. Palaeoclimatol. Palaeoecol. 154, 133160. https://doi.org/10.1016/S0031-0182(99)00107-8

Najarro, M., Rosales, I., Moreno-Bedmar, J.A., de Gea, G.A., Barrón, E., Company, M., Delanoy, G., 2011. High-resolution chemo- and biostratigraphic records of the Early Aptian oceanic anoxic event in Cantabria (N Spain): Palaeoceanographic and palaeoclimatic implications. Palaeogeogr. Palaeoclimatol. Palaeoecol. 299, 137-158. https://doi.org/10.1016/j.palaeo.2010.10.042 
Navale, V., 1994. Comparative study of low and high temperature hydrous pyrolysis products of monoglycerol diether lipid from archaebacteria. J. Anal. Appl. Pyrolysis 29, 33-43. https://doi.org/10.1016/0165-2370(93)00786-M

Navidad, M., Castiñeiras, P., Casas, J.M., Liesa, M., Fernández Suárez, J., Barnolas, A., Carreras, J., Gil-Peña, I., 2010. Geochemical characterization and isotopic age of Caradocian magmatism in the northeastern Iberian Peninsula: Insights into the Late Ordovician evolution of the northern Gondwana margin. Gondwana Res. 17, 325337. https://doi.org/10.1016/j.gr.2009.11.013

Neal, C.R., Coffin, M.F., Arndt, N.T., Duncan, R.A., Eldholm, O., Erba, E., Farnetani, C., Fitton, J.G., Ingle, S.P., Ohkouchi, N., Rampino, M.R., Reichow, M.K., Self, S., Tatsumi, Y., 2008. Investigating Large Igneous Province Formation and Associated Paleoenvironmental Events: A White Paper for Scientific Drilling. Sci. Drill. https://doi.org/10.2204/lodp.sd.6.01.2008

O’Leary, M.H., 1988. Carbon Isotopes in Photosynthesis. Bioscience 38, 328-336. https://doi.org/10.2307/1310735

Olivet, J.-L., 1996. Kinematics of the Iberian plate, Bulletin des Centres de Recherches Elf Exploration Production 20, 191-195.

Olivier, P., Druguet, E., Castaño, L.M., Gleizes, G., 2016. Granitoid emplacement by multiple sheeting during Variscan dextral transpression: The Saint-Laurent - La Jonquera pluton (Eastern Pyrenees). J. Struct. Geol. 82, 80-92. https://doi.org/10.1016/j.jsg.2015.10.006

Özsoy, E., Ünlüata, Ü., 1997. Oceanography of the Black Sea: A review of some recent results. Earth-Science Rev. 4, 231-272. https://doi.org/10.1016/S00128252(97)81859-4

Papp, D.C., Cociuba, I., Lazâr, D.F., 2013. Carbon and oxygen-isotope stratigraphy of the Early Cretaceous carbonate platform of Pâdurea Craiului (Apuseni Mountains, Romania): A chemostratigraphic correlation and paleoenvironmental tool. Appl. Geochemistry 32, 3-16. https://doi.org/10.1016/j.apgeochem.2012.09.005

Pattan, J.N., Pearce, N.J.G., 2009. Bottom water oxygenation history in southeastern Arabian Sea during the past 140 ka: Results from redox-sensitive elements. Palaeogeogr. Palaeoclimatol. Palaeoecol. 280, 396-405. https://doi.org/10.1016/j.palaeo.2009.06.027

Paytan, A., McLaughlin, K., 2007. The oceanic phosphorus cycle. Chem. Rev. 107, 563576. https://doi.org/10.1021/cr0503613 
Pearson, K., 1896. Mathematical Contributions to the Theory of Evolution.--On a Form of Spurious Correlation Which May Arise When Indices Are Used in the Measurement of Organs. Proc. R. Soc. London 60, 489-498. https://doi.org/10.1098/rspl.1896.0076

Peters, K.E., Walters, C.C., Meldovan, J.M., 2005. The Biomarker Guide Volume 1: Biomarkers and Isotopes in the Environment and Human History, Cambridge University Press. https://doi.org/10.1016/0146-6380(9

Peters, K.E., Walters, C.C., Moldowan, J.M., 2007. The Biomarker Guide Volume 2: Biomarkers and isotopes in petroleum systems and earth history, Cambridge University Press.

Phelps, R.M., Kerans, C., Da-Gama, R.O.B.P., Jeremiah, J., Hull, D., Loucks, R.G., 2015. Response and recovery of the Comanche carbonate platform surrounding multiple Cretaceous oceanic anoxic events, northern Gulf of Mexico. Cretac. Res. 54, 117-144. https://doi.org/10.1016/j.cretres.2014.09.002

Popendorf, K.J., Duhamel, S., 2015. Variable phosphorus uptake rates and allocation across microbial groups in the oligotrophic Gulf of Mexico. Environ. Microbiol. 17, 3992-4006. https://doi.org/10.1111/1462-2920.12932

Poujol, M., Boulvais, P., Kosler, J., 2010. Regional-scale Cretaceous albitization in the Pyrenees: evidence from in situ U-Th-Pb dating of monazite, titanite and zircon. J. Geol. Soc. London. 167, 751-767. https://doi.org/10.1144/0016-76492009-144

Poulsen, C.J., Barron, E.J., Johnson, C.C., Fawcett, P., 1999. Links between major climatic factors and regional oceanic circulation in the mid-Cretaceous. Evol. Cretac. Ocean. Syst. 73-90. https://doi.org/10.1130/0-8137-2332-9.73

Poulsen, C.J., Barron, E.J., Arthur, M.A., Peterson, W.H., 2001. Response of the midCretaceous global oceanic circulation to tectonic and $\mathrm{CO} 2$ forcings. Paleoceanography 16, 576-592. https://doi.org/10.1029/2000PA000579

Poulsen, C.J., Gendaszek, A.S., Jacob, R.L., 2003. Did the rifting of the Atlantic Ocean cause the Cretaceous thermal maximum? Geology 31, 115-118. https://doi.org/10.1130/0091-7613(2003)031<0115:DTROTA >2.0.CO;2

Powell, T.G., 1988. Pristane/phytane ratio as environmental indicator. Nature 333, 604.

Powell, T.G., McKirdy, D.M., 1973. Relationship between Ratio of Pristane to Phytane, Crude Oil Composition and Geological Environment in Australia. Nature 243, $37-$ 39. https://doi.org/10.1038/10.1038/PHYSCI243037A0 
Poynter, J., Eglinton, G., 1990. Molecular Composition of Three Sediments from Hole 717C: The Bengal Fan, in: Proceedings of the Ocean Drilling Program, 116 Scientific Results. Ocean Drilling Program, pp. 155-161. https://doi.org/10.2973/odp.proc.sr.116.151.1990

Ransom, B., Bennett, R.H., Baerwald, R., Shea, K., 1997. TEM study of in situ organic matter on continental margins: Occurrence and the "monolayer" hypothesis. Mar. Geol. 138, 1-9. https://doi.org/10.1016/S0025-3227(97)00012-1

Rashid, M.A., 1979. Pristane-phytane ratios in relation to source and diagenesis of ancient sediments from the Labrador Shelf. Chem. Geol. 25, 109-122. https://doi.org/10.1016/0009-2541(79)90087-1

Riederer, M., Markstädter, C., 1996. Cuticular waxes: a critical assessment of current knowledge. Plant Cuticles an Integr. Funct. Approach 189-200.

Rimmer, S.M., 2004. Geochemical paleoredox indicators in Devonian-Mississippian black shales, Central Appalachian Basin (USA). Chem. Geol. 206, 373-391. https://doi.org/10.1016/j.chemgeo.2003.12.029

Rückheim, S., Bornemann, A., Mutterlose, J., 2006. Planktic foraminifera from the midCretaceous (Barremian-Early Albian) of the North Sea Basin: Palaeoecological and palaeoceanographic implications. Mar. Micropaleontol. 58, 83-102. https://doi.org/10.1016/j.marmicro.2005.10.002

Rueter, J.G., Ades., D.R., 1987. The role of iron nutrition in photosynthesis and nitrogen assimilation in SCENEDESMUS QUADRICAUDA (Chlorophyceae). J. Phycol. 23, 452-457. https://doi.org/10.1111/j.1529-8817.1987.tb02531.x

Ruiz-Ortiz, P.A., Castro, J.M., 1998. Carbonate depositional sequences in shallow to hemipelogic platform deposits: Aptian, Prebetic of Alicante (SE Spain). Bull. La Soc. Geol. Fr. 169, 21-33.

Sachse, D., Radke, J., Gleixner, G., 2006. $\delta$ D values of individual n-alkanes from terrestrial plants along a climatic gradient - Implications for the sedimentary biomarker record. Org. Geochem. 37, 469-483. https://doi.org/10.1016/j.orggeochem.2005.12.003

Salas, R., Martín-Closas, C., Querol, X., Guimerà, J., Roca, E., 1995. Evolución tectonosedimentaria de las cuencas del Maestrazgo y Aliaga - Penyagolosa durante el Cretácico inferior, El Cretácico inferior del Nordeste de Iberia. Universitat de Barcelona. 
Salas, R., Casas, A., 1993. Mesozoic extensional tectonics, stratigraphy and crustal evolution during the Alpine cycle of the eastern Iberian basin. Tectonophysics 228, 33-55. https://doi.org/10.1016/0040-1951(93)90213-4

Salas, R., Guimerà, J., Mas, R., Martín-Closas, C., Hevia, A., Millán, A., 2001. Evolution of the Mesozoic Central Iberian Rift System and its Cainozoic inversion (Iberian Chain), Mémoires du Musée National d'Histoire Naturelle, Peri-Tethys Memoir.

Sanchez-Hernandez, Y., Maurrasse, F.J.M.R., 2016. The influence of regional factors in the expression of oceanic anoxic event 1a (OAE1a) in the semi-restricted Organyà Basin, south-central Pyrenees, Spain. Palaeogeogr. Palaeoclimatol. Palaeoecol. 441, 582-598. https://doi.org/10.1016/j.palaeo.2015.06.031

Sanchez-Hernandez, Y., Maurrasse, F.J.M.R., 2014. Geochemical characterization and redox signals from the latest Barremian to the earliest Aptian in a restricted marine basin: El Pui section, Organyà Basin, south-central Pyrenees. Chem. Geol. 372, 12 31. https://doi.org/10.1016/j.chemgeo.2014.02.011

Sanchez-Hernandez, Y., Maurrasse, F.J.M.R., Melinte-Dobrinescu, M.C., He, D., Butler, S.K., 2014. Assessing the factors controlling high sedimentation rates from the latest Barremian-earliest Aptian in the hemipelagic setting of the restricted Organyà Basin, NE Spain. Cretac. Res. 51, 1-21. https://doi.org/10.1016/j.cretres.2014.05.010

Sandoval, J., Bill, M., Aguado, R., O’Dogherty, L., Rivas, P., Morard, A., Guex, J., 2012. The Toarcian in the Subbetic basin (southern Spain): Bio-events (ammonite and calcareous nannofossils) and carbon-isotope stratigraphy. Palaeogeogr.

Palaeoclimatol. Palaeoecol. 342-343, 40-63. https://doi.org/10.1016/j.palaeo.2012.04.028

Satterberg, J., Arnarson, T.S., Lessard, E.J., Keil, R.G., 2003. Sorption of organic matter from four phytoplankton species to montmorillonite, chlorite and kaolinite in seawater. Mar. Chem. 81, 11-18. https://doi.org/10.1016/S0304-4203(02)00136-6

Schandl, E.S., Gorton, M.P., 2004. A textural and geochemical guide to the identification of hydrothermal monazite: Criteria for selection of samples for dating epigenetic hydrothermal ore deposits. Econ. Geol. 99, 1027-1035. https://doi.org/10.2113/gsecongeo.99.5.1027

Schlanger, S.O., Jenkyns, H.C., 1976. Cretaceous oceanic anoxic events: Causes and consequences. Geol. en Mijnb. 55, 179-184.

Schlanger, S.O., Arthur, M.A., Jenkyns, H.C., Scholle, P.A., 1987. The CenomanianTuronian oceanic event, I. Stratigraphy and distribution of organic carbon-rich beds and the marine d13C excursion. Mar. Pet. Source Rocks 26, 371-400. https://doi.org/10.1144/gsl.sp.1987.026.01.24 
Scholle, P.A., Arthur, M.A., 1980. Carbon isotope fluctuations in Cretaceous pelagic limestones: potential stratigraphic and petroleum exploration tool. Am. Assoc. Pet. Geol. Bull. 64, 67-87. https://doi.org/10.1306/2F91892D-16CE-11D7$8645000102 \mathrm{C} 1865 \mathrm{D}$

Schouten, S., Woltering, M., Rijpstra, W.I.C., Sluijs, A., Brinkhuis, H., Sinninghe Damsté, J.S., 2007. The Paleocene-Eocene carbon isotope excursion in higher plant organic matter: Differential fractionation of angiosperms and conifers in the Arctic. Earth Planet. Sci. Lett. 258, 581-592. https://doi.org/10.1016/j.eps1.2007.04.024

Schwark, L., Zink, K., Lechterbeck, J., 2002. Reconstruction of postglacial to early Holocene vegetation history in terrestrial Central Europe via cuticular lipid biomarkers and pollen records from lake sediments. Geology 30, 463-466. https://doi.org/10.1130/0091-7613(2002)030<0463:ROPTEH $>2.0 . C O ; 2$

Scott, R.W., 1993. Cretaceous carbonate platform, US Gulf coast. Mem. Am. Assoc. Pet. Geol. 56, 97-109.

Scott, R.W., 2016. Barremian-Aptian-Albian carbon isotope segments as chronostratigraphic signals : Numerical age calibration and durations. Stratigraphy $13,21-47$.

Shanmugam, G., 1985. Significance of Coniferous Rain Forests and Related Organic Matter in Generating Commercial Quantities of Oil, Gippsland Basin, Australia. Am. Assoc. Pet. Geol. Bull. 69, 1241-1254. https://doi.org/10.1306/AD462BC316F7-11D7-8645000102C1865D

Sigal, J., 1952. Aperçu stratigraphique sur la micropaléontologie du Crétacé, in: XIXe Congrès Géologique International. Impr. de Protat frères, p. 48.

Sinton, C.W., Duncan, R.A., 1997. Potential links between ocean plateau volcanism and global ocean anoxia at the Cenomanian-Turonian boundary. Econ. Geol. 92, 836842. https://doi.org/10.2113/gsecongeo.92.7-8.836

Socorro, J., Maurrasse, F.J.M.R., Sanchez-Hernandez, Y., 2017. Characterization of the negative carbon isotope shift in segment $\mathrm{C} 2$, its global implications as a harbinger of OAE1a. Sci. China Earth Sci. 60, 30-43. https://doi.org/10.1007/s11430-016-0092-5

Spear, F.S., Pyle, J.M., 2002. Apatite, Monazite, and Xenotime in Metamorphic Rocks. Rev. Mineral. Geochemistry 48, 293-335. https://doi.org/https://doi.org/10.2138/rmg.2002.48.7

Stein, M., Westermann, S., Adatte, T., Matera, V., Fleitmann, D., Spangenberg, J.E., Föllmi, K.B., 2012. Late Barremian-Early Aptian palaeoenvironmental change: The 
Cassis-La Bédoule section, southeast France. Cretac. Res. 37, 209-222.

https://doi.org/10.1016/j.cretres.2012.03.021

Takashima, R., Kawabe, F., Nishi, H., Moriya, K., Wani, R., Ando, H., 2004. Geology and stratigraphy of forearc basin sediments in Hokkaido, Japan: Cretaceous environmental events on the north-west Pacific margin. Cretac. Res. 25, 365-390. https://doi.org/10.1016/j.cretres.2004.02.004

Tarduno, J.A., Brinkman, D.B., Renne, P.R., Cottrell, R.D., Scher, H., Castillo, P., 1998. Evidence for extreme climatic warmth from late cretaceous arctic vertebrates. Science (80-. ). 282, 2241-2244. https://doi.org/10.1126/science.282.5397.2241

Taylor, A.M., Goldring, R., 1993. Description and analysis of bioturbation and ichnofabric. J. Geol. Soc. London. 150, 141-148. https://doi.org/10.1144/gsjgs.150.1.0141

Tejada, M.L.G., Suzuki, K., Kuroda, J., Coccioni, R., Mahoney, J.J., Ohkouchi, N., Sakamoto, T., Tatsumi, Y., 2009. Ontong Java Plateau eruption as a trigger for the early Aptian oceanic anoxic event. Geology 37, 855-858. https://doi.org/10.1130/G25763A.1

ten Haven, H.L., De Leeuw, J.W., Rullkötter, J., Damsté, J.S.S., 1987. Restricted utility of the pristane/phytane ratio as a palaeoenvironmental indicator. Nature 330, 641643. https://doi.org/10.1038/330641a0

ten Haven, H.L., Rullkötter, J., De Leeuw, J.W., Damsté, J.S.S., 1988. Pristane/phytane ratio as environmental indicator. Nature 333, 604. https://doi.org/10.1038/333604b0

Terry, R.D., Chilingar, G. V., 1955. Summary of "Concerning some additional aids in studying sedimentary formations," by M. S. Shvetsov. J. Sediment. Res. 25, 229234. https://doi.org/10.1306/74D70466-2B21-11D7-8648000102C1865D

Tipple, B.J., Pagani, M., 2013. Environmental control on eastern broadleaf forest species' leaf wax distributions and d/h ratios. Geochim. Cosmochim. Acta 111, 64-77. https://doi.org/10.1016/j.gca.2012.10.042

Torsvik, T.H., Steinberger, B., Burke, K., Smethurst, M.A., 2008. Supercontinents, Plate Tectonics, Large Igneous Provinces and Deep Mantle Heterogeneities. AGU Fall Meet. Abstr.

Tribovillard, N., Riboulleau, A., Lyons, T., Baudin, F., 2004. Enhanced trapping of molybdenum by sulfurized marine organic matter of marine origin in Mesozoic limestones and shales. Chem. Geol. https://doi.org/10.1016/j.chemgeo.2004.08.011 
Turekian, K.K., Wedepohl, K.H., 1961. Distribution of the Elements in Some Major Units of the Earth's Crust. GSA Bull. 72, 175-192. https://doi.org/https://doi.org/10.1130/0016-7606(1961)72[175:DOTEIS]2.0.CO;2

Tyrrell, T., 1999. The relative influences of nitrogen and phosphorus on oceanic primary production. Nature 400, 525-531. https://doi.org/10.1038/22941

Tyson, R. V, Pearson, T.H., 1991. Modern and ancient continental shelf anoxia: an overview. Geol. Soc. London, Spec. Publ. 58, 1 LP-24. https://doi.org/https://doi.org/10.1144/GSL.SP.1991.058.01.01

Van der Voo, R., 1969. Paleomagnetic evidence for the rotation of the Iberian Peninsula. Tectonophysics 7, 5-56. https://doi.org/10.1016/0040-1951(69)90063-8

Van Der Weijden, C.H., 2002. Pitfalls of normalization of marine geochemical data using a common divisor. Mar. Geol. 184, 167-187. https://doi.org/10.1016/S00253227(01)00297-3

Verga, D., Premoli Silva, I., 2002. Early Cretaceous planktonic foraminifera from the Tethys: The genus Leupoldina. Cretac. Res. 23, 189-212. https://doi.org/10.1006/cres.2002.0309

Vergés, J., Fernàndez, M., Martìnez, A., 2002. The Pyrenean orogen: Pre-, syn-, and post-collisional evolution. J. Virtual Explor. 8. https://doi.org/10.3809/jvirtex.2002.00058

Wark, D.A., Miller, C.F., 1993. Accessory mineral behavior during differentiation of a granite suite: monazite, xenotime and zircon in the Sweetwater Wash pluton, southeastern California, U.S.A. Chem. Geol. 110, 49-67. https://doi.org/10.1016/0009-2541(93)90247-G

Weber, C., Barbey, P., Cuney, M., Martin, H., 1985. Trace element behaviour during migmatization. Evidence for a complex melt-residuum-fluid interaction in the St. Malo migmatitic dome (France). Contrib. to Mineral. Petrol. 90, 52-62. https://doi.org/10.1007/BF00373041

Wedepohl, K.H., 1971. Environmental influences on the chemical composition of shales and clays. Phys. Chem. Earth 8, 307-333. https://doi.org/10.1016/00791946(71)90020-6

Weissert, H.J., Mckenzie, J.A., Channell, J.E.T., 1985. Natural Variations in the Carbon Cycle During the Early Cretaceous. Carbon Cycle Atmos. CO2 Nat. Var. Archean to Present, Geophysical Monograph Series 32, 531-545. https://doi.org/doi:10.1029/GM032p0531 
Weissert, H., Erba, E., 2004. Volcanism, CO2 and palaeoclimate: a Late Jurassic-Early Cretaceous carbon and oxygen isotope record. J. Geol. Soc. London. 161, 695-702. https://doi.org/10.1144/0016-764903-087

Weissert, H., 1989. C-Isotope stratigraphy, a monitor of paleoenvironmental change: A case study from the early cretaceous. Surv. Geophys. 10, 1-61.

https://doi.org/10.1007/BF01901664

Weissert, H., Lini, A., Föllmi, K.B., Kuhn, O., 1998. Correlation of Early Cretaceous carbon isotope stratigraphy and platform drowning events: A possible link?

Palaeogeogr. Palaeoclimatol. Palaeoecol. 137, 189-203.

https://doi.org/10.1016/S0031-0182(97)00109-0

Weissert, H., McKenzie, J., Hochuli, P., 1979. Cyclic anoxic events in the Early Cretaceous Tethys Ocean. Geology 7, 147-151. https://doi.org/10.1130/00917613(1979)7<147:CAEITE $>2.0 . \mathrm{CO} ; 2$

Wendler, I., 2013. A critical evaluation of carbon isotope stratigraphy and biostratigraphic implications for Late Cretaceous global correlation. Earth-Science Rev. 126, 116-146. https://doi.org/10.1016/j.earscirev.2013.0

Wignall, P.B., Myers, K.J., 1988. Interpreting benthic oxygen levels in mudrocks: A new approach. Geology 16, 452-455. https://doi.org/10.1130/00917613(1988)016<0452:IBOLIM >2.3.CO;2

Wignall, P.B., Twitchett, R.J., 1996. Oceanic anoxia and the end permian mass extinction. Science (80-. ). 272, 1155-1158. https://doi.org/10.1126/science.272.5265.1155

Williams, C.A., 1975. Sea-floor spreading in the Bay of Biscay and its relationship to the North Atlantic. Earth Planet. Sci. Lett. 24, 440-456. https://doi.org/10.1016/0012821X(75)90151-X

Wu, J., Filippidi, A., Davies, G.R., de Lange, G.J., 2018. Riverine supply to the eastern Mediterranean during last interglacial sapropel S5 formation: A basin-wide perspective. Chem. Geol. 485, 74-89. https://doi.org/10.1016/j.chemgeo.2018.03.037

Xu, G., Hannah, J.L., Bingen, B., Georgiev, S., Stein, H.J., 2012. Digestion methods for trace element measurements in shales: Paleoredox proxies examined. Chem. Geol. 324-325, 132-147. https://doi.org/10.1016/j.chemgeo.2012.01.029

Yamada, M., Tsunogai, S., 1984. Postdepositional enrichment of uranium in sediment from the Bering Sea. Mar. Geol. 54, 263-276. https://doi.org/10.1016/00253227(84)90042-2 
Yarincik, K.M., Murray, R.W., Lyons, T.W., Peterson, L.C., Haug, G.H., 2000.

Oxygenation history of bottom waters in the Cariaco Basin, Venezuela, over the past 578,000 years: Results from redox-sensitive metals (Mo, V, Mn, and Fe).

Paleoceanography 15, 593-604. https://doi.org/10.1029/1999PA000401

Yilmaz, I., Vennemann, T., ALTINER, D., Satir, M., 2004. Stable Isotope Evidence for meter-scale sea level changes in Lower Cretaceous inner platform and pelagic carbonate successions of Turkey. Geol. Carpathica 55, 19-36.

Yuste, A., Bauluz, B., Mayayo, M.J., 2017. Origin and geochemical evolution from ferrallitized clays to karst bauxite: An example from the Lower Cretaceous of NE Spain. Ore Geol. Rev. 84, 67-79. https://doi.org/10.1016/j.oregeorev.2016.12.025

Zech, M., 2006. Evidence for Late Pleistocene climate changes from buried soils on the southern slopes of Mt. Kilimanjaro, Tanzania. Palaeogeogr. Palaeoclimatol. Palaeoecol. 242, 303-312. https://doi.org/10.1016/j.palaeo.2006.06.008

Zhang, Z., Zhao, M., Eglinton, G., Lu, H., Huang, C.Y., 2006. Leaf wax lipids as paleovegetational and paleoenvironmental proxies for the Chinese Loess Plateau over the last 170 kyr. Quat. Sci. Rev. 25, 575-594.

https://doi.org/10.1016/j.quascirev.2005.03.009

Zheng, Y., Anderson, R.F., van Geen, A., Fleisher, M.Q., 2002. Remobilization of authigenic uranium in marine sediments by bioturbation. Geochim. Cosmochim. Acta 66, 1759-1772. https://doi.org/10.1016/S0016-

Zohary, T., Robarts, R.D., 1998. Experimental study of microbial P limitation in the eastern Mediterranean. Limnol. Oceanogr. 43, 387-395.

https://doi.org/10.4319/lo.1998.43.3.0387 


\subsection{Appendices}

Appendix 5A Carbon geochemistry values for the $13.77 \mathrm{~m}$ section with their respective sample ID and stratigraphic position.

\begin{tabular}{ccccc}
\hline Sample ID & Height $(\mathrm{m})$ & ${ }^{13} \mathrm{C}$ & $\mathrm{TIC}\left(\mathrm{CaCO}_{3} \%\right)$ & $\mathrm{TOC}(\mathrm{C} \mathrm{wt} \%)$ \\
\hline $\mathrm{C}-15-42$ & 13.77 & -24.23 & 76.07 & 0.91 \\
$\mathrm{C}-15-41$ & 13.36 & -24.17 & 72.95 & 1.12 \\
$\mathrm{C}-15-40$ & 12.96 & -24.12 & 74.22 & 0.97 \\
$\mathrm{C}-15-39$ & 12.54 & -24.09 & 66.54 & 1.25 \\
$\mathrm{C}-15-38$ & 12.2 & -24.09 & 65.33 & 1.34 \\
$\mathrm{C}-15-37$ & 11.95 & -24.20 & 65.00 & 1.27 \\
$\mathrm{C}-15-36$ & 11.67 & -24.14 & 67.33 & 1.18 \\
$\mathrm{C}-15-35$ & 11.3 & -23.93 & 69.58 & 1.17 \\
$\mathrm{C}-15-34$ & 10.9 & -23.96 & 70.26 & 1.25 \\
$\mathrm{C}-15-33$ & 10.55 & -23.81 & 70.77 & 1.23 \\
$\mathrm{C}-15-32$ & 10.2 & -23.87 & 73.75 & 0.96 \\
$\mathrm{C}-15-31$ & 9.78 & -23.86 & 67.38 & 1.28 \\
$\mathrm{C}-15-30$ & 9.48 & -23.97 & 75.88 & 0.80 \\
$\mathrm{C}-15-29$ & 9.1 & -23.75 & 71.77 & 1.05 \\
$\mathrm{C}-15-28$ & 8.7 & -23.81 & 71.04 & 1.18 \\
$\mathrm{C}-15-27$ & 8.33 & -23.75 & 70.72 & 1.17 \\
$\mathrm{C}-15-26$ & 7.98 & -23.76 & 72.24 & 1.12 \\
$\mathrm{C}-15-25$ & 7.67 & -23.73 & 67.13 & 1.26 \\
$\mathrm{C}-15-24$ & 7.4 & -24.03 & 73.82 & 1.03 \\
$\mathrm{C}-15-23$ & 7.12 & -23.80 & 73.22 & 0.99 \\
$\mathrm{C}-15-22$ & 6.82 & -23.91 & 72.09 & 1.09 \\
$\mathrm{C}-15-21$ & 6.45 & -23.71 & 68.47 & 1.19 \\
$\mathrm{C}-15-20$ & 6.09 & -23.85 & 66.17 & 1.15 \\
$\mathrm{C}-15-19$ & 5.82 & -23.75 & 62.03 & 1.68 \\
$\mathrm{C}-15-18$ & 5.52 & -24.18 & 63.66 & 1.73 \\
$\mathrm{C}-15-17$ & 5.15 & -23.82 & 67.79 & 1.39 \\
$\mathrm{C}-15-16$ & 4.74 & -23.80 & 70.35 & 1.43 \\
$\mathrm{C}-15-15$ & 4.38 & -23.39 & 74.53 & 1.28 \\
$\mathrm{C}-15-14$ & 4.03 & -23.55 & 76.82 & 1.19 \\
$\mathrm{C}-15-13$ & 3.68 & -23.49 & 72.12 & 1.49 \\
$\mathrm{C}-15-12$ & 3.32 & -23.13 & 77.61 & 1.15 \\
$\mathrm{C}-15-11$ & 3.04 & -23.15 & 78.09 & 1.25 \\
$\mathrm{C}-15-10$ & 2.79 & -23.18 & 77.30 & 1.21 \\
$\mathrm{C}-15-9$ & 2.52 & -23.05 & 77.28 & 0.99 \\
$\mathrm{C}-15-8$ & 2.2 & -23.34 & 76.20 & 1.14 \\
$\mathrm{C}-15-7$ & 1.84 & -22.84 & 74.09 & 1.19 \\
$\mathrm{C}-15-6$ & 1.47 & -22.85 & 72.15 & 1.42 \\
$\mathrm{C}-15-5$ & 1.12 & -23.20 & 79.84 & 0.95 \\
$\mathrm{C}-15-4$ & 0.82 & -22.58 & 79.48 & 1.09 \\
$\mathrm{C}-15-3$ & 0.55 & -22.55 & 78.30 & 0.99 \\
$\mathrm{C}-15-2$ & 0.25 & -22.63 & 78.75 & 0.80 \\
$\mathrm{C}-15-1$ & 0 & -22.59 & 76.60 & 1.18 \\
& & & &
\end{tabular}


Appendix 5B Absolute values of terrestrially derived elements (Al, Si, Ti), biolimiting elements (Fe, P), RSTEs $(\mathrm{V}, \mathrm{Ni}, \mathrm{Co}, \mathrm{Cr}, \mathrm{Cu}, \mathrm{Mo})$ and redox index $(\mathrm{Th} / \mathrm{U})$. Concentrations ppm = parts per million.

\begin{tabular}{|c|c|c|c|c|c|c|c|c|c|c|c|c|c|}
\hline Sample ID & Height (m) & $\mathrm{Al}$ & Si & $\mathrm{Ti}$ & $\mathrm{Fe}$ & $\mathrm{P}$ & V & $\mathrm{Ni}$ & Co & $\mathrm{Cr}$ & $\mathrm{Cu}$ & Mo & $\mathrm{Th} / \mathrm{U}$ \\
\hline C-15-42 & 13.77 & 17761 & 51579 & 641 & 7787 & 150 & 26.0 & 29.3 & 1.1 & 32.3 & 4.9 & 1.2 & 2.0 \\
\hline C-15-41 & 13.36 & 19509 & 55742 & 711 & 8673 & 160 & 27.6 & 34.6 & 0.6 & 35.5 & 5.3 & 1.8 & 2.2 \\
\hline C-15-40 & 12.96 & 18385 & 52829 & 666 & 8149 & 153 & 26.0 & 43.9 & 0.6 & 36.8 & 5.5 & 2.3 & 2.0 \\
\hline C-15-39 & 12.54 & 23037 & 67392 & 872 & 10811 & 264 & 36.4 & 33.1 & 0.6 & 38.7 & 6.2 & 1.8 & 2.8 \\
\hline C-15-38 & 12.2 & 27125 & 77468 & 957 & 11573 & 238 & 41.0 & 34.2 & 0.9 & 43.9 & 7.1 & 1.7 & 3.0 \\
\hline C-15-37 & 11.95 & 27698 & 75073 & 974 & 10702 & 226 & 39.1 & 40.4 & 0.6 & 42.8 & 7.2 & 1.9 & 3.0 \\
\hline C-15-36 & 11.67 & 23730 & 66954 & 866 & 10427 & 216 & 36.6 & 41.0 & 0.4 & 41.4 & 7.0 & 2.1 & 3.5 \\
\hline C-15-35 & 11.3 & 22009 & 60247 & 775 & 10867 & 195 & 32.3 & 24.0 & 0.4 & 32.7 & 5.7 & 1.2 & 1.9 \\
\hline C-15-34 & 10.9 & 21565 & 59415 & 840 & 8710 & 188 & 30.8 & 33.5 & 0.4 & 35.4 & 5.2 & 1.7 & 2.8 \\
\hline C-15-33 & 10.55 & 20962 & 58267 & 824 & 9866 & 214 & 29.8 & 43.8 & 0.8 & 37.6 & 5.5 & 2.4 & 2.5 \\
\hline C-15-32 & 10.2 & 18229 & 52329 & 704 & 8282 & 195 & 26.6 & 32.1 & 0.7 & 34.5 & 4.5 & 1.4 & 2.6 \\
\hline C-15-31 & 9.78 & 23541 & 70231 & 919 & 11327 & 264 & 35.2 & 45.2 & 1.2 & 46.7 & 6.1 & 2.5 & 3.2 \\
\hline C-15-30 & 9.48 & 18122 & 49975 & 681 & 7798 & 239 & 27.5 & 28.6 & 0.6 & 32.8 & 4.6 & 1.1 & 2.5 \\
\hline C-15-29 & 9.1 & 18810 & 54860 & 712 & 8871 & 177 & 30.9 & 37.3 & 0.8 & 36.4 & 5.4 & 2.0 & 1.7 \\
\hline C-15-28 & & 20196 & 56015 & 752 & 8806 & 174 & 32.3 & 30.3 & 0.6 & 41.1 & 5.1 & 1.4 & 2.6 \\
\hline C-15-27 & 8.33 & 20712 & 58128 & 796 & 9614 & 189 & 32.0 & 30.9 & 0.5 & 34.8 & 5.3 & 1.5 & 2.6 \\
\hline C-15-26 & 7.98 & 20307 & 56625 & 722 & 8776 & 214 & 30.7 & 27.3 & 0.9 & 34.1 & 4.9 & 1.3 & 2.7 \\
\hline$C-15$ & 7.67 & 26030 & 68933 & 942 & 10456 & 254 & 39.6 & 40.7 & 1.3 & 46.3 & 6.1 & 2.0 & 3.6 \\
\hline C-15-24 & 7.4 & 20022 & 53403 & 691 & 8320 & 171 & 32.3 & 33.1 & 1.6 & 36.4 & 5.0 & 1.5 & 2.7 \\
\hline C-15-23 & 7.12 & 19390 & 53176 & 757 & 8936 & 188 & 33.3 & 29.9 & 2.1 & 37.1 & 5.6 & 1.5 & 2.0 \\
\hline C-15-22 & 6.82 & 21156 & 57519 & 772 & 8833 & 188 & 32.9 & 32.5 & 0.9 & 39.9 & 5.0 & 1.5 & 2.5 \\
\hline C-15-21 & 6.45 & 34762 & 89223 & 1143 & 14194 & 283 & 49.3 & 48.3 & 1.5 & 58.5 & 7.7 & 2.6 & 3.0 \\
\hline C-15-20 & 6.09 & 34710 & 97770 & 1304 & 15255 & 361 & 57.8 & 64.9 & 1.3 & 68.0 & 9.3 & 3.5 & 3.0 \\
\hline C-15-19 & 5.82 & 40502 & 106870 & 1388 & 15919 & 396 & 60.5 & 88.0 & 2.5 & 82.0 & 10.4 & 3.6 & 3.6 \\
\hline C-15-18 & 5.52 & 37687 & 97865 & 1267 & 15425 & 357 & 56.1 & 96.1 & 2.9 & 89.6 & 10.7 & 5.0 & 3.0 \\
\hline C-15-17 & 5.15 & 31605 & 87444 & 1102 & 14119 & 302 & 48.4 & 57.6 & 2.1 & 62.2 & 8.2 & 3.8 & 2.5 \\
\hline C-15-16 & 4.74 & 19167 & 50785 & 707 & 9357 & 185 & 30.5 & 55.9 & 1.4 & 45.2 & 5.7 & 3.5 & 2.5 \\
\hline C-15-15 & 4.38 & 22162 & 62226 & 831 & 11606 & 200 & 35.1 & 45.5 & 0.7 & 46.4 & 6.3 & 2.5 & 1.7 \\
\hline C-15-14 & 4.03 & 18382 & 54459 & 705 & 10395 & 236 & 30.5 & 51.4 & 0.7 & 44.3 & 6.4 & 3.0 & 2.0 \\
\hline$C-15-13$ & 3.68 & 23721 & 64569 & 822 & 11771 & 275 & 42.0 & 44.8 & 1.6 & 49.5 & 7.9 & 2.4 & 2.2 \\
\hline C-15-12 & 3.32 & 18232 & 50397 & 690 & 9774 & 263 & 31.9 & 56.8 & 0.6 & 43.0 & 6.2 & 3.3 & 2.3 \\
\hline C-15-11 & 3.04 & 18717 & 50274 & 630 & 9052 & 243 & 30.6 & 51.5 & 1.1 & 42.3 & 6.1 & 2.8 & 1.8 \\
\hline C-15-10 & 2.79 & 19379 & 49210 & 658 & 8815 & 215 & 31.2 & 50.1 & 0.7 & 42.5 & 6.2 & 2.6 & 2.2 \\
\hline C-15-9 & 2.52 & 14626 & 40878 & 549 & 6530 & 199 & 23.6 & 33.6 & 1.1 & 30.8 & 4.6 & 1.6 & 2.0 \\
\hline C-15-8 & 2.2 & 21503 & 57957 & 774 & 9697 & 217 & 34.0 & 38.1 & 1.2 & 56.5 & 6.4 & 1.8 & 2.3 \\
\hline C-15-7 & 1.84 & 24086 & 65027 & 867 & 11040 & 262 & 36.9 & 48.4 & 1.0 & 49.1 & 6.8 & 2.8 & 2.5 \\
\hline C-15-6 & 1.47 & 26022 & 70920 & 939 & 11079 & 230 & 40.1 & 56.6 & 0.9 & 51.3 & 7.9 & 3.1 & 2.2 \\
\hline C-15-5 & 1.12 & 17252 & 46366 & 668 & 9276 & 268 & 28.1 & 39.4 & 0.5 & 34.7 & 5.1 & 2.1 & 2.5 \\
\hline C-15-4 & 0.82 & 17325 & 43487 & 649 & 9019 & 298 & 24.7 & 50.5 & 0.9 & 38.4 & 6.2 & 3.0 & 1.6 \\
\hline C-15-3 & 0.55 & 20125 & 54038 & 727 & 9403 & 229 & 27.5 & 51.6 & 1.1 & 45.0 & 6.3 & 2.9 & 2.6 \\
\hline C-15-2 & 0.25 & 20312 & 55129 & 778 & 9881 & 290 & 28.8 & 46.8 & 1.8 & 46.7 & 7.0 & 1.9 & 2.7 \\
\hline \multirow[t]{2}{*}{ C-15-1 } & 0 & 22201 & 60407 & 817 & 10664 & 280 & 29.8 & 54.0 & 1.9 & 59.4 & 7.1 & 2.3 & \multirow[t]{2}{*}{3.0} \\
\hline & erage $\% \mathrm{R}$ & 9.6 & 4.7 & 2.9 & 3.5 & 14 & 1.1 & 4.7 & 11 & 5.7 & 5.8 & 6.1 & \\
\hline
\end{tabular}


Appendix 5C Values of various n-alkane and acyclic isoprenoid based parameters.

\begin{tabular}{|c|c|c|c|c|c|c|c|}
\hline Sample ID & Height (m) & TAR & $\mathrm{Pr} / \mathrm{Ph}$ & $\mathrm{Pr} / n \mathrm{C}_{17}$ & $\mathrm{Ph} / n \mathrm{C}_{18}$ & $n \mathrm{C}_{17} / n \mathrm{C}_{31}$ & $\mathrm{ACL}$ \\
\hline C-15-42 & 13.77 & 0.3 & 1.6 & 0.3 & 0.2 & 5.3 & 27.0 \\
\hline C-15-41 & 13.36 & 0.3 & 1.7 & 0.2 & 0.2 & 5.4 & 27.0 \\
\hline C-15-40 & 12.96 & 0.4 & 1.2 & 0.3 & 0.2 & 4.9 & 27.2 \\
\hline C-15-39 & 12.54 & 0.3 & 1.8 & 0.3 & 0.2 & 7.7 & 26.9 \\
\hline C-15-38 & 12.2 & 0.2 & 1.2 & 0.2 & 0.2 & 7.2 & 27.1 \\
\hline C-15-37 & 11.95 & 0.2 & 1.5 & 0.3 & 0.2 & 8.9 & 26.9 \\
\hline C-15-36 & 11.67 & 0.3 & 1.6 & 0.3 & 0.2 & 5.8 & 27.0 \\
\hline C-15-35 & 11.3 & 0.3 & 1.7 & 0.3 & 0.2 & 5.3 & 27.0 \\
\hline C-15-34 & 10.9 & 0.3 & 1.4 & 0.3 & 0.2 & 5.4 & 27.0 \\
\hline C-15-33 & 10.55 & 0.3 & 1.9 & 0.3 & 0.2 & 8.3 & 26.8 \\
\hline C-15-32 & 10.2 & 0.2 & 2.3 & 0.3 & 0.2 & 7.8 & 27.0 \\
\hline C-15-31 & 9.78 & 0.2 & 1.7 & 0.4 & 0.2 & 7.3 & 26.9 \\
\hline C-15-30 & 9.48 & 0.2 & 1.8 & 0.3 & 0.1 & 11.6 & 26.9 \\
\hline C-15-29 & 9.1 & 0.3 & 1.5 & 0.3 & 0.2 & 5.4 & 27.3 \\
\hline C-15-28 & 8.7 & 0.3 & 1.4 & 0.3 & 0.2 & 6.4 & 27.2 \\
\hline C-15-27 & 8.33 & 0.3 & 1.3 & 0.2 & 0.2 & 5.6 & 27.2 \\
\hline C-15-26 & 7.98 & 0.2 & 1.8 & 0.3 & 0.2 & 6.7 & 27.1 \\
\hline C-15-25 & 7.67 & 0.2 & 2.0 & 0.3 & 0.2 & 18.8 & 26.7 \\
\hline C-15-24 & 7.4 & 0.2 & 1.6 & 0.3 & 0.2 & 8.6 & 26.8 \\
\hline C-15-23 & 7.12 & 0.2 & 2.0 & 0.4 & 0.2 & 7.0 & 27.0 \\
\hline C-15-22 & 6.82 & 0.1 & 2.1 & 0.4 & 0.2 & 18.0 & 26.6 \\
\hline C-15-21 & 6.45 & 0.1 & 1.9 & 0.4 & 0.2 & 20.9 & 26.5 \\
\hline C-15-20 & 6.09 & 0.1 & 1.3 & 0.4 & 0.3 & 37.1 & 26.5 \\
\hline C-15-19 & 5.82 & 0.1 & 2.0 & 0.4 & 0.2 & 22.0 & 26.6 \\
\hline C-15-18 & 5.52 & 0.1 & 1.3 & 0.4 & 0.3 & 60.6 & 26.0 \\
\hline C-15-17 & 5.15 & 0.1 & 2.2 & 0.4 & 0.2 & 24.3 & 26.6 \\
\hline C-15-16 & 4.74 & 0.1 & 1.8 & 0.4 & 0.3 & 25.3 & 26.5 \\
\hline C-15-15 & 4.38 & 0.1 & 1.8 & 0.4 & 0.2 & 24.3 & 26.5 \\
\hline C-15-14 & 4.03 & 0.4 & 2.1 & 0.3 & 0.2 & 5.0 & 27.0 \\
\hline C-15-13 & 3.68 & 0.1 & 2.1 & 0.5 & 0.3 & 18.8 & 26.7 \\
\hline C-15-12 & 3.32 & 0.3 & 1.5 & 0.3 & 0.2 & 4.7 & 27.2 \\
\hline C-15-11 & 3.04 & 0.3 & 1.6 & 0.4 & 0.2 & 5.3 & 27.1 \\
\hline C-15-10 & 2.79 & 0.3 & 1.6 & 0.3 & 0.2 & 5.3 & 27.1 \\
\hline C-15-9 & 2.52 & 0.3 & 1.9 & 0.3 & 0.2 & 5.1 & 27.1 \\
\hline C-15-8 & 2.2 & 0.3 & 2.3 & 0.4 & 0.2 & 9.6 & 26.9 \\
\hline C-15-7 & 1.84 & 0.2 & 2.2 & 0.3 & 0.2 & 8.0 & 27.0 \\
\hline C-15-6 & 1.47 & 0.2 & 2.1 & 0.4 & 0.2 & 12.0 & 26.8 \\
\hline C-15-5 & 1.12 & 0.3 & 2.3 & 0.5 & 0.2 & 7.4 & 27.0 \\
\hline C-15-4 & 0.82 & 0.2 & 1.9 & 0.4 & 0.2 & 11.9 & 26.7 \\
\hline C-15-3 & 0.55 & 0.2 & 2.0 & 0.5 & 0.2 & 10.7 & 26.8 \\
\hline C-15-2 & 0.25 & 0.2 & 2.0 & 0.5 & 0.2 & 8.0 & 26.8 \\
\hline C-15-1 & 0 & 0.2 & 2.7 & 0.5 & 0.2 & 8.5 & 26.8 \\
\hline
\end{tabular}


Appendix 5D Summary of scores and loadings from the PCA.

\begin{tabular}{|c|c|c|c|c|c|}
\hline \multicolumn{3}{|l|}{ Scores } & \multicolumn{3}{|c|}{ Loadings } \\
\hline Stratigraphic Height (m) & PC1 & PC2 & Variable & $\mathrm{PC} 1$ & $\mathrm{PC2}$ \\
\hline 0 & 1.0252 & 1.1335 & TIC & -0.208 & 0.4605 \\
\hline 0.25 & -0.623 & 1.1444 & TOC & 0.2243 & 0.0168 \\
\hline 0.55 & -0.879 & 1.6063 & Si & 0.2788 & -0.184 \\
\hline 0.82 & -1.911 & 3.2195 & $\mathrm{Al}$ & 0.2836 & -0.129 \\
\hline 1.12 & -2.87 & 1.0964 & $\mathrm{Ti}$ & 0.2807 & -0.158 \\
\hline 1.47 & 1.7181 & 1.107 & $\mathrm{Fe}$ & 0.2811 & -0.007 \\
\hline 1.84 & 0.3457 & 1.0413 & $P$ & 0.2359 & 0.1854 \\
\hline 2.2 & -0.902 & 0.9989 & V & 0.2798 & -0.097 \\
\hline 2.52 & -4.438 & 0.8162 & $\mathrm{Cr}$ & 0.2757 & 0.1777 \\
\hline 2.79 & -1.867 & 1.3081 & Co & 0.2042 & 0.221 \\
\hline 3.04 & -1.707 & 2.0341 & $\mathrm{Ni}$ & 0.2377 & 0.3491 \\
\hline 3.32 & -1.524 & 1.7523 & $\mathrm{Cu}$ & 0.2765 & 0.1245 \\
\hline 3.68 & 1.8746 & 0.9135 & Mo & 0.2128 & 0.3949 \\
\hline 4.03 & -1.597 & 1.7911 & $\mathrm{Th} / \mathrm{U}$ & 0.1702 & -0.37 \\
\hline 4.38 & 0.3305 & 1.1983 & Foram $\rho$ & -0.178 & 0.3548 \\
\hline 4.74 & 0.7263 & 0.8795 & TAR & -0.223 & -0.001 \\
\hline 5.15 & 5.5609 & 0.4106 & $A C L$ & -0.224 & -0.179 \\
\hline 5.52 & 10.743 & 1.9524 & & & \\
\hline 5.82 & 10.311 & -0.369 & & & \\
\hline 6.09 & 7.0863 & -0.445 & & & \\
\hline 6.45 & 4.6571 & -0.72 & & & \\
\hline 6.82 & -1.286 & -0.341 & & & \\
\hline 7.12 & -2.006 & 0.3414 & & & \\
\hline 7.4 & -1.871 & -0.468 & & & \\
\hline 7.67 & 1.5785 & -1.38 & & & \\
\hline 7.98 & -2.205 & -1.119 & & & \\
\hline 8.33 & -2.164 & -1.096 & & & \\
\hline 8.7 & -2.087 & -1.278 & & & \\
\hline 9.1 & -2.298 & -0.586 & & & \\
\hline 9.48 & -3.037 & -0.856 & & & \\
\hline 9.78 & 1.5406 & -1.487 & & & \\
\hline 10.2 & -2.763 & -0.907 & & & \\
\hline 10.55 & -0.84 & -0.303 & & & \\
\hline 10.9 & -1.589 & -1.683 & & & \\
\hline 11.3 & -1.764 & -1.598 & & & \\
\hline 11.67 & 0.5801 & -2.312 & & & \\
\hline 11.95 & 1.5893 & -2.331 & & & \\
\hline 12.2 & 1.7653 & -2.667 & & & \\
\hline 12.54 & 0.1669 & -1.979 & & & \\
\hline 12.96 & -3.104 & 0.0583 & & & \\
\hline 13.36 & -2.601 & -0.509 & & & \\
\hline 13.77 & -3.669 & -0.37 & & & \\
\hline
\end{tabular}




\title{
6 REGIONAL PALEOENVIRONMENTAL INFLUENCE ON OM SEQUESTRATION AND CHARACTERISTICS OF CARBON ISOTOPE SEGMENT C5 IN A HEMIPELAGIC SEQUENCE, ORGANYÀ BASIN, NORTHEAST SPAIN
}

\section{Socorro, J., Maurrasse, F.J-M.R., 2020. Regional paleoenvironmental influence on OM sequestration and characteristics of carbon isotope segment $\mathrm{C} 5$ in a hemipelagic sequence, Organyà Basin, northeast Spain. The Depositional Record. Accepted - In Revision.}

\begin{abstract}
The Cretaceous marine sedimentary record is punctuated by brief episodes of unusually high rates of organic carbon burial termed Oceanic Anoxic Events (OAEs). The El Pujal Section consists of an expanded series of limestones, argillaceous limestones and marlstones that chronicles the response to perturbations of the global carbon cycle associated with OAE1a in a hemipelagic setting of the Organyà Basin. In this study, we aim to understand the lithological and geochemical responses to changing paleoenviromental conditions associated with carbon isotope segment $\mathrm{C} 5$ of OAE1a. We apply a multi-proxy approach to characterize how regional factors influenced the accumulation of organic-rich sediments during this period of severe oxygen deficient conditions in the ocean.
\end{abstract}

Results from biomarker thermal maturity indices suggest that the sediments are thermally immature; therefore, the preserved organic geochemical data characterizes the original signal. Source specific biomarkers demonstrate that the bulk organic matter (OM) derives from in-situ production, with lesser inputs from allochthonous sources. High-resolution stable carbon isotope data $\left(\delta^{13} \mathrm{C}_{\mathrm{org}}\right)$ permits to establish refined details of segment C5 within OAE1a not perceivable in correlative sections elsewhere. Pulses of fluvial fluxes associated with climatic fluctuations supplied variable quantities of 
terrestrially derived OM with more negative isotopic values, which left their intrinsic signature superimposed on the global $\delta^{13} \mathrm{C}_{\text {org }}$ signal of segment $\mathrm{C} 5$ as minor negative spikes. Pulses of fluvial discharge also explain the alternating lithology with limestones representing the least terrestrially influenced end-member and marlstones representing episodes of highest terrigenous influence.

Primary production sustained by fluvial inputs of biolimiting elements provided abundant labile OM conducive to oxygen-deprived conditions as attested by concomitant peaks in TOC, relatively lower benthic faunal counts, lower bioturbation index, higher concentration of pyrite and enrichments in RSTEs. The presence of gammacerane in marlstone intervals implies a stratified water column, which may have been a controlling factor in preventing vertical mixing and oxygenation of the basin. However, OM preservation was not chiefly controlled by redox condition as physical encapsulation by clay minerals likely played a significant role. In addition, coincident inputs of terrestrial OM with more recalcitrant properties and prone to be bound to clay minerals resulting from soil forming processes supplemented the accumulation of OM, especially during intervals of enhanced terrigenous fluxes. Appraisal of the aromatic lipid fraction revealed elevated concentrations of perylene coeval with increases in biomarkers indicative of allochthonous OM, thus supporting its link with terrestrial vegetation input. Perylene occurrence at El Pujal covaries closely with intervals of more humid climatic conditions. Given its demonstrated link with wood degrading fungi, high abundance of sedimentary perylene might therefore serve as a biomarker indicating a moist continental climate in the depositional setting. 
This study further highlights the continuous local expression of OAE1a in the hemipelagic setting of the semi-restricted Organyà Basin. The combined result underscore how despite sharing common global forcing factors, regional paleoenvironmental conditions are probably more important in determining the sedimentary expression of OAE1a.

\subsection{Introduction}

The Cretaceous marine sedimentary record is punctuated by brief episodes of severe oxygen depletion in bottom waters termed Oceanic Anoxic Events (OAEs) (Schlanger and Jenkyns, 1976; Jenkyns, 1980; Leckie et al., 2002). These short-lived episodes lasting $~ 1$ Myr (Li et al., 2008) are characterized by sediments with unusually high content of organic carbon and distinct positive shifts in the stable carbon isotope $\left(\delta^{13} \mathrm{C}\right)$ record of marine sediments on a global scale (e.g. Scholle and Arthur, 1980; Erbacher et al., 1996; Hasegawa, 1997; Menegatti et al., 1998; Leckie et al., 2002; Herrle et al., 2004). The Early Aptian OAE1a, also known as the Livello Selli or Goguel event, represents one such event with its global signal recorded in organic matter (OM)-rich marine sediments of various settings (Schlanger and Jenkyns, 1976; Arthur and Schlanger, 1979; Coccioni et al., 1987; Menegatti et al., 1998; Arthur et al., 1990;

Bellanca et al., 2002; Dumitrescu and Brassell, 2005; 2006; Luciani et al., 2006; Ando et al., 2008; Heldt et al., 2008; Roban and Melinte-Dobrinescu, 2012; Aguado et al., 2014a,b; Sanchez-Hernandez and Maurrasse, 2014; 2016). In general, these sediments tend to be pyritic, laminated, enriched in redox sensitive trace elements (RSTEs), lack diversity, or may be devoid of benthic organisms. 
The geochemical hallmark of OAE1a is a distinct $\delta^{13} \mathrm{C}$ signature which begins with a pronounced negative shift, recognized as segment C3 (Menegatti et al., 1998) succeeded by more positive values during segments C4 through C6 (Menegatti et al., 1998). The negative carbon isotope excursion (CIE) reported for segment $\mathrm{C} 3$ has been interpreted as ensuing from massive outgassing of large quantities of isotopically light $\mathrm{CO}_{2}\left(\delta^{13} \mathrm{C} \sim\right.$ $5 \%$ ), related to the emplacement of the Ontong Java-Manihiki-Hikurangi large igneous province (LIP) (e.g. Larson, 1991; Tarduno et al., 1991; Ingram et al., 1994; Larson and Erba, 1999; Méhay et al., 2009; Tejada et al., 2009). The C3 negative CIE has also been attributed to rapid dissociation of methane hydrates $\left(\delta^{13} \mathrm{C} \sim-60 \%\right.$ ) (Kvenvolden, 1993) into the atmosphere (e.g. Jahren et al., 2001; 2005; Beerling et al., 2002; van Breugel et al., 2007). The subsequent positive trend $\left(\delta^{13} \mathrm{C}\right.$ excursion segments $\left.\mathrm{C} 4-\mathrm{C} 6\right)$ is accepted to represent periods of enhanced OM sequestration because primary productivity in the ocean preferentially takes up the lighter carbon $\left({ }^{12} \mathrm{C}\right)$, thus leaving the remaining global carbon reservoir enriched in ${ }^{13} \mathrm{C}$ (Arthur et al., 1988; Weissert, 1989; Arthur et al., 1990; Menegatti et al., 1998; Leckie et al., 2002; Jenkyns, 2010; van Bentum et al., 2012). The effects of these pertubations on the global carbon reservoir are expressed on the synchroneity of the isotopic shifts which manifests in marine carbonates $\left(\delta^{13} \mathrm{C}_{\text {carb }}\right)$ (Menegatti et al., 1998; Moullade et al., 1998; Kuhnt et al., 1998; Erba et al., 1999; Bellanca et al., 2002; de Gea et al., 2003; Herrle et al., 2004; Heldt et al., 2008; Michalík et al., 2008; Moreno-Bedmar et al., 2009; Masse and Fenerci-Masse, 2011; Elkhazri et al., 2013; Papp et al., 2013; Godet et al., 2014; Graziano and Raspini, 2018) and OM $\left(\delta^{13} \mathrm{C}_{\text {org }}\right.$ ) from both marine (Menegatti et al., 1998; Dumitrescu and Brassell, 2006; Millán et al., 2009; Gaona-Narvaez et al., 2013a; Sanchez-Hernandez et al., 2014; Sanchez- 
Hernandez and Maurrasse, 2016) and terrestrial sources (Gröcke et al., 1999; Ando et al., 2002). Thus, the consistency and reproducibility of the carbon isotope shifts in widely distributed locations during OAE1a provide a robust chronostratigraphic tool for stratigraphic correlation (e.g. Scholle and Arthur, 1980; Weissert and Bréhéret, 1991; Menegatti et al., 1998; Herrle et al., 2004). Nonetheless, noticeable lithologic and isotopic variations develop regionally and locally as specific responses related to basin physiography, atmospheric and basinal circulation patterns, water chemistry, ecosystem structure and dynamics, as well as the amount and type of terrestrial fluxes (Jenkyns, 1995; Moullade et al., 1998; Grötsch et al., 1998; Danelian et al., 2004; Yilmaz et al., 2004; Immenhauser et al., 2005; Dumitrescu and Brassell, 2006; Chaabani and Razgallah, 2006; Heldt et al., 2010; Huck et al., 2010; Najarro et al., 2011; Stein et al., 2012; Gaona-Narvaez et al., 2013a, 2013b; Sanchez-Hernandez et al., 2014; NúñezUseche et al., 2015; Sanchez-Hernandez and Maurrasse, 2016).

The Organyà Basin located in the Iberian Peninsula (Fig. 6-1A, B) developed as a semi-enclosed basin during the Early Cretaceous, and previous studies document extensive successions of continuous hemipelagic marls and limestones (Peybernès and Souquet, 1973; Berástegui et al., 1990; Bachmann and Willems, 1996; García-Senz, 2002; Bernaus et al., 2000, 2002, 2003; Gong et al., 2009; Sanchez-Hernandez et al., 2014; Sanchez-Hernandez and Maurrasse, 2014, 2016; Llaguno, 2017; Socorro and Maurrasse, 2019). This study further extends our analyses of the Early Aptian related to OAE1a at the El Pujal section (Fig. 6-1C, D) (Socorro and Maurrasse, 2019) and aims at understanding the lithological and geochemical responses to changing paleoenviromental conditions associated with carbon isotope segment C5. We apply a multi-proxy 


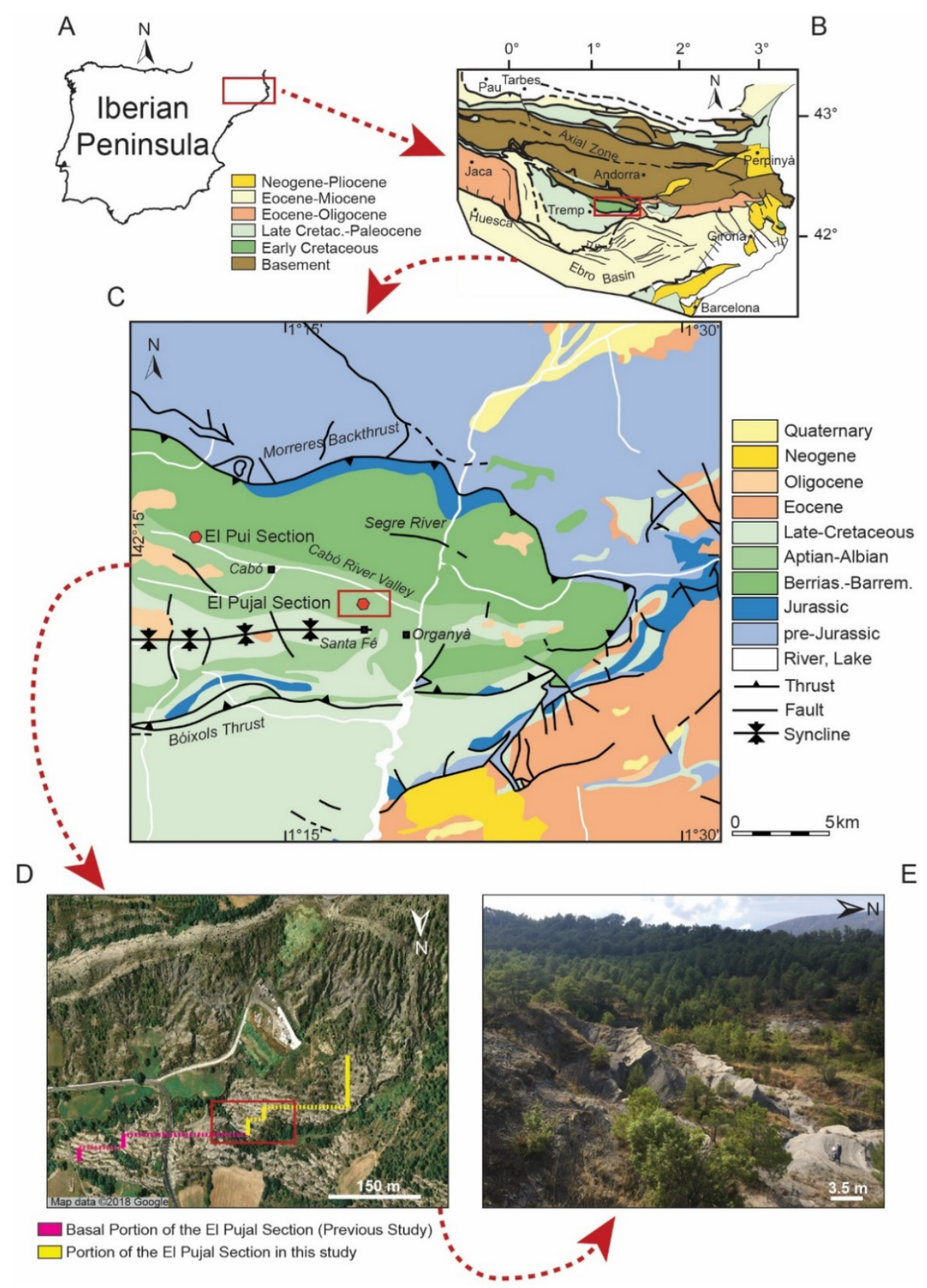

Figure 6-1 A) Location map of the Organyà Basin in the Iberian Peninsula. B) Regional geologic map showing the area of interest. A) and B) modified from Dinarès-Turell and GarcíaSenz, 2000). C) Detailed geologic map of the studied area showing the location of the El Pui Section (Sanchez-Hernandez et al., 2014; Sanchez-Hernandez and Maurrasse, 2014, 2016) and the El Pujal Section (Socorro and Maurrasse, 2019; and this study). C) Modified from Gong et al. (2009). D) Satellite image showing the portion of the El Pujal Section studied thus far. Basal portion refers to a previous study by Socorro and Maurrasse (2019). D) Modified from Google Earth Map Data 2018. E) Photograph of the outcrop showing the expanded sequence of hemipelagic sediments exposed as differentially weathered packets.

methodology to better characterize the local factors that resulted in the accumulation of organic-rich sediments during this period known for widespread severe oxygen deficient 
conditions. The results provide additional insight on the effects of regional factors during intervals of enhanced OM sequestration, and how the input of terrestrial vegetation linked with lower values of $\delta^{13} \mathrm{Corg}_{\text {rg }}$ may have altered the global $\delta^{13} \mathrm{C}_{\text {org }}$ archive in the Organyà Basin. The expanded section generated a $\delta^{13} \mathrm{C}_{\text {org }}$ curve with great detail of an amplified record suitable for more precise chemostratigraphic correlations.

\subsection{Geologic Framework}

From the Late Jurassic to the Early Cretaceous the gradual opening of the North Atlantic Ocean led to the separation of the Iberian Plate from Eurasia and Africa (Srivastava et al., 1990; Olivet, 1996; Vergés et al., 2002; Sibuet et al., 2004). The Bay of Biscay opened concurrently with this rifting phase while Iberia underwent $\sim 35^{\circ}$ counter-clockwise rotation relative to Eurasia (Van der Voo, 1969; Williams, 1975; Montadert et al., 1979; Montigny et al., 1986; Srivastava et al., 1990; Sibuet and Collette., 1991; Choukroune, 1992; Rosenbaum et al., 2002; Sibuet et al., 2004; Gong et al., 2008; Vissers and Meijer., 2012). The syn-rotational rifting along the northern portion of the Iberian plate produced significant extensional faulting which generated a series of pull-apart depocenters, including the Central Pyrenean Basin that is associated with the Organyà deposits (Fig. 61B). The basin became inverted due to the onset of convergence between Africa, Iberia and Europe in the Late Cretaceous (Puigdefäbregas and Souquet, 1986; Berástegui et al., 1990; Vergés and Muñoz, 1990; Muñoz, 1992; Vergés and García-Senz., 2001; GarcíaSenz, 2002; Golonka, 2004). The paleogeographic position of the Organyà Basin in the Early Cretaceous was on the northern margin of the Ebro block with an estimated width of at least $15 \mathrm{~km}$ and between $70 \mathrm{~km}$ to $100 \mathrm{~km}$ long along its extensional axis (DinarèsTurell and García-Senz, 2000; Vacherat et al., 2017). It accommodated a continuous 
4,000 $\mathrm{m}$ sequence of shallow platform carbonates, and hemipelagic to pelagic marine sediments from the upper Tithonian to the lower Turonian, after which the basin fill was inverted and thrusted southward along a detachment fault in a compressional phase associated with the Pyrenean orogeny (Berástegui et al., 1990;Vergés and García-Senz., 2001; García-Senz, 2002). Sedimentary deposits of the Organyà Basin situated in the South Pyrenean Central Unit (SPCU) comprise a complex series of thrust sheets (e.g. Bóixols and Montsec; Cotiella and Pedraforca nappes; and the Sierras Marginales (Seguret, 1972; Vergés and Muñoz, 1990; Puigdefàbregas et al., 1992; García-Senz, 2002). Remnants of the Basin outcrop in the hanging wall of the Bóixols thrust system, bounded to the north by the Morreres backthrust (Fig. 6-1C) (García-Senz, 2002; Gong et al., 2009). A prominent E-W trending asymmetric syncline (Santa Fé syncline) divides the northern, relatively thick limb, from a thinner southern limb (Gong et al., 2009). Structurally the outcrop is located along the northern limb of the Santa Fé syncline $\left(42^{\circ} 13^{\prime} 06.15^{\prime \prime} \mathrm{N}, 1^{\circ} 18^{\prime} 55.85^{\prime \prime} \mathrm{E}\right)$, and on the south side of the Cabó River valley in the municipality of Organyà (Fig. 6-1C). Previous studies of lower beds exposed on the north side of the valley reported the record of OAE1a up to carbon isotope segment C5 (Sanchez-Hernandez et al., 2014; Sanchez-Hernandez and Maurrasse, 2014, 2016), which has been correlated with the lowermost part of the El Pujal section (Socorro and Maurrasse, 2019).

Here, we investigate $70.75 \mathrm{~m}$ of the succession in continuity with the previously discussed $13.77 \mathrm{~m}$ basal segment of the El Pujal Section (Fig. 6-1D) (Socorro and Maurrasse, 2019), which consists of a succession of limestones, argillaceous limestones and marlstones exposed as differentially weathered packets (Fig. 6-1E). 


\subsection{Materials and Methods}

\subsubsection{Field Sampling and Microscopy}

Field sampling of the present study extends from $14.29 \mathrm{~m}$ to $85.04 \mathrm{~m}(70.75 \mathrm{~m})$ with a total of 109 samples collected at an average resolution of 1 sample per $65 \mathrm{~cm}$. Samples were selected based on apparent bedding and the top $\sim 1 \mathrm{~m}$ surface of the weakly lithified layers was cleared away to ensure collection of unweathered rocks. Color description of samples is based on the modified Munsell color system as proposed by Goddard et al., (1963).

A total of 109 thin sections were analyzed using an Olympus BH-2 light transmitting microscope. The microscopic analysis focused on microfacies, mineralogical composition, index fauna identification, bioturbation, presence/absence of benthic fauna, and minerals indicative of redox conditions. The micropaleontological analysis of planktonic foraminifera was accomplished primarily using the help of illustrations in the published literature (e.g. Verga and Premoli-Silva, 2002; Heldt et al., 2008; Moullade et al., 2015). Visual estimates of allochems follow Shvetsov's proposed percentage diagrams as summarized by Terry and Chilingarian, (1955). A bioturbation index was assigned to each sample following the proposed scheme in Taylor and Goldring (1993). In addition, a sample count of benthic fauna focused on benthic foraminifera and echinoid fragments. The total counts were divided by the area of each thin section and are expressed as density $(\rho)$ or number of specimens per $\mathrm{cm}^{2}$.

\subsubsection{Carbon Analyses}

All samples $(\mathrm{n}=109)$ were analyzed for total carbon $(\mathrm{TC})$ and total inorganic carbon (TIC) at Florida International University (FIU) using a LECO CR-412 carbon 
analyzer following the methodology used in our Carbon Analysis Laboratory (Ponton, 2005; Gaona-Narvaez et al., 2013b; Sanchez-Hernandez and Maurrasse, 2014), and modified as proposed by Socorro and Maurrasse (2019). The LECO CR-412 instrument uses an infrared cell to measure the total $\mathrm{CO}_{2}$ produced by the combustion at $1450 \pm 2^{\circ} \mathrm{C}$ of $0.3000 \mathrm{~g}$ of a powdered rock sample (Gaona-Narvaez et al., 2013b; SanchezHernandez and Maurrasse, 2014). Calibration of the instrument was performed by producing a 15-point, best-fit calibration curve $(0.0500 \mathrm{~g}, 0.0700 \mathrm{~g}, 0.1000 \mathrm{~g}, 0.1200 \mathrm{~g}$, $0.1500 \mathrm{~g}, 0.1700 \mathrm{~g}, 0.2000 \mathrm{~g}, 0.2200 \mathrm{~g}, 0.2500 \mathrm{~g}, 0.2700 \mathrm{~g}, 0.3000 \mathrm{~g}, 0.3200 \mathrm{~g}, 0.3500 \mathrm{~g}$, $0.3700 \mathrm{~g}, 0.4000 \mathrm{~g}$ ) using pure calcite $\geq 99.0 \%$ (C64-500, Fisher Scientific)(SanchezHernandez and Maurrasse, 2014). Analytical precision was estimated at $0.03 \%$ or better, based on 4 replicate analyses of the same sample and accuracy was verified by analyzing a reference material (Dolomitic Limestone NIST 88b). TIC values are reported as $\mathrm{CaCO}_{3}$ $\%$ and are used to assign a general lithologic nomenclature modified from SanchezHernandez and Maurrasse (2014) to allow for a wider range of representation of lithologic variation observed in the field. Hence, TIC $>70 \%=$ limestone, $65-70 \%=$ argillaceous limestone and $35-65 \%=$ marlstone. Total organic carbon $(\mathrm{TOC})$ was determined by taking the difference between TC and TIC (TC-TIC) and dividing the result by 8.33 , thus TOC is expressed as $\mathrm{C} w \mathrm{t} \%$ (detailed in Sanchez-Hernandez and Maurrasse, 2014).

For stable carbon isotope analysis on the organic fraction $\left(\delta^{13} \mathrm{Corg}_{\mathrm{o}}\right)$ powdering and de-carbonation of samples $(n=109)$ follow the procedures outlined in Socorro and Maurrasse (2019). Analysis of the samples were conducted at the Rosenstiel School of Marine and Atmospheric Science (RSMAS) stable isotope laboratory (SIL) using a 
Costech elemental combustion system interfaced with a Thermo Scientific Delta V Advantage continuous flow isotope ratio mass spectrometer. $\delta^{13} \mathrm{C}_{\text {org }}$ results are reported in per mil (\%) relative to the Vienna Peedee Belemnite standard (VPDB).

\subsubsection{Major and Redox Sensitive Trace Elements (RSTEs) Analysis}

Samples $(\mathrm{n}=65)$ were analyzed for major $(\mathrm{Si}, \mathrm{Al}, \mathrm{Ti}, \mathrm{P}, \mathrm{Fe})$ and RSTEs $(\mathrm{V}, \mathrm{Cr}, \mathrm{Co}$, $\mathrm{Ni}, \mathrm{Cu}, \mathrm{Mo}, \mathrm{U}$ ) at the FIU Trace Evidence Analysis Facility (TEAF) using an ELAN DRC II (Perkin Elmer LAS) inductively coupled plasma mass spectrometer (ICP/MS). Sample introduction was achieved through laser ablation (LA) using a $266 \mathrm{~nm}$ Nd-YAG laser (LSX 500, CETAC) set at a spot size of $200 \mu \mathrm{m}$ and $10 \mathrm{~Hz}$. Sample preparation and calibration followed the methodology developed by Arroyo et al., (2009) and outlined in Sanchez-Hernandez and Maurrasse (2014), and Socorro and Maurrasse (2019). Results for major elements are expressed as parts per thousand $\left(\mathrm{ppm} \cdot 10^{-3}\right)$ and RSTEs are expressed as parts per million (ppm).

Additionally, because RSTEs show significant enrichments under reducing conditions relative to the average background value (Wedepohl, 1971, Tribovillard et al., 2004), enrichment indices (EIs) were calculated based on the average values of the section (e.g. Bodin et al., 2007; Socorro and Maurrasse, 2019). Usually, the background level for these elements is taken from those reported for average shale values such as the Post Archean Australian Shale (PAAS) of Taylor and McLennan (1985), the North American Shale Composite (NASC) of Gromet et al, (1984) or the average shale value (ASV) of Turekian and Wedepohl (1961), Wedepohl $(1971,1991)$. As discussed in Socorro and Maurrasse (2019) this method may overlook the critical effects of crustal heterogeneity, chemical fractionation during weathering, and grain-size sorting that can 
produce sediments very specific to the region of interest (Van der Weijden, 2002;

Brumsack, 2006; White, 2013). Thus, depending on the area, the detrital portion of the sediment may have a chemical composition that substantially differs from those reported for the "average shale". For example, given an element with a relatively low crustal abundance, but the parent rock of the sediments in the adjacent region are enriched in such element, the EIs calculated for this element will be artificially inflated, even though the value might be even lower than the regional's background average value. Therefore, an assessment of the regional lithological background value (Cole et al., 2017) is required before calculating EIs. Based on uncertainties about the magnitude of the background natural value of the regional detrital signal unrelated to the redox conditions at time of deposition, here we rely on a baseline of the Organyà Basin's Average Background Value (OBABV) unique to the region, modified from the earlier study (Socorro and Maurrasse., 2019). Hence, the EI values should be more representative of the true detrital signal of the Organyà Basin watershed. Extensive studies for the period spanning the latest Barremian to the early Aptian provided reliable data to calculate the OBABV by combining RSTEs values from 4 studied upper Barremian - lower Aptian hemipelagic to pelagic sections at various sites of the basin. These include: 1) the El Pui section (233.3 m) with a total of 84 samples (Sanchez-Hernandez, 2014); 2) the Eastern Prada Quarry Section (27.98 m) with 31 samples (Llaguno, 2017); 3) the Cabó Section (35.6 m) with 17 samples (Carlos Herdocia - Appendix 6A); and 6D) the basal portion of the El Pujal Section (13.77 m) with 42 samples (Socorro and Maurrasse, 2019). The OBABV presented here also includes new data obtained for this study $(70.75 \mathrm{~m})$ with 65 samples (Table 6-1). 
Table 6-1 Calculated OBABV values for various redox-sensitive elements.

\begin{tabular}{rccccccc}
\hline Redox-Sensitive Elements & $\mathrm{V}$ & $\mathrm{Cr}$ & $\mathrm{Co}$ & $\mathrm{Ni}$ & $\mathrm{Cu}$ & $\mathrm{Mo}$ & $\mathrm{U}$ \\
\hline 27.56 & 33.46 & 3.68 & 32.31 & 5.72 & 2.56 & 1.1
\end{tabular}

The EI for each RSTE relative to the OBABV is calculated using the following equation:

$$
\text { EIs }=\frac{[\text { RSTEs }]}{[\text { RSTEs }]_{\text {regional background }}}
$$

Here, the numerator [RSTEs] represents the concentration of each sample in ppm, and the denominator [RSTEs] regional background is the average value in ppm of the corresponding RSTE from the OBABV as discussed above. Relative enrichments are thus expressed as EIs $>1$, whereas depleted elements are represented by EIs $<1$. To allow for easier correlation between RSTEs and other proxies, we calculated the sum of all enrichment indices $\sum$ EIs by adding all the EIs of each element for each sample.

\subsubsection{Clay Mineral Analysis ( $<2 \mu \mathrm{m}$ Fraction)}

Based on the lithological characteristics of the section provided by the TIC and TOC, seven samples $(n=7)$ were selected for X-ray diffraction (XRD) analysis to represent the different temporal variations of terrigenous supply to the basin. The analyses were performed at the Illinois State Geological Survey (ISGS), Geochemistry Section, Prairie Research Institute, University of Illinois. The methodology used is as follows: 1) each sample was gently ground, sieved and the $<250-\mu \mathrm{m}$ fraction was collected; 2) $15 \mathrm{~g}$ of the sample was dispersed in $100 \mathrm{ml}$ deionized (DI) water for $24 \mathrm{hrs}$; 3) transfer of the sample to a mixer stirring for one minute, and the suspension was then poured back to the beaker and allowed to settle overnight; 4) the next day, 1/3 of the clear supernatant was decanted and the beaker refilled with fresh DI water; 5) two drops of 
dispersant (sodium hexa-metaphosphate) were added to the suspension, stirred for one minute and allowed to settle; 6) after 15 min the suspension was transferred onto a glass slide using an eye dropper and dried overnight; 7) all slides were then saturated using ethylene glycol vapors for $48 \mathrm{hrs}$. The oriented and glycolated clay slides were analyzed with a Scintag ${ }^{\circledR}$ XDS2000 diffractometer. Step-scanned data was collected from $2^{\circ}$ to $34^{\circ} 2 \theta$ with a fixed rate of $2^{\circ}$ per min with a step size of $0.05^{\circ} 2 \theta$ for each sample. All resulting traces were analyzed using the semi-quantitative data reduction software from Materials Data Inc. (MDI) known as Jade+ ${ }^{\circledR}$.

\subsubsection{Lipid Analyses}

A total of 64 samples were prepared and extracted following the procedures

proposed by Socorro and Maurrasse (2019) and references therein. Briefly, the total lipid extract (TLE) obtained was evaporated until almost dry and dissolved in hexane. Then, the TLE was mounted on a silica gel-packed glass pipette and separated into two fractions (F1 and F2). Fraction F1 containing the aliphatic components was extracted using $4 \mathrm{ml}$ of hexane, and fraction F2 containing the aromatic components was extracted using $4 \mathrm{ml}$ of dichloromethane (DCM).

The aliphatic fractions $(\mathrm{F} 1)(\mathrm{n}=64)$ and the aromatic fractions F2 $(\mathrm{n}=3)$ were analyzed using an Agilent 6890/Agilent 5973 gas chromatography mass spectrometer (GC/MS) at the FIU Advanced Mass Spectrometry Facility. The GC was equipped with an HP-5MS UI $30 \mathrm{~m}, 0.25 \mathrm{~mm}, 0.25 \mu \mathrm{m}$, capillary column. A $5 \mu \mathrm{L}$ volume of each sample was injected in splitless mode with the injector temperature set at $280^{\circ} \mathrm{C}$. The oven temperature program was set to hold at $65^{\circ} \mathrm{C}$ for $2 \mathrm{~min}$, then ramped to $300^{\circ} \mathrm{C}$ at a rate of $4^{\circ} \mathrm{C} / \mathrm{min}$ and held at $300^{\circ} \mathrm{C}$ for $8 \mathrm{~min}$. Detection was performed by using a single 
quadrupole operating in positive mode electron impact ionization (EI+) with a scan range from $\mathrm{m} / \mathrm{z} 42$ to $\mathrm{m} / \mathrm{z} 500$ and a solvent delay time of $4 \mathrm{~min}$.

Selected samples $(n=5)$ were chosen for further purification of hopanes and steranes through the removal of $n$-alkanes. The $n$-alkanes were isolated from the branched and cyclic hydrocarbons using urea adduction. For this, the previously separated aliphatic fraction (F1) was combined in a ratio of 2:1 hexane/acetone $(4 \mathrm{ml}$ hexane $/ 2 \mathrm{ml}$ acetone) in a previously cleaned (combusted at $560^{\circ} \mathrm{C}$ for $2 \mathrm{hrs}$ ) 11-dram vial in which $2 \mathrm{ml}$ of a urea saturated methanol $(\mathrm{MeOH})$ solution was added drop-wise. The saturated urea $\mathrm{MeOH}$ solution was prepared by dissolving $16.6 \mathrm{~g}$ of urea in $100 \mathrm{ml}$ of $\mathrm{MeOH}$ at $60^{\circ} \mathrm{C}$. The dropwise addition of the urea saturated $\mathrm{MeOH}$ solution resulted in the immediate precipitation of white urea crystals. The mixture was allowed to settle overnight and then centrifuged at 2,000 rpm for 5 min to separate the non-adduct fraction from the urea crystals. The non-adduct fraction was collected and stored in a second 11dram vial. The dry urea crystals were then washed with $3 \mathrm{ml}$ of a 2:1 hexane/acetone solution and the resulting non-adduct solution was combined with the original non-adduct fraction. The urea adduction procedure was repeated $3 \mathrm{x}$ on the non-adduct fraction to ensure that all the $n$-alkanes were removed. At the end, the non-adduct fractions containing branched and cyclic hydrocarbons (including hopanes and steranes) were combined and evaporated to $\sim 1 \mathrm{ml}$ before GC/MS analysis.

Analysis of the non-adduct fraction $(\mathrm{n}=5)$ focused on hopanes and steranes and was conducted at the FIU Advanced Mass Spectrometry Facility. Separation was performed using an Agilent 6890 GC equipped with an UI HP-5MS UI $30 \mathrm{~m}, 0.250 \mathrm{~mm}$, $0.25 \mu \mathrm{m}$, capillary column. Injections ( $5 \mu \mathrm{L})$ were performed in splitless mode with an 
injector temperature of $280^{\circ} \mathrm{C}$. The oven temperature program was set to hold at $65^{\circ} \mathrm{C}$ for $2 \mathrm{~min}$, then ramped to $300^{\circ} \mathrm{C}$ at a rate of $4^{\circ} \mathrm{C} / \mathrm{min}$ and hold at $300^{\circ} \mathrm{C}$ for $8 \mathrm{~min}$. Detection was performed by using a single quadrupole mass spectrometer (Agilent 5973) operating in EI+ mode. The instrument was operated in selective ion monitoring (SIM) with a dwell time of $40 \mathrm{~ms}$ and a solvent delay time of $4 \mathrm{~min}$. Identification of analytes was achieved on the basis of comparison of published retention times and mass spectra (Watson et al., 2000; Peters et al., 2005; 2007).

The terrigenous to aquatic ratio (TAR) was determined using the equation proposed by Bourbonniere and Meyers (1996):

$$
\mathrm{TAR}=\frac{\mathrm{nC}_{27}+\mathrm{nC}_{29}+\mathrm{nC}_{31}}{\mathrm{nC}_{15}+\mathrm{nC}_{17}+\mathrm{nC}_{19}}
$$

The relative abundance of odd to even preferences of long-chain length $n$-alkanes were determined using the carbon preference index (CPI) after Bray and Evans (1961):

$$
\mathrm{CPI}=\frac{1}{2}\left[\frac{\mathrm{nC}_{25}+\mathrm{nC}_{27}+\mathrm{nC}_{29}+\mathrm{nC}_{31}+\mathrm{nC}_{33}}{\mathrm{nC}_{24}+\mathrm{nC}_{26}+\mathrm{nC}_{28}+\mathrm{nC}_{30}+\mathrm{nC}_{32}}+\frac{\mathrm{nC}_{25}+\mathrm{nC}_{27}+\mathrm{nC}_{29}+\mathrm{nC}_{31}+\mathrm{nC}_{33}}{\mathrm{nC}_{26}+\mathrm{nC}_{28}+\mathrm{nC}_{30}+\mathrm{nC}_{32}+\mathrm{nC}_{34}}\right]
$$

The odd to even preferences (OEP) of long-chain length $n$-alkanes was calculated by adapting the OEP equation of Scalan and Smith (1970) to OEP (2) as published in Peters et al. (2007):

$$
\operatorname{OEP}(2)=\frac{\mathrm{nC}_{25}+6 * \mathrm{nC}_{27}+\mathrm{nC}_{29}}{4 * \mathrm{nC}_{26}+4 * \mathrm{nC}_{28}}
$$


Various hopane and sterane parameters were calculated as follows:

$$
\begin{gathered}
\frac{\mathrm{Ts}}{\mathrm{Ts}+\mathrm{Tm}}=\frac{18 \alpha 22,29,30 \text { trisnorneohopane }}{18 \alpha 22,29,30 \text { trisnorneohopane }+17 \alpha 22,29,30 \text { trisnorhopane }} \\
\mathrm{C}_{31} \frac{22 \mathrm{~S}}{22 \mathrm{~S}+22 \mathrm{R}}=\frac{\mathrm{C}_{31} 17 \alpha, 21 \beta(\mathrm{H}) \text { homohopane }(22 \mathrm{~S})}{\mathrm{C}_{31} 17 \alpha, 21 \beta(\mathrm{H}) \text { homohopane }(22 \mathrm{~S})+\mathrm{C}_{31} 17 \alpha, 21 \beta(\mathrm{H}) \text { homohopane }(22 \mathrm{R})}
\end{gathered}
$$

$$
\text { Gammacerane Index }=\frac{\mathrm{C}_{30} \text { Gammacerane }}{\mathrm{C}_{31} 17 \alpha, 21 \beta(\mathrm{H}) \text { homohopane }(22 \mathrm{R})}
$$

$$
\begin{aligned}
& \% \mathrm{C}_{27} \alpha \alpha \alpha \mathrm{R}=\frac{100 * \mathrm{C}_{27} 5 \alpha, 14 \alpha, 17 \alpha(\mathrm{H}) \text { sterane (20R) }}{\mathrm{C}_{27}+\mathrm{C}_{28}+\mathrm{C}_{29} 5 \alpha, 14 \alpha, 17 \alpha(\mathrm{H}) \text { sterane (20R) }} \\
& \% \mathrm{C}_{28} \alpha \alpha \alpha \mathrm{R}=\frac{100 * \mathrm{C}_{28} 5 \alpha, 14 \alpha, 17 \alpha(\mathrm{H}) \text { sterane (20R) }}{\mathrm{C}_{27}+\mathrm{C}_{28}+\mathrm{C}_{29} 5 \alpha, 14 \alpha, 17 \alpha(\mathrm{H}) \text { sterane (20R) }} \\
& \% \mathrm{C}_{29} \alpha \alpha \alpha \mathrm{R}=\frac{100 * \mathrm{C}_{29} 5 \alpha, 14 \alpha, 17 \alpha(\mathrm{H}) \text { sterane (20R) }}{\mathrm{C}_{27}+\mathrm{C}_{28}+\mathrm{C}_{29} 5 \alpha, 14 \alpha, 17 \alpha(\mathrm{H}) \text { sterane (20R) }}
\end{aligned}
$$

$$
\frac{\mathrm{C}_{27}}{\mathrm{C}_{29}}=\frac{\mathrm{C}_{27} 5 \alpha, 14 \alpha, 17 \alpha(\mathrm{H}) \text { sterane }(20 \mathrm{R})}{\mathrm{C}_{29} 5 \alpha, 14 \alpha, 17 \alpha(\mathrm{H}) \text { sterane }(20 \mathrm{R})}
$$

$\mathrm{C}_{29} \frac{20 \mathrm{~S}}{20 \mathrm{~S}+20 \mathrm{R}}=\frac{\mathrm{C}_{29} 5 \alpha, 14 \alpha, 17 \alpha(\mathrm{H}) \text { sterane }(20 \mathrm{~S})}{\mathrm{C}_{29} 5 \alpha, 14 \alpha, 17 \alpha(\mathrm{H}) \text { sterane }(20 \mathrm{~S})+\mathrm{C}_{29} 5 \alpha, 14 \alpha, 17 \alpha(\mathrm{H}) \text { sterane }(20 \mathrm{R})}$

$$
\mathrm{C}_{29} \frac{\beta \beta}{\beta \beta+\alpha \alpha}=\frac{\mathrm{C}_{29} 5 \alpha, 14 \beta, 17 \beta(\mathrm{H}) \text { sterane }(20 \mathrm{~S}+20 \mathrm{R})}{\mathrm{C}_{29} 5 \alpha, 14 \beta, 17 \beta(\mathrm{H}) \text { sterane }(20 \mathrm{~S}+20 \mathrm{R})+\mathrm{C}_{29} 5 \alpha, 14 \alpha, 17 \alpha(\mathrm{H}) \text { sterane }(20 \mathrm{~S}+20 \mathrm{R})}
$$

Selected samples $(n=5)$ were chosen for quantification of polycyclic aromatic hydrocarbons (PAHs). Certified deuterated surrogate PAH mixture (Z-014J-0.5x), p- 
Terphenyl-d14 internal standard (M-525-FS-2) and perylene standard solution (H-121S) were purchased from AccuStandard (New Haven, CT, USA). Additional standard mixture EPA 525 PAH Mix A and PAH Mix CRM47543 were purchased from SigmaAldrich (St. Louis, Mo, USA). Standard solutions were refrigerated at $4{ }^{\circ} \mathrm{C}$ until needed. Exactly $5.0000 \mathrm{~g}$ (dry weight) of each powdered sample was weighed and transferred to a cleaned (combusted at $560^{\circ} \mathrm{C}$ for $2 \mathrm{hrs}$ ) 11-dram vial. To validate the extraction method and efficiency, $100 \mu \mathrm{L}$ of the diluted $(1 \mathrm{ng} / \mu \mathrm{L})$ deuterated surrogate $\mathrm{PAH}$ mixture (acenaphthene-d10, chrysene-d12, perylene-d12, phenanthrene-d10) was added to each vial prior to solvent extraction. Then, $10 \mathrm{ml}$ of a 1:9 mixture of $\mathrm{MeOH}$ to $\mathrm{DCM}$ was added to each vial and sonicated for $30 \mathrm{~min}$. Each sample was then centrifuged at 2,000 rpm for 10 min and the sediment-free supernatant transferred to a 4-dram vial. The latter process was repeated with $10 \mathrm{ml}$ 1:9 $\mathrm{MeOH} / \mathrm{DCM}$ fresh solvent and the extracts combined in the 4-dram vial. Following the extraction, activated copper was added to each extract until the copper turned a black color ( $\sim 3-4$ hrs), signifying complete reaction with elemental sulfur after which it was removed. The copper was activated by placing it in $10 \%$ hydrochloric acid $(\mathrm{HCl})$ solution for approximately $5 \mathrm{~min}$ and then washed 3 times with deionized water and three more times with DCM. The total extracts were concentrated by evaporation until almost dry and then solvent-exchanged with $1 \mathrm{ml}$ of hexane. Separation of the aliphatic fraction (F1) from the aromatic fraction (F2) was achieved using a silica gel-packed glass pipette, first eluted with $4 \mathrm{ml}$ of hexane to remove the aliphatic components (F1) and subsequently eluted with $4 \mathrm{ml}$ of DCM (F2). The second fraction (F2) containing the targeted PAHs was evaporated until almost dry and re-dissolved in $100 \mu \mathrm{L}$ of DCM containing the internal standard, p-Terphenyl-d14 (1 
$\mathrm{ng} / \mu \mathrm{L})$. In addition, for quality control purposes, 3 additional samples were prepared following the previous procedure: A method blank containing only the deuterated surrogate PAH mixture $(1 \mathrm{ng} / \mu \mathrm{L})$, a fortified blank containing the deuterated surrogate PAH mixture $(1 \mathrm{ng} / \mu \mathrm{L})$ and the targeted PAH standards $(1 \mathrm{ng} / \mu \mathrm{L})$ and a fortified sample containing a powdered sample, the deuterated surrogate PAH mixture $(1 \mathrm{ng} / \mu \mathrm{L})$ and the targeted PAH standards $(1 \mathrm{ng} / \mu \mathrm{L})$.

The PAH analyses were conducted at the FIU Advanced Mass Spectrometry Facility. Sample injection and GC separation were performed by an Agilent 6890 gas chromatograph equipped with an autosampler and an HP-5MS UI $30 \mathrm{~m}, 0.250 \mathrm{~mm}, 0.25$ $\mu \mathrm{m}$, capillary column using Ultra-pure 6.0 helium as the carrier gas maintained at a constant flow of $1 \mathrm{ml} / \mathrm{min}$. The sample was introduced in splitless mode with a purge time of $1 \mathrm{~min}$. The oven temperature was maintained at $70^{\circ} \mathrm{C}$ for $2 \mathrm{~min}$ and then programmed to increase to $150^{\circ} \mathrm{C}$ at $30^{\circ} \mathrm{C} / \mathrm{min}$ and then to $310^{\circ} \mathrm{C}$ at $4{ }^{\circ} \mathrm{C} / \mathrm{min}$, where it was held isothermally for $10 \mathrm{~min}$. Detection was performed by a single-quadrupole mass spectrometer (Agilent 5973) using EI+ mode. The mass spectrometer was operated under selective ion monitoring (SIM) mode with two or three ions per target PAH or deuterated PAH. A calibration curve was prepared by serially diluting the standard solutions to prepare 6 calibration standards of increasing concentrations: $25 \mu \mathrm{g} / \mathrm{L}, 50 \mu \mathrm{g} / \mathrm{L}, 100 \mu \mathrm{g} / \mathrm{L}$, $500 \mu \mathrm{g} / \mathrm{L}, 1,000 \mathrm{ug} / \mathrm{L}, 3,000 \mu \mathrm{g} / \mathrm{L}$. The internal standard, p-Terphenyl-d14 was introduced by serially diluting the stock solution to yield a concentration of $1000 \mathrm{ug} / \mathrm{L}$. The obtained quadratic calibration equations (all $\mathrm{R}^{2}>0.99$ ) were then used to quantify the unknown samples. Concentrations are reported in nanograms per gram of initial dry weight (5.0000 g) powdered-rock (ng/g dw). The serially diluted EPA 525 PAH Mix A 
was used as an initial calibration verification standard (ICVS), allowing a percent recovery ranging from $80-120 \%$. Analysis of the method blank demonstrated that the analytical system and glassware were free of contaminants (Appendix 6B). Additionally, analysis of the fortified blank established the efficacy of the extraction and separation method with an average percent recovery of $101 \%$ for the primarily targeted analytes (perylene, chrysene and phenanthrene) (Appendix 6B). Furthermore, analysis of the fortified sample showed that influence from matrix-induced bias was not an issue for the targeted analytes (Appendix 6B). Surrogate average recovery calculated from all samples for the three primary deuterated analytes (perylene-d12, chrysene-d12 and phenanthrened10) were $100 \%, 103 \%$ and $77 \%$, respectively.

\subsubsection{Correlation Analysis}

Correlation coefficients were determined for various proxies using Microsoft Office Excel 2013. The correlation coefficient is based on the Pearson's r equation (1896) expressed as:

$$
\operatorname{Correl}(X, Y)=\frac{\sum(x-\bar{x})(y-\bar{y})}{\sqrt{\sum(x-\bar{x})^{2} \sum(y-\bar{y})^{2}}}
$$

Where $\overline{\mathrm{x}}$ and $\overline{\mathrm{y}}$ are the corresponding sample's average. The results of this equation vary from a perfect negative correlation (-1), no correlation (0) to a perfect positive correlation (1). Values in between will be labeled as: $0.1-0.3=$ weak, $0.4-0.6=$ moderate, $0.7-0.9=$ strong.

\subsection{Results}

\subsubsection{Lithology and Fossil Content}

In the field, the El Pujal section generally occurs as a scarp slope topography, cut by obsequent streams that allow easy exposure of the rock sequence of the present study 
(14.29 $\mathrm{m}-85.04 \mathrm{~m})$ (Fig. 6-1D, E). The outcrop is composed of a repetitive series of differentially weathered packets of indurated beds that are followed by soft, more easily weathered beds. The surficial gray (N6) to medium dark gray (N4) coloration of the beds is unvarying throughout but vanishes with depth to the unweathered rock into a grayish black (N2) hue. The lower $25 \mathrm{~m}(14.29 \mathrm{~m}-39.29 \mathrm{~m})$ includes a repetitive series of soft/hard beds with a flaky-fissile weathered surface yet having excellent consolidated condition once the unweathered level is reached below the surface. This sequence intergrades with a $21.15 \mathrm{~m}$-thick $(39.29 \mathrm{~m}-60.44 \mathrm{~m})$ well-indurated rock series, and the uppermost $24.7 \mathrm{~m}(60.44 \mathrm{~m}-85.14 \mathrm{~m})$ of the succession shows a recurrence of the lithology similar to the lower $25 \mathrm{~m}$, but with more extended levels of the softer interbeds between $72.03 \mathrm{~m}$ and $85.04 \mathrm{~m}$ (Fig. 6-2I). Identifiable macrofossils are absent throughout the section, except for occasional unidentifiable ferruginous clumps $(\sim 3-4 \mathrm{~mm})$ and pyritized burrow fillings.

At the microscopic scale changes are inconspicuous revealing a monotonous matrix, however subtle textural and allochem variations are detectable as summarized in photomicrographs of Figure 6-2. Thin section analysis reveals a uniform, kerogen-rich micritic matrix with dispersed pyrite and allochems that rarely exceed $30 \%$ as the hallmark of this interval of the studied El Pujal section. Pyrite is common in less indurated samples and less frequent in more lithified beds (Fig. 6-2R, S). Pyrite grains appear disseminated throughout the samples with framboids infilling burrows and bioclasts, especially benthic foraminifera. Typical bioclasts include benthic and planktic foraminifera (Fig. 6-2A, B, C, D, E, F, G, L, N), echinoid fragments (Fig. 6-2H, I, J), rare ostracods (Fig. 6-2K), roveacrinid fragments (Fig. 6-2M) and rare small sized (300 - 800 


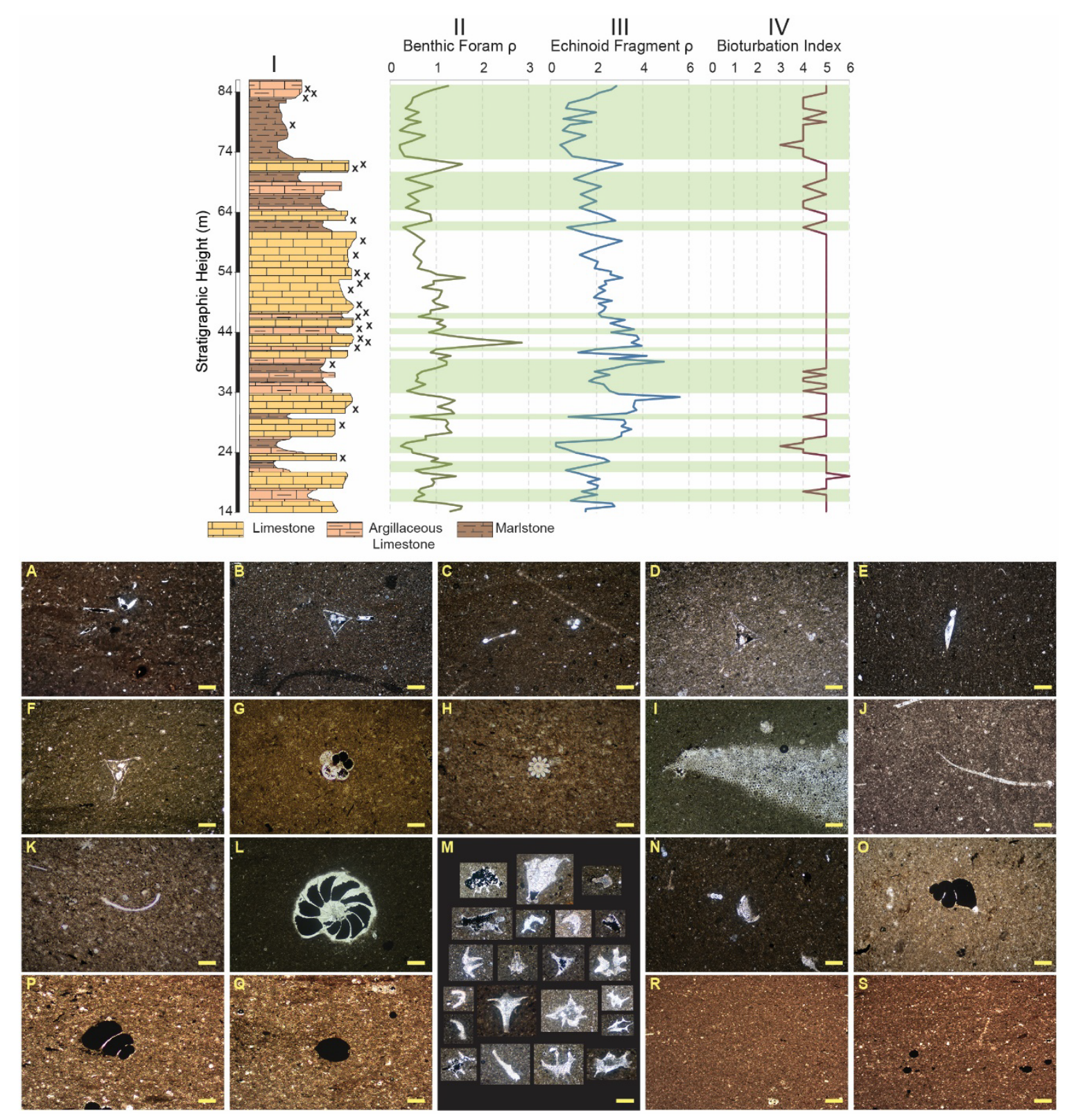

Figure 6-2 I) Simplified lithostratigraphic column depicting the distribution of various lithologies in this $70.75 \mathrm{~m}$-interval covering from $14.29 \mathrm{~m}$ to $85.04 \mathrm{~m}$ of the El Pujal section. Points marked with an X represent intervals where Leupoldina Cabri specimens are present. II-III) Time series counts of benthic foraminifera and echinoid fragments. IV) Bioturbation index following the proposed scheme in Taylor and Goldring (1993). Greenish bands correspond to argillaceous limestone and marlstone intervals. A-S) Thin section images of common microfossils and fragments as well as the rock matrix found throughout this study, scale at $200 \mu \mathrm{m}$. A-F) Images of representative Leupoldina cabri from El Pujal. G) Image of a planktonic foraminfera with chambers partly infilled with pyrite. H) Image of an echinoid spine cut perpendicular to axis. I-J) Images of a large echinoid fragment and spine. K) Image of an ostracod valve. L) Image of a benthic foraminifera with pyritized chambers. M) Images of roveacrinid fragments found throughout this interval. N) Image of an Ammodiscus benthic foraminifera. O-Q) Images of minute gastropods and bivalve generally found in marlsone layers. R) Image of a representative limestone sample, with high bioturbation $(\mathrm{BI}=6)$. S) Image of a representative marlsone sample with low bioturbation $(\mathrm{BI}=$ 3) and abundant pyrite.

$\mu \mathrm{m}$ ) bivalves and gastropods (Fig. 6-2O, P, Q) mostly occurring in marlstone intervals. 
Temporal occurrences of bioclasts vary throughout, but benthic foraminifera $\rho$ and echinoid fragments $\rho$ yield the smallest concentrations at the levels corresponding to marlstone and argillaceous limestones (Fig. 6-2II, III). The bioturbation index (BI) varies between 3 and 6, with minimum values correlative with intervals with the lowest benthic fauna $\rho$ (Fig. 6-2IV).

The index taxon Leupoldina cabri was first identified in the El Pujal sequence in the basal portion of the section at a stratigraphic height of $13.77 \mathrm{~m}$ (Socorro and Maurrasse, 2019), and other specimens (e,g. Fig. 6-2A, B, C, D, E, F) are further identified in this interval $(14.29 \mathrm{~m}-85.04 \mathrm{~m})$ where it occurs at least in 25 samples of the studied section (Fig. 6-2I noted with an X).

\subsubsection{TIC/TOC $/ \delta^{13} \mathrm{C}_{\text {org }}$}

Carbon geochemistry results for this $70.75 \mathrm{~m}$ interval of the El Pujal section are shown in Appendix 6D and Figure 6-3 as follows:

TIC concentrations yield an average of $69.86 \%$ with the lowest value of $54.92 \%$ at 75.93 $\mathrm{m}$ and the highest of $81.46 \%$ at $20.14 \mathrm{~m}$. As previously explained (section 6.3.2), three distinct lithologies are recognized based on the range of TIC values, namely limestones, argillaceous limestones and marlstones (Fig. 6-3A). TIC values (Fig. 6-3B) starting at stratigraphic level $14.29 \mathrm{~m}$ oscillate above and below the average of $70 \%$ up to $46.65 \mathrm{~m}$. Succeeding TIC values increase above the average over an interval of $13.69 \mathrm{~m}$ ending at $60.34 \mathrm{~m}$. Above this level the values begin to fluctuate again within a $24.7 \mathrm{~m}$-interval where they remain primarily below the average $(\bar{x}=64.08 \%)$, except at the levels of two limestone layers at $63.67 \mathrm{~m}$ and $72.03 \mathrm{~m}$, respectively (Fig. 6-3B). In general, TIC has a moderate positive correlation with benthic fauna $\rho$, whereby higher benthic foraminifera 
$\rho(r=0.64)$ and echinoid fragment $\rho(r=0.57)$ occur in limestone layers (Fig. 6-2I, II, III). A similarly moderate correlation occurs between TIC and BI $(r=0.69)$ with higher values in limestone layers, and lower values as low as 3 occurring in marlstone layers (Fig. 6-2IV).

The TOC record (Fig. 6-3C) displays an inverse $(\mathrm{r}=-0.76)$ pattern to that recorded by the TIC curve. Values fluctuate throughout with an average of $1.07 \%$, reaching a minimum of $0.41 \%$ at $72.03 \mathrm{~m}$ and a maximum of $1.83 \%$ at $75.22 \mathrm{~m}$. The lower $24.37 \mathrm{~m}$ interval (14.29 m - 38.66 m) exhibits a fluctuating pattern mostly above average. By contrast, the succeeding $21.68 \mathrm{~m}(38.66-60.34 \mathrm{~m})$ transitions into values that drop below the average. The overlying $11.69 \mathrm{~m}$-interval, between $60.34 \mathrm{~m}$ and $72.03 \mathrm{~m}$, yields TOC values oscillating below and slightly above the average. The end point reaches the lowest value of the studied section, but on the whole this interval yields higher values than the subjacent interval. The remainder $(\sim 13 \mathrm{~m})$ of the studied section shows another relative increase in TOC values consistently above the average $(\overline{\mathrm{x}}=1.42 \%)$ while TIC dips inversely below the average (Fig. 6-3B, C). Also, variations in TOC inversely correlate with fluctuations in benthic foraminifera $\rho(r=-0.56)$ and echinoid $\rho(r=-0.51)$, (Fig. 6-2II, III) whereby these benthic organisms are less frequent in intervals of argillaceous limestones and marlstones, higher in TOC values. A similar inverse relationship occurs between TOC and BI values $(r=-0.68)$, which are lower in intervals of higher organic carbon concentration.

The $\delta^{13} \mathrm{C}_{\text {org }}$ values measured on the bulk organic fraction fluctuate throughout the studied section around an average of $\sim-24.02 \%$ (Fig. 6-3D) and within a range of $1.65 \%$, from a minimum of $-25.09 \%$ o to a maximum value of $-23.44 \%$. The lower part of 


\section{B}

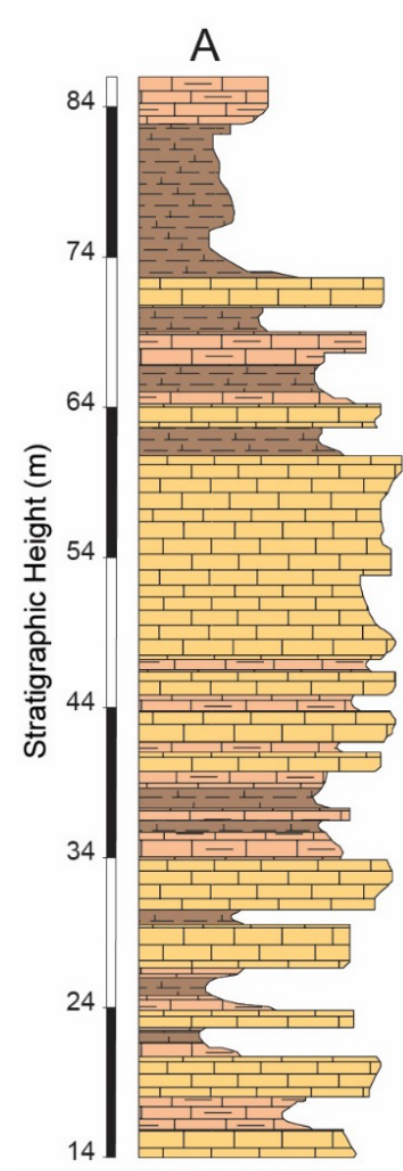

$\operatorname{TIC}\left(\mathrm{CaCO}_{3} \%\right)$

50

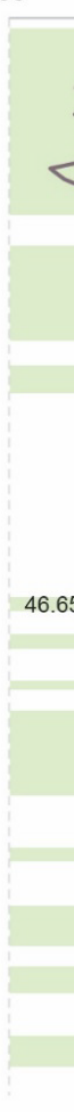

$\begin{array}{cccccc}\mathrm{TIC}\left(\mathrm{CaCO}_{3} \%\right) \\ 60 & 70 \quad 80 & 90 & 0 & \mathrm{TOC}(\mathrm{C} \text { wt } \%)\end{array}$

$\begin{array}{cccccc}\mathrm{TIC}\left(\mathrm{CaCO}_{3} \%\right) & & & \mathrm{TOC}(\mathrm{C} \mathrm{wt} \%) \\ 60 & 70 & 80 & 90 & 0 & 1\end{array}$

C

D

$\mathrm{E}$

1

2

$2 \quad-26$

${ }^{13} \mathrm{C}_{\text {org }}(\%)$

$-23$

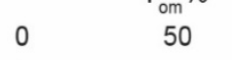

100

Limestone

Figure 6-3 A-D) Stratigraphic variation of carbon geochemical data compared with lithology. Vertical red dashed line represents the average value of the respective variable. Greenish bands correspond to argillaceous limestone and marlstone intervals. E) Relative proportion of terrestrial organic matter derived from a simplified two end-member mixing model utilizing carbon isotope data (refer to discussion). 
the studied section (14.29 $\mathrm{m}-33.3 \mathrm{~m}$ ) yields $\delta^{13} \mathrm{C}_{\text {org }}$ values fluctuating above and below the average with a maximum shift of $0.92 \%$. The following values starting at $33.8 \mathrm{~m}$ to $59.27 \mathrm{~m}(\sim 25.47 \mathrm{~m})$ stay predominantly above the average except for a point at $51.52 \mathrm{~m}$ where the values decrease to $-24.03 \%$. This interval includes the highest carbon isotope value $(-23.44 \%$ ) recorded in the studied section at $52.58 \mathrm{~m}$. The upper $25.7 \mathrm{~m}$ of the section $(59.27 \mathrm{~m}-85.04 \mathrm{~m})$, shows a pattern of $\delta^{13} \mathrm{C}_{\text {org }}$ values consistently below the average, and yields the most negative value $(-25.09 \%)$ in the sequence at $75.22 \mathrm{~m}$ coincident with the highest TOC value (Fig. 6-3C). It is worth noting that the pattern displayed by the $\delta^{13} \mathrm{C}_{\text {org }}$ is somewhat similar to the TIC curve $(\mathrm{r}=0.50)$, however the relationship is inverse with TOC $(\mathrm{r}=-0.46)$. Overall, as illustrated in Figure 6-3, more negative $\delta^{13} \mathrm{C}_{\text {org }}$ values are associated with argillaceous limestone and marlstone intervals that are more enriched in TOC and with lower TIC.

\subsubsection{Elemental Analysis}

Appendix 6E and Figure 6-4 shows temporal variations of relevant major elemental ( $\mathrm{Si}, \mathrm{Al}, \mathrm{Ti}$ ) concentrations which vary in concordance throughout the studied section with highest values in marlstones (Fig. 6-4A, B, C, D). Si has the highest concentration ( $\overline{\mathrm{x}}=$ $38.97 \mathrm{ppm} \cdot 10^{-3}$ ) with values between $20.90 \mathrm{ppm} \cdot 10^{-3}$ and $66.47 \mathrm{ppm} \cdot 10^{-3}$, followed by $\mathrm{Al}$ $\left(\overline{\mathrm{x}}=16.35 \mathrm{ppm} \cdot 10^{-3}\right)$ that fluctuate from a minimum of $9.19 \mathrm{ppm} \cdot 10^{-3}$ to a maximum of $26.14 \mathrm{ppm} \cdot 10^{-3}$. Ti exhibits the lowest concentration with an average of $0.67 \mathrm{ppm} \cdot 10^{-3}$ and values that change from $0.34 \mathrm{ppm} \cdot 10^{-3}$ to $1.19 \mathrm{ppm} \cdot 10^{-3}$. In the basal $18.44 \mathrm{~m}$ portion of the section $(14.0-32.44 \mathrm{~m}), \mathrm{Si}, \mathrm{Al}$, and $\mathrm{Ti}$ show a pattern of values that oscillates above and below the average, nearly consistent with the lithological variations. Fluctuations of these elements reach the lowest recorded values in a limestone layer at 
$32.73 \mathrm{~m}$ (Fig. 6-4A, B, C, D) and continue in a similar pattern of variation up to $47.16 \mathrm{~m}$ (an interval of $\sim 14.43 \mathrm{~m}$ ). Upward, their values stay generally below the average throughout the limestone until $60.34 \mathrm{~m}$, except for two minor spikes at $52.58 \mathrm{~m}$ and 54.7 $\mathrm{m}$, respectively. Above $60.34 \mathrm{~m}$ where marlstone interbeds recur more prominently, Si,

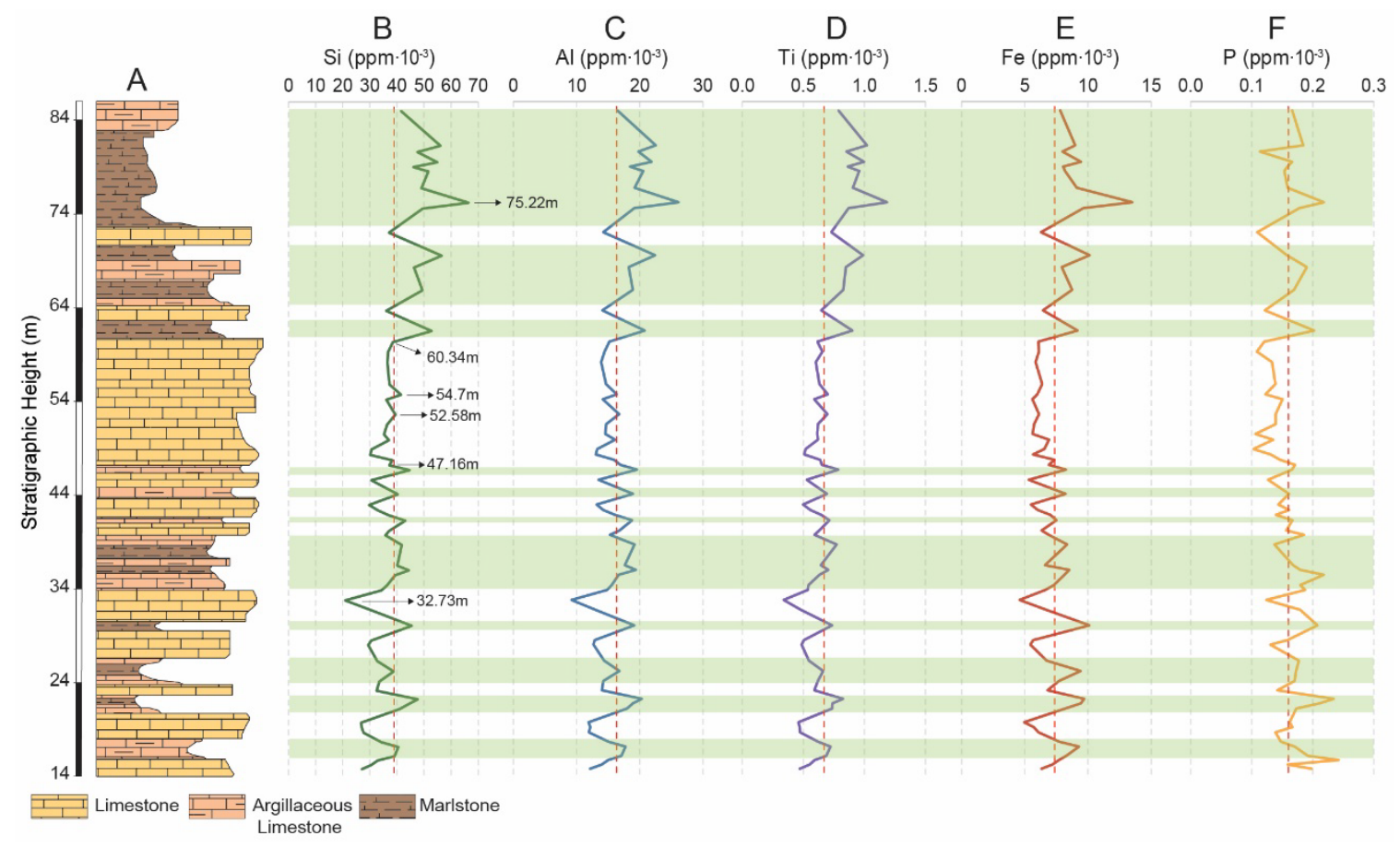

Figure 6-4 A-F) Vertical plots of major elements ( $\mathrm{Si}, \mathrm{Al}, \mathrm{Ti})$ and biolimiting elements (Fe, $\mathrm{P})$ compared with lithology. Values in parts per thousand $\left(\mathrm{ppm} \cdot 10^{-3}\right)$. Vertical red dashed line represents the respective element's average value. Greenish bands correspond to argillaceous limestone and marlstone intervals.

$\mathrm{Al}$, and $\mathrm{Ti}$ fluctuations essentially show a distinct trend above the average with the highest values at $75.22 \mathrm{~m}$ within the thickest marlstone interbed. Overall, $\mathrm{Si}, \mathrm{Al}$ and $\mathrm{Ti}$ show above average concentrations concurrent with argillaceous limestone and marlstone intervals, whereas limestone intervals tend to have below average concentrations. Compared with the carbon geochemistry, these major elements show a strong negative correlation with $\mathrm{TIC}(\mathrm{r}=\mathrm{Si},-0.92 ; \mathrm{Al},-0.91 ; \mathrm{Ti},-0.90)$, a moderate positive correlation with $\mathrm{TOC}(\mathrm{r}=\mathrm{Si}, 0.54 ; \mathrm{Al}, 0.57 ; \mathrm{Ti}, 0.51)$ and a moderate negative correlation with 
$\delta^{13} \mathrm{C}_{\text {org }}$ for $\mathrm{Si}(\mathrm{r}=-0.50)$ and $\mathrm{Ti}(-0.56)$, but a weak negative correlation with $\mathrm{Al}(\mathrm{r}=-$ $0.38)$.

Biolimiting elements (Fe, P) (Fig. 6-4E, F) have a temporal pattern of fluctuation similar to that exhibited by the major elements. Fe shows a strong correlation with $\mathrm{Al}(\mathrm{r}=$ 0.87 ) with values that vary from $4.58 \mathrm{ppm} \cdot 10^{-3}$ to $13.52 \mathrm{ppm} \cdot 10^{-3}$ and average 7.36 $\mathrm{ppm} \cdot 10^{-3}$. $\mathrm{P}$ shows a moderate correlation with $\mathrm{Al}(\mathrm{r}=0.42)$ and its values are lower $(\overline{\mathrm{x}}=$ $0.16 \mathrm{ppm} \cdot 10^{-3}$ ) than those recorded for $\mathrm{Fe}$, as they fluctuate between $0.10 \mathrm{ppm} \cdot 10^{-3}$ and $0.24 \mathrm{ppm} \cdot 10^{-3}$. For the most part, biolimiting elements tend to be enriched in argillaceous limestone and marlstone layers but have lower values in limestone layers. This relationship is highlighted by the strong negative correlation between TIC and $\mathrm{Fe}(\mathrm{r}=$ 0.87), and the moderate negative correlation of TIC with $\mathrm{P}(\mathrm{r}=-0.43)$. Conversely, intervals of higher TOC show higher concentration of $\mathrm{Fe}(\mathrm{r}=0.71)$ and $\mathrm{P}(\mathrm{r}=0.48)$. $\delta^{13} \mathrm{C}_{\text {org }}$ and $\mathrm{Fe}$ shows a negative relationship $(\mathrm{r}=-0.41)$, while $\mathrm{P}$ shows a weak negative correlation $(\mathrm{r}=-0.12)$.

The values for RSTEs ( $\mathrm{V}, \mathrm{Cr}, \mathrm{Co}, \mathrm{Ni}, \mathrm{Cu}, \mathrm{Mo}$ and $\mathrm{U})$ analyzed in this study are shown in Appendix 6E and Figure 6-5. Like the previously reported major elements, the RSTEs all show comparable trends throughout the section, with values in the lower 33.41 $\mathrm{m}(14.29 \mathrm{~m}-47.7 \mathrm{~m})$ fluctuating above and below average of each respective element. Above $47.7 \mathrm{~m}$ and up to $60.34 \mathrm{~m}$ (12.64 m-interval) the limestone shows most RSTE variations within relatively low values (below their respective average), but $\mathrm{Cu}$ has an anomalously high peak at $59.27 \mathrm{~m}$, and Mo increases (Fig. 6-5F, G). Above $60.34 \mathrm{~m}$, the 


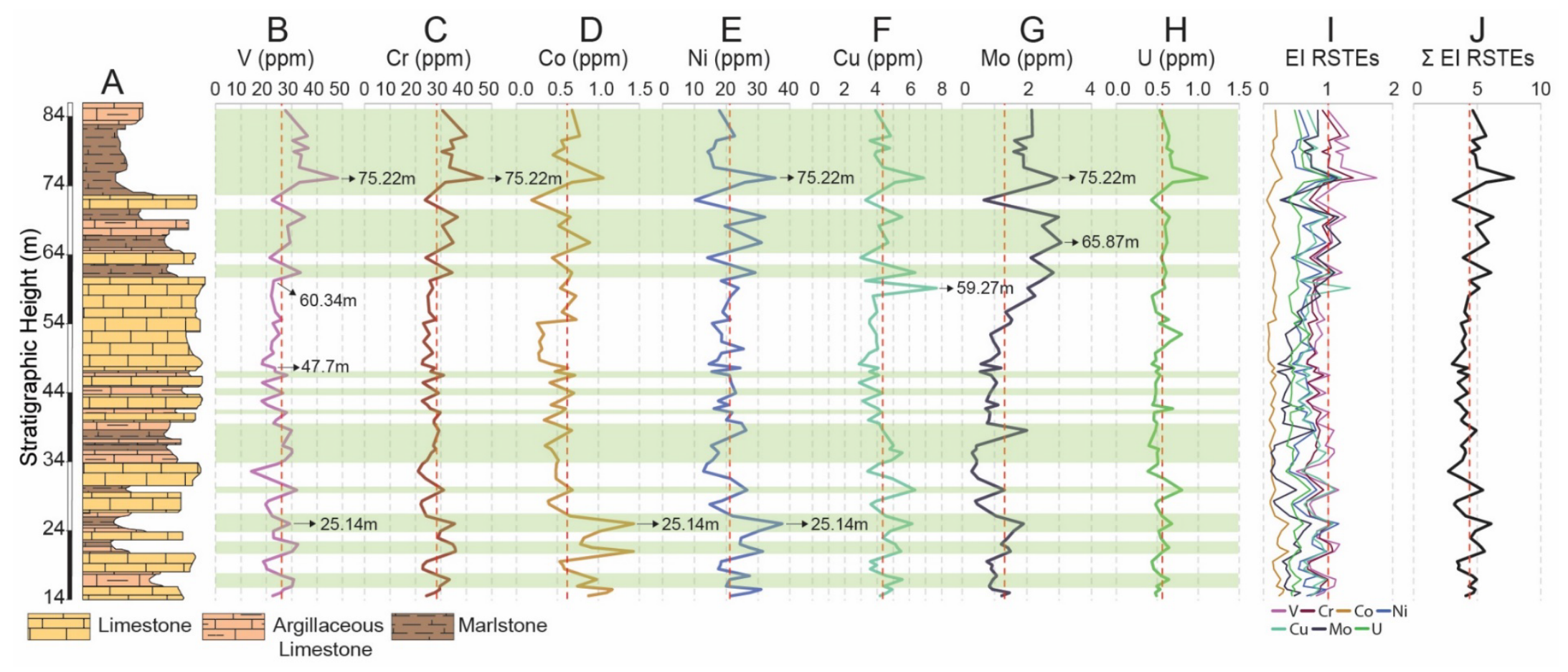

Figure 6-5 A-H) Vertical plots of RSTEs reported as absolute values in parts per million (ppm). I) Vertical plot of RSTEs enrichment indices (EI RSTEs) relative to the Organyà Basin's Average Background Value (OBABV) (for a detailed description refer to the methodology section). 
overlying $24.7 \mathrm{~m}$ of the studied section is characterized by the highest concurrent RSTE concentrations with maximum values of V (48.24 ppm), $\mathrm{Cr}$ (46.48 ppm), and U (1.11 ppm) at $75.22 \mathrm{~m}$ in the uppermost marlstone layer. Similarly, $\mathrm{Co}, \mathrm{Ni}, \mathrm{Cu}$ and $\mathrm{Mo}$ also show significantly higher values at that same level, although their maximum values occured in different previous marlstone beds: 25.14 m (Co, 1.44 ppm; Ni, 37.66 ppm); $59.27 \mathrm{~m} \mathrm{(Cu,} 7.68 \mathrm{ppm})$; and $65.87 \mathrm{~m}(\mathrm{Mo}, 3.06 \mathrm{ppm})$.

Enrichment Indices (EIs) were calculated for each RSTE in an effort to quantify their fluctuations relative to the Organyà Basin's Average Background Value (OBABV). As shown in Figure 6-5, most RSTEs show peaks coinciding with argillaceous limestone and marlstone intervals, while they shift to lower values in limestone layers. Overall, RSTEs fluctuate close to the average, but only a few elements show enrichments above the OBABV (EIs > 1) (Fig. 6-5I, J) and they are mostly correlated with marlstone layers. One such element is $\mathrm{V}$ with consistent enrichments above the OBABV in intervals of high TOC $(r=0.69)$ especially at $75.22 \mathrm{~m}$ where $\mathrm{V}$ content is 1.75 times higher than the background value (Fig. 6-5I). When the EIs are combined (EEIs) (Fig. 6-5J), the pattern simulates the TOC curve $(\mathrm{r}=0.62)$. Conversely, the $\sum$ EIs reflects a strong negative correlation $(r=-0.80)$ with TIC, and a moderate negative correlation $(r=-0.45)$, with $\delta^{13} \mathrm{C}_{\text {org. }}$. A similar negative affinity is present with benthic foraminifera $\rho(\mathrm{r}=-0.53)$, echinoid fragment $\rho(\mathrm{r}=-0.67)$ and $\mathrm{BI}(\mathrm{r}=-0.60)$.

\subsubsection{Clay Mineralogy}

Results of the clay mineral analyses performed on the $<2 \mu \mathrm{m}$ fraction of seven selected samples representative of the different recurrent lithologies are shown in Figure 6-6. The clay fraction is composed of smectite, illite, kaolinite and chlorite, but is 
consistently dominated by illite with percentages between $5 \%$ and $70 \%$, and an average of $63 \%$. No apparent association is visible between lithology and illite, whose abundance shares a weak inverse relation with major elemental concentrations, especially $\mathrm{Al}(\mathrm{r}=$ 0.22). Chlorite is the next most abundant clay as it varies between $4 \%$ and $19 \%(\overline{\mathrm{x}}=$

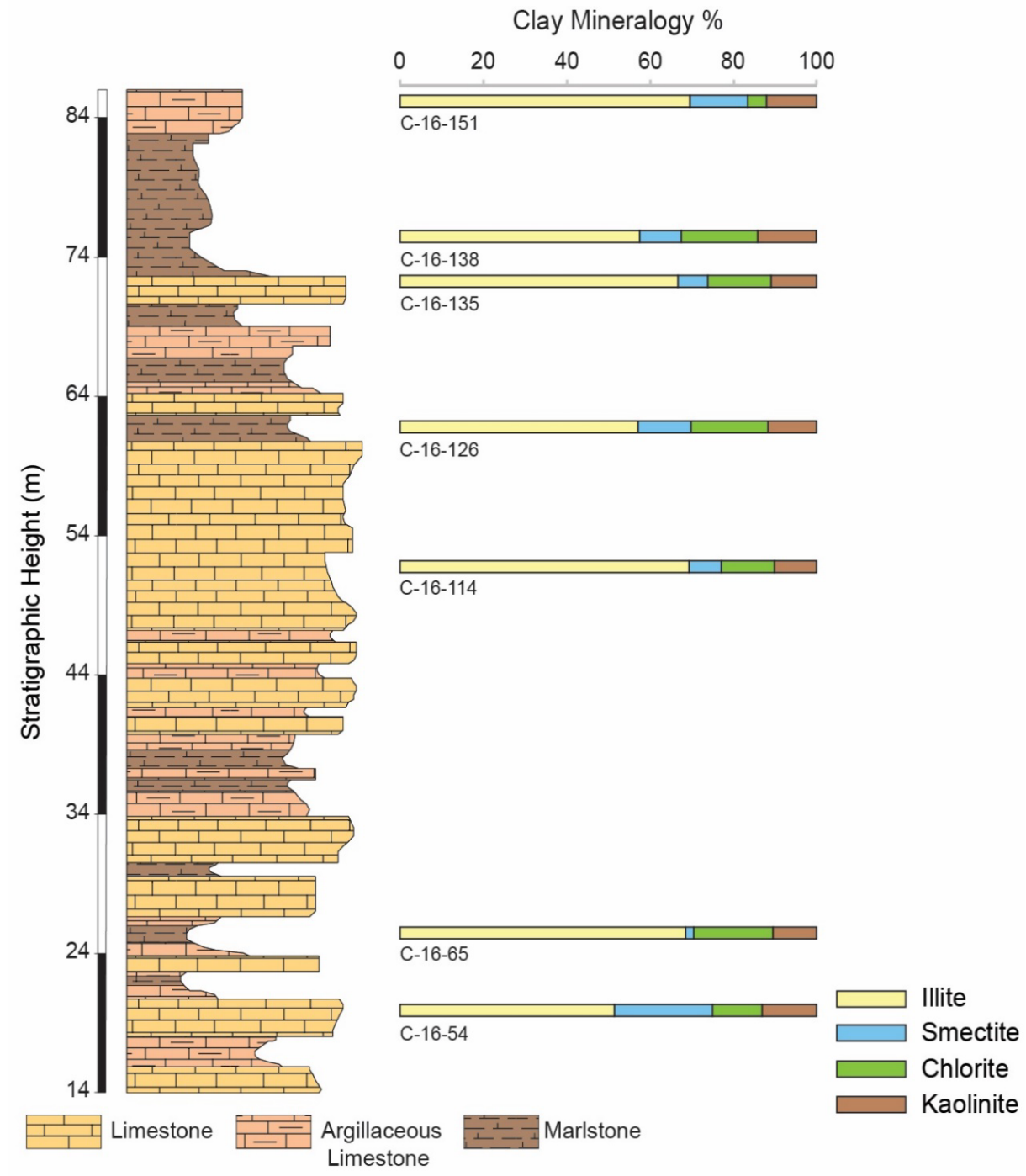

Figure 6-6 Temporal variation in clay mineral content $(<2 \mu \mathrm{m}$ fraction). Selected samples were taken as representative of the various lithologies.

$14 \%)$ and displays a moderate negative association with lithology (TIC) $(r=-0.49)$.

Kaolinite follows with relatively small variability $(10 \%-14 \%, \overline{\mathrm{x}}=12 \%)$ with the higher percentages associated with argillaceous limestone and marlstone intervals. Smectite 
represents the smallest fraction of the clay mineral assemblage and varies between $2 \%$ and $23 \%(\bar{x}=11 \%)$ with higher values in limestone intervals (TIC) $r=0.42$.

\subsubsection{Biomarkers}

Total lipid extracts (TLE) yielded color variations ranging from grayish yellow (5Y 8/4), moderate yellow (5Y 7/6) and moderate olive brown (5Y 4/4) (Fig. 6-7VI). Regardless of extract color intensity, all samples display a bright, light blue (5B 7/6) fluorescence under both long- and shortwave UV radiation (Fig. 6-7VI). Color variations in TLE show a relationship with lithology whereby lighter, grayish yellow extracts are associated with low TOC of the limestone intervals; moderate yellow extracts mainly coincide with argillaceous limestone intervals; and the darkest, moderate olive brown extracts correspond with high TOC, marlstone layers.

Biomarker analysis of the aliphatic portion focused on $n$-alkanes, hopanes $(\mathrm{m} / \mathrm{z}$ 191) and steranes (m/z 217, m/z 218, m/z 259). Figure 6-8 (A-E) shows values obtained for different biomarker parameters. In Figure 6-8E the aliphatic fraction of the studied samples reveals a very low unresolved complex mixture hump (UCM) and is dominated by $n$-alkanes and the acyclic isoprenoids pristane $(\operatorname{Pr})$ and phytane $(\mathrm{Ph})$. The $n$-alkanes display an asymmetric range between $n \mathrm{C}_{10}$ and $n \mathrm{C}_{37}$ with a general unimodal positively skewed distribution. Estimated relative input of terrestrial vs aquatic OM input or Terrestrial Aquatic Ratio (TAR) (Bourbonniere and Meyers 1996) were calculated from the results of the 64 samples analyzed and plotted in Figure 6-8D. TAR $\left(n \mathrm{C}_{27}+n \mathrm{C}_{29}+\right.$ 
$\left.n \mathrm{C}_{31}\right) /\left(n \mathrm{C}_{15}+n \mathrm{C}_{17}+n \mathrm{C}_{19}\right)$ values average 0.27 owing to the predominance of shorter

chain $n$-alkanes $\left(n \mathrm{C}_{15}, n \mathrm{C}_{17}, n \mathrm{C}_{19}\right)$ over the relatively less abundant longer chain

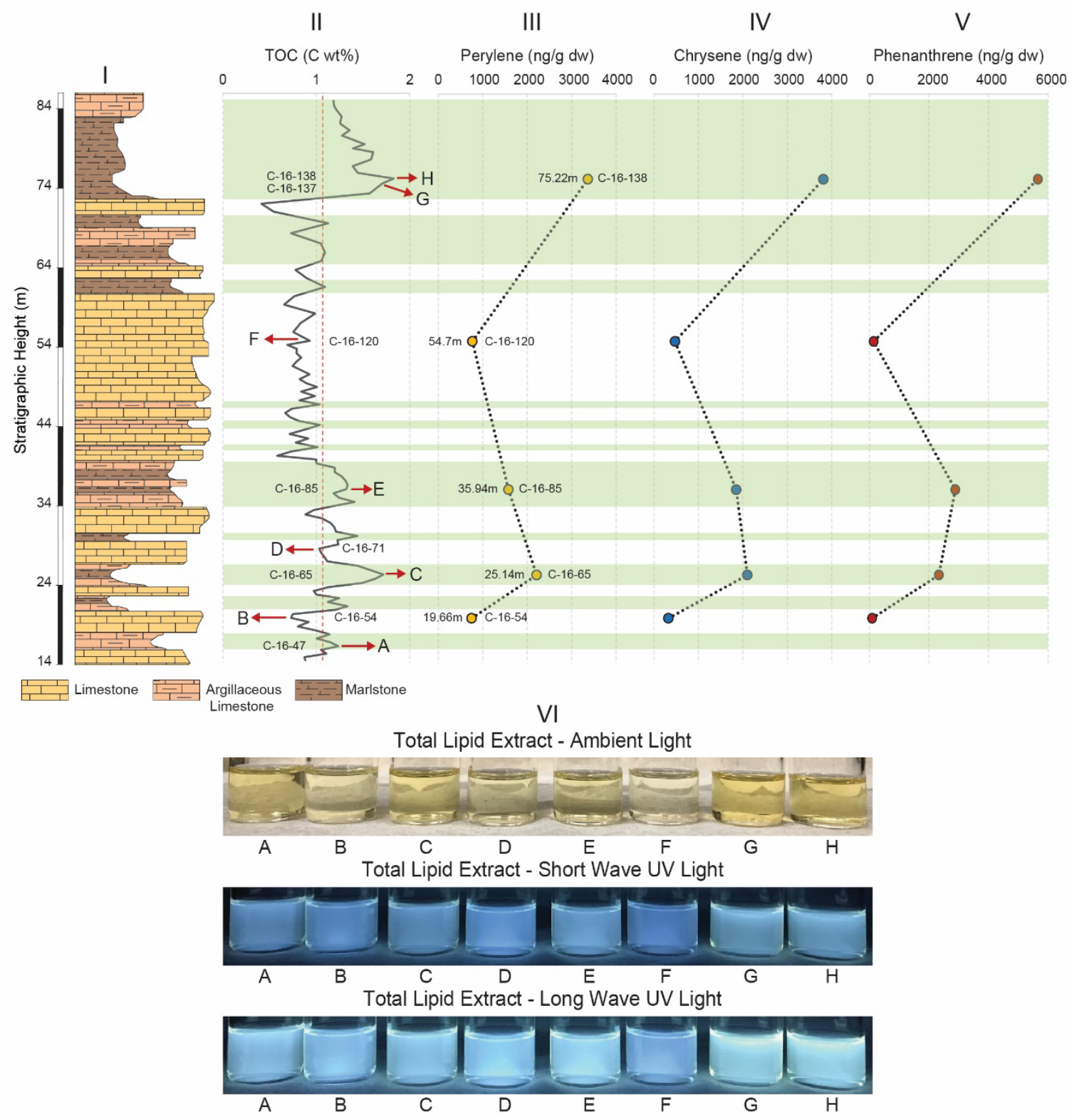

Figure 6-7 I-V) Plots of analyzed PAHs compared with lithology and TOC. VI) Coloration of total lipid extract compared with lithology (I) and TOC (II). Letters A-H next to the TOC curve (II) correspond to letters under images in VI showing images taken under ambient light and both, short wave and long wave UV light. Notice the intensity in lipid coloration varies with lithology and TOC content, with darker yellow extracts in argillaceous limestone and marlstone/higher TOC intervals and lighter yellow extracts in limestone/lower TOC intervals. 


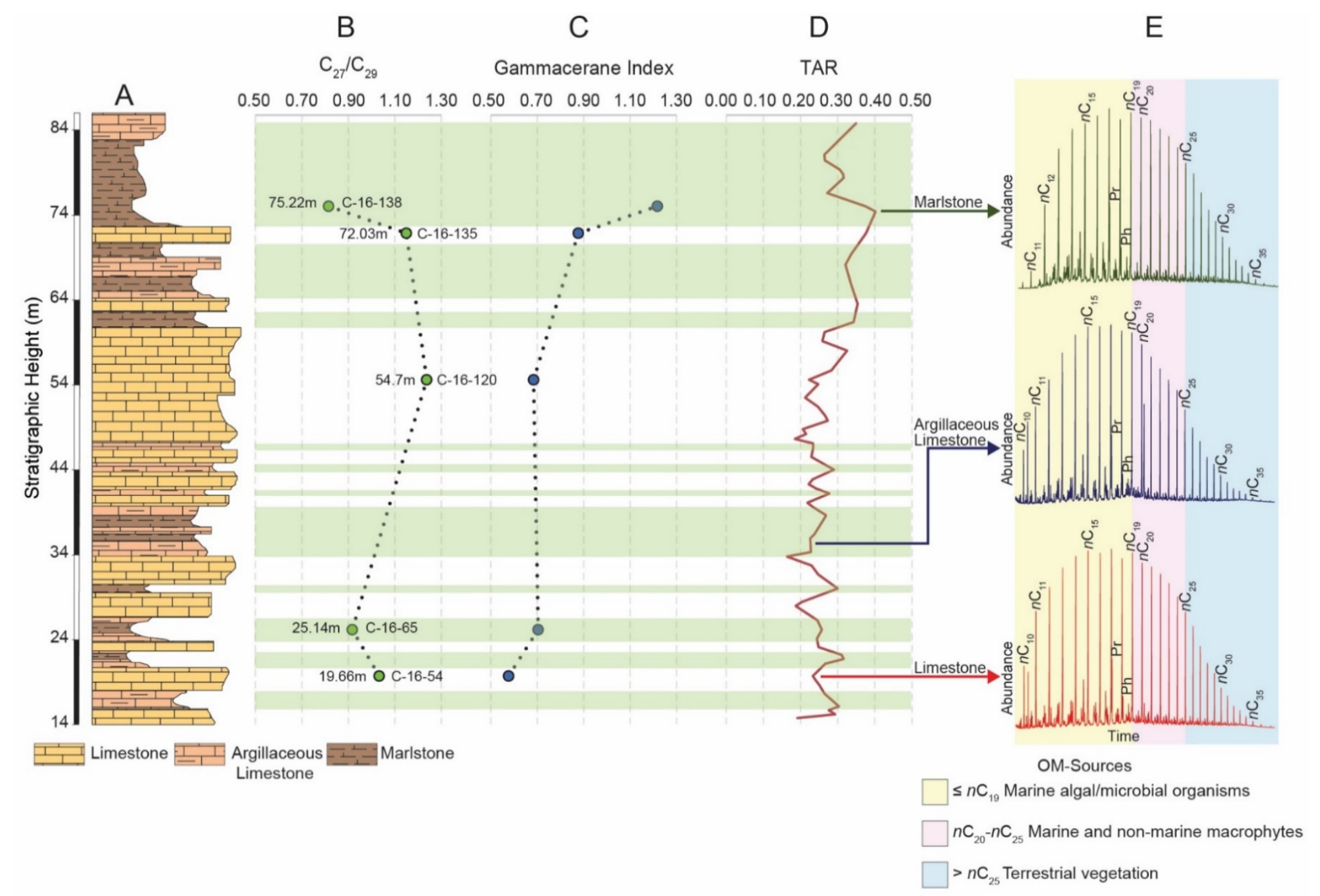

Figure 6-8 A-D) Comparison between lithology and various organic geochemical proxies. E) Representative total ion chromatograms of the aliphatic fraction from the three lithologies. The large peaks in the chromatograms are mainly a homologous series of n-alkanes. Labeled peaks refer to $\mathrm{n}$ alkane's carbon chain length for reference purposes. Peaks labeled as Pr and Ph refer to pristane and phytane, respectively. 
homologs $\left(n \mathrm{C}_{27}, n \mathrm{C}_{29}, n \mathrm{C}_{31}\right)$. When compared with lithologic variations the general trend shows higher TAR values associated with argillaceous limestone and marlstone intervals, while lower values occur in limestone layers. In addition, TOC displays a positive correlation $(r=0.28)$ with TAR values, whereas higher TAR values concur with intervals of lowest $\delta^{13} \mathrm{C}_{\text {org }}$ values $(\mathrm{r}=-0.53)$. As shown in Table 6-2 the longer chain $\left(>n \mathrm{C}_{24}\right) n$ alkanes show no odd-to-even predominance with an average OEP (2) of 1.01 (OEP (2),

Table 6-2 List of biomarker thermal maturity parameters, their corresponding sample number and stratigraphic position.

\begin{tabular}{lccccc}
\hline Sample ID & Height $(\mathrm{m})$ & $\mathrm{Ts} /(\mathrm{Ts}+\mathrm{Tm})$ & $\mathrm{C}_{31} 22 \mathrm{~S} /(22 \mathrm{~S}+22 \mathrm{R})$ & $\mathrm{C}_{29} 20 \mathrm{~S} /(20 \mathrm{~S}+20 \mathrm{R})$ & $\mathrm{C}_{29} \beta \beta /(\beta \beta+\alpha \alpha)$ \\
\hline $\mathrm{C}-16-138$ & 75.22 & 0.74 & 0.56 & 0.46 & 0.63 \\
$\mathrm{C}-16-135$ & 72.03 & 0.79 & 0.58 & 0.48 & 0.67 \\
$\mathrm{C}-16-120$ & 54.7 & 0.64 & 0.58 & 0.45 & 0.64 \\
$\mathrm{C}-16-65$ & 25.14 & 0.72 & 0.60 & 0.44 & 0.62 \\
$\mathrm{C}-16-54$ & 19.66 & 0.69 & 0.54 & 0.46 & 0.61 \\
\hline
\end{tabular}

\begin{tabular}{cc}
$\mathrm{CPI}_{\mathrm{avg}}$ & $\mathrm{OEP}(2)_{\mathrm{avg}}$ \\
\hline 1.05 & 1.01
\end{tabular}

after Scalan and Smith, 1970), and an average carbon preference index (CPI) of 1.05

(CPI, after Bray and Evans, 1961). Both OEP (2) and CPI show no correlative variations with lithology (for a complete list of values refer to Appendix 6C). Among the isoprenoids, pristane to phytane ratios $(\mathrm{Pr} / \mathrm{Ph})$ range from a low of 1.91 to a maximum value of 3.13 and an overall average of 2.55 . Values of Pristane $/ n-\mathrm{C}_{17}$ and Phytane $/ n-\mathrm{C}_{18}$ are relatively low as they average 0.32 and 0.13 , respectively. A plot of Pristane $/ n-\mathrm{C}_{17}$ vs Phytane/n-C ${ }_{18}$ (Fig. 6-9A) shows most samples fall within the mixed type II/III kerogen, and some plotting towards the upper boundary into the terrigenous type III kerogen area.

The hopanoids (m/z 191 chromatograms) show a similar distribution pattern, but with varying proportions depending on lithology. In general, the studied samples are dominated by $\mathrm{C}_{30}$ hopane and $\mathrm{C}_{29}$ norhopane, $18 \alpha-22,29,30$-trisnorneohopane (Ts), $17 \alpha-$ 


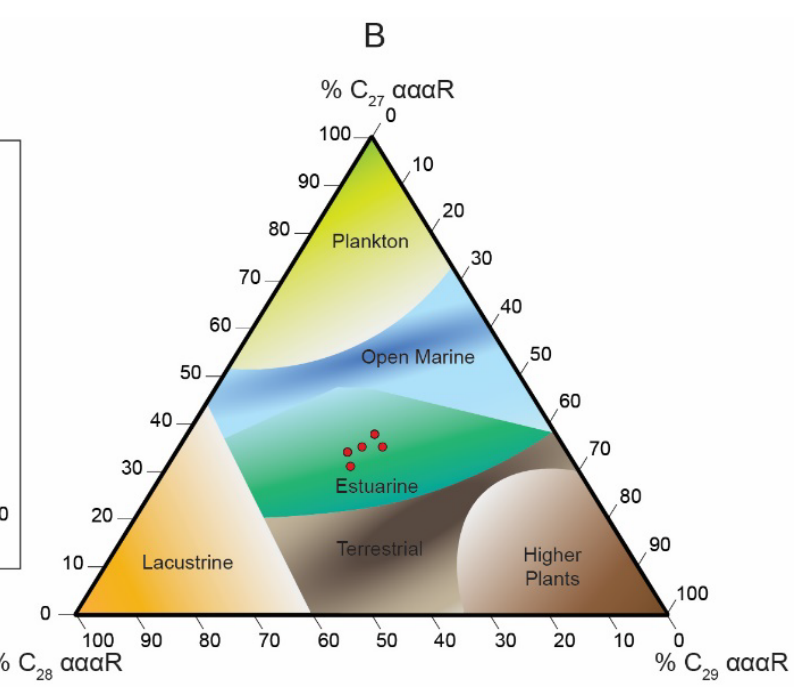

Figure 6-9 A) Cross plot of Pristane/n- $\mathrm{C}_{17}$ vs. Phytane/n- $\mathrm{C}_{18}$ of selected samples. Fields after Shanmugam (1985) from concepts proposed by Lijmbach (1975). B) Ternary diagram showing the sterane composition of selected samples and their relationship with source. Fields after Shanmugam (1985) from concepts proposed by Huang and Meinschein (1979).

22,29,30-trisnorhopane (Tm) and the extended hopanes or homohopanes $\left(\mathrm{C}_{31}-\mathrm{C}_{34}\right)$ (Fig. 6-10, Table 6-3). The $\mathrm{Ts} /(\mathrm{Ts}+\mathrm{Tm})$ ratio ranges from 0.64 to 0.79 , averages 0.72 (Table 62) and shows no particular relationship with lithology. Homohopanes show a distribution from $\mathrm{C}_{31}$ to $\mathrm{C}_{34}$, whereby $\mathrm{C}_{31}>\mathrm{C}_{32}>\mathrm{C}_{33}>\mathrm{C}_{34}$. The $\mathrm{C}_{31}$ and $\mathrm{C}_{32} 22 \mathrm{~S} /(22 \mathrm{~S}+22 \mathrm{R})$

homohopane isomerization ratio yields average values of 0.57 and 0.60 , respectively.

Gammacerane is also present in all the samples where it is usually found eluting just after the $\mathrm{C}_{31}(22 \mathrm{R})$ homohopane isomer. A plot of the gammacerane index (gammacerane/ $\mathrm{C}_{31} \mathrm{R}$-homohopane) shows a general trend with higher values, up to 1.21 in marlstone intervals and lower values (0.58) in limestone intervals (Fig. 6-8C).

Regular steranes and diasteranes occur in all the studied samples ranging from $\mathrm{C}_{27}$ to $\mathrm{C}_{29}$ (Fig. 6-10, Table 6-3). The samples are characterized by having relatively high percentages of $5 \alpha, 14 \alpha, 17 \alpha(\mathrm{H})(20 \mathrm{R}) \mathrm{C}_{27}(\overline{\mathrm{x}}=34.59 \%)$ and $5 \alpha, 14 \alpha, 17 \alpha(\mathrm{H})(20 \mathrm{R}) \mathrm{C}_{29}$ regular sterane $(\alpha \alpha \alpha \mathrm{R})(\overline{\mathrm{x}}=34.02 \%)$, but more moderate values of $5 \alpha, 14 \alpha, 17 \alpha(\mathrm{H})(20 \mathrm{R})$ $\mathrm{C}_{28}$ regular sterane $(\overline{\mathrm{x}}=31.39 \%)$. A ternary diagram of $\alpha \alpha \alpha \mathrm{R}_{27} \%, \alpha \alpha \alpha \mathrm{R} \mathrm{C}_{28} \%$, and 

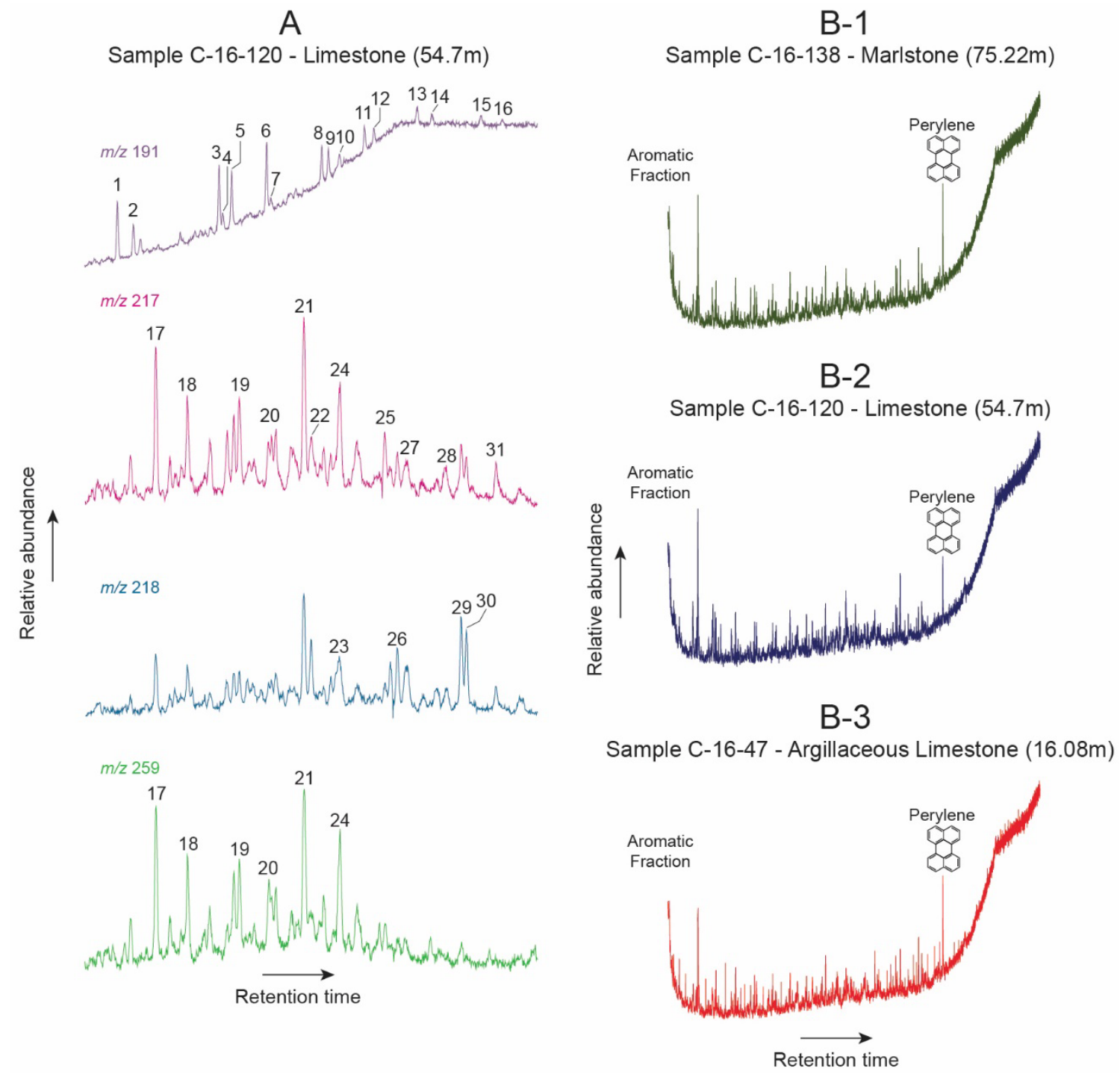

Figure 6-10 A) Trace chromatograms of a representative sample showing the relative distribution of hopanes (m/z 191), steranes (m/z 217 and 218) and diasteranes (m/z 259). For peak identification, refer to Table 6-3. B-1-3) Total ion chromatograms of the aromatic fraction from representative samples of marlstone (C-16-138), limestone (C-16-120) and argillaceous limestone sample (C-16-47) showing the relative abundance of perylene.

$\alpha \alpha \alpha \mathrm{R}_{29} \%$ shows that the samples plot in the general area of estuarine to open marine OM (Fig. 6-9B). A plot of the ratio of $5 \alpha, 14 \alpha, 17 \alpha(\mathrm{H})(20 \mathrm{R}) \mathrm{C}_{27}$ to $5 \alpha, 14 \alpha, 17 \alpha(\mathrm{H})(20 \mathrm{R})$ $\mathrm{C}_{29}\left(\mathrm{C}_{27} / \mathrm{C}_{29}\right)$ reveals values as low as 0.82 for marlstone layers and much higher values, up to 1.24 in a limestone bed at $54.7 \mathrm{~m}$ (Fig. 6-8B). Isomerization of the C-20 stereocenter in the $5 \alpha, 14 \alpha, 17 \alpha(\mathrm{H}) \mathrm{C}_{29}$ regular sterane given as the $20 \mathrm{~S} /(20 \mathrm{~S}+20 \mathrm{R})$ ratio 
Table 6-3 Various biomarker compounds. The numbers are used for compound assignment in Figure $6-10 \mathrm{~A}$.
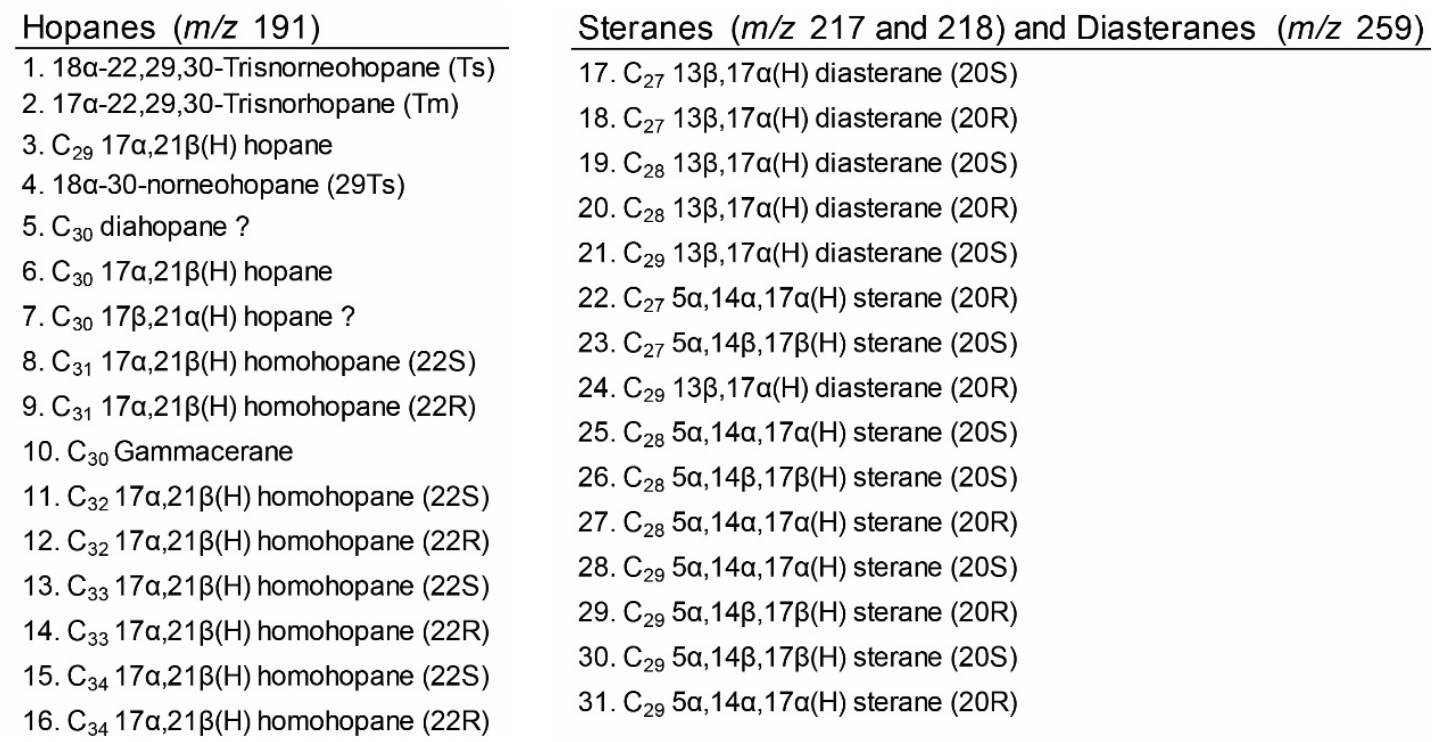

ranges from 0.44 to 0.48 with an average of 0.46 (Table 6-2). Similarly, betaisomerization at $\mathrm{C}-14$ and $\mathrm{C}-17$ in the $5 \alpha, 14 \alpha, 17 \alpha(\mathrm{H}) \mathrm{C}_{29} 20 \mathrm{~S}$ and $20 \mathrm{R}$ regular sterane given as the $\mathrm{C}_{29} \beta \beta /(\beta \beta+\alpha \alpha)$ ratio or $5 \alpha, 14 \beta, 17 \beta(\mathrm{H}) \mathrm{C}_{29}(20 \mathrm{~S}+20 \mathrm{R}) /\left(5 \alpha, 14 \beta, 17 \beta(\mathrm{H}) \mathrm{C}_{29}\right.$ $(20 \mathrm{~S}+20 \mathrm{R})+5 \alpha, 14 \alpha, 17 \alpha(\mathrm{H}) \mathrm{C}_{29}(20 \mathrm{~S}+20 \mathrm{R})$, ranges from 0.61 to 0.67 with an average of 0.64 (Table 6-2).

Three aromatic fractions from samples representative of the three principal lithologies were analyzed because they yielded the yellow color variations and fluorescence previously described. Analysis by full-scan GC/MS reveals that marlstone and argillaceous limestone samples contain elevated concentrations of the pentacyclic aromatic hydrocarbon, perylene (Fig. 6-10B-1, B-3). In contrast, a similar chromatogram from a limestone bed representative sample, displays a relatively depressed perylene peak (Fig. 6-10B-2).

Further analysis of the aromatic fraction focused on the quantification of PAHs. Of particular interest was the concentration of perylene and other PAHs such as chrysene 
and phenanthrene, which were detected in significant concentrations and their results, are reported in Appendix 6B. As presented in Figure 6-7III, the concentration of perylene varies from 747 to $3,365 \mathrm{ng} / \mathrm{g}$ dw with an average value of $1,733 \mathrm{ng} / \mathrm{g} \mathrm{dw}$. The concentration of perylene was higher in an argillaceous limestone (sample: C-16-85: $1,577 \mathrm{ng} / \mathrm{g} \mathrm{dw})$ and in marlstone intervals $(\overline{\mathrm{x}}=2,788 \mathrm{ng} / \mathrm{g} \mathrm{dw})$, but lower in limestone intervals ( $\bar{x}=757 \mathrm{ng} / \mathrm{g} \mathrm{dw})$. Similarly, the concentration of chrysene fluctuates with lithologies between 325 and 3,812 ng/g dw (Fig. 6-7IV) ( $\overline{\mathrm{x}}=1,712 \mathrm{ng} / \mathrm{g}$ dw: limestone: $\overline{\mathrm{x}}$ $=399 \mathrm{ng} / \mathrm{g} \mathrm{dw}$; argillaceous limestone: $1,851 \mathrm{ng} / \mathrm{g} \mathrm{dw}$; marlstone: $\overline{\mathrm{x}}=2,957 \mathrm{ng} / \mathrm{g} \mathrm{dw}$ ). Relatively high concentrations of phenanthrene were also detected with values ranging from $89 \mathrm{ng} / \mathrm{g} \mathrm{dw}$ to $5,654 \mathrm{ng} / \mathrm{g} \mathrm{dw}$ (Fig. 6-7V) and an average of 2,219 ng/g dw. Much like perylene and chrysene, phenanthrene values follow lithologic variations (limestone: $\overline{\mathrm{x}}=114 \mathrm{ng} / \mathrm{g} \mathrm{dw}$; argillaceous limestone: $2,882 \mathrm{ng} / \mathrm{g} \mathrm{dw}$; marlstone: $\overline{\mathrm{x}}=3,992 \mathrm{ng} / \mathrm{g} \mathrm{dw}$ ).

\subsection{Discussion}

\subsubsection{Biomarker Interpretations: Thermal Maturity}

Thermal maturity concerning OM-rich sedimentary rocks is a measure of the degree of heat-driven reactions generally associated with burial, which converts OM to kerogen, petroleum, gas and graphite (Curiale et al., 1989; Peters et al., 2005; 2007). Thermal maturity assessment based on molecular parameters has become common practice in most geochemical studies used as a critical tool similar to conventional methods (e.g. Rock-Eval pyrolysis, vitrinite reflectance) (Peters et al., 2007). Evaluating thermal maturity through biomarker analysis relies on the essential principle of structural modification of compounds from a precursor molecule with biological functions to a thermodynamically stable, molecular fossil (Curiale et al., 1989). In the following, we 
discuss the reliability of the different parameters applicable to evaluate the potential OM thermal maturity of the different lithologies in the $70.75 \mathrm{~m}$ continuing study of the El Pujal section.

One of the simplest molecular-based maturity parameters is the relative abundance of odd versus even carbon numbered $n$-alkanes, CPI, or OEP (2) (e.g. Peters et al., 2005; 2007). This parameter relies on the observation that unaltered lipids derived from terrestrial plant OM yield a predominance of odd over even numbered $n$-alkanes because they can produce a reaction that builds a complex with two-carbon units three times to obtain six, which is then split in half to yield three. Thus, the CPI, or OEP (2) values are significantly above 1 . Thermal degradation brings OEP (2) values close to unity (Bray and Evans, 1961; Eglinton and Hamilton, 1967). The relatively low values for CPI (1.05) and OEP (2) (1.01) recorded in the El Pujal section would thus imply thermally mature OM (Table 6-2). However, the reliability of either CPI or OEP(2) as a strict thermal maturity parameter remains debatable because it can also be affected by a number of factors, including OM source, as well as the environmental conditions in which the source vegetation grew (Luo et al., 2012; Bush and McInerney, 2013; Stroeva et al., 2013; Huang et al., 2016; Zhao et al., 2018a).

Thermal maturity can be further assessed based on the relative thermodynamic stability difference between $\mathrm{C}_{27}$ hopanes, particularly the more stable $18 \alpha-22,29,30$ trisnorneohopane (Ts) and the less stable 17 $\alpha$-22,29,30-trisnorhopane (Tm) (Kolaczkowska et al., 1990). This parameter is reportedly more reliable and is commonly represented as the $\mathrm{Ts} /(\mathrm{Ts}+\mathrm{Tm})$ ratio, whose value increases up to a maximum of 1 as $\mathrm{Tm}$ is completely exhausted during advanced stages of thermal maturation (Peters et al., 
2007). The results obtained for the studied samples yield $\mathrm{Ts} /(\mathrm{Ts}+\mathrm{Tm})$ values consistently $<1$, with an average of 0.72 (Table 6-2), which again suggests that the OM experienced noticeable thermal stress. However, the $\mathrm{Ts} /(\mathrm{Ts}+\mathrm{Tm})$ ratio is also not strictly controlled by thermal maturity, it can be altered depending on variable sources of OM, as well as the presence of clay minerals (McKirdy et al., 1983; Moldowan et al., 1986; Peters et al., 2007). These factors thus constrain the effective use of the $\mathrm{Ts} /(\mathrm{Ts}+\mathrm{Tm})$ ratio to the evaluation of thermal maturity of lithologies with low clay content and consistent $\mathrm{OM}$ sources, prerequisites which are not met for the El Pujal sequence.

Arguably, perhaps the most reliable thermal maturity indicators applicable to the El Pujal rocks are those resulting from isomerization reactions involving the hydrogen atoms at the $\mathrm{C}-22$ position in the homohopane $\left(\mathrm{C}_{31}-\mathrm{C}_{35}\right)$ homolog series (Curiale et al., 1989; Peters et al., 2007). At the C-22 chiral center, the biological form of these homohopanes carry a 22R configuration, which during thermal alteration converts to the $22 \mathrm{~S}$ epimer (Curiale et al., 1989; Peters et al., 2007). The ratio of 22R to 22S, often calculated as $22 \mathrm{~S} /(22 \mathrm{~S}+22 \mathrm{R})$, can be determined for all of the $\mathrm{C}_{31}-\mathrm{C}_{35}$ homohopanes (Peters et al., 2007), but the $\mathrm{C}_{31}$-homohopane is typically the ratio used since variations in the ratio of homopanes $C_{32}$ to $C_{35}$ could occur with higher homologs (Zumberge, 1987; Köster et al., 1997; Pan et al., 2008). The 22S/(22S+22R) ratio rises from 0, ultimately reaching a value of approximately 0.6 at equilibrium (Seifert and Moldowan, 1986; Peters et al., 2007). In the El Pujal section, the $\mathrm{C}_{31}$ homohopane $22 \mathrm{~S} /(22 \mathrm{~S}+22 \mathrm{R})$ ratio varies from 0.54 to 0.60 and has an average value of 0.57 (Table 6-2), which indicates that the samples have probably not exceeded a thermal maturity equivalent to an early stage of the oil window $\left(\sim 50^{\circ} \mathrm{C}\right)$ (Peters et al., 2007). Similarly, isomerization of certain 
steranes can also be used as thermal maturity indicators. Isomerization at the C-20 position in the $5 \alpha, 14 \alpha, 17 \alpha(\mathrm{H}) \mathrm{C}_{29}$ regular sterane shifts from an exclusive $20 \mathrm{R}$ configuration in biologically derived steroid precursors to a $20 \mathrm{~S}$ epimer during thermal alteration (Curiale et al., 1989; Peters et al., 2007). The 20S/(20S+20R) $\mathrm{C}_{29}$ regular sterane ratio for the El Pujal section yielded values that range from 0.44 up to 0.48 with an average of 0.46 (Table 6-2). Since these values are below the equilibrium value of $\sim$ $0.52-0.55$, they also corroborate that $\mathrm{OM}$ in the section reached thermal conditions nearing the early oil window (Seifert and Moldowan, 1986; Peters et al., 2007). In addition, the $\beta \beta /(\beta \beta+\alpha \alpha)$ ratio of $\mathrm{C}_{29} 20 \mathrm{R}$ and $20 \mathrm{~S}$ regular steranes caused by the isomerization of asymmetric centers at the $\mathrm{C}-14$ and $\mathrm{C}-17$ positions is another parameter used as a maturity indicator. The $\mathrm{C}_{29} \beta \beta /(\beta \beta+\alpha \alpha)$ ratio changes from 0 to an equilibrium value of $\sim$ 0.67-0.71 with increasing thermal maturity (Seifert and Moldowan, 1986; Peters et al., 2007). The El Pujal section has $C_{29} \beta \beta /(\beta \beta+\alpha \alpha)$ values of 0.61 to 0.67 with an average of 0.64 , below the calculated equilibrium values. Once more, the values of this thermal proxy concur with the previous criteria indicating that that $\mathrm{OM}$ in the different lithologies reached temperatures not exceeding the early oil window (Peters et al., 2007). The consistency between the biomarker thermal maturity indicators (e.g. plot $\mathrm{f}$ $\mathrm{C}_{29} 20 \mathrm{~S} /(20 \mathrm{~S}+20 \mathrm{R})$ vs $\left.\mathrm{C}_{29} \beta \beta /(\beta \beta+\alpha \alpha)\right)$ (Fig. 6-11) with values below equilibrium endpoints indicate that the sediments probably experienced mild temperatures of $\sim 50^{\circ} \mathrm{C}$ to $60^{\circ} \mathrm{C}$, equivalent to the onset of oil generation. The results permit to deduce that thermal over maturity can be ruled out when interpreting the organic geochemical results of the El Pujal section; hence, as a corollary the preserved biomarker data presumably characterizes the original signals with minor to no alteration. 


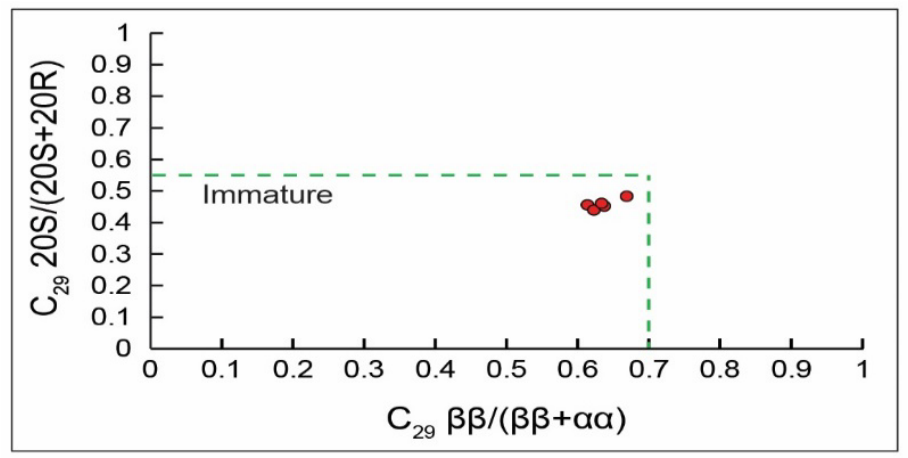

Figure 6-11 Plot of $\mathrm{C}_{29} 20 \mathrm{~S} /(20 \mathrm{~S}+20 \mathrm{R})$ vs $\mathrm{C}_{29} \beta \beta /(\beta \beta+\alpha \alpha)$ thermal maturity indicator values for selected samples. Dashed lines indicate equilibrium values.

\subsubsection{Biomarker Interpretations: Biological Source Evaluation}

$n$-Alkanes are straight chain alkanes or the simplest of a class of organic compounds biosynthesized by a variety of organisms, from microbial phytoplankton of marine and fresh water environments to terrestrial plants. Lipid extracts from extant organisms reveal that frequently shorter chain $n$-alkanes $\left(n \mathrm{C}_{14}-n \mathrm{C}_{19}\right)$ dominate in microbial phytoplankton, while aquatic macrophytes and sphagnum species (peat moss) are enriched in $n \mathrm{C}_{20}$ to $n \mathrm{C}_{25}$, and higher plants have longer chains $\left(>n \mathrm{C}_{25}\right)$, derived from leaf epicuticular waxes (Eglinton and Hamilton, 1967; Han et al., 1968; Winters et al., 1969; Gelpi et al., 1970; Blumer et al., 1971; Cranwell, 1984; Viso et al., 1993; Riederer and Markstädter, 1996; Baas et al., 2000; Ficken et al., 2000; Mead et al., 2005; Koch et al., 2009; Schirmer et al., 2010; Gao et al., 2011). These characteristic differences in carbon chain length produced by various organisms make the distribution of $n$-alkanes in sediments an effective proxy for determining OM sources (Cranwell, 1973; Giger et al., 1980; Meyers, 1997; Forster et al., 2004; Peters et al., 2005; 2007; Brocks and Summons, 2014). The general distribution of $n$-alkanes in the El Pujal section (Fig. 6-8E) ranges from $n \mathrm{C}_{10}$ to $n \mathrm{C}_{37}$, with a positive skew and dominance of mid to short-chain $\left(\leq n \mathrm{C}_{25}\right)$ homologs. Hence, these $n$-alkanes reflect a mixed OM source, dominantly derived from 
microbial phytoplankton and aquatic macrophytes, with a relatively minor, but still noticeable input from terrestrial higher plants. The plot of the values of Pristane $/ n-\mathrm{C}_{17}$ vs Phytane $/ n$-C $\mathrm{C}_{18}$ (Fig. 6-9A) show that most samples fall within the mixed type II/III kerogen indicative of marine and terrestrial environments, thus lending further support to the original source provided by the $n$-alkane chain lengths. Nonetheless, given the possible constraint associated with the use of this ratio because heterotrophic bacteria generally degrade the more labile $n$-alkanes before the isoprenoids, our interpretation relies on the fact that the UCM hump is almost non-existent in the chromatograms, which indicates that biodegradation is at least minimum (Wenger and Isaksen, 2002; Peters et al., 2005).

The $n$-alkane data imply that the OM pattern of mixed origin recorded in the El Pujal lithologies is compatible with typical continental margin environments where sediments archive a complex OM signal with influence from distinct interconnected ecosystems that include rivers, estuaries and the ocean system itself (Méjanelle and Laureillard, 2008; Ramaswamy et al., 2008; Carreira et al., 2010; Schmidt et al., 2010; Bauer et al., 2013; Cordeiro et al., 2018). The present results also concur with previous works in the Organyà Basin (García-Senz, 2002; Sanchez-Hernandez et al., 2014; Sanchez-Hernandez and Maurrasse, 2014, 2016; Socorro and Maurrasse, 2019). While the range of the $n$-alkanes distribution in the chromatograms reveals clues on the various sources of OM supplied to the basin in the studied interval, it does not permit a clear conclusion concerning significant temporal variability with the lithologies because most chromatograms show only subtle differences (Fig. 6-8E). A more distinct delineation emerges when we used the TAR to estimate the relative input of terrestrial vs aquatic OM 
by comparing the relative abundances of short $\left(n \mathrm{C}_{15}, n \mathrm{C}_{17}, n \mathrm{C}_{19}\right)$ and long $\left(n \mathrm{C}_{27}, n \mathrm{C}_{29}\right.$, $n \mathrm{C}_{31}$ ) chain length $n$-alkanes (Bourbonniere and Meyers 1996; Meyers, 1997). The TAR temporal trend shows variation with lithologies (Fig. 6-8D), with elevated values associated with argillaceous limestone and marlstone beds concurrent with peaks in TOC, whereas lower values are in limestone layers. A possible explanation for higher TAR in beds with greater TOC values may be related to the labile characteristics of the type of chain length associated with the source OM. For instance, studies of modern open ocean environments of the Pacific have shown that degradation of plankton-derived OM only allows $\sim 0.1 \%$ to $1 \%$ of the $\mathrm{OM}$ produced in the epipelagic zone to reach the seafloor, and only $\sim 0.01 \%$ actually accumulates in the sediment (e.g. Hernes et al., 2001). In the case of the Organyà Basin, the long-chain homologs having more recalcitrant properties were probably more readily preserved, thus an increase of terrestrially-derived OM with more resistant qualities may explain their higher relative concentration in beds with greater amount of preserved TOC (Cranwell, 1981; Kawamura et al., 1987; Meyers and Eadie, 1993; Meyers, 1997; Hernes et al., 2001). In fact, higher Si, Al, and Ti content (Fig. 6-4) concurrent with stronger terrestrial biomarker signatures in the OM-rich beds supports enhanced fluvial pulses as the principal delivery system of these long chain $n$ alkanes to the basin (e.g. Hedges et al., 1997; Schefuß et al., 2004; Schmidt et al., 2010; Schreuder et al., 2018).

The general phylogenetic specificity of certain steranes makes them also a viable proxy for OM source identification. For instance, while prokaryotic organisms use particular types of hopanoids in their cell walls, all eukaryotic cell walls, particularly the outer membrane, include abundant specific types of sterols. Diagenetic alteration of 
sterols produce steranes as a class of tetracyclic triterpanes (Nes, 1974; Mackenzie et al., 1982; Moldowan et al., 1985; Hartmann, 1998; ; Méjanelle et al., 2000; Schaller, 2003; Volkman, 2003, 2005; Peters et al., 2005; Dufourc, 2008). Commonly, red algae and zooplankton show elevated values of $\mathrm{C}_{27}$ sterols, phytoplankton (green algae, coccolithophores, diatoms) and some fungi are dominated by $\mathrm{C}_{28}$ sterols, while $\mathrm{OM}$ derived from terrestrial plants have higher concentrations of $\mathrm{C}_{29}$ sterols (Huang and Meninshein, 1979; Volkman, 1986; Sailot et al., 1991; Volkman et al., 1998; Volkman, 2003; Peters et al., 2005). In the El Pujal section, the presence of regular steranes ( $\alpha \alpha \alpha \mathrm{R})$ at averages of $\mathrm{C}_{27}(34.59 \%), \mathrm{C}_{28}(31.39 \%)$, and $\mathrm{C}_{29}(34.02 \%)$, further suggests a mixed input of OM from various eukaryotic organisms. A ternary diagram (Fig. 6-9B) of the relative abundances of $\mathrm{C}_{27}, \mathrm{C}_{28}$, and $\mathrm{C}_{29} \alpha \alpha \alpha \mathrm{R}$ steranes shows that the samples plot in the general area of estuarine to open marine OM. These results lend support to the complex nature of OM preserved in the semi-restricted Organyà Basin which accumulated hemipelagic sediments typically derived from both allochthonous terrestrial sources and autochthonous marine sources, consistent with the evidence obtained from the $n$-alkanes distribution (Sikes et al., 2009; Zhang et al., 2014a; O’Reilly et al., 2014). A lithologic relationship also occurs similar to that discussed for the $n$-alkanes. Higher proportion of $\mathrm{C}_{29} \alpha \alpha \alpha \mathrm{R}$ relative to $\mathrm{C}_{27} \alpha \alpha \alpha \mathrm{R}\left(\mathrm{C}_{27} / \mathrm{C}_{29}\right)$ (Fig. 6-8B) is recorded in marlstone beds in further agreement attesting to heightened input of terrestrially-derived plant OM during these intervals. Because these intervals also coincide with higher TAR values together with peaks in $\mathrm{Si}, \mathrm{Al}$ and $\mathrm{Ti}$, thus the sterane record underscores the influence of increased fluvial fluxes associated with deposition of these beds. By comparison with possible modern analogs, perhaps the modern-day East China Sea (ECS) may represent a 
corresponding environment since it is reported that the Cháng Jiāng (Yangtze) River delivers higher amount of $\mathrm{C}_{29}$ sitosterol and stigmasterols during the spring and summer wet seasons (Kim et al., 2016; Duan et al., 2017).

At El Pujal, the approximate duration of the increased terrigenous influence on sedimentation in the Organyà Basin can be estimated using the average thickness of $\sim 3.3$ $\mathrm{m}$ for the argillaceous limestone and marlstone beds. Assuming the highest sedimentation rate of $7.5 \mathrm{~cm} / \mathrm{ky}$ calculated by Sanchez-Hernandez et al, (2014) for earlier deposits also applies at this younger level, these beds translate approximately to 44 kyrs. These intervals with increased terrigenous input therefore indicate that enhanced riverine discharge in the Organyà Basin lasted with frequencies that approach the known Milankovitch cycle (period $\sim 41,000$ years) associated with changes in the obliquity of the earth's axis of rotation (e.g. Hays et al., 1976). Similar duration of regional climatic effects related to insolation-driven forcing of intensified continental runoff have been demonstrated in the Mediterranean area during the latest Miocene (Mayser et al., 2017) and the Pleistocene last interglacial (Wu et al., 2018).

The presence of hopanes, the altered and saturated version of hopanoids, provide useful information on prokaryotic contribution to the preserved OM in the section. Hopanoids are a class of pentacyclic triterpenoids found in the lipid membrane of various prokaryotes, including aerobic-heterotrophic bacteria, anaerobic sulfate-reducing bacteria, and cyanobacteria (Ourisson et al., 1979; 1982; 1987; Ourisson and Rohmer, 1992; Sinninghe Damsté et al., 2004; Härtner et al., 2005; Blumenberg et al., 2006; Peters et al., 2007). Since these hopanoids contain a rigid, amphiphilic structure similar to that of sterols, thus they have comparable structural roles in cells of prokaryotic organisms as 
sterols do in eukaryotic cells (Rohmer et al., 1979). The hopanoids in these bacterial membranes such as bacteriohopanetetrol are biochemically derived from the complex cyclization reaction of squalene precursors (Kannenberg and Poralla, 1999). The diagenetic derivatives of hopanoid lipids are pentacyclic triterpanes containing between 27 to 35 carbon atoms commonly referred to as hopanes (Peters et al., 2007). The presence of hopanes in all the studied samples thus implies that bacteria were also an important source of OM input in the sediments. In addition, all the samples show elevated levels of gammacerane, a non-bacterially derived compound, seen eluting after the $C_{31}$ (22R) homohopane isomer (Fig. 6-10A, Table 6-3). Gammacerane contributes to further our understanding of the biotic factors involved in the supply of OM into the basin

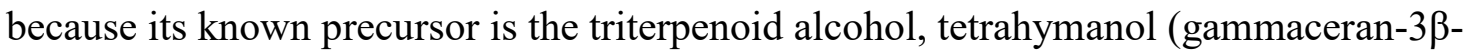
ol) generated through various biochemical mechanisms originating from freshwater and marine ciliates feeding on anaerobic bacteria (Mallory et al., 1963; Venkatesan, 1989; Ten Haven et al., 1989; Harvey and Mcmanus, 1991; Sinninghe Damsté et al., 1995; Harvey et al., 1997; Peters et al., 2007). Usually, these ciliates incorporate sterols derived from a sterol-rich algal diet in their membranes. When their diet is deprived of sterols, they feed on heterotrophic bacterial communities and begin to replace certain sterols in their membranes with tetrahymanol (Conner et al., 1968, 1971; 1982). This is especially true of marine ciliates when they are allowed to feed on natural bacterial communities (Harvey et al., 1997). In modern environments, bacterivorous ciliates occur at the aerobic/anaerobic interface of stratified water columns where chemoautotrophic and purple sulfur bacteria thrive (Zubkov et al., 1992; Guhl and Finlay, 1993; Sinninghe Damsté et al., 1995; Sass et al., 2001; Lin et al., 2006). Therefore, the occurrence of 
gammacerane in the El Pujal samples further provides compelling biomarker evidence of stratification of the water column at that time in corroboration of previous studies of earlier development of the Organyà Basin (Sanchez-Hernandez and Maurrasse, 2014; 2016; Socorro and Maurrasse, 2019). Moreover, temporal variation in gammacerane expressed as the gammacerane index (Fig. 6-8C), with relatively high values up to 1.21 in marlstones and lower values (0.58) in limestones, reveals persistent stratification of the water column.

In summary, the temporal distribution pattern of the biomarkers (Fig. 6-8) concur with the terrestrially derived elements (Si, Al, Ti) (Fig. 6-4) of the studied section to indicate the influence of periodic intensified riverine fluxes on the origin of the sedimentary organic matter.

\subsubsection{Polycyclic Aromatic Hydrocarbons (PAHs) Distribution: Paleo-implications and their Potential as Geochemical Proxies}

During the total lipid extraction (TLE) phase for biomarker analysis, a curious relationship between lithology and extract coloration was observed, whereby lighter grayish yellow (5Y 8/4) extracts were associated with low TOC limestones, whereas moderate yellow (5Y 7/6) extracts coincided with argillaceous limestones, and the darkest, moderate olive brown (5Y 4/4) extracts, corresponded with high TOC marlstones (Fig. 6-7VI). Preliminary GC/MS analysis conducted on the aromatic fractions of a representative sample from each of the three lithologies yielded a pronounced late-eluting perylene peak (Fig. 6-10B-1, B-2, B-3) in concordance with the yellow coloration and the vivid blue fluorescence (Fig. 6-7VI) characteristic of this compound (Forster et al.,2004). 
The pattern of variable temporal presence of perylene in the sediments thus prompted for further investigation of its origin and significance in the Organyà Basin.

Perylene is a five-membered ring $\mathrm{PAH}\left(\mathrm{C}_{20} \mathrm{H}_{12}\right)$ that commonly occurs under a wide range of recent environments, including marine (Orr and Grady, 1967; Wakeham et al., 1979; Soclo et al., 2000; Dahle et al., 2003; Hu et al., 2014; Kumar et al.,2017); lacustrine (Wakeham et al., 1980; Tan and Heit, 1981; Soma et al., 1996; Silliman et al., 1998; Bakhtiari et al., 2009; Itoh and Hanari, 2010; Fan et al., 2011), and fluvial settings (Hites et al., 1980; Countway et al., 2003; Yunker and Macdonald, 2003; Liu et al., 2008). Perylene has also been found in peat, coal (Bergmann et al., 1964; Shan-Tan and Kaplan, 1992; Bechtel et al., 2007), crude oils (Golovko et al., 1999; Scarlett et al., 2019), ancient sediments, and rocks (Louda and Baker, 1984; Baker and Louda, 1986; Garrigues et al., 1988; Venkatesan, 1988; Jiang et al., 2000; Hasegawa, 2001; Forster et al., 2004; Grice et al., 2009; Suzuki et al., 2010; Romero-Sarmiento et al., 2011; Zhang et al., 2014b). Perylenequinone pigments are recognized as the most probable precursor of perylene, and they are largely produced by wood-degrading fungi (Sato, 1976; Griffith and Boddy, 1991; Jiang et al., 2000; Bechtel et al., 2007; Grice et al., 2009; Itoh and Hanari, 2010; Suzuki et al., 2010; Itoh et al., 2012; Marynowski et al., 2013) under very humid conditions (Gilbertson, 1980; Harris, 2001). In most cases perylene exhibits a strong positive relationship with terrestrial OM proxies (Aizenshtat, 1973; Countway et al., 2003; Bertrand et al., 2013; Varnosfaderany et al., 2014; Zhang et al., 2014b), or is directly found in terrestrial material such as peat bogs and fungi-degraded wood (Malawska et al., 2002, 2006; Bechtel et al., 2007; Jiang and Liu, 2008; Marynowski et al., 2013). Some studies have postulated that perylene is from land-derived biological 
precursors, while others have argued that different perylenequinone pigments (e.g. 4,9dihydroxyperylene-3,10-quinone) are the most probable precursors, because of their structural similarities with perylene (Orr and Grady, 1967; Kumada, 1988; Jiang et al., 2000; Itoh et al., 2012). Because perylene is usually found associated with anoxic sediments and is absent, or present only in low concentrations in oxic surface sediments (Choudhary and Routh, 2010) its occurrence also indicates that reducing conditions are involved in its depositional processes, since quinone compounds are sensitive to oxidation (Orr and Grady, 1967; Aizenshtat, 1973).

The perylene concentration in each of the selected El Pujal samples (Fig. 6-7III) revealed a variable pattern linked with lithology: values are higher in argillaceous limestones $(1,577 \mathrm{ng} / \mathrm{g} \mathrm{dw})$ and marlstones $(\overline{\mathrm{x}}=2,788 \mathrm{ng} / \mathrm{g} \mathrm{dw})$ than in limestones $(\overline{\mathrm{x}}$ $=757 \mathrm{ng} / \mathrm{g} \mathrm{dw}$ ). Also, significant positive correlation exist between perylene and the major elements $\mathrm{Al}, \mathrm{Si}$ and $\mathrm{Ti}(\mathrm{r}=0.87,0.84,0.86)$, which is in accord with evidence from biomarker proxies (TAR, $\left.\mathrm{C}_{27} / \mathrm{C}_{29}\right)$ that show a strong relationship $(\mathrm{r}=0.90,-0.88)$ between periods of intensified land-derived OM influx and elevated perylene concentration. Concurrence of these data for the El Pujal section thus provides robust evidence to suggest fluvial transport of land-based OM as the main pathway to supply perylene and /or its biogenic precursors to the Organyà Basin. This assumption is in agreement with modern findings that revealed high perylene abundances in soils (Krauss et al., 2005; Gocht et al., 2007) and in suspended river particles (Luo et al., 2006; Varnosfaderany et al., 2014). The lithological and biomarker characteristics of the El Pujal succession concur that periodic higher riverine discharges delivered increased soil and/or woody debris from forests and wetlands during inundation (Robertson et al., 1999; 
Hilton et al., 2012). Conditions at that time were, perhaps, analogous to the episodic flow and flood pulses (Junk et al., 1989) characteristic of large modern river systems such as the Amazon (e.g. Fisher and Parsley, 1979; Hedges et al., 1986; Junk et al., 1989; Richey et al., 1989; Quay et al., 1992; Junk, 1997; Dunne et al., 1998; McClain et al., 2001; Moreira-Turcq et al., 2003; 2013; Clark et al., 2013). Given that the source of perylene precursors are essentially from terrestrially-derived plant OM of humid climates (e.g. Baldrian and Valášková, 2008; Varnosfaderany et al., 2014), its occurrence in the El Pujal sediments implies a humid climate in the Organyà Basin region during OAE1a. Our data thus confirm previous studies to suggest that perylene may also be used as a dependable proxy of moist and humid continental paleoclimatic conditions (Suzuki et al., 2010; and references herein). Additionally, because the formation of perylene may involve reducing conditions, its highest concentrations (Fig. 5I, Fig. 7III) in marlstones coeval with RSTEs enrichments above the OBABV lends evidence for some degree of recurring reducing conditions related to enhanced riverine discharges of terrestrial OM (Orr and Grady, 1967; Aizenshtat, 1973; Garrigues et al., 1988).

Chrysene $\left(\mathrm{C}_{18} \mathrm{H}_{12}\right.$, composed of four fused benzene rings) and phenanthrene $\left(\mathrm{C}_{14} \mathrm{H}_{10}\right.$, composed of three fused benzene rings) were also found in relatively high concentration (chrysene up to $3,812 \mathrm{ng} / \mathrm{g} \mathrm{dw}$; phenanthrene up to $5,654 \mathrm{ng} / \mathrm{g} \mathrm{dw}$ ) in the same samples that contain perylene. These PAHs are recognized to be widespread constituents of crude oils, coal tar and rock extracts that contain remains of OM (Borrego et al., 1997; Li et al., 2012; Gross et al., 2015; Kashirtsev et al., 2018). Some studies have suggested a diagenetic origin of chrysene from hopanes by cleavage of ring-E and successive aromatization from ring-D to ring-A (Borrego et al., 1997), or by cleavage of 
ring-A and successive aromatization from ring-A to ring-D (Laflamme and Hites, 1979). The distribution pattern of chrysene is concomitant with perylene $(r=0.99)$, which also suggests a connection to a terrestrial precursor. Since chrysene can form from hopanes, whose precursors are hopanoids found in the lipid membrane of various bacteria (Ourisson et al., 1979; 1982; 1987; Ourisson and Rohmer, 1992; Sinninghe Damsté et al., 2004; Härtner et al., 2005; Blumenberg et al., 2006; Peters et al., 2007), its presence suggests that intervals of intermittent intensified input of land-derived nutrients $(\mathrm{Fe}, \mathrm{P})$

(Fig. 6-4E, F) increased in-situ primary productivity which heightened heterotrophic bacteria activities.

Similarly, phenanthrene has been reported to be genetically related to steroids found in non-specific biological source material (Mair, 1964; Greiner et al., 1976; Tissot and Welte, 1984). Given that prevalent humid conditions existed at that time in the area, it is possible that the hygrophilous Hepaticae, which contains large numbers of phenanthrenes (Adam and Becker, 1993; Flegel et al., 1999; Rycroft et al., 1999), are potential source of the precursors. Indeed, the Hepaticae originated in the Ordovician (Wellman et al., 2003), and are reported to have flourished in the Lower Cretaceous (Cantrill, 1997; Limarino et al., 2012; Diéguez et al., 2007; Mendes et al., 2018).

\subsubsection{Significance of Small-sized Mollusks in OM-rich Layers Versus Riverine Fluxes}

In addition to their distinct geochemical characteristics, the OM-rich marlstones also include unusually high concentration of microscopic bivalves $(\overline{\mathrm{x}} \sim 200 \mu \mathrm{m})$ and gastropods ( $\overline{\mathrm{x}} \sim 300 \mu \mathrm{m})$ (Fig. 6-2O, P, Q). These microscopic shells reccur in the Organyà Basin deposits during the time interval under study as well as in the older basal 
13.77 m portion of the El Pujal section (Socorro and Maurrasse, 2019). Their steady small size is of interest because they have apparent similarities in size and morphologies to pteropod shells, but these pelagic mollusks can be ruled out because their known first fossil occurrence is in the middle to late Campanian (Janssen and Goedert, 2016; Janssen and Peijnenburg, 2017). Instead, these minuscule shells are comparable to those found associated with immature veliger larvae of mollusk bivalves and gastropods (Boué and Chanton, 1962). The micro mollusk shells occur exclusively in OM-rich marlstone beds together with gammacerane, a proxy indicative of a well-stratified water column at that time in the Organyà Basin (Sanchez-Hernandez et al., 2014; Sanchez-Hernandez and Maurrasse, 2014, 2016; Socorro and Maurrasse, 2019). Thus, their presence in sediments with elevated values of $\mathrm{Si}, \mathrm{Al}$ and $\mathrm{Ti}$ (Fig. 6-4B, C, D), concomitant with increased inputs of terrestrial OM (Fig. 6-8B, D) and nutrients, establishes their relationship with recurrent heightened riverine fluxes. Hence, these microscopic shells may be interpreted to represent remains of molluscan planktonic larvae that flourished intermittently during wet climatic conditions conducive to unusual molluscan larval production. Such scenario is compatible with the $n$-alkane results for these intervals yielding significant mid-chain length compounds $\left(n \mathrm{C}_{20}-n \mathrm{C}_{25}\right)$ characteristic of aquatic macrophytes (Cranwell, 1984; Viso et al., 1993; Ficken et al., 2000; Mead et al., 2005; Gao et al., 2011) and sphagnum species (Baas et al., 2000). The influence of this type of vegetation is evident in the estuarine $\mathrm{OM}$ signature recorded in the ternary plot of $\% \mathrm{C}_{27}, \% \mathrm{C}_{28}, \% \mathrm{C}_{29} \alpha \alpha \alpha \mathrm{R}$ steranes (Fig. 6-9B). Additional evidence in support of this assumption is found in uppermost Barremian riverine/estuarine deposits of similar age found approximately 30 miles southwest of the El Pujal section in the Montsec chains, which contain abundant 
Montsechia, a primitive aquatic angiosperm (Selden and Nudds, 2012; Gomez et al., 2015). Accordingly, the vegetal fossil record in the adjacent area also demonstrates that sphagnum species and aquatic angiosperms were common in the region in the Early Cretaceous and may have played a major role in the supply of OM to the Organyà Basin.

\subsubsection{Factors Involved in OM Production and Preservation}

The conditions required for the accumulation of OM-rich sediments have been extensively debated in the literature. One of the primary factors is a supply of $\mathrm{OM}$ generated either in-situ by enhanced surface productivity in the photic zone or through a combination of local productivity and fluvial transportation of terrestrial $\mathrm{OM}$ to the marine realm (Suess, 1980; Deuser, 1988; Pedersen and Calvert, 1990; Hedges et al., 1997). Minor amount may also reach the marine environment by aeolian processes (Gagosian et al., 1981; 1986; 1987; Schreuder et al., 2018). However, productivity alone may not be sufficient, as it has been estimated that generally under normal oceanic conditions only approximately $0.1 \%-1 \%$ of the OM produced in the upper water column reaches the seafloor (Hernes et al., 2001; Middelburg and Meysman, 2007). Therefore, in order to increase OM preservation, factors such as reducing conditions with less efficient anaerobic degraders (Demaison and Moore, 1980; Canfield, 1994), rapid burial, grain size, and types of clays also control OM protection. Given that preservation of OM is a complex, multivariable process, unique features of each basin must be taken into account when examining the predominant factors involved in their origin (Suess, 1973; Tanoue and Handa, 1979; Mayer, 1994; Keil et al., 1994a, 1994b; Hedges and Keil, 1995; Bergamaschi et al., 1997; Ransom et al., 1997; Satterberg et al., 2003; Kennedy et al., 2002, 2014). 
In the El Pujal section, substantial amount of preserved OM ( $\bar{x}=1.07 \%)$ occurs throughout the interval under study $(14.29 \mathrm{~m}-85.04 \mathrm{~m})$ with peaks reaching up to $1.83 \%$ (Fig. 6-3C). Since the biomarkers are dominated by shorter chain $n$-alkanes $\left(\leq n \mathrm{C}_{19}\right)$, they indicate that the bulk of the OM was produced in the basin (Fig. 6-8E). As the short chain $n$-alkanes suggest, primary productivity may have been fueled by relatively high concentrations of biolimiting $\mathrm{Fe}\left(\overline{\mathrm{x}}=7.36 \mathrm{ppm} \cdot 10^{-3}\right)$ and $\mathrm{P}\left(\overline{\mathrm{x}}=0.16 \mathrm{ppm} \cdot 10^{-3}\right)(\mathrm{e} . \mathrm{g}$. Hart, 1934; Martin and Fitzwater, 1988; Martin et al., 1990, 1994; Krom et al., 1991; de Baar et al., 1995; Zohary and Robarts, 1998; Boyd et al., 1999, 2000; Diaz et al., 2001; Gervais et al., 2002; Coale et al., 2004; Blain et al., 2007; Moore et al., 2009). The presence of gammacerane distinctive of stratification in the basin, and a lack of siliceous microfossils such as radiolaria imply that upwelling was not a controlling mechanism for the delivery of the critical biolimiting nutrients to the epipelagic zone. Since the temporal distribution of major elemental concentrations parallels that of Fe and P (Fig. 6-4), these critical nutrients were, therefore, apparently supplied together with terrigenous materials via fluvial fluxes sourced from the weathering of crystalline terranes and apatite-bearing Variscan rocks in the watershed (García-Alcade et al., 2002; Ábalos et al., 2002; Sanchez-Hernandez et al., 2014). Moreover, because the presence of perylene concurs adequately with other proxies that imply a humic-rich catchment area was associated with the Organyà Basin, Fe chelation with soil humic and fulvic acids is an alternative pathway for its delivery into the basin. In fact, these chelation complexes are water soluble and allow Fe to be transported from fluvial waters offshore where siderophore ligands released by microorganisms and photodegradation greatly enhances its 
bioavailability (Batchelli et al., 2010; Nieto-Cid et al., 2006; Laglera and van den Berg, 2009; Kuhn et al., 2014; Krachler et al., 2015, 2019).

Intensified biological productivity also produces largely labile OM (Romankevich, 1984; Tissot and Welte, 1984) which may lead to enhanced bacterial degradation and to oxygen-deprived conditions. In fact, intervals of marlstones and argillaceous limestones higher in TOC (Fig. 6-3A, C) reflect some level of oxygen deficiency because they yielded relatively lower benthic faunal counts, lower bioturbation index and higher concentration of pyrite (Fig. 6-2). RSTE values (Fig. 6-5) compared with benthic fauna $\rho$ (Fig. 6-2II, III) also show trends in agreement with fluctuating low oxygenation level in the basin as peaks in these elements coincide with intervals depleted in benthic organisms. Similarly, bioturbation index (BI) and RSTEs exhibit a largely inverse relationship, as indicated by the moderate negative correlation between $\mathrm{V}$ and $\mathrm{BI}(\mathrm{r}=$ 0.57). RSTE values are characteristically lower within intervals with high TIC/low TOC (limestone layers), and more elevated within those with low TIC/high TOC (argillaceous limestones and marlstones). This relationship is further demonstrated by the strong negative correlation between $\mathrm{V}$ and TIC $(\mathrm{r}=-0.92)$ and moderate positive correlation with TOC $(r=0.69)$. Overall, RSTE enrichments beyond the background natural value shown in Figure 6-5 are synchronous with high TOC, consistent with previously discussed oxygenation proxies. Of particular interest is the constant enrichment of $\mathrm{V}$ and $\mathrm{Cr}$ above the OBABV at intervals associated with peaks in TOC, especially in the lowermost $10.85 \mathrm{~m}(14.29 \mathrm{~m}-25.14 \mathrm{~m})$, and the uppermost part of the section. Considering that $\mathrm{V}$ and $\mathrm{Cr}$ are the most easily reduced of the RSTEs, their fluctuating enrichment only at these levels substantiate weakly oscillating reducing conditions 
(Calvert and Pederson, 1993; Li et al., 2015). The absence of RSTE enrichments in the succeeding limestone interval (47.16 m - 60.34 m), which also contains relatively low TOC $(\overline{\mathrm{x}}=0.83 \%)$, signifies a time of improved oxygenation, inducing higher rate of remineralization of the marine snow, hence reducing export production. By contrast, the uppermost $24.70 \mathrm{~m}$ of the section $(60.34 \mathrm{~m}-85.04 \mathrm{~m})$ comprises again OM-rich argillaceous limestones and marlstones with simultaneous enrichments of most RSTEs above the OBABV yielding peaks up to 1.75 times the background natural value as recorded at $75.22 \mathrm{~m}$ (Fig. 6-5I, J). Concurrence of RSTE enrichments with these OM-rich intervals thus provides robust evidence that stronger reducing conditions dominated during the deposition of these beds and contributed to OM preservation. The biochemical processes controlling the amount of OM recorded in the sediments of the Organyà Basin at that time can thus be summarized as resulting from a combination of enhanced OM production associated with terrigenous fluxes supplying biolimiting elements together with abundant land-derived OM. Preservation was influenced by decreased remineralization due to exacerbated oxygen deficiency related to poor vertical mixing of a stratified water body.

In addition to the factors discussed above, as peaks in TOC are associated with argillaceous and marlstone beds which correlate well with major elements, especially Al $(\mathrm{r}=0.57)$ derived from clays, OM preservation must have also involved physicochemical processes related to the enclosing minerals. XRD analysis conducted on the clay fraction $(<2-\mu \mathrm{m})$ reveals illite as the predominant clay mineral $(\overline{\mathrm{x}}=63 \%)($ Fig. 6-6). OM protective sorption is activated onto mineral grains especially clays with high surface areas (Hedges and Keil, 1995), and surface reactivity, unique to its composition. By this 
process $\sim 90 \%$ of the total sedimentary OM from various marine settings cannot be physically separated from its mineral matrix (Hedges and Keil, 1995). Since illite contains exposed Al-OH groups that act as amphoteric points (Eslinger and Pevear, 1988), it is capable of binding negatively and/or positively charged polar organic compounds, physically encapsulating the $\mathrm{OM}$ and preventing bacterial degradation (Chen et al., 2018). Other organic compounds without polar functional groups, such as $n$ alkanes, may also bond to clay minerals through Van der Waals and hydrogen bonding (Keil and Mayer, 2014). In addition to illite, the fraction consisting of smectite ( $\overline{\mathrm{x}}=$ $11 \%)$, kaolinite $(\overline{\mathrm{x}}=12 \%)$ and chlorite $(\overline{\mathrm{x}}=14 \%)($ Fig. $6-6)$ has been demonstrated to show strong affinity to dissolved organic matter associated with phytoplankton biomasses, thereby improving their preservation potential (Satterberg et al., 2003). Besides the physicochemical processes associated with clay minerals, simple increase of suspended sediment loads causing rapid burial is another preservation factor that enhances the export of OM to the sediment by decreasing its exposure time to rapid remineralization.

The OM preserved in the El Pujal section may have also experienced different preservation potentials because of their various sources (Haddad et al., 1992). The biomarker data associated with the OM-rich beds yielded higher proportion of $\mathrm{C}_{29}$ to $\mathrm{C}_{27}$ regular steranes and higher TAR values implying an increase in terrestrially-derived OM (Fig. 6-8B, D), which consists essentially of recalcitrant, nitrogen-free compounds like lignin, cutin and cellulose. These kinds of OM are stable because they have already undergone extensive biological and abiological degradation from source to sink (Cummins and Klug, 1979; De Leeuw and Largeau, 1993; Meyers, 1997). They are often 
bound to clay minerals that result from soil forming processes, hence becoming inaccessible to microbes and thereby increasing their preservation potential as compared to the readily accessible OM generated in-situ (Volkman et al., 1981; Haddad et al., 1992; Meyers and Ishiwatari, 1993; Santos et al., 1994; Jaffé et al., 2001; Holtvoeth et al., 2010).

\subsubsection{Chemo/Biostratigraphic Correlation}

Results of numerous studies of Lower Cretaceous sequences coeval with OAE1a have established correlation in the long-term patterns of variations in carbon isotopic values $\left(\delta^{13} \mathrm{C}_{\text {org }}\right.$ and $\left.\delta^{13} \mathrm{C}_{\text {carb }}\right)$ which have also been integrated in a robust stratigraphic framework (Menegatti et al., 1998; Dumitrescu and Brassell, 2006; Moullade et al., 1998, 2015; Westermann et al., 2013; Gaona-Narvaez et al., 2013a; Sanchez-Hernandez et al., 2014; Sanchez-Hernandez and Maurrasse, 2016; Naafs et al., 2016). The established records of carbon isotope data can, therefore, be used not only as an effective correlation tool (e.g. Scholle and Arthur, 1980; Weissert, 1989; Weissert and Bréhéret, 1991; Menegatti et al., 1998; Herrle et al., 2004; Jarvis et al., 2015), but also as a proxy to recognize changes in the global carbon reservoir associated with major crises (Jarvis et al., 2015) that affected both marine and non-marine environments (Gröcke et al., 1999; Ando et al., 2002).

The high sediment accumulation rate in the Organyà Basin (Sanchez-Hernandez et al., 2014) generated an expanded archive that documents continuous changes that permit high-resolution chemostratigraphic studies of OAEla. Hence, the carbon isotopic data of the Organyà Basin have revealed details of the carbon isotope segments identified with OAE1a not disclosed elsewhere (Fig. 6-12) (e.g. Menegatti et al., 1998; García-Senz, 
2002; Sanchez-Hernandez et al., 2014; Aguado et al., 2014a; Sanchez-Hernandez and Maurrasse, 2014, 2016; Socorro et al., 2017). The present results (70.75 m-portion) of the El Pujal section complement two previous carbon isotopic curves obtained for segment C1 through the early part of C5 from the El Pui section (Sanchez-Hernandez et al., 2014; Sanchez-Hernandez and Maurrasse, 2014, 2016) and the lower $14 \mathrm{~m}$ at El Pujal (Socorro and Maurrasse, 2019). The combined $\delta^{13} \mathrm{C}_{\text {org }}$ data extended at El Pujal show a pattern consistent with the positive plateau equated to segment $\mathrm{C} 5$ and its characteristic shortlived positive spike (Fig. 6-12, point marked with a star) (Socorro and Maurrasse, 2019). Furthermore, the high-resolution $\delta^{13} \mathrm{C}_{\text {org }}$ data enables us to establish in details the variations of segment $\mathrm{C} 5$, beginning with the positive peak recorded at $211.40 \mathrm{~m}$ within the El Pui section (Fig. 6-12F), which differentiates the end of segment C4. The composite curve (Fig. 6-12F) shows a greatly expanded segment C5 starting at El Pui. The upwards extension into the El Pujal section (Fig. 6-12F) permits to subdivide segment C5 into six subsegments. The first subsegment (C5-a) starts at El Pui with a value of $-23.68 \%$ at $211.40 \mathrm{~m}$ and extends over $16.90 \mathrm{~m}$ revealing an overall slight negative trend ending at $228.30 \mathrm{~m}$ with a value of $-24.60 \%$. Subsegment C5-b records a pronounced positive shift of $2.05 \%$ from $228.30 \mathrm{~m}$ at El Pui up to the maximum value of $-22.55 \%$ recorded at a stratigraphic height of $0.55 \mathrm{~m}$ correlated in the El Pujal section (Fig. 6-12F, point marked with a star). Upward subsegment $\mathrm{C} 5-\mathrm{c}, \delta^{13} \mathrm{C}_{\text {org }}$ values progress stepwise to a minimum of $-24.54 \%$ at $26.81 \mathrm{~m}$. In subsegment $\mathrm{C} 5-\mathrm{d}$ the curve fluctuates over a total of $25.77 \mathrm{~m}$, displaying a general positive trend up to a value of $-23.44 \%$ at $52.58 \mathrm{~m}$. Subsegment C5-e extends over $22.64 \mathrm{~m}(52.58 \mathrm{~m}-75.22 \mathrm{~m})$ and shows a progressive decrease in values to a minimum of $-25.09 \%$ at $75.22 \mathrm{~m}$. The final 


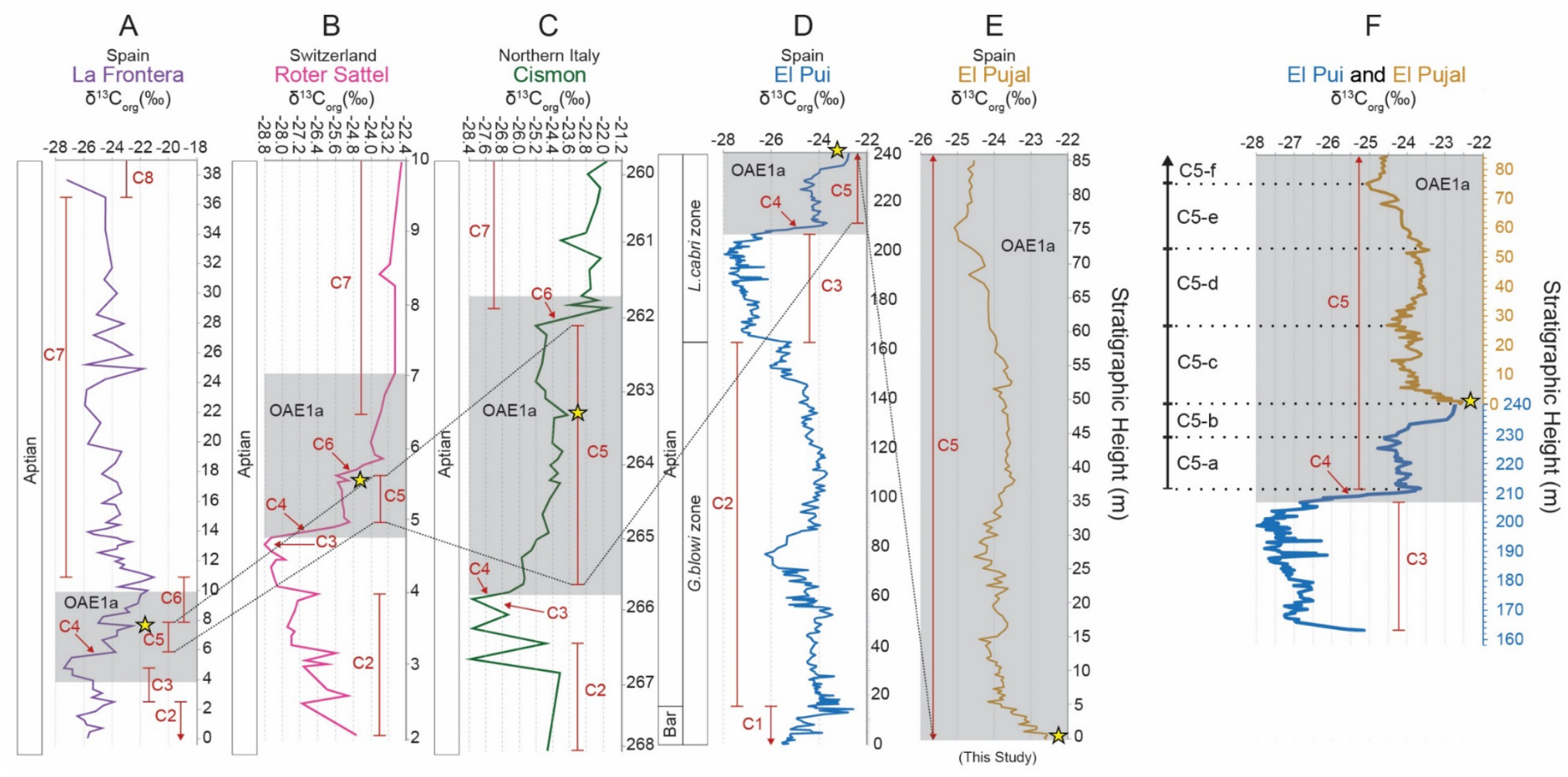

Figure 6-12 A-E) Chemostratigraphic correlation based on $\delta^{13} \mathrm{C}_{\text {org }}$ of the El Pujal section (Socorro and Maurrasse (2019) and this study) with La Frontera (Aguado et al., 2014a,b), Roter Sattel (Menegatti et al., 1998), Cismon (Menegatti et al., 1998) and El Pui (Sanchez-Hernandez and Maurrasse, 2016). The C segments correspond to the subdivisions proposed by Menegatti et al. (1998). The yellow star marks the highest value within segment C5 and corresponds to equivalent points in each section. The gray band indicates the position of OAEla or its equivalent for each section. F) Plot of El Pui and El Pujal $\delta^{13} \mathrm{C}_{\mathrm{org}}$ data with identical vertical and horizontal scales. For a detailed description of labeled subsegments C5-a through C5-f refer to the discussion section. 
subsegment (C5-f) spans from $75.22 \mathrm{~m}$ to $85.04 \mathrm{~m}$, but this interval may include only the initial portion of an overextended C5 because the end of that segment includes a pronounced negative inflection identifiable in sequences elsewhere that is still lacking in the El Pujal data (Fig. 6-12A, B, C). We infer that forthcoming additional $\delta^{13} \mathrm{C}_{\text {org }}$ data in progress in the section will help clarify, and likely disclose the negative shift (e.g. La Frontera (Fig. 6-12A) (Aguado et al., 2014 a, b); Roter Sattel, and Cismon sections (Menegatti et al., 1998) (Fig. 6-12B, C).

Recent biostratigraphic results from lower Aptian successions are in agreement that the occurrence of the index planktonic foraminifer, L.cabri parallels the stratigraphic interval that includes OAE1a (Magniez-Janin et al., 1997; Aguado et al., 1999; Bellanca et al., 2002; Verga and Premoli Silva 2002; Erba, 2004; Coccioni et al., 2006; Heldt et al., 2008; Moullade et al., 2015). The presence of L. cabri throughout the El Pujal section (Socorro and Maurrasse, 2019) (Fig. 6-2I, marked with an X) further corroborates the chemostratigraphic correlation with OAE1a (Fig. 6-12).

\subsubsection{Regional Influence on the Distribution of $\delta^{13} \mathrm{C}$ values of TOC}

The general structure of the $\delta^{13} \mathrm{C}_{\text {org }}$ curve at El Pujal reveals a pattern comparable to the global signature of segment C5 in other sections elsewhere (Fig. 6-12), albeit small regional modulating influences. The minor $\delta^{13} \mathrm{C}_{\text {org }}$ variations in the expanded succession are of particular importance with regards to fluxes of in-situ vs allochthonous OM discussed above, as distinct organisms are known to produce different $\delta^{13} \mathrm{C}_{\text {org }}$ values (Burns and Beardall, 1987; Raven and Johnston, 1991; Ehleringer et al., 1993). It is well established that the $\delta^{13} \mathrm{C}_{\text {org }}$ values of terrestrial C-3 plants are more negative (typically 26\% to -28.5\%) (Bender, 1971; Boutton, 1991; Dawson et al., 2002; Fry, 2006; Kohn, 
2010) than OM produced in the open ocean (generally -21\%o) (Wainright and Fry, 1994). Based on these distinct characteristics we attempt to determine the extent of modulation of the $\delta^{13} \mathrm{C}_{\text {org }}$ values due to the effects of the OM source on the data. The $\delta^{13} \mathrm{C}_{\text {org }}$ values show a moderate negative relationship with TOC $(\mathrm{r}=-0.46)$, with essentially more negative values associated with argillaceous limestone and marlstone beds. Since increases in TAR and higher proportion of $\mathrm{C}_{29} \alpha \alpha \alpha R$ sterane relative to $\mathrm{C}_{27}$ $\alpha \alpha \alpha$ R sterane $\left(\mathrm{C}_{27} / \mathrm{C}_{29}\right)$ (Fig. 6-8B, D) demonstrate the influence of elevated inputs of terrestrial $\mathrm{OM}$ in these intervals, then the regional modulating effect on the $\delta^{13} \mathrm{C}_{\text {org }}$ curve produced by variable OM sources becomes apparent.

To estimate the relative contribution of terrestrial and marine OM in the TOC, the carbon isotope data was used as the basis of a simplified two end-member mixing model (e.g. Calder and Parker, 1968; Shultz and Calder, 1976; Minoura et al., 1997; Schlünz et al., 1999; Hu et al., 2006; Ramaswamy et al., 2008; Xu et al., 2017; Cordeiro et al., 2018).

The equation used: $\mathrm{T}_{\mathrm{om}} \%=\frac{\delta^{13} \mathrm{C}_{\text {marine }}-\delta^{13} \mathrm{C}_{\text {org }}}{\delta^{13} \mathrm{C}_{\text {marine }}-\delta^{13} \mathrm{C}_{\text {terrestrial }}} \times 100$

Where $\mathrm{T}_{\mathrm{om}} \%$ is the percent terrestrial organic carbon, $\delta^{13} \mathrm{C}_{\text {org }}$ is the measured $\delta^{13} \mathrm{C}_{\text {org }}$ of an individual sample, $\delta^{13} \mathrm{C}_{\text {terrestrial }}$ is the $\delta^{13} \mathrm{C}_{\text {org }}$ value of the local terrestrial end member, and $\delta^{13} \mathrm{C}_{\text {marine }}$ is the $\delta^{13} \mathrm{C}_{\text {org }}$ value of the marine end member. The terrestrial end member at $\mathrm{El}$ Pujal was taken as $-25.09 \%$ from a marlstone sample at stratigraphic height $75.22 \mathrm{~m}$, because it includes the lowest $\delta^{13} \mathrm{C}_{\text {org }}$ value recorded in this interval and simultaneously yielded the highest terrestrial OM input previously discussed with the biomarkers. The marine end member was taken as $-23.44 \%$ from a limestone sample at $52.58 \mathrm{~m}$ which has the most positive $\delta^{13} \mathrm{C}_{\text {org }}$ value recorded in this interval and coincides with one of the 
lowest TAR values. Concordance of these parameters should reflect the closest value of marine OM. The results from the end-member mixing model are presented in Figure 6-3E where distinct trends in temporal OM distribution concerning the different lithologies are in accord with other proxies. Note that the results using this approach are approximate, because of the absence of authentic end member $\delta^{13} \mathrm{C}_{\text {org }}$ values for terrestrial vegetation and marine OM.

\subsubsection{Clay Mineralogy vs Paleoclimatic Signals}

A relatively high percentage of illite compared with other clays (Fig. 6-6) characterizes the El Pujal rocks. The lack of variability with depth suggests that illite concentration represents the source composition rather than diagenetic effects (Weaver, 1958). As the condition of thermal maturity from biomarker data suggests, the sediments experienced temperatures equivalent to the onset of oil generation $\left(\sim 50^{\circ} \mathrm{C}-60^{\circ} \mathrm{C}\right)$, which is too low to initiate smectite illitization (Cuadros and Linares, 1996; Kübler and Jaboyedoff, 2000; Du et al., 2019). The high abundance of illite may find its source from low grade terranes of mica-rich metamorphic rocks related to the Hercynian orogeny that are abundant in the Pyrenees (Guitard, 1970; Wickham et al., 1987). Illite also lacks correlation with lithology, which implies that its concentration represents the constant background clay mineral input from terrigenous fluxes of the adjacent eroding landmasses. By contrast, smectite increases in limestones while kaolinite is prevalent in marlstones (Fig. 6-6), which suggests that their variation is mostly controlled by the modulating effects of weathering processes (Biscaye, 1965; Griffin et al., 1968; Singer, 1984; Eslinger and Pevear, 1988; Chamley, 1989; Weaver, 1989; Bühmann and Schoeman, 1995). Here, kaolinite and smectite are interpreted as products of soil 
weathering under pulses of contrasting climate regimes, humid versus dry, respectively (Weaver, 1989; Wilson, 1999). Chlorite concentration also varies with lithology as higher values occur in marlstones relative to limestones (Fig. 6-6). Co-variation of kaolinite and chlorite seems to be inconsistent because these two clay minerals form under dissimilar conditions (Chamley, 1989). Their simultaneous occurences therefore suggest two distinct sources, from the mechanical weathering of low-grade metamorphic terranes in the headwater catchment areas, while kaolinite originated from mature soils that likely developed in the watersheds. Thus, periods of enhanced fluvial discharge associated with a more humid climate are also reflected in the deposition of argillaceous limestone and marlstone intervals with higher kaolinite and chlorite content.

\subsection{Conclusions}

The El Pujal section of the Organyà Basin provided the opportunity for a highresolution geochemical study of a unique expanded hemipelagic facies of continuous sediment accumulation. The results of the multiproxy study on a continuous $70.75 \mathrm{~m}$ portion of the section reveal intricate details archived in the sediments as specific responses of the basin to perturbations of the global carbon cycle associated with OAE1a.

- Deposits during the studied interval consist of a repetitive sequence of limestones, argillaceous limestones and marlstones with varying proportions of $\mathrm{OM}$, carbonate and siliciclastic materials indicative of changing hydrologic conditions.

- New biomarker evidence of reliable sterane $\left(\mathrm{C}_{29} 20 \mathrm{~S} /(20 \mathrm{~S}+20 \mathrm{R})\right.$ and $\left.\mathrm{C}_{29} \beta \beta /(\beta \beta+\alpha \alpha)\right)$ and hopane $\left(\mathrm{C}_{31} 22 \mathrm{~S} /(22 \mathrm{~S}+22 \mathrm{R})\right)$ thermal maturity indices with values below equilibrium endpoints suggest that sediments probably experienced mild temperatures of $\sim 50^{\circ} \mathrm{C}$ to $60^{\circ} \mathrm{C}$, equivalent to the onset of oil generation. Thermal over maturity 
can thus be ruled out when interpreting the organic geochemical results of the El Pujal section. Therefore, the preserved organic geochemical data characterizes the original signals with minor to no alteration.

- The presence of $n$-alkanes ranging from $n \mathrm{C}_{10}$ to $n \mathrm{C}_{37}$ regular steranes $(\alpha \alpha \alpha \mathrm{R})$ at averages of $\mathrm{C}_{27}(34.59 \%), \mathrm{C}_{28}(31.39 \%)$, and $\mathrm{C}_{29}(34.02 \%)$ and hopanes in all the studied samples demonstrates a mixed source of OM from in-situ primary production, bacteria, aquatic macrophytes and terrestrial vegetation. The relative abundances of $\mathrm{C}_{27}, \mathrm{C}_{28}$, and $\mathrm{C}_{29} \alpha \alpha \alpha \mathrm{R}$ steranes shows that the samples plot in the general area of estuarine to open marine OM. The results lend support to the complex nature of OM preserved in the semi-restricted Organyà Basin that derived from both autochthonous marine sources and allochthonous sources including aquatic macrophytes from coastal estuaries and terrestrial vegetation that likely flourished in the floodplain of rivers and streams that emptied into the Basin. Also, elevated levels of gammacerane in all the samples provides compelling biomarker evidence of stratification of the water column at that time in corroboration of previous studies of earlier development of the Organyà Basin. The stratigraphic distribution of the biomarkers coincides with the terrestrially derived elements $(\mathrm{Si}, \mathrm{Al}, \mathrm{Ti})$ to indicate the influence of periodic intensified riverine fluxes on the origin of the sedimentary organic matter.

- Appraisal of the aromatic lipid fraction revealed elevated concentrations of perylene and a variable pattern with higher values in argillaceous limestones $(1,577 \mathrm{ng} / \mathrm{g} \mathrm{dw})$ and marlstones $(\overline{\mathrm{x}}=2,788 \mathrm{ng} / \mathrm{g} \mathrm{dw})$ and lower ones in limestones $(\overline{\mathrm{x}}=757 \mathrm{ng} / \mathrm{g} \mathrm{dw})$. Concurrence of elevated values of perylene with higher contents of major elements provides robust evidence to suggest fluvial transport of land-based $\mathrm{OM}$ as the main 
pathway to supply perylene and /or its biogenic precursors to the Organyà Basin. Considering that the source of perylene precursors are essentially from terrestriallyderived plant OM of humid climates its occurrence in the El Pujal sediments implies a humid climate in the Organyà Basin region during OAE1a. Our data thus confirm previous studies to suggest that perylene may also be used as a dependable proxy of moist and humid continental paleoclimatic conditions. Since the formation of perylene may involve reducing conditions, its highest concentrations in marlstones coeval with RSTEs enrichments lends evidence for some degree of recurring reducing conditions related to enhanced riverine discharges of terrestrial OM.

- The aromatic fraction also revealed relatively high concentrations of phenanthrene, up to $5,654 \mathrm{ng} / \mathrm{g} \mathrm{dw}$ and chrysene, up to $3,812 \mathrm{ng} / \mathrm{g} \mathrm{dw}$, in the same samples that contain perylene. We postulate that the hygrophilous Hepaticae, which contains large numbers of phenanthrenes are potential source of the precursors as they are reported to have flourished in the Lower Cretaceous of the area. In addition, the presence of chrysene that can form from hopanes, whose precursors are hopanoids of bacterial lipid membranes, its presence suggests that intervals of intermittent intensified input of land-derived nutrients $(\mathrm{Fe}, \mathrm{P})$ increased in-situ primary productivity, which heightened heterotrophic bacteria activities.

- Unusual micro mollusk shells occur only in OM-rich beds together with gammacerane indicative of a well-stratified water column. They are interpreted as remains of molluscan planktonic larvae that flourished intermittently during wet climatic conditions and were likely flushed from adjacent swamps and estuaries, in 
accord with the $n$-alkane results for these intervals yielding significant mid-chain length compounds $\left(n \mathrm{C}_{20}-n \mathrm{C}_{25}\right)$ characteristic of aquatic macrophytes.

- The biomarkers are dominated by shorter chain $n$-alkanes $\left(\leq n \mathrm{C}_{19}\right)$, thus indicating that the bulk of the OM was produced in the basin. As the short chain $n$-alkanes suggest, primary productivity may have been fueled by relatively high concentrations of critical biolimiting Fe and P. At the same time, RSTE enrichments are coeval with OM-rich intervals, thus providing robust evidence that stronger reducing conditions dominated at these times and contributed to OM preservation. Therefore, preservation was influenced by decreased remineralization due to oxygen deficiency related to poor vertical mixing of a stratified water body. Physicochemical processes associated with clay mineral adsorption, enhanced by recalcitrant $\mathrm{OM}$ from terrestrial vegetation and rapid burial were also preservation factors that enhanced the export of $\mathrm{OM}$ and their preservation.

- The combined $\delta^{13} \mathrm{C}_{\text {org }}$ data extended at El Pujal show a pattern consistent with the positive plateau equated to segment $\mathrm{C} 5$ and its characteristic short-lived positive spike, but the studied interval may comprise only part of an overextended C5 because elsewhere the end of that segment includes a pronounced negative inflection that is still lacking in the El Pujal data. The presence of L. cabri throughout the El Pujal section also corroborates the chemostratigraphic correlation with OAE1a.

- Increases in TAR and higher proportion of $\mathrm{C}_{29} \alpha \alpha \alpha \mathrm{R}$ sterane relative to $\mathrm{C}_{27} \alpha \alpha \alpha \mathrm{R}$ sterane $\left(\mathrm{C}_{27} / \mathrm{C}_{29}\right)$ demonstrate the influence of elevated inputs of terrestrial OM in marlstone intervals, producing a regional modulating effect on the $\delta^{13} \mathrm{C}_{\text {org }}$ curve due 
to variable OM sources. A two end-member mixing model of terrestrial and marine OM confirms the relationship between TOC and the values of the carbon isotope data.

- Illite is the dominant clay mineral throughout implying steady input from terrigenous fluxes of the adjacent eroding landmasses where it apparently derived from low-grade terranes of mica-rich metamorphic rocks related to the Hercynian orogeny. Periods of enhanced fluvial discharge associated with a more humid climate are also reflected in the deposition of argillaceous limestone and marlstone intervals with higher kaolinite and chlorite content.

The combined results of this study on the $70.75 \mathrm{~m}$ portion of the El Pujal section further highlight how the specific responses of a semi-restricted basin modulated the superimposed effects of global forcing factors and determined the fundamental sedimentary expression of OAE1a.

\subsection{Acknowledgements}

This study is made possible thanks to financial support from the Glenn A. Goodfriend Memorial funds. We particularly acknowledge the help and technical support of Diane Pirie with instrumentation troubleshooting and for maintaining our FIU labs stocked with supplies. We thank Peter Swart and Amel Saied at the Rosenstiel School of Marine and Atmospheric Sciences (RSMAS) for the carbon isotope analyses, Cesar Ramirez and Mario Gomez at FIU's Advanced Mass Spectrometry Facility for their help with biomarker analyses, and Sarah Jantzi at FIU's Trace Elements Analytical Facilities (TEAF) for her help with the LA-ICP-MS. The Earth and Environment Department at FIU generously provided supplies and other laboratory materials. 


\subsection{References}

Ábalos, B., Carreras, J., Druguet, E., Escuder Viruete, J., Gómez Pugnaire, T., Lorenzo Alvarez, S., Quesada, C., Rodríguez Fernández, L.R., Gil-Ibarguchi, J.., 2002. Variscan and Pre-Variscan Tectonics., in: Gibbons, W., Moreno, T. (Ed.), The Geology of Spain. The Geological Society of London, pp. 155-185.

Adam, K.P., Becker, H., 1993. Phenanthrenes and other phenolics from in vitro cultures of Marchantia polymorpha. Phytochemistry 35, 139-143.

https://doi.org/10.1016/S0031-9422(00)90522-3

Aguado, R., Castro, J.M., Company, M., Alfonso De Gea, G., 1999. Aptian bio-eventsan integrated biostratigraphic analysis of the Almadich Formation, Inner Prebetic Domain, SE Spain. Cretac. Res. 20, 663-683. https://doi.org/10.1006/CRES.1999.0176

Aguado, R., de Gea, G.A., Castro, J.M., O’Dogherty, L., Quijano, M.L., Naafs, B.D.A., Pancost, R.D., 2014a. Late Barremian-early Aptian dark facies of the Subbetic (Betic Cordillera, southern Spain): Calcareous nannofossil quantitative analyses, chemostratigraphy and palaeoceanographic reconstructions. Palaeogeogr.

Palaeoclimatol. Palaeoecol. 395, 198-221.

https://doi.org/10.1016/J.PALAEO.2013.12.031

Aguado, R., de Gea, G.A., O’Dogherty, L. 2014b. Integrated biostratigraphy (calcareous nannofossils, planktonic foraminifera, and radiolarians) of an uppermost Barremian -lower Aptian pelagic succession in the Subbetic Basin (southern Spain). Cretaceous Research 51, 153-173.

Aizenshtat, Z., 1973. Perylene and its geochemical significance. Geochim. Cosmochim. Acta 37, 559-567. https://doi.org/10.1016/0016-7037(73)90218-4

Ando, A., Kaiho, K., Kawahata, H., Kakegawa, T., 2008. Timing and magnitude of early Aptian extreme warming: Unraveling primary $\delta 180$ variation in indurated pelagic carbonates at Deep Sea Drilling Project Site 463, central Pacific Ocean.

Palaeogeogr. Palaeoclimatol. Palaeoecol. 260, 463-476.

https://doi.org/10.1016/j.palaeo.2007.12.007

Ando, A., Kakegawa, T., Takashima, R., Saito, T., 2002. New perspective on Aptian carbon isotope stratigraphy: Data from $\delta 13 \mathrm{C}$ records of terrestrial organic matter. Geology 30, 227-230. https://doi.org/10.1130/0091-

7613(2002)030<0227:NPOACI $>2.0 . \mathrm{CO} ; 2$

Arroyo, L., Trejos, T., Gardinali, P.R., Almirall, J.R., 2009. Optimization and validation of a Laser Ablation Inductively Coupled Plasma Mass Spectrometry method for the 
routine analysis of soils and sediments. Spectrochim. Acta - Part B At. Spectrosc. 64, 16-25. https://doi.org/10.1016/j.sab.2008.10.027

Arthur, M.A., Dean, W.E., Pratt, L.M., 1988. Geochemical and climatic effects of increased marine organic carbon burial at the Cenomanian/Turonian boundary. Nature 335, 714-717. https://doi.org/10.1038/335714a0

Arthur, M.A., Brumsack, H.J., Jenkyns, H.C., Schlanger, S.O., 1990. Stratigraphy, geochemistry, and paleoceanography of organic carbon- rich Cretaceous sequences. Cretac. Resour. events Rhythm. 75-119. https://doi.org/10.1007/978-94-015-68616_6

Arthur, M.A., Schlanger, S.O., 1979. Cretaceous 'oceanic anoxic events' as causal factors in development of reef-reservoired giant oil fields. Am. Assoc. Pet. Geol. Bull. 63, $870-885$.

Baas, M., Pancost, R., Van Geel, B., Sinninghe Damsté, J.S., 2000. A comparative study of lipids in Sphagnum species. Org. Geochem. 31, 535-541. https://doi.org/10.1016/S0146-6380(00)00037-1

Bachmann, M., Willems, H., 1996. High-frequency cycles in the upper Aptian carbonates of the Organyà basin, NE Spain. Int. J. Earth Sci. 85, 586-605. https://doi.org/10.1007/BF02369013

Baker, E.W., Louda, J.W., 1986. Porphyrin geochemistry of Atlantic Jurassic-Cretaceous black shales. Org. Geochem. 10, 905-914. https://doi.org/10.1016/S01466380(86)80028-6

Bakhtiari, A.R., Zakaria, M.P., Yaziz, M.I., Lajis, M.N.H., Bi, X., Rahim, M.C.A., 2009. Vertical distribution and source identification of polycyclic aromatic hydrocarbons in anoxic sediment cores of Chini Lake, Malaysia: Perylene as indicator of land plant-derived hydrocarbons. Appl. Geochemistry 24, 1777-1787. https://doi.org/10.1016/J.APGEOCHEM.2009.05.008

Baldrian, P., Valášková, V., 2008. Degradation of cellulose by basidiomycetous fungi. FEMS Microbiol. Rev. 32, 501-521. https://doi.org/10.1111/j.15746976.2008.00106.x

Batchelli, S., Muller, F.L.L., Chang, K.-C., Lee, C.-L., 2010. Evidence for Strong but Dynamic Iron-Humic Colloidal Associations in Humic-Rich Coastal Waters. Environ. Sci. Technol. 44, 8485-8490. https://doi.org/10.1021/es101081c

Bauer, J.E., Cai, W.J., Raymond, P.A., Bianchi, T.S., Hopkinson, C.S., Regnier, P.A.G., 2013. The changing carbon cycle of the coastal ocean. Nature 504, 61-70. https://doi.org/10.1038/nature12857 
Bechtel, A., Widera, M., Sachsenhofer, R.F., Gratzer, R., Lücke, A., Woszczyk, M., 2007. Biomarker and stable carbon isotope systematics of fossil wood from the second Lusatian lignite seam of the Lubstów deposit (Poland). Org. Geochem. 38, 1850-1864. https://doi.org/10.1016/J.ORGGEOCHEM.2007.06.018

Beerling, D.J., 2002. On the nature of methane gas-hydrate dissociation during the Toarcian and Aptian Oceanic anoxic events. Am. J. Sci. 302, 28-49. https://doi.org/10.2475/ajs.302.1.28

Bellanca, A., Erba, E., Neri, R., Premoli Silva, I., Sprovieri, M., Tremolada, F., Verga, D., 2002. Palaeoceanographic significance of the Tethyan "Livello Selli" (Early Aptian) from the Hybla Formation, northwestern Sicily: Biostratigraphy and highresolution chemostratigraphic records. Palaeogeogr. Palaeoclimatol. Palaeoecol. 185, 175-196. https://doi.org/10.1016/S0031-0182(02)00299-7

Bender, M.M., 1971. Variations in the $13 \mathrm{C} / 12 \mathrm{C}$ ratios of plants in relation to the pathway of photosynthetic carbon dioxide fixation. Phytochemistry 10, 1239-1244. https://doi.org/10.1016/S0031-9422(00)84324-1

Berástegui, X., Garcia-Senz, J., Losantos, M., 1990. Tecto-sedimentary evolution of the Organyà extensional basin (central south Pyrenean unit, Spain) during the Lower Cretaceous. Bull. la Société géologique Fr. 6, 251-264. https://doi.org/10.2113/gssgfbull.VI.2.251

Bergamaschi, B.A., Tsamakis, E., Keil, R.G., Eglinton, T.I., Montluçon, D.B., Hedges, J.I., 1997. The effect of grain size and surface area on organic matter, lignin and carbohydrate concentration, and molecular compositions in Peru Margin sediments. Geochim. Cosmochim. Acta 61, 1247-1260. https://doi.org/10.1016/S00167037(96)00394-8

Bergmann, E.D., Ikan, R., Kashman, J., n.d., 1964. The Occurrence of Perylene in Huleh Peat. Isr. J. Chem. 2, 171-172. https://doi.org/10.1002/ijch.196400046

Bernaus, J.M., Arnaud-Vanneau, A., Caus, E., 2002. Stratigraphic distribution of Valanginian-Early Aptian shallow-water benthic foraminifera and algae, and depositional sequences of a carbonate platform in a tectonically-controlled basin: The Organyà Basin, Pyrenees, Spain. Cretac. Res. 23, 25-36. https://doi.org/10.1006/cres.2001.0300

Bernaus, J.M., Arnaud-Vanneau, A., Caus, E., 2003. Carbonate platform sequence stratigraphy in a rapidly subsiding area: The Late Barremian-Early Aptian of the Organyà basin, Spanish Pyrenees. Sediment. Geol. 159, 177-201. https://doi.org/10.1016/S0037-0738(02)00316-0 
Bernaus, J.M., Caus, E., Arnaud-Vanneau, A., 2000. Aplicación de los análisis micropaleontológicos cuantittivos en estratigrafía secuential: El Cretácico inferior de la cuenca de Organyà (Pirineos, España). Rev. la Soc. Geológica España 13, 53-63.

Bertrand, O., Montargès-Pelletier, E., Mansuy-Huault, L., Losson, B., Faure, P., Michels, R., Pernot, A., Arnaud, F., 2013. A possible terrigenous origin for perylene based on a sedimentary record of a pond (Lorraine, France). Org. Geochem. 58, 69-77. https://doi.org/10.1016/J.ORGGEOCHEM.2013.02.015

Biscaye, P.E., 1965. Mineralogy and Sedimentation of Recent Deep-Sea Clay in the Atlantic Ocean and Adjacent Seas and Oceans. GSA Bull. 76, 803-832.

Blain, S., Quéguiner, B., Armand, L., Belviso, S., Bombled, B., Bopp, L., Bowie, A., Brunet, C., Brussaard, C., Carlotti, F., Christaki, U., Corbière, A., Durand, I., Ebersbach, F., Fuda, J.-L., Garcia, N., Gerringa, L., Griffiths, B., Guigue, C., Guillerm, C., Jacquet, S., Jeandel, C., Laan, P., Lefèvre, D., Lo Monaco, C., Malits, A., Mosseri, J., Obernosterer, I., Park, Y.-H., Picheral, M., Pondaven, P., Remenyi, T., Sandroni, V., Sarthou, G., Savoye, N., Scouarnec, L., Souhaut, M., Thuiller, D., Timmermans, K., Trull, T., Uitz, J., van Beek, P., Veldhuis, M., Vincent, D., Viollier, E., Vong, L., Wagener, T., 2007. Effect of natural iron fertilization on carbon sequestration in the Southern Ocean. Nature 446, 1070.

Blumenberg, M., Krüger, M., Nauhaus, K., Talbot, H.M., Oppermann, B.I., Seifert, R., Pape, T., Michaelis, W., 2006. Biosynthesis of hopanoids by sulfate-reducing bacteria (genus Desulfovibrio). Environ. Microbiol. 8, 1220-1227.

https://doi.org/10.1111/j.1462-2920.2006.01014.x

Blumer, M., Guillard, R.R.L., Chase, T., 1971. Hydrocarbons of marine phytoplankton. Mar. Biol. 8, 183-189. https://doi.org/10.1007/BF00355214

Bodin, S., Godet, A., Matera, V., Steinmann, P., Vermeulen, J., Gardin, S., Adatte, T., Coccioni, R., Föllmi, K.B., 2007. Enrichment of redox-sensitive trace metals (U, V, Mo, As) associated with the late Hauterivian Faraoni oceanic anoxic event. Int. J. Earth Sci. 96, 327-341. https://doi.org/10.1007/s00531-006-0091-9

Borrego, A.G., Blanco, C.G., Püttmann, W., 1997. Geochemical significance of the aromatic hydrocarbon distribution in the bitumens of the Puertollano oil shales, Spain. Org. Geochem. 26, 219-228. https://doi.org/10.1016/S0146-6380(96)00158-1

Boué, H., Chanton, R. 1962. Zoologie, I (2), Invertébrés. 2nd edition. G. Doin \& Cie, Publisher, $722 \mathrm{pp}$.

Bourbonniere, R.A., Meyers, P.A., 1996. Sedimentary geolipid records of historical changes in the watersheds and productivities of Lakes Ontario and Erie. Limnol. Oceanogr. 41, 352-359. https://doi.org/10.4319/1o.1996.41.2.0352 
Boutton, T.W., 1991. Stable carbon isotope ratios of natural materials: II. Atmospheric, terrestrial, marine, and freshwater environments. Carbon Isot. Tech. 1, 173.

Boyd, P., LaRoche, J., Gall, M., Frew, R., McKay, R.M.L., 1999. Role of iron, light, and silicate in controlling algal biomass in subantarctic waters SE of New Zealand. J. Geophys. Res. Ocean. 104, 13395-13408. https://doi.org/10.1029/1999JC900009

Boyd, P.W., Watson, A.J., Law, C.S., Abraham, E.R., Trull, T., Murdoch, R., Bakker, D.C.E., Bowie, A.R., Buesseler, K.O., Chang, H., Charette, M., Croot, P., Downing, K., Frew, R., Gall, M., Hadfield, M., Hall, J., Harvey, M., Jameson, G., LaRoche, J., Liddicoat, M., Ling, R., Maldonado, M.T., McKay, R.M., Nodder, S., Pickmere, S., Pridmore, R., Rintoul, S., Safi, K., Sutton, P., Strzepek, R., Tanneberger, K., Turner, S., Waite, A., Zeldis, J., 2000. A mesoscale phytoplankton bloom in the polar Southern Ocean stimulated by iron fertilization. Nature 407, 695-702. https://doi.org/10.1038/35037500

Bray, E.E., Evans, E.D., 1961. Distribution of n-paraffins as a clue to recognition of source beds. Geochim. Cosmochim. Acta 22, 2-15. https://doi.org/10.1016/00167037(61)90069-2

Brocks, J.J., Summons, R.E., 2014. Sedimentary Hydrocarbons, Biomarkers for Early Life, in: Treatise on Geochemistry: Second Edition. Elsevier, pp. 61-103. https://doi.org/10.1016/B978-0-08-095975-7.00803-2

Brumsack, H.J., 2006. The trace metal content of recent organic carbon-rich sediments: Implications for Cretaceous black shale formation. Palaeogeogr. Palaeoclimatol. Palaeoecol. 232, 344-361. https://doi.org/10.1016/j.palaeo.2005.05.011

Bühmann, C., Schoeman, J.L., 1995. A mineralogical characterization of vertisols from the northern regions of the Republic of South Africa. Geoderma 66, 239-257. https://doi.org/10.1016/0016-7061(94)00080-T

Burns, B.D., Beardall, J., 1987. Utilization of inorganic carbon by marine microalgae. J. Exp. Mar. Bio. Ecol. 107, 75-86. https://doi.org/10.1016/0022-0981(87)90125-0

Bush, R.T., McInerney, F.A., 2013. Leaf wax n-alkane distributions in and across modern plants: Implications for paleoecology and chemotaxonomy. Geochim. Cosmochim. Acta 117, 161-179. https://doi.org/10.1016/j.gca.2013.04.016

Calder, J.A., Parker, P.L., 1968. Stable carbon isotope ratios as indexes of petrochemical pollution of aquatic systems. Environ. Sci. Technol. 2, 535-539.

https://doi.org/10.1021/es60019a001 
Calvert, S.E., Pedersen, T.F., 1993. Geochemistry of Recent oxic and anoxic marine sediments: Implications for the geological record. Mar. Geol. 113, 67-88. https://doi.org/10.1016/0025-3227(93)90150-T

Canfield, D.E., 1994. Factors influencing organic carbon preservation in marine sediments. Chem. Geol. 114, 315-329. https://doi.org/10.1016/00092541(94)90061-2

Cantrill, D.J., 1997. Hepatophytes from the early cretaceous of Alexander Island, Antarctica: Systematics and paleoecology. Int. J. Plant Sci. 158, 476-488. https://doi.org/10.1086/297458

Carreira, R.S., Araújo, M.P., Costa, T.L.F., Ansari, N.R., Pires, L.C.M., 2010. Lipid biomarkers in deep sea sediments from the Campos Basin, SE Brazilian continental margin. Org. Geochem. 41, 879-884. https://doi.org/10.1016/j.orggeochem.2010.04.017

Chaabani, F., Razgallah, S., 2006. Aptian sedimentation: an example of interaction between tectonics and eustatics in Central Tunisia. Geol. Soc. London, Spec. Publ. 262, 55-74. https://doi.org/10.1144/GSL.SP.2006.262.01.03

Chamley, H., 1989. Clay Sedimentology. Springer Berlin Heidelberg, Berlin, Heidelberg. https://doi.org/10.1007/978-3-642-85916-8

Chen, S., Hong, H., Huang, X., Fang, Q., Yin, K., Wang, C., Zhang, Y., Cheng, L., Algeo, T.J., 2018. The role of organo-clay associations in limiting organic matter decay: Insights from the Dajiuhu peat soil, central China. Geoderma 320, 149-160. https://doi.org/10.1016/J.GEODERMA.2018.01.013

Choudhary, P., Routh, J., 2010. Distribution of polycyclic aromatic hydrocarbons in Kumaun Himalayan Lakes, northwest India. Org. Geochem. 41, 891-894. https://doi.org/10.1016/J.ORGGEOCHEM.2010.01.009

Choukroune, P., 1992. Tectonic evolution of the Pyrenees. Annu. Rev. Earth Planet. Sci. Vol. 20 20, 143-158. https://doi.org/10.1146/annurev.earth.20.1.143

Clark, K.E., Hilton, R.G., West, A.J., Malhi, Y., Gröcke, D.R., Bryant, C.L., Ascough, P.L., Robles Caceres, A., New, M., 2013. New views on "old" carbon in the Amazon River: Insight from the source of organic carbon eroded from the Peruvian Andes. Geochemistry, Geophys. Geosystems 14, 1644-1659. https://doi.org/10.1002/ggge.20122

Coale, K.H., Johnson, K.S., Chavez, F.P., Buesseler, K.O., Barber, R.T., Brzezinski, M.A., Cochlan, W.P., Millero, F.J., Falkowski, P.G., Bauer, J.E., Wanninkhof, R.H., Kudela, R.M., Altabet, M.A., Hales, B.E., Takahashi, T., Landry, M.R., Bidigare, 
R.R., Wang, X., Chase, Z., Strutton, P.G., Friederich, G.E., Gorbunov, M.Y., Lance, V.P., Hilting, A.K., Hiscock, M.R., Demarest, M., Hiscock, W.T., Sullivan, K.F., Tanner, S.J., Gordon, R.M., Hunter, C.N., Elrod, V.A., Fitzwater, S.E., Jones, J.L., Tozzi, S., Koblizek, M., Roberts, A.E., Herndon, J., Brewster, J., Ladizinsky, N., Smith, G., Cooper, D., Timothy, D., Brown, S.L., Selph, K.E., Sheridan, C.C., Twining, B.S., Johnson, Z.I., 2004. Southern Ocean Iron Enrichment Experiment: Carbon Cycling in High- and Low-Si Waters. Science (80-. ). 304, 408-414. https://doi.org/10.1126/science. 1089778

Coccioni, A., Nesci, O., Tramontana, M., Wezel, F.C., Moretti, E., 1987. Descrizione di un livello-guida "Radiolaritico-bituminoso ittiolitico "alla base delle marne a fucoidi nell'Appennino umbro-marchigiano. Ital. J. Geosci. 106, 183-192.

Coccioni, R., Luciani, V., Marsili, A., 2006. Cretaceous oceanic anoxic events and radially elongated chambered planktonic foraminifera: Paleoecological and paleoceanographic implications. Palaeogeogr. Palaeoclimatol. Palaeoecol. 235, 6692. https://doi.org/10.1016/J.PALAEO.2005.09.024

Cole, D.B., Zhang, S., Planavsky, N.J., 2017. A new estimate of detrital redox-sensitive metal concentrations and variability in fluxes to marine sediments. Geochim. Cosmochim. Acta 215, 337-353. https://doi.org/10.1016/J.GCA.2017.08.004

Conner, R.L., Landrey, J.R., Czarkowski, N., 1982. The effect of specific sterols on cell size and fatty acid composition of Tetrahymena pyriformis W. J. Protozool. 29, 105109.

Conner, R.L., Landrey, J.R., Burns, C.H., Mallory, F.B., 1968. Cholesterol Inhibition of Pentacyclic Triterpenoid Biosynthesis in Tetrahymena pyriformis. J. Protozool. 15, 600-605. https://doi.org/10.1111/j.1550-7408.1968.tb02178.x

Conner, R.L., Mellory, F.B., Landrey, J.R., Ferguson, K.A., Kaneshiro, E.S., Ray, E., 1971. Ergosterol replacement of tetrahymanol in Tetrahymena membranes. Biochem. Biophys. Res. Commun. 44, 995-1000. https://doi.org/10.1016/0006291X(71)90810-2

Cordeiro, L.G.M.S., Wagener, A.L.R., Carreira, R.S., 2018. Organic matter in sediments of a tropical and upwelling influenced region of the Brazilian continental margin (Campos Basin, Rio de Janeiro). Org. Geochem. 120, 86-98. https://doi.org/10.1016/j.orggeochem.2018.01.005

Countway, R.E., Dickhut, R.M., Canuel, E.A., 2003. Polycyclic aromatic hydrocarbon (PAH) distributions and associations with organic matter in surface waters of the York River, VA Estuary. Org. Geochem. 34, 209-224. https://doi.org/10.1016/S0146-6380(02)00162-6 
Cranwell, P.A., 1973. Chain-length distribution of n-alkanes from lake sediments in relation to post-glacial environmental change. Freshw. Biol. 3, 259-265. https://doi.org/10.1111/j.1365-2427.1973.tb00921.x

Cranwell, P.A., 1981. Diagenesis of free and bound lipids in terrestrial detritus deposited in a lacustrine sediment. Org. Geochem. 3, 79-89. https://doi.org/10.1016/01466380(81)90002-4

Cranwell, P.A., 1984. Lipid geochemistry of sediments from Upton Broad, a small productive lake. Org. Geochem. 7, 25-37. https://doi.org/10.1016/01466380(84)90134-7

Cuadros, J., Linares, J., 1996. Experimental kinetic study of the smectite-to-illite transformation. Geochim. Cosmochim. Acta 60, 439-453. https://doi.org/10.1016/0016-7037(95)00407-6

Cummins, K.W., Klug, M.J., 1979. Feeding Ecology of Stream Invertebrates. Annu. Rev. Ecol. Syst. 10, 147-172. https://doi.org/10.1146/annurev.es.10.110179.001051

Curiale, J.A., Larter, S.R., Sweeney, R.E., Bromley, B.W., 1989. Molecular Thermal Maturity Indicators in Oil and Gas Source Rocks, in: Naeser, N.D., McCulloh, T.H. (Eds.), Thermal History of Sedimentary Basins. Springer New York, New York, NY, pp. 53-72.

Dahle, S., Savinov, V.M., Matishov, G.G., Evenset, A., Næs, K., 2003. Polycyclic aromatic hydrocarbons (PAHs) in bottom sediments of the Kara Sea shelf, Gulf of $\mathrm{Ob}$ and Yenisei Bay. Sci. Total Environ. 306, 57-71. https://doi.org/10.1016/S00489697(02)00484-9

Danelian, T., Tsikos, H., Gardin, S., Baudin, F., Bellier, J.P., Emmanuel, L., 2004. Global and regional palaeoceanographic changes as recorded in the mid-Cretaceous (Aptian-Albian sequence of the Ionian zone (NW Greece). J. Geol. Soc. London. 161, 703-709. https://doi.org/10.1144/0016-764903-088

Dawson, T.E., Mambelli, S., Plamboeck, A.H., Templer, P.H., Tu, K.P., 2002. Stable Isotopes in Plant Ecology. Annu. Rev. Ecol. Syst. 33, 507-559. https://doi.org/10.1146/annurev.ecolsys.33.020602.095451

de Baar, H.J.W., de Jong, J.T.M., Bakker, D.C.E., Löscher, B.M., Veth, C., Bathmann, U., Smetacek, V., 1995. Importance of iron for plankton blooms and carbon dioxide drawdown in the Southern Ocean. Nature 373, 412.

de Gea, G.A., Castro, J.M., Aguado, R., Ruiz-Ortiz, P.A., Company, M., 2003. Lower Aptian carbon isotope stratigraphy from a distal carbonate shelf setting: The Cau 
section, Prebetic zone, SE Spain, in: Palaeogeography, Palaeoclimatology, Palaeoecology. pp. 207-219. https://doi.org/10.1016/S0031-0182(03)00451-6

De Leeuw, J.W., Largeau, C., 1993. A Review of Macromolecular Organic Compounds That Comprise Living Organisms and Their Role in Kerogen, Coal, and Petroleum Formation, in: Engel, M.H., Macko, S.A. (Eds.), Organic Geochemistry: Principles and Applications. Springer US, Boston, MA, pp. 23-72. https://doi.org/10.1007/9781-4615-2890-6_2

Demaison, G.J., Moore, G.T., 1980. Anoxic environments and oil source bed genesis. Org. Geochem. 2, 9-31. https://doi.org/10.1016/0146-6380(80)90017-0

Deuser, W.G., 1988. Whither organic carbon? Nature 332, 396.

Diaz, P., Raimbault, F., Boudjellal, B., Garcia, N., Moutin, T., 2001. Early spring phosphorus limitation of primary productivity in a NW Mediterranean coastal zone (Gulf of Lions). Mar. Ecol. Prog. Ser. 211, 51-62. https://doi.org/10.3354/meps211051

Diéguez, C., Rodríguez-López, J.P., Meléndez, N., 2007. Marchantiopsid colonization mats from the Upper Aptian-Lower Albian of the Escucha Formation (Oliete SubBasin, Iberian Ranges, eastern Spain). Comptes Rendus Palevol 6, 413-422. https://doi.org/10.1016/J.CRPV.2007.09.022

Dinarès-Turell, J., Garcia-Senz, J., 2000. Remagnetization of Lower Cretaceous limestones from the southern Pyrenees and relation to the Iberian plate geodynamic evolution. J. Geophys. Res. Solid Earth 105, 19405-19418. https://doi.org/10.1029/2000jb900136

Du, J., Cai, J., Chen, Z., Lei, T., Zhang, S., Xie, Z., 2019. A contrastive study of effects of different organic matter on the smectite illitization in hydrothermal experiments. Appl. Clay Sci. 168, 249-259. https://doi.org/10.1016/J.CLAY.2018.11.016

Duan, L.Q., Song, J.M., Yuan, H.M., Li, X.G., Li, N., Peng, Q.C., 2017. The use of sterols combined with isotope analyses as a tool to identify the origin of organic matter in the East China Sea. Ecol. Indic. 83, 144-157. https://doi.org/10.1016/j.ecolind.2017.07.042

Dufourc, E.J., 2008. Sterols and membrane dynamics. J. Chem. Biol. 1, 63-77. https://doi.org/10.1007/s12154-008-0010-6

Dumitrescu, M., Brassell, S.C., 2005. Biogeochemical assessment of sources of organic matter and paleoproductivity during the early Aptian Oceanic Anoxic Event at Shatsky Rise, ODP Leg 198. Org. Geochem. 36, 1002-1022. https://doi.org/10.1016/j.orggeochem.2005.03.001 
Dumitrescu, M., Brassell, S.C., 2006. Compositional and isotopic characteristics of organic matter for the early Aptian Oceanic Anoxic Event at Shatsky Rise, ODP Leg 198. Palaeogeogr. Palaeoclimatol. Palaeoecol. 235, 168-191. https://doi.org/10.1016/j.palaeo.2005.09.028

Dunne, T., Mertes, L.A.K., Meade, R.H., Richey, J.E., Forsberg, B.R., 1998. Exchanges of sediment between the flood plain and channel of the Amazon River in Brazil. GSA Bull. 110, 450-467.

Eglinton, G., Hamilton, R.J., 1967. Leaf epicuticular waxes. Science (80-. ). 156, 1322 1335. https://doi.org/10.1126/science.156.3780.1322

Ehleringer, J.R., Hall, A.E., Farquhar, G.D., 1993. Stable Isotopes and Plant Carbonwater Relations. Elsevier. https://doi.org/10.1016/C2009-0-03312-1

Elkhazri, A., Abdallah, H., Razgallah, S., Moullade, M., Kuhnt, W., 2013. Carbonisotope and microfaunal stratigraphy bounding the Lower Aptian Oceanic Anoxic Event 1a in northeastern Tunisia. Cretac. Res. 39, 133-148. https://doi.org/10.1016/j.cretres.2012.05.011

Erba, E., 2004. Calcareous nannofossils and Mesozoic oceanic anoxic events, in: Marine Micropaleontology. pp. 85-106. https://doi.org/10.1016/j.marmicro.2004.04.007

Erba, E., Channell, J.E.T., Claps, M., Jones, C., Larson, R., Opdyke, B., Premoli Silva, I., Riva, A., Salvini, G., Torricelli, S., 1999. Integrated stratigraphy of the Cismon Apticore (southern Alps, Italy); a "reference section" for the Barremian-Aptian interval at low latitudes. J. Foraminifer. Res. 29, 371-391.

Erbacher, J., Thurow, J., Littke, R., 1996. Evolution patterns of radiolaria and organic matter variations: A new approach to identify sea-level changes in mid-Cretaceous pelagic environments. Geology 24, 499-502. https://doi.org/10.1130/00917613(1996)024<0499:EPORAO>2.3.CO;2

Eslinger, E., Pevear, D.R., 1988. Clay minerals for petroleum geologists and engineers, SEPM short course notes. SEPM.

Fan, C.-W., Shiue, J., Wu, C.-Y., Wu, C.-Y., 2011. Perylene dominance in sediments from a subtropical high mountain lake. Org. Geochem. 42, 116-119. https://doi.org/10.1016/J.ORGGEOCHEM.2010.10.008

Ficken, K.J., Li, B., Swain, D.L., Eglinton, G., 2000. An n-alkane proxy for the sedimentary input of submerged/floating freshwater aquatic macrophytes, in: Organic Geochemistry. pp. 745-749. https://doi.org/10.1016/S0146-6380(00)000814 
Fisher Jr., T.R., Parsley, P.E., 1979. Amazon lakes: Water storage and nutrient stripping by algae. Limnol. Oceanogr. 24, 547-553. https://doi.org/10.4319/lo.1979.24.3.0547

Flegel, M., Adam, K.-P., Becker, H., 1999. Sesquiterpene lactones and bisbibenzyl derivatives from the neotropical liverwort Frullania convoluta. Phytochemistry 52, 1633-1638. https://doi.org/10.1016/S0031-9422(99)00200-9

Forster, A., Sturt, H., Meyers, P., Party, L., 2004. Molecular biogeochemistry of Cretaceous black shales from the Demerara Rise; preliminary shipboard results from Sites 1257 and 1258, ODP Leg 207. Proc. Ocean Drill. Progr. Initial Rep 207, 1-22.

Fry, B., 2006. Stable Isotope Ecology. Springer New York, New York, NY. https://doi.org/10.1007-0-387-33745-8

Gagosian, R.B., Peltzer, E.T., 1986. The importance of atmospheric input of terrestrial organic material to deep sea sediments. Organic Geochemistry 10, 661-669.

Gagosian, R.B., Peltzer, E.T., Merrill, J.T., 1987. Long-range transport of terrestrially derived lipids in aerosols from the South Pacific. Nature 325, 800-803.

Gagosian, R.B., Peltzer, E.T., Zafiriou, O.C., 1981. Atmospheric transport of continentally derived lipids to the tropical North Pacific. Nature 291, 312-314.

Gao, L., Hou, J., Toney, J., MacDonald, D., Huang, Y., 2011. Mathematical modeling of the aquatic macrophyte inputs of mid-chain n-alkyl lipids to lake sediments: Implications for interpreting compound specific hydrogen isotopic records. Geochim. Cosmochim. Acta 75, 3781-3791. https://doi.org/10.1016/j.gca.2011.04.008

Gaona-Narvaez, T., Maurrasse, F.J.-M.R., Etayo-Serna, F., 2013b. Geochemistry, palaeoenvironments and timing of Aptian organic-rich beds of the Paja Formation (Curití, Eastern Cordillera, Colombia). Geol. Soc. London, Spec. Publ. 382, 31-48. https://doi.org/10.1144/SP382.6

Gaona-Narvaez, T., Maurrasse, F.J.-M.R., Moreno-Bedmar, J.A., 2013a. Stable carbonisotope stratigraphy and ammonite biochronology at Madotz, Navarra, northern Spain: implications for the timing and duration of oxygen depletion during OAE-1a. Cretac. Res. 40, 143-157. https://doi.org/10.1016/J.CRETRES.2012.06.005

García-Alcade J.L., Carls, P., Pardo Alonso, M.V., Sanz Lopez, J., Soto, F., T.-M., M., Valenzuela-Ríos, J.I., 2002. Devonian, in: Gibbons, W., and Moreno, T. (Ed.), The Geology of Spain. The Geological Society of London, pp. 67-91.

García-Senz, J., 2002. Cuencas Extensivas del Cretácico Inferior en los Pirineos Centrales, Formación y Subsecuente Inversión. PhD Thesis Univ. Barcelona. 
Garrigues, P., Parlanti, E., Lapouyade, R., Bellocq, J., 1988. Distribution of methylperylene isomers in selected sediments. Geochim. Cosmochim. Acta 52, 901907. https://doi.org/10.1016/0016-7037(88)90360-2

Gelpi, E., Schneider, H., Mann, J., Oro, J., 1970. Hydrocarbons of geochemical significance in microscopic algae. Phytochemistry 9, 603-612.

Gervais, F., Riebesell, U., Gorbunov, M.Y., 2002. Changes in primary productivity and chlorophyll a in response to iron fertilization in the Southern Polar Frontal Zone. Limnol. Oceanogr. 47, 1324-1335. https://doi.org/10.4319/lo.2002.47.5.1324

Giger, W., Schaffner, C., Wakeham, S.G., 1980. Aliphatic and olefinic hydrocarbons in recent sediments of Greifensee, Switzerland. Geochim. Cosmochim. Acta 44, 119 129. https://doi.org/10.1016/0016-7037(80)90182-9

Gilbertson, R.L., 1980. Wood-Rotting Fungi of North America. Mycologia 72, 1-49. https://doi.org/10.2307/3759417

Gocht, T., Barth, J.A.C., Epp, M., Jochmann, M., Blessing, M., Schmidt, T.C., Grathwohl, P., 2007. Indications for pedogenic formation of perylene in a terrestrial soil profile: Depth distribution and first results from stable carbon isotope ratios. Appl. Geochemistry 22, 2652-2663. https://doi.org/10.1016/J.APGEOCHEM.2007.06.004

Goddard, E.N., Trask, P.D., De Ford, R.K., Rove, O.N., Singewald, J.T., Overbeck, R.M., 1963. Rock-Color Chart. Geological Society of America, Colorado.

Godet, A., Hfaiedh, R., Arnaud-Vanneau, A., Zghal, I., Arnaud, H., Ouali, J., 2014. Aptian palaeoclimates and identification of an OAE1 a equivalent in shallow marine environments of the southern Tethyan margin: Evidence from Southern Tunisia (Bir Oum Ali section, Northern Chott Chain). Cretac. Res. 48, 110-129. https://doi.org/10.1016/j.cretres.2013.12.006

Golonka, J., 2004. Plate tectonic evolution of the southern margin of Eurasia in the Mesozoic and Cenozoic. Tectonophysics 381, 235-273. https://doi.org/10.1016/j.tecto.2002.06.004

Golovko, A.K., Mozzhelina, T.K., Serebrennikova, O. V., 1999. Distribution of perylene hydrocarbons in oils and organic matter of deposits of different age. Polycycl. Aromat. Compd. 1999, 209-220. https://doi.org/10.1080/10406639908019127

Gomez, B., Daviero-Gomez, V., Coiffard, C., Martín-Closas, C., Dilcher, D.L., 2015. Montsechia, an ancient aquatic angiosperm. Proc. Natl. Acad. Sci. U. S. A. 112, 10985-10988. https://doi.org/10.1073/pnas. 1509241112 
Gong, Z., Langereis, C.G., Mullender, T.A.T., 2008. The rotation of Iberia during the Aptian and the opening of the Bay of Biscay. Earth Planet. Sci. Lett. 273, 80-93. https://doi.org/10.1016/j.eps1.2008.06.016

Gong, Z., van Hinsbergen, D.J.J., Vissers, R.L.M., Dekkers, M.J., 2009. Early Cretaceous syn-rotational extension in the Organyà basin-New constraints on the palinspastic position of Iberia during its rotation. Tectonophysics 473, 312-323. https://doi.org/10.1016/j.tecto.2009.03.003

Graziano, R., Raspini, A., 2018. High-resolution chronostratigraphy of palaeoecologic and isotopic changes in shallow-marine carbonates: Deciphering the completeness of the Aptian record in the Apennine carbonate platform (southern Italy). Cretac. Res. 86, 97-128. https://doi.org/10.1016/j.cretres.2017.12.008

Greiner, A.C., Spyckerelle, C., Albrecht, P., 1976. Aromatic hydrocarbons from geological sources-I : New naturally occurring phenanthrene and chrysene derivatives. Tetrahedron 32, 257-260. https://doi.org/10.1016/0040-4020(76)870111

Grice, K., Lu, H., Atahan, P., Asif, M., Hallmann, C., Greenwood, P., Maslen, E., Tulipani, S., Williford, K., Dodson, J., 2009. New insights into the origin of perylene in geological samples. Geochim. Cosmochim. Acta 73, 6531-6543. https://doi.org/10.1016/J.GCA.2009.07.029

Griffin, J.J., Windom, H., Goldberg, E.D., 1968. The distribution of clay minerals in the World Ocean. Deep Sea Res. Oceanogr. Abstr. 15, 433-459. https://doi.org/10.1016/0011-7471(68)90051-X

Griffith, G.S., Boddy, L., 1991. Fungal decomposition of attached angiosperm twigs. New Phytol. 117, 259-269. https://doi.org/10.1111/j.1469-8137.1991.tb04907.x

Gröcke, D.R., Hesselbo, S.P., Jenkyns, H.C., 1999. Carbon-isotope composition of Lower Cretaceous fossil wood: Ocean-atmosphere chemistry and relation to sealevel change. Geology 27, 155-158. https://doi.org/10.1130/00917613(1999)027<0155:CICOLC $>2.3 . C O ; 2$

Gromet, L.P., Haskin, L.A., Korotev, R.L., Dymek, R.F., 1984. The "North American shale composite": Its compilation, major and trace element characteristics. Geochim. Cosmochim. Acta 48, 2469-2482. https://doi.org/10.1016/0016-7037(84)90298-9

Gross, D., Sachsenhofer, R.F., Bechtel, A., Pytlak, L., Rupprecht, B., Wegerer, E., 2015. Organic geochemistry of Mississippian shales (Bowland Shale Formation) in central Britain: Implications for depositional environment, source rock and gas shale potential. Mar. Pet. Geol. 59, 1-21. https://doi.org/10.1016/J.MARPETGEO.2014.07.022 
Grötsch, J., Billing, I., Vahrenkamp, V., 1998. Carbon-isotope stratigraphy in shallowwater carbonates: Implications for Cretaceous black-shale deposition.

Sedimentology 45, 623-634. https://doi.org/10.1046/j.1365-3091.1998.00158.x

Guhl, B.E., Finlay, B.J., 1993. Anaerobic predatory ciliates track seasonal migrations of planktonic photosynthetic bacteria. FEMS Microbiol. Lett. 107, 313-316. https://doi.org/10.1111/j.1574-6968.1993.tb06049.x

Guitard, G., 1970. Le métamorphisme hercynien mésozonal et les gneiss œillés du massif du Canigou:(Pyrénées-Orientales). Mém. BRGM 63, 0-353.

Haddad, R.I., Martens, C.S., Farrington, J.W., 1992. Quantifying early diagenesis of fatty acids in a rapidly accumulating coastal marine sediment. Org. Geochem. 19, 205216. https://doi.org/10.1016/0146-6380(92)90037-X

Han, J., McCarthy, E.D., Calvin, M., Benn, H., 1968. Hydrocarbon Constituents of the Blue-Green Algae Nostoc muscorum, Anacystis nidulans, Phormidium luridum and Chlorogloea fritschii. J. Chem. Soc. 22, 2785-2791. https://doi.org/10.1039/j39680002785

Harris, S.Y., 2001. Building pathology: deterioration, diagnostics, and intervention. John Wiley \& Sons.

Hart, T.J., 1934. On the phytoplankton of the south-west Atlantic and the Bellingshausen Sea, 1929-31. Discov. Rep. VIII, 1-268.

Hartmann, M.A., 1998. Plant sterols and the membrane environment. Trends Plant Sci. 3, 170-175. https://doi.org/10.1016/S1360-1385(98)01233-3

Härtner, T., Straub, K.L., Kannenberg, E., 2005. Occurrence of hopanoid lipids in anaerobic Geobacter species. FEMS Microbiol. Lett. 243, 59-64. https://doi.org/10.1016/j.femsle.2004.11.039

Harvey, H.R., Ederington, M.C., Mcmanus, G.B., 1997. Lipid composition of the marine ciliates Pleuronema sp. and Fabrea salina: Shifts in response to changes in diet. J. Eukaryot. Microbiol. 44, 189-193. https://doi.org/10.1111/j.15507408.1997.tb05698.x

Harvey, H.R., Mcmanus, G.B., 1991. Marine ciliates as a widespread source of tetrahymanol and hopan-3 $\beta$-ol in sediments. Geochim. Cosmochim. Acta 55, 33873390. https://doi.org/10.1016/0016-7037(91)90496-R

Hasegawa, T., 1997. Cenomanian-Turonian carbon isotope events recorded in terrestrial organic matter from northern Japan. Palaeogeogr. Palaeoclimatol. Palaeoecol. 130, 251-273. https://doi.org/10.1016/S0031-0182(96)00129-0 
Hasegawa, T., 2001. Predominance of terrigenous organic matter in Cretaceous marine fore-arc sediments, Japan and Far East Russia. Int. J. Coal Geol. 47, 207-221. https://doi.org/10.1016/S0166-5162(01)00043-X

Hays, J. D., Imbrie, J., Shackleton, N. J. 1976. Variations in the Earth's Orbit: Pacemaker of the Ice Ages. Science 194 (4270), 1121-32.

Hedges, J.I., Clark, W.A., Quay, P.D., Richey, J.E., Devol, A.H., Santos, M., 1986. Compositions and fluxes of particulate organic material in the Amazon River. Limnol. Oceanogr. 31, 717-738. https://doi.org/10.4319/1o.1986.31.4.0717

Hedges, J.I., Keil, R.G., 1995. Sedimentary organic matter preservation: an assessment and speculative synthesis. Mar. Chem. 49, 81-115. https://doi.org/10.1016/03044203(95)00008-F

Hedges, J.I., Keil, R.G., Benner, R., 1997. What happens to terrestrial organic matter in the ocean?, in: Organic Geochemistry. pp. 195-212. https://doi.org/10.1016/S01466380(97)00066-1

Heldt, M., Bachmann, M., Lehmann, J., 2008. Microfacies, biostratigraphy, and geochemistry of the hemipelagic Barremian-Aptian in north-central Tunisia: Influence of the OAE 1a on the southern Tethys margin. Palaeogeogr. Palaeoclimatol. Palaeoecol. 261, 246-260. https://doi.org/10.1016/j.palaeo.2008.01.013

Heldt, M., Lehmann, J., Bachmann, M., Negra, H., Kuss, J., 2010. Increased terrigenous influx but no drowning: Palaeoenvironmental evolution of the Tunisian carbonate platform margin during the Late Aptian. Sedimentology 57, 695-719. https://doi.org/10.1111/j.1365-3091.2009.01115.x

Hernes, P.J., Peterson, M.L., Murray, J.W., Wakeham, S.G., Lee, C., Hedges, J.I., 2001. Particulate carbon and nitrogen fluxes and compositions in the central equatorial Pacific. Deep Sea Res. Part I Oceanogr. Res. Pap. 48, 1999-2023.

Herrle, J.O., Kößler, P., Friedrich, O., Erlenkeuser, H., Hemleben, C., 2004. Highresolution carbon isotope records of the Aptian to Lower Albian from SE France and the Mazagan Plateau (DSDP Site 545): A stratigraphic tool for paleoceanographic and paleobiologic reconstruction. Earth Planet. Sci. Lett. 218, 149-161. https://doi.org/10.1016/S0012-821X(03)00646-0

Hilton, R.G., Galy, A., Hovius, N., Kao, S.-J., Horng, M.-J., Chen, H., 2012. Climatic and geomorphic controls on the erosion of terrestrial biomass from subtropical mountain forest. Global Biogeochem. Cycles 26.

https://doi.org/10.1029/2012GB004314 
Hites, R.A., Laflamme, R.E., Windsor, J.G., Farrington, J.W., Deuser, W.G., 1980. Polycyclic aromatic hydrocarbons in an anoxic sediment core from the Pettaquamscutt River (Rhode Island, U.S.A.). Geochim. Cosmochim. Acta 44, 873878. https://doi.org/10.1016/0016-7037(80)90267-7

Holtvoeth, J., Vogel, H., Wagner, B., Wolff, G.A., 2010. Lipid biomarkers in Holocene and glacial sediments from ancient Lake Ohrid (Macedonia, Albania).

Biogeosciences 7, 3473-3489. https://doi.org/10.5194/bg-7-3473-2010

Hu, J., Peng, P., Jia, G., Mai, B., Zhang, G., 2006. Distribution and sources of organic carbon, nitrogen and their isotopes in sediments of the subtropical Pearl River estuary and adjacent shelf, Southern China. Mar. Chem. 98, 274-285. https://doi.org/10.1016/J.MARCHEM.2005.03.008

Hu, L., Shi, X., Lin, T., Guo, Z., Ma, D., Yang, Z., 2014. Perylene in surface sediments from the estuarine-inner shelf of the East China Sea: A potential indicator to assess the sediment footprint of large river influence. Cont. Shelf Res. 90, 142-150. https://doi.org/10.1016/J.CSR.2014.04.014

Huang, W.Y., Meinschein, W.G., 1979. Sterols as ecological indicators. Geochim. Cosmochim. Acta 43, 739-745. https://doi.org/10.1016/0016-7037(79)90257-6

Huang, X., Meyers, P.A., Xue, J., Zhang, Y., Wang, X., 2016. Paleoclimate significance of n-alkane molecular distributions and $\delta 2 \mathrm{H}$ values in surface peats across the monsoon region of China. Palaeogeogr. Palaeoclimatol. Palaeoecol. 461, 77-86. https://doi.org/10.1016/j.palaeo.2016.08.011

Huck, S., Rameil, N., Korbar, T., Heimhofer, U., Wieczorek, T.D., Immenhauser, A., 2010. Latitudinally different responses of Tethyan shoal-water carbonate systems to the Early Aptian oceanic anoxic event (OAE 1a). Sedimentology 57, 1585-1614. https://doi.org/10.1111/j.1365-3091.2010.01157.x

Immenhauser, A., Hillgärtner, H., van Bentum, E., 2005. Microbial-foraminiferal episodes in the Early Aptian of the southern Tethyan margin: Ecological significance and possible relation to oceanic anoxic event 1a. Sedimentology 52, 77-99. https://doi.org/10.1111/j.1365-3091.2004.00683.x

Ingram, B.L., Coccioni, R., Montanari, A., Richter, F.M., 1994. Strontium isotopic composition of mid-cretaceous seawater. Science (80-. ). 264, 546-550. https://doi.org/10.1126/science.264.5158.546

Itoh, N., Hanari, N., 2010. Possible precursor of perylene in sediments of Lake Biwa elucidated by stable carbon isotope composition. Geochem. J. 44, 161-166. https://doi.org/10.2343/geochemj.1.0054 
Itoh, N., Sakagami, N., Torimura, M., Watanabe, M., 2012. Perylene in Lake Biwa sediments originating from Cenococcum geophilum in its catchment area. Geochim. Cosmochim. Acta 95, 241-251. https://doi.org/10.1016/J.GCA.2012.07.037

Jaffé, R., Mead, R., Hernandez, M.E., Peralba, M.C., DiGuida, O.A., 2001. Origin and transport of sedimentary organic matter in two subtropical estuaries: a comparative, biomarker-based study. Org. Geochem. 32, 507-526. https://doi.org/10.1016/S01466380(00)00192-3

Jahren, A.H., Arens, N.C., Sarmiento, G., Guerrero, J., Amundson, R., 2001. Terrestrial record of methane hydrate dissociation in the Early Cretaceous. Geology 29, 159162. https://doi.org/10.1130/0091-7613(2001)029<0159:TROMHD>2.0.CO;2

Jahren, A.H., Conrad, C.P., Arens, N.C., Mora, G., Lithgow-Bertelloni, C., 2005. A plate tectonic mechanism for methane hydrate release along subduction zones. Earth Planet. Sci. Lett. 236, 691-704. https://doi.org/10.1016/j.eps1.2005.06.009

Janssen, A.W., Goedert, J.L., 2016. Notes on the systematics, morphology and biostratigraphy of fossil holoplanktonic Mollusca, 24. First observation of a genuinely Late Mesozoic thecosomatous pteropod. Basteria 80, 59-63.

Janssen, A.W., Peijnenburg, K., 2017. An overview of the fossil record of Pteropoda (Mollusca, Gastropoda, Heterobranchia). Cainozoic Res. 17, 3-10.

Jenkyns, H.C., 1980. Cretaceous anoxic events: from continents to oceans. J. Geol. Soc. London. 137, 171-188. https://doi.org/10.1144/gsjgs.137.2.0171

Jenkyns, H.C., 1995. Carbon-isotope stratigraphy and paleoceanographic significance of the Lower Cretaceous shallow-water carbonates of Resolution Guyot, Mid-Pacific Mountains. Proc. Ocean Drill. Program, Sci. Results, Vol 143.

Jenkyns, H.C., 2010. Geochemistry of oceanic anoxic events. Geochemistry, Geophys. Geosystems 11. https://doi.org/10.1029/2009GC002788

Jiang, C., Alexander, R., Kagi, R.I., Murray, A.P., 2000. Origin of perylene in ancient sediments and its geological significance. Org. Geochem. 31, 1545-1559. https://doi.org/10.1016/S0146-6380(00)00074-7

Jiang, Y.L., Liu, Y.-S., 2008. A simple and convenient determination of perylene preserved in the Late Neogene wood from northeastern Tennessee using fluorescence spectroscopy. Org. Geochem. 39, 1462-1465. https://doi.org/10.1016/J.ORGGEOCHEM.2008.06.006

Junk, W.J., 1997. The central Amazon floodplain : ecology of a pulsing system, Ecological studies; vol. 126. Springer, Berlin ; New York. 
Junk, W.J., Bayley, P.B., Sparks, R.E., 1989. The flood pulse concept in river-floodplainsystems. Can. J. Fish. Aquat. Sci. 106, 110-127.

Kannenberg, E.L., Poralla, K., 1999. Hopanoid Biosynthesis and Function in Bacteria. Naturwissenschaften 86, 168-176. https://doi.org/10.1007/s001140050592

Kashirtsev, V.A., Parfenova, T.M., Golovko, A.K., Nikitenko, B.L., Zueva, I.N., Chalaya, O.N., 2018. Phenanthrene biomarkers in the organic matter of Precambrian and Phanerozoic deposits and in the oils of the Siberian Platform. Russ. Geol. Geophys. 59, 1380-1388. https://doi.org/10.1016/J.RGG.2018.09.013

Kawamura, K., Ishiwatari, R., Ogura, K., 1987. Early diagenesis of organic matter in the water column and sediments: Microbial degradation and resynthesis of lipids in Lake Haruna. Org. Geochem. 11, 251-264. https://doi.org/10.1016/01466380(87)90036-2

Keil, R.G., Mayer, L.M., 2014. Mineral Matrices and Organic Matter. Treatise on Geochemistry 337-359. https://doi.org/10.1016/B978-0-08-095975-7.01024-X

Keil, R.G., Montluçon, D.B., Prahl, F.G., Hedges, J.I., 1994a. Sorptive preservation of labile organic matter in marine sediments. Nature 370, 549-552. https://doi.org/10.1038/370549a0

Keil, R.G., Tsamakis, E., Fuh, C.B., Giddings, J.C., Hedges, J.I., 1994b. Mineralogical and textural controls on the organic composition of coastal marine sediments: Hydrodynamic separation using SPLITT-fractionation. Geochim. Cosmochim. Acta 58, 879-893. https://doi.org/10.1016/0016-7037(94)90512-6

Kennedy, M.J., Löhr, S.C., Fraser, S.A., Baruch, E.T., 2014. Direct evidence for organic carbon preservation as clay-organic nanocomposites in a Devonian black shale; from deposition to diagenesis. Earth Planet. Sci. Lett. 388, 59-70. https://doi.org/10.1016/j.eps1.2013.11.044

Kennedy, M.J., Pevear, D.R., Hill, R.J., 2002. Mineral surface control of organic carbon in black shale. Science (80-. ). 295, 657-660. https://doi.org/10.1126/science.1066611

Kim, M., Jung, J., Jin, Y., Han, G.M., Lee, T., Hong, S.H., Yim, U.H., Shim, W.J., Choi, D.-L., Kannan, N., 2016. Origins of suspended particulate matter based on sterol distribution in low salinity water mass observed in the offshore East China Sea. Mar. Pollut. Bull. 108, 281-288. https://doi.org/10.1016/J.MARPOLBUL.2016.04.049

Koch, K., Bhushan, B., Barthlott, W., 2009. Multifunctional surface structures of plants: An inspiration for biomimetics. Prog. Mater. Sci. 54, 137-178. https://doi.org/10.1016/j.pmatsci.2008.07.003 
Kohn, M.J., 2010. Carbon isotope compositions of terrestrial C3 plants as indicators of (paleo)ecology and (paleo)climate. Proc. Natl. Acad. Sci. U. S. A. 107, 19691-5. https://doi.org/10.1073/pnas.1004933107

Kolaczkowska, E., Slougui, N.E., Watt, D.S., Maruca, R.E., Michael Moldowan, J., 1990. Thermodynamic stability of various alkylated, dealkylated and rearranged $17 \alpha-$ and 17 $\beta$-hopane isomers using molecular mechanics calculations. Org. Geochem. 16, 1033-1038. https://doi.org/10.1016/0146-6380(90)90140-U

Köster, J., Van Kaam-Peters, H.M.E., Koopmans, M.P., De Leeuw, J.W., Damsté, J.S.S., 1997. Sulphurisation of homohopanoids: Effects on carbon number distribution, speciation, and 22S22R epimer ratios. Geochim. Cosmochim. Acta 61, 2431-2452.

Krachler, R., Krachler, R., Valda, A., Keppler, B.K., 2019. Natural iron fertilization of the coastal ocean by "blackwater rivers." Sci. Total Environ. 656, 952-958. https://doi.org/10.1016/J.SCITOTENV.2018.11.423

Krachler, R., Krachler, R.F., Wallner, G., Hann, S., Laux, M., Cervantes Recalde, M.F., Jirsa, F., Neubauer, E., von der Kammer, F., Hofmann, T., Keppler, B.K., 2015. River-derived humic substances as iron chelators in seawater. Mar. Chem. 174, 8593. https://doi.org/10.1016/J.MARCHEM.2015.05.009

Krauss, M., Wilcke, W., Martius, C., Bandeira, A.G., Garcia, M.V.B., Amelung, W., 2005. Atmospheric versus biological sources of polycyclic aromatic hydrocarbons (PAHs) in a tropical rain forest environment. Environ. Pollut. 135, 143-154. https://doi.org/10.1016/J.ENVPOL.2004.09.012

Krom, M.D., Kress, N., Brenner, S., Gordon, L.I., 1991. Phosphorus limitation of primary productivity in the eastern Mediterranean Sea. Limnol. Oceanogr. 36, 424432. https://doi.org/10.1021/acsami.5b10724

Kübler, B., Jaboyedoff, M., 2000. Illite crystallinity. Comptes Rendus l'Académie des Sci. - Ser. IIA - Earth Planet. Sci. 331, 75-89. https://doi.org/10.1016/S12518050(00)01395-1

Kuhn, K.M., Maurice, P.A., Neubauer, E., Hofmann, T., von der Kammer, F., 2014. Accessibility of Humic-Associated Fe to a Microbial Siderophore: Implications for Bioavailability. Environ. Sci. Technol. 48, 1015-1022. https://doi.org/10.1021/es404186v

Kuhnt, W., Moullade, M., Masse, J.-P., Erlenkeuser, H., 1998. Carbon isotope stratigraphy of the lower Aptian historical stratotype at Cassis-La Bédoule (SE France). Geol. Mediterr. 25, 63-79.

Kumada, K., 1988. Chemistry of soil organic matter. Elsevier. 
Kumar, A., Schimmelmann, A., Sauer, P.E., Brassell, S.C., 2017. Distribution and sources of polycyclic aromatic hydrocarbons (PAHs) in laminated Santa Barbara Basin sediments. Org. Geochem. 113, 303-314. https://doi.org/10.1016/J.ORGGEOCHEM.2017.07.022

Kvenvolden, K.A., 1993. Gas hydrates - geological perspective and global change. Rev. Geophys. 31, 173-187. https://doi.org/10.1029/93RG00268

Laflamme, R.E., Hites, R.A., 1979. Tetra- and pentacyclic, naturally-occurring, aromatic hydrocarbons in recent sediments. Geochim. Cosmochim. Acta 43, 1687-1691. https://doi.org/10.1016/0016-7037(79)90188-1

Laglera, L.M., van den Berg, C.M.G., 2009. Evidence for geochemical control of iron by humic substances in seawater. Limnol. Oceanogr. 54, 610-619. https://doi.org/10.4319/lo.2009.54.2.0610

Larson, R.L., 1991. Geological consequences of superplumes. Geology 19, 963-966. https://doi.org/10.1130/0091-7613(1991)019<0963:GCOS>2.3.CO;2

Larson, R.L., Erba, E., 1999. Onset of the mid-Cretaceous greenhouse in the BarremianAptian: Igneous events and the biological, sedimentary, and geochemical responses. Paleoceanography 14, 663-678. https://doi.org/10.1029/1999PA900040

Leckie, R.M., Bralower, T.J., Cashman, R., 2002. Oceanic anoxic events and plankton evolution: Biotic response to tectonic forcing during the mid-Cretaceous. Paleoceanography 17, 13-29. https://doi.org/10.1029/2001PA000623

Li, C., Planavsky, N.J., Shi, W., Zhang, Z., Zhou, C., Cheng, M., Tarhan, L.G., Luo, G., Xie, S., 2015. Ediacaran Marine Redox Heterogeneity and Early Animal Ecosystems. Sci. Rep. 5, 17097.

Li, M., Shi, S., Wang, T.-G., 2012. Identification and distribution of chrysene, methylchrysenes and their isomers in crude oils and rock extracts. Org. Geochem. 52, 55-66. https://doi.org/10.1016/J.ORGGEOCHEM.2012.08.011

Li, Y.X., Bralower, T.J., Montañez, I.P., Osleger, D.A., Arthur, M.A., Bice, D.M., Herbert, T.D., Erba, E., Premoli Silva, I., 2008. Toward an orbital chronology for the early Aptian Oceanic Anoxic Event (OAE1a, $120 \mathrm{Ma}$ ). Earth Planet. Sci. Lett. 271, 88-100. https://doi.org/10.1016/j.eps1.2008.03.055

Lijmbach, G.W.M., 1975. On the origin of petroleum, in: Proceedings Ninth World Petroleum Congress. Applied Sciences Publisher, London, pp. 357-369.

Limarino, C.O., Passalia, M.G., Llorens, M., Vera, E.I., Loinaze, V.S.P., Césari, S.N., 2012. Depositional environments and vegetation of Aptian sequences affected by 
volcanism in Patagonia. Palaeogeogr. Palaeoclimatol. Palaeoecol. 323-325, 22-41. https://doi.org/10.1016/J.PALAEO.2012.01.021

Lin, X., Wakeham, S.G., Putnam, I.F., Astor, Y.M., Scranton, M.I., Chistoserdov, A.Y., Taylor, G.T., 2006. Comparison of vertical distributions of prokaryotic assemblages in the anoxic cariaco basin and black sea by use of fluorescence in situ hybridization. Appl. Environ. Microbiol. 72, 2679-2690. https://doi.org/10.1128/AEM.72.4.2679-2690.2006

Liu, Y., Chen, L., Jianfu, Z., Qinghui, H., Zhiliang, Z., Hongwen, G., 2008. Distribution and sources of polycyclic aromatic hydrocarbons in surface sediments of rivers and an estuary in Shanghai, China. Environ. Pollut. 154, 298-305. https://doi.org/10.1016/J.ENVPOL.2007.10.020

Llaguno, R.J., 2017. Paleoenvironments, origin, and relative maturity of organic matter in Barremian-Aptian limestones of the eastern Prada Quarry, Organyà Basin, NE Spain. MS Thesis. 101 p. Florida International University.

Louda, J.W., Baker, E.W., 1984. Perylene occurrence, alkylation and possible sources in deep-ocean sediments. Geochim. Cosmochim. Acta 48, 1043-1058. https://doi.org/10.1016/0016-7037(84)90195-9

Luciani, V., Cobianchi, M., Lupi, C., 2006. Regional record of a global oceanic anoxic event: OAE1a on the Apulia Platform margin, Gargano Promontory, southern Italy. Cretac. Res. 27, 754-772. https://doi.org/10.1016/j.cretres.2006.01.003

Luo, P., Peng, P.A., Lü, H.Y., Zheng, Z., Wang, X., 2012. Latitudinal variations of CPI values of long-chain n-alkanes in surface soils: Evidence for CPI as a proxy of aridity. Sci. China Earth Sci. 55, 1134-1146. https://doi.org/10.1007/s11430-012$4401-8$

Luo, X.-J., Chen, S.-J., Mai, B.-X., Yang, Q.-S., Sheng, G.-Y., Fu, J.-M., 2006. Polycyclic aromatic hydrocarbons in suspended particulate matter and sediments from the Pearl River Estuary and adjacent coastal areas, China. Environ. Pollut. 139, 9-20. https://doi.org/10.1016/J.ENVPOL.2005.05.001

Mackenzie, A.S., Brassell, S.C., Eglinton, G., Maxwell, J.R., 1982. Chemical fossils: The geological fate of steroids. Science (80-. ). 217, 491-504. https://doi.org/10.1126/science.217.4559.491

Magniez-Jannin, F., Bréhéret, J.-G., Delanoy, G., 1997. Un exemple de spéciation lié à l'eustatisme: l'apparition précoce de Schackoina cabri (foraminifère planctonique mésogéen). Comptes Rendus l'Académie des Sci. - Ser. IIA - Earth Planet. Sci. 325, 225-230. https://doi.org/10.1016/S1251-8050(97)88293-6 
Mair, B.J., 1964. Terpenoids, fatty acids and alcohols as source materials for petroleum hydrocarbons. Geochim. Cosmochim. Acta 28, 1303-1321.

https://doi.org/10.1016/0016-7037(64)90131-0

Malawska, M., Bojakowska, I., Wiłkomirski, B., 2002. Polycyclic aromatic hydrocarbons (PAHs) in peat and plants from selected peat-bogs in the north-east of Poland. J. Plant Nutr. Soil Sci. 165, 686-691. https://doi.org/10.1002/jpln.200290004

Malawska, M., Ekonomiuk, A., Wilkomirski, B., 2006. Polycyclic aromatic hydrocarbons in peat cores from southern Poland : distribution in stratigraphic profiles as an indicator of PAH sources. Mires Peat 1, 1-14.

Mallory, F.B., Gordon, J.T., Conner, R.L., 1963. The isolation of a pentacyclic triterpenoid alcohol from a protozoan. J. Am. Chem. Soc. 85, 1362-1363. https://doi.org/10.1021/ja00892a042

Moore, C., Mills, M.M., Achterberg, E.P., Geider, R.J., LaRoche, J., Lucas, M.I., McDonagh, E.L., Pan, X., Poulton, A.J., Rijkenberg, M.J.A., Suggett, D.J., Ussher, S.J., Woodward, E.M.S., 2009. Large-scale distribution of Atlantic nitrogen fixation controlled by iron availability. Nat. Geosci. 2, 867.

Martin, J.H., Coale, K.H., Johnson, K.S., Fitzwater, S.E., Gordon, R.M., Tanner, S.J., Hunter, C.N., Elrod, V.A., Nowicki, J.L., Coley, T.L., Barber, R.T., Lindley, S., Watson, A.J., Van Scoy, K., Law, C.S., Liddicoat, M.I., Ling, R., Stanton, T., Stockel, J., Collins, C., Anderson, A., Bidigare, R., Ondrusek, M., Latasa, M., Millero, F.J., Lee, K., Yao, W., Zhang, J.Z., Friederich, G., Sakamoto, C., Chavez, F., Buck, K., Kolber, Z., Greene, R., Falkowski, P., Chisholm, S.W., Hoge, F., Swift, R., Yungel, J., Turner, S., Nightingale, P., Hatton, A., Liss, P., Tindale, N.W., 1994. Testing the iron hypothesis in ecosystems of the equatorial Pacific Ocean. Nature 371, 123.

Martin, J.H., Fitzwater, S.E., 1988. Iron deficiency limits phytoplankton growth in the north-east pacific subarctic. Nature 331, 341-343. https://doi.org/10.1038/331341a0

Martin, J.H., Fitzwater, S.E., Gordon, R.M., 1990. Iron deficiency limits phytoplankton growth in Antarctic waters. Global Biogeochem. Cycles 4, 5-12. https://doi.org/10.1029/GB004i001p00005

Marynowski, L., Smolarek, J., Bechtel, A., Philippe, M., Kurkiewicz, S., Simoneit, B.R.T., 2013. Perylene as an indicator of conifer fossil wood degradation by wooddegrading fungi. Org. Geochem. 59, 143-151. https://doi.org/10.1016/J.ORGGEOCHEM.2013.04.006 
Mayer, L.M., 1994. Surface area control of organic carbon accumulation in continental shelf sediments. Geochim. Cosmochim. Acta 58, 1271-1284.

https://doi.org/10.1016/0016-7037(94)90381-6

Mayser, J.P., Flecker, R., Marzocchi, A., Kouwenhoven, T.J., Lunt, D.J., Pancost, R.D., 2017. Precession driven changes in terrestrial organic matter input to the Eastern Mediterranean leading up to the Messinian Salinity Crisis. Earth Planet. Sci. Lett. 462, 199-211. https://doi.org/10.1016/J.EPSL.2017.01.029

McClain, M.E., Kainer, K.A., Richey, J.E., Victoria, R.L., 2001. The biogeochemistry of the Amazon Basin. Oxford University Press, New York.

McKirdy, D.M., Aldridge, A.K., Ypma, P.J.M., 1983. A geochemical comparison of some crude oils from pre-Ordovician carbonate rocks, in: Advances in Organic Geochemistry 1981. Wiley Chichester, pp. 99-107.

Mead, R., Xu, Y., Chong, J., Jaffé, R., 2005. Sediment and soil organic matter source assessment as revealed by the molecular distribution and carbon isotopic composition of n-alkanes. Org. Geochem. 36, 363-370. https://doi.org/10.1016/j.orggeochem.2004.10.003

Méhay, S., Keller, C.E., Bermasconi, S.M., Weissert, H., Erba, E., Bottini, C., Hochuli, P.A., 2009. A volcanic CO2 pulse triggered the Cretaceous oceanic Anoxic event 1a and a biocalcification crisis. Geology 37, 819-822. https://doi.org/10.1130/G30100A.1

Méjanelle, L., Laureillard, J., 2008. Lipid biomarker record in surface sediments at three sites of contrasting productivity in the tropical North Eastern Atlantic. Mar. Chem. 108, 59-76. https://doi.org/10.1016/j.marchem.2007.10.002

Méjanelle, L., Lòpez, J.F., Gunde-Cimerman, N., Grimalt, J.O., 2000. Sterols of melanized fungi from hypersaline environments. Org. Geochem. 31, 1031-1040. https://doi.org/10.1016/S0146-6380(00)00094-2

Mendes, M.M., Barrón, E., Dinis, P., Rey, J., Batten, D.J., 2018. A new palynoflora from upper Barremian-lower Aptian rocks at Casal do Borracho, Torres Vedras, western Portugal, and its palaeoecological significance. Cretac. Res. 90, 363-374. https://doi.org/10.1016/J.CRETRES.2018.06.012

Menegatti, A.P., Weissert, H., Brown, R.S., Tyson, R. V., Farrimond, P., Strasser, A., Caron, M., 1998. High-resolution $\delta 13 \mathrm{C}$ stratigraphy through the early Aptian "Livello Selli" of the Alpine Tethys. Paleoceanography 13, 530-545. https://doi.org/10.1029/98PA01793 
Meyers, P.A., 1997. Organic geochemical proxies of paleoceanographic, paleolimnologic, and paleoclimatic processes. Org. Geochem. 27, 213-250. https://doi.org/10.1016/S0146-6380(97)00049-1

Meyers, P.A., Eadie, B.J., 1993. Sources, degradation and recycling of organic matter associated with sinking particles in Lake Michigan. Org. Geochem. 20, 47-56. https://doi.org/10.1016/0146-6380(93)90080-U

Meyers, P.A., Ishiwatari, R., 1993. Lacustrine organic geochemistry-an overview of indicators of organic matter sources and diagenesis in lake sediments. Org. Geochem. 20, 867-900. https://doi.org/10.1016/0146-6380(93)90100-P

Michalík, J., Soták, J., Lintnerová, O., Halásová, E., Bak, M., Skupien, P., Boorová, D., 2008. The stratigraphic and paleoenvironmental setting of Aptian OAE black shale deposits in the Pieniny Klippen Belt, Slovak Western Carpathians. Cretac. Res. 29, 871-892. https://doi.org/10.1016/j.cretres.2008.05.005

Middelburg, J.J., Meysman, F.J.R., 2007. Burial at Sea. Science (80-. ). 316, 1294 LP1295. https://doi.org/10.1126/science.1144001

Millán, M.I., Weissert, H.J., Fernández-Mendiola, P.A., García-Mondéjar, J., 2009. Impact of Early Aptian carbon cycle perturbations on evolution of a marine shelf system in the Basque-Cantabrian Basin (Aralar, N Spain). Earth Planet. Sci. Lett. 287, 392-401. https://doi.org/10.1016/j.eps1.2009.08.023

Minoura, K., Hoshino, K., Nakamura, T., Wada, E., 1997. Late Pleistocene-Holocene paleoproductivity circulation in the Japan Sea: sea-level control on $\delta 13 \mathrm{C}$ and $\delta 15 \mathrm{~N}$ records of sediment organic material. Palaeogeogr. Palaeoclimatol. Palaeoecol. 135, 41-50. https://doi.org/10.1016/S0031-0182(97)00026-6

Moldowan, J.M., Seifert, W.K., Gallegos, E.J., 1985. Relationship between petroleum composition and depositional environment of petroleum source rocks. Am. Assoc. Pet. Geol. Bull. 69, 1255-1268. https://doi.org/10.1080/10916469808949779

Moldowan, J.M., Sundararaman, P., Schoell, M., 1986. Sensitivity of biomarker properties to depositional environment and/or source input in the Lower Toarcian of SW-Germany. Org. Geochem. 10, 915-926.

Montadert, L., de Charpal, O., Roberts, D., Guennoc, P., Sibuet, J., 1979. Northeast Atlantic passive continental margins: rifting and subsidence processes. Deep Drill. results Atl. Ocean Cont. margins Paleoenviron. 3, 154-186.

Montigny, R., Azambre, B., Rossy, M., Thuizat, R., 1986. K-Ar Study of cretaceous magmatism and metamorphism in the pyrenees: Age and length of rotation of the 
Iiberian Peninsula. Tectonophysics 129, 257-273. https://doi.org/10.1016/00401951(86)90255-6

Moreira-Turcq, P., Bonnet, M.-P., Amorim, M., Bernardes, M., Lagane, C., Maurice, L., Perez, M., Seyler, P., 2013. Seasonal variability in concentration, composition, age, and fluxes of particulate organic carbon exchanged between the floodplain and Amazon River. Global Biogeochem. Cycles 126, 119-130. https://doi.org/10.1002/gbc.20022

Moreira-Turcq, P., Seyler, P., Guyot, J.L., Etcheber, H., 2003. Exportation of organic carbon from the Amazon River and its main tributaries. Hydrol. Process. 17, 13291344. https://doi.org/10.1002/hyp.1287

Moullade, M., Kuhnt, W., Bergen, J.A., Masse, J.-P., Tronchetti, G., 1998. Correlation of biostratigraphic and stable isotope events in the Aptian historical stratotype of $\mathrm{La}$ Bédoule (southeast France). Comptes Rendus l'Académie des Sci. - Ser. IIA - Earth Planet. Sci. 327, 693-698. https://doi.org/10.1016/S1251-8050(99)80027-5

Moullade, M., Tronchetti, G., Granier, B., Bornemann, A., Kuhnt, W., Lorenzen, J., 2015. High-resolution integrated stratigraphy of the OAE1a and enclosing strata from core drillings in the Bedoulian stratotype (Roquefort-La Bédoule, SE France). Cretac. Res. 56, 119-140. https://doi.org/10.1016/J.CRETRES.2015.03.004

Muñoz, J.A., 1992. Evolution of a continental collision belt: ECORS-Pyrenees crustal balanced cross-section, in: Thrust Tectonics. pp. 235-246.

https://doi.org/10.1007/978-94-011-3066-0_21

Naafs, B.D.A., Castro, J.M., De Gea, G.A., Quijano, M.L., Schmidt, D.N., Pancost, R.D., 2016. Gradual and sustained carbon dioxide release during Aptian Oceanic Anoxic Event 1a. Nat. Geosci. 9, 135.

Najarro, M., Rosales, I., Moreno-Bedmar, J.A., de Gea, G.A., Barrón, E., Company, M., Delanoy, G., 2011. High-resolution chemo- and biostratigraphic records of the Early Aptian oceanic anoxic event in Cantabria (N Spain): Palaeoceanographic and palaeoclimatic implications. Palaeogeogr. Palaeoclimatol. Palaeoecol. 299, 137-158. https://doi.org/10.1016/j.palaeo.2010.10.042

Nes, W.R., 1974. Role of sterols in membranes. Lipids 9, 596-612. https://doi.org/10.1007/BF02532509

Nieto-Cid, M., Álvarez-Salgado, X.A., PÉrez, F.F., 2006. Microbial and photochemical reactivity of fluorescent dissolved organic matter in a coastal upwelling system. Limnol. Oceanogr. 51, 1391-1400. https://doi.org/10.4319/lo.2006.51.3.1391 
Núñez-Useche, F., Barragán, R., Moreno-Bedmar, J.A., Canet, C., 2015. Geochemical and paleoenvironmental record of the early to early late Aptian major episodes of accelerated change: Evidence from Sierra del Rosario, Northeast Mexico. Sediment. Geol. 324, 47-66. https://doi.org/10.1016/j.sedgeo.2015.04.006

O'Reilly, S.S., Szpak, M.T., Flanagan, P. V., Monteys, X., Murphy, B.T., Jordan, S.F., Allen, C.C.R., Simpson, A.J., Mulligan, S.M., Sandron, S., Kelleher, B.P., 2014. Biomarkers reveal the effects of hydrography on the sources and fate of marine and terrestrial organic matter in the western Irish Sea. Estuar. Coast. Shelf Sci. 136, 157171. https://doi.org/10.1016/j.ecss.2013.11.002

Olivet, J.L., 1996. Kinematics of the Iberian plate, in: Bulletin Des Centres de Recherches Elf Exploration Production. pp. 191-195.

Orr, W.L., Grady, J.R., 1967. Perylene in basin sediments off southern california. Geochim. Cosmochim. Acta 31, 1201-1209. https://doi.org/10.1016/S00167037(67)80058-9

Ourisson, G., Albrecht, P., Rohmer, M., 1979. The hopanoids: palaeochemistry and biochemistry of a group of natural products. Pure Appl. Chem. 51, 709-729.

Ourisson, G., Albrecht, P., Rohmer, M., 1982. Predictive microbial biochemistry - from molecular fossils to procaryotic membranes. Trends Biochem. Sci. 7, 236-239. https://doi.org/10.1016/0968-0004(82)90028-7

Ourisson, G., Rohmer, M., 1992. Hopanoids. 2. Biohopanoids: A Novel Class of Bacterial Lipids. Acc. Chem. Res. 25, 403-408. https://doi.org/10.1021/ar00021a004

Ourisson, G., Rohmer, M., Poralla, K., 1987. Prokaryotic hopanoids and other polyterpenoid sterol surrogates. Annu. Rev. Microbiol. 41, 301-333.

Özsoy, E., Ünlüata, Ü., 1997. Oceanography of the Black Sea: A review of some recent results. Earth-Science Rev. 42, 231-272. https://doi.org/10.1016/S00128252(97)81859-4

Pan, C., Peng, D., Zhang, M., Yu, L., Sheng, G., Fu, J., 2008. Distribution and isomerization of $\mathrm{C} 31-\mathrm{C} 35$ homohopanes and $\mathrm{C} 29$ steranes in oligocene saline lacustrine sediments from Qaidam Basin, Northwest China. Org. Geochem. 39, 646657. https://doi.org/10.1016/j.orggeochem.2008.02.024

Papp, D.C., Cociuba, I., Lazâr, D.F., 2013. Carbon and oxygen-isotope stratigraphy of the Early Cretaceous carbonate platform of Pâdurea Craiului (Apuseni Mountains, Romania): A chemostratigraphic correlation and paleoenvironmental tool. Appl. Geochemistry 32, 3-16. https://doi.org/10.1016/j.apgeochem.2012.09.005 
Pedersen, T.F., Calvert, S.E., 1990. Anoxia vs. productivity: what controls the formation of organic- carbon-rich sediments and sedimentary rocks? Am. Assoc. Pet. Geol. Bull. 74, 454-466.

Pearson, K., 1896. Mathematical contributions to the theory of evolution. - on a form of spurious correlation which may arise when indices are used in the measurement of organs. Proceedings of the royal society of London, 60(359-367), pp.489-498.

Peters, K.E., Walters, C.C., Moldowan, J.M., 2005. The Biomarker Guide, Volume 1: Biomarkers and Isotopes in the Environment and Human History, Cambridge University Press. https://doi.org/10.1016/0146-6380(93)90028-A

Peters, K.E., Walters, C.C., Moldowan, J.M., 2007. The Biomarker Guide Volume 2: Biomarkers and isotopes in petroleum systems and earth history, Cambridge University Press.

Peybernès, B., Souquet, P., 1973. Biostratigraphie des marnes noires de l'Aptien-Albien de la zone sud-pyrénéenne. CR Acad. Sc. Paris 276, 2501-2504.

Ponton, C. 2005. Barremian-Aptian deposits of the Mexican versus the Provencal (France) Platforms: Paleoenvironmental Implications. MS Thesis. 109 p. Florida International University

Puigdefäbregas, C., Muñoz, J.A., Vergés, J., 1992. Thrusting and foreland basin evolution in the southern Pyrenees, in: Thrust Tectonics. Springer, pp. 247-254.

Puigdefäbregas, C., Souquet, P., 1986. Tecto-sedimentary cycles and depositional sequences of the Mesozoic and Tertiary from the Pyrenees. Tectonophysics 129, 173-203. https://doi.org/10.1016/0040-1951(86)90251-9

Quay, P.D., Wilbur, D. 0., Richey, J.E., Hedges, J.I., Devol, A.H., Victoria, R., 1992. Carbon cycling in the Amazon River: Implications from the $13 \mathrm{C}$ compositions of particles and solutes. Limnol. Oceanogr. 37, 857-871. https://doi.org/10.4319/lo.1992.37.4.0857

Ramaswamy, V., Gaye, B., Shirodkar, P.V., Rao, P.S., Chivas, A.R., Wheeler, D., Thwin, S., 2008. Distribution and sources of organic carbon, nitrogen and their isotopic signatures in sediments from the Ayeyarwady (Irrawaddy) continental shelf, northern Andaman Sea. Mar. Chem. 111, 137-150. https://doi.org/10.1016/J.MARCHEM.2008.04.006

Ransom, B., Bennett, R.H., Baerwald, R., Shea, K., 1997. TEM study of in situ organic matter on continental margins: Occurrence and the "monolayer" hypothesis. Mar. Geol. 138, 1-9. https://doi.org/10.1016/S0025-3227(97)00012-1 
Raven, J.A., Johnston, A.M., 1991. Mechanisms of inorganic-carbon acquisition in marine phytoplankton and their implications for the use of other resources. Limnol. Oceanogr. 36, 1701-1714. https://doi.org/10.4319/lo.1991.36.8.1701

Richey, J.E., Mertes, L.A.K., Dunne, T., Victoria, R.L., Forsberg, B.R., Tancredi, A.C.N.S., Oliveira, E., 1989. Sources and routing of the Amazon River Flood Wave. Global Biogeochem. Cycles 3, 191-204. https://doi.org/10.1029/GB003i003p00191

Riederer, M., Markstädter, C., 1996. Cuticular waxes: a critical assessment of current knowledge. Plant Cuticles an Integr. Funct. Approach 189-200.

Roban, R-D., Melinte-Dobrinescu, M. C., 2012. Lower Cretaceous lithofacies of the black shales rich Audia Formation, Tarcau Nappe, Eastern Carpathians: Genetic significance and sedimentary palaeoenvironments. Cretaceous Research 38, 52 - 67.

Robertson, A.I., Bunn, S.E., Boon, P.I., Walker, K.F., 1999. Sources, sinks and transformations of organic carbon in Australian floodplain rivers. Mar. Freshw. Res. 50, 813-829. https://doi.org/10.1071/MF99112

Rohmer, M., Bouvier, P., Ourisson, G., 1979. Molecular evolution of biomembranes: Structural equivalents and phylogenetic precursors of sterols. Proc. Natl. Acad. Sci. U. S. A. 76, 847-851. https://doi.org/10.1073/pnas.76.2.847

Romankevich, E.A., 1984. Geochemistry of Organic Matter in the Ocean, 1st ed. Springer-Verlag Berlin Heidelberg. https://doi.org/10.1007/978-3-642-49964-7

Romero-Sarmiento, M.-F., Riboulleau, A., Vecoli, M., Versteegh, G.J.-M., 2011. Aliphatic and aromatic biomarkers from Gondwanan sediments of Late Ordovician to Early Devonian age: An early terrestrialization approach. Org. Geochem. 42, 605-617. https://doi.org/10.1016/J.ORGGEOCHEM.2011.04.005

Rosenbaum, G., Lister, G.S., Duboz, C., 2002. Relative motions of Africa, Iberia and Europe during Alpine orogeny. Tectonophysics 359, 117-129. https://doi.org/10.1016/S0040-1951(02)00442-0

Rycroft, D.S., Cole, W.J., Aslam, N., Lamont, Y.M., Gabriel, R., 1999. Killarniensolide, methyl orsellinates and 9,10-dihydrophenanthrenes from the liverwort Plagiochila killarniensis from Scotland and the Azores. Phytochemistry 50, 1167-1173. https://doi.org/10.1016/S0031-9422(98)00664-5

Saliot, A., Laureillard, J., Scribe, P., Sicre, M.A., 1991. Evolutionary trends in the lipid biomarker approach for investigating the biogeochemistry of organic matter in the marine environment. Mar. Chem. 36, 233-248. https://doi.org/10.1016/S03044203(09)90064-0 
Sanchez-Hernandez, Y., 2014. Paleoenvironments and geochemical signals from the late Barremian to the middle Aptian in a Tethyan marginal basin, northeast Spain: Implications for carbon sequestration in restricted basins. Florida International University.

Sanchez-Hernandez, Y., Maurrasse, F.J.M.R., 2014. Geochemical characterization and redox signals from the latest Barremian to the earliest Aptian in a restricted marine basin: El Pui section, Organyà Basin, south-central Pyrenees. Chem. Geol. 372, 12 31. https://doi.org/10.1016/j.chemgeo.2014.02.011

Sanchez-Hernandez, Y., Maurrasse, F.J.M.R., 2016. The influence of regional factors in the expression of oceanic anoxic event $1 \mathrm{a}(\mathrm{OAE} 1 \mathrm{a})$ in the semi-restricted Organyà Basin, south-central Pyrenees, Spain. Palaeogeogr. Palaeoclimatol. Palaeoecol. 441, 582-598. https://doi.org/10.1016/j.palaeo.2015.06.031

Sanchez-Hernandez, Y., Maurrasse, F.J.M.R., Melinte-Dobrinescu, M.C., He, D., Butler, S.K., 2014. Assessing the factors controlling high sedimentation rates from the latest Barremian-earliest Aptian in the hemipelagic setting of the restricted Organyà Basin, NE Spain. Cretac. Res. 51, 1-21. https://doi.org/10.1016/j.cretres.2014.05.010

Santos, V., Billett, D.S.M., Rice, A.L., Wolff, G.A., 1994. Organic matter in deep-sea sediments from the Porcupine Abyssal Plain in the north-east Atlantic Ocean. ILipids. Deep Sea Res. Part I Oceanogr. Res. Pap. 41, 787-819.

https://doi.org/10.1016/0967-0637(94)90077-9

Sass, A.M., Sass, H., Coolen, M.J.L., Cypionka, H., Overmann, J., 2001. Microbial Communities in the Chemocline of a Hypersaline Deep-Sea Basin (Urania Basin, Mediterranean Sea). Appl. Environ. Microbiol. 67, 5392-5402. https://doi.org/10.1128/AEM.67.12.5392-5402.2001

Sato, O., 1976. A green pigment similar to the pg fraction of $\mathrm{P}$ type humic acids and related compounds produced by litter-decomposing fungi. Soil Sci. Plant Nutr. 22, 269-275. https://doi.org/10.1080/00380768.1976.10432989

Satterberg, J., Arnarson, T.S., Lessard, E.J., Keil, R.G., 2003. Sorption of organic matter from four phytoplankton species to montmorillonite, chlorite and kaolinite in seawater. Mar. Chem. 81, 11-18. https://doi.org/10.1016/S0304-4203(02)00136-6

Scalan, E.S., Smith, J.E., 1970. An improved measure of the odd-even predominance in the normal alkanes of sediment extracts and petroleum. Geochim. Cosmochim. Acta 34, 611-620. https://doi.org/10.1016/0016-7037(70)90019-0

Scarlett, A.G., Despaigne-Diaz, A.I., Wilde, S.A., Grice, K., 2019. An examination by $\mathrm{GC} \times \mathrm{GC}-\mathrm{TOFMS}$ of organic molecules present in highly degraded oils emerging 
from Caribbean terrestrial seeps of Cretaceous age. Geosci. Front. 10, 5-15. https://doi.org/10.1016/J.GSF.2018.03.011

Schaller, H., 2003. The role of sterols in plant growth and development. Prog. Lipid Res. 42, 163-175. https://doi.org/10.1016/S0163-7827(02)00047-4

Schefuß, E., Versteegh, G.J.M., Jansen, J.H.F., Sinninghe Damsté, J.S., 2004. Lipid biomarkers as major source and preservation indicators in SE Atlantic surface sediments. Deep. Res. Part I Oceanogr. Res. Pap. 51, 1199-1228.

https://doi.org/10.1016/j.dsr.2004.05.002

Schirmer, A., Rude, M.A., Li, X., Popova, E., Del Cardayre, S.B., 2010. Microbial biosynthesis of alkanes. Science (80-. ). 329, 559-562. https://doi.org/10.1126/science. 1187936

Schlanger, S.O., Jenkyns, H.C., 1976. Cretaceous oceanic anoxic events: Causes and consequences. Geol. en Mijnb. 55, 179-184.

Schlünz, B., Schneider, R.., Müller, P.., Showers, W.., Wefer, G., 1999. Terrestrial organic carbon accumulation on the Amazon deep sea fan during the last glacial sea level low stand. Chem. Geol. 159, 263-281. https://doi.org/10.1016/S00092541(99)00041-8

Schmidt, F., Hinrichs, K.U., Elvert, M., 2010. Sources, transport, and partitioning of organic matter at a highly dynamic continental margin. Mar. Chem. 118, 37-55. https://doi.org/10.1016/j.marchem.2009.10.003

Scholle, P.A., Arthur, M.A., 1980. Carbon isotope fluctuations in Cretaceous pelagic limestones: potential stratigraphic and petroleum exploration tool. Am. Assoc. Pet. Geol. Bull. 64, 67-87. https://doi.org/10.1306/2F91892D-16CE-11D7$8645000102 \mathrm{C} 1865 \mathrm{D}$

Schreuder, L.T., Stuut, J.-B.W., Korte, L.F., Sinninghe Damsté, J.S., Schouten, S., 2018. Aeolian transport and deposition of plant wax n-alkanes across the tropical North Atlantic Ocean. Org. Geochem. 115, 113-123. https://doi.org/10.1016/J.ORGGEOCHEM.2017.10.010

Seguret, M., 1972. Étude tectonique des nappes et séries décollées de la partie centrale du versant sud des Pyrénées. Pub. Estela, Ser geol. struct. 2, 1-155.

Seifert, W.K., Moldowan, J.M., 1986. Use of Biological Markers in Petroleum Exploration. Mothods in Geochemistry and Geophysics. 24, 261-290. 
Selden, P., Nudds, J., 2012. El Montsec and Las Hoyas, in: Evolution of Fossil Ecosystems, Second Edition. CRC Press, pp. 183-201.

https://doi.org/10.1201/b15128

Shanmugam, G., 1985. Significance of Coniferous Rain Forests and Related Organic Matter in Generating Commercial Quantities of Oil, Gippsland Basin, Australia. Am. Assoc. Pet. Geol. Bull. 69, 1241-1254. https://doi.org/10.1306/AD462BC316F7-11D7-8645000102C1865D

Shan-Tan, L., Kaplan, I.R., 1992. Diterpanes, triterpanes, steranes and aromatic hydrocarbons in natural bitumens and pyrolysates from different mimic coals. Geochim. Cosmochim. Acta 56, 2761-2788. https://doi.org/10.1016/00167037(92)90358-P

Shultz, D.J., Calder, J.A., 1976. Organic carbon 13C12C variations in estuarine sediments. Geochim. Cosmochim. Acta 40, 381-385. https://doi.org/10.1016/00167037(76)90002-8

Sibuet, J.C., Collette, B.J., 1991. Triple junctions of Bay of Biscay and North Atlantic: new constraints on the kinematic evolution. Geology 19, 522-525. https://doi.org/10.1130/0091-7613(1991)019<0522:TJOBOB >2.3.CO;2

Sibuet, J.C., Srivastava, S.P., Spakman, W., 2004. Pyrenean orogeny and plate kinematics. J. Geophys. Res. Solid Earth 109, 1-18. https://doi.org/10.1029/2003JB002514

Sikes, E.L., Uhle, M.E., Nodder, S.D., Howard, M.E., 2009. Sources of organic matter in a coastal marine environment: Evidence from n-alkanes and their $\delta 13 \mathrm{C}$ distributions in the Hauraki Gulf, New Zealand. Mar. Chem. 113, 149-163.

https://doi.org/10.1016/j.marchem.2008.12.003

Silliman, J.E., Meyers, P.A., Eadie, B.J., 1998. Perylene: an indicator of alteration processes or precursor materials? Org. Geochem. 29, 1737-1744. https://doi.org/10.1016/S0146-6380(98)00056-4

Singer, A., 1984. The paleoclimatic interpretation of clay minerals in sediments - a review. Earth-Science Rev. 21, 251-293. https://doi.org/10.1016/00128252(84)90055-2

Sinninghe Damsté, J.S., Kenig, F., Koopmans, M.P., Köster, J., Schouten, S., Hayes, J.M., de Leeuw, J.W., 1995. Evidence for gammacerane as an indicator of water column stratification. Geochim. Cosmochim. Acta 59, 1895-1900. https://doi.org/10.1016/0016-7037(95)00073-9 
Sinninghe Damsté, J.S., Rijpstra, W.I.C., Schouten, S., Fuerst, J.A., Jetten, M.S.M., Strous, M., 2004. The occurrence of hopanoids in planctomycetes: Implications for the sedimentary biomarker record. Org. Geochem. 35, 561-566. https://doi.org/10.1016/j.orggeochem.2004.01.013

Soclo, H.., Garrigues, P., Ewald, M., 2000. Origin of Polycyclic Aromatic Hydrocarbons (PAHs) in Coastal Marine Sediments: Case Studies in Cotonou (Benin) and Aquitaine (France) Areas. Mar. Pollut. Bull. 40, 387-396. https://doi.org/10.1016/S0025-326X(99)00200-3

Socorro, J., Maurrasse, F.J.-M.R., 2019. Continuous accumulation of organic matter-rich sediments associated with Oceanic Anoxic Event 1a in the El Pujal section, Organyà Basin, Catalunyà Spain and its relation to episodic dysoxia. Cretac. Res. 95, 225251. https://doi.org/10.1016/J.CRETRES.2018.11.009

Socorro, J., Maurrasse, F.J-M.R., Sanchez-Hernandez, Y., 2017. Characterization of the negative carbon isotope shift in segment $\mathrm{C} 2$, its global implications as a harbinger of OAE1a. SCIENCE CHINA, Earth Science, 60 (1), 30 - 43.

Soma, Y., Tanaka, A., Soma, M., Kawai, T., 1996. Photosynthetic pigments and perylene in the sediments of southern basin of Lake Baikal. Org. Geochem. 24, 553-561. https://doi.org/10.1016/0146-6380(96)00036-8

Srivastava, S.P., Schouten, H., Roest, W.R., Klitgord, K.D., Kovacs, L.C., Verhoef, J., Macnab, R., 1990. Iberian plate kinematics: A jumping plate boundary between Eurasia and Africa. Nature 344, 756-759. https://doi.org/10.1038/344756a0

Stein, M., Westermann, S., Adatte, T., Matera, V., Fleitmann, D., Spangenberg, J.E., Föllmi, K.B., 2012. Late Barremian-Early Aptian palaeoenvironmental change: The Cassis-La Bédoule section, southeast France. Cretac. Res. 37, 209-222. https://doi.org/10.1016/j.cretres.2012.03.021

Stroeva, A. R., Giruts, M.V., Koshelev, V.N., Gordadze, G.N. 2013. Petroleum Chemistry, Vol. 53, No. 5, pp. 331-334. Pleiades Publishing, Ltd., 2013. Original Russian Text A. R. Stroeva, M.V. Giruts, V.N. Koshelev, G.N. Gordadze, 2013, published in Neftekhimiya, 2013, Vol. 53, No. 5, pp. 374-377.

Suess, E., 1973. Interaction of organic compounds with calcium carbonate-II. Organocarbonate association in Recent sediments. Geochim. Cosmochim. Acta 37, 24352447. https://doi.org/10.1016/0016-7037(73)90290-1

Suess, E., 1980. Particulate organic carbon flux in the oceans - surface productivity and oxygen utilization. Nature 288, 260. 
Suzuki, N., Yessalina, S., Kikuchi, T., 2010. Probable fungal origin of perylene in Late Cretaceous to Paleogene terrestrial sedimentary rocks of northeastern Japan as indicated from stable carbon isotopes. Org. Geochem. 41, 234-241. https://doi.org/10.1016/J.ORGGEOCHEM.2009.11.010

Tan, Y.., Heit, M., 1981. Biogenic and abiogenic polynuclear aromatic hydrocarbons in sediments from two remote Adirondack lakes. Geochim. Cosmochim. Acta 45, 2267-2279. https://doi.org/10.1016/0016-7037(81)90076-4

Tanoue, E., Handa, N., 1979. Differential sorption of organic matter by various sized sediment particles in recent sediment from the bering sea. J. Oceanogr. Soc. Japan 35, 199-208. https://doi.org/10.1007/BF02108640

Tarduno, J.A., Sliter, W. V, Kroenke, L., Leckie, M., Mayer, H., Mahoney, J.J., Musgrave, R., Storey, M., Winterer, E.L., 1991. Rapid Formation of Ontong Java Plateau by Aptian Mantle Plume Volcanism. Science (80-. ). 254, 399-403.

Taylor SR, McLennan SM, 1985. The continental crust: its composition and evolution. Blackwell Scientific Publication.

Taylor, A.M., Goldring, R., 1993. Description and analysis of bioturbation and ichnofabric. J. Geol. Soc. London. 150, 141-148. https://doi.org/10.1144/gsjgs.150.1.0141

Tejada, M.L.G., Suzuki, K., Kuroda, J., Coccioni, R., Mahoney, J.J., Ohkouchi, N., Sakamoto, T., Tatsumi, Y., 2009. Ontong Java Plateau eruption as a trigger for the early Aptian oceanic anoxic event. Geology 37, 855-858. https://doi.org/10.1130/G25763A.1

Ten Haven, H.L.T., Rohmer, M., Rullkötter, J., Bisseret, P., 1989. Tetrahymanol, the most likely precursor of gammacerane, occurs ubiquitously in marine sediments. Geochim. Cosmochim. Acta 53, 3073-3079. https://doi.org/10.1016/00167037(89)90186-5

Terry, R.D., Chilingar, G. V., 1955. Summary of "Concerning some additional aids in studying sedimentary formations," by M. S. Shvetsov. J. Sediment. Res. 25, 229234. https://doi.org/10.1306/74D70466-2B21-11D7-8648000102C1865D

Tissot, B.P., Welte, D.H., 1984. Petroleum Formation and Occurrence, 2nd ed. SpringerVerlag, Berlin. https://doi.org/10.1007/978-3-642-87813-8

Tribovillard, N., Riboulleau, A., Lyons, T., Baudin, F., 2004. Enhanced trapping of molybdenum by sulfurized marine organic matter of marine origin in Mesozoic limestones and shales. Chem. Geol. 213, 385-401. https://doi.org/10.1016/j.chemgeo.2004.08.011 
Turekian, K.K.,Wedepohl, K.H., 1961. Distribution of the elements in some major units of the Earth's crust. Geol. Soc. Am. Bull. 72, 175-192.

Vacherat, A., Mouthereau, F., Pik, R., Huyghe, D., Paquette, J.L., Christophoul, F., Loget, N., Tibari, B., 2017. Rift-to-collision sediment routing in the Pyrenees: A synthesis from sedimentological, geochronological and kinematic constraints. EarthScience Rev. 172, 43-74. https://doi.org/10.1016/j.earscirev.2017.07.004

van Bentum, E.C., Reichart, G.J., Sinninghe Damsté, J.S., 2012. Organic matter provenance, palaeoproductivity and bottom water anoxia during the Cenomanian/Turonian oceanic anoxic event in the Newfoundland Basin (northern proto North Atlantic Ocean). Org. Geochem. 50, 11-18. https://doi.org/10.1016/j.orggeochem.2012.05.013

van Breugel, Y., Schouten, S., Tsikos, H., Erba, E., Price, G.D., Damsté, J.S.S., 2007. Synchronous negative carbon isotope shifts in marine and terrestrial biomarkers at the onset of the early Aptian oceanic anoxic event 1a: Evidence for the release of 13C-depleted carbon into the atmosphere. Paleoceanography 22, 1-13. https://doi.org/10.1029/2006PA001341

Van der Voo, R., 1969. Paleomagnetic evidence for the rotation of the Iberian Peninsula. Tectonophysics 7, 5-56. https://doi.org/10.1016/0040-1951(69)90063-8

Van Der Weijden, C.H., 2002. Pitfalls of normalization of marine geochemical data using a common divisor. Mar. Geol. 184, 167-187. https://doi.org/10.1016/S00253227(01)00297-3

Varnosfaderany, M.N., Bakhtiari, A.R., Gu, Z., Chu, G., 2014. Perylene as an indicator of land-based plant biomarkers in the southwest Caspian Sea. Mar. Pollut. Bull. 80, 124-131. https://doi.org/10.1016/J.MARPOLBUL.2014.01.033

Venkatesan, M.I., 1988. Occurrence and possible sources of perylene in marine sediments-a review. Mar. Chem. 25, 1-27. https://doi.org/10.1016/03044203(88)90011-4

Venkatesan, M.I., 1989. Tetrahymanol: Its widespread occurrence and geochemical significance. Geochim. Cosmochim. Acta 53, 3095-3101. https://doi.org/10.1016/0016-7037(89)90190-7

Verga, D., Premoli Silva, I., 2002. Early Cretaceous planktonic foraminifera from the Tethys: The genus Leupoldina. Cretac. Res. 23, 189-212. https://doi.org/10.1006/cres.2002.0309 
Vergés, J., Fernàndez, M., Martìnez, A., 2002. The Pyrenean orogen: Pre-, syn-, and post-collisional evolution. J. Virtual Explor. 8, 55-74.

https://doi.org/10.3809/jvirtex.2002.00058

Vergés, J., García-Senz, J., 2001. Mesozoic evolution and Cainozoic inversion of the Pyrenean rift. Mémoires du Muséum Natl. d'histoire Nat. 186, 187-212.

Vergés, J., Muñoz, J.A., 1990. Thrust sequences in the southern central Pyrenees. Bull. Soc. Geol. Fr. 6, 265-271. https://doi.org/10.2113/gssgfbull.vi.2.265

Viso, A.-C., Pesando, D., Bernard, P., Marty, J.-C., 1993. Lipid components of the Mediterranean seagrass Posidonia oceanica. Phytochemistry 34, 381-387.

Vissers, R.L.M., Meijer, P.T., 2012. Mesozoic rotation of Iberia: Subduction in the Pyrenees? Earth-Science Rev. 110, 93-110. https://doi.org/10.1016/j.earscirev.2011.11.001

Volkman, J., 2003. Sterols in microorganisms. Appl. Microbiol. Biotechnol. 60, 495-506.

Volkman, J.K., 1986. A review of sterol markers for marine and terrigenous organic matter. Org. Geochem. 9, 83-99. https://doi.org/10.1016/0146-6380(86)90089-6

Volkman, J.K., 2005. Sterols and other triterpenoids: Source specificity and evolution of biosynthetic pathways. Org. Geochem. 36, 139-159. https://doi.org/10.1016/j.orggeochem.2004.06.013

Volkman, J.K., Barrett, S.M., Blackburn, S.I., Mansour, M.P., Sikes, E.L., Gelin, F., 1998. Microalgal biomarkers: A review of recent research developments, in: Organic Geochemistry. pp. 1163-1179. https://doi.org/10.1016/S01466380(98)00062-X

Volkman, J.K., Farrington, J.W., Gagosian, R.B., Wakeham, S.G., 1981. Lipid composition of coastal marine sediments from the Peru upwelling region. Adv. Org. geochemistry $228-240$.

Wainright, S.C., Fry, B., 1994. Seasonal variation of the stable isotopic compositions of coastal marine plankton from Woods Hole, Massachusetts and Georges Bank. Estuaries 17, 552-560. https://doi.org/10.2307/1352403

Wakeham, S.G., Schaffner, C., Giger, W., 1980. Poly cyclic aromatic hydrocarbons in Recent lake sediments - II. Compounds derived from biogenic precursors during early diagenesis. Geochim. Cosmochim. Acta 44, 415-429. https://doi.org/10.1016/0016-7037(80)90041-1 
Wakeham, S.G., Schaffner, C., Giger, W., Boon, J.J., De Leeuw, J.W., 1979. Perylene in sediments from the Namibian Shelf. Geochim. Cosmochim. Acta 43, 1141-1144. https://doi.org/10.1016/0016-7037(79)90100-5

Watson, D.F., Hindle, A.D., Farrimond, P., 2000. Organic geochemistry of petroleum seepages within the Jurassic Bencliff Grit, Osmington Mills, Dorset, UK. Pet. Geosci. 6, 289-297.

Weaver, C.E., 1958. A discussion on the origin of clay minerals in sedimentary rocks. Clays Clay Miner. 566, 159-173.

Weaver, C.E., 1989. Clays, muds, and Shales. Elsevier, Amsterdam.

Wedepohl, K.H., 1971. Environmental influences on the chemical composition of shales and clays. Phys. Chem. Earth 8, 307-333. https://doi.org/10.1016/00791946(71)90020-6

Wedepohl, K.H., 1991. Chemical composition and fractionation of the continental crust. Geol. Rundschau 80, 207-223. https://doi.org/10.1007/BF01829361

Weissert, H., 1989. C-Isotope stratigraphy, a monitor of paleoenvironmental change: A case study from the early cretaceous. Surv. Geophys. 10, 1-61. https://doi.org/10.1007/BF01901664

Weissert, H., Bréhéret, J.G., 1991. A carbonate-isotope record from Aptian-Albian sediments of the Vocontian Trough (SE France). Bull. la Société Géologique Fr. $162,1133-1140$.

Wellman, C.H., Osterloff, P.L., Mohiuddin, U., 2003. Fragments of the earliest land plants. Nature 425, 282.

Wenger, L.M., Isaksen, G.H., 2002. Control of hydrocarbon seepage intensity on level of biodegradation in sea bottom sediments. Org. Geochem. 33, 1277-1292. https://doi.org/10.1016/S0146-6380(02)00116-X

Westermann, S., Stein, M., Matera, V., Fiet, N., Fleitmann, D., Adatte, T., Föllmi, K.B., 2013. Rapid changes in the redox conditions of the western Tethys Ocean during the early Aptian oceanic anoxic event. Geochim. Cosmochim. Acta 121, 467-486. https://doi.org/10.1016/j.gca.2013.07.023

White M, W., 2013. Geochemistry. John Wiley \& Sons.

Wickham, S.M., Oxburgh, E.R., Reading, H.G., Vissers, R.L.M., 1987. Low-Pressure Regional Metamorphism in the Pyrenees and its Implications for the Thermal 
Evolution of Rifted Continental Crust [and Discussion]. Philos. Trans. R. Soc. London. Ser. A, Math. Phys. Sci. 321, 219-242.

Williams, C.A., 1975. Sea-floor spreading in the Bay of Biscay and its relationship to the North Atlantic. Earth Planet. Sci. Lett. 24, 440-456. https://doi.org/10.1016/0012821X(75)90151-X

Wilson, M.J., 1999. The origin and formation of clay minerals in soils; past, present and future perspectives. Clay Miner. 34, 7-25.

Winters, K., Parker, P.L., Van Baalen, C., 1969. Hydrocarbons of blue-green algae: Geochemical significance. Science (80-. ). 163, 467-468. https://doi.org/10.1126/science.163.3866.467

Wu, J., Filippidi, A., Davies, G.R., de Lange, G.J., 2018. Riverine supply to the eastern Mediterranean during last interglacial sapropel S5 formation: A basin-wide perspective. Chem. Geol. 485, 74-89. https://doi.org/10.1016/j.chemgeo.2018.03.037

Xu, G., Liu, J., Hu, G., Jonell, T.N., Chen, L., 2017. Distribution and source of organic matter in surface sediment from the muddy deposit along the Zhejiang coast, East China Sea. Mar. Pollut. Bull. 123, 395-399. https://doi.org/10.1016/J.MARPOLBUL.2017.08.053

Yilmaz, I. O., Vennemann, T., Altiner, D., Satir, M. 2004. Stable isotope evidence for meter-cale sea level changes in Lower Cretaceous inner platform and pelagic carbonate successions of Turkey. Geologica Carpathica 55 (1), $19-36$.

Yunker, M.B., Macdonald, R.W., 2003. Alkane and PAH depositional history, sources and fluxes in sediments from the Fraser River Basin and Strait of Georgia, Canada. Org. Geochem. 34, 1429-1454. https://doi.org/10.1016/S0146-6380(03)00136-0

Zhang, S., Li, S., Dong, H., Zhao, Q., Lu, X., Shi, J., 2014a. An analysis of organic matter sources for surface sediments in the central South Yellow Sea, China: Evidence based on macroelements and n-alkanes. Mar. Pollut. Bull. 88, 389-397. https://doi.org/10.1016/j.marpolbul.2014.07.064

Zhang, X., Xu, Y., Ruan, J., Ding, S., Huang, X., 2014b. Origin, distribution and environmental significance of perylene in Okinawa Trough since last glaciation maximum. Org. Geochem. 76, 288-294. https://doi.org/10.1016/J.ORGGEOCHEM.2014.09.008

Zhao, B., Zhang, Y., Huang, X., Qiu, R., Zhang, Z., Meyers, P.A., 2018a. Comparison of n-alkane molecular, carbon and hydrogen isotope compositions of different types of plants in the Dajiuhu peatland, central China. Org. Geochem. 124, 1-11. 
Zohary, T., Robarts, R.D., 1998. Experimental study of microbial P limitation in the eastern Mediterranean. Limnol. Oceanogr. 43, 387-395.

https://doi.org/10.4319/1o.1998.43.3.0387

Zubkov, M. V., Sazhin, A.F., Flint, M. V., 1992. The microplankton organisms at the oxic-anoxic interface in the pelagial of the Black Sea. FEMS Microbiol. Lett. 101, 245-250. https://doi.org/10.1111/j.1574-6968.1992.tb05781.x

Zumberge, J.E., 1987. Terpenoid biomarker distributions in low maturity crude oils. Org. Geochem. 11, 479-496. https://doi.org/10.1016/0146-6380(87)90004-0 


\subsection{Appendices}

Appendix 6A Carlos Herdocia - RSTE values.

\begin{tabular}{lcccccccc}
\hline Sample ID & Height $(\mathrm{m})$ & $\mathrm{V}$ & $\mathrm{Cr}$ & $\mathrm{Co}$ & $\mathrm{Ni}$ & $\mathrm{Cu}$ & $\mathrm{Mo}$ & $\mathrm{U}$ \\
\hline COR-16-17 & 35.6 & 16.41 & 16.95 & 1.23 & 26.30 & 4.53 & 4.61 & 2.76 \\
COR-16-16 & 32.74 & 6.87 & 11.95 & 0.86 & 17.34 & 1.28 & 1.43 & 1.24 \\
COR-16-15 & 31.95 & 14.44 & 21.43 & 0.84 & 31.61 & 3.58 & 3.74 & 5.53 \\
COR-16-14 & 29.95 & 14.34 & 17.50 & 1.07 & 26.02 & 3.89 & 12.02 & 3.35 \\
COR-16-13 & 27.44 & 13.32 & 14.17 & 0.45 & 12.44 & 1.94 & 1.43 & 3.27 \\
COR-16-12 & 23.44 & 8.97 & 14.99 & 0.67 & 12.77 & 1.44 & 0.82 & 1.63 \\
COR-16-11 & 17.81 & 10.15 & 14.35 & 0.66 & 17.43 & 3.04 & 2.15 & 2.11 \\
COR-16-10 & 14.85 & 30.54 & 16.57 & 1.39 & 22.19 & 4.66 & 14.73 & 1.27 \\
COR-16-9 & 10.75 & 6.59 & 11.81 & 0.66 & 12.16 & 1.54 & 1.08 & 1.35 \\
COR-16-8 & 7.65 & 11.88 & 14.82 & 0.85 & 15.76 & 2.65 & 3.10 & 2.27 \\
COR-16-7 & 6.38 & 7.67 & 13.00 & 0.56 & 17.49 & 2.15 & 1.88 & 1.10 \\
COR-16-6 & 4.38 & 17.56 & 12.00 & 0.95 & 16.30 & 3.74 & 5.14 & 1.26 \\
COR-16-5 & 3.93 & 12.45 & 7.92 & 0.37 & 4.20 & 1.10 & 0.47 & 1.61 \\
COR-16-4 & 1.93 & 7.65 & 12.05 & 0.43 & 9.89 & 1.27 & 1.23 & 2.00 \\
COR-16-3 & 0.68 & 9.93 & 14.74 & 0.62 & 11.24 & 1.32 & 1.37 & 1.54 \\
COR-16-2 & 0.43 & 25.31 & 17.12 & 0.95 & 26.87 & 4.98 & 12.29 & 4.26 \\
COR-16-1 & 0 & 7.34 & 18.10 & 2.19 & 8.95 & 1.13 & 0.69 & 1.22 \\
\cline { 2 - 7 } & & & \multicolumn{7}{c}{ *Values in (ppm) } & &
\end{tabular}

Appendix 6B PAH analysis data.

Sample ID

\begin{tabular}{|c|c|c|c|c|c|c|c|c|c|}
\hline \multirow[b]{2}{*}{ Analyte } & \multirow[b]{2}{*}{ Ion } & \multicolumn{8}{|c|}{ Sample ID } \\
\hline & & Blank & Fortified Blank & Fortified Sample & C-16-54 & C-16-65 & C-16-85 & $\mathrm{C}-16-120$ & C-16-138 \\
\hline Perylene-d12 & 264 & 1256 & 1384 & 1225 & 635 & 796 & 926 & 793 & 1012 \\
\hline Perylene & 252 & - & 937 & 1760 & 747 & 2212 & 1577 & 766 & 3365 \\
\hline Benzo(g,h,i)perylene & 276 & - & 1098 & 1487 & 265 & 508 & 747 & 179 & 1468 \\
\hline Dibenz(a,h)anthracene & 278 & - & 1263 & 1715 & 334 & 343 & 449 & 175 & 864 \\
\hline Indeno(1,2,3-cd)pyrene & 276 & - & 1021 & 1335 & - & - & - & 58 & - \\
\hline Benzo(a)pyrene & 252 & - & 1078 & 1144 & - & - & - & - & - \\
\hline Benzo(k)fluoranthene & 252 & - & 1162 & 1034 & - & - & 249 & - & - \\
\hline Benzo(b)fluoranthene & 252 & - & 1073 & 1309 & 152 & 292 & 308 & 117 & 357 \\
\hline Chrysene-D12 & 240 & 1271 & 1392 & 1325 & 391 & 1026 & 1144 & 722 & 954 \\
\hline Chrysene & 228 & 25 & 1189 & 1402 & 325 & 2102 & 1851 & 473 & 3812 \\
\hline Benzo(a)anthracene & 228 & 48 & 1126 & 1167 & 398 & 82 & 89 & 52 & 179 \\
\hline Acenaphthene-d10 & 164 & 863 & 587 & 42 & - & 58 & 166 & - & 47 \\
\hline Fluorene & 166 & - & 873 & 369 & - & 56 & 54 & - & 151 \\
\hline Acenaphthene & 154 & - & 249 & 37 & - & - & 56 & - & 168 \\
\hline Acenaphthylene & 152 & - & 504 & 36 & - & - & - & - & - \\
\hline Phenanthrene-D10 & 188 & 1254 & 1168 & 314 & 61 & 918 & 1232 & 126 & 1088 \\
\hline Pyrene & 202 & - & 979 & 260 & 30 & 394 & 642 & 40 & 1151 \\
\hline Fluoranthene & 202 & - & 961 & 842 & - & 90 & 82 & - & - \\
\hline Anthracene & 178 & - & 866 & 107 & - & - & - & - & 102 \\
\hline Phenanthrene & 178 & - & 905 & 499 & 89 & 2329 & 2882 & 138 & 5654 \\
\hline
\end{tabular}


Appendix 6C Values of calculated biomarker parameters.

\begin{tabular}{|c|c|c|c|c|c|c|c|c|c|c|c|c|}
\hline Sample ID & Height (m) & $\mathrm{CPI}$ & OEP-2 & TAR & $\mathrm{Pr} / \mathrm{n}-\mathrm{C}_{17}$ & $\mathrm{Ph} / \mathrm{n}-\mathrm{C}_{18}$ & Gammacerane Index & $\mathrm{C}_{27} / \mathrm{C}_{29}$ & $\mathrm{Ts} /(\mathrm{Ts}+\mathrm{Tm})$ & $\mathrm{C}_{31} 22 \mathrm{~S} /(22 \mathrm{~S}+22 \mathrm{R})$ & $\mathrm{C}_{29} 20 \mathrm{~S} /(20 \mathrm{~S}+20 \mathrm{R})$ & $C_{29} \beta \beta /(\beta \beta+\alpha \alpha)$ \\
\hline C-16-151 & 85.04 & 1.03 & 1.00 & 0.35 & 0.31 & 0.12 & & & & & & \\
\hline C-16-146 & 81.31 & 0.96 & 0.87 & 0.26 & 0.29 & 0.13 & & & & & & \\
\hline C-16-145 & 80.64 & 0.92 & 0.89 & 0.27 & 0.32 & 0.13 & & & & & & \\
\hline C-16-144 & 79.55 & 1.08 & 1.05 & 0.31 & 0.32 & 0.12 & & & & & & \\
\hline$C-16-143$ & 79.03 & 1.01 & 0.97 & 0.31 & 0.26 & 0.11 & & & & & & \\
\hline C-16-142 & 78.56 & 1.02 & 0.97 & 0.32 & 0.24 & 0.12 & & & & & & \\
\hline$C-16-140$ & 76.78 & 0.94 & 0.91 & 0.27 & 0.23 & 0.12 & & & & & & \\
\hline C-16-138 & 75.22 & 1.04 & 0.99 & 0.37 & 0.43 & 0.20 & 1.22 & 0.82 & 0.74 & 0.56 & 0.46 & 0.63 \\
\hline C-16-137 & 74.6 & 0.95 & 0.90 & 0.40 & 0.39 & 0.21 & & & & & & \\
\hline C-16-135 & 72.03 & 1.05 & 0.99 & 0.38 & 0.32 & 0.13 & 0.88 & 1.15 & 0.79 & 0.58 & 0.48 & 0.67 \\
\hline C-16-133 & 69.56 & 1.08 & 1.04 & 0.34 & 0.46 & 0.17 & & & & & & \\
\hline C-16-132 & 68.3 & 1.06 & 1.03 & 0.32 & 0.40 & 0.16 & & & & & & \\
\hline C-16-130 & 65.87 & 1.06 & 1.01 & 0.34 & 0.37 & 0.17 & & & & & & \\
\hline C-16-128 & 63.67 & 1.06 & 1.01 & 0.35 & 0.36 & 0.17 & & & & & & \\
\hline C-16-126 & 61.51 & 1.08 & 1.06 & 0.34 & 0.36 & 0.14 & & & & & & \\
\hline C-16-125 & 60.34 & 1.04 & 1.01 & 0.26 & 0.30 & 0.11 & & & & & & \\
\hline C-16-124 & 59.27 & 1.08 & 1.01 & 0.26 & 0.27 & 0.10 & & & & & & \\
\hline C-16-123 & 58.15 & 1.05 & 1.02 & 0.33 & 0.30 & 0.14 & & & & & & \\
\hline C-16-121 & 55.8 & 0.97 & 0.89 & 0.28 & 0.32 & 0.14 & & & & & & \\
\hline$C-16-120$ & 54.7 & 1.10 & 1.05 & 0.22 & 0.33 & 0.12 & 0.68 & 1.24 & 0.64 & 0.58 & 0.45 & 0.64 \\
\hline C-16-119 & 54.18 & 1.08 & 1.04 & 0.25 & 0.34 & 0.13 & & & & & & \\
\hline C-16-116 & 52.58 & 1.01 & 0.95 & 0.21 & 0.31 & 0.12 & & & & & & \\
\hline C-16-114 & 51.52 & 1.02 & 0.96 & 0.25 & 0.33 & 0.15 & & & & & & \\
\hline C-16-112 & 50.46 & 1.05 & 0.97 & 0.27 & 0.29 & 0.15 & & & & & & \\
\hline C-16-111 & 49.85 & 1.05 & 1.01 & 0.27 & 0.30 & 0.14 & & & & & & \\
\hline C-16-109 & 48.86 & 1.07 & 1.01 & 0.21 & 0.35 & 0.14 & & & & & & \\
\hline C-16-108 & 48.27 & 0.98 & 0.95 & 0.21 & 0.29 & 0.13 & & & & & & \\
\hline C-16-107 & 47.7 & 1.04 & 0.97 & 0.18 & 0.29 & 0.12 & & & & & & \\
\hline C-16-106 & 47.16 & 1.07 & 1.01 & 0.23 & 0.25 & 0.10 & & & & & & \\
\hline C-16-105 & 46.65 & 1.09 & 1.02 & 0.23 & 0.25 & 0.11 & & & & & & \\
\hline C-16-103 & 45.57 & 1.07 & 0.99 & 0.23 & 0.36 & 0.13 & & & & & & \\
\hline C-16-100 & 44.06 & 1.03 & 1.02 & 0.29 & 0.39 & 0.13 & & & & & & \\
\hline C-16-98 & 42.92 & 1.04 & 0.99 & 0.23 & 0.34 & 0.12 & & & & & & \\
\hline C-16-97 & 42.35 & 1.11 & 1.07 & 0.22 & 0.35 & 0.12 & & & & & & \\
\hline C-16-96 & 41.82 & 1.10 & 1.05 & 0.24 & 0.34 & 0.13 & & & & & & \\
\hline C-16-95 & 41.25 & 1.10 & 1.08 & 0.28 & 0.43 & 0.16 & & & & & & \\
\hline C-16-93 & 40.16 & 1.08 & 1.05 & 0.22 & 0.31 & 0.12 & & & & & & \\
\hline C-16-92 & 39.69 & 1.05 & 0.99 & 0.23 & 0.31 & 0.13 & & & & & & \\
\hline C-16-90 & 38.66 & 1.10 & 1.09 & 0.27 & 0.35 & 0.14 & & & & & & \\
\hline C-16-86 & 36.44 & 1.06 & 1.01 & 0.24 & 0.32 & 0.13 & & & & & & \\
\hline C-16-85 & 35.94 & 1.07 & 1.04 & 0.23 & 0.34 & 0.14 & & & & & & \\
\hline C-16-82 & 34.32 & 1.10 & 1.05 & 0.23 & 0.30 & 0.14 & & & & & & \\
\hline C-16-81 & 33.8 & 1.08 & 1.02 & 0.16 & 0.32 & 0.14 & & & & & & \\
\hline C-16-79 & 32.73 & 1.10 & 1.03 & 0.23 & 0.25 & 0.11 & & & & & & \\
\hline C-16-77 & 31.67 & 1.08 & 1.03 & 0.25 & 0.28 & 0.13 & & & & & & \\
\hline C-16-74 & 30.02 & 1.06 & 1.03 & 0.30 & 0.32 & 0.14 & & & & & & \\
\hline C-16-71 & 28.43 & 1.05 & 1.00 & 0.20 & 0.28 & 0.14 & & & & & & \\
\hline C-16-70 & 27.95 & 1.08 & 1.01 & 0.19 & 0.27 & 0.15 & & & & & & \\
\hline C-16-67 & 26.25 & 1.08 & 1.01 & 0.25 & 0.29 & 0.14 & & & & & & \\
\hline C-16-65 & 25.14 & 1.05 & 0.98 & 0.26 & 0.31 & 0.15 & 0.70 & 0.92 & 0.72 & 0.60 & 0.44 & 0.62 \\
\hline C-16-63 & 24.07 & 1.10 & 1.05 & 0.24 & 0.21 & 0.12 & & & & & & \\
\hline C-16-61 & 23.07 & 1.10 & 1.05 & 0.25 & 0.33 & 0.13 & & & & & & \\
\hline C-16-59 & 22.16 & 1.05 & 1.00 & 0.31 & 0.37 & 0.16 & & & & & & \\
\hline C-16-58 & 21.68 & 1.04 & 1.01 & 0.32 & 0.37 & 0.16 & & & & & & \\
\hline C-16-57 & 21.13 & 1.06 & 1.01 & 0.27 & 0.36 & 0.15 & & & & & & \\
\hline C-16-54 & 19.66 & 1.06 & 0.99 & 0.23 & 0.32 & 0.12 & 0.58 & 1.03 & 0.69 & 0.54 & 0.46 & 0.61 \\
\hline C-16-53 & 19.14 & 1.05 & 1.04 & 0.24 & 0.27 & 0.11 & & & & & & \\
\hline C-16-52 & 18.58 & 1.04 & 1.01 & 0.25 & 0.28 & 0.11 & & & & & & \\
\hline C-16-50 & 17.58 & 1.05 & 1.00 & 0.26 & 0.32 & 0.12 & & & & & & \\
\hline C-16-49 & 17.06 & 1.11 & 1.07 & 0.28 & 0.35 & 0.13 & & & & & & \\
\hline C-16-47 & 16.08 & 1.09 & 1.04 & 0.30 & 0.35 & 0.13 & & & & & & \\
\hline C-16-46 & 15.62 & 1.10 & 1.09 & 0.28 & 0.35 & 0.12 & & & & & & \\
\hline C-16-45 & 15.14 & 1.07 & 1.07 & 0.29 & 0.39 & 0.13 & & & & & & \\
\hline C-16-44 & 14.69 & 0.99 & 0.93 & 0.19 & 0.33 & 0.19 & & & & & & \\
\hline
\end{tabular}


Appendix 6D Carbon geochemistry values with their respective sample ID and stratigraphic position.

\begin{tabular}{|c|c|c|c|c|}
\hline Sample ID & Height (m) & $\delta^{13} \mathrm{C}$ & $\operatorname{TIC}\left(\mathrm{CaCO}_{3} \%\right)$ & TOC (C wt\%) \\
\hline C-16-97 & 42.35 & -23.68 & 74.42 & 0.91 \\
\hline C-16-96 & 41.82 & -23.63 & 72.82 & 0.78 \\
\hline C-16-95 & 41.25 & -23.69 & 68.62 & 1.01 \\
\hline C-16-94 & 40.71 & -23.68 & 75.4 & 0.74 \\
\hline C-16-93 & 40.16 & -23.59 & 73.72 & 0.58 \\
\hline C-16-92 & 39.69 & -23.71 & 71.37 & 1.00 \\
\hline C-16-91 & 39.19 & -23.54 & 68.67 & 1.00 \\
\hline C-16-90 & 38.66 & -23.58 & 66.58 & 1.20 \\
\hline C-16-89 & 38.09 & -23.52 & 64 & 1.20 \\
\hline C-16-88 & 37.54 & -23.51 & 62.81 & 1.27 \\
\hline C-16-87 & 36.98 & -23.71 & 69.23 & 1.31 \\
\hline C-16-86 & 36.44 & -23.74 & 67.51 & 1.33 \\
\hline C-16-85 & 35.94 & -23.88 & 64.48 & 1.32 \\
\hline C-16-84 & 35.42 & -23.85 & 69.30 & 1.18 \\
\hline C-16-83 & 34.86 & -23.80 & 70.17 & 1.24 \\
\hline C-16-82 & 34.32 & -23.80 & 69.73 & 1.41 \\
\hline C-16-81 & 33.8 & -23.94 & 72.78 & 1.18 \\
\hline C-16-80 & 33.3 & -24.02 & 73.50 & 0.97 \\
\hline C-16-79 & 32.73 & -23.82 & 81.34 & 0.88 \\
\hline C-16-78 & 32.25 & -23.98 & 73.78 & 1.06 \\
\hline C-16-77 & 31.67 & -24.28 & 72.85 & 1.15 \\
\hline C-16-76 & 31.13 & -24.06 & 72.58 & 1.19 \\
\hline C-16-75 & 30.57 & -24.21 & 72.34 & 1.21 \\
\hline C-16-74 & 30.02 & -23.90 & 62.57 & 1.44 \\
\hline C-16-73 & 29.5 & -24.27 & 72.40 & 1.22 \\
\hline C-16-72 & 28.95 & -24.41 & 72.10 & 1.23 \\
\hline C-16-71 & 28.43 & -24.19 & 72.60 & 1.03 \\
\hline C-16-70 & 27.95 & -24.20 & 73.80 & 1.05 \\
\hline C-16-69 & 27.4 & -24.22 & 72.53 & 1.08 \\
\hline C-16-68 & 26.81 & -24.54 & 72.85 & 1.12 \\
\hline C-16-67 & 26.25 & -24.07 & 68.28 & 1.44 \\
\hline C-16-66 & 25.7 & -24.09 & 61.90 & 1.58 \\
\hline$C-16-65$ & 25.14 & -24.31 & 63.42 & 1.72 \\
\hline C-16-64 & 24.62 & -23.87 & 67.10 & 1.63 \\
\hline C-16-63 & 24.07 & -23.69 & 67.05 & 1.49 \\
\hline C-16-62 & 23.55 & -24.00 & 73.73 & 1.13 \\
\hline C-16-61 & 23.07 & -23.78 & 74.01 & 0.97 \\
\hline$C-16-60$ & 22.61 & -24.21 & 67.24 & 1.00 \\
\hline C-16-59 & 22.16 & -23.62 & 64.92 & 1.24 \\
\hline C-16-58 & 21.68 & -23.76 & 67.45 & 1.12 \\
\hline C-16-57 & 21.13 & -23.97 & 67.95 & 1.33 \\
\hline C-16-56 & 20.68 & -23.87 & 69.22 & 1.20 \\
\hline C-16-55 & 20.14 & -23.95 & 81.46 & 0.75 \\
\hline C-16-54 & 19.66 & -24.04 & 78.74 & 0.73 \\
\hline C-16-53 & 19.14 & -23.99 & 77.36 & 0.92 \\
\hline C-16-52 & 18.58 & -23.90 & 77.99 & 0.80 \\
\hline C-16-51 & 18.08 & -23.77 & 74.03 & 0.99 \\
\hline C-16-50 & 17.58 & -23.72 & 71.08 & 1.14 \\
\hline C-16-49 & 17.06 & -23.64 & 68.22 & 1.00 \\
\hline C-16-48 & 16.58 & -23.65 & 66.85 & 1.15 \\
\hline C-16-47 & 16.08 & -23.71 & 68.11 & 1.24 \\
\hline C-16-46 & 15.62 & -23.82 & 72.25 & 1.05 \\
\hline C-16-45 & 15.14 & -23.92 & 73.79 & 1.11 \\
\hline C-16-44 & 14.69 & -24.41 & 77.03 & 0.87 \\
\hline C-16-43 & 14.29 & -24.10 & 76.25 & 0.88 \\
\hline
\end{tabular}

\begin{tabular}{|c|c|c|c|c|}
\hline Sample ID & Height $(m)$ & $\delta^{13} \mathrm{C}$ & $\operatorname{TIC}\left(\mathrm{CaCO}_{3} \%\right)$ & TOC (C wt \%) \\
\hline C-16-151 & 85.04 & -24.55 & 68.13 & 1.18 \\
\hline C-16-150 & 84.43 & -24.56 & 67.76 & 1.19 \\
\hline C-16-149 & 83.89 & -24.71 & 67 & 1.21 \\
\hline C-16-148 & 83.08 & -24.59 & 64.63 & 1.27 \\
\hline C-16-147 & 82.17 & -24.69 & 60.7 & 1.25 \\
\hline C-16-146 & 81.31 & -24.60 & 58 & 1.36 \\
\hline C-16-145 & 80.64 & -24.67 & 62.66 & 1.27 \\
\hline C-16-144 & 79.55 & -24.63 & 57.84 & 1.52 \\
\hline C-16-143 & 79.03 & -24.61 & 63.13 & 1.39 \\
\hline C-16-142 & 78.56 & -24.74 & 59.64 & 1.61 \\
\hline C-16-141 & 77.63 & -24.71 & 59.12 & 1.59 \\
\hline C-16-140 & 76.78 & -24.76 & 62.25 & 1.39 \\
\hline C-16-139 & 75.93 & -24.96 & 54.92 & 1.44 \\
\hline C-16-138 & 75.22 & -25.09 & 56.6 & 1.83 \\
\hline C-16-137 & 74.6 & -25.01 & 59.25 & 1.71 \\
\hline C-16-136 & 73.33 & -24.96 & 65 & 1.57 \\
\hline C- $16-135$ & 72.03 & -24.57 & 74.85 & 0.41 \\
\hline C-16-134 & 71.03 & -24.36 & 72.13 & 0.54 \\
\hline C-16-133 & 69.56 & -24.25 & 61.15 & 1.13 \\
\hline C-16-132 & 68.3 & -24.69 & 68 & 0.73 \\
\hline C-16-131 & 67 & -24.28 & 64.97 & 1.05 \\
\hline C-16-130 & 65.87 & -24.15 & 64.41 & 1.09 \\
\hline C-16-129 & 64.8 & -24.16 & 68.58 & 1.05 \\
\hline C-16-128 & 63.67 & -24.16 & 72.15 & 0.78 \\
\hline C-16-127 & 62.62 & -24.16 & 70.6 & 0.90 \\
\hline C-16-126 & 61.51 & -24.15 & 62.52 & 1.09 \\
\hline C-16-125 & 60.34 & -24.12 & 74.42 & 0.77 \\
\hline C-16-124 & 59.27 & -23.96 & 73.75 & 0.65 \\
\hline C-16-123 & 58.15 & -23.92 & 72.87 & 0.99 \\
\hline C-16-122 & 56.95 & -23.98 & 71.99 & 0.83 \\
\hline C-16-121 & 55.8 & -23.74 & 72.66 & 0.75 \\
\hline C-16-120 & 54.7 & -23.63 & 70.62 & 0.93 \\
\hline C-16-119 & 54.18 & -23.75 & 73.86 & 0.69 \\
\hline C-16-118 & 53.68 & -23.67 & 72.2 & 0.79 \\
\hline C-16-117 & 53.12 & -23.64 & 75.68 & 0.79 \\
\hline C-16-116 & 52.58 & -23.44 & 70.93 & 0.84 \\
\hline C-16-115 & 52.06 & -23.57 & 72.48 & 0.79 \\
\hline C-16-114 & 51.52 & -24.03 & 73.19 & 0.75 \\
\hline C-16-113 & 51.01 & -23.80 & 72.92 & 0.83 \\
\hline C-16-112 & 50.46 & -23.87 & 73.12 & 0.93 \\
\hline C-16-111 & 49.85 & -23.74 & 71.13 & 0.82 \\
\hline C-16-110 & 49.33 & -23.70 & 71.79 & 0.89 \\
\hline C-16-109 & 48.86 & -23.67 & 75.5 & 1.01 \\
\hline C-16-108 & 48.27 & -23.79 & 76.71 & 0.84 \\
\hline C-16-107 & 47.7 & -23.64 & 71.2 & 0.99 \\
\hline C-16-106 & 47.16 & -23.64 & 72.09 & 0.82 \\
\hline C-16-105 & 46.65 & -23.63 & 66.54 & 1.04 \\
\hline C-16-104 & 46.12 & -23.62 & 78.41 & 0.74 \\
\hline C-16-103 & 45.57 & -23.60 & 76.59 & 0.67 \\
\hline C-16-102 & 45.04 & -23.66 & 75.07 & 0.72 \\
\hline C-16-101 & 44.56 & -23.64 & 70.51 & 0.81 \\
\hline C-16-100 & 44.06 & -23.59 & 69.56 & 1.04 \\
\hline C-16-99 & 43.51 & -23.56 & 73.13 & 0.89 \\
\hline C-16-98 & 42.92 & -23.62 & 77.07 & 0.71 \\
\hline
\end{tabular}


Appendix 6E Absolute values of major elements (Al, Si, Ti, Fe, P) and RSTEs (V, Ni, Co, Cr, Cu, Mo) in $\mathrm{ppm}=$ parts per million.

\begin{tabular}{|c|c|c|c|c|c|c|c|c|c|c|c|c|}
\hline Sample ID & Height (m) & $\mathrm{Al}$ & Si & $\mathrm{Ti}$ & $\mathrm{Fe}$ & $P$ & V & $\mathrm{Ni}$ & Co & $\mathrm{CrCu}$ & Mo & $U$ \\
\hline C-16-151 & 85.04 & 8460 & 41500 & 787 & 7802 & 166 & 27.5 & 17.8 & 0.7 & 0.63 .9 & 2.2 & 0.53 \\
\hline$C-1$ & .31 & 22508 & 56082 & 1021 & 8984 & 184 & & 22.7 & 0.8 & 0.04 .8 & 2.2 & 0.64 \\
\hline C-16-145 & 80.64 & 19782 & 47536 & 852 & 7979 & 113 & 30.3 & 16.9 & 0.5 & 33.83 .5 & 1.6 & 0.64 \\
\hline C-16-144 & 79.55 & 21860 & 54947 & 997 & 9448 & 166 & 36.6 & & 0.6 & & & 0.61 \\
\hline C-16-143 & 9.03 & 18451 & 46084 & 862 & 8034 & 158 & & & 0.5 & 30.34 .0 & 1.6 & 0.69 \\
\hline C-16-142 & 78.56 & 20549 & 51602 & 958 & 8189 & 154 & 33.9 & 15.0 & 0.4 & 34.43 .9 & 1.9 & 0.65 \\
\hline C-16-140 & .78 & 19189 & 49050 & 906 & 9117 & 159 & 32.9 & 16. & 0.8 & & 1.9 & 0.68 \\
\hline C-16-138 & 5.22 & 26142 & 66473 & 1186 & 13523 & 218 & & 35.5 & 51.1 & 46.56 .9 & 2.9 & 1.11 \\
\hline C-16-137 & 4.6 & 19136 & 49493 & 871 & 9635 & 178 & & 25.9 & 0.7 & 31.75 .1 & 2.7 & 0.69 \\
\hline C-16-135 & 72.03 & 14209 & 37058 & 729 & 6274 & 109 & 22.3 & 10.2 & 0.2 & 3.83 .3 & 0.7 & 0.43 \\
\hline C-1 & 256 & 22422 & 56519 & 988 & 10136 & & 35.2 & & 0.7 & 36.65 .5 & 3.0 & 0.65 \\
\hline C-16-132 & 3.3 & 18239 & 46334 & 849 & 7922 & 190 & & & 0.5 & 30.54 .1 & 2.5 & 0.59 \\
\hline C-1 & 87 & 18902 & 49407 & 826 & 8748 & 169 & 29.4 & 31.1 & 0.9 & 4.84 .7 & 3.1 & 0.62 \\
\hline$C-1$ & & 14079 & 36063 & 646 & 6435 & & & & & 3.0 & & 0.55 \\
\hline C-16-126 & 1.51 & 20792 & 52847 & 902 & 9178 & 203 & & & 0.7 & 34.56 .4 & 2.8 & 0.61 \\
\hline$C-1$ & 6 & 15189 & 38532 & 615 & 6075 & 121 & 22.9 & 18.4 & 0.6 & 25.73 .3 & 2.4 & 0.57 \\
\hline C-1 & & 1429 & 36747 & 656 & 6119 & & & & 0.5 & 37.7 & & 0.59 \\
\hline C-16-123 & 5 & 13893 & 36482 & 603 & 5855 & 133 & & & 0.7 & 3.7 & 2.3 & 0.44 \\
\hline C-1 & & 14671 & 37277 & 632 & 6377 & 139 & 23.7 & 18.9 & 0.6 & 44.0 & 1.3 & 0.49 \\
\hline$C-1$ & & 351 & 41508 & 700 & 5994 & 123 & & & 0.7 & 3.5 & 1.5 & 0.64 \\
\hline C-16 & 8 & 14141 & 36102 & 590 & 5600 & 150 & & & 0.3 & 3.5 & 1.5 & 0.52 \\
\hline C-1 & & 16731 & 39430 & 698 & 6123 & 139 & 25.1 & 18.6 & 0.3 & 3.64 .0 & 0.9 & 0.80 \\
\hline & & 14686 & 36403 & 619 & 5735 & 139 & 22.3 & 185 & 0.3 & 4.0 & 1.0 & 0.65 \\
\hline C-1 & 5 & 14549 & 35211 & 615 & 5623 & 106 & & & 0.3 & & 1.1 & 0.55 \\
\hline C-16-111 & & 16081 & 37063 & 619 & 6919 & 135 & & & 0.3 & 26.83 .5 & 1.1 & 0.47 \\
\hline C-1 & & 3272 & 30607 & 518 & 6548 & 103 & 18.8 & 17.3 & 0.3 & 3.2 & 0.9 & 0.49 \\
\hline$C-1$ & & 13039 & 30169 & 508 & 5647 & 131 & 18.4 & & 0.4 & 62.9 & 0.6 & 0.43 \\
\hline C-16 & & 15931 & 38314 & 638 & 7359 & 146 & & & 0.6 & 27.54 .1 & 1.2 & 0.53 \\
\hline C-1 & & 9935 & 37211 & 652 & 6895 & 171 & 23.5 & 15.4 & 0.5 & 3.5 & 0.5 & 0.48 \\
\hline C-1 & & 19570 & 44735 & 787 & 8258 & 166 & 28.3 & 21.1 & 0.7 & 31.24 .1 & 0.9 & 0.53 \\
\hline$C-1$ & 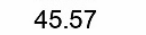 & 13450 & 30563 & 527 & 5300 & 127 & & & 0.4 & 22.92 .9 & 1.1 & 0.48 \\
\hline C-1 & & 6 & 40328 & 694 & 8229 & 161 & 26.6 & 23.0 & 0.7 & 4.3 & 0.9 & 0.48 \\
\hline & & 3171 & 29728 & 498 & 5484 & 144 & 18.2 & 17.5 & 0.5 & 63.1 & 0.8 & 0.47 \\
\hline$C-1$ & 4 & 14210 & 33046 & 558 & 6029 & 161 & 2 & 7 & 0.4 & & 1.1 & 0.44 \\
\hline & & 1 & 370 & 647 & 7027 & 139 & & & 0.6 & 4.1 & 0.7 & 0.69 \\
\hline & & 18783 & 43074 & 713 & 7504 & 167 & 28.1 & 21.9 & 0.5 & 84.3 & 0.9 & 0.46 \\
\hline$C-1$ & 6 & 16793 & 37133 & 630 & 6331 & 157 & 23.9 & 20.0 & 0.3 & 43.4 & 0.8 & 0.46 \\
\hline & & & & 591 & 69 & 186 & & & & 34.1 & 0.8 & 0.50 \\
\hline & & 166 & 41766 & 772 & 8349 & 137 & 30.0 & 26.3 & 0. & 24.3 & 2.0 & 0.48 \\
\hline C- $16-86$ & 3 & 17638 & 40143 & 643 & 6591 & 168 & 26.4 & 15.2 & 0.3 & 5.0 & 0.4 & 0.40 \\
\hline & & & & 704 & & 180 & & & & & 0 & 0.52 \\
\hline & & 77 & 39 & 632 & 8135 & 218 & 30.2 & 17.7 & 0 & 35.6 & 0.3 & 0.50 \\
\hline C-16-82 & 5 & 15563 & 36301 & 543 & 7303 & 180 & 27.3 & 15.7 & 0 & 64.9 & 0.4 & 0.51 \\
\hline & & & & 536 & 6617 & 188 & & & & & 0.4 & 0.51 \\
\hline & & & 20 & 338 & 4584 & 124 & 14 & 12 & 0 & 3.4 & 0.3 & 0.38 \\
\hline C-16-7 & 3 & 12971 & 30576 & 479 & 6691 & 179 & 21.0 & 21.4 & 0.5 & 04.9 & 0.5 & 0.58 \\
\hline & & & & 735 & & 208 & & & & & 1.3 & 0.80 \\
\hline & & & & 504 & 56 & 15 & & & 0 & 4.0 & 0 & 051 \\
\hline C-16- & & 12684 & 29438 & 486 & 5443 & 130 & 19.7 & 14.8 & 0.4 & 22.13 .6 & 0.5 & 0.48 \\
\hline & & & & 545 & 6727 & 177 & & & & 4.5 & 1.0 & 0.56 \\
\hline & & & & 662 & & & & & & & & \\
\hline C-1 & & 1 & 33546 & 619 & 7703 & 170 & 22.8 & 30.1 & 1.0 & 29.84 .8 & 1.6 & 0.52 \\
\hline & & & & 590 & 6801 & 142 & & & & & 1.4 & 0.54 \\
\hline & & & & 826 & & 23 & & & & & 1 & \\
\hline C-1 & & 7 & 445 & 739 & & 211 & 31.5 & 27.3 & 0.9 & 5.3 & 1.4 & 0.64 \\
\hline & & & & 736 & 8194 & 173 & 30.3 & 31.6 & & & 1.5 & 0.57 \\
\hline & & & & 459 & & 16 & & 1 & & 6 & & 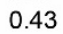 \\
\hline & & & & 470 & 5708 & 167 & 19.7 & 18.2 & 0.6 & 04.0 & 0.9 & 0.44 \\
\hline C-16-52 & & 948 & 27752 & 474 & 6088 & 139 & 20.2 & 17.5 & 0 & 22.83 .6 & 0.9 & 0.46 \\
\hline & & & & 620 & 7722 & 140 & & & & 44.6 & 1 & \\
\hline & & & & 722 & 9299 & 17 & 30 & 21.1 & & 33.35 .6 & 0.9 & \\
\hline C-16-47 & 1 & 17088 & 39108 & 688 & 8287 & 192 & 30.2 & 20.0 & 0.7 & 29.64 .4 & 0.8 & 0.49 \\
\hline & & & 32890 & 594 & 7700 & 242 & & & & & & \\
\hline & & & 30516 & 551 & 7182 & 159 & & 27.4 & & 27.64 .6 & 1. & 017 \\
\hline \multirow[t]{2}{*}{ C-16-44 } & 14.69 & 12152 & 27058 & 472 & 6333 & 198 & & 21.7 & 0 & 24.34 .2 & 1.2 & 0.49 \\
\hline & & & & & & & & & & & & \\
\hline
\end{tabular}




\title{
7 DEMISE OF OM-RICH FACIES AND CHANGING PALEOENVIROMENTAL CONDITIONS ASSOCIATED WITH THE END OF CARBON ISOTOPE SEGMENT C5 OF OAE1A IN THE NORTH AND NORTHEASTERN IBERIAN PENINSULA
}

\section{Socorro, J., Maurrasse, F.J-M.R., 2020.Demise of OM-rich facies and changing paleoenvironmental conditions associated with the end of carbon isotope segment C5 of OAE1a in the north and northeastern Iberian Peninsula. International Journal of Earth Sciences - Pending Submission.}

\begin{abstract}
During the Cretaceous the concurrence of changing paleoceanographic and paleoclimatic conditions coupled with considerable variations in eustatic sea level contributed to brief episodes characterized by globally widespread deposition of organic matter (OM)-rich marine sediments collectively termed Oceanic Anoxic Events (OAEs). Here, the aim is to investigate the response of a lower Aptian hemipelagic sequence from the northeastern Iberian margin in the context of OAE1a and integrate the recorded signals within a broader spatial frame to establish parallelisms that may help in assessing the regional expression superimposed on the global factors related to this event.

Results from molecular thermal maturity indices with average ratios consistently below equilibrium values indicate thermal immaturity, with minor to no effect on the organic geochemical signals. Source-specific biomarkers demonstrate that the OM consists of a mixture of autochthonous marine and allochthonous terrigenous sources, typical of hemipelagic settings. Stable carbon isotope $\left(\delta^{13} \mathrm{C}_{\mathrm{org}}\right)$ data are consistent with the pattern reported for the end of carbon isotope segment C5 within OAE1a. Moreover, high sediment accumulation rates (bulk $=37.13 \mathrm{~cm} / \mathrm{kyr}$, wet $=63.29 \mathrm{~cm} / \mathrm{kyr}$ ) for this interval, permits to establish refined details suitable for precise chemostratigraphic correlations. Integration of field observations, microfacies and geochemical data allows
\end{abstract}


the recognition of three distinct Units. Within Unit 1, variable pulses of fluvial fluxes associated with climate fluctuations explain the alternating lithology with limestones depicting the least terrestrially influenced endmember and marlstones representing episodes of highest terrigenous input. Primary production enhanced during periods of intensified fluvial inputs of biolimiting elements $(\mathrm{P}, \mathrm{Fe})$ provided abundant labile $\mathrm{OM}$ conducive to oxygen-deprived conditions as attested by concomitant peaks in total organic carbon (TOC), relatively lower benthic faunal counts, lower bioturbation index, higher concentration of pyrite and enrichments in redox sensitive trace elements (RSTEs). In the ensuing marlstone-dominated Unit 2-interval, results show relatively higher TOC, RSTEs, P, Fe, Al, Si, and Ti values than before. These results suggest that an increase in runoff due to established humid continental conditions prevailed in this period with quasi-permanent eutrophic surface waters and continuously established oxygen-deprived conditions, but still without a fully anoxic phase, as benthic fauna while relatively reduced are still present throughout. At the same time, higher gammacerane index in this interval attests to a stratified water column, which may have been a controlling factor in preventing vertical mixing and oxygenation of the basin. Unit 3 registers a sharp change with hard limestones impoverished in TOC, Al, Si, Ti, P and Fe, and with lower relative proportion of autochthonous to allochthonous OM, indicating a reduction in fluvial fluxes and surface water fertility linked to dryer climate conditions, as further suggested by an increase in smectite and a decrease in illite content. In accord, RSTEs decrease and gammacerane indices drop to near zero, signaling the termination of density stratification and renewed ventilation of the water column. Simultaneous changes in microfacies, with coarser grained packstones, with reduced planktonic foraminifera 
and an increase in benthic taxa, imply a shallowing of the basin, similar to that reported for sequences in the neighboring Basque-Cantabrian Basin synchronous with the negative $\delta^{13} \mathrm{C}_{\text {org }}$ shift heralding the end of carbon isotope segment C5.

\subsection{Introduction}

The sedimentary expression of marine depositional sequences are primarily controlled by the interactions between global forcing variables, including eustatic sea level and climatic fluctuations, plate tectonics, astronomical cycles, and to local variables such as regional tectonics, sediment supply, basin physiography, atmospheric and basinal circulation patterns, and biotic community structure and dynamics (Posamentier et al., 1988; Haq, 1995; Brenchley and Harper, 1998; Flügel, 2004; Tucker and Wright, 2009; Pomar and Kendall, 2012). The Early Aptian witnessed pronounced changes in the ocean/climate system, and as such had a remarkable impact on the associated sedimentary record (Jenkyns, 2003; Föllmi, 2012). Potential causes of these changes include the restructuring of both, major landmasses and ocean/atmosphere circulation patterns and extreme greenhouse conditions, likely triggered by the outgassing of $\mathrm{CO}_{2}$ during the emplacement of large igneous provinces (LIPs e.g. Ontong Java-ManihikiHikurangi plateau) combined with coeval intervals of intensified oceanic crust production (Arthur et al., 1985; Barron and Washington, 1985; Larson, 1991; Tarduno et al., 1991; Larson and Erba, 1999; Leckie et al., 2002; Erba and Tremolada, 2004; Weissert and Erba, 2004; Méhay et al., 2009; Tejada et al., 2009; Van Der Meer et al., 2014; Wang et al., 2014; Sun et al 2016; Naafs et al., 2016; Charbonnier and Föllmi, 2017). Additionally, the presence of extensive wetlands may have provided water vapor as a supplementary greenhouse gas (Hay et al., 2019). 
In response to globally warm climates, reduced equatorial to polar temperature gradients problably developed, thus decreasing the ocean-heat transport system (Barron, 1983; Huber et al., 1995; 2018; Littler et al., 2011; Jenkyns et al., 2012; Mutterlose et al., 2014; O'Brien et al., 2017). Concurrent increases in continental weathering and runoff induced by intensified hydrological cycles may have occurred (Barron et al., 1989; Blättler et al., 2011; Föllmi, 2012; Lechler, 2015; Charbonnier et al., 2018). Superimposed or interlaced are also long and short-term eustatic sea level rises, which formed large epicontinental seas (Haq, 2014). The concurrence of changing paleoceanographic and paleoclimatic conditions, and considerable variations in sea level deeply affected the depositional pattern of most marine settings at that time (Föllmi et al., 1994; Burla et al., 2008; Huck et al., 2010; Föllmi, 2012). For instance, carbonate platforms in the Tethyan realm witnessed a complete shutdown (Funk et al., 1993, Föllmi et al., 1994; Weissert et al., 1998; Bosellini et al., 1999; Graziano, 1999; Wissler et al., 2003; Föllmi and Gainon, 2008; Gaona-Narvaez et al., 2013; Godet, 2013; Pictet et al., 2015) and a micro-encrusting-dominated community temporarily replaced once flourishing rudist and coral reefs, especially along the southern Tethyan margin (Immenhauser et al., 2005; Huck et al., 2010; Rameil et al., 2010). Equally, deeper hemipelagic and pelagic settings of the Tethys and elsewhere were affected, recording black shales with high OM content (Bralower et al., 1994; Cobianchi et al., 1999; Dumitrescu and Brassell, 2005; Dumitrescu et al., 2006; de Gea et al., 2008; Heldt et al., 2008; Emeis and Weissert, 2009; Patruno et al., 2015). This interval, estimated to have lasted $\sim 1.1 \mathrm{Ma}$ (Li et al., 2008; Malinverno et al., 2010) in the Early Aptian is recognized as Oceanic Anoxic Event 1a (OAE1a), because most sequences show 
evidence of oxygen starved conditions (Schlanger and Jenkyns, 1976; Jenkyns, 1980; Arthur et al., 1990; Jenkyns, 2010). In addition to the widespread occurrence of OM-rich sediments, OAE1a is accompanied by synchronous anomalies in the carbon isotope record $\left(\delta^{13} \mathrm{C}\right)$ which serve as a useful correlation tool and as a proxy to recognize changes in the global carbon reservoir associated with this major crisis that affected both shallow and deep marine settings (Scholle and Arthur, 1980; Weissert, 1989; Weissert and Bréhéret, 1991; Menegatti et al., 1998; Herrle et al., 2004).

The high sediment accumulation rate in the Organyà Basin of the south-central Pyrenees of Spain (Fig. 7-1 A, B, C) generated an expanded archive that documents continuous changes that permit high-resolution chemostratigraphic studies of OAE1a (Sanchez-Hernandez et al., 2014). The focus of this study is on the $85.82 \mathrm{~m}$-interval of the uppermost El Pujal sequence of the Organyà Basin (Fig. 7-1D) to complement previous studies of El Pujal (Socorro and Maurrasse, 2019a,b) and El Pui (SanchezHernandez et al., 2014; Sanchez-Hernandez and Maurrasse, 2014, 2016; SanchezHernandez, 2014). This study seeks to: 1) Investigate the response of an Early Aptian hemipelagic system from the northeastern Iberian margin during the close of carbon isotope segment C5 (Menegatti et al., 1998) in the context of OAE1a. 2) Document regional paleoclimatic, paleoceanographic and in particular, regional sea level fluctuations that may be responsible for synchronous facies variabilities recorded in the Organyà Basin and at coeval sites in the Basque-Cantabrian Basin. 3) Integrate the sedimentary and geochemical signals recorded at the El Pujal section within a broader spatial frame in order to establish parallelisms and differences that may help in assessing the regional expression of global perturbations associated with OAE1a. 


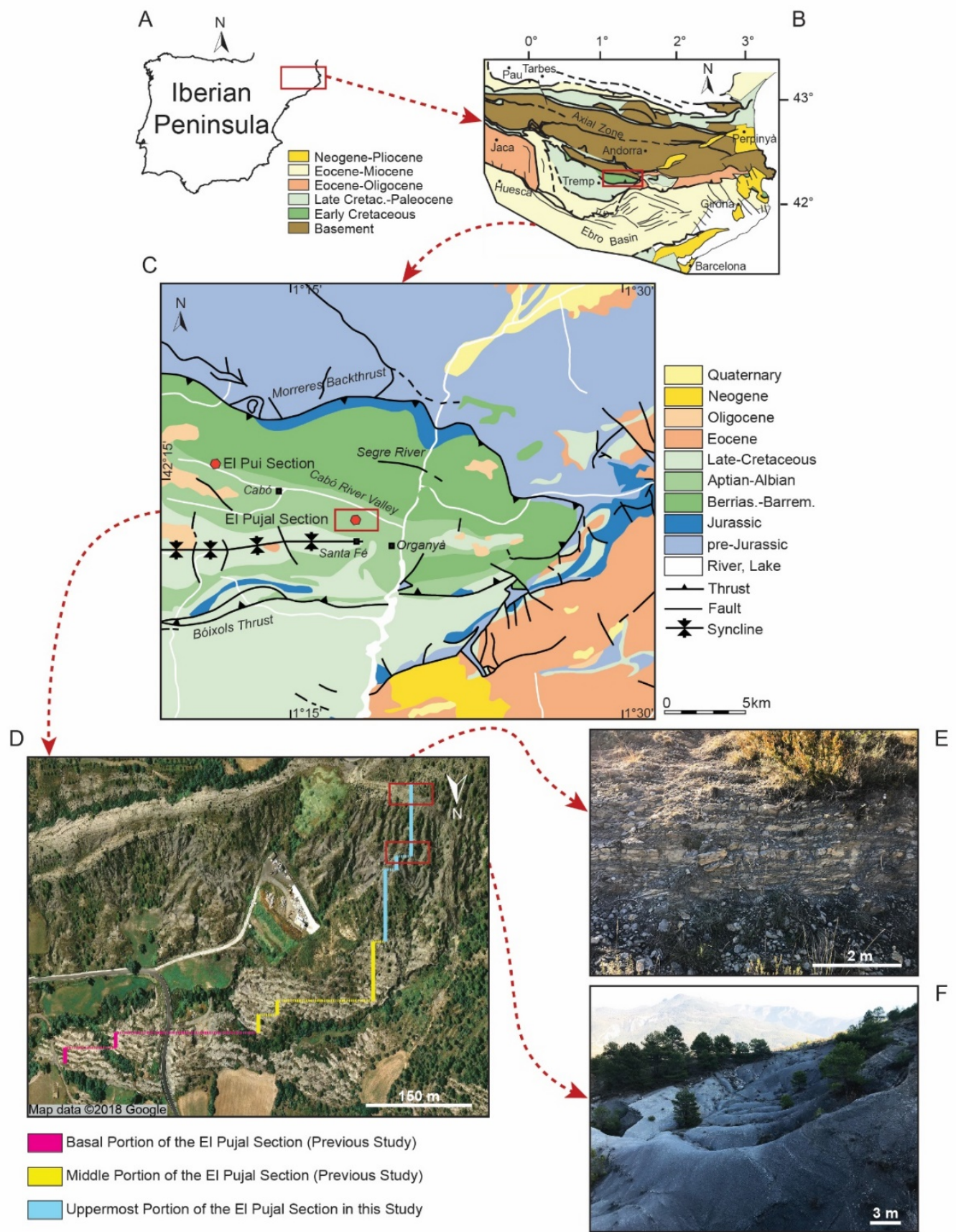

Figure 7-1 A) Location map of the Organyà Basin in the Iberian Peninsula. B) Regional geologic map showing the area of interest. A) and B) Modified from Dinarès-Turell and García-Senz, 2000). C) Detailed geologic map of the studied area showing the location of the El Pui Section (Sanchez-Hernandez et al., 2014; Sanchez-Hernandez and Maurrasse, 2014, 2016) and the El Pujal Section (Socorro and Maurrasse, 2019a,b); and this study). C) Modified from Gong et al. (2009). D) Satellite image showing the portion of the El Pujal Section studied thus far (Basal Portion - Socorro and Maurrasse, 2019a; Middle Portion Socorro and Maurrasse, 2019b; Uppermost Portion - This study). D) Modified from Google Earth Map Data 2018. E). Photograph of the uppermost portion of the outcrop showing remarkably hard, closely spaced grayish orange (10 YR 7/4) beds, intercalated by medium light gray (N6) beds, with an enduring hard nature. F) Photograph of a portion of the outcrop showing a large expanse of dark gray to medium dark gray (N3 to N4), marly beds. 


\subsection{Geologic Setting}

The Late Jurassic to Early Cretaceous initiation of strike-slip movement of Iberia relative to Europe associated with the plate tectonic kinematic evolution of the Bay of Biscay and the North Atlantic generated a series of depocenters, including the BasqueCantabrian Basin, the North Pyrenean Basin and the Central Pyrenean Basin. (Masson and Miles, 1984; Puigdefàbregas and Souquet, 1986; Berástegui et al., 1990; Vergés and García-Senz., 2001; García-Senz., 2002; Rosenbaum et al., 2002; Sibuet et al., 2004; Gong et al., 2008; 2009; Jammes et al., 2010; Vissers and Meijer., 2012). The Organyà Basin forms part of the Central Pyrenean Basin and thus represents one such example of these extensional basins (Berástegui et al., 1990; García-Senz 2002). Associated sedimentary deposits archive expansive ( $\sim 4 \mathrm{~km}$-thick) sequences consisting of shallow, platform carbonates and hemipelagic to pelagic marine sediments that span the upper Tithonian to the lower Turonian (Berástegui et al., 1990; García-Senz, 2002). During the Early and mid-Cretaceous, the Organyà Basin was located along an elongated, narrow stretch of sea $(\sim 200 \mathrm{~km})$ that extended from the proto-North Atlantic to the southeast, cutting between Iberia and Europe (Jammes et al., 2009; Vacherat et al., 2017). Eventual northward movement of Africa and collision of Iberia with Europe associated with the Late Cretaceous to Cenozoic Pyrenean Orogeny brought about the closure and inversion of these Mesozoic sedimentary basins (Vergés and García-Senz., 2001; García-Senz 2002; Golonka, 2004).

In its present position, the Organyà Basin is located in the South-Central Pyrenees of Spain on the eastern portion of the South Pyrenean Central Unit (SPCU). Rocks associated with the Basin largely outcrop in the hanging wall of the Bóixols thrust sheet, 
bound to the north by the Morreres backthrust (Gong et al., 2008; 2009; Mencos et al., 2015). As illustrated by García-Senz (2002), the internal geometry of its remnants is structurally dominated by the east to west trending asymmetric Santa Fé syncline (Fig. 71C). Samples for this study were collected from the northern limb of the syncline, south of the Cabó River Valley (Fig. 7-1C). The section is well exposed and easily accessible via the Avenida Santa Fé road, which stems from the main town of Organyà. Here, we focus on the uppermost $85.82 \mathrm{~m}$-interval or third segment of the composite El Pujal section which includes two previously studied segments: the basal $13.77 \mathrm{~m}$ (Socorro and Maurrasse, 2019a) and the middle 70.75 m-interval (Socorro and Maurrasse, 2019b), continuous with the neighboring El Pui section (Fig. 7-1C) (Sanchez-Hernandez et al., 2014; Sanchez-Hernandez and Maurrasse, 2014, 2016).

\subsection{Experimental Methods}

\subsubsection{Sampling and Microscopic Analysis}

The 106 samples of this interval were collected from well-exposed outcrops near the hamlet of El Pujal de Cabó in the municipality of Organyà. They achieved an approximate resolution of one sample every $0.81 \mathrm{~cm}$ over a distance of $85.82 \mathrm{~m}(86.07 \mathrm{~m}$ - $171.89 \mathrm{~m})$, representative of the uppermost portion of the El Pujal Section $\left(42^{\circ} 13^{\prime} 04.8^{\prime \prime N} 1^{\circ} 18^{\prime} 35.3^{\prime \prime E}\right)$ (Fig. 7-1D, E, F). The preparation and petrographic study of thin sections $(\mathrm{n}=106)$ were performed at Florida International University (FIU). Microfacies analysis was accomplished on an Olympus BH-2 petrographic microscope. To complement field observations, the microscopic study also considered content and quantity of the benthic fauna, and degree of bioturbation which was assigned a value ranging from 0 to 6 following the description in Taylor and Goldring (1993). Counts of 
benthic foraminifera and echinoid fragments were taken from thin sections and are thus expressed as number of specimens per $\mathrm{cm}^{2}$ or $\rho$. Compositional proportions were assessed using visual estimates as summarized by Terry and Chilingarian (1955). Color description of samples at all scales is based on the modified Munsell color system as proposed by Goddard et al. (1963). Petrographic classification of carbonate rocks described here follows the guidelines of Folk (1959) and (1962). Index planktonic foraminifera were identified with the aid of illustrations in published works by Verga and Premoli-Silva (2002), Heldt et al. (2008) and Moullade et al. (2015). In addition, certain samples (limestone intervals $n=17$ ) were selected to be counted for the ratio between planktonic and benthic foraminifera as a tool to estimate paleodepths. The ratio is expressed as the percentage of planktonic foraminifera or $\% \mathrm{P}$ and depth is calculated using the relationship between bathymetry and \%P as proposed by van der Zwaan et al. (1990):

$$
\operatorname{Depth}(\mathrm{m})=\mathrm{e}^{(3.58718+(0.03534 * \% \mathrm{P}))}
$$

The $\% \mathrm{P}$ is the percentage planktonics in the total foraminiferal association, calculated as $100 * \mathrm{P} /(\mathrm{P}+\mathrm{B})$, where $\mathrm{P}$ is the number of planktonic individuals and $\mathrm{B}$ is the number of benthic individuals.

\subsubsection{Bulk Carbon Geochemistry}

Organic carbon (TOC) and carbonate (TIC) contents were measured from 106 powdered rock samples at FIU within the Carbon Analysis Laboratory (CAL) using a LECO CR-412 carbon analyzer following the methodology detailed in Socorro and Maurrasse (2019a) and references therein. The instrument was calibrated by creating a 15-point linear calibration curve using C64-500 Fisher Scientific $\geq 99.0 \%$ calcite 
standard and the accuracy $(0.15 \%)$ of the calibration was verified by analyzing a dolomitic limestone standard (NIST 88b). The analytical precision calculated from the coefficient of variation of four replicate runs $(\overline{\mathrm{x}}=76.66 \% \mathrm{~s}=0.07 \%)$ of the same sample was $0.09 \%$. Results of the TOC/TIC analyses are reported as percentages of total dry weight of organic carbon $(\mathrm{C} \mathrm{wt} \%)$ and inorganic carbon $\left(\mathrm{CaCO}_{3} \%\right)$, respectively in the bulk sample. TIC values are used to assign a general lithologic nomenclature modified from Sanchez-Hernandez and Maurrasse (2014) to enable for better representation of lithologic variation observed in the field, whereby TIC $>70 \%=$ limestone, $65 \%-70 \%=$ argillaceous limestone, and $35 \%-65 \%=$ marlstone.

Stable carbon isotope analysis was conducted at the FIU Stable Isotope Laboratory (SIL) on the bulk organic $\left(\delta^{13} \mathrm{C}_{\mathrm{org}}\right)$ fraction of 106 powdered samples. Prior to the analysis, samples were processed following the procedures outlined in Socorro and Maurrasse (2019a) and references therein. The $\delta^{13} \mathrm{C}_{\text {org }}$ values were measured using a Thermo Scientific Delta V elemental analyzer isotope ratio mass spectrometer (EAIRMS) and the results are expressed as per mil (\%o) relative to the Vienna-Pee Dee Belemnite (VPDB) standard. The analytical precision calculated from the standard deviation of 32 replicate glycine standard samples was better than $0.58 \%$.

\subsubsection{Elemental Concentration Analysis}

Concentrations of major elements including silicon ( $\mathrm{Si}$ ), aluminum (Al), titanium (Ti), phosphorus $(\mathrm{P})$, iron $(\mathrm{Fe})$ and redox-sensitive trace elements (RSTEs) including vanadium $(\mathrm{V})$, chromium $(\mathrm{Cr})$, cobalt $(\mathrm{Co})$, nickel $(\mathrm{Ni})$, copper $(\mathrm{Cu})$, molybdenum $(\mathrm{Mo})$ and uranium (U) were analyzed from 37 samples distributed throughout the studied interval and selected to be representative of lithologic variations. Sample preparation 
followed the general method developed for the routine analysis of soils and sediments by Arroyo et al. (2009), and further detailed in Sanchez-Hernandez and Maurrasse (2014) and Socorro and Maurrasse (2019a). Analyses were conducted at the FIU Trace Evidence Analysis Facility (TEAF) using an ELAN DRC II (Perkin Elmer LAS) inductively coupled plasma mass spectrometer (ICP/MS). Samples were introduced via laser ablation using an Applied Spectra J200 $266 \mathrm{~nm}$ Nd-YAG laser set at a spot size of $200 \mu \mathrm{m}$ and a frequency of $10 \mathrm{~Hz}$. Prepared pellets were ablated 5 times and the results were averaged for each sample. Integration of raw data was performed on the GLITTER software. Analytical precision calculated from the coefficient of variation averaged $2.1 \%(\mathrm{Si}), 1.7 \%$ (Al), 5.4\% (Ti), 12\% (Fe), 9.4\% (P), 5.7\% (V), 12\% (Ni), 14\% (Co), 15\% (Cr), 18\% $(\mathrm{Cu}), 12 \%(\mathrm{Mo})$ and $17 \%(\mathrm{U})$. Analytical performance of the method was evaluated by running 3 standard reference materials (NIST2710, PACS-2, NIST2704) at the start, every 10 samples, and at the end of the analysis. Results for major elements are expressed as parts per thousand $\left(\mathrm{ppm} \cdot 10^{-3}\right)$ and RSTEs are expressed as parts per million (ppm).

Following early works by Turekian and Wedepohl (1961), and Wedepohl, (1971) enrichments in RSTEs relative to the background natural value denote sediments deposited under reducing conditions (e.g., Brumsack, 1980, 2006; Calvert and Pedersen, 1993; Dean, 1999; Yarincik., et al., 2000; Tribovillard et al., 2004, 2006; Pattan and Pearce, 2009; Föllmi et al., 2012; Stein et al., 2012; Westermann et al., 2013; Ruebsam et al., 2017). The uncertainty about the actual magnitude of the background natural value or detrital signal, unrelated to the redox conditions at the time of deposition, is undoubtedly the pitfall of this method (Van Der Weijden, 2002; Cole et al., 2017; Socorro and 
Maurrasse 2019b). Therefore, we rely on a baseline detrital value, previously calculated for the region by Socorro and Maurrasse (2019b) and referred to as the Organyà Basin's Average Background Value (OBABV), to assess enrichment indices (EIs) relative to the natural background levels.

$$
\text { EIs }=\frac{[\text { RSTEs }]}{[\text { RSTEs }]_{\text {regional background }}}
$$

In this equation [RSTEs] is the concentration in ppm of a particular element in a sample and [RSTEs] $]_{\text {regional background }}$ is the average value in ppm of the corresponding RSTE from the calculated OBABV of Socorro and Maurrasse (2019b). OBABV averages of V, Cr, Co, Ni, Cu, Mo and U are 27.56 ppm, 33.46 ppm, 3.68 ppm, 32.31 ppm, 5.72 ppm, 2.56 ppm, and 1.10 ppm, respectively. Relative enrichments are thus expressed as EIs $>1$, whereas depleted elemental values are represented by EIs $<1$. To allow for easier correlation between RSTEs and other proxies, we calculated $\sum$ EIs by adding all the EIs of each element for each sample.

\subsubsection{Lipid Extraction and Analyses}

Powdered samples $(n=26)$ were processed and analyzed following the methodology outlined in Socorro and Maurrasse (2019a) and references therein. The analysis focused on the distribution of the aliphatic fraction; hence, total lipid extracts (TLE) were separated from the aromatic and polar fraction by elution with $4 \mathrm{ml}$ of hexane using a silica gel-packed glass pipette. The collected fractions were concentrated down to $1 \mathrm{ml}$ and stored at $4^{\circ} \mathrm{C}$ in amber vials before analysis.

Aliphatic fractions $(n=26)$ were analyzed at the FIU Advanced Mass Spectrometry Facility via gas chromatography-mass spectrometry (GC/MS) technique using an Agilent 
6890/Agilent 5973 GC/MS. A 5 $\mu \mathrm{L}$ volume of each sample was injected in split-less mode through an HP-5MS UI $30 \mathrm{~m}, 0.25 \mathrm{~mm}, 0.25 \mu \mathrm{m}$, capillary column. The injector temperature was set at $280^{\circ} \mathrm{C}$ and the oven temperature program was set to hold at $65^{\circ} \mathrm{C}$ for $2 \mathrm{~min}$, then ramped to $300^{\circ} \mathrm{C}$ at a rate of $4^{\circ} \mathrm{C} / \mathrm{min}$ and held at $300^{\circ} \mathrm{C}$ for $8 \mathrm{~min}$. The single quadrupole MS detector was configured in scan mode to monitor from 42 to 500 $\mathrm{m} / \mathrm{z}$. The resulting data was analyzed using OpenChrom.

Selected aliphatic fractions $(n=10)$ were further analyzed for their distribution of hopanes and steranes at the FIU Advanced Mass Spectrometry Facility using a Bruker EvoQ GC triple quadrupole (TQ) MS in metastable reaction monitoring (MRM) mode (MRM-GC-MS/MS). A $1 \mu \mathrm{L}$ volume of each sample was injected in split-less mode through an HP-5MS $60 \mathrm{~m}, 0.25 \mathrm{~mm}, 0.25 \mu \mathrm{m}$, capillary column. The injector temperature was set at $260^{\circ} \mathrm{C}$ and the oven was programmed from $65^{\circ} \mathrm{C}$ for $2 \mathrm{~min}$, followed by a temperate ramp of $4^{\circ} \mathrm{C} / \mathrm{min}$ up to $310^{\circ} \mathrm{C}$ and held isothermally for $10 \mathrm{~min}$. Metastable transitions of $\mathrm{C}_{27}, \mathrm{C}_{28}, \mathrm{C}_{29}, \mathrm{C}_{30}, \mathrm{C}_{31}, \mathrm{C}_{32}, \mathrm{C}_{33}, \mathrm{C}_{34}$ and $\mathrm{C}_{35}$ hopanes included m/z: 370 $\rightarrow 191(370.40 \rightarrow 191), 384 \rightarrow 191(384.40 \rightarrow 191), 398 \rightarrow 191(398.4 \rightarrow 191), 412 \rightarrow 191$ $(412.40 \rightarrow 191), 426 \rightarrow 191(426.40 \rightarrow 191), 440 \rightarrow 191(440.40 \rightarrow 191), 454 \rightarrow 191$ $(454.50 \rightarrow 191), 468 \rightarrow 191(468.50 \rightarrow 191)$, and $482 \rightarrow 191(482.50 \rightarrow 191)$, respectively. Metastable transition of $\mathrm{C}_{27}, \mathrm{C}_{28}, \mathrm{C}_{29}, \mathrm{C}_{30}$ steranes included $\mathrm{m} / \mathrm{z}: 372 \rightarrow 217$ $(372.40 \rightarrow 217), 386 \rightarrow 217(386.40 \rightarrow 217), 400 \rightarrow 217(400.40 \rightarrow 217)$, and $414 \rightarrow 217$ $(414.40 \rightarrow 217)$, respectively. The compounds were identified by comparing retention times and elution patterns with GC-MS/MS results from literature references (Peters et al., 2005; Peters et al., 2007; Ahmed et al 2013). 
The terrigenous to aquatic ratio (TAR) was determined using the equation proposed by Bourbonniere and Meyers (1996):

$$
\mathrm{TAR}=\frac{\mathrm{nC}_{27}+\mathrm{nC}_{29}+\mathrm{nC}_{31}}{\mathrm{nC}_{15}+\mathrm{nC}_{17}+\mathrm{nC}_{19}}
$$

The relative abundance of odd to even preferences of long-chain length $n$-alkanes were determined using the carbon preference index (CPI) after Bray and Evans (1961):

$$
\mathrm{CPI}=\frac{1}{2}\left[\frac{\mathrm{nC}_{25}+\mathrm{nC}_{27}+\mathrm{nC}_{29}+\mathrm{nC}_{31}+\mathrm{nC}_{33}}{\mathrm{nC}_{24}+\mathrm{nC}_{26}+\mathrm{nC}_{28}+\mathrm{nC}_{30}+\mathrm{nC}_{32}}+\frac{\mathrm{nC}_{25}+\mathrm{nC}_{27}+\mathrm{nC}_{29}+\mathrm{nC}_{31}+\mathrm{nC}_{33}}{\mathrm{nC}_{26}+\mathrm{nC}_{28}+\mathrm{nC}_{30}+\mathrm{nC}_{32}+\mathrm{nC}_{34}}\right]
$$

Various hopane and sterane parameters were calculated as follows:

$$
\frac{\mathrm{Ts}}{\mathrm{Ts}+\mathrm{Tm}}=\frac{18 \alpha 22,29,30 \text { trisnorneohopane }}{18 \alpha 22,29,30 \text { trisnorneohopane }+17 \alpha 22,29,30 \text { trisnorhopane }}
$$

$$
\mathrm{C}_{31} \frac{22 \mathrm{~S}}{22 \mathrm{~S}+22 \mathrm{R}}=\frac{\mathrm{C}_{31} 17 \alpha, 21 \beta(\mathrm{H}) \text { homohopane (22S) }}{\mathrm{C}_{31} 17 \alpha, 21 \beta(\mathrm{H}) \text { homohopane }(22 \mathrm{~S})+\mathrm{C}_{31} 17 \alpha, 21 \beta(\mathrm{H}) \text { homohopane }(22 \mathrm{R})}
$$

$$
\begin{gathered}
\text { Gammacerane Index }=\frac{\mathrm{C}_{30} \text { Gammacerane }}{\mathrm{C}_{30} 17 \alpha, 21 \beta(\mathrm{H}) \text { hopane }} \\
\% \mathrm{C}_{27} \alpha \alpha \alpha \mathrm{R}=\frac{100 * \mathrm{C}_{27} 5 \alpha, 14 \alpha, 17 \alpha(\mathrm{H}) \text { sterane (20R) }}{\mathrm{C}_{27}+\mathrm{C}_{28}+\mathrm{C}_{29} 5 \alpha, 14 \alpha, 17 \alpha(\mathrm{H}) \text { sterane (20R) }} \\
\% \mathrm{C}_{28} \alpha \alpha \alpha \mathrm{R}=\frac{100 * \mathrm{C}_{28} 5 \alpha, 14 \alpha, 17 \alpha(\mathrm{H}) \text { sterane (20R) }}{\mathrm{C}_{27}+\mathrm{C}_{28}+\mathrm{C}_{29} 5 \alpha, 14 \alpha, 17 \alpha(\mathrm{H}) \text { sterane (20R) }}
\end{gathered}
$$




$$
\begin{gathered}
\% \mathrm{C}_{29} \alpha \alpha \alpha \mathrm{R}=\frac{100 * \mathrm{C}_{29} 5 \alpha, 14 \alpha, 17 \alpha(\mathrm{H}) \text { sterane }(20 \mathrm{R})}{\mathrm{C}_{27}+\mathrm{C}_{28}+\mathrm{C}_{29} 5 \alpha, 14 \alpha, 17 \alpha(\mathrm{H}) \text { sterane }(20 \mathrm{R})} \\
\frac{\mathrm{C}_{27}}{\mathrm{C}_{29}}=\frac{\mathrm{C}_{27} 5 \alpha, 14 \alpha, 17 \alpha(\mathrm{H}) \text { sterane }(20 \mathrm{R})}{\mathrm{C}_{29} 5 \alpha, 14 \alpha, 17 \alpha(\mathrm{H}) \text { sterane }(20 \mathrm{R})} \\
\mathrm{C}_{29} \frac{20 \mathrm{~S}}{20 \mathrm{~S}+20 \mathrm{R}}=\frac{\mathrm{C}_{29} 5 \alpha, 14 \alpha, 17 \alpha(\mathrm{H}) \text { sterane }(20 \mathrm{~S})}{\mathrm{C}_{29} 5 \alpha, 14 \alpha, 17 \alpha(\mathrm{H}) \operatorname{sterane}(20 \mathrm{~S})+\mathrm{C}_{29} 5 \alpha, 14 \alpha, 17 \alpha(\mathrm{H}) \text { sterane }(20 \mathrm{R})} \\
\mathrm{C}_{29} \frac{\beta \beta}{\beta \beta+\alpha \alpha}=\frac{\mathrm{C}_{29} 5 \alpha, 14 \beta, 17 \beta(\mathrm{H}) \text { sterane }(20 \mathrm{~S}+20 \mathrm{R})}{\mathrm{C}_{29} 5 \alpha, 14 \beta, 17 \beta(\mathrm{H}) \text { sterane }(20 \mathrm{~S}+20 \mathrm{R})+\mathrm{C}_{29} 5 \alpha, 14 \alpha, 17 \alpha(\mathrm{H}) \text { sterane }(20 \mathrm{~S}+20 \mathrm{R})}
\end{gathered}
$$

\subsubsection{Bulk and Clay Mineral Analyses}

Bulk and clay mineral $(<2 \mu \mathrm{m}$ fraction) analyses were performed on selected samples $(n=10)$ via X-ray diffraction $(X R D)$ method at the Illinois State Geological Survey in the Prairie Research Institute of the University of Illinois. For the analysis of bulk-mineral content, samples were micronized with deionized (DI) water for $10 \mathrm{~min}$ in a McCrone micronizing mill. To remove the majority of the DI water, the samples were transferred to $50 \mathrm{~mL}$ tubes and centrifuged for $20 \mathrm{~min}$ at $2000 \mathrm{rpm}$, after which the clear supernatant was poured off. The remaining sample was dried overnight at $40^{\circ} \mathrm{C}$, homogenized with a mortar and pestle and packed into an end-loading sample holder as a random powder bulk-pack. The prepared samples were analyzed on a Scintag XDS2000 diffractometer with data collection set from $2^{\circ}$ to $60^{\circ} 2 \theta$ with a fixed time of 5 seconds per $0.05^{\circ} 2 \theta$ for each sample. The intensity of the identified mineral phases, including quartz, potassium feldspar (K-feldspar), plagioclase feldspar (P-feldspar), calcite, 
dolomite, siderite, pyrite/marcasite and bulk clay, was analyzed using the semiquantitative data reduction software Jade+ and reported as relative percent.

The composition of the clay mineral fraction $(<2 \mu \mathrm{m})$ was determined using oriented and glycolated clay slides following the procedure detailed in Socorro and Maurrasse (2019b). The slides were analyzed with a Scintag XDS2000 diffractometer set to collect data from $2^{\circ}$ to $34^{\circ} 2 \theta$ at a fixed rate of $2^{\circ}$ per minute and a step size of $0.05^{\circ} 2 \theta$. Smectite, illite, kaolinite and chlorite were identified and their proportions, expressed as relative percent, were acquired using the Jade+ software.

\subsubsection{Correlation Analysis}

Correlation coefficients were determined for various proxies using Microsoft Office

Excel 2013. The correlation coefficient is based on the Pearson's $r$ equation expressed as:

$$
\operatorname{Correl}(\mathrm{X}, \mathrm{Y})=\frac{\sum(x-\bar{x})(y-\overline{\mathrm{y}})}{\sqrt{\sum(\mathrm{x}-\overline{\mathrm{x}})^{2} \sum(y-\overline{\mathrm{y}})^{2}}}
$$

Where $\bar{x}$ and $\bar{y}$ are the corresponding sample's average. The results of this equation go from a perfect negative correlation (-1), no correlation (0) to a perfect positive correlation (1). Values in between will be labeled as $0.1-0.3=$ weak, $0.4-0.6=$ moderate, $0.7-0.9=$ strong.

\subsection{Results}

\subsubsection{Field Observations and Petrographic Analysis}

Field observations of the uppermost $85.82 \mathrm{~m}$ portion of the El Pujal section reveals a sequence that generally consists of marlstone and limestone beds (Fig. 7-2A) with superficially medium light gray (N6) to dark gray (N3) coloration and a flaky appearance (Fig. 7-2B) that dissipates at depth as the unweathered rocks are well lithified. The 
lithostratigraphic pattern recorded in this interval permits the recognition of three distinct units. Unit 1 spans from $86.07 \mathrm{~m}$ up to $\sim 114.15 \mathrm{~m}(\sim 28 \mathrm{~m})$ and is composed of a repetitive series of differentially weathered packets of indurated beds that are followed by soft, easily weathered, argillaceous to marly beds (Fig. 7-2A, B). This pattern transitions into Unit 2, which spans from $114.15 \mathrm{~m}$ to $\sim 167.96 \mathrm{~m}(\sim 53.81 \mathrm{~m})$ and consists of dark gray to medium dark gray (N3 to N4), marly beds, interspersed with at least three intervals of protruding, indurated beds (Fig. 7-2A, B). Unit 3 extends from $167.96 \mathrm{~m}$ up to $171.89 \mathrm{~m}(\sim 3.93 \mathrm{~m})$ and constitutes a distinct facies change, as it is dominated by remarkably hard, closely spaced grayish orange (10 YR 7/4) beds, intercalated by medium light gray (N6) beds (Fig. 7-2A, B).

The microscopic analysis reveals temporal changes in allochems, texture and fabric of the matrix, in accord with field observations. A uniform, kerogen rich, micritic matrix with less than $30 \%$ allochems including dispersed pyritized skeletal fragments characterizes Unit 1 (Fig. 7-2C), which reveal subtle differences in benthic faunal content and degree of bioturbation between the different lithology. The indurated beds contain higher benthic foraminifera $\rho$, echinoid fragment $\rho$ and a higher degree of bioturbation $(\geq 5)$ as compared with the softer, argillaceous to marly beds (Fig. 7-3A, B, C). Moreover, relative to the more indurated beds, marly intervals contain higher abundances of pyrite, which is found disseminated throughout as euhedral crystals and infilling bioclasts. Skeletal remains consist mainly of planktonic and benthic foraminifera, echinoderm fragments, sponge spicules and minute gastropods $(300-800 \mu \mathrm{m})$. 
A

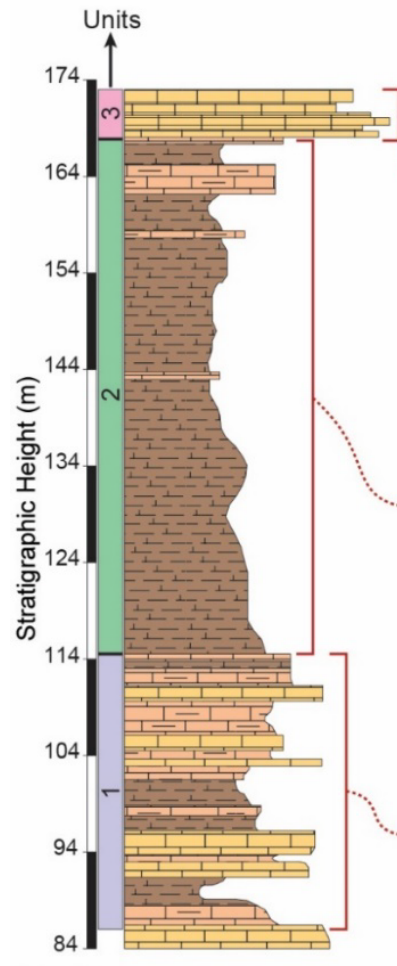

Limestone
B
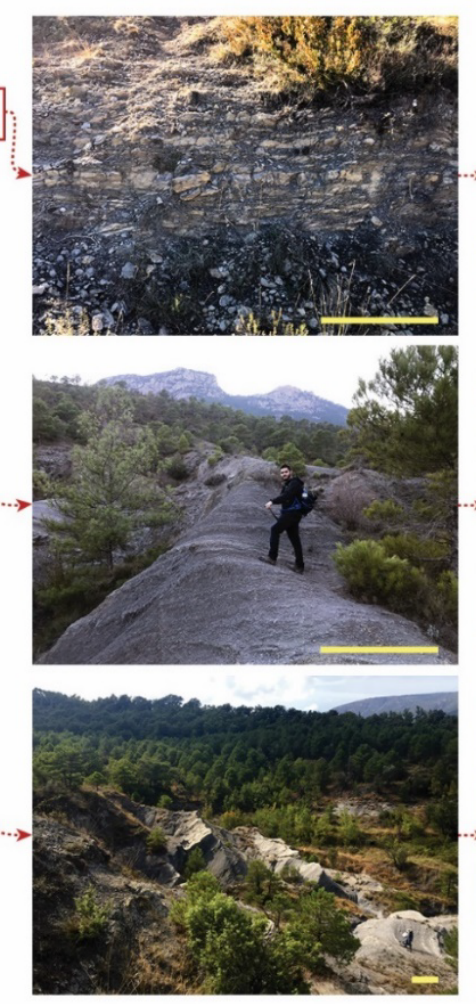

C
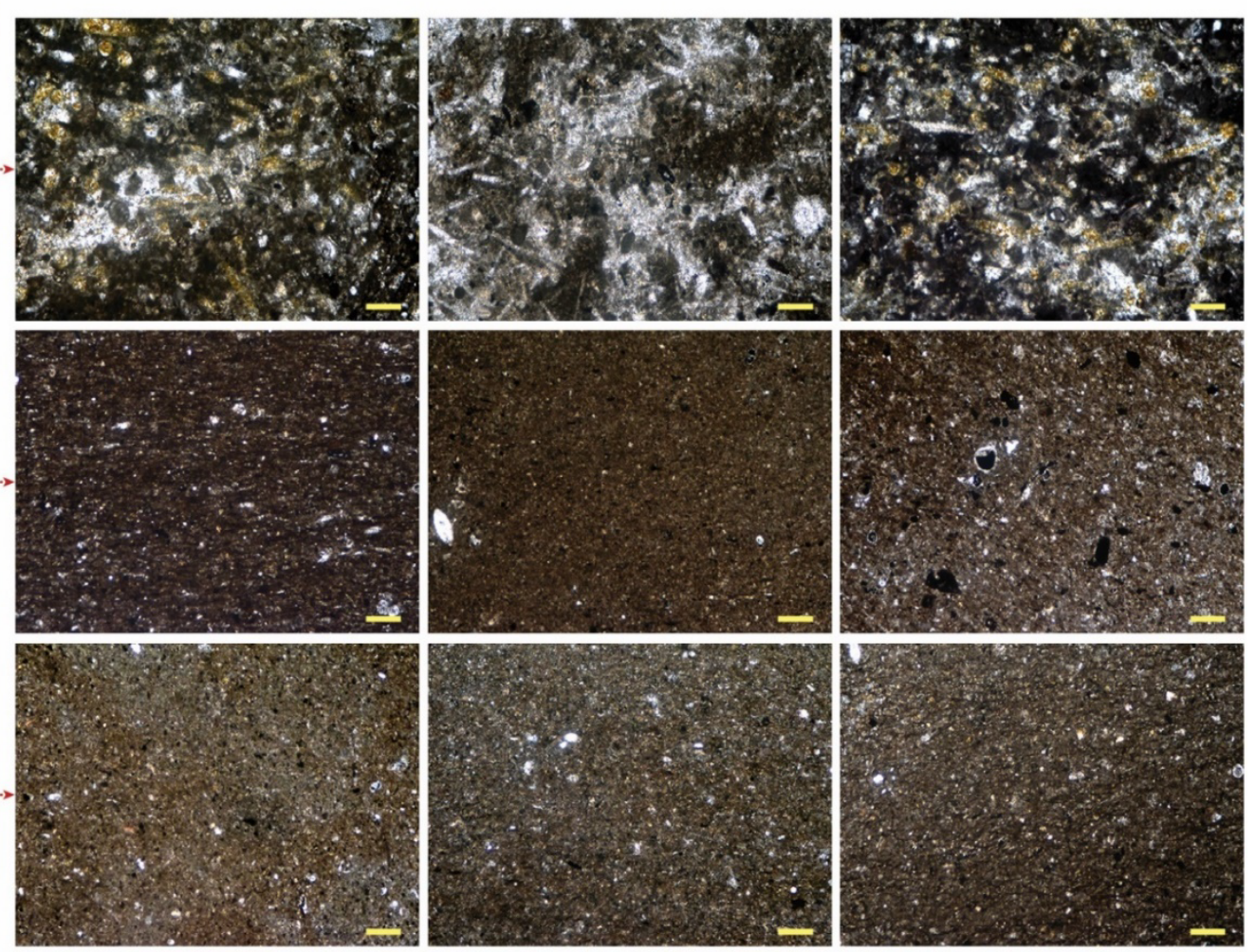

Argillaceous Limestone

TI Marlstone

Figure 7-2 A) Simplified lithostratigraphic column depicting the distribution of various lithologies present in this studied interval. Units 1-3 refer to various lithostratigraphic units demarcated based on their respective lithological pattern. B) Outcrop photographs representative of each Unit, scale at 2 m. C). Thin section images representative of each Unit, scale at $200 \mu \mathrm{m}$. 
Unit 2 is dominated by biomicrites (Fig. 7-2C) with a relatively lower degree of bioturbation (generally $<4$ ), impoverished benthic fauna $\rho$ and less than $10 \%$ allochems (Fig. 7-3A, B, C), most of which are completely infilled with pyrite (Fig. 7-2C). The composition of bioclasts in Unit 2 is identical to Unit 1, except that nearing the top, at $150.21 \mathrm{~m}$, the monotonous microfacies is interrupted by a gradual increase of calcareous sponge spicules. Additionally, a subtle coarsening of the grains recognized at $\sim 162.39 \mathrm{~m}$ precedes the uppermost portion of Unit 2 starting at $167.61 \mathrm{~m}$, where microfacies transition into mainly packed biomicrites. Unit 3 is marked by further grain coarsening and a microfacies shift towards highly bioturbated (>5), packed biosparites (Fig. 7-2C).

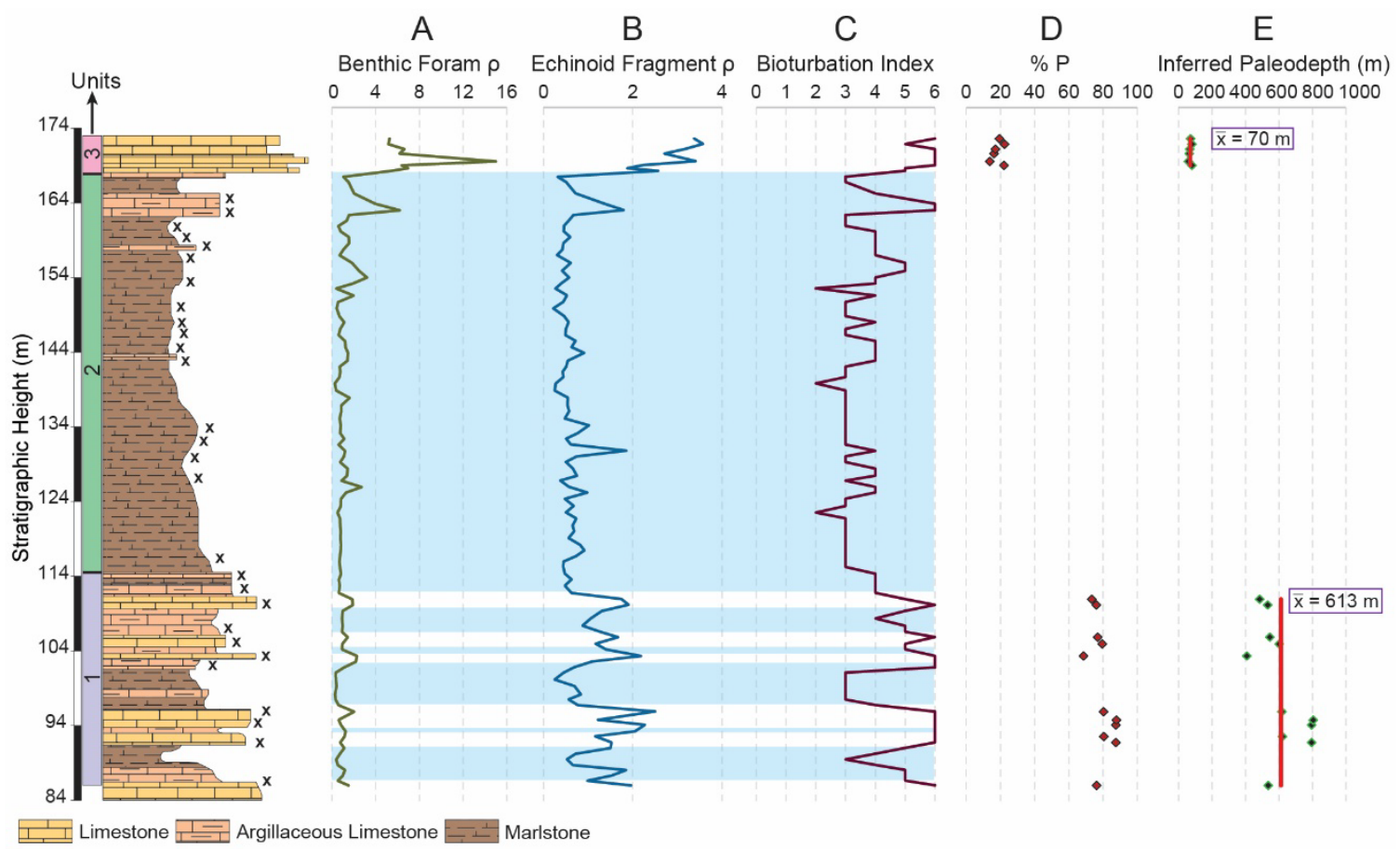

Figure 7-3 A) and B) Time series counts of benthic foraminifera and echinoid fragments. C) Bioturbation index for each sample following the proposed scheme in Taylor and Goldring (1993). A-C) Bluish bands correspond to argillaceous limestone and marlstone intervals. D) Limestone interval counts of the ratio between planktonic and benthic foraminifera. The ratio is expressed as the percentage of planktonic foraminifera or $\% \mathrm{P}$ calculated as $100 * \mathrm{P} /(\mathrm{P}+\mathrm{B})$, where $\mathrm{P}$ is the number of planktonic individuals and $\mathrm{B}$ is the number of benthic individuals. E) Calculated paleodepths based on the relationship between bathymetry and \%P as proposed by van der Zwaan et al. (1990). Solid red lines represent the average depth value. 
These rocks contain on average $>50 \%$ allochems dominated by a fibrous matrix of sponge spicules, abundant and diversified benthic foraminifera assemblages, in particular Glomospira sp. (Fig. 7-2C), increased echinoid skeletal debris, but lesser amounts of planktonic foraminifera as compared to previous Units 1 and 2 (Fig. 7-3A, B, C, D).

The Zonal marker Leupoldina cabri (L.cabri), originally identified in the basal portion (height of $13.77 \mathrm{~m}$ ) of the El Pujal sequence (Socorro and Maurrasse, 2019a), ubiquitous henceforth (Socorro and Maurrasse, 2019b), also occurs at 28 intervals of Unit 1, and 2, but disappears in Unit 3 (Fig. 7-3 marked with an X next to lithologic column). Further analysis of planktonic foraminifera focusing on their percentages $(\% \mathrm{P})$ in limestone intervals $(n=17)$, yielded an average $\% P$ of $79 \%$ for the lower Unit 1 and $18 \%$ for uppermost Unit 3 (Fig. 7-3D). Utilizing the relationship of \%P and depth (van der Zwaan et al., 1990), these values suggest an estimated average depth of $613 \mathrm{~m}$ for Unit 1 and $70 \mathrm{~m}$ for Unit 3 (Fig. 7-3E), a decrease of $543 \mathrm{~m}$.

\subsubsection{Inorganic, Organic and Carbon Isotope Stratigraphy (TIC, TOC and $\delta^{13} \mathrm{Corg}$ )}

The carbonate content (TIC) throughout this $85.82 \mathrm{~m}$ interval varies from $54.31 \%$ to $85.63 \%$ with an average of $64.59 \%$ (Fig. $7-4 \mathrm{~A}$ ) (For a complete list of values refer to Appendix 7A). The differentially weathered packets of alternating marlstones and limestones that comprise Unit 1 ( $86.07 \mathrm{~m}-114.15 \mathrm{~m})$ show considerable fluctuation in TIC values (56.67 \% to $73.15 \%)$. The overlying Unit 2, consisting mostly of marlstones, shows a distinct decline in TIC, with an average of $61.91 \%$. This pattern continues up to the very top of Unit 2, after which values gradually increase as the lithology transitions into a limestone dominated, $3.93 \mathrm{~m}$ interval (Unit 3), where carbonate content averages $79.17 \%$ and peaks up to $85.63 \%$. 
The organic carbon content (TOC) of the studied samples averages $0.90 \%$ and varies from $0.27 \%$ to $1.29 \%$ (Fig. $7-4 \mathrm{~B}$ ) (For a complete list of values refer to Appendix 7A). Overall, a clear inverse relationship between TOC and TIC $(r=-0.77)$ is visible with enriched TOC values in argillaceous limestone and marlstone beds. Samples in the lower $28.08 \mathrm{~m}$ of Unit 1 contain on average $0.78 \%$ organic carbon, with pronounced peaks up to $1.07 \%, 1.24 \%$ and $0.90 \%$ at $89.51 \mathrm{~m}, 100.1 \mathrm{~m}$ and $108.19 \mathrm{~m}$, respectively. Unit 2 shows a sharp increase in TOC ( $\bar{x}=1.01 \%)$, with values generally above the section's

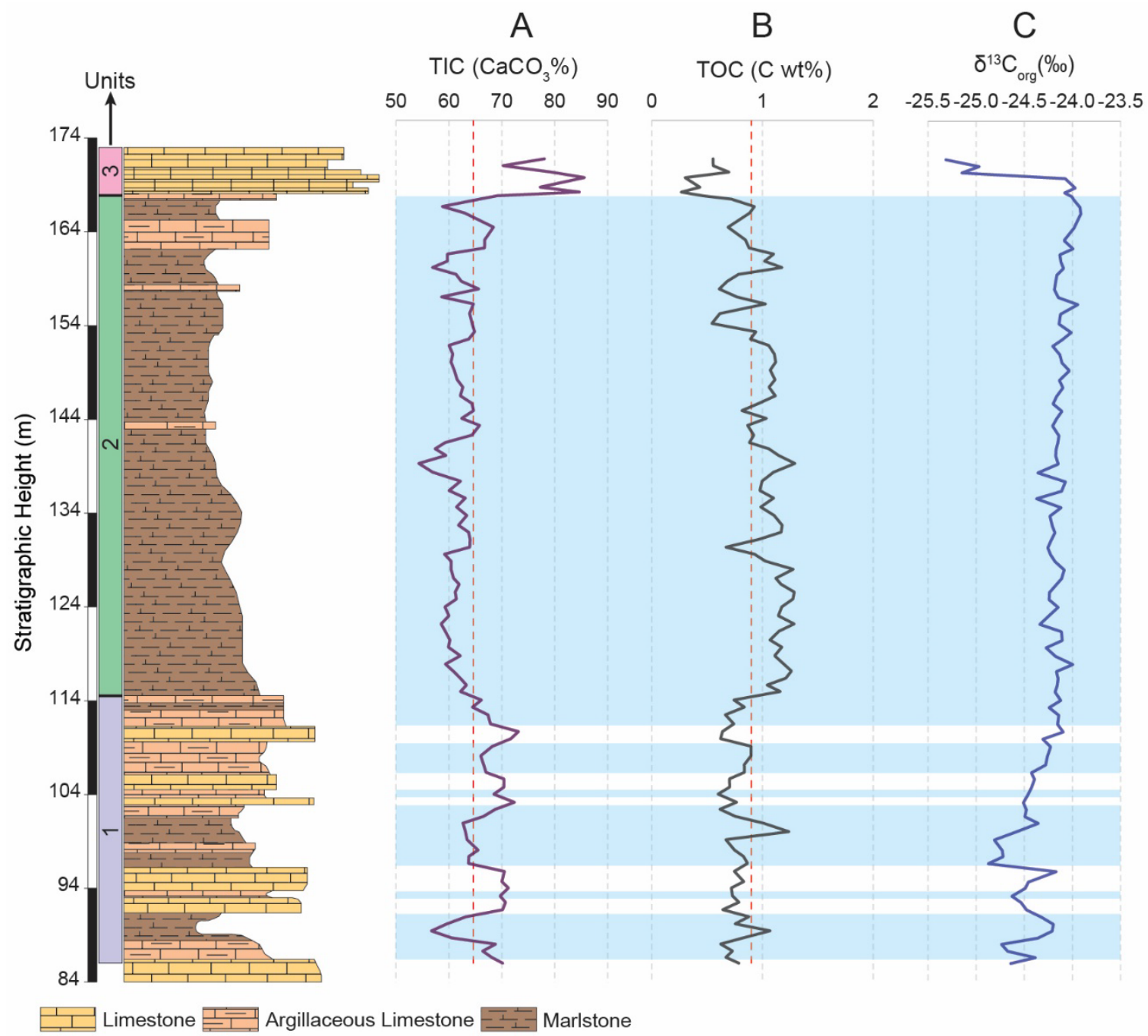

Figure 7-4 A-C) Stratigraphic variation of carbon geochemical data including total inorganic carbon (TIC), total organic carbon (TOC) and stable carbon isotope $\left(\delta^{13} \mathrm{C}_{\text {org }}\right)$. A) and B) Vertical red dashed lines represent the average TIC and TOC values for this interval. A-C) Bluish bands correspond to argillaceous limestone and marlstone intervals. 
average up to $\sim 152 \mathrm{~m}$. Subsequently, TOC values fluctuate between $1.18 \%$ and $0.54 \%$ up to a stratigraphic height of $166.81 \mathrm{~m}$, and then gradually gradually decrease to $0.46 \%$ at $167.96 \mathrm{~m}$, which marks the transition into the succeeding Unit 3. The TOC values decline in Unit $3(\overline{\mathrm{x}}=0.47 \%)$ reaching a minimum of $0.27 \%$ at $168.36 \mathrm{~m}$, the lowest recorded value of the entire El Pujal sequence.

The stable carbon isotope $\left(\delta^{13} \mathrm{C}_{\text {org }}\right)$ measured in the bulk organic fraction averages $24.26 \%$ with values that vary between $-25.31 \%$ and $-23.91 \%$ (Fig. $7-4 \mathrm{C}$ ) (For a complete list of values refer to Appendix 7A). Overall, the $\delta^{13} \mathrm{C}_{\text {org }}$ curve displays a weak negative relationship with TIC $(r=-0.36)$ and a weak positive relationship with TOC $(r=$ 0.28). The lowermost part of the section, equivalent to Unit 1 , shows fluctuating values between $-24.87 \%$ and $-24.10 \%$. Overlying Unit 2 displays a uniform trend $(\overline{\mathrm{x}}=-$ $24.14 \%$ ) with only minor variability of $\leq 0.46 \%$. The most striking aspect of the $\delta^{13} \mathrm{C}_{\text {org }}$ curve is a pronounced negative shift of $1.34 \%$, recorded in the uppermost $3.93 \mathrm{~m}$ of the succession or Unit 3 (Fig. 7-4C).

\subsubsection{Distribution Pattern of Major and Trace Elements}

Concentrations of major elements ( $\mathrm{Si}, \mathrm{Al}, \mathrm{Ti}, \mathrm{P}$, and $\mathrm{Fe}$ ) are presented in Figure 7-5 (For a complete list of values refer to Appendix 7B). In general, the major elements ( $\mathrm{Si}$, $\mathrm{Al}, \mathrm{Ti})$ display a trend that largely mirrors lithology and as such their vertical profile can be subdivided into the previously demarcated units. Within Unit 1, Si, Al and Ti show an oscillating trend with peaks that are usually higher than their respective averages $(\mathrm{Si} \overline{\mathrm{x}}=$ $58.78 \mathrm{ppm} \cdot 10^{-3}, \mathrm{Al} \overline{\mathrm{x}}=23.28 \mathrm{ppm} \cdot 10^{-3}$, Ti $\left.\overline{\mathrm{x}}=1.11 \mathrm{ppm} \cdot 10^{-3}\right)$ in marlstone and argillaceous limestone beds. Conversely, limestone beds within Unit 1 show relatively lower concentration of $\mathrm{Si}, \mathrm{Al}$ and $\mathrm{Ti}$, i.e. below their respective average. In the interval 
corresponding to Unit 2, the concentration of $\mathrm{Si}, \mathrm{Al}$ and $\mathrm{Ti}$ simultaneously increase above their respective average, except at discrete intervals of argillaceous limestone beds, mainly at $158.02 \mathrm{~m}$ and $164.61 \mathrm{~m}$, where values decrease below the average. A strong decrease in concentration of these elements is registered in the limesotne beds corresponding to Unit 3. In particular, $\mathrm{Al}$ and $\mathrm{Ti}$ show acute declines with minimums of $4.61 \mathrm{ppm} \cdot 10^{-3}$ and $0.26 \mathrm{ppm} \cdot 10^{-3}$, respectively, followed by Si whose concentration decreases to $35.54 \mathrm{ppm} \cdot 10^{-3}$. On average, the concentration of $\mathrm{Si}, \mathrm{Al}$ and $\mathrm{Ti}$ in Unit 3 represents a $19.04 \%, 60.57 \%$ and $57.87 \%$ percent reduction, respectively, relative to the average value of these elements in the $85.82 \mathrm{~m}$ studied interval. The two remaining biolimiting elements $\mathrm{P}$ and $\mathrm{Fe}$ display a vertical trend analogous to $\mathrm{Si}, \mathrm{Al}$ and $\mathrm{Ti}$. In fact, both $\mathrm{P}$ and $\mathrm{Fe}$ have a strong positive correlation of $\mathrm{r}=0.71$ and $\mathrm{r}=0.95$, respectively, when compared with Al. Essentially, in Unit 1, peaks in P and Fe exceed their respective

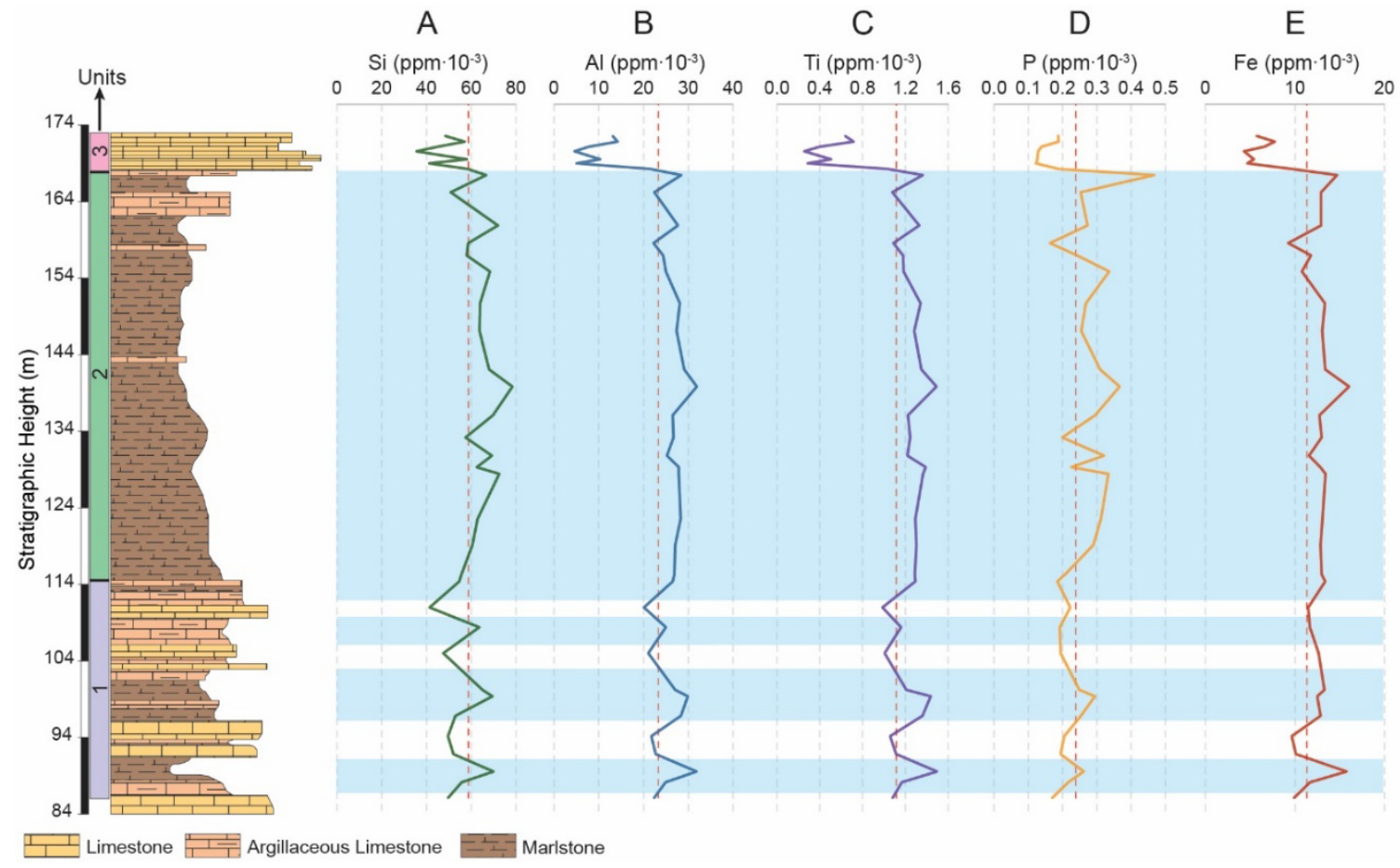

Figure 7-5 A-E) Vertical plots of major elements compared with lithology. All values are expressed in parts per thousand $\left(\mathrm{ppm} \cdot 10^{-3}\right)$. Vertical red dashed lines represent the respective element's average value. A-E) Bluish bands correspond to argillaceous limestone and marlstone intervals. 
averages $\left(\mathrm{P} \overline{\mathrm{x}}=0.24 \mathrm{ppm} \cdot 10^{-3}, \mathrm{Fe} \overline{\mathrm{x}}=11.35 \mathrm{ppm} \cdot 10^{-3}\right)$ in argillaceous limestone and marlstone beds. In the overlying Unit 2 interval, $\mathrm{P}$ and Fe show a marked increase with values that mostly stay above their individual averages. The uppermost rocks of Unit 3 display impoverished $\mathrm{P}\left(\overline{\mathrm{x}}=0.15 \mathrm{ppm} \cdot 10^{-3}\right)$ and $\mathrm{Fe}\left(\overline{\mathrm{x}}=5.75 \mathrm{ppm} \cdot 10^{-3}\right)$ concentrations, which represent a $37.5 \%$ and $49.34 \%$ decrease, relative to their respective average. Detailed variations of RSTEs (V $\overline{\mathrm{x}}=37.82 \mathrm{ppm}, \mathrm{Cr} \overline{\mathrm{x}}=33.87 \mathrm{ppm}, \mathrm{Co} \overline{\mathrm{x}}=0.79 \mathrm{ppm}$, Ni $\overline{\mathrm{x}}=16.16 \mathrm{ppm}, \mathrm{Cu} \overline{\mathrm{x}}=5.15 \mathrm{ppm}, \mathrm{Mo} \overline{\mathrm{x}}=1.69 \mathrm{ppm}$, and $\mathrm{U} \overline{\mathrm{x}}=0.95 \mathrm{ppm}$ ) are presented in Figure 7-6 (For a complete list of values refer to Appendix 7B). In the $28.08 \mathrm{~m}$-interval of Unit 1, RSTEs show similar trends characterized by fluctuating values that closely follow lithologic variations. Higher values above their respective average usually occur in argillaceous limestone and marlstone beds. Conversely, lower values below the element's average usually correspond to limestone beds. The ensuing $53.81 \mathrm{~m}$-interval of Unit 2 that consists predominantly of marlstones shows increased RSTE values that mostly stay above each element's respective average. The uppermost 3.93 m-interval of Unit 3 exhibits an abrupt decrease in all RSTEs. For example, V decreases to $9.62 \mathrm{ppm}$ at $169.89 \mathrm{~m}$, recording the lowest concentration in the entire El Pujal section. Comparing the RSTEs vertical trend with benthic fauna counts and bioturbation index reveals essentially an inverse relationship, whereby peaks in RSTEs concur with intervals of lower benthic fauna counts and lower degree of bioturbation. As an example, the concentration of $\mathrm{V}$ displays a strong negative correlation with benthic foraminifera $\rho(\mathrm{r}=$ $-0.79)$, echinoid fragments $\rho(r=-0.85)$ and bioturbation index $(r=-0.81)$. Compared with the carbon geochemistry, RSTEs mainly display decreased values in intervals of high TIC/low TOC (limestone layers) and elevated values in intervals of low TIC/high 
TOC (argillaceous limestone and marlstone layers). This relationship is exemplified by the strong negative correlation between $\mathrm{V}$ and TIC $(\mathrm{r}=-0.93)$ and strong positive correlation with TOC $(\mathrm{r}=0.75)$.

In addition to their absolute values, degrees of enrichment of RSTEs (expressed as EIs) relative to background levels (OBABV) were calculated and presented in Figure 7-6H, I. Most RSTEs are enriched (values $>1$ ) in argillaceous limestone and marlstone beds, but show depleted values in limestone beds throughout this $85.82 \mathrm{~m}$ representing the upper part of the studied El Pujal section. Nonetheless, V is an exception, because it is enriched throughout, regardless of lithology, albeit its apparent depletion in Unit 3. On the contrary, Co and $\mathrm{Ni}$ are never enriched, although they show minor peaks in argillaceous limestone and marlstone beds. There is a distinct, concurrent depletion in all RSTEs coincident with the hard limestone at the onset of Unit 3. Summing the EIs ( $\sum$ EIs) of each element, their interrelationship with TIC results show a strong negative correlation $(\mathrm{r}=-0.94)$. Similar relationships are recorded when $\sum$ EIs are compared with benthic foraminifera $\rho(r=-0.78)$, echinoid fragment $\rho(r=-0.84)$ and bioturbation index $(r=-$ $0.85)$. On the contrary, $\sum$ EIs displays a strong positive correlation with TOC $(\mathrm{r}=0.81)$.

\subsubsection{Lipid Analysis Results}

Analysis via full scan GC/MS of aliphatic fractions reveals that the extractable hydrocarbons are dominated by $n$-alkanes and the acyclic isoprenoids pristane $(\operatorname{Pr})$ and phytane (Ph) (Fig. 7-7). Chromatograms show a homologous series of $n$-alkanes ranging from $n \mathrm{C}_{11}$ to $n \mathrm{C}_{32}$ with a unimodal positively skewed distribution in samples taken from Unit 1 and 2, but a unimodal negatively skewed distribution in samples from Unit 3 (Fig. 


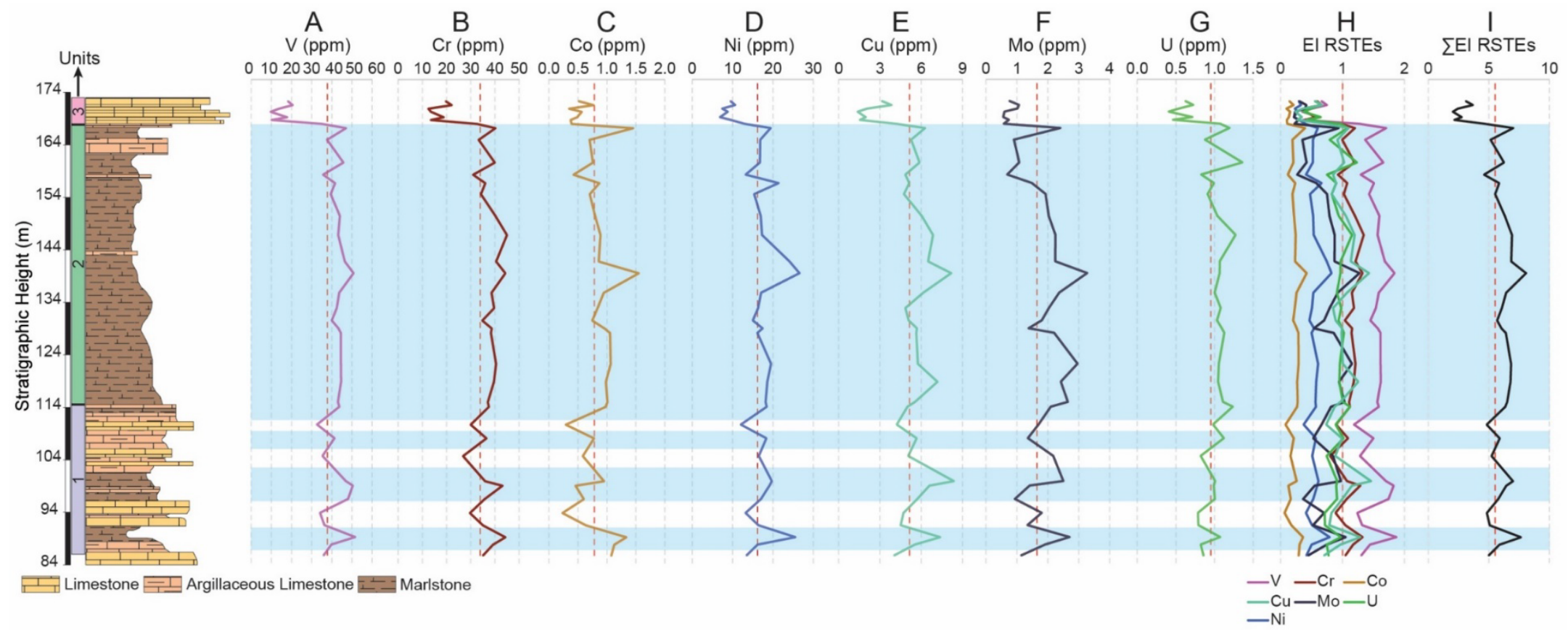

Figure 7-6 A-G) Vertical plots of redox-sensitive trace elements (RSTEs) reported as absolute values in parts per million (ppm). H) Vertical plot of RSTEs enrichment indices (EI RSTEs) relative to the Organyà Basin's Average Background Value (OBABV) from Socorro and Maurrasse (2019b). I) Vertical plot of the addition of all the EIs of each element for each sample. A-I) Bluish bands correspond to argillaceous limestone and marlstone intervals. 


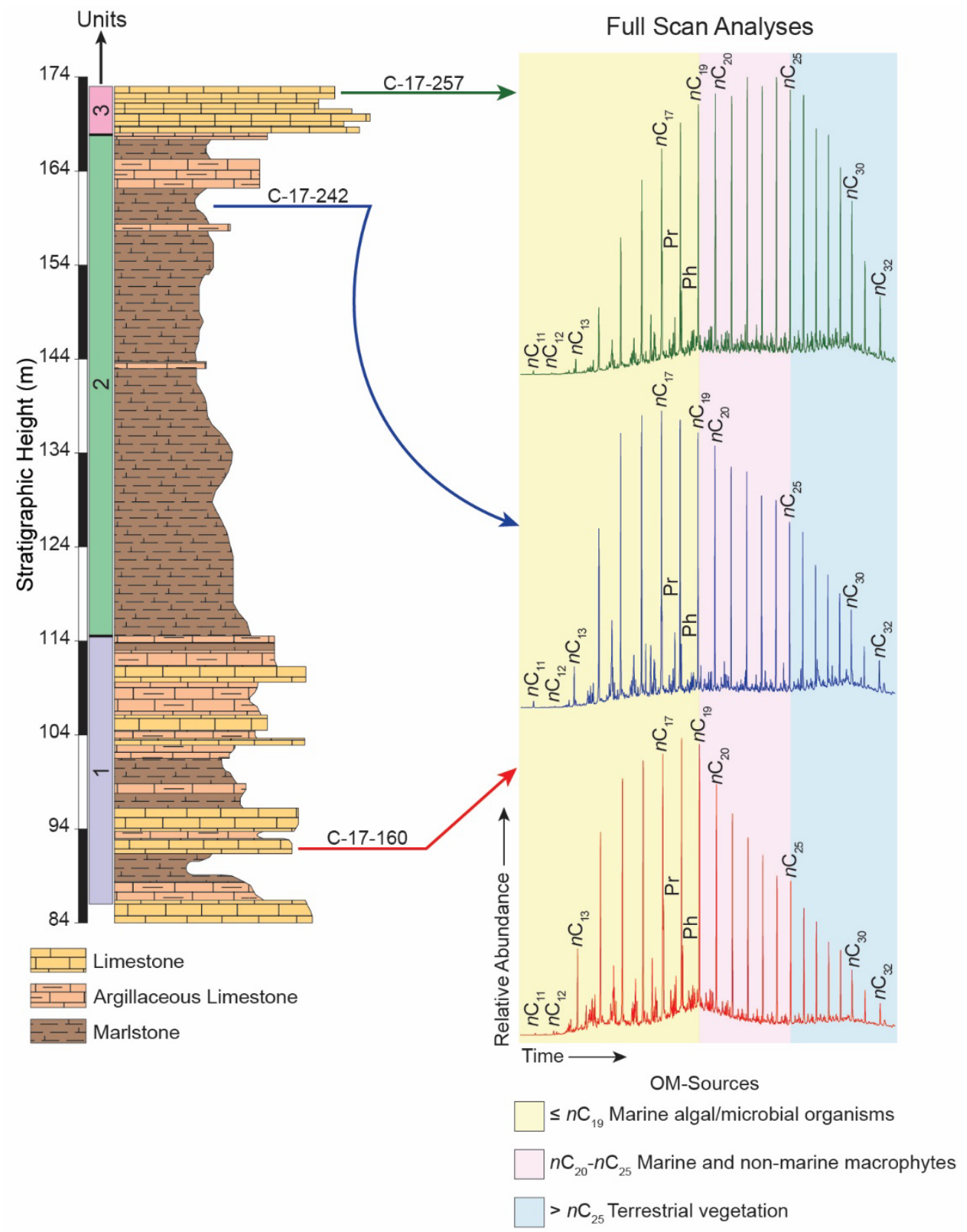

Figure 7-7 Representative total ion chromatograms of the aliphatic fraction from three samples. Labeled peaks refer to n-alkane's carbon chain length. Peaks labeled as $\mathrm{Pr}$ and $\mathrm{Ph}$ refer to pristane and phytane, respectively.

7-7). Indications for biodegradation, such as an elevated chromatographic baseline or unresolved complex mixture (UCM) hump, were absent. To facilitate the interpretation of the $n$-alkanes distributions, terrigenous/aquatic ratio (TAR) values were calculated and plotted in Figure 7-8A. TAR values vary between 0.25 to 0.84, with an average of 0.37 . 
A shift occurs in the TAR record at the onset of Unit 3 correlative with decreasing organic carbon accumulation. Also, compared to Unit 1 and 2, the relative contribution of long-chain length $\left(>n \mathrm{C}_{19}\right)$ increases and remains significan throughout Unit 3 which yielded the highest TAR values that reach up to 0.84 (171.89 m). Values of carbon preference index $(\mathrm{CPI})$ ranged from 0.93 to $1.09(\overline{\mathrm{x}}=1.03)$ with the majority of the lower values (0.93-1.02) being recorded within Unit 3 (Refer to Appendix 7C). The acyclic

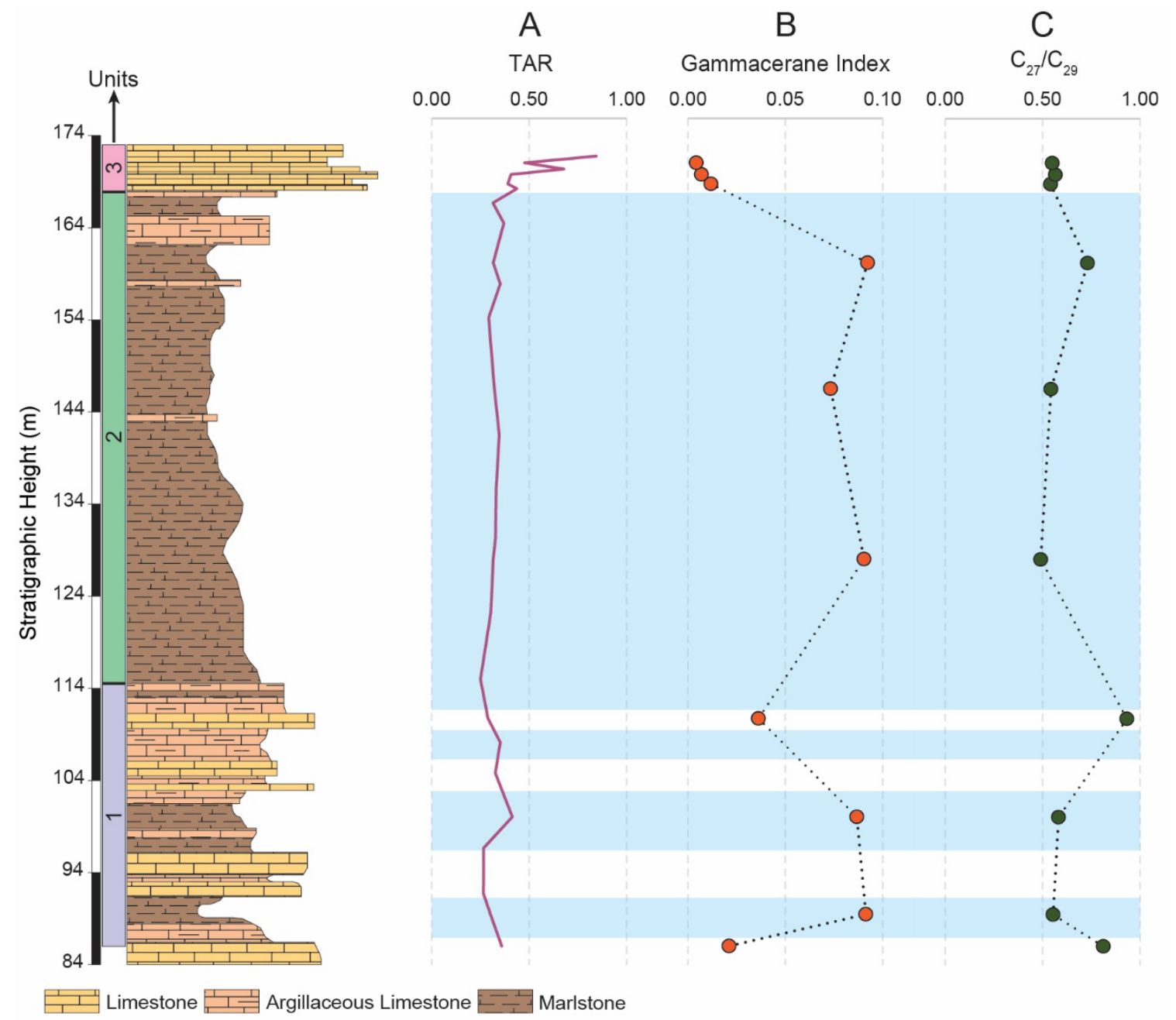

Figure 7-8 A) Vertical plot of the relative proportion of terrestrial to aquatic organic matter (i.e. TAR). B) Vertical plot of the relative proportion of $\mathrm{C}_{30}$ Gammacerane to $\mathrm{C}_{30} 17 \alpha, 21 \beta(\mathrm{H})$ hopane (i.e. Gammacerane Index). C) Vertical plot of the relative proportion of $\mathrm{C}_{27} 5 \alpha, 14 \alpha, 17 \alpha(\mathrm{H})$ sterane (20R) to $\mathrm{C}_{29}$ $5 \alpha, 14 \alpha, 17 \alpha(\mathrm{H})$ sterane (20R) (i.e. $\mathrm{C}_{27} / \mathrm{C}_{29}$ ). A-C) Bluish bands correspond to argillaceous limestone and marlstone intervals. 
isoprenoids represented by $\mathrm{Pr}$ and $\mathrm{Ph}$ are abundant in all the samples. The $\mathrm{Pr} / \mathrm{Ph}$ ratios vary from 0.83 to $1.59(\overline{\mathrm{x}}=1.20)$, with generally lower values $(0.83-1.25)$ in Unit 3 (Refer to Appendix 7C). Values of isoprenoid $/ n$-alkanes ratios $\left(\mathrm{Pr} / n \mathrm{C}_{17} \mathrm{vs} \mathrm{Ph} / n \mathrm{C}_{18}\right)$ are relatively low as they average 0.26 and 0.22 , respectively. A plot of $\operatorname{Pr} / n \mathrm{C}_{17} \mathrm{vs} \mathrm{Ph} / n \mathrm{C}_{18}$ shows most samples plotting in the region of mixed type II/III kerogen and marine type II kerogen (Fig. 7-9).

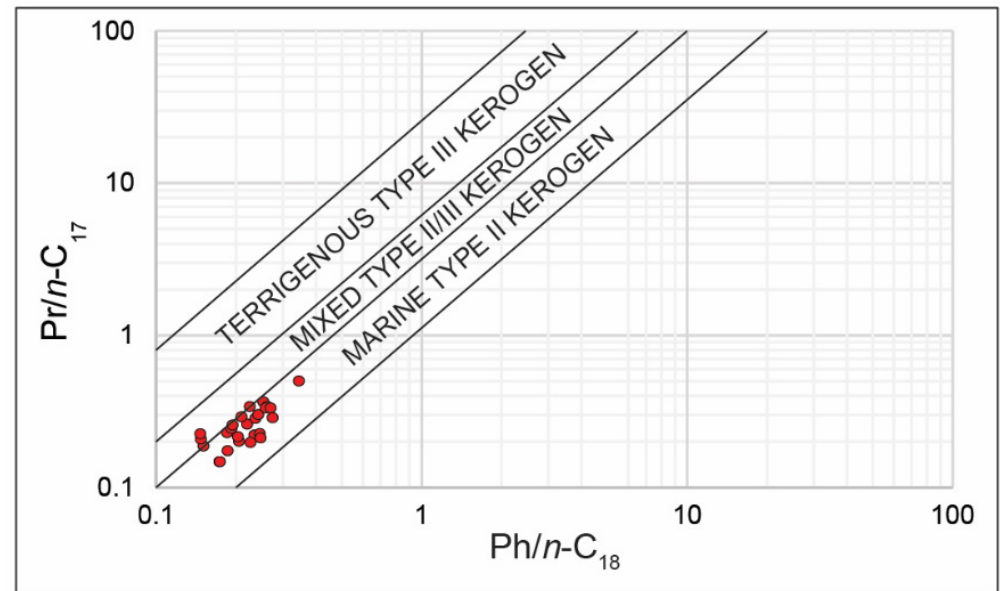

Figure 7-9 Log-log cross plot of Pristane/n- $\mathrm{C}_{17}$ vs. Phytane $/ \mathrm{n}-\mathrm{C}_{18}$ values of selected samples. Kerogen type fields after Shanmugam (1985) from concepts proposed by Lijmbach (1975).

Hopanes with carbon numbers ranging from $\mathrm{C}_{27}$ to $\mathrm{C}_{35}$ are present in all of the analyzed samples (for representative chromatograms refer to Figure 7-10A and Table 71). The $\mathrm{C}_{27}$ hopanes $(\mathrm{m} / \mathrm{z} 370 \rightarrow 191)$ are dominated by $18 \alpha-22,29,30$-trisnorneohopane (Ts) and 17 $\alpha-22,29,30$-trisnorhopane $(\mathrm{Tm})$. Calculated $\mathrm{Ts} /(\mathrm{Ts}+\mathrm{Tm})$ ratios vary between 0.58 to 0.63 , with an average of 0.61 (Refer to Appendix 7C) and show a weak negative correlation with lithology (TIC) $(\mathrm{r}=-0.21)$. The $\mathrm{C}_{30}$ hopanes $(\mathrm{m} / \mathrm{z} 412 \rightarrow 191)$ is dominated by $\mathrm{C}_{30} 17 \alpha, 21 \beta(\mathrm{H})$ hopane $\left(\mathrm{C}_{30} \alpha \beta\right)$. Also, the presence of the triterpenoid alcohol, tetrahymanol (gammaceran-3 $\beta$-ol), typically referred to as gammacerane is of importance in the $\mathrm{m} / \mathrm{z} 412 \rightarrow 191$ chromatograms. Gammacerane is present in all of the 
studied samples, but with varying proportions as illustrated by the plot of the gammacerane index (gammacerane/ $\mathrm{C}_{30} \alpha \beta$ ) (Fig. 7-8B). In Unit 1 and 2 the gammacerane index displays a strong negative correlation with TIC $(\mathrm{r}=-0.92)$ and a strong positive correlation with TOC $(r=0.90)$, while in Unit 3 the gammacerane peak is barely detectible, thus leading to near zero values (Fig. 7-8B). The homohopane homologous series as summarized in Figure 7-10B (m/z 426, 440, 454, 468, 482 $\rightarrow 191)$ ranges from $\mathrm{C}_{31}$ to $\mathrm{C}_{35}$. The $\mathrm{C}_{31}$ homohopane $22 \mathrm{~S} /(22 \mathrm{~S}+22 \mathrm{R})$ isomerization ratio yields values that vary from 0.48 to 0.59 with an average of 0.55 (Table 7-2).

A range of $\mathrm{C}_{27}$ to $\mathrm{C}_{30}$ diasteranes and steranes occur in all of the studied samples (for representative chromatograms refer to Figure 7-10 and Table 7-1). The relative distribution of $5 \alpha, 14 \alpha, 17 \alpha(\mathrm{H})(20 \mathrm{R}) \mathrm{C}_{27}, 5 \alpha, 14 \alpha, 17 \alpha(\mathrm{H})(20 \mathrm{R}) \mathrm{C}_{28}$ and $5 \alpha, 14 \alpha, 17 \alpha(\mathrm{H})$ (20R) $\mathrm{C}_{29}$ steranes $(\alpha \alpha \alpha R)$ varies $\left(\mathrm{C}_{27} \alpha \alpha \alpha \mathrm{R} \overline{\mathrm{x}}=29.61 \%, \mathrm{C}_{28} \alpha \alpha \alpha \mathrm{R} \overline{\mathrm{x}}=22.54, \mathrm{C}_{29} \alpha \alpha \alpha \mathrm{R} \overline{\mathrm{x}}\right.$ $=47.85)$, with $\mathrm{C}_{29} \alpha \alpha \alpha \mathrm{R}$ always being dominant (37.65\% - 55.90\%). The ternary diagram plot of $\% \mathrm{C}_{27} \alpha \alpha \alpha \mathrm{R}, \% \mathrm{C}_{28} \alpha \alpha \alpha \mathrm{R}$ and $\% \mathrm{C}_{29} \alpha \alpha \alpha \mathrm{R}$ indicates that most samples have an estuarine to terrestrial sterane signature (Fig. 7-11). Plots of $5 \alpha, 14 \alpha, 17 \alpha(\mathrm{H})(20 \mathrm{R}) \mathrm{C}_{27}$ to $5 \alpha, 14 \alpha, 17 \alpha(\mathrm{H})(20 \mathrm{R}) \mathrm{C}_{29}$ ratio $\left(\mathrm{C}_{27} / \mathrm{C}_{29}\right)($ Fig. $7-8)$ display variable values $(0.49-0.93 \overline{\mathrm{x}}=$ $0.66)$ in Unit 1 and 2 that inversely correlate with TOC $(r=-0.87)$, while Unit 3 contains almost no variability $(0.54-0.57)$ and consistently lower values $(\overline{\mathrm{x}}=0.55)$. Isomerization of the $\mathrm{C}-20$ stereocenter in the $5 \alpha, 14 \alpha, 17 \alpha(\mathrm{H}) \mathrm{C}_{29}$ sterane expressed as the $\mathrm{C}_{29}$ $20 \mathrm{~S} /(20 \mathrm{~S}+20 \mathrm{R})$ ratio varies from 0.42 to 0.59 and averages 0.52 (Table $7-2)$. Betaisomerization at $\mathrm{C}-14$ and $\mathrm{C}-17$ in the $5 \alpha, 14 \alpha, 17 \alpha(\mathrm{H}) \mathrm{C}_{29} 20 \mathrm{~S}$ and $20 \mathrm{R}$ sterane expressed as the $\mathrm{C}_{29} \beta \beta /(\beta \beta+\alpha \alpha)$ ratio varies from 0.56 to 0.66 and averages 0.62 (Table 7-2). 
A

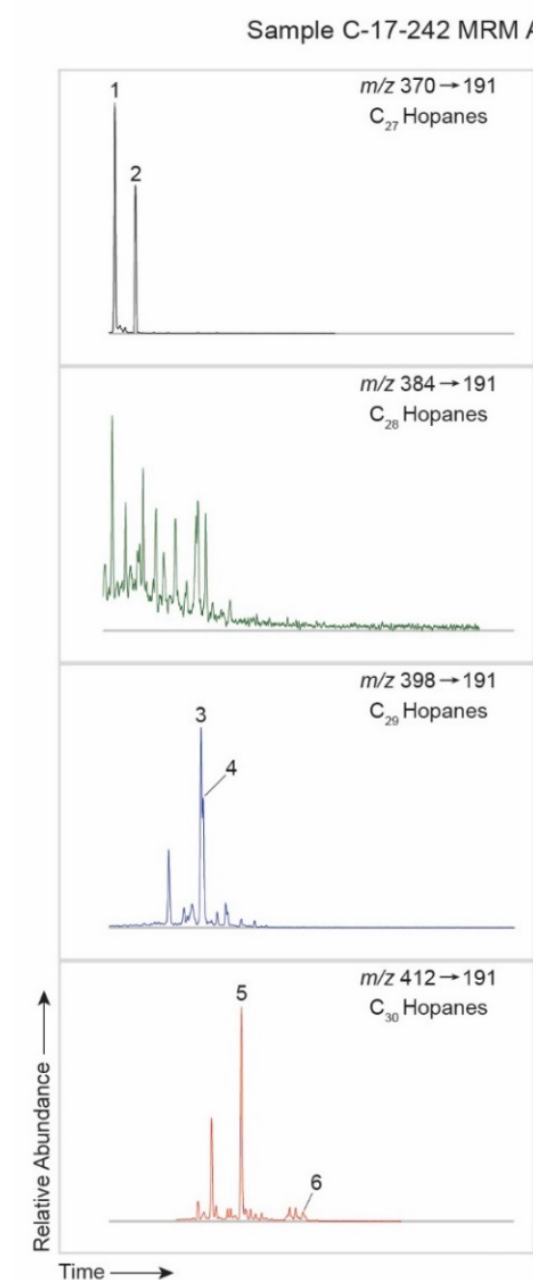

B

Sample C-17-242 MRM Analysis of Steranes and Diasteranes

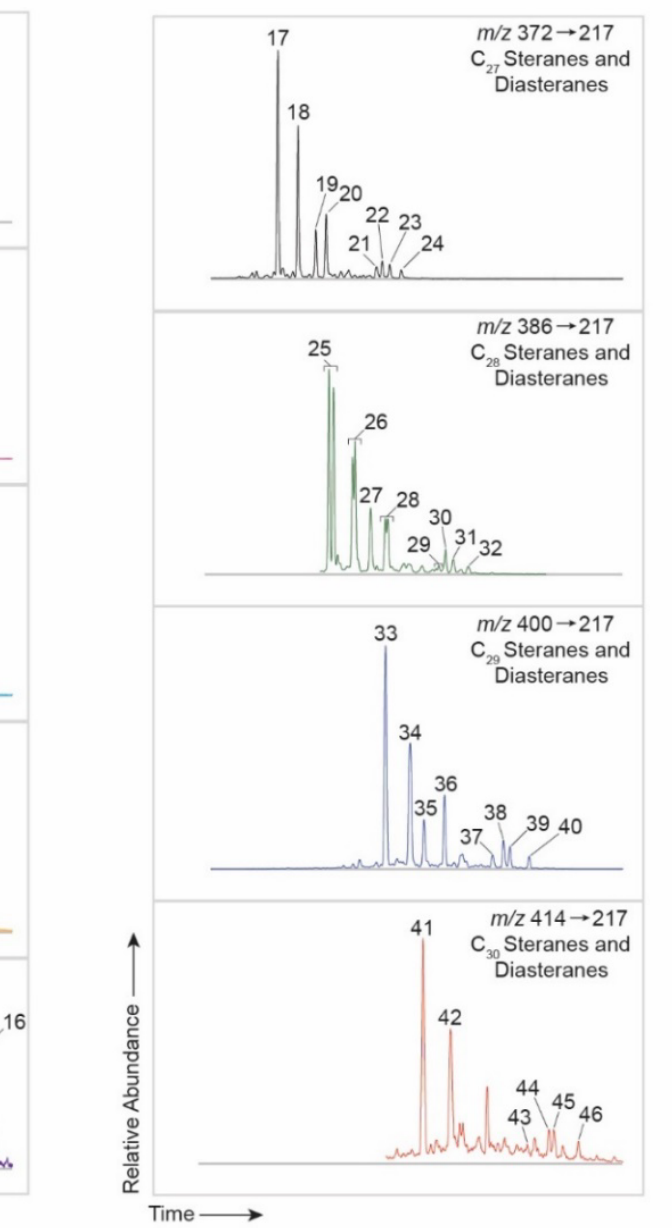

Figure 7-10 MRM transition profiles from a representative sample showing the distribution of various hopanes, steranes and diasteranes.

Refer to Table 7-1 for peak identification.

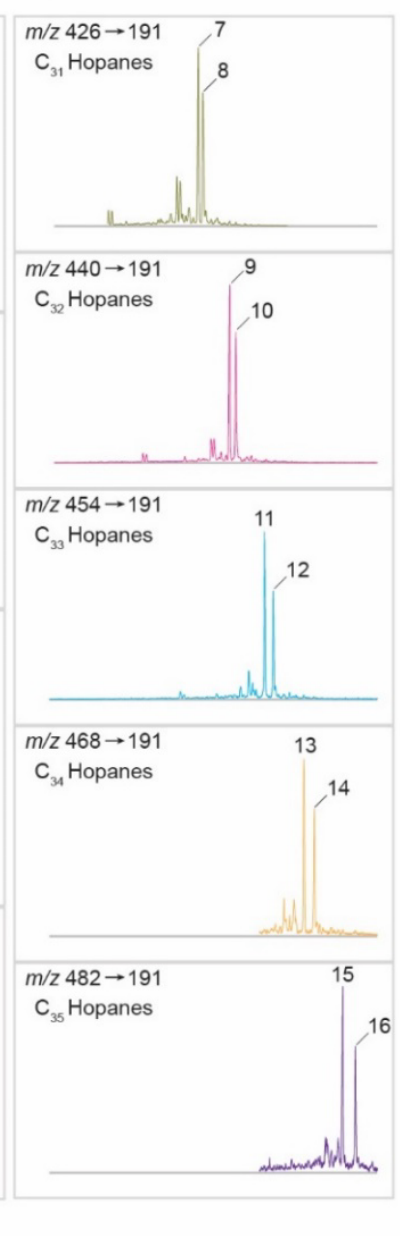


Table 7-1 Identified biomarkers compounds. The numbers next to the respective compounds refers to the numbered peaks in Figure 7-10.

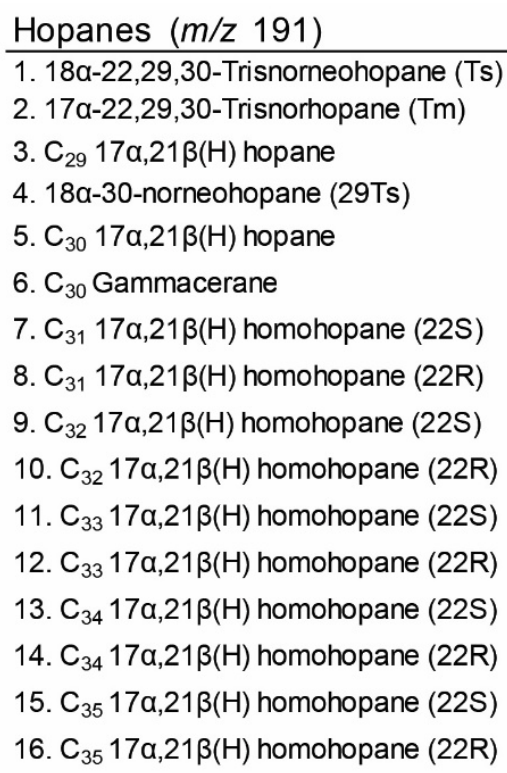

\author{
Steranes and Diasteranes $(\mathrm{m} / \mathrm{z} 217)$ \\ 17. $\mathrm{C}_{27} 13 \beta, 17 \alpha(\mathrm{H})$ diasterane $(20 \mathrm{~S})$ \\ 18. $\mathrm{C}_{27} 13 \beta, 17 \alpha(\mathrm{H})$ diasterane (20R) \\ 19. $\mathrm{C}_{27} 13 \alpha, 17 \beta(\mathrm{H})$ diasterane (20S) \\ 20. $\mathrm{C}_{27} 13 \alpha, 17 \beta(\mathrm{H})$ diasterane (20R) \\ 21. $\mathrm{C}_{27} 5 \alpha, 14 \alpha, 17 \alpha(\mathrm{H})$ sterane $(20 \mathrm{~S})$ \\ 22. $\mathrm{C}_{27} 5 \alpha, 14 \beta, 17 \beta(\mathrm{H})$ sterane $(20 \mathrm{R})$ \\ 23. $\mathrm{C}_{27} 5 \alpha, 14 \beta, 17 \beta(\mathrm{H})$ sterane $(20 \mathrm{~S})$ \\ 24. $\mathrm{C}_{27} 5 \alpha, 14 \alpha, 17 \alpha(\mathrm{H})$ sterane (20R) \\ 25. $\mathrm{C}_{28} 13 \beta, 17 \alpha(\mathrm{H})$ diasterane (20S) isomeric peaks (24S and 24R) \\ 26. $\mathrm{C}_{28} 13 \beta, 17 \alpha(\mathrm{H})$ diasterane (20R) isomeric peaks (24S and $24 \mathrm{R}$ ) \\ 27. $\mathrm{C}_{28} 13 \alpha, 17 \beta(\mathrm{H})$ diasterane (20S) \\ 28. $\mathrm{C}_{28} 13 \alpha, 17 \beta(\mathrm{H})$ diasterane $(20 \mathrm{R})$ isomeric peaks (24S and $\left.24 \mathrm{R}\right)$ \\ 29. $\mathrm{C}_{28} 5 \alpha, 14 \alpha, 17 \alpha(\mathrm{H})$ sterane (20S) isomeric peaks (24S and $24 \mathrm{R}$ ) \\ 30. $\mathrm{C}_{28} 5 \alpha, 14 \beta, 17 \beta(\mathrm{H})$ sterane (2OR) \\ 31. $\mathrm{C}_{28} 5 \alpha, 14 \beta, 17 \beta(\mathrm{H})$ sterane (20S) \\ 32. $\mathrm{C}_{28} 5 \alpha, 14 \alpha, 17 \alpha(\mathrm{H})$ sterane $(20 \mathrm{R})$ \\ 33. $\mathrm{C}_{29} 13 \beta, 17 \alpha(\mathrm{H})$ diasterane (20S) \\ 34. $\mathrm{C}_{29} 13 \beta, 17 \alpha(\mathrm{H})$ diasterane (20R) \\ 35. $\mathrm{C}_{29} 13 \alpha, 17 \beta(\mathrm{H})$ diasterane (20S) \\ 36. $\mathrm{C}_{29} 13 \alpha, 17 \beta(\mathrm{H})$ diasterane (20R) \\ 37. $\mathrm{C}_{29} 5 \alpha, 14 \alpha, 17 \alpha(\mathrm{H})$ sterane (20S) \\ 38. $\mathrm{C}_{29} 5 \alpha, 14 \beta, 17 \beta(\mathrm{H})$ sterane $(20 \mathrm{R})$ \\ 39. $\mathrm{C}_{29} 5 \alpha, 14 \beta, 17 \beta(\mathrm{H})$ sterane (20S) \\ 40. $\mathrm{C}_{29} 5 \alpha, 14 \alpha, 17 \alpha(\mathrm{H})$ sterane (2OR) \\ 41. $\mathrm{C}_{30} 13 \beta, 17 \alpha(\mathrm{H})$ diasterane (20S) \\ 42. $\mathrm{C}_{30} 13 \beta, 17 \alpha(\mathrm{H})$ diasterane (2OR) \\ 43. $\mathrm{C}_{30} 5 \alpha, 14 \alpha, 17 \alpha(\mathrm{H})$ sterane (20S) \\ 44. $\mathrm{C}_{30} 5 \alpha, 14 \beta, 17 \beta(\mathrm{H})$ sterane (20R) \\ 45. $\mathrm{C}_{30} 5 \alpha, 14 \beta, 17 \beta(\mathrm{H})$ sterane $(20 \mathrm{~S})$ \\ 46. $\mathrm{C}_{30} 5 \alpha, 14 \alpha, 17 \alpha(\mathrm{H})$ sterane (2OR)
}

Table 7-2 Values of calculated biomarker thermal maturation indices.

\begin{tabular}{ccccc}
\hline Sample ID & Height $(m)$ & $C_{31} 22 S /(22 S+22 R)$ & $C_{29} 20 S /(20 S+20 R)$ & $C_{29} \beta \beta /(\beta \beta+\alpha \alpha)$ \\
\hline$C-17-256$ & 171.16 & 0.56 & 0.42 & 0.58 \\
C-17-254 & 169.89 & 0.54 & 0.54 & 0.65 \\
$\mathrm{C}-17-253$ & 168.87 & 0.58 & 0.54 & 0.66 \\
$\mathrm{C}-17-242$ & 160.3 & 0.54 & 0.54 & 0.65 \\
$\mathrm{C}-17-226$ & 146.61 & 0.52 & 0.48 & 0.62 \\
$\mathrm{C}-17-204$ & 128.1 & 0.59 & 0.42 & 0.60 \\
$\mathrm{C}-17-183$ & 110.79 & 0.56 & 0.57 & 0.60 \\
$\mathrm{C}-17-170$ & 100.1 & 0.48 & 0.55 & 0.64 \\
$\mathrm{C}-17-157$ & 89.51 & 0.55 & 0.59 & 0.62 \\
$\mathrm{C}-17-152$ & 86.07 & 0.53 & 0.52 & 0.56 \\
\hline \multicolumn{2}{c}{ Average } & 0.55 & 0.52 & 0.62 \\
\hline
\end{tabular}




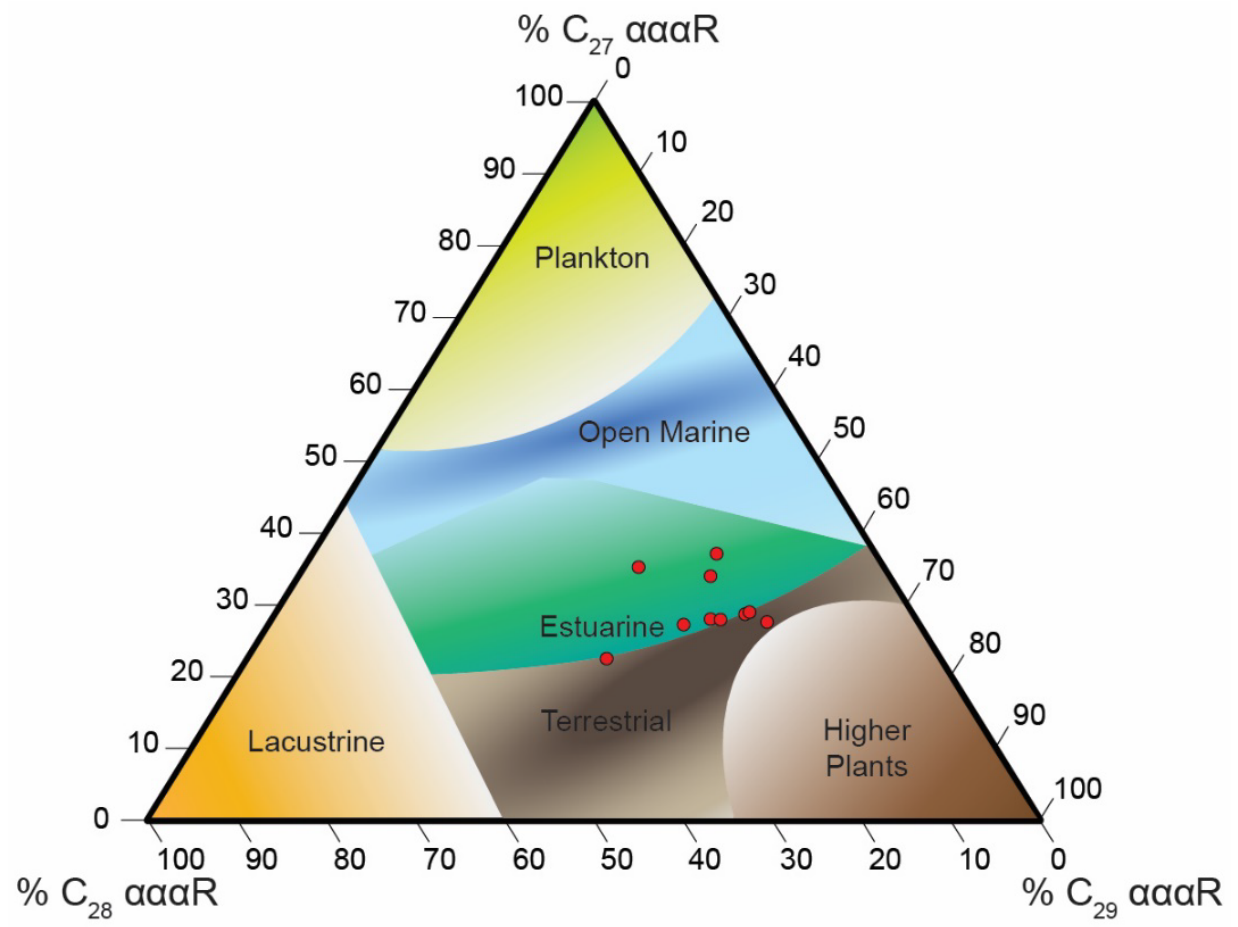

Figure 7-11 Ternary diagram showing the sterane composition of selected samples and their relationship with source input. Fields after Shanmugam (1985) from concepts proposed by Huang and Meinschein (1979).

\subsubsection{Bulk and Clay Mineralogy}

Results of the bulk mineral content of 10 samples from representative lithologies of the El Pujal section are presented in Table 7-3. Their composition consists mainly of calcite $(57 \%-73 \%, \bar{x}=66 \%)$, quartz $(9 \%-15 \%, \bar{x}=12 \%)$, clay minerals $(8 \%-12 \%, \bar{x}=$ $9 \%)$, with minor amounts of siderite $(2 \%-7 \%, \bar{x}=4 \%)$, P-feldspar $(2 \%-5 \%, \bar{x}=3 \%)$,

K-feldspar $(1 \%-4 \%, \overline{\mathrm{x}}=2 \%)$, pyrite/marcasite $(1 \%-3 \%, \overline{\mathrm{x}}=2 \%)$ and dolomite $(1 \%$ -

Table 7-3 Bulk mineralogical composition of selected samples distributed throughout the studied interval.

\begin{tabular}{rccccccccc}
\hline Sample ID & Height $(\mathrm{m})$ & Clay & Quartz & K-feldspar & P-feldspar & Calcite & Dolomite & Siderite & Pyrite/Marcasite \\
\hline C-17-257 & 171.89 & $9 \%$ & $11 \%$ & $2 \%$ & $2 \%$ & $72 \%$ & $1 \%$ & $3 \%$ & $1 \%$ \\
C-17-255 & 170.49 & $10 \%$ & $12 \%$ & $1 \%$ & $2 \%$ & $69 \%$ & $1 \%$ & $2 \%$ & $3 \%$ \\
C-17-249 & 166.81 & $9 \%$ & $14 \%$ & $4 \%$ & $3 \%$ & $64 \%$ & $1 \%$ & $4 \%$ & $1 \%$ \\
C-17-217 & 139.39 & $8 \%$ & $15 \%$ & $3 \%$ & $3 \%$ & $65 \%$ & $1 \%$ & $4 \%$ & $1 \%$ \\
C-17-197 & 122.27 & $8 \%$ & $14 \%$ & $2 \%$ & $2 \%$ & $65 \%$ & $2 \%$ & $4 \%$ & $3 \%$ \\
C-17-183 & 110.79 & $9 \%$ & $10 \%$ & $2 \%$ & $2 \%$ & $73 \%$ & $1 \%$ & $2 \%$ & $1 \%$ \\
C-17-180 & 108.19 & $12 \%$ & $12 \%$ & $2 \%$ & $2 \%$ & $66 \%$ & $1 \%$ & $4 \%$ & $1 \%$ \\
C-17-170 & 100.1 & $9 \%$ & $11 \%$ & $3 \%$ & $3 \%$ & $67 \%$ & $1 \%$ & $3 \%$ & $2 \%$ \\
C-17-157 & 89.51 & $9 \%$ & $14 \%$ & $3 \%$ & $5 \%$ & $57 \%$ & $2 \%$ & $7 \%$ & $3 \%$ \\
C-17-152 & 86.07 & $12 \%$ & $9 \%$ & $3 \%$ & $3 \%$ & $66 \%$ & $1 \%$ & $4 \%$ & $2 \%$
\end{tabular}


$2 \%, \overline{\mathrm{x}}=1 \%)$. The overall averages for each lithologic Unit indicate only minor $(\leq 5 \%)$ temporal variability of the bulk mineral content (Fig. 7-12). Appreciable shifts ( $\geq 3 \%)$ occur only in the quartz and calcite contents. Quartz shows a 4\% increase between Unit 1 $(11 \%)$ and Unit $2(15 \%)$ and a decrease of 3\% between Unit $2(15 \%)$ and Unit $3(12 \%)$

(Fig. 7-12). Similarly, calcite increases by 5\%, but only between Unit 2 and Unit 3 (Fig. 7-12).

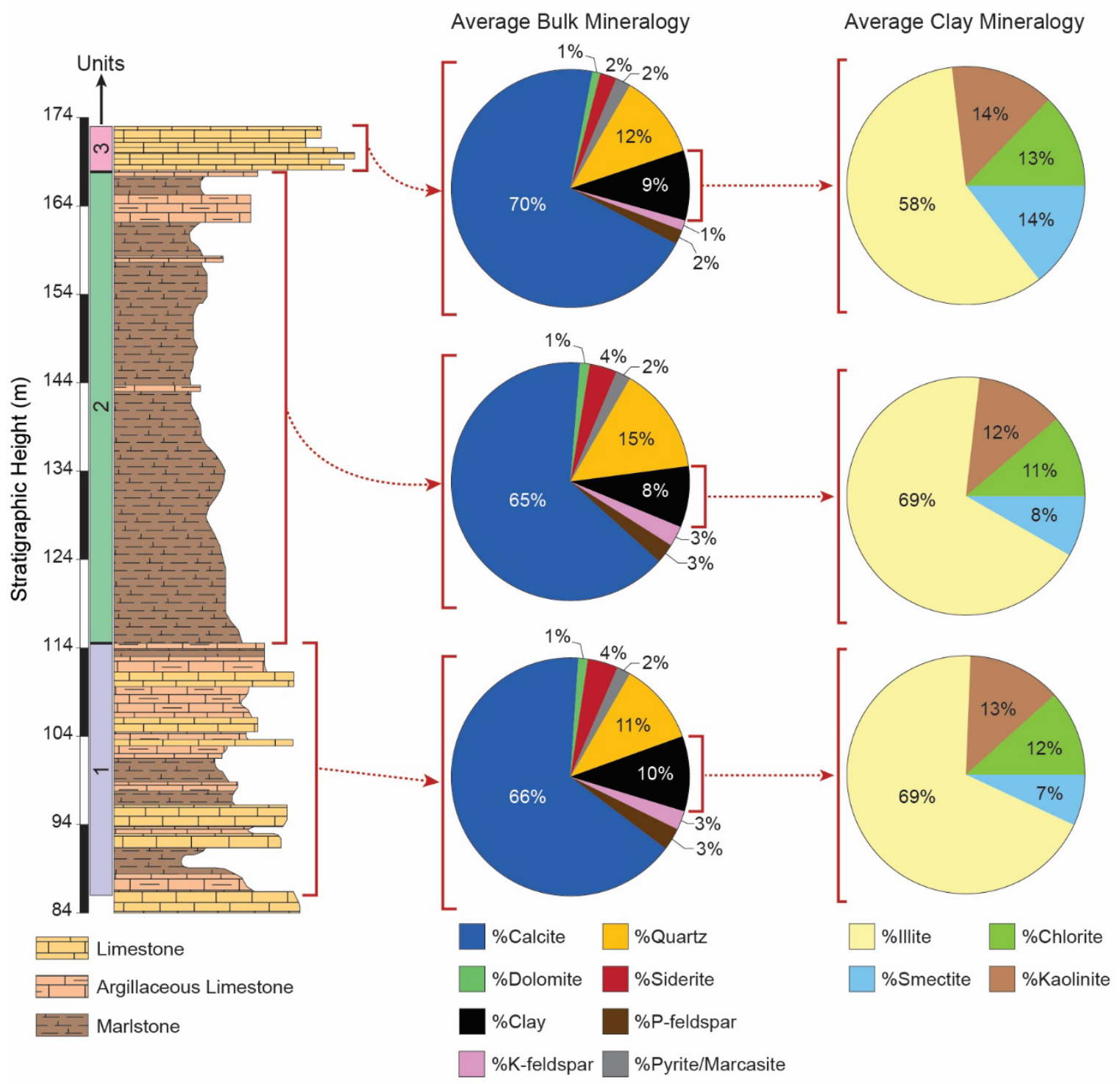

Figure 7-12 Pie diagrams of average bulk and clay mineralogy for Units 1-3. For a comprehensive bulk mineralogical composition of the analyzed samples, refer to Table 7-3. 
Specific clay mineral constituents of the El Pujal sediments were also determined for the 10 samples analyzed for bulk mineral content. The results shown in Figure 7-13 reveal that the clay fraction is dominated by illite $(\overline{\mathrm{x}}=67 \%)$ with percentages that fluctuate between $55 \%$ and $78 \%$. Kaolinite $(\overline{\mathrm{x}}=13 \%)$ represents the next most abundant clay mineral, but unlike illite it has a much smaller variability (11\%), oscillating between $7 \%$ and $18 \%$. Chlorite follows in abundance with an average of $12 \%$ and values that

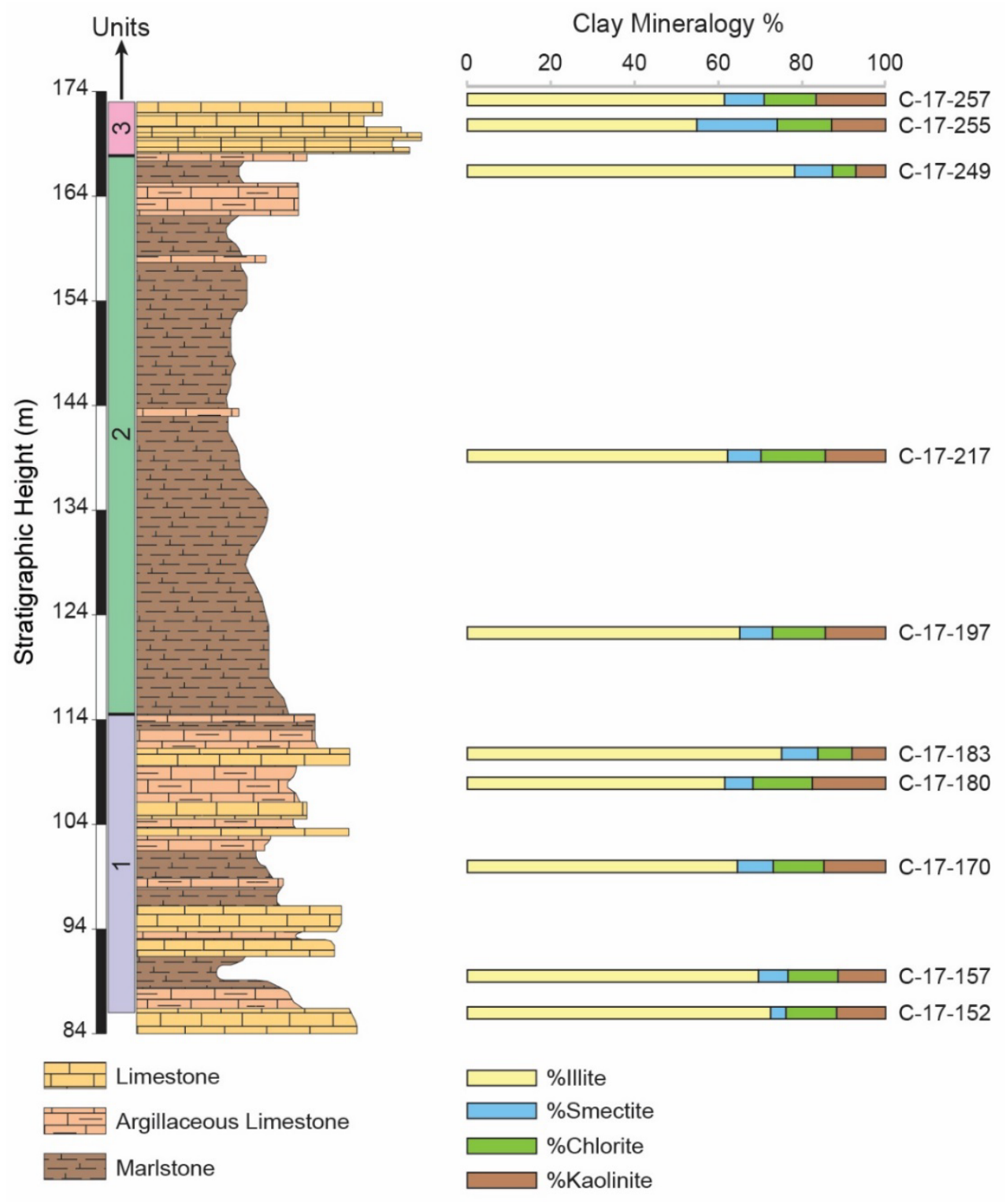

Figure 7-13 Temporal variation of clay mineral content compared with lithology. 
oscillate between $6 \%$ and $15 \%$, a range of $9 \%$. Smectite constitutes the smallest portion $(9 \%)$ of the clay minerals, yet a relatively high range $(15 \%)$ of values that vary from $4 \%$ to $19 \%$ characterizes it. The trends in the clay mineral averages for each lithologic Unit (Fig. 7-12) shows a marked 11\% decrease in illite content between Unit 2 and Unit 3, coeval with a $6 \%$ increase in smectite.

\subsection{Discussion}

\subsubsection{Paleoenviromental Conditions: Integration of Stratigraphy and Geochemistry}

The distinctive field-scale characteristics of facies corresponding to Unit $1(86.07 \mathrm{~m}$ - $114.15 \mathrm{~m})$ (Fig. 7-2) in the present study of the El Pujal section include a repetitive series of alternating indurated limestones and softer argillaceous limestones to marlstones, suggestive of recurring different paleoenviromental conditions. The microfacies reveal that only the softer argillaceous limestone and marlstone beds include frequent dispersive pyritized allochems, low bioturbation indices $(\sim 3$, indicative of restricted burrowing activity) and impoverished benthic faunal counts (Fig. 7-3A, B, C), which all imply oxygen-deficient conditions at these times (Wignall and Myers, 1988; Taylor and Goldring, 1993). Coeval peaks in TOC (Fig. 7-4B) that demonstrate preservation of OM together with enrichment of most RSTEs (Fig. 7-6H) support the assumption of episodic oxygen-restricted conditions in the basin, whereas the limestone beds indicate periods of higher ventilation. In addition to the concurrence of these oxygenation proxies, major elemental contents and biolimiting elements further show a striking pattern of synchronicity with peaks in $\mathrm{Si}, \mathrm{Al}$, and Ti (Fig. 7-5A, B, C), coeval with those of $\mathrm{Fe}$ and $\mathrm{P}$ (Fig. 7-5D, E), and higher contribution of OM from terrestrial sources (Fig. 7-8A, C), thus suggesting coincident intensified pulses of fluvial discharge 
and nutrient loads. Under such conditions, freshwater runoff may have resulted in density stratification of the water column preventing vertical mixing of oxygen depleted bottom waters with more oxygenated surface waters. The biomarker results also show concurrent peaks of gammacerane (Fig. 7-8B), therefore providing further corroborative evidence for stratification of the water column (Harvey and Mcmanus, 1991; Sinninghe Damsté et al., 1995). As previously discussed for the lower $\sim 85 \mathrm{~m}$ portion of the El Pujal section (Socorro and Maurrasse, 2019a,b), the present results also permit to infer that Unit 1 represents an interval of variable fluvial fluxes possibly related to climatic fluctuations similar to those reported in the Mediterranean area during the latest Miocene (Mayser et al., 2017) and the Pleistocene last interglacial (Wu et al., 2018). These conditions may thus explain the alternating lithology with limestones representing the least terrestrially influenced endmember and marlstones representing points of highest terrestrial influences.

The subsequent Unit 2 can be interpreted to represent a facies transition consisting predominately of marlstone between $114.15 \mathrm{~m}$ and $167.96 \mathrm{~m}$ (Fig. 7-2). It is the upward extension of alternating lithologies previously studied in the lower part of the section ( 85 m-interval) (Socorro and Maurrasse, 2019a,b) which is also continuous into Unit 1 of the present study (Fig. 7-2). Unit 2 consists of homogenous microfacies including mostly pyritized allochems (Fig. 7-2C), reduced benthic fauna counts and lower degree of bioturbation ( 3) (Fig. 7-3A, B, C), analogous to the marlstone intervals in Unit 1. The change in facies occurs simultaneously with further sustained increase in TOC $(\overline{\mathrm{x}}=$ 1.01\%), and RSTEs. Together, these data suggest continuous oxygen-deprived conditions, but without a fully anoxic phase, as benthic fauna while relatively reduced, 
are still present throughout. Concurrent lasting terrigenous fluxes are implied as evidenced by elevated major elements (Si, Al, Ti) (Fig. 7-5A, B, C), biolimiting elements (Fe, P) (Fig. 7-5D, E) and higher terrestrial OM contents (Fig. 7-8A, C). Freshwater discharge must have been persistent during this time as indicated by continually elevated gammacerane indices (Fig. 7-8B). Thus, these results suggest an increase in runoff apparently related to established humid continental conditions that prevailed in this interval causing strong, quasi-permanent eutrophic surface waters in the Organyà Basin. That is not to say, however, that recurrent periods of dry climatic conditions did not develop during this interval in the Organyà Basin as presumably they did (refer to Figure 7-2A Unit 2 - notice intervals of argillaceous limestones). However, it appears that if they did occur, they were of short duration and their signal, typified by the deposition of OM-lean limestones, is not perceivable as it was likely subdued by the amplified signal from more persistent wet climate intervals.

Hard limestones associated with Unit 3 (167.96 m - $171.89 \mathrm{~m})$ represent a sharp change in lithology (Fig. 7-2) as the microfacies gradually shifts to coarser grain, highly bioturbated (>5) packed biosparites (Fig. 7-2C; Fig. 7-3C). These changes indicate an increase in energy conditions and a shift towards more aerobic bottom waters. The biogenic assemblage is composed of abundant benthic foraminifera, echinoid fragments, sponge spicules, scarce planktonic foraminifera and varying amounts of unidentifiable skeletal detritus (Fig. 7-2C). The change in allochem components occurs together with decreases in TOC $(\overline{\mathrm{x}}=0.47 \%)$ (Fig. $7-4 \mathrm{~B})$ and depletion of all RSTEs relative to background values (Fig. 7-6H), which attests to increases in oxygen content. Dryer climatic conditions can be inferred on the adjacent land masses as suggested by an 
increase in smectite $(\overline{\mathrm{x}}=14 \%)$, but decreases in illite $(\overline{\mathrm{x}}=58 \%)$ (Fig. 7-12), $\mathrm{Si}, \mathrm{Al}$, and Ti (Fig. 7-5A, B, C) (Singer, 1984; Eslinger and Pevear, 1988; Bühmann and Schoeman, 1995). We may also postulate that simultaneous decreases in biolimiting elements Fe and P (Fig. 7-5D, E) resulted in a decline of in-situ primary production (Fig. 7-7; Fig. 7-8 A, C). Furthermore, gammacerane indices also drop to near zero (Fig. 7-8B), revealing an apparent termination of density stratification of the water column in the Organyà Basin.

\subsubsection{Thermal Maturity Assessment}

Assessing the thermal history of the sediment is a critical step before attempting interpretations of the organic geochemical data, because it can affect the interpretation of OM sources as well as the stable carbon isotope data $\left(\delta^{13} \mathrm{C}_{\text {org }}\right)$ (Philippi, 1965; Tissot, 1974; Tissot Clayton, 1991; Clayton and Bjorøy, 1994; Tang et al., 2005; Peters et al., 2005, 2007 ). Here we rely on hopane and sterane biomarker parameters to define the magnitude of thermal maturation in the El Pujal section. Our premise relies on established evidence that thermal maturation causes predictable transformation of the original hopanoid and sterol stereochemical configuration (Mackenzie et al., 1980; Seifert and Moldowan, 1980; Curiale et al., 1989; Peters et al., 2005, 2007). For instance, the biological form of the $\mathrm{C}_{31}$ homohopane contains a C-22 chiral center with a $22 \mathrm{R}$ configuration, which during thermal maturation converts to the $22 \mathrm{~S}$ isomer (Curiale et al., 1989; Peters et al., 2007). Increasing thermal maturity increases the $\mathrm{C}_{31}$ homohopane $22 \mathrm{~S} /(22 \mathrm{~S}+22 \mathrm{R})$ ratio from 0 up to an equilibrium value of 0.6 (Seifert and Moldowan, 1986; Peters et al., 2007)). Analyzed samples at El Pujal show that the $\mathrm{C}_{31}$ homohopane $22 \mathrm{~S} /(22 \mathrm{~S}+22 \mathrm{R})$ has an average value of 0.55 (Table 7-2), below the established equilibrium endpoint. Similarly, as thermal maturity increases the isomerization at the C- 
20 position in the $\mathrm{C}_{29} 5 \alpha, 14 \alpha, 17 \alpha(\mathrm{H})$ sterane converts from a $20 \mathrm{R}$ configuration in biologically derived steroid precursors to a $20 \mathrm{~S}$ isomer, thus increasing the $20 \mathrm{~S} /(20 \mathrm{~S}+20 \mathrm{R})$ ratio from 0 to an equilibrium value of 0.55 (Seifert and Moldowan, 1986; Peters et al., 2007). The $\mathrm{C}_{29} 20 \mathrm{~S} /(20 \mathrm{~S}+20 \mathrm{R})$ values for the El Pujal section averages 0.52 (Table 7-2), which is also below the equilibrium value of this parameter. Beta-isomerization at the asymmetric centers of the C-14 and C-17 in the $\mathrm{C}_{29}$ $5 \alpha, 14 \alpha, 17 \alpha(\mathrm{H}) 20 \mathrm{R}$ and $20 \mathrm{~S}$ sterane provides and additional constrain of thermal maturity, because the less stable $5 \alpha, 14 \alpha, 17 \alpha(\mathrm{H})$ configuration converts to the more stable $5 \alpha, 14 \beta, 17 \beta(\mathrm{H})$ configuration. Abundances of the $5 \alpha, 14 \alpha, 17 \alpha(\mathrm{H})$ configuration typically decrease relative to the $5 \alpha, 14 \beta, 17 \beta(\mathrm{H})$ configuration with increasing thermal maturity causing the $\mathrm{C}_{29} \beta \beta /(\beta \beta+\alpha \alpha)$ ratio to increase from 0 to 0.71 (Seifert and Moldowan, 1986; Peters et al., 2007). The El Pujal section has $C_{29} \beta \beta /(\beta \beta+\alpha \alpha)$ values that average 0.62 (Table 7-2), in accord with previous maturity parameters since it is also below the endpoint equilibrium value. These results indicate that sediments of the El Pujal section experienced temperatures of $\sim 50^{\circ} \mathrm{C}$ to $60^{\circ} \mathrm{C}$, which falls within the onset of the oil window (Peters et al., 2007). The consistency between the analyzed biomarker thermal maturity indicators thus suggests that thermal maturity should not be an issue when interpreting the organic geochemical results.

\subsubsection{OM Sources and Temporal Variability}

Previous studies on older sediments of the Organyà Basin associated with the El Pui sequence confirmed their hemipelagic setting (Sanchez-Hernandez et al., 2014; SanchezHernandez and Maurrasse, 2014, 2016) during a time influenced by episodes of intensified terrestrial influx, as also demonstrated in the succeeding deposits of the lower 
portion of the El Pujal section (Socorro and Maurrasse, 2019a,b). Owing to these findings, OM source identification becomes a more involved task since these marine settings preserve a complex signal that is influenced by distinct, but connected ecosystems that include rivers, estuaries and the ocean (Méjanelle and Laureillard, 2008; Ramaswamy et al., 2008; Carreira et al., 2010; Schmidt et al., 2010; Bauer et al., 2013; Cordeiro et al., 2018). Despite this tangled archive, the molecular biomarker approach, especially from lipids ( $n$-alkanes, hopanes and steranes), provides the most robust proxy for identifying OM sources because of their phylogenetic specificity, which in some cases can even identify particular class of organisms (e.g. types of bacteria and plants), further complemented by the relative diagenetic and chemical stability of some of these compounds (Cranwell, 1973; Giger et al., 1980; Meyers, 1997; Forster et al., 2004; Peters et al., 2005; 2007; Brocks and Summons, 2014). Because most living organisms have specific environmental requirements, thus characterizing the source of $\mathrm{OM}$ in a paleodepositional system can provide additional insights about the paleoenviromental conditions present during deposition.

The $n$-alkanes distribution of the present study in the upper $85.82 \mathrm{~m}$ of the El Pujal section reveals a homologous series that spans from $n \mathrm{C}_{11}$ to $n \mathrm{C}_{32}$ (Fig. 7-7). These results signify a mixed supply of OM derived from varied sources including bacteria and phytoplankton by in-situ production $\left(\leq n \mathrm{C}_{19}\right)$, and allochthonous material originating from aquatic macrophytes/sphagnum species $\left(n \mathrm{C}_{20}-n \mathrm{C}_{25}\right)$ and, terrestrial vegetation $\left(>n \mathrm{C}_{25}\right)$ (Eglinton and Hamilton, 1967; Han et al., 1968; Winters et al., 1969; Gelpi et al., 1970; Blumer et al., 1971; Cranwell, 1984; Viso et al., 1993; Riederer and Markstädter, 1996; Baas et al., 2000; Ficken et al., 2000; Mead et al., 2005; Schirmer et al., 2010; Gao 
et al., 2011). The values of Pristane $/ n \mathrm{C}_{17}$ vs Phytane $/ n \mathrm{C}_{18}$ further provide corroborating evidence, as they show that the samples plot within the marine type II kerogen to mixed type II/III kerogen indicative of marine and terrestrial OM sources (Fig. 7-9). Arguably, this ratio can be problematic because bacteria generally degrade the more labile $n$-alkanes before the isoprenoids. However, the almost non-existent UCM displayed in the chromatograms (Fig. 7-7) indicates that biodegradation can be ruled out (Wenger and Isaksen, 2002; Peters et al., 2005). Additionally, steranes, a class of tetracyclic triterpanes originating from the diagenetic alteration of sterols derived from the cell membranes of eukaryotic organisms were detected (Fig. 7-10B) (Nes, 1974; Mackenzie et al., 1982; Moldowan et al., 1985; Hartmann, 1998; Volkman, 2003, 2005; Peters et al., 2005; Dufourc, 2008). The presence of all three of the $\alpha \alpha \alpha-20 R$ epimers of $C_{27}, C_{28}$ and $C_{29}$ sterane originating from various eukaryotic sources including zooplankton, phytoplankton and terrestrial vegetation provides further evidence in support of this conclusion (Fig. 7-10B and Table 7-1). A dominant estuarine to terrestrial OM signature is recorded (Fig. 7-11) in the ternary distribution plot of the $\mathrm{C}_{27}, \mathrm{C}_{28}$, and $\mathrm{C}_{29} \alpha \alpha \alpha-20 \mathrm{R}$ steranes, a useful metric to determine OM source input and depositional environment, thus attesting to the mixed contribution of OM sources to the TOC (Huang and Meinschein, 1979). Hopanoids, a class of pentacyclic triterpenoids found in the lipid membrane of various prokaryotes, including oxic-heterotrophic bacteria, anaerobic sulfate-reducing bacteria and cyanobacteria were also detected (Fig. 7-10A), hence implying that bacteria were also an important source of OM input in the sediments associated with the El Pujal section (Ourisson et al., 1979, 1982, 1987; Ourisson and 
Rohmer, 1992; Sinninghe Damsté et al., 2004; Härtner et al., 2005; Blumenberg et al., 2006; Peters et al., 2007).

The complex nature of OM at El Pujal complicates appraisal of the temporal variability in the relative contribution of autochthonous marine versus allochthonous OM sources. Accordingly, we used taxonomically diagnostic biomarker indices for these two end-member OM sources, including the terrestrial to aquatic ratio (TAR) and the ratio of the $\alpha \alpha \alpha-20 \mathrm{R} \mathrm{C}_{27}$ sterane to $\alpha \alpha \alpha-20 \mathrm{R} \mathrm{C}_{29}$ sterane $\left(\mathrm{C}_{27} / \mathrm{C}_{29}\right)$. Their usefulness stems from the distribution of carbon as for example, $n$-alkanes with more than $\sim 25$ carbon occur in epicuticular leaf wax of terrestrial plants where they contribute to hydrophobic properties and as s barrier from the external environment (Post-Beittenmiller, 1996; Riederer and Markstädter, 1996; Jetter et al., 2006). By contrast, $n$-alkanes with odd carbon numbers between $n \mathrm{C}_{15}$ and $n \mathrm{C}_{19}$ are characteristically enriched in phytoplankton and bacteria, which encompasses the bulk of the in-situ produced biomass (Winters et al., 1969; Blumer et al., 1971; Cranwell, 1984). A similar relationship can be derived from the $\alpha \alpha \alpha-$ 20R sterane homologous series, although not as certain as that derived for $n$-alkanes (Volkman, 1986, 1988). It relies on the observation that $\mathrm{C}_{27}$ homologs are mainly of autochthonous origins while the $\mathrm{C}_{29}$ homologs are mostly associated with terrestrial vegetation (Huang and Meinschein, 1979; Volkman, 1986; Volkman et al., 1998; Volkman, 2003; Peters et al., 2005; Kim et al., 2016; Duan et al., 2017). Thus, a ratio between high molecular weight to low molecular weight $n$-alkanes (i.e. TAR) and $\alpha \alpha \alpha$ 20R $\mathrm{C}_{27}$ to $\mathrm{C}_{29}$ steranes $\left(\mathrm{C}_{27} / \mathrm{C}_{29}\right)$ can provide an effective proxy to discriminate the relative contribution from these two end-member OM sources. At El Pujal, Unit 1 and Unit 2 are characterized by fluctuating TAR paralleling with lithology, whereby higher 
values are associated with OM-rich, argillaceous limestone and marlstone intervals (Fig. 7-8A). Thus, coeval increases in the proportion of $\mathrm{C}_{29}$ to $\mathrm{C}_{27} \alpha \alpha \alpha-20 \mathrm{R}$ steranes (otherwise a decrease in $\mathrm{C}_{27} / \mathrm{C}_{29}$ ) (Fig. 7-8C) and $\mathrm{Si}, \mathrm{Al}$ and Ti content (Fig. 7-5A, B, C) suggest enhanced fluvial pulses during the deposition of OM-rich lithology. However, a subsequent increase in TAR and decrease in $\mathrm{C}_{27} / \mathrm{C}_{29}$ within Unit 3 (Fig. 7-8A, C) is inconsistent with terrigenous fluxes because that interval also shows a sharp decreasing trend in Si, Al, Ti and biolimiting elements Fe and P (Martin and Fitzwater, 1988; Krom et al., 1991; Zohary and Robarts, 1998; Boyd et al., 2000; Diaz et al., 2001; Gervais et al., 2002; Coale et al., 2004; Blain et al., 2007) (Fig. 7-5). Moreover, the clay mineral assemblages show concurrent increase in smectite and decrease in illite content (Fig. 712), which lend support to a shift toward a dryer climate (Singer, 1984; Eslinger and Pevear, 1988; Bühmann and Schoeman, 1995). To resolve these paradoxical results we postulate that since fluvial fluxes are the main transporting agent of $\mathrm{Fe}$ and $\mathrm{P}$ in the Organyà Basin (Sanchez-Hernandez et al., 2014; Sanchez-Hernandez and Maurrasse, 2014, 2016; Socorro and Maurrasse, 2019a,b), therefore their decrease would have caused limited in-situ primary production of OM, thereby indirectly increasing the TAR and decreasing the $\mathrm{C}_{27} / \mathrm{C}_{29}$ ratio. This apparent divergence further highlights the limitation of ratio indices, and attests to the necessity of incorporating the multiproxy approach when conducting comparable investigations.

\subsubsection{Biostratigraphy and Stable Carbon Isotope Stratigraphy}

Recent biostratigraphic studies of numerous Lower Aptian sequences concur that the occurrence of the index planktonic foraminifer, L.cabri parallels the OAE1a interval (e.g., Magniez-Janin et al., 1997; Aguado et al., 1999; Bellanca et al., 2002; Verga and 
Premoli Silva 2002; Erba, 2004; Coccioni et al., 2006; Heldt et al., 2008; Moullade et al., 2015). Thin section analysis of the uppermost 85.82 m-interval at El Pujal reveals the presence of L.cabri in Unit 1 and 2 of the section which concur with previous findings that provide a chronostratigraphic positions of the El Pujal coeval with OAE1a (Socorro and Maurrasse, 2019a,b). The absence of L.cabri in Unit 3 is possibly related to ecological restraints induced by shallowing of the basin at this time as previously discussed.

Organic $\left(\delta^{13} \mathrm{C}_{\text {org }}\right)$ and inorganic stable carbon $\left(\delta^{13} \mathrm{C}_{\text {carb }}\right)$ isotope data of Cretaceous sequences consistently yield simultaneous excursions characteristic of intervals coincident with major perturbations in the global carbon reservoir or OAEs (e.g., Scholle and Arthur, 1980; Weissert, 1989; Weissert and Bréhéret, 1991; Gale et al., 1993; Jenkyns et al., 1994; Mitchell et al., 1996; Menegatti et al., 1998; Bralower et al., 1999; Herrle et al., 2004; Jarvis et al., 2006; Wendler, 2013). Such, carbon isotope archive thus represents a robust proxy of paleoenviromental changes and a powerful correlation tool for both marine and terrestrial Cretaceous deposits (Gröcke et al., 1999; Ando et al., 2002; Hesselbo and Pieńkowski, 2011; Ludvigson et al., 2015). Moreover, the short mixing time of carbon in the ocean/atmosphere system $\left(\sim 10^{3} \mathrm{yrs}\right)$ (e.g. Siegenthaler and Sarmiento, 1993), will permit correlation of $\delta^{13} \mathrm{C}_{\text {org }}$ records at millennial time scales especially at sites with high sediment accumulation rates such as the Organyà Basin.

As demonstrated in previous studies the combined $\delta^{13} \mathrm{C}_{\text {org }}$ results at El Pujal (Socorro and Maurrasse, 2019a,b) (Fig. 7-14) is continuous with the neighboring El Pui section (Sanchez-Hernandez et al., 2014; Sanchez-Hernandez and Maurrasse, 2014, 2016) (Fig. 7-14) and they coincide with OAE1a. The present results further corroborate 
the precise position of the El Pujal section as concurrent with carbon-isotope segment C5 (Menegatti et al., 1998). The combined high-resolution $\delta^{13} \mathrm{C}_{\text {org }}$ data (Socorro and Maurrasse 2019b) also revealed six apparent subsegments of carbon-isotope segment C5 (C5-a to $\mathrm{C} 5-\mathrm{f})$ prior to the pronounced negative inflection heralding the end of that segment seen elsewhere (Fig. 7-14). The $\delta^{13} \mathrm{C}_{\text {org }}$ results of the present study complete the carbon isotope curve of this expanded section as the positive trend of subsegment C5-f up at $166.11 \mathrm{~m}$ reaches its maximum value $(-23.91 \%)$. Hence, the positive excursion characteristic of carbon isotope segment C5 in the Organyà Basin extends over 90.89 m (75.22 $\mathrm{m}-166.11 \mathrm{~m})$ (Fig. 7-14F). The closing distinctive negative shift to $-25.31 \%$ (Fig. 7-14F) can be considered an additional subsegment (C5-g) which extends $5.78 \mathrm{~m}$ $(166.11 \mathrm{~m}-171.89 \mathrm{~m})$. This remarkable negative excursion of the $\delta^{13} \mathrm{C}_{\text {org }}$ curve is a robust feature that permits explicit correlation of the El Pujal section with sections elsewhere in the Tethyan realm (Fig. 7-14) (Aguado et al., 2014a,b) (Fig. 7-14A), Roter Sattel and Cismon (Menegatti et al. (1998) (Fig. 7-14B, C), Angles (Bodin et al., 2015), Gorgo a Cerbara (Li et al., 2016), Djebel Serdj (Heldt et al., 2008), the BasqueCantabrian Basin (Fig. 7-15), Cuchía (García-Mondéjar et al., 2015), Igaratza (Millán et al., 2011), Madotz (Gaona-Narvaez et al., 2013)..

A similar negative excursion is also reported in the Santa Rosa Canyon in Mexico (Bralower et al., 1999; Li et al., 2008), Comanche Platform in the northern Gulf of Mexico (Phelps et al., 2015), and in the central Pacific Ocean at Deep Sea Drilling Project (DSDP) Site 463 (Ando et al., 2008), among others. The global occurrence of the negative excursion at the close of carbon isotope segment $\mathrm{C} 5$ thus suggests a causal mechanism that affected the global carbon reservoir. The worldwide significance of the 
signal is further recorded in coeval lacustrine deposits (Zhang et al., 2016), confirming its effect on the ocean/atmosphere system. Sources of ${ }^{13} \mathrm{C}$ depleted $\mathrm{CO}_{2}$ such as from volcanic emissions $\left(\delta^{13} \mathrm{C} \sim-5 \%\right)$ and/or from abrupt release of methane hydrates $\left(\delta^{13} \mathrm{C} \sim\right.$ $-60 \%$ ) (Kvenvolden, 1993) have been postulated as potential causes of these negative shifts for similar excursions (e.g., Larson and Erba, 1999; Hesselbo et al., 2000; Jahren et al., 2001, 2005; Beerling et al., 2002; de Wit et al., 2002; van Breugel et al., 2007; Méhay et al., 2009; McInerney and Wing, 2011; Socorro et al., 2017)). Since the emplacement of massive LIPs (e.g. Ontong Java-Manihiki-Hikurangi plateau) (Larson, 1991; Tarduno et al., 1991; Ingram et al., 1994; Tejada et al., 2009) and massive volcanism in Asia (e.g. Songliao Basin volcanism) (Wang et al., 2002; 2016) are coeval with the development of OAE1a, volcanic $\mathrm{CO}_{2}$ release in pulses of different magnitudes and duration may be invoked as the driving mechanism for the worldwide occurrences of various negative CIE during OAE1a, including those of carbon-isotope segment C2 (Socorro et al., 2017), C3 (Menegatti et al., 1998; Tejada et al., 2009; Charbonnier and Föllmi, 2017 ) and C5. Dissociation of methane hydrates is an additional possible factor; however, this mechanism is more likely related to large-scale negative CIEs $(\sim>-3.5 \%)$ of short duration $(\sim<10,000$ yrs) as for example during the Paleocene Eocene Thermal Maximum (Kirtland Turner and Ridgwell, 2016). 


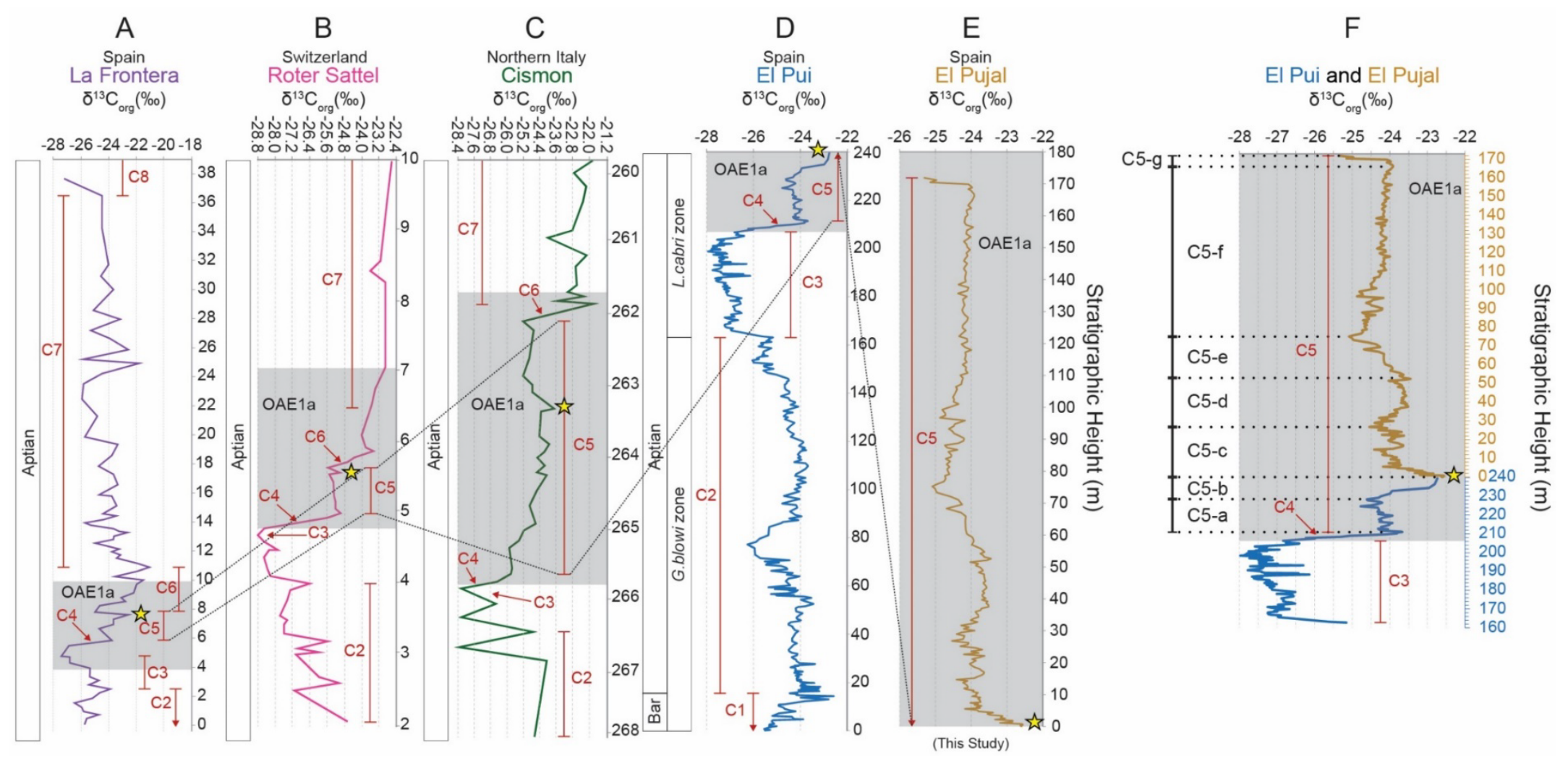

Figure 7-14 A-E) Chemostratigraphic correlation based on $\delta^{13} \mathrm{C}_{\text {org }}$ of the El Pujal section with other sections: La Frontera (Aguado et al., 2014a,b), Roter Sattel (Menegatti et al., 1998), Cismon (Menegatti et al., 1998) and El Pui (Sanchez-Hernandez and Maurrasse, 2016). The C segments correspond to the subdivisions proposed by Menegatti et al. (1998). The yellow star marks the highest value within segment C5 and corresponds to equivalent points in each section. The gray band indicates the position of OAEla or its equivalent for each section. F) Plot of El Pui and El Pujal $\delta^{13} \mathrm{C}_{\text {org }}$ data with identical vertical and horizontal scales. For a detailed description of labeled subsegments C5-a through C5-g refer to the discussion section. 
Evaluating the negative CIE range from the most positive value of segment C5 (Fig. 7-14, Point marked with a star) to the most negative value recorded at the transition from segment $\mathrm{C} 5$ to $\mathrm{C} 6$ reveals that the amplitude is noticeably different from one section to another (Fig. 7-14). For instance, in the La Frontera section (Fig. 7-14A, Spain) the most positive value of segment $\mathrm{C} 5(\sim-22.5 \%)$ occurs at $\sim 7.5 \mathrm{~m}$, while the transition to segment $\mathrm{C} 6$ is at $\sim 7.9 \mathrm{~m}$ with a value of $\sim-25 \%$, thus representing a $-2.5 \%$ shift. At Roter Sattel (Fig. 7-14B, Switzerland) the most positive value $(\sim 25 \%)$ is recorded at $\sim$ $5.5 \mathrm{~m}$ and the negative shift to $\sim-25.6 \%$, signaling the end of segment $\mathrm{C} 5$ comes immediately after $\sim 5.6 \mathrm{~m}$, hence recording a $-0.6 \%$ shift. In the Cismon section (Fig. 7$14 \mathrm{C}$, Italy) the positive plateau $(\sim-23.6 \%)$ occurs at $\sim 263.34 \mathrm{~m}$ and the minimum $(\sim$ $25.3 \%$ ) occurs at $\sim 262.13 \mathrm{~m}$, giving an amplitude of $-1.7 \%$. At El Pujal (Fig. 7-14E, F) the peak of the short-lived positive CIE of segment C5 (-22.55\%) appears concurrent with the end of subsegment C5-b (Fig. 7-14F) (Socorro and Maurrasse, 2019b) and the most negative value (-25.31\%) appears at $171.89 \mathrm{~m}$, which marks the end of subsegment C5-g and conclude segment C5. The amplitude of the negative CIE at El Pujal thus represents a $-2.76 \%$ shift, comparable to the value recorded at La Frontera $(-2.5 \%)$, but higher than at Roter Sattel (-0.6\%) and Cismon (-1.7\%o). The differences in amplitude may be related to local modulating factors such as source of $\mathrm{OM}$, biological fractionation, climate, thermal maturation, among others as the results of these studies suggest. Further detailed geochemical characterization of these other sections should shed more light on the causal mechanisms associated with these different sedimentary basins. Concerning El Pujal, the cause of the amplified negative shift $(-2.76 \%)$ can be postulated based on the reliability of the biomarker thermal maturity indicators that are consistently below their 
respective equilibrium values (Table 7-2), hence effects of thermal overmaturity can be ruled out (Clayton, 1991). The OM at EL Pujal consists mainly of a mixture of marine and terrestrial OM (Fig. 7-7; Fig. 7-9; Fig. 7-11), each with differing $\delta^{13} \mathrm{C}_{\text {org }}$ values (e.g. marine $\delta^{13} \mathrm{C}_{\text {org }}=\sim-21 \%$ (Wainright and Fry, 1994); terrestrial $\delta^{13} \mathrm{C}_{\text {org }}=\sim-26 \%$ o to $\sim$ 28.5\% (Bender, 1971; Boutton, 1991; Dawson et al., 2002; Fry, 2006; Kohn, 2010)), whose combined averaged values is the resultant measured $\delta^{13} \mathrm{C}_{\text {org. }}$. Therefore, a decrease in marine primary productivity in the uppermost $3.93 \mathrm{~m}$ of Unit 3, a source of OM with more positive $\delta^{13} \mathrm{C}_{\mathrm{org}}$ values may explain the amplified negative CIE in the Organyà Basin as recorded at E1 Pujal at end of carbon-isotope segment C5.

\subsubsection{Sedimentation Rate during Carbon Isotope Segment C5}

The Organyà Basin developed as a narrow marginal basin resulting from extensional faulting generated from the sinistral translation of Iberia relative to Eurasia concurrent with the opening of the North Atlantic and the Bay of Biscay (Van der Voo, 1969; Berástegui et al., 1990; Srivastava et al., 1990; Olivet, 1996; Vergés and GarcíaSenz, 2001; García-Senz., 2002; Vergés et al., 2002; Sibuet et al., 2004; Gong et al., 2008, 2009; Oliva-Urcia et al., 2011; Vacherat et al., 2017). Increased subsidence rates during the Aptian provided ample accommodation space for deposition (Berástegui et al., 1990; García-Senz., 2002; Bernaus et al., 2003; Gong et al., 2008, 2009). Moreover, increases in continental weathering and runoff induced by intensified hydrological cycles in response to global greenhouse conditions at that time (e.g., Dumitrescu et al., 2006; Blättler et al., 2011; Föllmi, 2012; Lechler, 2015), heightened transport of continental material and nutrient loads into the basin (Sanchez-Hernandez et al., 2014; SanchezHernandez and Maurrasse, 2014, 2016; Socorro and Maurrasse, 2019a,b). These regional 
and global forcing factors resulted in high sediment accumulation rates $(\mathrm{e} . \mathrm{g} \sim 27 \mathrm{~cm} / \mathrm{kyr}$ in Gong et al., 2008) as attested by an expanded interval for carbon-isotope segments C2 (Sanchez-Hernandez and Maurrasse, 2014, 2016; Socorro et al., 2017) and C5 herein (0 $171.89 \mathrm{~m}$ ) (Fig. 7-14F), which expands a thickness of $200.49 \mathrm{~m}$ including the uppermost $28.6 \mathrm{~m}(211.40 \mathrm{~m}-240 \mathrm{~m})$ (Fig. 7-14F) of the El Pui section.

To estimate the bulk sedimentation rate during carbon-isotope segment $\mathrm{C} 5$ in the Organyà Basin based on the suggested duration of this segment as established by Li et al. (2008) and Malinverno et al. (2010) using spectral analysis of orbital cycles and orbital tuning of high-resolution records. Assuming a duration of $570 \mathrm{kyr}$ (Li et al., 2008), the approximate dry bulk accumulation rate for the $200.49 \mathrm{~m}$ of segment C5 is $35.17 \mathrm{~cm} / \mathrm{kyr}$. Alternatively, a duration of $510 \pm 70 \mathrm{kyr}$ (Malinverno et al., 2010) gives $39.31 \mathrm{~cm} / \mathrm{kyr}$ (at $510 \mathrm{kyr}$ ) and $34.57 \mathrm{~cm} / \mathrm{kyr}$ (at $580 \mathrm{kyr}$ ); whereas a lower value of $440 \mathrm{kyr}$ yields 45.57 $\mathrm{cm} / \mathrm{kyr}$. An overall average of $540 \mathrm{kyr}$ give an estimated dry bulk sedimentation rate of about $37.13 \mathrm{~cm} / \mathrm{kyr}$. To underscore the magnitude of the accumulation rates in the Organyà Basin, as compared to wet accumulation rates in similar known settings, we apply a correction factor for compaction history with an estimate of the changes in porosity with depth. The original thickness of a sedimentary unit $\left(\mathrm{T}_{\mathrm{O}}\right)$ and any time after $\left(T_{N}\right)$ is related to the change in porosity of the sediment (van Hinte, 1978):

$$
\mathrm{T}_{O}=\frac{\left(1-\Phi_{N}\right) \mathrm{T}_{N}}{1-\Phi_{O}}
$$

where $\Phi_{\mathrm{O}}$ is the original porosity and $\Phi_{\mathrm{N}}$ is the porosity at any time after. Given that comparable hemipelagic sediments yield porosity in the range of $40 \%$ to $67 \%$ with typical values at 56\% (Edgar et al., 1973), we chose this value (56\%) as the original 
porosity (i.e. $\Phi_{\mathrm{O}}$ ). In the absence of actual porosity data for El Pujal (i.e. $\Phi_{\mathrm{N}}$ ), we may use reported porosity versus depth models for similar lithology (e.g., Mallon and Swarbrick, 2002 and reference therein). The burial depth was extrapolated from the biomarker thermal maturation data that suggest a thermal history of $\sim 60^{\circ} \mathrm{C}$. Assuming a relatively high geothermal gradient $\left(30^{\circ} \mathrm{C} / \mathrm{km}\right)$, which is not uncommon for pull-apart analogs with closely related physiographic conditions to the Organyà Basin (e.g., Bohai Basin: $\mathrm{Hu}$ et al., 2001), the estimated burial depth is $\sim 2 \mathrm{~km}$. Assuming that all the changes of porosity with depth result from compaction, on average, comparable carbonate-rich hemipelagic sediments decrease in porosity to $\sim 25 \%$ (i.e. $\Phi_{\mathrm{N}}$ ) when compacted to similar depths $\sim 2 \mathrm{~km}$ (e.g. North Sea: Mallon and Swarbrick, 2002). Thus, based on these criteria, the combined results for segment C5 in the Organyà Basin yields an estimated original thickness ( $\mathrm{T}_{\mathrm{O}}$ ) of $341.74 \mathrm{~m}$. Taking an average duration for carbonisotope segment C5 of $540 \mathrm{kyr}$ the wet or decompacted sedimentation rate should be $63.29 \mathrm{~cm} / \mathrm{kyr}$. Such high value is not unusual in comparable settings because much higher wet sediment accumulation rates are reported for instance, in clastic-dominated shelf areas heavily influenced by rivers (Table 1 in Gibbs, 1981), the semi-restricted Cariaco Basin (75 cm/kyr) (Spiker and Simoneit, 1982), and the East China Sea throughout the past $\sim 385 \mathrm{kyr}(\overline{\mathrm{x}}=48 \mathrm{~cm} / \mathrm{kyr}$ ) with peaks well over $80 \mathrm{~cm} / \mathrm{kyr}$ (Sagawa et al., 2018).

\subsubsection{Evidence of Regional Shallowing}

Facies changes at the closing of carbon isotope segment C5 are of particular interest because this interval has been correlated with the progressive shallowing of depositional systems in the northern Iberian region (García-Mondéjar et al., 2009, 2015a, 2015b; 
Millán et al., 2009, 2011; Najarro et al., 2011a, 2011b; Gaona-Narvaez et al., 2013). Shallowing is particularly evident in the Cuchía, Igaratza and Madotz sections of the Basque-Cantabrian Basin (Fig. 7-15). In the Cuchía section (Fig. 7-15), most of the deposits associated with carbon isotope segment $\mathrm{C} 5(\sim 37 \mathrm{~m}$ to $\sim 77 \mathrm{~m})$ are predominately deeper-water shales grading upwards into carbonate platform deposits with orbitolinids and interbeds of siltstones and sandstones towards the end of C5 (García-Mondéjar et al., 2015a, 2015b). Sandstones with cross laminations indicative of a delta front continue into C6 (García-Mondéjar et al., 2015a, 2015b). Subsequently, siliciclastic sedimentation is replaced by limestones rich in rudists, corals, benthic foraminifera and calcareous algae (Wilmsen, 2005; Najarro et al., 2011a, 2011b; GarcíaMondéjar et al., 2015a, 2015b). Similarly, in the Igaratza section (Fig. 7-15), segment C5 $(\sim 112 \mathrm{~m}$ to $\sim 170 \mathrm{~m})$ includes essentially siltstones and marlstones coarsening upwards into interbeds of marly to sandy limestones with orbitolinids, oysters and branching corals at the close of this carbon isotope segment, and into limestones with rudists and massive corals in C6 and C7 (Millán et al., 2009, 2011). The Madotz section (Fig. 7-15), shows similar pattern as segment C5 $(\sim 30.5 \mathrm{~m}$ to $\sim 40.8 \mathrm{~m})$ is dominated by marlstones/claystones, which develop into grain-supported biocalcirudites dominated by orbitolinids at the onset of segment C6 with further biocalcirudites and calcarenites containing wavy contacts and fragments of non-rudist bivalves, brachiopods and echinoderms (Gaona-Narvaez et al., 2013). In summary, marine depositional settings in northern Iberia include a synchronous archive of facies change towards the end of carbon isotope segment C5 evolving into C6, not seen in contemporaneous sequences elsewhere (e.g. Heldt et al., 2008; Li et al., 2016; Aguado et al., 2014a,b). These concurrent facies 
changes in the northern Iberian Peninsula are thus likely related to regional tectonic uplift rather than eustatic change in sea level.

Microfacies recorded in Unit 3 (Fig. 7-2) of the El Pujal section interpreted as changes in basin bathymetry coeval with the end of carbon isotope segment C5 suggests that the basin-wide shallowing reported for the Basque-Cantabrian Basin extended to the southeast and affected the Organyà Basin as well. Paleogeographic reconstruction of the Pyrenean realm around this time (Vacherat et al., 2017), suggests the interconnectedness of these basins via an elongated narrow $(\sim 200 \mathrm{~km})$ sea that stretched from the protoNorth Atlantic to the southeast, cutting between Iberia and Europe (Jammes et al., 2009; Vacherat et al., 2017). Here the association of progressively coarser sediments and allochems (> 50\%) in Unit 3 at El Pujal (Fig. 7-2) with a decreasing trend in planktonic foraminifera (Fig. 7-3D) supports shallowing at that time. Thus, this study further illustrate how more accurate interpretations can be achieved when sedimentary indicators are combined with faunal distribution patterns.

Foraminifera are a useful tool bathymetric tool because the abundance of benthic taxa generally reaches a maximum on the outer shelf to upper slope, while the planktonic groups are virtually lacking in neritic environments and increasing with greater water depth (Phleger, 1951; Parker, 1954; Grimsdale and Van Morkhoven, 1955; Smith, 1955; Van Marle et al., 1987; Gibson, 1989; van der Zwaan et al., 1990). The ratio between planktonic and benthic foraminifera typically expressed as the percentage of planktonic foraminifera $(\% \mathrm{P})$ is thus a useful tool to infer paleodepths, although two-thirds of the variation in the $\% \mathrm{P}$ may also be controlled by factors such as upwelling water masses and variations in salinity and turbidity (Wright, 1977). Studies of modern settings, laboratory 


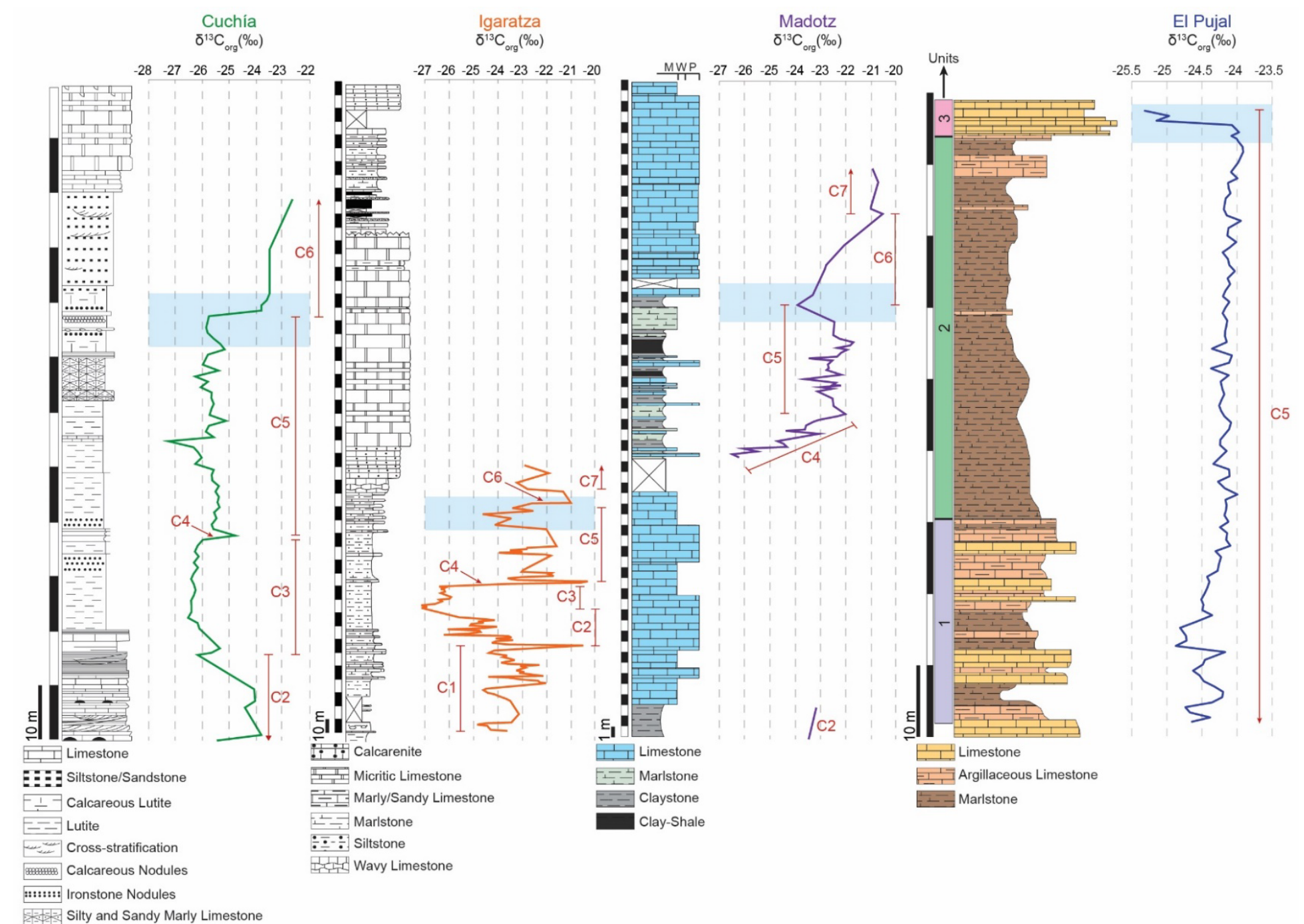

Figure 7-15 Comparison of the lithostragraphic changes recorded for the end of carbon isotope segment C5 at El Pujal and various sections in the Basque Cantabrian Basin: Cuchía (García-Mondéjar et al., 2015), Igaratza (Millán et al., 2011), Madotz (Gaona-Narvaez et al., 2013). 
experiments and the fossil record have also established a strong link between abundance and diversity of benthic foraminifera and oxygen content (Harman, 1964; Nolet and Corliss, 1990; Kaiho, 1994, 1999; Alve and Bernhard, 1995; Jorissen et al., 1995; den Dulk et al., 1998; Seidenkrantz et al., 2000; van Hinsbergen et al., 2005; Singh et al., 2015). These factors were taken into account in additional assessment of bathymetric changes in the El Pujal section as sedimentological and geochemical data at intervals of argillaceous limestone and marlstone beds show strong evidence of increased riverine discharge and oxygen-deficient bottom waters (Socorro and Maurrasse, 2019a,b). Therefore, these intervals were excluded in the faunal counts (van Hinsbergen et al., $2005)$, of the depth estimates that follow. The results show higher $\% \mathrm{P}(\overline{\mathrm{x}}=79 \%)$ for the limestones in the lowermost Unit 1, whereas the limestone beds that comprise Unit 3 show marked decrease to $18 \%$ (Fig. 7-3D). Applying the relationship between bathymetry and \%P (van der Zwaan et al., 1990) the estimated average depth for Unit 1 is $\sim 613 \mathrm{~m}$ and for Unit 3 it is $\sim 70 \mathrm{~m}$ (Fig. 7-3E). These estimates thus suggest a bathymetric change of $543 \mathrm{~m}$ during the interval concurrent with carbon isotope segment C5 in the Organyà Basin. Despite the inherent limitations of the \%P bathymetric method (e.g., restricted to thin section counts, lack of taxonomic control, fluctuation of $\% \mathrm{P}$ with non-depth related variables, etc.), the conclusion justifies a reduction in the bathymetry of the Organyà Basin between Unit 1 and Unit 3. It further substantiates the sedimentological evidence for higher energy and shallower conditions in the Organyà Basin, similar to facies changes reported for coeval sequences in the neighboring BasqueCantabrian Basin. 


\subsection{Conclusions}

The present study of the uppermost $85.82 \mathrm{~m}$-portion of the El Pujal section in complement with previous investigations provides a detailed sedimentological and geochemical record of the global and regional impact of the Aptian carbon cycle perturbations associated with carbon isotope segment $\mathrm{C} 5$ in the context of OAE1a. Salient results permit to draw the following conclusions:

1). Integration of field observations, microfacies and geochemical data allows the recognition of three distinct Units:

1a). Unit 1 (86.07 m-114.15 m): Iincreases in RSTEs, P, Fe, Al, Si, and Ti occur in argillaceous limestone and marlstone beds of this interval concurrently with episodes of enhanced OM preservation and microfacies with higher pyrite concentration, reduced benthic fauna and lower degree of bioturbation. These results suggest short-lived, intermittent pulses of fluvial discharge and enhanced nutrient loads that likely fueled in-situ primary productivity, thus providing a source of readily mineralizable OM whose consumption led to periodic oxygendeprived conditions. Concurrenly, freshwater runoff may have led to density stratification of the water column as evidenced by recurring peaks in the gammacerane index. Unit 1 thus represents an interval of variable fluvial fluxes related to climatic fluctuations analogous to the fluctuating sedimentary facies recorded in the Mediterranean area associated with insolation-driven forcing factors during the latest Miocene and Pleistocene. Therefore, these variables explain the alternating lithology with limestones representing the least terrestrially 
influenced endmember and marlstones representing points of highest terrestrial influence.

1b). Unit 2 (114.15 m - 167.96 m): Relatively higher TOC, RSTEs, P, Fe, Al, Si, and Ti occur in this marlstone-dominated interval. These higher values suggest that an increase in runoff due to established humid continental conditions prevailed in this period with quasi-permanent eutrophic surface waters and continuously established oxygen-deprived conditions. Nonetheless, a fully anoxic phase did not develop, as benthic fauna while relatively reduced are still present throughout. Freshwater discharge must have been persistent during this time as it records continually elevated gammacerane indices.

1c). Unit 3 (167.96 m-171.89 m): Hard limestones low in TOC, P, Fe, Al, Si, and $\mathrm{Ti}$, in this interval indicate the demise of previous conditions concomitant with reduction in fluvial fluxes and surface water fertility. These results are interpreted to reveal dryer climatic conditions as further suggested by an increase in smectite and a decrease in illite content. In accord, RSTEs decrease and gammacerane indices drop to near zero, signaling the termination of density stratification and renewed ventilation of the water column. Changes in microfacies, with coarser grain packstones, fewer planktonic foraminifera and increase in benthic taxa, imply a shallowing of the basin, an increase in energy conditions and a shift towards more aerobic bottom waters.

2). Molecular thermal maturity indices with average ratios consistently below equilibrium values indicate thermal immaturity. The results agree with temperatures in the range of $50^{\circ} \mathrm{C}$ to $60^{\circ} \mathrm{C}$, equivalent to the onset of the oil window. 
3). Results from source specific biomarkers demonstrate that the OM consists of a mixture of autochthonous marine and allochthonous terrigenous sources, typical of hemipelagic settings. The relative contribution from these two end-member OM sources displays temporal variability with higher relative proportion of terrestrial OM in the argillaceous limestone and marlstone beds of Unit 1 and 2. The limestone beds that comprise Unit 3 record unusually low $\mathrm{C}_{27} / \mathrm{C}_{29}$ and high $\mathrm{TAR}$ values, which signals to an inconclusive increasing flux of terrestrial OM. However, coeval decreases in biolimiting elements $(\mathrm{Fe}, \mathrm{P})$ suggests a decline in surface water productivity and thus reduced in-situ primary OM input, consequently decreasing the $\mathrm{C}_{27} / \mathrm{C}_{29}$ and increasing the TAR values.

4). The pattern recorded by the $\delta^{13} \mathrm{C}_{\text {org }}$ curve at El Pujal is consistent with those reported elsewhere for carbon isotope segment C5. Most importantly, the curve records a pronounced 2.76\% negative shift, indicating the end of carbon isotope segment C5. $5)$. Based on the average duration ( $\sim 540 \mathrm{kyr})$ calculated by other studies for carbon isotope segment $\mathrm{C} 5$, the calculated compacted bulk accumulation rate for this interval in the Organyà Basin equals $\sim 37.13 \mathrm{~cm} / \mathrm{kyr}$. When this value is decompacted, the wet sedimentation rate equals $\sim 63.29 \mathrm{~cm} / \mathrm{kyr}$, which is comparable with rates reported for shelf areas that are heavily influenced by rivers, the Cariaco Basin and the East China Sea.

6). Because of the continuous record and high sediment accumulation rate of the section, the generated $\delta^{13} \mathrm{C}_{\text {org }}$ curve offers a unique detailed temporal resolution of the paleoenviromental events recorded during carbon isotope segment $\mathrm{C} 5$, thus providing a refined tool for chemostratigraphic correlation. 
7). Facies changes comparable to Unit 3 at El Pujal coeval with the closing of carbon isotope segment $\mathrm{C} 5 / \mathrm{base}$ of segment $\mathrm{C} 6$ suggest progressive basin-wide shallowing of depositional sequences in the Basque-Cantabrian Basin, not seen elsewhere. The contrast indicates a regional shallowing of these two basins possibly related to tectonics in addition to a regional shift towards dryer climatic conditions.

\subsection{Acknowledgements}

This study is made possible thanks to financial support from the Glenn A. Goodfriend Memorial funds. We particularly acknowledge the help and technical support of Diane Pirie with instrumentation troubleshooting and for maintaining our FIU labs stocked with supplies. We are thankful to Cesar Ramirez and Mario Gomez at FIU's Advanced Mass Spectrometry Facility for their help with biomarker analyses, and Sarah Jantzi at FIU's Trace Elements Analytical Facilities (TEAF) for her help with the LA-ICP-MS. Jander Socorro gratefully acknowledges financial support provided by the Dissertation Year Fellowship (DYF) from the FIU Graduate School.

\subsection{References}

Aguado, R., Castro, J.M., Company, M., Alfonso De Gea, G., 1999. Aptian bio-eventsan integrated biostratigraphic analysis of the Almadich Formation, Inner Prebetic Domain, SE Spain. Cretac. Res. 20, 663-683. https://doi.org/10.1006/CRES.1999.0176

Aguado, R., de Gea, G.A., Castro, J.M., O’Dogherty, L., Quijano, M.L., Naafs, B.D.A., Pancost, R.D., 2014. Late Barremian-early Aptian dark facies of the Subbetic (Betic Cordillera, southern Spain): Calcareous nannofossil quantitative analyses, chemostratigraphy and palaeoceanographic reconstructions. Palaeogeogr. Palaeoclimatol. Palaeoecol. 395, 198-221. https://doi.org/10.1016/j.palaeo.2013.12.031

Aguado, R., de Gea, G.A., O’Dogherty, L., 2014. Integrated biostratigraphy (calcareous nannofossils, planktonic foraminifera, and radiolarians) of an uppermost Barremian- 
lower Aptian pelagic succession in the Subbetic Basin (southern Spain). Cretac. Res. 51, 153-173. https://doi.org/10.1016/j.cretres.2014.06.002

Ahmed, S. Gong, D. Fuentes, S. Sestak, F. Theobald, K.D., 2013. Molecular Characterisation of Petroleum. Thermo Scientific CSIRO Application Note 30263.

Alve, E., Bernhard, J., 1995. Vertical migratory response of benthic foraminifera to controlled oxygen concentrations in an experimental mesocosm. Mar. Ecol. Ser. MAR ECOL-PROGR SER 116, 137-151. https://doi.org/10.3354/meps116137

Ando, A., Kaiho, K., Kawahata, H., Kakegawa, T., 2008. Timing and magnitude of early Aptian extreme warming: Unraveling primary $\delta 180$ variation in indurated pelagic carbonates at Deep Sea Drilling Project Site 463, central Pacific Ocean. Palaeogeogr. Palaeoclimatol. Palaeoecol. 260, 463-476. https://doi.org/10.1016/j.palaeo.2007.12.007

Ando, A., Kakegawa, T., Takashima, R., Saito, T., 2002. New perspective on Aptian carbon isotope stratigraphy: Data from $\delta 13 \mathrm{C}$ records of terrestrial organic matter. Geology 30, 227-230. https://doi.org/10.1130/00917613(2002)030<0227:NPOACI $>2.0 . \mathrm{CO} ; 2$

Arroyo, L., Trejos, T., Gardinali, P.R., Almirall, J.R., 2009. Optimization and validation of a Laser Ablation Inductively Coupled Plasma Mass Spectrometry method for the routine analysis of soils and sediments. Spectrochim. Acta - Part B At. Spectrosc. 64, 16-25. https://doi.org/10.1016/j.sab.2008.10.027

Arthur, M.A., Jenkyns, H.C., Brumsack, H.J., Schlanger, S.O., 1990. Stratigraphy, geochemistry and paleoceanography of organic-carbon rich Cretaceous sequences. Cretac. Resour. Events Rhythm. https://doi.org/10.1007/978-94-015-6861-6_6

Arthur, M.A., Dean, W.E., Schlanger, S.O., 1985. Variations in the Global Carbon Cycle During the Cretaceous Related to Climate, Volcanism, and Changes in Atmospheric $\mathrm{CO} 2$, in: The Carbon Cycle and Atmospheric CO2: Natural Variations Archean to Present. pp. 504-529. https://doi.org/10.1159/000020165

Baas, M., Pancost, R., Van Geel, B., Sinninghe Damsté, J.S., 2000. A comparative study of lipids in Sphagnum species. Org. Geochem. 31, 535-541. https://doi.org/10.1016/S0146-6380(00)00037-1

Barron, E.J., 1983. A warm, equable Cretaceous: The nature of the problem. EarthScience Rev. 19, 305-338. https://doi.org/10.1016/0012-8252(83)90001-6

Barron, E.J., Hay, W.W., Thompson, S., 1989. The hydrologic cycle: A major variable during earth history. Glob. Planet. Change 1, 157-174. https://doi.org/10.1016/09218181(89)90001-5 
Barron, E.J., Washington, W.M., 1985. Warm Cretaceous Climates: High Atmospheric CO 2 as a Plausible Mechanism, in: The Carbon Cycle and Atmospheric CO2:

Natural Variations Archean to Present. pp. 546-553.

https://doi.org/10.1029/GM032p0546

Bauer, J.E., Cai, W.J., Raymond, P.A., Bianchi, T.S., Hopkinson, C.S., Regnier, P.A.G., 2013. The changing carbon cycle of the coastal ocean. Nature 504, 61-70. https://doi.org/10.1038/nature12857

Beerling, D.J., 2006. On the nature of methane gas-hydrate dissociation during the Toarcian and Aptian Oceanic anoxic events. Am. J. Sci. 302, 28-49.

https://doi.org/10.2475/ajs.302.1.28

Bellanca, A., Erba, E., Neri, R., Premoli Silva, I., Sprovieri, M., Tremolada, F., Verga, D., 2002. Palaeoceanographic significance of the Tethyan "Livello Selli" (Early Aptian) from the Hybla Formation, northwestern Sicily: Biostratigraphy and highresolution chemostratigraphic records. Palaeogeogr. Palaeoclimatol. Palaeoecol. 185, 175-196. https://doi.org/10.1016/S0031-0182(02)00299-7

Bender, M.M., 1971. Variations in the $13 \mathrm{C} / 12 \mathrm{C}$ ratios of plants in relation to the pathway of photosynthetic carbon dioxide fixation. Phytochemistry 10, 1239-1244. https://doi.org/10.1016/S0031-9422(00)84324-1

Berástegui, X., Garcia-Senz, J., Losantos, M., 1990. Tecto-sedimentary evolution of the Organyà extensional basin (central south Pyrenean unit, Spain) during the Lower Cretaceous. Bull. la Société géologique Fr. 6, 251-264. https://doi.org/10.2113/gssgfbull.VI.2.251

Bernaus, J.M., Arnaud-Vanneau, A., Caus, E., 2003. Carbonate platform sequence stratigraphy in a rapidly subsiding area: The Late Barremian-Early Aptian of the Organyà basin, Spanish Pyrenees. Sediment. Geol. 159, 177-201. https://doi.org/10.1016/S0037-0738(02)00316-0

Blain, S., Quéguiner, B., Armand, L., Belviso, S., Bombled, B., Bopp, L., Bowie, A., Brunet, C., Brussaard, C., Carlotti, F., Christaki, U., Corbière, A., Durand, I., Ebersbach, F., Fuda, J.-L., Garcia, N., Gerringa, L., Griffiths, B., Guigue, C., Guillerm, C., Jacquet, S., Jeandel, C., Laan, P., Lefèvre, D., Lo Monaco, C., Malits, A., Mosseri, J., Obernosterer, I., Park, Y.-H., Picheral, M., Pondaven, P., Remenyi, T., Sandroni, V., Sarthou, G., Savoye, N., Scouarnec, L., Souhaut, M., Thuiller, D., Timmermans, K., Trull, T., Uitz, J., van Beek, P., Veldhuis, M., Vincent, D., Viollier, E., Vong, L., Wagener, T., 2007. Effect of natural iron fertilization on carbon sequestration in the Southern Ocean. Nature 446, 1070.

Blättler, C.L., Jenkyns, H.C., Reynard, L.M., Henderson, G.M., 2011. Significant increases in global weathering during Oceanic Anoxic Events 1a and 2 indicated by 
calcium isotopes. Earth Planet. Sci. Lett. 309, 77-88.

https://doi.org/10.1016/J.EPSL.2011.06.029

Blumenberg, M., Krüger, M., Nauhaus, K., Talbot, H.M., Oppermann, B.I., Seifert, R., Pape, T., Michaelis, W., 2006. Biosynthesis of hopanoids by sulfate-reducing bacteria (genus Desulfovibrio). Environ. Microbiol. 8, 1220-1227.

https://doi.org/10.1111/j.1462-2920.2006.01014.x

Blumer, M., Guillard, R.R.L., Chase, T., 1971. Hydrocarbons of marine phytoplankton. Mar. Biol. 8, 183-189. https://doi.org/10.1007/BF00355214

Bodin, S., Meissner, P., Janssen, N.M.M., Steuber, T., Mutterlose, J., 2015. Large igneous provinces and organic carbon burial: Controls on global temperature and continental weathering during the Early Cretaceous. Glob. Planet. Change 133, 238253. https://doi.org/10.1016/j.gloplacha.2015.09.001

Bosellini, a., Morsilli, M., Neri, C., 1999. Long-term event stratigraphy of the Apulia Platform margin (Upper Jurassic to Eocene, Gargano, southern Italy). J. Sediment. Res. 69, 1241-1252. https://doi.org/10.2110/jsr.69.1241

Bourbonniere, R.A., Meyers, P.A., 1996. Sedimentary geolipid records of historical changes in the watersheds and productivities of Lakes Ontario and Erie. Limnol. Oceanogr. 41, 352-359. https://doi.org/10.4319/1o.1996.41.2.0352

Boutton, T.W., 1991. Stable carbon isotope ratios of natural materials: II. Atmospheric, terrestrial, marine, and freshwater environments. Carbon Isot. Tech. 1, 173.

Boyd, P.W., Watson, A.J., Law, C.S., Abraham, E.R., Trull, T., Murdoch, R., Bakker, D.C.E., Bowie, A.R., Buesseler, K.O., Chang, H., Charette, M., Croot, P., Downing, K., Frew, R., Gall, M., Hadfield, M., Hall, J., Harvey, M., Jameson, G., LaRoche, J., Liddicoat, M., Ling, R., Maldonado, M.T., McKay, R.M., Nodder, S., Pickmere, S., Pridmore, R., Rintoul, S., Safi, K., Sutton, P., Strzepek, R., Tanneberger, K., Turner, S., Waite, A., Zeldis, J., 2000. A mesoscale phytoplankton bloom in the polar Southern Ocean stimulated by iron fertilization. Nature 407, 695-702. https://doi.org/10.1038/35037500

Bralower, T.J., Cobabe, E., Clement, B., Sliter, W. V, Osburn, C.L., Longoria, J., 1999. The record of global change in mid-Cretaceous (Barremian-Albian) sections from the Sierra Madre, Northeastern Mexico. J. Foraminifer. Res. 29, 418-437.

Bralower, T.J., Arthur, M.A., Leckie, R.M., Sliter, W.V., Allard, D.J., Schlanger, S.O., 1994. Timing and paleoceanography of oceanic dysoxia/anoxia in the Late Barremian to Early Aptian (Early Cretaceous). Palaios 335-369. 
Bray, E.E., Evans, E.D., 1961. Distribution of n-paraffins as a clue to recognition of source beds. Geochim. Cosmochim. Acta 22, 2-15. https://doi.org/10.1016/00167037(61)90069-2

Brenchley, P., Harper, D., 1998. Palaeoecology: Ecosystems, environments and evolution. CRC Press, london, UK.

Brocks, J.J., Summons, R.E., 2014. Sedimentary Hydrocarbons, Biomarkers for Early Life, in: Treatise on Geochemistry: Second Edition. Elsevier, pp. 61-103. https://doi.org/10.1016/B978-0-08-095975-7.00803-2

Brumsack, H.J., 1980. Geochemistry of Cretaceous black shales from the Atlantic Pcean (DSDP Legs 11, 14, 36 and 41). Chem. Geol. 31, 1-25. https://doi.org/10.1016/0009-2541(80)90064-9

Brumsack, H.J., 2006. The trace metal content of recent organic carbon-rich sediments: Implications for Cretaceous black shale formation. Palaeogeogr. Palaeoclimatol. Palaeoecol. 232, 344-361. https://doi.org/10.1016/j.palaeo.2005.05.011

Bühmann, C., Schoeman, J.L., 1995. A mineralogical characterization of vertisols from the northern regions of the Republic of South Africa. Geoderma 66, 239-257. https://doi.org/10.1016/0016-7061(94)00080-T

Burla, S., Heimhofer, U., Hochuli, P.A., Weissert, H., Skelton, P., 2008. Changes in sedimentary patterns of coastal and deep-sea successions from the North Atlantic (Portugal) linked to Early Cretaceous environmental change. Palaeogeogr.

Palaeoclimatol. Palaeoecol. 257, 38-57. https://doi.org/10.1016/j.palaeo.2007.09.010

Calvert, S.E., Pedersen, T.F., 1993. Geochemistry of Recent oxic and anoxic marine sediments: Implications for the geological record. Mar. Geol. 113, 67-88. https://doi.org/10.1016/0025-3227(93)90150-T

Carreira, R.S., Araújo, M.P., Costa, T.L.F., Ansari, N.R., Pires, L.C.M., 2010. Lipid biomarkers in deep sea sediments from the Campos Basin, SE Brazilian continental margin. Org. Geochem. 41, 879-884.

https://doi.org/10.1016/j.orggeochem.2010.04.017

Charbonnier, G., Boulila, S., Spangenberg, J.E., Adatte, T., Föllmi, K.B., Laskar, J., 2018. Obliquity pacing of the hydrological cycle during the Oceanic Anoxic Event

2. Earth Planet. Sci. Lett. 499, 266-277. https://doi.org/10.1016/J.EPSL.2018.07.029

Charbonnier, G., Föllmi, K.B., 2017. Mercury enrichments in lower Aptian sediments support the link between Ontong Java large igneous province activity and oceanic anoxic episode 1a. Geology 45, 63-66. https://doi.org/10.1130/G38207.1 
Clayton, C.J., 1991. Effect of maturity on carbon isotope ratios of oils and condensates. Org. Geochem. 17, 887-899. https://doi.org/10.1016/0146-6380(91)90030-N

Clayton, C.J., 1991. Effect of maturity on carbon isotope ratios of oils and condensates. Org. Geochem. 17, 887-899. https://doi.org/10.1016/0146-6380(91)90030-N

Clayton, C.J., Bjorøy, M., 1994. Effect of maturity on 13C12C ratios of individual compounds in North Sea oils. Org. Geochem. 21, 737-750. https://doi.org/10.1016/0146-6380(94)90016-7

Coale, K.H., Johnson, K.S., Chavez, F.P., Buesseler, K.O., Barber, R.T., Brzezinski, M.A., Cochlan, W.P., Millero, F.J., Falkowski, P.G., Bauer, J.E., Wanninkhof, R.H., Kudela, R.M., Altabet, M.A., Hales, B.E., Takahashi, T., Landry, M.R., Bidigare, R.R., Wang, X., Chase, Z., Strutton, P.G., Friederich, G.E., Gorbunov, M.Y., Lance, V.P., Hilting, A.K., Hiscock, M.R., Demarest, M., Hiscock, W.T., Sullivan, K.F., Tanner, S.J., Gordon, R.M., Hunter, C.N., Elrod, V.A., Fitzwater, S.E., Jones, J.L., Tozzi, S., Koblizek, M., Roberts, A.E., Herndon, J., Brewster, J., Ladizinsky, N., Smith, G., Cooper, D., Timothy, D., Brown, S.L., Selph, K.E., Sheridan, C.C., Twining, B.S., Johnson, Z.I., 2004. Southern Ocean Iron Enrichment Experiment: Carbon Cycling in High- and Low-Si Waters. Science (80-. ). 304, 408-414. https://doi.org/10.1126/science.1089778

Cobianchi, M., Luciani, V., Menegatti, A., 1999. The Selli Level of the Gargano Promontory, Apulia, southern Italy: foraminiferal and calcareous nannofossil data. Cretac. Res. 20, 255-269. https://doi.org/10.1006/CRES.1999.0155

Coccioni, R., Luciani, V., Marsili, A., 2006. Cretaceous oceanic anoxic events and radially elongated chambered planktonic foraminifera: Paleoecological and paleoceanographic implications. Palaeogeogr. Palaeoclimatol. Palaeoecol. 235, 6692. https://doi.org/10.1016/J.PALAEO.2005.09.024

Cole, D.B., Zhang, S., Planavsky, N.J., 2017. A new estimate of detrital redox-sensitive metal concentrations and variability in fluxes to marine sediments. Geochim. Cosmochim. Acta 215, 337-353. https://doi.org/10.1016/J.GCA.2017.08.004

Cordeiro, L.G.M.S., Wagener, A.L.R., Carreira, R.S., 2018. Organic matter in sediments of a tropical and upwelling influenced region of the Brazilian continental margin (Campos Basin, Rio de Janeiro). Org. Geochem. 120, 86-98. https://doi.org/10.1016/j.orggeochem.2018.01.005

Cranwell, P.A., 1984. Lipid geochemistry of sediments from Upton Broad, a small productive lake. Org. Geochem. 7, 25-37. https://doi.org/10.1016/01466380(84)90134-7 
Cranwell, P.A., 1973. Chain-length distribution of n-alkanes from lake sediments in relation to post-glacial environmental change. Freshw. Biol. 3, 259-265.

https://doi.org/10.1111/j.1365-2427.1973.tb00921.x

Curiale, J.A., Larter, S.R., Sweeney, R.E., Bromley, B.W., 1989. Molecular Thermal Maturity Indicators in Oil and Gas Source Rocks, in: Naeser, N.D., McCulloh, T.H. (Eds.), Thermal History of Sedimentary Basins. Springer New York, New York, NY, pp. 53-72.

Dawson, T.E., Mambelli, S., Plamboeck, A.H., Templer, P.H., Tu, K.P., 2002. Stable Isotopes in Plant Ecology. Annu. Rev. Ecol. Syst. 33, 507-559.

https://doi.org/10.1146/annurev.ecolsys.33.020602.095451

de Gea, G.A., Aguado, R., Castro, J.M., Molina, J.M., O’Dogherty, L., Ruiz-Ortiz, P.A., 2008. Lower Aptian Subbetic organic-rich facies, radiolarites, and associated deposits: the local expression of Oceanic Anoxic Event 1a (Carbonero Formation, southern Spain). Cretac. Res. 29, 861-870.

https://doi.org/10.1016/J.CRETRES.2008.05.011

de Wit, M.J., Ghosh, J.G., de Villiers, S., Rakotosolofo, N., Alexander, J., Tripathi, A., Looy, C., 2002. Multiple Organic Carbon Isotope Reversals across the PermoTriassic Boundary of Terrestrial Gondwana Sequences: Clues to Extinction Patterns and Delayed Ecosystem Recovery. J. Geol. 110, 227-240.

https://doi.org/10.1086/338411

Dean, W.E., Piper, D.Z., Peterson, L.C., 1999. Molybdenum accumulation in Cariaco basin sediment over the past 24 k.y.: A record of water-column anoxia and climate. Geology 27, 507-510. https://doi.org/10.1130/00917613(1999)027<0507:MAICBS>2.3.CO;2

Deines, P., 2002. The carbon isotope geochemistry of mantle xenoliths. Earth-Science Rev. 58, 247-278. https://doi.org/10.1016/S0012-8252(02)00064-8

den Dulk, M., Reichart, G.J., Memon, G.M., Roelofs, E.M.P., Zachariasse, W.J., van der Zwaan, G.J., 1998. Benthic foraminiferal response to variations in surface water productivity and oxygenation in the northern Arabian Sea. Mar. Micropaleontol. 35, 43-66. https://doi.org/10.1016/S0377-8398(98)00015-2

Diaz, P., Raimbault, F., Boudjellal, B., Garcia, N., Moutin, T., 2001. Early spring phosphorus limitation of primary productivity in a NW Mediterranean coastal zone (Gulf of Lions). Mar. Ecol. Prog. Ser. 211, 51-62. https://doi.org/10.3354/meps211051 
Dinarès-Turell, J., Garcia-Senz, J., 2000. Remagnetization of Lower Cretaceous limestones from the southern Pyrenees and relation to the Iberian plate geodynamic evolution. J. Geophys. Res. https://doi.org/10.1029/2000JB900136

Duan, L.Q., Song, J.M., Yuan, H.M., Li, X.G., Li, N., Peng, Q.C., 2017. The use of sterols combined with isotope analyses as a tool to identify the origin of organic matter in the East China Sea. Ecol. Indic. 83, 144-157. https://doi.org/10.1016/j.ecolind.2017.07.042

Dufourc, E.J., 2008. Sterols and membrane dynamics. J. Chem. Biol. 1, 63-77. https://doi.org/10.1007/s12154-008-0010-6

Dumitrescu, M., Brassell, S.C., 2006. Compositional and isotopic characteristics of organic matter for the early Aptian Oceanic Anoxic Event at Shatsky Rise, ODP Leg 198. Palaeogeogr. Palaeoclimatol. Palaeoecol. 235, 168-191. https://doi.org/10.1016/j.palaeo.2005.09.028

Dumitrescu, M., Brassell, S.C., 2005. Biogeochemical assessment of sources of organic matter and paleoproductivity during the early Aptian Oceanic Anoxic Event at Shatsky Rise, ODP Leg 198. Org. Geochem. 36, 1002-1022. https://doi.org/10.1016/j.orggeochem.2005.03.001

Edgar, N.T., Saunders, J.B., Bolli, H.M., Donnelly, T.W., Hay, W.W., Maurrasse, F., Nieto, H.P., Premoli Silva, I., Riedel, W.R., Schneidermann, N., 1973. Site 147, in: Initial Reports of the Deep Sea Drilling Project, 15. U.S. Government Printing Office, pp. 169-178. https://doi.org/10.2973/dsdp.proc.15.103.1973

Eglinton, G., Hamilton, R.J., 1967. Leaf epicuticular waxes. Science (80-. ). 156, 1322 1335. https://doi.org/10.1126/science.156.3780.1322

Emeis, K.C., Weissert, H., 2009. Tethyan-Mediterranean organic carbon-rich sediments from Mesozoic black shales to sapropels, Sedimentology. https://doi.org/10.1111/j.1365-3091.2008.01026.x

Erba, E., 2004. Calcareous nannofossils and Mesozoic oceanic anoxic events, in: Marine Micropaleontology. pp. 85-106. https://doi.org/10.1016/j.marmicro.2004.04.007

Erba, E., Tremolada, F., 2004. Nannofossil carbonate fluxes during the Early Cretaceous: Phytoplankton response to nutrification episodes, atmospheric $\mathrm{CO} 2$, and anoxia. Paleoceanography 19. https://doi.org/10.1029/2003PA000884

Eslinger, E., Pevear, D.R., 1988. Clay minerals for petroleum geologists and engineers: SEPM Short Course Notes, SEPM short course 22. SEPM, Tulsa, Oklahoma. 
Ficken, K.J., Li, B., Swain, D.L., Eglinton, G., 2000. An n-alkane proxy for the sedimentary input of submerged/floating freshwater aquatic macrophytes, in: Organic Geochemistry. pp. 745-749. https://doi.org/10.1016/S0146-6380(00)000814

Flügel, E., 2004. Microfacies of Carbonate Rocks: Analysis, Interpretation and Application. Springer-Verlag Berlin Heidelb. 976. https://doi.org/10.1007/978-3642-03796-2

Folk, R.L., 1962. Spectral subdivision of limestone types, in: Ham, W.E. (Ed.), Classification of Carbonate Rocks-A Symposium: American Association of Petroleum Geologists Memoir 1. pp. 62-84.

Folk, R.L., 1959. Practical Petrographic Classification of Limestones. Am. Assoc. Pet. Geol. Bull.

Föllmi, K.B., Bôle, M., Jammet, N., Froidevaux, P., Godet, A., Bodin, S., Adatte, T., Matera, V., Fleitmann, D., Spangenberg, J.E., 2012. Bridging the Faraoni and Selli oceanic anoxic events: Late Hauterivian to early Aptian dysaerobic to anaerobic phases in the Tethys. Clim. Past 8, 171-189. https://doi.org/10.5194/cp-8-171-2012

Föllmi, K.B., 2012. Early Cretaceous life, climate and anoxia. Cretac. Res. 35, 230-257. https://doi.org/10.1016/J.CRETRES.2011.12.005

Föllmi, K.B., Gainon, F., 2008. Demise of the northern Tethyan Urgonian carbonate platform and subsequent transition towards pelagic conditions: The sedimentary record of the Col de la Plaine Morte area, central Switzerland. Sediment. Geol. 205, 142-159. https://doi.org/10.1016/J.SEDGEO.2008.02.005

Föllmi, K.B., Weissert, H., Bisping, M., Funk, H., 1994. Phosphogenesis, carbon-isotope stratigraphy, and carbonate-platform evolution along the Lower Cretaceous northern Tethyan margin. GSA Bull. 106, 729-746. https://doi.org/10.1130/00167606(1994)106<0729:PCISAC $>2.3 . C O ; 2$

Föllmi, K.B., Weissert, H., Bisping, M., Funk, H., 1994. Phosphogenesis, carbon-isotope stratigraphy, and carbonate-platform evolution along the Lower Cretaceous northern Tethyan margin. GSA Bull. 106, 729-746. https://doi.org/10.1130/00167606(1994)106<0729:PCISAC $>2.3 . C O ; 2$

Forster, A., Sturt, H., Meyers, P., Party, L., 2004. Molecular biogeochemistry of Cretaceous black shales from the Demerara Rise; preliminary shipboard results from Sites 1257 and 1258, ODP Leg 207. Proc. Ocean Drill. Progr. Initial Rep 207, 1-22.

Fry, B., 2006. Stable isotope ecology, Stable Isotope Ecology. Springer New York, New York, NY. https://doi.org/10.1007-0-387-33745-8 
Funk, H., Follmi, K.B., Mohr, H., 1993. Evolution of the Tithonian-Aptian carbonate platform along the northern Tethyan margin, eastern Helvetic Alps. Cretac. carbonate platforms 387-407.

Gale, A.S., Jenkyns, H.C., Kennedy, W.J., Corfield, R.M., 1993. Chemostratigraphy versus biostratigraphy: data from around the Cenomanian-Turonian boundary. J. Geol. Soc. London. 150, 29-32. https://doi.org/10.1144/gsjgs.150.1.0029

Gao, L., Hou, J., Toney, J., MacDonald, D., Huang, Y., 2011. Mathematical modeling of the aquatic macrophyte inputs of mid-chain n-alkyl lipids to lake sediments: Implications for interpreting compound specific hydrogen isotopic records. Geochim. Cosmochim. Acta 75, 3781-3791. https://doi.org/10.1016/j.gca.2011.04.008

Gaona-Narvaez, T., Maurrasse, F.J.-M.R., Moreno-Bedmar, J.A., 2013. Stable carbonisotope stratigraphy and ammonite biochronology at Madotz, Navarra, northern Spain: implications for the timing and duration of oxygen depletion during OAE-1a. Cretac. Res. 40, 143-157. https://doi.org/10.1016/J.CRETRES.2012.06.005

García-Mondéjar, J., Owen, H.G., Raisossadat, N., Millán, M.I., Fernández-Mendiola, P.A., 2009. The Early Aptian of Aralar (northern Spain): stratigraphy, sedimentology, ammonite biozonation, and OAE1. Cretac. Res. 30, 434-464. https://doi.org/10.1016/J.CRETRES.2008.08.006

García-Mondéjar, J., Fernández-Mendiola, P.A., Owen, H.G., 2015. The OAE1a in Cuchía (Early Aptian, Spain): C and O geochemistry and global correlation. Acta Geol. Pol. 65, 525-543. https://doi.org/10.1515/agp-2015-0023

García-Mondéjar, J., G. Owen, H., Fernandez-Mendiola, K., 2015. Early Aptian sedimentary record and OAE1a in Cuchía (northern Spain): New data on facies and ammonite dating. Neues Jahrb. für Geol. und Paläontologie - Abhandlungen 276, 126. https://doi.org/10.1127/njgpa/2015/0466

García-Senz, J., 2002. Cuencas extensivas del Cretácico inferior en los Pirineos centrales, formación y subsiguiente inversión. Dpt. Geodinàmica i Geofísica 310.

Gelpi, E., Schneider, H., Mann, J., Oro, J., 1970. Hydrocarbons of geochemical significance in microscopic algae. Phytochemistry 9, 603-612.

Gervais, F., Riebesell, U., Gorbunov, M.Y., 2002. Changes in primary productivity and chlorophyll a in response to iron fertilization in the Southern Polar Frontal Zone. Limnol. Oceanogr. 47, 1324-1335. https://doi.org/10.4319/lo.2002.47.5.1324

Gibbs, R.J., 1981. Sites of river-derived sedimentation in the ocean. Geology 9, 77-80. https://doi.org/10.1130/0091-7613(1981)9<77:SORSIT>2.0.CO;2 
Gibson, T.G., 1989. Planktonic benthonic foraminiferal ratios: Modern patterns and Tertiary applicability. Mar. Micropaleontol. 15, 29-52. https://doi.org/10.1016/0377-8398(89)90003-0

Giger, W., Schaffner, C., Wakeham, S.G., 1980. Aliphatic and olefinic hydrocarbons in recent sediments of Greifensee, Switzerland. Geochim. Cosmochim. Acta 44, 119 129. https://doi.org/10.1016/0016-7037(80)90182-9

Goddard, E.N., Trask, P.D., De Ford, R.K., Rove, O.N., Singewald, J.T., Overbeck, R.M., 1963. Rock-Color Chart. Geological Society of America, Colorado.

Godet, A., 2013. Drowning unconformities: Palaeoenvironmental significance and involvement of global processes. Sediment. Geol. 293, 45-66. https://doi.org/10.1016/j.sedgeo.2013.05.002

Golonka, J., 2004. Plate tectonic evolution of the southern margin of Eurasia in the Mesozoic and Cenozoic. Tectonophysics 381, 235-273. https://doi.org/10.1016/j.tecto.2002.06.004

Gong, Z., Langereis, C.G., Mullender, T.A.T., 2008. The rotation of Iberia during the Aptian and the opening of the Bay of Biscay. Earth Planet. Sci. Lett. 273, 80-93. https://doi.org/10.1016/j.epsl.2008.06.016

Gong, Z., van Hinsbergen, D.J.J., Vissers, R.L.M., Dekkers, M.J., 2009. Early Cretaceous syn-rotational extension in the Organyà basin-New constraints on the palinspastic position of Iberia during its rotation. Tectonophysics 473, 312-323. https://doi.org/10.1016/j.tecto.2009.03.003

Graziano, R., 1999. The Early Cretaceous drowning unconformities of the Apulia carbonate platform (Gargano Promontory, southern Italy): Local fingerprints of global palaeoceanographic events. Terra Nov. 11, 245-250. https://doi.org/10.1046/j.1365-3121.1999.00256.x

Grimsdale, T.F., Van Morkhoven, F.P.C.M., 1955. The Ratio between Pelagic \& Benthonic Foraminifera as a Means of Estimating Depth of Deposition of Sedimentary Rocks, in: Proceedings of the 4th World Petroleum Congress (Rome) Section 1/D4. pp. 473-491.

Gröcke, D.R., Hesselbo, S.P., Jenkyns, H.C., 1999. Carbon-isotope composition of Lower Cretaceous fossil wood: Ocean-atmosphere chemistry and relation to sealevel change. Geology 27, 155-158. https://doi.org/10.1130/00917613(1999)027<0155:CICOLC $>2.3$. CO;2

Han, J., McCarthy, E.D., Calvin, M., Benn, H., 1968. Hydrocarbon Constituents of the Blue-Green Algae Nostoc muscorum, Anacystis nidulans, Phormidium luridum and 
Chlorogloea fritschii. J. Chem. Soc. 22, 2785-2791. https://doi.org/10.1039/j39680002785

Haq, B.U. (Ed.), 1995. Sequence stratigraphy and depositional response to eustatic, tectonic, and climatic forcing. Kluwer Academic Publishers, Dordrecht ; Boston.

Haq, B.U., 2014. Cretaceous eustasy revisited. Glob. Planet. Change 113, 44-58. https://doi.org/10.1016/J.GLOPLACHA.2013.12.007

Harman, R.A., 1964. Distribution of Foraminifera in the Santa Barbara Basin, California. Micropaleontology 10, 81-96. https://doi.org/10.2307/1484628

Hartmann, M.A., 1998. Plant sterols and the membrane environment. Trends Plant Sci. 3, 170-175. https://doi.org/10.1016/S1360-1385(98)01233-3

Härtner, T., Straub, K.L., Kannenberg, E., 2005. Occurrence of hopanoid lipids in anaerobic Geobacter species. FEMS Microbiol. Lett. 243, 59-64. https://doi.org/10.1016/j.femsle.2004.11.039

Harvey, H.R., Mcmanus, G.B., 1991. Marine ciliates as a widespread source of

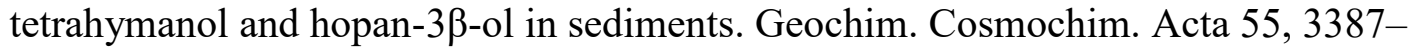
3390. https://doi.org/10.1016/0016-7037(91)90496-R

Hay, W.W., DeConto, R.M., de Boer, P., Flögel, S., Song, Y., Stepashko, A., 2019. Possible solutions to several enigmas of Cretaceous climate. Int. J. Earth Sci. 108, 587-620. https://doi.org/10.1007/s00531-018-1670-2

Heldt, M., Bachmann, M., Lehmann, J., 2008. Microfacies, biostratigraphy, and geochemistry of the hemipelagic Barremian-Aptian in north-central Tunisia: Influence of the OAE 1a on the southern Tethys margin. Palaeogeogr. Palaeoclimatol. Palaeoecol. 261, 246-260. https://doi.org/10.1016/j.palaeo.2008.01.013

Herrle, J.O., Kößler, P., Friedrich, O., Erlenkeuser, H., Hemleben, C., 2004. Highresolution carbon isotope records of the Aptian to Lower Albian from SE France and the Mazagan Plateau (DSDP Site 545): A stratigraphic tool for paleoceanographic and paleobiologic reconstruction. Earth Planet. Sci. Lett. 218, 149-161. https://doi.org/10.1016/S0012-821X(03)00646-0

Hesselbo, S.P., Pieńkowski, G., 2011. Stepwise atmospheric carbon-isotope excursion during the Toarcian Oceanic Anoxic Event (Early Jurassic, Polish Basin). Earth Planet. Sci. Lett. 301, 365-372. https://doi.org/10.1016/J.EPSL.2010.11.021 
Hesselbo, S.P., Gröcke, D.R., Jenkyns, H.C., Bjerrum, C.J., Farrimond, P., Morgans Bell, H.S., Green, O.R., 2000. Massive dissociation of gas hydrate during a Jurassic oceanic anoxic event. Nature 406, 392-395. https://doi.org/10.1038/35019044

Hu, S., O’Sullivan, P.B., Raza, A., Kohn, B.P., 2001. Thermal history and tectonic subsidence of the Bohai Basin, northern China: a Cenozoic rifted and local pullapart basin. Phys. Earth Planet. Inter. 126, 221-235. https://doi.org/10.1016/S00319201(01)00257-6

Huang, W.Y., Meinschein, W.G., 1979. Sterols as ecological indicators. Geochim. Cosmochim. Acta 43, 739-745. https://doi.org/10.1016/0016-7037(79)90257-6

Huber, B.T., Hodell, D.A., Hamilton, C.P., 1995. Middle-late Cretaceous climate of the southern high latitudes: stable isotopic evidence for minimal equator-to-pole thermal gradients. Geol. Soc. Am. Bull. 107, 1164-1191. https://doi.org/10.1130/00167606(1995)107<1164:MLCCOT>2.3.CO;2

Huber, B.T., MacLeod, K.G., Watkins, D.K., Coffin, M.F., 2018. The rise and fall of the Cretaceous Hot Greenhouse climate. Glob. Planet. Change 167, 1-23. https://doi.org/10.1016/J.GLOPLACHA.2018.04.004

Huck, S., Rameil, N., Korbar, T., Heimhofer, U., Wieczorek, T.D., Immenhauser, A., 2010. Latitudinally different responses of Tethyan shoal-water carbonate systems to the Early Aptian oceanic anoxic event (OAE 1a). Sedimentology 57, 1585-1614. https://doi.org/10.1111/j.1365-3091.2010.01157.x

Immenhauser, A., Hillgärtner, H., van Bentum, E., 2005. Microbial-foraminiferal episodes in the Early Aptian of the southern Tethyan margin: Ecological significance and possible relation to oceanic anoxic event 1a. Sedimentology 52, 77-99. https://doi.org/10.1111/j.1365-3091.2004.00683.x

Ingram, B.L., Coccioni, R., Montanari, A., Richter, F.M., 1994. Strontium isotopic composition of mid-cretaceous seawater. Science (80-. ). 264, 546-550. https://doi.org/10.1126/science.264.5158.546

Jahren, A.H., Arens, N.C., Sarmiento, G., Guerrero, J., Amundson, R., 2001. Terrestrial record of methane hydrate dissociation in the Early Cretaceous. Geology 29, 159162. https://doi.org/10.1130/0091-7613(2001)029<0159:TROMHD>2.0.CO;2

Jahren, A.H., Conrad, C.P., Arens, N.C., Mora, G., Lithgow-Bertelloni, C., 2005. A plate tectonic mechanism for methane hydrate release along subduction zones. Earth Planet. Sci. Lett. 236, 691-704. https://doi.org/10.1016/j.eps1.2005.06.009 
Jammes, S., Manatschal, G., Lavier, L., Masini, E., 2009. Tectonosedimentary evolution related to extreme crustal thinning ahead of a propagating ocean: Example of the western Pyrenees. Tectonics 28. https://doi.org/10.1029/2008TC002406

Jammes, S., Tiberi, C., Manatschal, G., 2010. 3D architecture of a complex transcurrent rift system: The example of the Bay of Biscay-Western Pyrenees. Tectonophysics 489, 210-226. https://doi.org/10.1016/J.TECTO.2010.04.023

Jarvis, I., Gale, A.S., Jenkyns, H.C., Pearce, M.A., 2006. Secular variation in Late Cretaceous carbon isotopes: A new $\delta 13 \mathrm{C}$ carbonate reference curve for the Cenomanian-Campanian (99.6-70.6 Ma). Geol. Mag. 143, 561-608. https://doi.org/10.1017/S0016756806002421

Jenkyns, H.C., Schouten-Huibers, L., Schouten, S., Sinninghe Damsté, J.S., 2012. Warm Middle Jurassic-Early Cretaceous high-latitude sea-surface temperatures from the Southern Ocean. Clim. Past 8, 215-226. https://doi.org/10.5194/cp-8-215-2012

Jenkyns, H.C., 1980. Cretaceous anoxic events: from continents to oceans. J. Geol. Soc. London. 137, 171-188. https://doi.org/10.1144/gsjgs.137.2.0171

Jenkyns, H.C., Gale, A.S., Corfield, R.M., 1994. Carbon- and oxygen-isotope stratigraphy of the English Chalk and Italian Scaglia and its palaeoclimatic significance. Geol. Mag. 131, 1-34. https://doi.org/10.1017/s0016756800010451

Jenkyns, H., 2003. Evidence for rapid climate change in the Mesozoic-Paleogene greenhouse world. Philos. Trans. A. Math. Phys. Eng. Sci. 361, 1885-916; discussion 1916. https://doi.org/10.1098/rsta.2003.1240

Jenkyns, H.C., 2010. Geochemistry of oceanic anoxic events. Geochemistry, Geophys. Geosystems 11. https://doi.org/10.1029/2009GC002788

Jetter, R., Kunst, L., Samuels, A.L., 2006. Composition of Plant Cuticular Waxes. Annu. Plant Rev. Vol. 23 Biol. Plant Cuticle, Wiley Online Books. https://doi.org/doi:10.1002/9780470988718.ch4

Jorissen, F.J., de Stigter, H.C., Widmark, J.G.V., 1995. A conceptual model explaining benthic foraminiferal microhabitats. Mar. Micropaleontol. 26, 3-15. https://doi.org/10.1016/0377-8398(95)00047-X

Kaiho, K., 1994. Benthic foraminiferal dissolved-oxygen index and dissolved-oxygen levels in the modern ocean. Geology 22, 719-722. https://doi.org/10.1130/00917613(1994)022<0719:BFDOIA $>2.3 . \mathrm{CO} ; 2$ 
Kaiho, K., 1999. Effect of organic carbon flux and dissolved oxygen on the benthic foraminiferal oxygen index (BFOI). Mar. Micropaleontol. 37, 67-76. https://doi.org/10.1016/S0377-8398(99)00008-0

Kim, M., Jung, J., Jin, Y., Han, G.M., Lee, T., Hong, S.H., Yim, U.H., Shim, W.J., Choi, D.-L., Kannan, N., 2016. Origins of suspended particulate matter based on sterol distribution in low salinity water mass observed in the offshore East China Sea. Mar. Pollut. Bull. 108, 281-288. https://doi.org/10.1016/J.MARPOLBUL.2016.04.049

Kirtland Turner, S., Ridgwell, A., 2016. Development of a novel empirical framework for interpreting geological carbon isotope excursions, with implications for the rate of carbon injection across the PETM. Earth Planet. Sci. Lett. 435, 1-13. https://doi.org/10.1016/J.EPSL.2015.11.027

Kohn, M.J., 2010. Carbon isotope compositions of terrestrial C3 plants as indicators of (paleo)ecology and (paleo)climate. Proc. Natl. Acad. Sci. U. S. A. 107, 19691-5. https://doi.org/10.1073/pnas.1004933107

Krom, M.D., Kress, N., Brenner, S., Gordon, L.I., 1991. Phosphorus limitation of primary productivity in the eastern Mediterranean Sea. Limnol. Oceanogr. 36, 424432. https://doi.org/10.1021/acsami.5b10724

Kvenvolden, K.A., 1993. Gas hydrates - geological perspective and global change. Rev. Geophys. 31, 173-187. https://doi.org/10.1029/93RG00268

Larson, R.L., 1991. Geological consequences of superplumes. Geology 19, 963-966. https://doi.org/10.1130/0091-7613(1991)019<0963:GCOS>2.3.CO;2

Larson, R.L., Erba, E., 1999. Onset of the mid-Cretaceous greenhouse in the BarremianAptian: Igneous events and the biological, sedimentary, and geochemical responses. Paleoceanography 14, 663-678. https://doi.org/10.1029/1999PA900040

Lechler, M., Pogge von Strandmann, P.A.E., Jenkyns, H.C., Prosser, G., Parente, M., 2015. Lithium-isotope evidence for enhanced silicate weathering during OAE 1a (Early Aptian Selli event). Earth Planet. Sci. Lett. 432, 210-222. https://doi.org/10.1016/J.EPSL.2015.09.052

Leckie, R.M., Bralower, T.J., Cashman, R., 2002. Oceanic anoxic events and plankton evolution: Biotic response to tectonic forcing during the mid-Cretaceous. Paleoceanography 17, 13-29. https://doi.org/10.1029/2001PA000623

Li, J., Hu, X., Zhao, K., Cai, Y., Sun, T., 2016. Paleoceanographic evolution and chronostratigraphy of the Aptian Oceanic Anoxic Event 1a (OAE1a) to oceanic red bed 1 (ORB1) in the Gorgo a Cerbara section (central Italy). Cretac. Res. 66, 115128. https://doi.org/10.1016/J.CRETRES.2016.04.016 
Li, Y.X., Bralower, T.J., Montañez, I.P., Osleger, D.A., Arthur, M.A., Bice, D.M., Herbert, T.D., Erba, E., Premoli Silva, I., 2008. Toward an orbital chronology for the early Aptian Oceanic Anoxic Event (OAE1a, 120 Ma). Earth Planet. Sci. Lett. 271, 88-100. https://doi.org/10.1016/j.eps1.2008.03.055

Lijmbach, G.W.M., 1975. On the origin of petroleum, in: Proceedings Ninth World Petroleum Congress. Applied Sciences Publisher, London, pp. 357-369.

Littler, K., Robinson, S.A., Bown, P.R., Nederbragt, A.J., Pancost, R.D., 2011. High seasurface temperatures during the Early Cretaceous Epoch. Nat. Geosci. 4, 169.

Ludvigson, G.A., Joeckel, R.M., Murphy, L.R., Stockli, D.F., González, L.A., Suarez, C.A., Kirkland, J.I., Al-Suwaidi, A., 2015. The emerging terrestrial record of Aptian-Albian global change. Cretac. Res. 56, 1-24. https://doi.org/10.1016/J.CRETRES.2014.11.008

Mackenzie, A.S., Brassell, S.C., Eglinton, G., Maxwell, J.R., 1982. Chemical fossils: The geological fate of steroids. Science (80-. ). 217, 491-504. https://doi.org/10.1126/science.217.4559.491

Mackenzie, A.S., Patience, R.L., Maxwell, J.R., Vandenbroucke, M., Durand, B., 1980. Molecular parameters of maturation in the Toarcian shales, Paris Basin, France-I. Changes in the configurations of acyclic isoprenoid alkanes, steranes and triterpanes. Geochim. Cosmochim. Acta 44, 1709-1721. https://doi.org/10.1016/00167037(80)90222-7

Magniez-Jannin, F., Bréhéret, J.-G., Delanoy, G., 1997. Un exemple de spéciation lié à l'eustatisme: l'apparition précoce de Schackoina cabri (foraminifère planctonique mésogéen). Comptes Rendus l'Académie des Sci. - Ser. IIA - Earth Planet. Sci. 325, 225-230. https://doi.org/10.1016/S1251-8050(97)88293-6

Malinverno, A., Erba, E., Herbert, T.D., 2010. Orbital tuning as an inverse problem: Chronology of the early Aptian oceanic anoxic event 1a (Selli Level) in the Cismon APTICORE. Paleoceanography 25. https://doi.org/10.1029/2009PA001769

Mallon, A.J., Swarbrick, R.E., 2002. A compaction trend for non-reservoir North Sea Chalk. Mar. Pet. Geol. 19, 527-539. https://doi.org/10.1016/S0264-8172(02)000272

Martin, J.H., Fitzwater, S.E., 1988. Iron deficiency limits phytoplankton growth in the north-east pacific subarctic. Nature 331, 341-343. https://doi.org/10.1038/331341a0

Masson, D.G., Miles, P.R., 1984. Mesozoic seafloor spreading between Iberia, Europe and North America. Mar. Geol. 56, 279-287. https://doi.org/10.1016/00253227(84)90019-7 
Mayser, J.P., Flecker, R., Marzocchi, A., Kouwenhoven, T.J., Lunt, D.J., Pancost, R.D., 2017. Precession driven changes in terrestrial organic matter input to the Eastern Mediterranean leading up to the Messinian Salinity Crisis. Earth Planet. Sci. Lett. 462, 199-211. https://doi.org/10.1016/J.EPSL.2017.01.029

McInerney, F.A., Wing, S.L., 2011. The Paleocene-Eocene Thermal Maximum: A Perturbation of Carbon Cycle, Climate, and Biosphere with Implications for the Future. Annu. Rev. Earth Planet. Sci. 39, 489-516. https://doi.org/10.1146/annurevearth-040610-133431

Mead, R., Xu, Y., Chong, J., Jaffé, R., 2005. Sediment and soil organic matter source assessment as revealed by the molecular distribution and carbon isotopic composition of n-alkanes. Org. Geochem. 36, 363-370. https://doi.org/10.1016/j.orggeochem.2004.10.003

Méhay, S., Keller, C.E., Bermasconi, S.M., Weissert, H., Erba, E., Bottini, C., Hochuli, P.A., 2009. A volcanic CO2 pulse triggered the Cretaceous oceanic Anoxic event 1a and a biocalcification crisis. Geology 37, 819-822. https://doi.org/10.1130/G30100A.1

Méjanelle, L., Laureillard, J., 2008. Lipid biomarker record in surface sediments at three sites of contrasting productivity in the tropical North Eastern Atlantic. Mar. Chem. 108, 59-76. https://doi.org/10.1016/j.marchem.2007.10.002

Mencos, J., Carrera, N., Mnoz, J.A., 2015. Influence of rift basin geometry on the subsequent postrift sedimentation and basin inversion: The Organyà Basin and the Bóixols thrust sheet (south central Pyrenees). Tectonics. https://doi.org/10.1002/2014TC003692

Menegatti, A.P., Weissert, H., Brown, R.S., Tyson, R. V., Farrimond, P., Strasser, A., Caron, M., 1998. High-resolution $\delta 13 \mathrm{C}$ stratigraphy through the early Aptian "Livello Selli" of the Alpine Tethys. Paleoceanography 13, 530-545. https://doi.org/10.1029/98PA01793

Meyers, P.A., 1997. Organic geochemical proxies of paleoceanographic, paleolimnologic, and paleoclimatic processes, in: Organic Geochemistry. pp. $213-$ 250. https://doi.org/10.1016/S0146-6380(97)00049-1

Millán, M.I., Weissert, H.J., Fernández-Mendiola, P.A., García-Mondéjar, J., 2009. Impact of Early Aptian carbon cycle perturbations on evolution of a marine shelf system in the Basque-Cantabrian Basin (Aralar, N Spain). Earth Planet. Sci. Lett. 287, 392-401. https://doi.org/10.1016/j.epsl.2009.08.023

Millán, M.I., Weissert, H.J., Owen, H., Fernández-Mendiola, P.A., García-Mondéjar, J., 2011. The Madotz Urgonian platform (Aralar, northern Spain): Paleoecological 
changes in response to Early Aptian global environmental events. Palaeogeogr. Palaeoclimatol. Palaeoecol. 312, 167-180.

https://doi.org/10.1016/j.palaeo.2011.10.005

Mitchell, S., Paul, C., Gale, A., 1996. Carbon isotopes and sequence stratigraphy, Geological Society, London, Special Publications.

https://doi.org/10.1144/GSL.SP.1996.104.01.02

Moldowan, J.M., Seifert, W.K., Gallegos, E.J., 1985. Relationship between petroleum composition and depositional environment of petroleum source rocks. Am. Assoc. Pet. Geol. Bull. 69, 1255-1268. https://doi.org/10.1080/10916469808949779

Moullade, M., Tronchetti, G., Granier, B., Bornemann, A., Kuhnt, W., Lorenzen, J., 2015. High-resolution integrated stratigraphy of the OAE1a and enclosing strata from core drillings in the Bedoulian stratotype (Roquefort-La Bédoule, SE France). Cretac. Res. 56, 119-140. https://doi.org/10.1016/j.cretres.2015.03.004

Mutterlose, J., Bottini, C., Schouten, S., Sinninghe Damsté, J.S., 2014. High sea-surface temperatures during the early Aptian Oceanic Anoxic Event 1a in the Boreal Realm. Geology 42, 439-442. https://doi.org/10.1130/G35394.1

Naafs, B.D.A., Castro, J.M., De Gea, G.A., Quijano, M.L., Schmidt, D.N., Pancost, R.D., 2016. Gradual and sustained carbon dioxide release during Aptian Oceanic Anoxic Event 1a. Nat. Geosci. 9, 135.

Najarro, M., Rosales, I., Martín-Chivelet, J., 2011. Major palaeoenvironmental perturbation in an Early Aptian carbonate platform: Prelude of the Oceanic Anoxic Event 1a? Sediment. Geol. 235, 50-71. https://doi.org/10.1016/J.SEDGEO.2010.03.011

Najarro, M., Rosales, I., Moreno-Bedmar, J.A., de Gea, G.A., Barrón, E., Company, M., Delanoy, G., 2011. High-resolution chemo- and biostratigraphic records of the Early Aptian oceanic anoxic event in Cantabria (N Spain): Palaeoceanographic and palaeoclimatic implications. Palaeogeogr. Palaeoclimatol. Palaeoecol. 299, 137-158. https://doi.org/10.1016/j.palaeo.2010.10.042

Nes, W.R., 1974. Role of sterols in membranes. Lipids 9, 596-612. https://doi.org/10.1007/BF02532509

Nolet, G.J., Corliss, B.H., 1990. Benthic foraminiferal evidence for reduced deep-water circulation during sapropel deposition in the eastern Mediterranean. Mar. Geol. 94, 109-130. https://doi.org/10.1016/0025-3227(90)90106-T

O’Brien, C.L., Robinson, S.A., Pancost, R.D., Sinninghe Damsté, J.S., Schouten, S., Lunt, D.J., Alsenz, H., Bornemann, A., Bottini, C., Brassell, S.C., Farnsworth, A., 
Forster, A., Huber, B.T., Inglis, G.N., Jenkyns, H.C., Linnert, C., Littler, K., Markwick, P., McAnena, A., Mutterlose, J., Naafs, B.D.A., Püttmann, W., Sluijs, A., van Helmond, N.A.G.M., Vellekoop, J., Wagner, T., Wrobel, N.E., 2017. Cretaceous sea-surface temperature evolution: Constraints from TEX86 and planktonic foraminiferal oxygen isotopes. Earth-Science Rev. 172, 224-247. https://doi.org/10.1016/J.EARSCIREV.2017.07.012

Oliva-Urcia, B., Casas, A.M., Soto, R., Villalaín, J.J., Kodama, K., 2011. A transtensional basin model for the Organyà basin (central southern Pyrenees) based on magnetic fabric and brittle structures. Geophys. J. Int. 184, 111-130. https://doi.org/10.1111/j.1365-246X.2010.04865.x

Olivet, J.L., 1996. Kinematics of the Iberian plate, in: Bulletin Des Centres de Recherches Elf Exploration Production. pp. 191-195.

Ourisson, G., Albrecht, P., Rohmer, M., 1982. Predictive microbial biochemistry - from molecular fossils to procaryotic membranes. Trends Biochem. Sci. 7, 236-239. https://doi.org/10.1016/0968-0004(82)90028-7

Ourisson, G., Albrecht, P., Rohmer, M., 1979. The hopanoids: palaeochemistry and biochemistry of a group of natural products. Pure Appl. Chem. 51, 709-729.

Ourisson, G., Rohmer, M., 1992. Hopanoids. 2. Biohopanoids: A Novel Class of Bacterial Lipids. Acc. Chem. Res. 25, 403-408. https://doi.org/10.1021/ar00021a004

Ourisson, G., Rohmer, M., Poralla, K., 1987. Prokaryotic hopanoids and other polyterpenoid sterol surrogates. Annu. Rev. Microbiol. 41, 301-333.

Parker, F.., 1954. Distribution of the foraminifera in the northeastern Gulf of Mexico. Bull. Mus. Comp. Zool. 111, 452-588.

Patruno, S., Triantaphyllou, M. V., Erba, E., Dimiza, M.D., Bottini, C., Kaminski, M.A., 2015. The Barremian and Aptian stepwise development of the "Oceanic Anoxic Event 1a" (OAE 1a) crisis: Integrated benthic and planktic high-resolution palaeoecology along the Gorgo a Cerbara stratotype section (Umbria-Marche Basin, Italy). Palaeogeogr. Palaeoclimatol. Palaeoecol. 424, 147-182. https://doi.org/10.1016/j.palaeo.2015.01.031

Pattan, J.N., Pearce, N.J.G., 2009. Bottom water oxygenation history in southeastern Arabian Sea during the past $140 \mathrm{ka}$ : Results from redox-sensitive elements. Palaeogeogr. Palaeoclimatol. Palaeoecol. 280, 396-405. https://doi.org/10.1016/j.palaeo.2009.06.027 
Peters, K.E., Walters, C.C., Meldovan, J.M., 2005. The Biomarker Guide, Volume 1: Biomarkers and Isotopes in the Environment and Human History, Cambridge University Press. https://doi.org/10.1016/0146-6380(93)90028-A

Peters, K.E., Walters, C.C., Moldowan, J.M., 2007. The Biomarker Guide Volume 2: Biomarkers and isotopes in petroleum systems and earth history. Cambridge University Press.

Phelps, R.M., Kerans, C., Da-Gama, R.O.B.P., Jeremiah, J., Hull, D., Loucks, R.G., 2015. Response and recovery of the Comanche carbonate platform surrounding multiple Cretaceous oceanic anoxic events, northern Gulf of Mexico. Cretac. Res. 54, 117-144. https://doi.org/10.1016/j.cretres.2014.09.002

Philippi, G.T., 1965. On the depth, time and mechanism of petroleum generation. Geochim. Cosmochim. Acta 29, 1021-1049. https://doi.org/10.1016/00167037(65)90101-8

Phleger, F.B., 1951. Foraminifera distribution, in: Phleger, F.B., Parker, F.L. (Eds.), Ecology of Foraminifera, Northwest Gulf of Mexico. Geological Society of America, p. 0. https://doi.org/10.1130/MEM46-p1-0001

Pictet, A., Delanoy, G., Adatte, T., Spangenberg, J.E., Baudouin, C., Boselli, P., Boselli, M., Kindler, P., Föllmi, K.B., 2015. Three successive phases of platform demise during the early Aptian and their association with the oceanic anoxic Selli episode (Ardèche, France). Palaeogeogr. Palaeoclimatol. Palaeoecol. 418, 101-125. https://doi.org/10.1016/J.PALAEO.2014.11.008

Pomar, L., Kendall, C.G.S.C., 2012. Architecture of Carbonate Platforms: A Response to Hydrodynamics and Evolving Ecology, in: Controls on Carbonate Platform and Reef Development. SEPM (Society for Sedimentary Geology), pp. 187-216. https://doi.org/10.2110/pec.08.89.0187

Posamentier, H.W., Jervey, M.T., Vail, P.R., 1988. Eustatic Controls on Clastic Deposition I-Conceptual Framework, in: Wilgus, C.K., Hastings, B.S., Posamentier, H., Wagoner, J. Van, Ross, C.A., Kendall, C.G.S.C. (Eds.), Sea-Level Changes: An Integrated Approach. SEPM Society for Sedimentary Geology, p. 0. https://doi.org/10.2110/pec.88.01.0109

Post-Beittenmiller, D., 1996. Biochemistry and molecular biology of wax production in plants. Annu. Rev. Plant Physiol. Plant Mol. Biol. 47, 405-430. https://doi.org/10.1146/annurev.arplant.47.1.405

Puigdefäbregas, C., Souquet, P., 1986. Tecto-sedimentary cycles and depositional sequences of the Mesozoic and Tertiary from the Pyrenees. Tectonophysics. https://doi.org/10.1016/0040-1951(86)90251-9 
Ramaswamy, V., Gaye, B., Shirodkar, P.V., Rao, P.S., Chivas, A.R., Wheeler, D., Thwin, S., 2008. Distribution and sources of organic carbon, nitrogen and their isotopic signatures in sediments from the Ayeyarwady (Irrawaddy) continental shelf, northern Andaman Sea. Mar. Chem. 111, 137-150. https://doi.org/10.1016/J.MARCHEM.2008.04.006

Rameil, N., Immenhauser, A., Warrlich, G., Hillgärtner, H., Droste, H.J., 2010. Morphological patterns of Aptian Lithocodium-Bacinella geobodies: Relation to environment and scale. Sedimentology 57, 883-911. https://doi.org/10.1111/j.13653091.2009.01124.x

Riederer, M., Markstädter, C., 1996. Cuticular waxes: a critical assessment of current knowledge, in: Plant Cuticles: An Integrated Functional Approach Vol. 47. Journal of Experimental Botany, pp. 189-200.

Rosenbaum, G., Lister, G.S., Duboz, C., 2002. Relative motions of Africa, Iberia and Europe during Alpine orogeny. Tectonophysics. https://doi.org/10.1016/S00401951(02)00442-0

Ruebsam, W., Dickson, A.J., Hoyer, E.-M., Schwark, L., 2017. Multiproxy reconstruction of oceanographic conditions in the southern epeiric Kupferschiefer Sea (Late Permian) based on redox-sensitive trace elements, molybdenum isotopes and biomarkers. Gondwana Res. 44, 205-218.

https://doi.org/10.1016/J.GR.2016.10.017

Sagawa, T., Nagahashi, Y., Satoguchi, Y., Holbourn, A., Itaki, T., Gallagher, S.J., Saavedra-Pellitero, M., Ikehara, K., Irino, T., Tada, R., 2018. Integrated tephrostratigraphy and stable isotope stratigraphy in the Japan Sea and East China Sea using IODP Sites U1426, U1427, and U1429, Expedition 346 Asian Monsoon. Prog. Earth Planet. Sci. 5, 18. https://doi.org/10.1186/s40645-018-0168-7

Sanchez-Hernandez, Y., 2014. Paleoenvironments and geochemical signals from the late Barremian to the middle Aptian in a Tethyan marginal basin, northeast Spain: Implications for carbon sequestration in restricted basins. Florida International University.

Sanchez-Hernandez, Y., Maurrasse, F.J.M.R., 2016. The influence of regional factors in the expression of oceanic anoxic event 1a (OAE1a) in the semi-restricted Organyà Basin, south-central Pyrenees, Spain. Palaeogeogr. Palaeoclimatol. Palaeoecol. 441, 582-598. https://doi.org/10.1016/j.palaeo.2015.06.031

Sanchez-Hernandez, Y., Maurrasse, F.J.M.R., 2014. Geochemical characterization and redox signals from the latest Barremian to the earliest Aptian in a restricted marine basin: El Pui section, Organyà Basin, south-central Pyrenees. Chem. Geol. 372, 12 31. https://doi.org/10.1016/j.chemgeo.2014.02.011 
Sanchez-Hernandez, Y., Maurrasse, F.J.M.R., Melinte-Dobrinescu, M.C., He, D., Butler, S.K., 2014. Assessing the factors controlling high sedimentation rates from the latest Barremian-earliest Aptian in the hemipelagic setting of the restricted Organyà Basin, NE Spain. Cretac. Res. 51, 1-21. https://doi.org/10.1016/j.cretres.2014.05.010

Schirmer, A., Rude, M.A., Li, X., Popova, E., Del Cardayre, S.B., 2010. Microbial biosynthesis of alkanes. Science (80-. ). 329, 559-562. https://doi.org/10.1126/science. 1187936

Schlanger, S.O., Jenkyns, H.C., 1976. Cretaceous oceanic anoxic events: Causes and consequences. Geol. en Mijnb. 55, 179-184.

Schmidt, F., Hinrichs, K.U., Elvert, M., 2010. Sources, transport, and partitioning of organic matter at a highly dynamic continental margin. Mar. Chem. 118, 37-55. https://doi.org/10.1016/j.marchem.2009.10.003

Scholle, P.A., Arthur, M.A., 1980. Carbon isotope fluctuations in Cretaceous pelagic limestones: potential stratigraphic and petroleum exploration tool. Am. Assoc. Pet. Geol. Bull. 64, 67-87. https://doi.org/10.1306/2F91892D-16CE-11D7$8645000102 \mathrm{C} 1865 \mathrm{D}$

Seidenkrantz, M.-S., Kouwenhoven, T.., Jorissen, F., Shackleton, N.., van der Zwaan, G.., 2000. Benthic foraminifera as indicators of changing Mediterranean-Atlantic water exchange in the late Miocene. Mar. Geol. 163, 387-407. https://doi.org/10.1016/S0025-3227(99)00116-4

Seifert, Wolfgang K.; Moldowan, J.M., 1986. Use of biological markers in petroleum exploration, in: Johns, R.B. (Ed.), Methods in Geochemistry and Geophysics, Vol 24. Elsevier, Amsterdam, pp. 261-290.

Seifert, W.K., Moldowan, J.M., 1980. The effect of thermal stress on source-rock quality as measured by hopane stereochemistry. Phys. Chem. Earth 12, 229-237. https://doi.org/10.1016/0079-1946(79)90107-1

Shanmugam, G., 1985. Significance of Coniferous Rain Forests and Related Organic Matter in Generating Commercial Quantities of Oil, Gippsland Basin, Australia. Am. Assoc. Pet. Geol. Bull. 69, 1241-1254. https://doi.org/10.1306/AD462BC316F7-11D7-8645000102C1865D

Sibuet, J.C., Srivastava, S.P., Spakman, W., 2004. Pyrenean orogeny and plate kinematics. J. Geophys. Res. Solid Earth 109. https://doi.org/10.1029/2003JB002514

Siegenthaler, U., Sarmiento, J.L., 1993. Atmospheric carbon dioxide and the ocean. Nature 365, 119-125. https://doi.org/10.1038/365119a0 
Singer, A., 1984. The paleoclimatic interpretation of clay minerals in sediments - a review. Earth-Science Rev. 21, 251-293. https://doi.org/10.1016/00128252(84)90055-2

Singh, A.D., Rai, A.K., Verma, K., Das, S., Bharti, S.K., 2015. Benthic foraminiferal diversity response to the climate induced changes in the eastern Arabian Sea oxygen minimum zone during the last $30 \mathrm{ka} \mathrm{BP}$. Quat. Int. 374, 118-125. https://doi.org/10.1016/J.QUAINT.2014.11.052

Sinninghe Damsté, J.S., Kenig, F., Koopmans, M.P., Köster, J., Schouten, S., Hayes, J.M., de Leeuw, J.W., 1995. Evidence for gammacerane as an indicator of water column stratification. Geochim. Cosmochim. Acta 59, 1895-1900. https://doi.org/10.1016/0016-7037(95)00073-9

Sinninghe Damsté, J.S., Rijpstra, W.I.C., Schouten, S., Fuerst, J.A., Jetten, M.S.M., Strous, M., 2004. The occurrence of hopanoids in planctomycetes: Implications for the sedimentary biomarker record. Org. Geochem. 35, 561-566. https://doi.org/10.1016/j.orggeochem.2004.01.013

Smith, F.D., 1955. Planktonic Foraminifera as Indicators of Depositional Environment. Micropaleontology 1, 147-151. https://doi.org/10.2307/1484167

Socorro, J., Maurrasse, F.J.M.R., Sanchez-Hernandez, Y., 2017. Characterization of the negative carbon isotope shift in segment $\mathrm{C} 2$, its global implications as a harbinger of OAE1a. Sci. China Earth Sci. 60, 30-43. https://doi.org/10.1007/s11430-016-0092-5

Socorro, J., Maurrasse, F.J.M.R., 2019a. Continuous accumulation of organic matter-rich sediments associated with Oceanic Anoxic Event 1a in the El Pujal section, Organyà Basin, Catalunyà Spain and its relation to episodic dysoxia. Cretac. Res. 95, 225251. https://doi.org/10.1016/j.cretres.2018.11.009

Socorro, J., Maurrasse, F.J.M.R., 2019b. Regional paleoenvironmental influence on OM sequestration and characteristics of carbon isotope segment $\mathrm{C} 5$ in a hemipelagic sequence, Organyà Basin, northeast Spain. Submitted: Under Review.

Spiker, C.E., Simoneit, B., 1982. Radiocarbon Dating of Sediments from the Cariaco Trench, Deep Sea Drilling Project Site 147, in: Initial Reports DSDP Leg 15. pp. 863-864. https://doi.org/10.2973/dsdp.proc.66.app3.1982

Srivastava, S.P., Schouten, H., Roest, W.R., Klitgord, K.D., Kovacs, L.C., Verhoef, J., Macnab, R., 1990. Iberian plate kinematics: A jumping plate boundary between Eurasia and Africa. Nature 344, 756-759. https://doi.org/10.1038/344756a0

Stein, M., Westermann, S., Adatte, T., Matera, V., Fleitmann, D., Spangenberg, J.E., Föllmi, K.B., 2012. Late Barremian-Early Aptian palaeoenvironmental change: The 
Cassis-La Bédoule section, southeast France. Cretac. Res. 37, 209-222.

https://doi.org/10.1016/j.cretres.2012.03.021

Sun, Y., Li, X., Zhao, G., Liu, H., Zhang, Y., 2016. Aptian and Albian atmospheric CO2 changes during oceanic anoxic events: Evidence from fossil Ginkgo cuticles in Jilin Province, Northeast China. Cretac. Res. 62, 130-141.

https://doi.org/10.1016/j.cretres.2015.12.007

Tang, Y., Huang, Y., Ellis, G.S., Wang, Y., Kralert, P.G., Gillaizeau, B., Ma, Q., Hwang, R., 2005. A kinetic model for thermally induced hydrogen and carbon isotope fractionation of individual n-alkanes in crude oil. Geochim. Cosmochim. Acta 69, 4505-4520. https://doi.org/10.1016/J.GCA.2004.12.026

Tarduno, J.A., Sliter, W. V, Kroenke, L., Leckie, M., Mayer, H., Mahoney, J.J., Musgrave, R., Storey, M., Winterer, E.L., 1991. Rapid Formation of Ontong Java Plateau by Aptian Mantle Plume Volcanism. Science (80-. ). 254, 399-403.

Taylor, A.M., Goldring, R., 1993. Description and analysis of bioturbation and ichnofabric. J. Geol. Soc. London. 150, 141-148. https://doi.org/10.1144/gsjgs.150.1.0141

Tejada, M.L.G., Suzuki, K., Kuroda, J., Coccioni, R., Mahoney, J.J., Ohkouchi, N., Sakamoto, T., Tatsumi, Y., 2009. Ontong Java Plateau eruption as a trigger for the early Aptian oceanic anoxic event. Geology 37, 855-858. https://doi.org/10.1130/G25763A.1

Terry, R.D., Chilingar, G. V., 1955. Summary of "Concerning some additional aids in studying sedimentary formations,” by M. S. Shvetsov. J. Sediment. Res. 25, 229234. https://doi.org/10.1306/74D70466-2B21-11D7-8648000102C1865D

Tissot, B., Durand, B., Espitalie, J., Combaz, A., 1974. Influence of nature and diagenesis of organic matter in formation of petroleum. Am. Assoc. Pet. Geol. Bull. 58, 499 506.

Tribovillard, N., Algeo, T.J., Lyons, T., Riboulleau, A., 2006. Trace metals as paleoredox and paleoproductivity proxies: An update. Chem. Geol. 232, 12-32. https://doi.org/10.1016/j.chemgeo.2006.02.012

Tribovillard, N., Riboulleau, A., Lyons, T., Baudin, F., 2004. Enhanced trapping of molybdenum by sulfurized marine organic matter of marine origin in Mesozoic limestones and shales. Chem. Geol. 213, 385-401. https://doi.org/10.1016/j.chemgeo.2004.08.011

Tucker, M.E., Wright, V.P., Dickson, J.A.D., 2009. Carbonate Sedimentology, Carbonate Sedimentology. https://doi.org/10.1002/9781444314175 
Vacherat, A., Mouthereau, F., Pik, R., Huyghe, D., Paquette, J.L., Christophoul, F., Loget, N., Tibari, B., 2017. Rift-to-collision sediment routing in the Pyrenees: A synthesis from sedimentological, geochronological and kinematic constraints. EarthScience Rev. 172, 43-74. https://doi.org/10.1016/j.earscirev.2017.07.004

van Breugel, Y., Schouten, S., Tsikos, H., Erba, E., Price, G.D., Damsté, J.S.S., 2007. Synchronous negative carbon isotope shifts in marine and terrestrial biomarkers at the onset of the early Aptian oceanic anoxic event 1a: Evidence for the release of 13C-depleted carbon into the atmosphere. Paleoceanography 22, 1-13. https://doi.org/10.1029/2006PA001341

Van Der Meer, D.G., Zeebe, R.E., van Hinsbergen, D.J.J., Sluijs, A., Spakman, W., Torsvik, T.H., 2014. Plate tectonic controls on atmospheric CO2 levels since the Triassic. Proc. Natl. Acad. Sci. 111, 4380-4385. https://doi.org/10.1073/pnas.1315657111

Van der Voo, R., 1969. Paleomagnetic evidence for the rotation of the Iberian Peninsula. Tectonophysics 7, 5-56. https://doi.org/10.1016/0040-1951(69)90063-8

Van Der Weijden, C.H., 2002. Pitfalls of normalization of marine geochemical data using a common divisor. Mar. Geol. 184, 167-187. https://doi.org/10.1016/S00253227(01)00297-3

van der Zwaan, G.., Jorissen, F.., de Stigter, H.., 1990. The depth dependency of planktonic/benthic foraminiferal ratios: Constraints and applications. Mar. Geol. 95, 1-16. https://doi.org/10.1016/0025-3227(90)90016-D

van Hinsbergen, D.J.J., Kouwenhoven, T.J., van der Zwaan, G.J., 2005. Paleobathymetry in the backstripping procedure: Correction for oxygenation effects on depth estimates. Palaeogeogr. Palaeoclimatol. Palaeoecol. 221, 245-265. https://doi.org/10.1016/J.PALAEO.2005.02.013

van Hinte, J.E., 1978. Geohistory Analysis--Application of Micropaleontology in Exploration Geology. Am. Assoc. Pet. Geol. Bull. 62, 201-222.

Van Marle, L.., Van Hinte, J.., Nederbragt, A.., 1987. Plankton percentage of the foraminiferal fauna in seafloor samples from the Australian-Irian Jaya continental margin, eastern Indonesia. Mar. Geol. 77, 151-156. https://doi.org/10.1016/00253227(87)90089-2

Verga, D., Premoli Silva, I., 2002. Early Cretaceous planktonic foraminifera from the Tethys: The genus Leupoldina. Cretac. Res. 23, 189-212. https://doi.org/10.1006/cres.2002.0309 
Vergés, J., Fernàndez, M., Martìnez, A., 2002. The Pyrenean orogen: Pre-, syn-, and post-collisional evolution. J. Virtual Explor. 8.

https://doi.org/10.3809/jvirtex.2002.00058

Vergés, J., García-Senz, J., 2001. Mesozoic evolution and Cainozoic inversion of the Pyrenean rift. Mémoires du Muséum Natl. d'histoire Nat. 186, 187-212.

Viso, A.-C., Pesando, D., Bernard, P., Marty, J.-C., 1993. Lipid components of the mediterranean seagrass Posidonia Oceanica. Phytochemistry 34, 381-387. https://doi.org/10.1016/0031-9422(93)80012-H

Vissers, R.L.M., Meijer, P.T., 2012. Mesozoic rotation of Iberia: Subduction in the Pyrenees? Earth-Science Rev. 110, 93-110. https://doi.org/10.1016/j.earscirev.2011.11.001

Volkman, J., 2003. Sterols in microorganisms. Appl. Microbiol. Biotechnol. 60, 495-506.

Volkman, J.K., 1988. Biological marker compounds as indicators of the depositional environments of petroleum source rocks. Geol. Soc. London, Spec. Publ. 40, 103122. https://doi.org/10.1144/gsl.sp.1988.040.01.10

Volkman, J.K., 1986. A review of sterol markers for marine and terrigenous organic matter. Org. Geochem. 9, 83-99. https://doi.org/10.1016/0146-6380(86)90089-6

Volkman, J.K., 2005. Sterols and other triterpenoids: Source specificity and evolution of biosynthetic pathways. Org. Geochem. 36, 139-159. https://doi.org/10.1016/j.orggeochem.2004.06.013

Volkman, J.K., Barrett, S.M., Blackburn, S.I., Mansour, M.P., Sikes, E.L., Gelin, F., 1998. Microalgal biomarkers: A review of recent research developments, in: Organic Geochemistry. pp. 1163-1179. https://doi.org/10.1016/S01466380(98)00062-X

Wainright, S.C., Fry, B., 1994. Seasonal variation of the stable isotopic compositions of coastal marine plankton from Woods Hole, Massachusetts and Georges Bank. Estuaries 17, 552-560. https://doi.org/10.2307/1352403

Wang, P., Chen, C., Liu, H., 2016. Aptian giant explosive volcanic eruptions in the Songliao Basin and northeast Asia: A possible cause for global climate change and OAE-1a. Cretac. Res. 62, 98-108. https://doi.org/10.1016/J.CRETRES.2015.09.021

Wang, P., Ren, Y., Shan, X., Sun, S., Wan, C., Bian, W., 2002. The Cretaceous volcanic succession around the Songliao Basin, NE China: relationship between volcanism and sedimentation. Geol. J. 37, 97-115. https://doi.org/10.1002/gj.905 
Wang, Y., Huang, C., Sun, B., Quan, C., Wu, J., Lin, Z., 2014. Paleo-CO2 variation trends and the Cretaceous greenhouse climate. Earth-Science Rev. 129, 136-147. https://doi.org/10.1016/J.EARSCIREV.2013.11.001

Weissert, H., Erba, E., 2004. Volcanism, CO2 and palaeoclimate: a Late Jurassic-Early Cretaceous carbon and oxygen isotope record. J. Geol. Soc. London. 161, 695-702. https://doi.org/10.1144/0016-764903-087

Weissert, H., Bréhéret, J.G., 1991. A carbonate-isotope record from Aptian-Albian sediments of the Vocontian Trough (SE France). Bull. la Société Géologique Fr. $162,1133-1140$.

Weissert, H., 1989. C-Isotope stratigraphy, a monitor of paleoenvironmental change: A case study from the early cretaceous. Surv. Geophys. 10, 1-61. https://doi.org/10.1007/BF01901664

Weissert, H., Lini, A., Föllmi, K.B., Kuhn, O., 1998. Correlation of Early Cretaceous carbon isotope stratigraphy and platform drowning events: a possible link? Palaeogeogr. Palaeoclimatol. Palaeoecol. 137, 189-203. https://doi.org/10.1016/S0031-0182(97)00109-0

Wendler, I., 2013. A critical evaluation of carbon isotope stratigraphy and biostratigraphic implications for Late Cretaceous global correlation. Earth-Science Rev. 126, 116-146. https://doi.org/10.1016/J.EARSCIREV.2013.08.003

Wenger, L.M., Isaksen, G.H., 2002. Control of hydrocarbon seepage intensity on level of biodegradation in sea bottom sediments. Org. Geochem. https://doi.org/10.1016/S0146-6380(02)00116-X

Westermann, S., Stein, M., Matera, V., Fiet, N., Fleitmann, D., Adatte, T., Föllmi, K.B., 2013. Rapid changes in the redox conditions of the western Tethys Ocean during the early Aptian oceanic anoxic event. Geochim. Cosmochim. Acta 121, 467-486. https://doi.org/10.1016/j.gca.2013.07.023

Wignall, P.B., Myers, K.J., 1988. Interpreting benthic oxygen levels in mudrocks: A new approach. Geology 16, 452-455. https://doi.org/10.1130/00917613(1988)016<0452:IBOLIM >2.3.CO;2

Wilmsen, M., 2005. Stratigraphy and biofacies of the Lower Aptian of Cuchía (Cantabria, northern Spain). J. Iber. Geol. 31, 253-275.

Winters, K., Parker, P.L., Van Baalen, C., 1969. Hydrocarbons of blue-green algae: Geochemical significance. Science (80-. ). 163, 467-468. https://doi.org/10.1126/science.163.3866.467 
Wissler, L., Funk, H., Weissert, H., 2003. Response of Early Cretaceous carbonate platforms to changes in atmospheric carbon dioxide levels. Palaeogeogr. Palaeoclimatol. Palaeoecol. 200, 187-205. https://doi.org/10.1016/S00310182(03)00450-4

Wright, R., 1977. Planktonic-Benthonic Ratio in Foraminifera as Paleobathymetric Tool-Quantitative Evaluation. Aapg Bull. - AAPG BULL 61. https://doi.org/10.1306/C1EA436F-16C9-11D7-8645000102C1865D

Wu, J., Filippidi, A., Davies, G.R., de Lange, G.J., 2018. Riverine supply to the eastern Mediterranean during last interglacial sapropel S5 formation: A basin-wide perspective. Chem. Geol. 485, 74-89. https://doi.org/10.1016/j.chemgeo.2018.03.037

Yarincik, K.M., Murray, R.W., Lyons, T.W., Peterson, L.C., Haug, G.H., 2000. Oxygenation history of bottom waters in the Cariaco Basin, Venezuela, over the past 578,000 years: Results from redox-sensitive metals ( $\mathrm{Mo}, \mathrm{V}, \mathrm{Mn}$, and $\mathrm{Fe}$ ). Paleoceanography 15, 593-604. https://doi.org/10.1029/1999PA000401

Zhang, X., Zhang, G., Sha, J., 2016. Lacustrine sedimentary record of early Aptian carbon cycle perturbation in western Liaoning, China. Cretac. Res. 62, 122-129. https://doi.org/10.1016/J.CRETRES.2015.10.001

Zohary, T., Robarts, R.D., 1998. Experimental study of microbial P limitation in the eastern Mediterranean. Limnol. Oceanogr. 43, 387-395. https://doi.org/10.4319/lo.1998.43.3.0387 


\subsection{Appendices}

Appendix 7A Full list of carbon geochemistry values including TIC, TOC and $\delta^{13} \mathrm{C}_{\text {org. }}$.

\begin{tabular}{|c|c|c|c|c|c|c|c|c|c|}
\hline C-17-203 & 127.15 & -24.11 & 60.88 & 1.12 & C-17-256 & 171.16 & -25 & 70.2 & 0.55 \\
\hline$C-17-201$ & 125.67 & -24.24 & 61.19 & 1.29 & $C-17-254$ & 169.89 & -24.1 & 85.63 & 0.30 \\
\hline$C-17-200$ & 124.92 & -24.24 & 61.39 & 1.28 & C-17-253 & 168.87 & -24 & 77.22 & 0.44 \\
\hline C-17-199 & 124.09 & -24.15 & 59.24 & 1.18 & $C-17-252$ & 168.36 & -24.1 & 84.64 & 0.27 \\
\hline C-17-196 & 121.49 & -24.11 & 59.3 & 1.15 & C-17-249 & 166.81 & -23.9 & 58.75 & 0.93 \\
\hline C-17-195 & 120.55 & -24.11 & 60.19 & 1.07 & C-17-248 & 166.11 & -23.9 & 62.96 & 0.88 \\
\hline C-17-194 & 119.78 & -24.27 & 59.91 & 1.18 & C-17-247 & 164.61 & -24 & 68.41 & 0.69 \\
\hline$C-17-193$ & 118.86 & -24.18 & 62.16 & 1.11 & C-17-246 & 163.26 & -24.1 & 66.77 & 0.85 \\
\hline C-17-192 & 117.99 & -23.99 & 59.33 & 1.19 & C-17-245 & 162.39 & -24 & 66.74 & 0.88 \\
\hline C-17-187 & 114.15 & -24.12 & 66.13 & 0.74 & C-17-240 & 158.82 & -24.2 & 62.35 & 0.68 \\
\hline C-17-186 & 113.39 & -24.24 & 64.45 & 0.84 & C-17-239 & 158.02 & -24.2 & 65.64 & 0.61 \\
\hline C-17-185 & 112.57 & -24.14 & 67.38 & 0.67 & C-17-238 & 157.17 & -24.1 & 58.6 & 0.77 \\
\hline C-17-184 & 111.6 & -24.15 & 67.85 & 0.74 & C-17-237 & 156.42 & -23.9 & 64.64 & 1.03 \\
\hline C-17-183 & 110.79 & -24.1 & 73.15 & 0.64 & C-17-236 & 155.4 & -24.1 & 63.9 & 0.61 \\
\hline C-17-182 & 110.02 & -24.31 & 71.7 & 0.62 & $C-17-235$ & 154.34 & -24.1 & 64.38 & 0.54 \\
\hline C-17-181 & 109.2 & -24.23 & 68.21 & 0.90 & C-17-234 & 153.44 & -24 & 64.85 & 0.94 \\
\hline$C-17-180$ & 108.19 & -24.26 & 66.02 & 0.90 & C-17-233 & 152.66 & -24.1 & 63.77 & 0.89 \\
\hline C-17-179 & 107.25 & -24.28 & 66.58 & 0.84 & C-17-232 & 151.99 & -24.2 & 60.03 & 1.06 \\
\hline $\mathrm{C}-17-178$ & 106.43 & -24.43 & 67.02 & 0.84 & C-17-231 & 151.07 & -24.1 & 60.71 & 1.11 \\
\hline C-17-177 & 105.73 & -24.39 & 70.38 & 0.70 & $C-17-230$ & 150.21 & -24.1 & 60.4 & 1.12 \\
\hline $\mathrm{C}-17-176$ & 104.85 & -24.43 & 70.38 & 0.70 & C-17-229 & 149.36 & -24 & 61 & 1.07 \\
\hline C-17-168 & 98.13 & -24.73 & 65.52 & 0.75 & C-17-221 & 142.42 & -24.1 & 64.34 & 0.92 \\
\hline C-17-167 & 97.46 & -24.72 & 63.77 & 0.83 & C-17-220 & 141.62 & -24.2 & 59.29 & 0.88 \\
\hline C-17-166 & 96.71 & -24.87 & 63.68 & 0.87 & C-17-219 & 140.95 & -24.2 & 57.41 & 1.06 \\
\hline C-17-165 & 95.86 & -24.17 & 70.49 & 0.75 & C-17-218 & 140.25 & -24.2 & 59.42 & 1.15 \\
\hline C-17-164 & 94.76 & -24.46 & 70.03 & 0.83 & C-17-217 & 139.39 & -24.1 & 54.31 & 1.29 \\
\hline C-17-163 & 94.09 & -24.49 & 71.23 & 0.72 & C-17-216 & 138.46 & -24.4 & 56.93 & 1.10 \\
\hline C-17-162 & 93.24 & -24.63 & 69.68 & 0.73 & C-17-215 & 137.51 & -24.1 & 62.2 & 1.00 \\
\hline C-17-161 & 92.57 & -24.53 & 70.72 & 0.79 & C-17-214 & 136.49 & -24.1 & 60.02 & 0.98 \\
\hline C-17-160 & 91.77 & -24.48 & 70.13 & 0.64 & C-17-213 & 135.69 & -24.4 & 63.11 & 1.10 \\
\hline C-17-159 & 91.02 & -24.32 & 63.21 & 0.88 & C-17-212 & 134.74 & -24.1 & 61.45 & 0.98 \\
\hline$C-17-158$ & 90.25 & -24.20 & 59.58 & 0.75 & C-17-211 & 133.84 & -24.2 & 63.37 & 1.11 \\
\hline C-17-157 & 89.51 & -24.21 & 56.67 & 1.07 & C-17-210 & 132.8 & -24.2 & 61.82 & 1.18 \\
\hline C-17-156 & 88.76 & -24.36 & 60.53 & 0.83 & C-17-209 & 132.06 & -24.2 & 63.71 & 1.17 \\
\hline C-17-155 & 88.11 & -24.74 & 68.82 & 0.62 & C-17-208 & 131.29 & -24.2 & 64.02 & 0.97 \\
\hline C-17-154 & 87.36 & -24.67 & 66.40 & 0.73 & C-17-207 & 130.46 & -24.3 & 63.93 & 0.67 \\
\hline C-17-153 & 86.68 & -24.38 & 68.12 & 0.67 & C-17-206 & 129.71 & -24.2 & 59.15 & 0.93 \\
\hline C-17-152 & 86.07 & -24.64 & 70.21 & 0.79 & C-17-205 & 128.97 & -24.2 & 60.4 & 1.03 \\
\hline
\end{tabular}


Appendix 7B Absolute values of major elements (Al, Si, Ti, Fe, P) and RSTEs (V, Ni, Co, Cr, Cu, Mo) in ppm $=$ parts per million.

\begin{tabular}{|c|c|c|c|c|c|c|c|c|c|c|c|c|c|}
\hline Sample ID & Height (m) & $\mathrm{Al}$ & Si & $\mathrm{Ti}$ & $\mathrm{Fe}$ & $P$ & V & $\mathrm{Ni}$ & Co & $\mathrm{Cr}$ & $\mathrm{Cu}$ & Mo & $U$ \\
\hline C-17-257 & 171.89 & 13111 & 48500 & 638 & 5745 & 187 & 18.2 & 9.5 & 0.5 & 19.7 & 3.2 & 0.8 & 0.62 \\
\hline C-17-256 & 171.16 & 14213 & 57139 & 717 & 7751 & 188 & 20.6 & 10.7 & 0.8 & 22.2 & 3.8 & 1.1 & 0.72 \\
\hline C-17-255 & 170.49 & 7768 & 44985 & 400 & 6573 & 139 & 13.8 & 7.4 & 0.3 & 12.5 & 2.1 & 1.0 & 0.54 \\
\hline C-17-254 & 169.89 & 4610 & 35536 & 255 & 4299 & 129 & 9.6 & 8.8 & 0.6 & 13.6 & 1.4 & 0.6 & 0.41 \\
\hline C-17-253 & 168.87 & 10320 & 58034 & 506 & 5420 & 126 & 17.8 & 6.9 & 0.5 & 18.8 & 2.0 & 0.6 & 0.71 \\
\hline C-17-252 & 168.36 & 5060 & 41324 & 290 & 4697 & 122 & 10.2 & 9.5 & 0.4 & 13.5 & 1.5 & 0.7 & 0.46 \\
\hline C-17-250 & 167.61 & 21472 & 58509 & 1033 & 9659 & 188 & 35.2 & 13.0 & 0.4 & 32.6 & 4.2 & 0.6 & 1.07 \\
\hline C-17-249 & 166.81 & 28443 & 66649 & 1363 & 14691 & 467 & 47.0 & 19.4 & 1.5 & 40.2 & 6.3 & 2.4 & 1.19 \\
\hline C-17-247 & 164.61 & 22422 & 50901 & 1078 & 12937 & 253 & 37.7 & 16.9 & 0.7 & 33.3 & 5.3 & 0.9 & 0.88 \\
\hline C-17-242 & 160.3 & 27691 & 71937 & 1328 & 12933 & 273 & 45.7 & 16.8 & 0.8 & 39.9 & 5.9 & 1.1 & 1.36 \\
\hline C-17-239 & 158.02 & 22214 & 58733 & 1088 & 9263 & 163 & 35.7 & 13.3 & 0.4 & 31.0 & 4.8 & 0.7 & 0.83 \\
\hline C-17-237 & 156.42 & 24393 & 57903 & 1178 & 11802 & 242 & 41.6 & 21.4 & 0.9 & 36.0 & 5.1 & 1.5 & 0.99 \\
\hline C-17-235 & 154.34 & 24984 & 68339 & 1182 & 10786 & 336 & 39.4 & 15.4 & 0.7 & 34.2 & 4.7 & 1.9 & 0.91 \\
\hline$C-17-230$ & 150.21 & 28108 & 64012 & 1343 & 13365 & 268 & 44.0 & 17.0 & 0.8 & 40.2 & 6.0 & 2.0 & 1.04 \\
\hline C-17-226 & 146.61 & 27357 & 63764 & 1284 & 13053 & 255 & 43.2 & 17.3 & 0.9 & 44.9 & 6.9 & 2.2 & 1.27 \\
\hline C-17-220 & 141.62 & 29085 & 68059 & 1350 & 13379 & 310 & 46.4 & 24.1 & 0.9 & 40.5 & 6.5 & 2.2 & 1.07 \\
\hline C-17-217 & 139.39 & 31912 & 78404 & 1490 & 16063 & 367 & 50.8 & 26.6 & 1.6 & 44.3 & 8.2 & 3.3 & 1.07 \\
\hline C-17-213 & 135.69 & 26535 & 69706 & 1223 & 12729 & 295 & 43.7 & 17.1 & 0.9 & 38.6 & 6.1 & 2.4 & 1.00 \\
\hline C-17-210 & 132.8 & 26694 & 57477 & 1244 & 12990 & 199 & 42.5 & 16.3 & 0.8 & 39.7 & 4.8 & 2.0 & 1.08 \\
\hline C-17-207 & 130.46 & 25270 & 69278 & 1220 & 11564 & 321 & 40.0 & 15.0 & 0.7 & 34.8 & 5.1 & 1.8 & 1.03 \\
\hline C-17-205 & 128.97 & 27869 & 62496 & 1391 & 12846 & 226 & 43.2 & 17.4 & 1.0 & 38.6 & 5.7 & 1.4 & 1.09 \\
\hline C-17-204 & 128.1 & 27860 & 72488 & 1366 & 13423 & 334 & 44.5 & 16.1 & 1.1 & 38.4 & 5.6 & 2.2 & 1.13 \\
\hline C-17-197 & 122.27 & 28299 & 62893 & 1292 & 13085 & 312 & 44.5 & 19.5 & 1.1 & 40.5 & 5.8 & 3.0 & 1.06 \\
\hline C-17-193 & 118.86 & 27087 & 60477 & 1304 & 12861 & 289 & 44.6 & 18.6 & 1.0 & 39.6 & 7.2 & 2.4 & 1.05 \\
\hline C-17-188 & 115.05 & 26894 & 55669 & 1288 & 12982 & 207 & 43.0 & 18.2 & 1.0 & 37.0 & 5.5 & 2.6 & 1.11 \\
\hline C-17-187 & 114.15 & 26497 & 54648 & 1293 & 13385 & 185 & 43.7 & 18.4 & 1.0 & 37.5 & 5.0 & 2.1 & 1.24 \\
\hline C-17-183 & 110.79 & 20087 & 41349 & 986 & 11486 & 222 & 32.7 & 12.0 & 0.3 & 30.0 & 4.2 & 1.7 & 0.98 \\
\hline C-17-180 & 108.19 & 24973 & 63645 & 1161 & 11669 & 192 & 41.3 & 18.4 & 0.8 & 36.5 & 5.7 & 1.4 & 1.12 \\
\hline C-17-176 & 104.85 & 21062 & 47494 & 1006 & 12641 & 194 & 35.4 & 16.5 & 0.6 & 26.8 & 5.1 & 2.2 & 0.82 \\
\hline C-17-170 & 100.1 & 27071 & 65075 & 1208 & 13294 & 249 & 46.9 & 19.7 & 1.0 & 35.9 & 8.4 & 2.5 & 1.01 \\
\hline C-17-169 & 99.25 & 29918 & 69461 & 1437 & 12497 & 294 & 50.4 & 19.1 & 0.5 & 43.1 & 6.6 & 1.4 & 0.99 \\
\hline C-17-166 & 96.71 & 28392 & 52938 & 1359 & 12860 & 253 & 48.1 & 17.0 & 0.6 & 35.7 & 5.7 & 0.9 & 1.00 \\
\hline$C-17-163$ & 94.09 & 21773 & 49609 & 1057 & 9654 & 205 & 34.1 & 13.2 & 0.2 & 29.7 & 4.7 & 1.8 & 0.79 \\
\hline C-17-160 & 91.77 & 22752 & 52081 & 1113 & 10116 & 195 & 36.3 & 16.4 & 0.6 & 35.0 & 4.5 & 1.3 & 0.79 \\
\hline C-17-157 & 89.51 & 31876 & 70021 & 1496 & 15769 & 262 & 51.6 & 25.5 & 1.3 & 44.3 & 7.4 & 2.7 & 1.07 \\
\hline C-17-155 & 88.11 & 24935 & 55810 & 1167 & 11701 & 217 & 39.8 & 16.2 & 1.1 & 39.2 & 5.5 & 1.9 & 0.82 \\
\hline \multirow[t]{2}{*}{ C-17-152 } & 86.07 & 22380 & 49585 & 1081 & 9884 & 169 & 35.9 & 13.5 & 1.1 & 35.1 & 4.0 & 1.1 & 0.86 \\
\hline & age $\% \mathrm{~F}$ & 1.7 & 2.1 & 5.4 & 12 & 9.4 & 5.7 & 12 & 14 & 15 & 18 & 12 & 17 \\
\hline
\end{tabular}


Appendix 7C Values of all the calculated biomarker parameters.

\begin{tabular}{|c|c|c|c|c|c|c|c|c|c|c|c|c|}
\hline Sample ID & Height $(m)$ & $\mathrm{Pr} / \mathrm{Ph}$ & $\mathrm{CPI}$ & TAR & $\mathrm{Pr} / \mathrm{n}-\mathrm{C}_{17}$ & $\mathrm{Ph} / \mathrm{n}-\mathrm{C}_{18}$ & Gammacerane Index & $\mathrm{C}_{27} / \mathrm{C}_{29}$ & $T s /(T s+T m)$ & $\mathrm{C}_{31} 22 \mathrm{~S} /(22 \mathrm{~S}+22 \mathrm{R})$ & $\mathrm{C}_{29} 20 \mathrm{~S} /(20 \mathrm{~S}+20 \mathrm{R})$ & $C_{29} \beta \beta /(\beta \beta+\alpha \alpha)$ \\
\hline C-17-257 & 171.89 & 0.97 & 0.95 & 0.84 & 0.29 & 0.27 & & & & & & \\
\hline C-17-256 & 171.16 & 0.87 & 0.93 & 0.48 & 0.20 & 0.23 & 0.00 & 0.55 & 0.62 & 0.56 & 0.42 & 0.58 \\
\hline C-17-255 & 170.49 & 0.83 & 0.95 & 0.68 & 0.21 & 0.25 & & & & & & \\
\hline C-17-254 & 169.89 & 1.25 & 1.02 & 0.41 & 0.33 & 0.27 & 0.01 & 0.57 & 0.63 & 0.54 & 0.54 & 0.65 \\
\hline C- $17-253$ & 168.87 & 0.99 & 0.96 & 0.39 & 0.17 & 0.19 & 0.01 & 0.54 & 0.60 & 0.58 & 0.54 & 0.66 \\
\hline C-17-252 & 168.36 & 0.89 & 0.98 & 0.44 & 0.15 & 0.17 & & & & & & \\
\hline C-17-249 & 166.81 & 1.59 & 1.07 & 0.31 & 0.22 & 0.15 & & & & & & \\
\hline C-17-247 & 164.61 & 1.49 & 1.05 & 0.37 & 0.21 & 0.15 & & & & & & \\
\hline C-17-242 & 160.3 & 0.90 & 0.94 & 0.32 & 0.15 & 0.17 & 0.09 & 0.73 & 0.61 & 0.54 & 0.54 & 0.65 \\
\hline C-17-239 & 158.02 & 1.36 & 1.05 & 0.35 & 0.26 & 0.19 & & & & & & \\
\hline C-17-235 & 154.34 & 1.35 & 1.06 & 0.29 & 0.19 & 0.15 & & & & & & \\
\hline C-17-226 & 146.61 & 1.55 & 1.09 & 0.32 & 0.34 & 0.23 & 0.07 & 0.54 & 0.62 & 0.52 & 0.48 & 0.62 \\
\hline C- $17-220$ & 141.62 & 1.38 & 1.05 & 0.35 & 0.33 & 0.26 & & & & & & \\
\hline C-17-213 & 135.69 & 1.31 & 1.07 & 0.33 & 0.34 & 0.26 & & & & & & \\
\hline C-17-207 & 130.46 & 0.88 & 1.05 & 0.33 & 0.23 & 0.25 & & & & & & \\
\hline C-17-204 & 128.1 & 1.26 & 1.05 & 0.32 & 0.30 & 0.24 & 0.09 & 0.49 & 0.63 & 0.59 & 0.42 & 0.60 \\
\hline C-17-197 & 122.27 & 1.45 & 1.07 & 0.30 & 0.29 & 0.21 & & & & & & \\
\hline C-17-188 & 115.05 & 1.31 & 1.07 & 0.25 & 0.24 & 0.19 & & & & & & \\
\hline C-17-183 & 110.79 & 1.04 & 1.05 & 0.29 & 0.22 & 0.20 & 0.04 & 0.93 & 0.58 & 0.56 & 0.57 & 0.60 \\
\hline C-17-180 & 108.19 & 1.44 & 1.06 & 0.35 & 0.37 & 0.25 & & & & & & \\
\hline C-17-176 & 104.85 & 0.97 & 1.02 & 0.33 & 0.20 & 0.20 & & & & & & \\
\hline C-17-170 & 100.1 & 1.54 & 1.04 & 0.41 & 0.50 & 0.34 & 0.09 & 0.58 & 0.63 & 0.48 & 0.55 & 0.64 \\
\hline C-17-166 & 96.71 & 1.28 & 1.07 & 0.27 & 0.23 & 0.18 & & & & & & \\
\hline C-17-160 & 91.77 & 0.94 & 1.06 & 0.27 & 0.22 & 0.23 & & & & & & \\
\hline C-17-157 & 89.51 & 1.23 & 1.06 & 0.30 & 0.28 & 0.24 & 0.09 & 0.55 & 0.62 & 0.55 & 0.59 & 0.62 \\
\hline C-17-152 & 86.07 & 1.20 & 1.05 & 0.36 & 0.26 & 0.22 & 0.02 & 0.81 & 0.60 & 0.53 & 0.52 & 0.56 \\
\hline
\end{tabular}




\section{GENERAL CONCLUSIONS}

Expanded sedimentary deposits recorded in a hemipelagic setting of the Organyà Basin provided the opportunity for this comprehensive study that revealed intricate details of the marine response to perturbations of the global carbon cycle during the Aptian. To achieve the main objectives and answer the proposed questions, I employed a multi-proxy methodology integrating field observations, petrographic analyses and organic and inorganic geochemical proxies. The combined results produced the following conclusions:

1) Large-scale ( $>1 \%$ ), negative, carbon isotope excursions (CIEs) that show no corresponding shifts in local sources of organic matter $(\mathrm{OM})$ and are simultaneously recorded at coeval localities appear to be the result of considerable input of isotopically light carbon into the ocean/atmosphere system that affects the isotopic ratio of the global carbon reservoir. Such is the case for the globally recorded, negative intra-C2 CIE superbly registered in the expanded sedimentary record of the Organyà Basin. Variations in magnitude and duration of Lower Cretaceous massive explosive volcanism in Asia and northeast Asia SB-V (Songliao Basin) coupled with the contemporaneous emplacement of LIPs (Ontong Java) offer a plausible explanation for the observed global negative shift.

2) Small-scale $(<1 \%)$, negative CIEs concurrent with elevated inputs of terrestrial $\mathrm{OM}$ are the result of regional climatic variabilities that alter riverine discharge volume and the content of terrestrially derived vegetation that contains more negative stable carbon isotope $\left(\delta^{13} \mathrm{C}_{\text {org }}\right)$ values. 
3) The $\delta^{13} \mathrm{C}_{\text {org }}$ data from the sequence at El Pujal is consistent with the pattern reported elsewhere for carbon isotope segment C5 within OAE1a. The micropaleontological associations give further credence to the chemostratigraphic correlation because petrographic analysis and results from selected disaggregated samples show that hedbergellids are the most common planktonic foraminifers in this interval, accompanied by rare to common globigerinelloidids and Leupoldina cf. cabri, whose Biozone parallels the OAE1a time-interval.

4) Deposits of the El Pujal sequence consist of a repetitive succession of limestones, argillaceous limestones and marlstones with varying proportions of OM, carbonate and siliciclastic material. Variations in fluvial discharge linked with climatic fluctuations explain the alternating lithology with limestones representing the least terrestrially influenced end-member and marlstones representing points of highest terrestrial influence.

5) Surficial primary production sustained by fluvial inputs of bio-limiting nutrients provided a source of readily mineralizable OM whose consumption led to episodic oxygen-deprived conditions. Indeed, peaks in TOC along marlstone and argillaceous limestone beds, correlate well with relatively lower benthic faunal counts, lower bioturbation index, higher concentration of pyrite and enrichments in RSTEs. Concomitant spikes in gammacerane indicates a stratified water column related to pulses of freshwater outputs that may have been influential in preventing vertical mixing of oxygen depleted bottom waters with more oxygenated surface waters. Higher content of minute bivalves and gastropods in these intervals presumably flushed offshore from adjacent swamps and estuaries, 
higher concentrations of lithophile elements as well as increased relative inputs of terrestrial OM, substantiates periods of intensified continental runoff.

6) OM preservation was not exclusively determined by redox conditions as additional aid through physical encapsulation by clay minerals likely played a significant role. In addition, coincident inputs of terrestrial OM, with more recalcitrant properties and prone to be bound to clay minerals resulting from soil forming processes, supplemented the accumulation of OM, especially during the deposition of marlstone and argillaceous limestone beds.

7) Molecular thermal maturity indices with average ratios consistently below equilibrium values indicate thermal immaturity. The results agree with temperatures in the range of $\sim 50^{\circ} \mathrm{C}$ to $60^{\circ} \mathrm{C}$, thus, the preserved organic geochemical data characterizes the original signals with minor to no alteration.

8) Data from source specific biomarkers reflects a mixed OM source, dominantly derived from bacteria, phytoplankton and aquatic macrophytes, with a relatively minor, but still significant input from terrestrial higher plants. The recorded pattern is typical of continental margins where sediments register a complex OM signal with influence from distinct, but connected ecosystems that include rivers, estuaries and the ocean system itself.

9) Appraisal of the aromatic lipid fraction revealed elevated concentrations of perylene coeval with increases in biomarkers indicative of allochthons OM, thus supporting its link with terrestrial vegetation input. Considering that perylene's concentration at El Pujal closely mirrors intervals of more humid climatic conditions as well as results from other studies which demonstrate its link with 
wood degrading fungi, high abundance of sedimentary perylene might therefore serve as a biomarker indicating a moist continental climate in the depositional setting.

10) High sediment accumulation rates calculated at $37.13 \mathrm{~cm} / \mathrm{kyr}$ dry and 63.29 $\mathrm{cm} / \mathrm{kyr}$ wet facilitated the generation of a high-resolution $\delta^{13} \mathrm{C}_{\text {org }}$ profile with refined details of segment C5.

11) The uppermost portion of the El Pujal section (Unit 3) registers the demise of previous conditions with hard limestones low in $\mathrm{TOC}, \mathrm{Al}, \mathrm{Si}, \mathrm{Ti}, \mathrm{P}$ and $\mathrm{Fe}$, and with lower ratios of autochthonous to allochthonous OM, indicating a reduction in fluvial fluxes and surface water fertility suggesting dryer climatic conditions. At the same time, RSTEs decrease and gammacerane indices drop to near zero, signaling the termination of density stratification in the basin and renewed ventilation of the water column. Changes in microfacies, with coarser grain packstones, fewer planktonic foraminifera and increase in benthic taxa, imply a shallowing of the basin, heralding the end of OM-rich sediments in the southcentral Spanish Pyrenees Basin at the end of segment C5 similar to that reported for the neighboring Basque-Cantabrian Basin.

Moreover, my dissertation has provided valuable new data applicable to the analysis of Cretaceous basins as follows:

a) My study is the first to emphasize the globally recorded, negative intra-C2 carbon isotope excursion. The excursion has since been identified by other studies e.g., Jenkyns, 2018 “Transient cooling episodes during Cretaceous Oceanic Anoxic Events with special reference to OAE1a (Early Aptian)" attesting to the global 
extent of this anomaly. Because of its common occurrence, the intra-C2 inflection is a useful chemostratigraphic marker preceding the more pronounced carbon isotope excursion of segment C3.

b) My study is the first to analyze the sedimentological, paleontological and geochemical archive at El Pujal and determine the paleoenvironmental conditions that led to the development of its lithological expression. The results help to clarify the oceanographic, climatic and tectonic circumstances of the eastern Iberian Peninsula at this time. In addition, my investigation has contributed to the everincreasing database of knowledge concerning the understanding of the unique depositional conditions that developed in semi-restricted basins during the Cretaceous, conditions that frequently compound to develop tremendous petroliferous potential and thus have significant economic implications.

c) My study generated the first high-resolution $\delta^{13} \mathrm{C}_{\text {org }}$ profile of carbon isotope segment C5 with details that are poorly recorded in more lithologically condensed sections. The detailed $\delta^{13} \mathrm{C}_{\text {org }}$ profile combined with the applied multi-proxy methodology, further improves the understanding of transient paleoenvironmental events within OAE1, and provides a refined asset suitable for precise chemostratigraphic correlations in the absence of biostratigraphic markers.

As a corollary to this investigation, further data collection on the section will help extend the $\delta^{13} \mathrm{C}_{\text {org }}$ profile, which due to the high sediment accumulation rates of the Basin; the sequence could conceivably serve as the "Chemotype" reference section for the OAE1a time-interval. Future research should also attempt to examine sea-surface temperatures and continental hydroclimate utilizing advanced geochemical proxies such as TEX $\mathrm{X}_{86}$ and 
stable hydrogen isotopes from epicuticular waxes of terrestrial higher plant leaves, as these data could evince a comprehensive understanding of the depositional conditions in the Organyà Basin during the Cretaceous. 
VITA

JANDER SOCORRO

Born, Cojímar, Cuba

2009-2013

B.S., Geosciences

Florida International University

Miami, Florida

2014-2018

M.S., Geosciences

Florida International University

Miami, Florida

2014-2020

Doctoral Candidate, Teaching Assistant

Florida International University

Miami, Florida

\section{PUBLICATIONS AND PRESENTATIONS}

Pending Submission - International Journal of Earth Sciences: Demise of OM-rich facies and changing paleoenviromental conditions associated with the end of carbon isotope segment C5 of OAE1a in the north and northeastern Iberian Peninsula.

Socorro, J., Maurrasse, F.J.-M.R., 2020. Regional palaeoenvironmental influence on organic matter sequestration and characteristics of carbon isotope segment $\mathrm{C} 5$ in a hemipelagic sequence, Organyà Basin, northeast Spain. The Depositional Record. In press.

Socorro, J., Maurrasse, F.J.-M.R., 2019. Continuous accumulation of organic matter-rich sediments associated with Oceanic Anoxic Event 1a in the El Pujal section, Organyà Basin, Catalunyà Spain and its relation to episodic dysoxia. Cretac. Res. 95, 225-251. https://doi.org/10.1016/J.CRETRES.2018.11.009.

Socorro, J., Maurrasse, F.J.M.R., Sanchez-Hernandez, Y., 2017. Characterization of the negative carbon isotope shift in segment $\mathrm{C} 2$, its global implications as a harbinger of OAE1a. Sci. China Earth Sci. 60, 30-43. https://doi.org/10.1007/s11430-016-0092-5.

"Geochemical and lithological characteristics of changing paleoenvironmental conditions associated with the end of carbon isotope segment C5 of OAE 1a in the south-central Spanish Pyrenees." Jander Socorro, Florentin J-M.R. Maurrasse. GSA 2019 September 22-25, Arizona, USA. 
"Geochemical and microfacies implication of the El Pujal section at the close of carbon isotope segment C5: Organyà Basin, Catalunyà, Spain." Jander Socorro, Florentin J-M.R. Maurrasse. AAPG 2019 May 19-22, Texas, USA.

"Regional fluctuating environmental conditions and shallowing event in the north and northeastern Iberian Peninsula during the end of carbon isotope segment C5: Organyà Basin, Catalunyà, Spain." Jander Socorro, Florentin J-M.R. Maurrasse. GSA 2018 November 4-7, Indiana, USA.

"Regional paleoenvironmental influence on OM sequestration and carbon isotope segment $\mathrm{C} 5$ in the hemipelagic sequence at the EL Pujal Section, Organyà Basin, northeast Spain." Jander Socorro, Florentin J-M.R. Maurrasse. AAPG 2018 May 20-23, Utah, USA.

"Local expression of global forcing factors in Lower Cretaceous, Aptian carbon isotope segment C5: El Pujal section, Organyà Basin, Catalunya Spain." Jander Socorro, Florentin J-M.R. Maurrasse. AGU 2017 December 11-15, Louisiana, USA.

"Geochemical characterization of the basal El Pujal section, Organyà Basin (NE Spain), in relation to its chronostratigraphic position to OAE1a." Jander Socorro, Florentin JM.R. Maurrasse. 10th ISC International Symposium on the Cretaceous 2017 August 2126, Vienna, Austria.

"Trace elements and biomarker results of the El Pujal section, Organyà Basin, Catalunya, NE Spain, in relation to OAE1a." Jander Socorro, Florentin J-M.R. Maurrasse. AGU 2016 December 12-16, California, USA.

"Continuous episodic dysoxia related to OAE1a, Organyà Basin, El Pujal section, Catalunya, NE Spain.” Jander Socorro, Florentin J-M.R. Maurrasse. GSA 2016 September 25-28, Colorado, USA.

"Characterization of the negative carbon isotope shift in segment $\mathrm{C} 2$ of the Organyà Basin, El Pui section, Spain; A potentially useful chemostratigraphic marker prior to OMrich interval associated with Oceanic Anoxic Event 1a (OAE 1a)." Jander Socorro, Florentin J-M.R. Maurrasse, Yosmel Sanchez-Hernandez. AAPG 2016 September 6-9, Cancun, Mexico.

"Biomarker characterization of the negative carbon isotope shift in segment $\mathrm{C} 2$ of the $\mathrm{El}$ Pui section, Organyà Basin, Catalunya, Spain.” Jander Socorro, Florentin J-M.R. Maurrasse, Yosmel Sanchez-Hernandez. IGCP 609 Workshop September 5-11, 2015. Nanjing, China. 